UNIVERSIDADE DE SÃO PAULO

FACULDADE DE FILOSOFIA, LETRAS E CIÊNCIAS HUMANAS DEPARTAMENTO DE SOCIOLOGIA PROGRAMA DE PÓS-GRADUAÇÃO EM SOCIOLOGIA

\title{
LILIAN VICTORINO
}

O documentário vai à Hollywood: a paixão pelo "real" e os filmes de Michael Moore

São Paulo 


\author{
UNIVERSIDADE DE SÃO PAULO \\ FACULDADE DE FILOSOFIA, LETRAS E CIÊNCIAS HUMANAS \\ DEPARTAMENTO DE SOCIOLOGIA \\ PROGRAMA DE PÓS-GRADUAÇÃO EM SOCIOLOGIA
}

\title{
LILIAN VICTORINO
}

O DOCUMENTÁRIO VAI À HOLLYWOOD:

a paixão pelo "real" e os filmes de Michael Moore.

Tese apresentada ao programa de PósGraduação em Sociologia da Faculdade de Filosofia, Letras e Ciências Humanas da Universidade de São Paulo, para a obtenção do título de Doutor(a) em Sociologia.

Orientador: Prof. Dr. Paulo Menezes

"Exemplar original"

São Paulo/ 2014 
Aos meus pais, Anésia e Osvaldo, pelo apoio incondicional.

Aos meus filhos, Caroline e Gilberto, pelos motivos para continuar. 


\section{AGRADECIMENTOS}

Ao professor Paulo Menezes, pela oportunidade e contribuição para minha formação intelectual na Universidade de São Paulo. Pela confiança, desafios e rigor sociológico.

Aos professores que foram membros da banca de qualificação: Maria Helena Oliva Augusto (FFLCH/ USP) e Eduardo Morettin (ECA/ USP), pela avaliação do trabalho inicial e sugestões. Aos professores que farão parte da banca de defesa da tese: Célia Tolentino (FFC-UNESP), Ana Lúcia de Freitas Teixeira (EFLCH-UNIFESP), Marina Soler Jorge (EFLCH-UNIFESP) e Anderson Ricardo Trevisan (FFLCH-USP).

Aos colegas do grupo de pesquisa do professor Paulo Menezes, pelas leituras atentas, críticas construtivas, amizade, motivações e cafés sociológicos: Anderson Trevisan, Carla Bernava, Flávia Brites, Michele Perusso, Natália Bonaldi, Paulo Scarpa e Túlio Rossi. Ao Jefferson Guedes pelo apoio constante.

Aos funcionários da secretaria de Pós-Graduação em Sociologia da USP: Maria Ângela Ferraro de Souza, Vicente Sedrângulo Filho e Gustavo Mascarenhas.

Aos que contribuíram de diversas formas e em diferentes momentos neste percurso: Alexandre Massella, Alexandro Paixão, Ana Lúcia Teixeira, Cristiane Maria Arruda, Fabiana Zulli, Fabrícia Carla Viviani, Gilberto Lima, Herbert Rodrigues, Luca Bernar, Mariana Thibes, Mary Shoptaw, Mauro Rovai, Patrícia Santos e Sean Purdy.

À Regina Carielo, minha colega de turma no doutorado, que se mostrou uma grande amiga nos últimos quatro anos.

Ao inesquecível professor Flávio Pierucci (in memoriam).

Aos companheiros da turma de Ciências Sociais na UNESP de Marília e da Revista Baleia na Rede: Carla Cordeiro, Célia Tolentino, Elisângela Santos, Héder dos Santos, Luana Hordones, Naira Reinaga de Lima, Rafaela Fernandes e Silvana Benevenuto. À Tatiane Pacanaro que me apresentou os filmes de Michael Moore no Clube do Cinema de Marília. Em especial, ao eterno amigo Odirlei Dias Pereira (in memoriam).

À Elisângela Silva Santos por muitos anos de amizade fraterna.

À minha família pelo apoio inestimável: Carol, Guga, Anésia, Osvaldo, Jane, Robson, Rafael, Keisy, Gabriel e Giovanna.

À Fundação de Amparo à Pesquisa do Estado de São Paulo - FAPESP, pela bolsa de Doutorado e por financiar praticamente todo o meu percurso acadêmico desde a Iniciação Científica e Mestrado. 
"Eu falo do americano no singular, como senão existissem milhões deles, ao norte e ao sul, a leste e a oeste, de ambos os sexos, de todas as idades, e de várias raças, profissões e religiões. Naturalmente, o americano de quem falo é mítico; todavia, falar por parábolas é inevitável em semelhante assunto e é talvez tanto quanto fazê-lo de maneira franca." Santayana, Character and Opinion in the United States. ${ }^{1}$

\footnotetext{
${ }^{1}$ RIESMAN, David. A multidão solitária. São Paulo: Ed. Perspectiva, 1995, p. 67.
} 


\title{
O DOCUMENTÁRIO VAI À HOLLYWOOD: A PAIXÃO PELO “REAL" E OS FILMES DE MICHAEL MOORE.
}

RESUMO: Esta tese apresenta uma análise sociológica de cinco filmes do cineasta Michael Moore: Roger e Eu (1989), The Big One (1997), Tiros em Columbine (2002), Fahrenheit 9/11 (2004) e Capitalismo: uma história de amor (2009). O principal objetivo da pesquisa foi investigar a particularidade dos filmes de Moore, reconhecido internacionalmente como o cineasta de documentário mais assistido na história do gênero. A partir da construção visual de cada filme, analiso em detalhe: os temas, os grupos formados, os valores sociais, os conflitos, as saídas para os problemas e as diversas construções simbólicas sugeridas para o espectador. Assim, considero que os filmes propõem construções acerca do "real" que podem ser percebidas e aceitas pelo publico espectador como referências de verdade e de realidade. A tarefa deste trabalho foi desconstruir e mediar o discurso dos filmes por meio de uma leitura sociológica acerca de suas narrativas e das relações sugeridas ao público espectador que conferiu grande audiência as essas obras.

PALAVRAS-CHAVE: Sociologia; Cinema; Documentário; Michael Moore; Construção do "real".

\section{THE DOCUMENTARY GOES TO HOLLYWOOD: MICHAEL MOORE'S MOVIES AND THE PASSION FOR "REAL".}

\begin{abstract}
My dissertation presents a sociological analysis of five Michael Moore's films: Roger \& Me (1989), The Big One (1997), Bowling for Columbine (2002), Fahrenheit 9/11 (2004), and Capitalism: a love story (2009). The main objective of this research is to investigate the particularity of Moore's films, as he is internationally recognized as the most watched documentary director in history. Through the visual construction of each film, I analyze in detail the film themes, group formation, social values, conflicts, Moore's proposed solutions, and the various symbolic constructions suggested to the viewer. I argue that his movies provide a social construction of the "real", which can be accepted and perceived by the audience as an accurate description of reality. The task of this dissertation is to deconstruct and mediate the discourse of his movies through a sociological analysis. I analyse the films' suggested stories and the social relations presented to viewers that have led to the popularity of his body of work.
\end{abstract}

KEYWORDS: Sociology; Cinema; Documentary; Michael Moore; The construction of the "real". 


\section{SUMÁRIO}

INTRODUÇÃO.

O CONTEXTO QUE MARCA AS RELAÇÕES ENTRE CINEMA E SOCIEDADE.. 1

I - AMEAÇAS AO AMERICAN WAY OF LIFE.

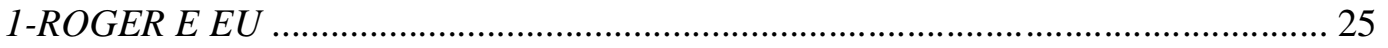

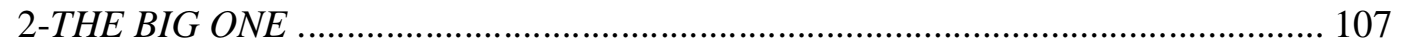

3-CAPITALISMO: UMA HISTÓRIA DE AMOR ………………………………….... 151

II- A INDUSTRIALIZAÇÃO DA GUERRA COMO FENÔMENO SOCIAL: O LADO SOMBRIO DA MODERNIDADE.

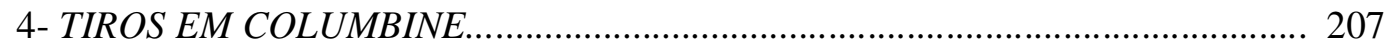

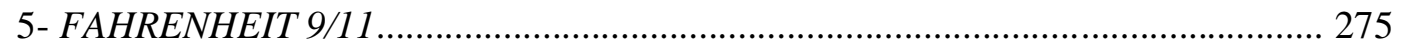

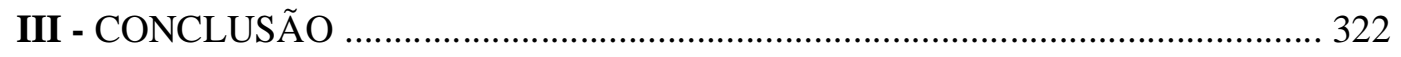

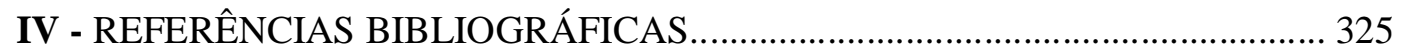

V- FILMOGRAFIA E WEBSITES CONSULTADOS................................................ 332 


\section{Introdução - $O$ contexto que marca as relações entre cinema e sociedade.}

De qualquer forma, é mediante a percepção que podemos compreender a significação do cinema: um filme não é pensado e, sim, percebido. Maurice Merleau-Ponty ${ }^{2}$

O trabalho que se inicia compreende uma análise sociológica dos seguintes filmes de Michael Moore: Roger e Eu, The Big One, Tiros em Columbine, Fahrenheit 9/11 e Capitalismo: uma história de amor. Esta introdução apresenta o panorama histórico-social no qual se encontram os filmes escolhidos para objeto de análise, e os principais conceitos que ancoram este trabalho em um estudo voltado para as relações entre cinema e sociedade.

A história humana é marcada por "descontinuidades" que evidenciaram processos não homogêneos de desenvolvimento das sociedades. As instituições sociais modernas diferem de todos os tipos de sociedades precedentes, seja em termos de organização política, estilo, costume de vida, relação com o tempo e o espaço, relações entre os grupos sociais, relações com o trabalho e outros fatores que emergiram na Europa do século XVII e se mundializaram em maior ou menor proporção graças aos avanços técnicos e científicos que essas transformações proporcionaram ${ }^{3}$.

Acerca do conceito de modernidade, como um feixe de transformações nas instituições sociais que distanciam as sociedades modernas das formas tradicionais antecedentes, Anthony Giddens afirma em "As consequências da modernidade" que "existem indiscutivelmente descontinuidades em várias fases do desenvolvimento histórico"4, algumas específicas associadas ao período moderno que são "mais profundas que a maioria dos tipos de mudança característicos dos períodos precedentes". . Nesta mesma direção, em seu trabalho "Modernidade e Identidade", esse autor apresenta três generalizações que marcam as principais descontinuidades no

\footnotetext{
${ }^{2}$ MERLEAU-PONTY, Maurice. O cinema e a nova psicologia. In: Xavier, I. (org.). "A experiência do cinema: antologia". Rio de Janeiro: Ed. Graal: Embrafilmes, 1983, p.115.

${ }^{3}$ GIDDENS, Anthony. As consequências da modernidade. São Paulo: Ed. UNESP, 1991, p. 14.

${ }^{4}$ GIDDENS, A. As consequências da modernidade, op.cit., p. 14.

${ }^{5}$ GIDDENS, A. As consequências da modernidade, op.cit., p. 15.
} 
desenvolvimento histórico e, por sua vez, caracterizam a modernidade: o ritmo de mudança, o escopo da mudança e a natureza intrínseca das instituições modernas.

As instituições modernas diferem de todas as formas anteriores de ordem social quanto ao seu dinamismo, ao grau em que interferem com hábitos e costumes tradicionais, e a seu impacto global. (...) a modernidade altera radicalmente a natureza da vida social cotidiana e afeta os aspectos mais pessoais de nossa existência ${ }^{6}$.

Assim, marcada por um ritmo dinâmico, a modernidade pode ser inicialmente compreendida a partir de três fontes dominantes ligadas entre si: a separação tempoespaço com o zoneamento preciso de ambos, o desenvolvimento de mecanismos de desencaixe que afastaram a vida social de sua localidade, ampliando as relações humanas através de grandes distâncias tempo-espaciais, e a apropriação reflexiva do conhecimento que possibilitou o distanciamento da fixidez que caracterizam as formas de vida tradicionais.

Nesta direção, o conceito de modernidade que atua como fio condutor deste trabalho está centrado nas obras de Anthony Giddens: "As Consequências da Modernidade" e "Modernidade e Identidade". Giddens analisa a natureza da modernidade, e o dinamismo que lhe é peculiar, alternando os termos entre modernidade alta e modernidade tardia para conceituar às transformações que diferem esse período histórico marcadamente pós-tradicional ${ }^{7}$. As especificidades deste processo também apontam para uma "cultura do risco", no sentido de que "o mundo moderno tardio - o mundo que chamo de alta modernidade - (...) introduz riscos que gerações anteriores não tiveram que enfrentar" ${ }^{\prime 8}$. Entre os principais riscos da modernidade alta, o autor cita: guerra nuclear ou a obtenção do conhecimento científico necessário para a construção de armas nucleares, catástrofes ecológicas, colapso dos mecanismos econômicos globais, surgimento de super Estados totalitários entre outros que diferenciam a experiência contemporânea das formas anteriores.

A fim de especificar as nuances deste processo, as análises que compõem este trabalho também observam as teses encontradas no diálogo travado entre Giddens, Scott

\footnotetext{
${ }^{6}$ GIDDENS, A. Modernidade e identidade. Rio de Janeiro: Zahar, 2002, p. 09.

${ }^{7}$ GIDDENS, A. Modernidade e identidade, op.cit., p. 11 e 12.

${ }^{8}$ GIDDENS, A. Modernidade e identidade, op.cit., p.12.
} 
Lash e Ulrich Beck na obra "Modernização Reflexiva: política, tradição e estética na ordem social moderna"9 cujo cerne analítico discute o conceito de modernização reflexiva como etapa da modernização, que a diferencia da "modernização simples" ou "formas sociais industriais" no sentido de uma desincorporação e posterior reincorporação dessas instituições, alterando seu papel e significado sociais ${ }^{10}$. Conforme pontua Beck,

(...) em virtude de seu dinamismo, a sociedade moderna está acabando com suas formações de classe, camadas sociais, ocupação, papéis dos sexos, família nuclear, agricultura, setores empresariais e, é claro, também com os pré-requisitos e as formas contínuas do progresso técnico-econômico. Este novo estágio, em que o progresso pode se transformar em auto-destruição, em que um tipo de modernização destrói outro e o modifica, é o que eu chamo de etapa da modernização reflexiva ${ }^{11}$.

$\mathrm{Na}$ esteira do que é proposto por Giddens no contexto de alta modernidade e seus riscos ${ }^{12}$, e por Beck com a modernidade reflexiva, adiciono ao conjunto dessas teorias outra obra de Beck "Sociedade de risco: rumo a outra modernidade", a fim de problematizar algumas especificidades relacionadas às formações sociais que emergem dos filmes que analiso.

Para delinear essas especificidades, Giddens aponta para uma reflexividade da vida social moderna no sentido de que "as práticas sociais são constantemente examinadas e reformadas à luz de informação renovada sobre estas próprias práticas, alterando assim constitutivamente seu caráter" ${ }^{, 14}$. De modo geral, a modernidade é constituída por um conhecimento reflexivamente aplicado e ao mesmo tempo incerto, porque é constantemente revisado, o que afeta profundamente as sociedades ocidentais, sobretudo no que envolve a confiança nos sistemas peritos, relações de poder e o papel dos valores.

\footnotetext{
${ }^{9}$ BECK, Ulrich. Modernização reflexiva: política, tradição e estética na ordem social moderna. - Ulrich Beck, Anthony Giddens, Scott Lash; [2ed.]. - São Paulo: Ed. UNESP, 2012. [1 ${ }^{\mathrm{a}}$ ed. 1995].

${ }^{10}$ BECK, U. Modernização reflexiva, op.cit., p.13.

${ }^{11}$ BECK, U. Modernização reflexiva, op.cit. p.13.

${ }^{12}$ GIDDENS, A. Modernidade e identidade. Rio de Janeiro: Zahar, 2002, p. 12.

${ }^{13}$ BECK, U. Sociedade de risco: rumo a uma outra modernidade. São Paulo: Ed. 34, 2010.

${ }^{14}$ GIDDENS, A. As consequências da modernidade. São Paulo: Ed. UNESP, 1991, p.45.
} 
A modernidade é constituída por e através de conhecimento reflexivamente aplicado, mas a equação entre conhecimento e certeza revelou-se erroneamente interpretada. Estamos em grande parte em um mundo que é inteiramente constituído através de conhecimento reflexivamente aplicado, mas onde, ao mesmo tempo, não podemos nunca estar seguros de que qualquer elemento dado deste conhecimento não será revisado ${ }^{15}$.

Assim, a apropriação do conhecimento não ocorre de forma homogênea nas sociedades, embora a modernidade alta ou tardia continuamente amplie e incorpore grandes extensões de tempo-espaço, o que a torna "inerentemente globalizante"16. Giddens define esse processo como,

A globalização pode assim ser definida como a intensificação das relações sociais em escala mundial, que ligam localidades distantes de tal maneira que acontecimentos locais são modelados por eventos ocorrendo a muitas milhas de distância e vice-versa. (...) A transformação local é tanto uma parte da globalização quanto a extensão lateral das conexões sociais através do tempo e do espaço ${ }^{17}$.

Em seu debate com Giddens, Beck afirma que a atual modernidade, pensada a partir de 1989 com o fim da guerra-fria, possibilitaria a destruição criativa para toda uma era precedente: a da sociedade industrial. Esse novo processo é considerado por Beck como modernização reflexiva, não no sentido de reflexão, mas no de autoconfrontação: "modernização reflexiva significa autoconfrontação com os efeitos da sociedade de risco que não podem ser tratados e assimilados no sistema da sociedade industrial" ${ }^{18}$. Para o autor, se a modernização simples pode ser caracterizada pela desincorporação e reincorporação das formas sociais tradicionais pelas formas industriais, a modernização reflexiva significa a desincorporação e a reincorporação das

\footnotetext{
${ }^{15}$ GIDDENS, A. As consequências da modernidade. São Paulo: Ed. UNESP, 1991, p. 46.

${ }^{16}$ GIDDENS, A. As consequências da modernidade. Op.cit., p. 69.

${ }^{17}$ GIDDENS, A. As consequências da modernidade. Op.cit., p.69-70.

${ }^{18}$ BECK, U. Modernização reflexiva: política, tradição e estética na ordem social moderna. São Paulo: Ed. UNESP, 2012, p.18.
} 
formas sociais industriais por outra modernidade, cujo inerente dinamismo estaria rompendo com antigas formações de classe, camadas sociais, ocupação, papéis sexuais, família nuclear, agricultura, setores empresariais e as formas continuadas de progresso técnico-econômico ${ }^{19}$.

Nesse sentido, sintonizado com as afirmações de Giddens, para Beck não estaríamos em um período de pós-modernidade, mas vivenciando a radicalização da modernidade com mudanças na sociedade industrial e com a emergência da sociedade de risco. Falar em sociedade de risco envolve enfrentar novas configurações na sociedade moderna em que "os riscos sociais, políticos, econômicos e individuais tendem cada vez mais a escapar das instituições para o controle e a proteção da sociedade industrial” ${ }^{, 20}$. No plano individual significa viver e agir em meio às incertezas, sem possibilidade de soluções definitivas, um processo de individualização em que as pessoas devem produzir, representar e acomodar suas próprias biografias aos novos modos de vida desincorporados e reincorporados à sociedade industrial ${ }^{21}$.

Nesse contexto de modernização reflexiva, tanto a individualização quanto a globalização são apresentadas como dois lados do mesmo processo, em que estariam cada vez mais desintegradas as certezas da sociedade industrial. Isso também promoveria nos indivíduos a busca compulsiva por novas certezas para si e para aqueles que não mais as possuem ${ }^{22}$. Alinhado às proposições de Beck a respeito da modernidade reflexiva, Giddens associa esse conceito aos desdobramentos da sociedade pós-tradicional $^{23}$, no sentido de que historicamente a modernidade reconstruiu a tradição enquanto a dissolvia. Para este autor, de um lado existe "a difusão extensiva das instituições modernas, universalizadas por meio de processos de globalização [e de outro] estão os processos de mudança intencional, que podem ser conectados à radicalização da modernidade" ${ }^{24}$. Com isto, as decisões individuais influenciam e são influenciadas por ordens cada vez mais globais. "A experiência global da modernidade está interligada - e influencia, sendo por ela influenciada - à penetração das instituições

\footnotetext{
${ }^{19}$ BECK, U. Modernização reflexiva: política, tradição e estética na ordem social moderna. São Paulo: Ed. UNESP, 2012, p.13.

${ }^{20} \mathrm{BECK}, \mathrm{U}$. Modernização reflexiva, op.cit., p. 17.

${ }^{21} C f$. BECK, U. Modernização reflexiva, op.cit., p. 17-28.

${ }^{22} \mathrm{Cf}$. BECK, U. Modernização reflexiva, op.cit.

${ }^{23}$ GIDDENS, A. A vida em uma sociedade pós-tradicional. IN: BECK, U. Modernização reflexiva. São Paulo: Ed. UNESP, 1997, p. 89-166.

${ }^{24}$ GIDDENS, A. A vida em uma sociedade pós-tradicional. IN: BECK, U. Modernização reflexiva, op. cit., p.91.
} 
modernas nos acontecimentos da vida cotidiana"25.

Em um contexto pós-tradicional, sem o peso da tradição e da localidade, os indivíduos não teriam outra escolha senão decidirem como ser e agir diante de um momento em que múltiplas possibilidades ocorreriam para a vida cada vez mais afastada da ordem tradicional. Giddens pontua que "a tradição proporcionava uma âncora para aquela "confiança básica" tão fundamental para a continuidade da identidade; era também o mecanismo orientador de outras relações de confiança" ${ }^{\text {26 }}$. Se na sociedade moderna os indivíduos encontravam líderes ou guardiões da tradição nos quais podiam confiar, a sociedade pós-tradicional é "um mundo de autoridades múltiplas" ${ }^{27}$ e a dúvida é a quem recorrer, em qual especialista ou superespecialista. Buscar e questionar as diferentes áreas do conhecimento se tornou "a verdadeira condição da "autenticidade" da vida cotidiana",28, visto que todo o conhecimento especializado estaria ao alcance daqueles que dispõem de tempo e recursos para serem instruídos e "a prevalência da reflexividade institucional significa que há uma contínua triagem de teorias, conceitos e achados especializados em relação à população leiga"29.

Em termos de alta modernidade, Giddens situa a atualidade como um mundo "repleto de riscos e perigos, para os quais o termo "crise" - não como mera interrupção, mas como um estado de coisas mais ou menos permanente - é particularmente adequado"30. Isso não quer dizer que nas sociedades tradicionais não havia riscos, temores e anseios, mas neste atual estado de radicalização dos efeitos da modernidade esses sintomas alterariam as relações pessoais tanto no meio social quanto na própria noção de identidade. Situações perturbadoras podem gerar ansiedade e incerteza, bem como possibilitarem alguma forma de adaptação através da busca por respostas e novas iniciativas $^{31}$.

Com isto, no contexto de uma sociedade pós-tradicional, é comum a pergunta em torno do modo "mais adequado" para viver. Esta pergunta envolve o cotidiano das pessoas e pode ser respondida em termos de "como comportar-se, o que vestir e o que comer - e muitas outras coisas - quanto ser interpretada no desdobrar temporal da auto

\footnotetext{
${ }^{25}$ GIDDENS, A. A vida em uma sociedade pós-tradicional. IN: BECK, U. "Modernização reflexiva". Op.cit., p.94.

${ }^{26}$ GIDDENS, A. A vida em uma sociedade pós-tradicional. IN: BECK, U. "Modernização reflexiva". São Paulo: Ed. UNESP, 2012, p.127.

${ }^{27}$ GIDDENS, A. A vida em uma sociedade pós-tradicional, op.cit., p.136.

${ }^{28}$ GIDDENS, A. A vida em uma sociedade pós-tradicional, op.cit., p.142.

${ }^{29}$ GIDDENS, A. A vida em uma sociedade pós-tradicional, op.cit., p.139-140.

${ }^{30}$ GIDDENS. A. Modernidade e identidade. Rio de Janeiro: Zahar, 2002, p. 19.

${ }^{31}$ GIDDENS. A. Modernidade e identidade, op.cit., p.19.
} 
identidade ${ }^{, 32}$. Este autor também assinala o que denomina de política-vida ${ }^{33}$ como estratégia de vida neste contexto. Isto consiste na emancipação da rigidez da tradição e das condições da vida hierárquica para uma escolha do modo ou estilo de vida, tanto no nível individual como no coletivo. Para efeito de definição, o conceito de política-vida refere-se ao processo de auto realização no contexto pós-tradicional "onde influências globalizantes penetram profundamente no projeto reflexivo do eu e, inversamente, onde os processos de auto realização influenciam as estratégias globais" 34 sendo uma política de decisões para a vida.

Outra perspectiva a respeito da atualidade está na ideia de Modernidade Líquida de Zygmunt Bauman ${ }^{35}$. Para sua construção teórica este autor utiliza a metáfora da fluidez dos líquidos: os líquidos possuem a qualidade de se acomodarem rapidamente às novas formas, porém não as retém com a mesma facilidade. Ele explica que a modernidade adquiriu essa qualidade dos líquidos, ou dos fluidos, pela maneira como novas formas ou configurações sociais são acomodadas e abandonadas com velocidade. Em um breve retrospecto, o autor aponta que a modernidade do século XX é caracterizada, entre outras coisas, pelo derretimento dos sólidos como a família, a classe, o bairro, e com a profanação do sagrado, sobretudo àquele ligado à tradição que seriam resíduos do passado como o eram "as lealdades tradicionais, os direitos costumeiros e as obrigações que atavam pés e mãos, impediam os movimentos e restringiam as iniciativas" ${ }^{\prime 36}$.

Para Bauman, os padrões e rotinas mais rígidos da modernidade pesada poupariam os homens da agonia promovida pelas incertezas, graças aos modos de conduta recomendados e cujas consequências eram tranquilizantemente conhecidas. As pessoas nasciam, cresciam e morriam após seguirem destinos pré-determinados pela sua localidade de origem, classe social, religião e família. Assim, após a modernidade "limpar o terreno", outros sólidos se formaram, sobretudo na esfera econômica, libertando a economia de seus "tradicionais embaraços políticos, éticos e culturais"37 sedimentando, assim, uma nova ordem, principalmente em termos econômicos.

Livres das antigas amarras que as prendiam à família e à localidade onde nasciam, as pessoas, partindo dos próprios esforços, deveriam se realocar em novos

\footnotetext{
${ }^{32}$ GIDDENS. A. Modernidade e identidade, op.cit., p. 20-21.

${ }^{33} C f$. GIDDENS, A. Modernidade e identidade, op. cit., 2002, p. 193-212.

${ }^{34}$ GIDDENS, A. Modernidade e identidade, op. cit., p. 197.

${ }^{35} C f$. BAUMAN, Z. Modernidade Líquida. Rio de Janeiro: Jorge Zahar Ed. 2001.

${ }^{36}$ BAUMAN, Z. Modernidade Líquida, op. cit., 2001, p. 05.

${ }^{37}$ BAUMAN, Z. Modernidade Líquida, op. cit., p.10.
} 
nichos pré-fabricados na sociedade, e isso transfere uma nova carga de responsabilidades pela produção da vida para os ombros dos indivíduos que devem buscar satisfação pessoal tendo consciência de que boa parte do sucesso alcançado seria uma contribuição sua, e não mais das velhas instituições que os mantinham presos a um destino pré-determinado.

Com a nova carga de responsabilidades, a incerteza acerca da possibilidade de obter conquistas, sucesso e o medo do fracasso, gerou-se um modo de vida centrado no indivíduo em que o outro é visto, na maioria das vezes, como concorrente. Para Bauman, nesta sociedade "tanto as condições como as narrativas sofrem um implacável processo de individualização" ${ }^{38}$, a ponto de os próprios indivíduos serem responsabilizados "pelas imperfeições das fórmulas de vida produzidas culturalmente e da desigualdade de sua distribuição produzida socialmente sobre os mesmos homens e mulheres para os quais as fórmulas são produzidas e os recursos necessários para dispôlas são fornecidos",39.

Nesse mesmo sentido, Giddens assinala que "a vida pessoal torna-se atenuada e privada de pontos de referência firmes: há uma volta para dentro, para a subjetividade humana, e o significado e estabilidade são buscados no eu interior" ${ }^{40}$. Isso não significa que os indivíduos encontrem sentidos para as suas vidas mesmo com liberdade de escolha, pois como lembra Bauman, "a liberdade não pode ser ganha contra a sociedade"41 e as antigas e novas configurações sociais estão cheias de normas de conduta e padrões a serem seguidos. Se a liberdade é sem precedentes, a impotência que a acompanha também o é.

Assim, na sociedade líquida todos são indivíduos, não por escolha, mas por necessidade. "Muitos de nós fomos individualizados sem que antes nos tornássemos indivíduos, e muitos são assombrados pela suspeita de que não são indivíduos o

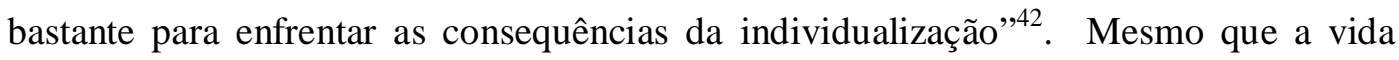
atual não tenha atingido os extremos dessas constatações que a destituiriam totalmente de sentido, o que se percebe são novíssimas rotinas que, por sua liquidez, não duram o suficiente para se tornarem hábitos, e todas as buscas por certezas serão "muletas e artifícios do engenho humano que só parecem a coisa em si se nos abstivermos de

\footnotetext{
${ }^{38}$ BAUMAN, Z. A sociedade individualizada: vidas contadas e histórias vividas. Rio de Janeiro: Jorge Zahar Editor, 2008, p.13.

${ }^{39}$ BAUMAN, Z. A sociedade individualizada, op.cit., p. 12.

${ }^{40}$ GIDDENS, A. As consequências da modernidade. São Paulo: Ed. UNESP, 1991, p. 118.

${ }^{41}$ BAUMAN, Z. Modernidade líquida. Rio de Janeiro: Jorge Zahar Ed. 2001, p. 28.

${ }^{42}$ BAUMAN, Z. A sociedade individualizada, op. cit., p. 137.
} 
examiná-las muito de perto" ${ }^{, 43}$.

Nessa direção, quanto mais líquida e incerta se apresenta a vida na atualidade, mais as pessoas estariam em busca de certezas e oportunidades de satisfação para combater temores e ansiedades decorrentes da vida neste "estado de fluidez". Neste contexto, a palavra agora ganha contornos de estratégia de vida, pois nenhum compromisso de hoje poderia representar obstáculo para as oportunidades de amanhã, bem como qualquer oportunidade que não for aproveitada aqui e agora seria uma oportunidade perdida. Para isso, quanto mais leves e fluidos os compromissos assumidos, menor o risco de prejuízo. Colocar-se objetivos distantes, abandonar o interesse privado em favor do grupo, sacrificar o presente num mundo em que o futuro poderia ser, na melhor das hipóteses, sombrio e nebuloso não parece algo razoável em tempos líquidos ${ }^{44}$.

Nesta nova configuração social, "não há mais o grande Irmão à espreita" ${ }^{45}$ diz Bauman, mas sim vários grandes irmãos e grandes irmãs observando uns aos outros em busca de encontrar algo que seja de utilidade para si mesmos, como exemplos a serem imitados, ou palavras de ajuda e consolo para os próprios problemas, que devem ser enfrentados individualmente. Com o derretimento das sólidas instituições e a liquidez das novas relações, a vida em comunidade entraria em declínio. Entretanto, ao mesmo tempo, os indivíduos cada vez mais impotentes sentem uma forte necessidade psicológica de encontrar alguém em que possam confiar, pois, paradoxalmente, ainda buscam solidificar os fluidos, e essa busca por solidificar o que está fluido é um grande sinal da liquidez dessa nova modernidade. Quando o indivíduo se encontra nessa situação de incerteza, devido à perda dos referenciais da modernidade sólida cheia de rotinas e hábitos, se vê imerso em novas configurações de trabalho e de relacionamentos humanos fugazes, além da dúvida a respeito do seu próprio destino. Com isto, tudo "o que prometa "assumir a responsabilidade pela certeza" é bem vindo" 46 .

Acerca das discussões que envolvem a ideia de incerteza crescente em meio à alta modernidade, destaco algumas considerações de Slavoj Zizek em seu livro "Bem vindo ao deserto do real!" "47. Apesar de não compartilhar das discussões dos autores citados anteriormente no que se refere ao conceito de modernidade, neste livro Zizek

\footnotetext{
${ }^{43}$ BAUMAN, Z. Modernidade líquida, op. cit., p. 29.

${ }^{44} C f$. BAUMAN, Z. Modernidade líquida. Rio de Janeiro: Jorge Zahar Ed. 2001, p. 145.

${ }^{45}$ BAUMAN, Z. Modernidade líquida, op. cit., p. 38.

${ }^{46}$ BAUMAN, Z. Modernidade líquida, op.cit. p. 28.

${ }^{47}$ ZIZEK, Slavoj. Bem vindo ao deserto do real!: cinco ensaios sobre o 11 de setembro e datas relacionadas. São Paulo: Boitempo editorial, 2003.
} 
discute questões atuais que vão de encontro aos filmes aqui estudados, de modo não apenas a auxiliar as análises que partem das proposições de sentido que os filmes aludem em suas narrativas, mas também para se pensar porque os filmes de Moore se tornaram tão popularizados.

Zizek aponta para o que chamou de "paixão pelo real" necessidade paradoxal de ver e sentir o "real virtual" em cada detalhe, sobretudo se for transmitido ao vivo pela televisão, na qual o "real" é destituído de sua materialidade e, portanto, de sua substância ou "do núcleo duro e resistente do Real"49. Com isto, haveria todo um processo de virtualização da própria "realidade real" como uma entidade virtual em que a realidade é sentida sem o ser, ou ainda, a realidade é desprovida de sua substância, pois provavelmente, a realidade em toda sua materialidade poderia causar efeitos colaterais. Este autor aponta uma lista de produtos e coisas que, na atualidade, estão desprovidos de suas propriedades malignas para sinalizar os indícios desse processo de virtualização do real: temos café sem cafeína, creme de leite sem gordura, cerveja sem álcool, sexo virtual ou sexo sem sexo, guerra sem baixas, guerra sem guerra, a política sem política ou a arte da administração competente, e a lista segue extensa ${ }^{50}$.

E nesse movimento de fuga dos efeitos colaterais do "real", busca-se viver o “espetáculo teatral" ${ }^{, 51}$ ou ainda, acostuma-se a perceber a própria "realidade real" como entidade virtual, o que é comum na atual sociedade afeita à ficção Hollywoodiana e seus efeitos especiais "esvaziados do peso e da inércia da materialidade." isso, vive-se o cotidiano fictício das aparências e a realidade como entidade virtual, onde real e ficção se confundem permanentemente. A vida social tornou-se teatralizada e pessoas ambientadas à ficção "se comportam na vida real como atores no palco",53 ao exibir suas vidas idealizadas em comunidades virtuais.

Nesse sentido, de uma suposta (con)fusão entre os limites da ficção e da "realidade", pode-se considerar que a inédita audiência observada nos filmes documentários de Moore podem fazer parte de uma tentativa de (re)dominar a realidade

\footnotetext{
${ }^{48}$ ZIZEK, S. Bem vindo ao deserto do real! Cinco ensaios sobre o "11 de setembro" e datas relacionadas. São Paulo: Boitempo editorial, 2003.

${ }^{49}$ ZIZEK, S. Bem vindo ao deserto do real! Op.cit., p. 25.

${ }^{50}$ ZIZEK, S. Bem vindo ao deserto do real! Op.cit., p.24-25.

${ }^{51}$ ZIZEK, S. Bem vindo ao deserto do real! Op.cit., p.23.

${ }^{52}$ ZIZEK, S. Bem vindo ao deserto do real! Op.cit., p. 28.

${ }^{53}$ ZIZEK, S. Bem vindo ao deserto do real! Op.cit., p. 28.
} 
devido à "angústia insuportável de se sentir inexistente" $"$, pois como aponta Zizek, existe uma estreita ligação entre a virtualização da realidade e o aparecimento de uma dor física infinita e ilimitada, que se coaduna com a busca de saciar um vício compulsivo de que fala Bauman a respeito de tempos líquidos, neste caso pelo consumo de imagens, bem como do que Sennett entende como sendo uma "paixão auto consumptiva" ${ }^{, 55}$. Todos esses efeitos envolvem dor, angústia e o consumo de tudo como "remédio" para a incerteza da vida em tempos líquidos.

Bauman acredita que esses efeitos da vida líquida são vícios e, como em todo vício, seria impossível se chegar à satisfação plena. Assim, na direção do que pensou Giddens, para Bauman essa busca se tornou uma "política de vida" pode ser experimentada ou vivida, subjetivamente. É como ir às compras, sendo que os produtos desejados não seriam apenas móveis, sapatos, comidas, ou vestuário, mas também novos grupos comunitários, e inúmeros itens de uma lista que parece não ter fim. Diante da instabilidade na qual se tornou a vida na modernidade fluida, "a pragmática do comprar" ${ }^{\text {"57 }}$ seria uma espécie de vício ou de compulsão em que a satisfação terminaria no ato da compra e o desejo de consumir novamente moveria o indivíduo como um ritual para aplacar a dor trazida pela insegurança de jamais poder possuir o mundo de maneira suficientemente completa ${ }^{58}$.

Alinhado às constatações de Bauman e discorrendo acerca das sensações promovidas pela busca de satisfação e suas consequências, Sennett chama de paixão auto consumptiva "uma paixão que se extingue na própria intensidade [...] equivale a dizer que, utilizando coisas, nós as estamos consumindo",59. Para esse autor, o desejo de consumir uma coisa qualquer pode ser ardente, porém, se esvai nos primeiros dias após o ato da compra, porque quando realizado, o desejo não mais entusiasma. É como se o desejo tivesse se exaurido no ato da aquisição daquilo que se desejou intensamente e, consequentemente, o desejo se renova em direção às novas coisas, visto que, nessa paixão auto-consumptiva não são mais as coisas que importam e sim a satisfação dos desejos individuais.

E a atual economia favoreceria e reforçaria essa paixão auto-consumptiva

\footnotetext{
${ }^{54}$ ZIZEK, S. Bem vindo ao deserto do real! Cinco ensaios sobre o 11 de setembro e datas relacionadas. São Paulo: Boitempo editorial, 2003, p. 24.

${ }^{55}$ SENNETT. Richard. A cultura no novo capitalismo. Rio de Janeiro: Record, 2006, p.128.

${ }^{56}$ BAUMAN, Z. Modernidade líquida. Rio de Janeiro: Jorge Zahar Ed. 2001, p. 87.

${ }^{57}$ BAUMAN, Z. Modernidade líquida, op.cit., p. 66.

${ }^{58} C f$. BAUMAN, Z. Modernidade líquida, op. cit., p. 96.

${ }^{59}$ SENNETT, R. A cultura no novo capitalismo, op.cit. p. 128.
} 
tanto dentro de um shopping quanto na cena política, pois "o consumo de bens desempenharia um papel chave na complementação e na legitimação dessas experiências" espiritualmente aquilo que diretamente sabem, usam ou precisam", e a "paixão consumptiva pode ser outro nome para a liberdade" ${ }^{\prime 61}$. Assim, essa nova liberdade mobiliza nos cidadãos, tanto na vida para o consumo quanto na política, um modo de vida voltado para o indivíduo, o que pode enfraquecer qualquer tipo de mobilização coletiva. Nessa direção, Sennett conclui que esse fenômeno também funciona como "apassivador" do indivíduo que, preso aos papéis de consumidor, espectador, cidadão, acaba afastado da política progressista e segue em direção a um estado cada vez mais passivo dentro da sociedade. "Com a palavra progressista quero dizer que uma boa forma de organização política é aquela em que todos os cidadãos acreditam que estão unidos num projeto comum"62.

Deste modo, nas palavras de Sennett, a chamada paixão consumptiva cultiva a mudança pessoal, mas não o progresso coletivo, o que, por sua vez, dependeria de "relações continuadas e experiências acumuladas"

Assim, a partir deste conjunto de análises apresentadas, estabelecendo o conceito de alta modernidade e apontando para teorias que dialogam com alguns desdobramentos e novas demandas sociais, destaco a relevância do cinema documental como objeto desta pesquisa. Isso porque, a meu ver, os filmes de Michael Moore podem ser associados aos incontáveis itens da lista de desejos sugerida por Bauman em "Modernidade Líquida", por Sennett em "A cultura no novo capitalismo" e por Zizek em "Bem vindo ao deserto do real!". Dialogando com essas teses, esses filmes constroem uma noção de "verdade" e "realidade" que pode atender aos anseios, incertezas e inquietações acerca da atualidade, e com isto, serem recebidos como referência para seus consumidores.

Ao explorar diferentes dramas vividos por indivíduos responsabilizados pelos rumos de sua própria existência, o atual cinema de documentário reúne discursos ${ }^{64}$ que poderiam seguir ao encontro dos anseios de pessoas que buscam satisfazer desejos de mobilização ou de (re)dominar a realidade, observando como os personagens enfrentam

\footnotetext{
${ }^{60}$ SENNETT, R. A cultura no novo capitalismo, Rio de Janeiro: Record, 2006, p. 128.

${ }^{61}$ SENNETT, R. A cultura no novo capitalismo, op. cit., p. 144.

${ }^{62}$ SENNETT, R. A cultura no novo capitalismo, op. cit., p. 150.

${ }^{63}$ SENNETT, R. A cultura no novo capitalismo, op. cit., p. 162.

${ }^{64}$ Sobre o filme como um discurso consultar: XAVIER, Ismail. O discurso cinematográfico: a opacidade e a transparência. Rio de Janeiro: Paz e Terra. 1977.
} 
nos filmes os problemas sociais de maneira individual. De modo geral, no momento da exibição dos filmes, muitos espectadores acreditam que estão diante de imagens que transmitem a "realidade", em razão da impressão de "autenticidade" que foi construída. No entanto, como lembra Bill Nichols em "Introdução ao documentário", os filmes "são prova da engenhosidade e inventividade dos documentaristas" ${ }^{\prime 65}$.

Bill Nichols assinala que a tradição do documentário está baseada na capacidade de transmitir a impressão de autenticidade. A característica básica de um documentário está na sua "representação reconhecível de mundo [...] pela capacidade que têm o filme e a fita de áudio de registrar situações e acontecimentos com notável fidelidade, vemos nos documentários: pessoas, lugares e coisas que também poderíamos ver por nós mesmos, fora do cinema"66. Além disso, a impressão de "realidade" pode ser reforçada através da postura de alguns documentaristas de se colocarem como representantes dos outros, seja das pessoas que entrevistam em seus filmes, seja dos grupos que compartilham valores ou conjuntos de valores.

Nesta direção, é possível afirmar que, a partir dos filmes de Michael Moore, o cinema documental se insere como fenômeno de crescente visibilidade, deixando de ser o "gênero marginal" 67 do cinema, com pouco espaço nas salas de projeções, devido, até então, à predominância dos filmes de ficção.

Como um item "privilegiado" da lista de compras na "sociedade individualizada"68, repletos de narrativas em torno de situações vividas e de como as pessoas lidam com os dramas individuais, o filme do gênero documentário está ocupando um lugar cada vez mais central nos cinemas de todo o mundo.

Para Fernão Ramos, isso se deve à crescente demanda por narrativas que reflitam sobre as imagens relacionadas com a realidade das pessoas ${ }^{69}$. Após alguns sucessos de cinema e televisão, além de prêmios como a Palma de Ouro em Cannes com o documentário de Michael Moore - Fahrenheit 9/11 (2004), o cinema de documentário cresceu exponencialmente em número de produções e audiência ${ }^{70}$, o que

\footnotetext{
${ }^{65}$ NICHOLS, Bill. Introdução ao documentário. Campinas, SP: Papirus, 2005, p. 21.

${ }^{66}$ NICHOLS, Bill. Introdução ao documentário, op. cit., p. 28.

${ }^{67} \mathrm{Cf}$. RAMOS, Fernão P. (org). Teoria contemporânea do cinema: documentário e narratividade ficcional. Volume II. São Paulo: Editora Senac São Paulo, 2005; RAMOS, Fernão P. Mas afinal... o que é mesmo documentário? São Paulo: Editora Senac São Paulo, 2008.

${ }^{68} C f$. BAUMAN, Zygmunt. A sociedade individualizada: vidas contadas e histórias vividas. Rio de Janeiro: Jorge Zahar Editor, 2008.

${ }^{69}$ RAMOS, Fernão P. Mas afinal... o que é mesmo documentário? São Paulo: Editora Senac SP, 2008.

${ }^{70}$ De 1995 a 2010, só nos EUA, foram cerca de 810 produções de filmes documentários com um lucro total de US\$ $1.805,863,478$, representando $1.11 \%$ da fatia total do mercado naquele país. A respeito do crescimento das produções: em 2003 foram 44 filmes com lucro de US\$ 86,914,139, representando
} 
o torna interessante para a indústria por ser lucrativo, ao mesmo tempo em que é, cada vez mais, estudado como produção cultural de nosso tempo.

Os sites que concentram os números oficiais de produção e repercussão mostram que houve um salto de 44 para 85 produções entre os anos de 2003 e 2004 , indicando o renascimento do gênero e a continuidade das produções nos anos seguintes $^{71}$. Em 2005 foram 97 produções de filmes documentários só nos EUA, em 2006 foram 106, em 2007 - 108, em 2008 - 125 e, em 2009, foram 83 produções. Esses números indicam que as produções de cinema documental se mantêm em número constante nos EUA, e também sugerem a popularização deste tipo de filme.

Dentre os diversos cineastas com os maiores índices de audiência do período ${ }^{72}$ a produção de Michael Moore é reconhecida como parâmetro ${ }^{73}$ neste momento de renascimento a partir da produção de Fahrenheit 9/11 (2004), devido ao lucro global inédito para o gênero, aos prêmios recebidos e aos debates que promoveu. Esse conjunto de fenômenos associados instiga a pesquisa voltada para os documentários de Michael Moore e não de outro cineasta, visto que Fahrenheit 9/11 lhe proporcionou a condição de documentarista mais assistido do planeta. No site Box Office Mojo $^{74}$ constam as listas dos índices de audiência interna (EUA) e nos demais países que esse filme foi exibido. O lucro total obtido com a audiência interna e estrangeira somou mais de US\$ 119 milhões de dólares arrecadados após a exibição em pelo menos 38 países, distribuídos principalmente no continente americano e europeu, embora alguns países asiáticos e do continente africano também figurem nessa lista.

Nesse sentido, o objetivo principal que norteou essa pesquisa foi investigar

0.93\% do mercado interno. Em 2004, ano de lançamento de Fahrenheit 9/11, as produções de documentários saltaram para 85 filmes com lucro de US\$217, 098,868 aumentando para $2.34 \%$ a fatia no mercado. Em 2005 foram 97 filmes com lucro de US\$155,673,323 e 1,74 no mercado.

Fonte: http://www.the-numbers.com/market/Genres/Documentary.php. (Acesso em 15 de maio de 2010).

${ }^{71}$ Os números oficiais dos índices de audiência em torno dessas produções podem ser encontrados em www.thenumbers.com/market/Genres/Documentary.php. Acesso em 15 de maio de 2010.

${ }^{72}$ Nesse período outros cineastas produziram filmes do gênero documentário, entre alguns os sites thenumbers e Box Office Mojo destacam: Morgan Spurlock com Super Size Me (EUA, 2004); Jacques Cluzaud, Michel Debats e Jacques Perrin com Winged Migration (França, 2003); Kevin Macdonald com Touching the Void (Inglaterra, 2003); Errol Morris com The Fog Of War (EUA, 2003). Zana Briski e Ross Kauffman com Born Into Brothels (Índia, 2004), Mark Achbar e Jennifer Abbott com The Corporation (Canadá, 2003), entre outros. Destaco que somados os lucros dos filmes acima citados observou-se que não ultrapassam a metade do valor arrecadado só com o filme Fahrenheit 9/11 de Moore dada a grande audiência que esse filme obteve.

${ }^{73} C f$. RAMOS. Fernão P. (org). In: Teoria contemporânea do cinema: documentário e narratividade ficcional. Volume II. São Paulo: Editora Senac São Paulo, 2005 e MOURÃO, Maria Dora \& LABAKI, Amir. Cinema do Real. São Paulo: Cosac Naify, 2005.

${ }^{74} \mathrm{http} / / /$ boxofficemojo.com/ (este site é associado ao IMDB - the internet moviedatabase www.imdb.com) - (acesso em 16 de maio de 2010). 
qual a particularidade dos filmes de Michael Moore que, em meio a tantos outros diretores, tornou-se o mais conhecido cineasta de filme documentário de todos os tempos, promovendo o renascimento do gênero e o incentivo às novas produções, devido à procura do público por este tipo de filme. Isto é realizado por meio da análise de como os filmes são construídos, bem como o que há de inovador ou de diferencial que desperta interesse no público, porque seus temas repercutem, prendem o espectador, promovem debates, críticas e até mesmo a criação de outros documentários em resposta às polêmicas geradas a respeito de uma suposta manipulação da "realidade"75.

\section{Relevância da amostra fílmica e metodologia de pesquisa.}

Para estudos em sociologia do cinema, Pierre Sorlin recomenda que para a escolha da amostra fílmica sejam considerados dois critérios ${ }^{76}$ :

1- Êxito comercial - o que significa que o filme foi amplamente assistido e, portanto, é bem conhecido do público.

2- Filmes que geraram debates, tomadas de posição, críticas, repercussão, etc. Esse segundo critério evita que a amostra contenha filmes muito assistidos, mas sem relevância social, ou que, por serem puro entretenimento, angariam vasta bilheteria sem, contudo, promover debates, polêmicas ou mobilizarem a opinião pública.

Nesse sentido, a escolha dos filmes de Moore incorpora os dois critérios de Sorlin, tanto pela inédita bilheteria que os filmes conquistaram, indicando sua popularidade, quanto aos debates acalorados que promoveram dentro e fora do seu país de origem.

A respeito da história dos Estados Unidos, Leandro Karnal considera que os filmes de Michael Moore o inserem como um dos críticos mais ácidos do país, figurando-o ao lado de nomes como Susan Sontag, Noam Chomsky e Immanuel

\footnotetext{
${ }^{75}$ Algumas produções foram criadas em resposta às polêmicas geradas pelos documentários de Moore, entre os quais se destacam: Manufacturing Dissent - Uncovering Michael Moore (Canadá, 2007), dirigido por Debbie Melnyk e Rick Caine; Michael Moore hates America (EUA, 2004) de Michael Wilson; Michael \& Me (EUA, 2004) de Larry Elder; Fahrenhype 9/11 (EUA, 2004) de Alan Peterson e Celsius 41.11 The Truth Behindthe Lies of Fahrenheit 9/11 (EUA, 2004) do diretor Kevin Knoblock. Esses filmes não figuram como representativos nas listas oficiais de audiência porque não obtiveram repercussão significativa.

${ }^{76}$ SORLIN, Pierre. Sociologia del cine: la apertura para la historia de mañana. México: Fundo de cultura económica, 1985, p. 173.
} 
Wallerstein. Ao citar Moore como um exemplo de popularidade, Karnal diz;

O cineasta Michael Moore notabilizou-se por documentários como Tiros em Columbine (2002) e Fahrenheit 11/09 (2004) e livros como Stupid White Men (2001). Nas obras, ele faz uma análise demolidora do sistema americano. [...] O centro da crítica de Moore é contra uma atitude errada ou um grupo mau que se apodera de um benefício que deveria ser mais coletivo ${ }^{77}$.

No que se refere à metodologia de pesquisa, este trabalho têm como ponto de partida os seguintes conceitos: Sistemas relacionais e pontos de fixação de Pierre Sorlin; representação de Irving Goffman e representificação de Paulo Menezes.

Conceito fundamental para esta análise, sistema relacional é o mapeamento da configuração social no filme. Esses sistemas são constituídos das relações estabelecidas entre os grupos sociais geralmente formados a partir de personagens principais e do conflito apresentado no filme. Através destas configurações, observam-se quais as negociações e saídas propostas, quais as relações de hierarquia entre os grupos, quais valores estão em jogo, se existem formas de intercâmbio e de influência entre esses grupos, e quais as relações de poder exercidas entre os mesmos. Se existem enfrentamentos, ausência de luta, soluções mistas, qual saída triunfa em cada situação relatada, quais conflitos persistem, ou ainda, que rosto é dado ao herói, aos aliados, aos adversários, quem são os injustiçados, e que regras norteiam os confrontos ${ }^{78}$. Assim, entende-se que a partir da configuração social que emerge com o mapeamento dos sistemas relacionais é que ganha relevo a forma como os filmes abordam seus temas, qual tipo de discurso é adotado pela narrativa e o que implica sua aceitação ou não pelo espectador.

Pierre Sorlin sintetiza sua proposta metodológica para o estudo sociológico dos filmes com as seguintes palavras:

Si hay que resumir, volveremos a três puntos esenciales. Para empezar, el cine pone em evidencia uma manera de contemplar; permite distinguir lo visible de lo no visible y, al hacerlo, reconoce los

\footnotetext{
${ }^{77}$ KARNAL, Leandro. [et. al.]. Introdução. In: História dos Estados Unidos: das origens ao século XXI. São Paulo: Contexto, 2010, p. 17.

${ }^{78}$ SORLIN, Pierre. Sociologia del cine: la apertura para la historia de mañana. México: Fundo de cultura económica, 1985, p. 195-197.
} 
limites ideológicos de la percepción em uma época determinada. Em seguida, revela zonas sensibles, los que hemos llamado "puntos de fijación", es decir, cuestiones, esperas, inquietudes, em apariencia completamente secundárias, cuya reaparición sistemática de filme em filme subraya su importância. Por último, propone diferentes interpretaciones de la sociedad y de las relaciones que em ella se desarrollan: bajo guisa de uma analogia com el mundo sensible que a menudo le hace parecer um testigo fiel, construye, por aproximación, puesta em paralelo, desarrollo, insistência, elipse, um universo fictício $^{79}$.

Além do conceito de sistema relacional, o de pontos de fixação ${ }^{80}$, apresentado no trecho supracitado, também será incorporado na análise a partir do segundo filme e desenvolvido no conjunto da amostra, fornecendo pistas de questões recorrentes entre os filmes. A respeito dos pontos de fixação, Sorlin os define por cenas recorrentes nos filmes que mesmo aparecendo como uma espécie de "pano de fundo" caracterizam-se por alusões, repetições, insistência particular de certas imagens ou de um efeito de construção. Permitem estabelecer os problemas sociais comuns aos filmes de uma amostra, qual a originalidade de cada película, sua parte de fidelidade ao modelo que a antecede e como dele se distancia. Também permitem comparar os temas e os relacionar com os problemas apresentados em cada filme separadamente.

Os pontos de fixação podem não ter a mesma intensidade no conjunto das obras e aderem a "zonas sensíveis" muito distintas, visto que podem estar relacionados a questões de gênero, de trabalho, de moral familiar, e uma série de elementos que podem ser descobertos a partir da observação do que é simples repetição ou revelar pontos nodais entre os filmes, de questões que, à primeira vista, podem não ser relevantes, mas que estão subjacentes em diferentes filmes de uma mesma época e indicam problemas que persistem entre as diferentes tramas ou que podem estar relacionados com o contexto histórico no qual os filmes estão inseridos.

Conforme Sorlin,

\footnotetext{
${ }^{79}$ SORLIN, Pierre. Sociologia del cine: la apertura para la historia de mañana, México: Fundo de cultura económica, 1985, p. 206.

${ }^{80}$ SORLIN, Pierre. Sociologia del cine, op.cit., p. 195-197.
} 
Al estudiar un conjunto de filmes, es posible contentarse con establecer la lista de las similitudes que aparecen entre diversas realizaciones; hay que concentrarse entonces sobre un objeto del que se supone que es importante, pero que uno mismo se impide definir. También se pueden apartar las variantes, buscar las relaciones elementares subyacentes en los filmes en que nos concentramos y, al hacerlo, poner en evidencia los puntos de fijación. El segundo trámite nos permite ir más lejos que el primero; revelando lo que es común a varias realizaciones, nos da la manera de definir la originalidad de cada filme, su parte de fidelidad al modelo y la manera en que se aparta de $\mathrm{el}^{81}$.

Embora, a rigor, os pontos de fixação foram pensados para uma amostra de diferentes filmes e diferentes autores, neste trabalho esse conceito será "subvertido" para o uso em uma amostra do mesmo autor, o que, a meu ver, não prejudica a apropriação do conceito para pensar os temas recorrentes nos filmes de Moore.

Nesse sentido, posso adiantar que o problema do desemprego e as transformações que envolvem o mundo do trabalho no sistema capitalista compõem um ponto de fixação entre os filmes Roger e Eu, The Big One e em Capitalism: a love story, os quais ficarão unidos em um capítulo inicial. Outros pontos de fixação, com os contornos da sociedade de risco permeiam os filmes Tiros em Columbine e Fahrenheit 9/11. Além disso, espera-se que, ao final deste trabalho, seja possível estabelecer questões gerais que permeiam todos os filmes estudados e indiquem pontos de vista do grupo social que prevalece nos filmes.

Outro conceito utilizado nesta pesquisa é o de representação que auxilia a análise acerca da participação tanto de Moore quanto dos demais personagens nos filmes, ou ainda, permite entender como os próprios personagens, na figura de pessoas que não são atores, estão se construindo diante das câmeras.

Segundo Erving Goffman, quando um indivíduo se apresenta diante de outros busca controlar a impressão que estes irão ter a seu respeito, bem como a da situação social apresentada. Para isto, como se fosse um ator e estivesse em um teatro, o indivíduo representa um personagem de si mesmo, a fim de marcar uma boa impressão e influenciar as pessoas com quem deseja se comunicar, evitando, assim, que lhe

\footnotetext{
${ }^{81}$ SORLIN, Pierre. Sociologia del cine: la apertura para la historia de mañana. México: Fundo de cultura econômica, 1985, p. 200-201.
} 
apliquem estereótipos. "Assim, quando uma pessoa chega à presença de outras, existe, em geral, alguma razão que a leva a atuar de forma a transmitir a elas a impressão que lhe interessa transmitir" ${ }^{\prime \prime 2}$.

Outro aspecto interessante da representação que o indivíduo faz de si para os outros está naquilo que Erving Goffman chamou de idealização, o que consiste na "tendência que os atores têm a oferecer a seus observadores uma impressão que é idealizada de várias maneiras diferentes" ${ }^{\prime 83}$. Esta idealização é percebida, sobretudo, quando Moore fala de sua família e da cidade de Flint nos anos áureos da indústria automotiva em Roger e Eu.

Antes de apresentar o conceito de representificação é importante fixar a diferença entre os conceitos: representação e representificação, no sentido de como são usados neste texto. O uso do conceito representação parte de Erving Goffman em "A representação do eu na vida cotidiana" (2009), e refere-se à construção do personagem, neste caso o próprio Michael Moore, e não à ideia de representação comumente usada para os filmes ou obras artísticas em geral que foi repensado, neste trabalho, a partir do conceito de representificação de Paulo Menezes em: "O cinema documental como representificação: verdades e mentiras nas relações (im)possíveis entre representação, documentário, filme etnográfico, filme sociológico e conhecimento" (2004).

Portanto, reforço a diferença entre os conceitos: representificação usado para pensar o filme na relação com o espectador no momento de sua exibição, de representação relacionado com a construção do personagem e seu meio social dentro do filme.

Assim, apresento de forma geral o conceito de representificação ${ }^{84}$. Para chegar ao conceito de representificação, Menezes problematiza os usos do termo representação em inúmeros tipos de análise artística, como a pintura, a fotografia, o teatro, as artes plásticas e o cinema. Seu objetivo é mostrar que, ao longo do tempo, devido aos inúmeros usos que sofreu, o sentido do termo foi esvaziado ou se desgastou em razão dos diferentes significados e contextos a que foi submetido, e, por isto, seria um conceito impreciso para explicar a relação entre real-imagem no cinema. Para isto, Menezes verificou a trajetória do conceito representação, "cunhado na Idade Média

\footnotetext{
${ }^{82}$ GOFFMAN, E. A representação do eu na vida cotidiana. Petrópolis: Vozes 2009, p. 15.

${ }^{83}$ GOFFMAN, E. A representação do eu na vida cotidiana, op.cit., p. 40.

${ }^{84}$ MENEZES, Paulo. O cinema documental como representificação: verdades e mentiras nas relações (im)possíveis entre representação, documentário, filme etnográfico, filme sociológico e conhecimento. In: Escrituras da Imagem. São Paulo: EDUSP/FAPESP. 2004, p. 21-47.
} 
com duplo significado de imagem e ideia" ${ }^{85}$, para situar-nos na flutuação de sentidos que foram atribuídos à ideia de representação por diferentes autores e em várias formas de arte. De saída, o autor exclui o termo reprodução, utilizado por Bazin para relacionar a imagem fotográfica ao seu modelo "real".

Menezes retoma as análises de Foucault em "As palavras e as coisas" ${ }^{86}$ para buscar as acepções que semelhança tomou até o final do século XVI, "a semelhança pode ser vista como uma qualidade comum, na forma de substrato da representação" 87 . Em seguida o autor cita Gombrich e sua afirmação de que "a representação se constrói a partir de uma relação de imagens com outras imagens" que se relacionam a partir de uma "imagem mental" 88 ou uma ideia do objeto, e que, no caso de um pintor, seria preciso ter um vocabulário formado para fazer uma representação do objeto préconcebido. Em outro momento, Menezes observou que o termo representação teve como paradigma algumas regras bem definidas pela academia de arte e, para isto, o autor cita o caso de Constable, que no auge do realismo inglês teve um de seus quadros acidentalmente apresentado em uma exposição, o que gerou reações de rejeição por parte do júri, simplesmente porque Constable se afastou das regras de representação ao pintar um tom de verde em uma imagem de relva que, ao se aproximar da cor observada em locais cotidianos, infringiu as regras da Royal Academia. Esta última prescrevia que relvas e campos deveriam ser pintados em "tons fulvos de uma caixa de violinos antiga" ${ }^{89}$. Com isto, Menezes pontua que,

[...] fica claro que em todas essas acepções, entre a coisa e a representação da coisa há sempre como mediação necessária um conceito, uma ideia, uma representação mental ou até mesmo uma regra, o que reforçaria o fato de a coisa em si e o seu olhar e perscrutar direto aparecerem sempre desvalorizadas ${ }^{90}$.

De volta à trajetória do termo, Menezes cita Francastel para situar as mudanças que representação adquire a partir do Renascimento quando passa a ser usado como

\footnotetext{
${ }^{85}$ MENEZES, P. O cinema documental como representificação: verdades e mentiras nas relações (im)possíveis entre representação, documentário, filme etnográfico, filme sociológico e conhecimento. In: Escrituras da Imagem. São Paulo: EDUSP/FAPESP. 2004, p. 25.

${ }^{86}$ MENEZES, P. O cinema documental como representificação, op.cit., p. 33-60.

${ }^{87}$ MENEZES, P. O cinema documental como representificação, op.cit., p. 26.

${ }^{88}$ MENEZES, P. O cinema documental como representificação, op.cit., p. 26.

${ }^{89}$ MENEZES, P. O cinema documental como representificação, op.cit.

${ }^{90}$ MENEZES, P. O cinema documental como representificação, op.cit.
} 
"representação plástica", com a "introdução do ponto de vista único"91 que "carrega consigo ainda implicações mais complexas ao pressupor a existência de apenas um lugar, que propiciaria o olhar perfeito e, no limite, correto, sobre a representação e, a partir dela, sobre as coisas" ${ }^{\prime 2}$. Nesse sentido, seria impossível conceber uma representação de realidade que comportaria a multiplicidade de olhares, e isto implica na aceitação da impossibilidade de que o termo representação indique uma correlação com o real, ou, nas palavras de Menezes, "como um documento deste real no sentido forte do termo" 93 . Os sentidos que o termo adquiriu se tornaram ainda mais flutuantes, pois surgem noções que ligam representação à de duplo ${ }^{94}$, à de réplica, clone, reprodução de um real exterior, cópia fiel em detalhes, ou de atributos do real, como ocorre a partir da disseminação da fotografia em 1840 e a ideia de semelhança entre a imagem fotográfica e seu suposto referencial real. Depois, o que era semelhante "transforma-se em parecido" 95 , tudo isto para mostrar que o termo representação, ao servir para explicar formas tão variadas de arte em situações tão diversas, perdeu o poder explicativo, pois de conceito o termo vira palavra e é usado em diferentes acepções até pelo senso comum. Sintetizando esse percurso de desconstrução do termo representação, Menezes conclui;

Ao fim deste processo confundem-se definitivamente representação, duplo e reprodução. Esfumaçam-se os conceitos que outrora constituíam o vocabulário das formas de representação. Esvaziado de suas características rituais, o duplo se transforma em reflexo, e, por isso, tenta ser parecido. O duplo, finalmente, vira clone. E com isso dissolvem-se as diferenças que outrora separavam no campo do saber estes conceitos. [...] Neste contexto, perguntamo-nos se o cinema não parece guardar uma relação peculiar com o real que poderia ser diferente da expressa pelas noções de duplo, de

\footnotetext{
${ }^{91}$ MENEZES, P. O cinema documental como representificação: verdades e mentiras nas relações (im)possíveis entre representação, documentário, filme etnográfico, filme sociológico e conhecimento. In: Escrituras da Imagem. São Paulo: EDUSP/FAPESP. 2004, p. 27.

${ }^{92}$ MENEZES, P. O cinema documental como representificação, op.cit., p. 30.

${ }^{93}$ MENEZES, P. O cinema documental como representificação, op.cit., p. 27.

${ }^{94}$ Menezes observou que o termo representação associado à noção de duplo como "algo que se coloca no lugar de," ganha um significado particular, pois remete aos usos rituais em diferentes momentos da história, como no caso das múmias do Egito antigo que eram guardadas em tumbas com uma gama de objetos ou duplos de objetos cheios de significados rituais, o que aproxima o termo duplo mais a um valor ritual do que a uma relação com o real. MENEZES, P. O cinema documental como representificação, op. cit., p.28.

${ }^{95}$ MENEZES, P. O cinema documental como representificação, op.cit., p.30.
} 
reprodução e de representação, fundada que está na ambiguidade fundamental desta relação entre imagem e real. ${ }^{96}$

Assim, diante da necessidade de dialogar com as teses sobre uma suposta "representação do real" que já fazem parte do repertório comum das relações entre espectador e imagem do cinema, Menezes também se deteve aos usos do termo nas teorias sobre o cinema. $\mathrm{O}$ autor observou que ainda não existe consenso quanto aos usos de representação, agora associado com a imagem fotográfica que é base do filme e suas representações acerca do "real". Nesta direção, a representação através da imagem fotográfica ganhou outros significados como, "impressão de realidade" em Morin; uma espécie de duplo sem ritual em Bazin; passa a ser dotada de um poder de "convencimento" em Carriére; um "realismo fundamental" em Merleau-Ponty; "ilusão de realidade" em Arnheim; "impressão de verdade" em Sorlin, e por fim, "ilusão fílmica" em Francastel ${ }^{97}$.

Percebe-se que o autor acompanhou um longo percurso dos significados atribuídos ao termo representação e suas flutuações históricas. No que concerne às relações entre cinema e sociedade, Menezes aponta que toda imprecisão conceitual se dirige à imprecisão metodológica acerca do potencial analítico e interpretativo que poderiam fundamentar a investigação sociológica do cinema.

Após analisar o termo representação, suas implicações históricas e seus desdobramentos nas diferentes formas de arte, Menezes estabelece o conceito de representificação como baliza para a pergunta sociológica de que tipo de informação e de conhecimento as imagens fílmicas comportam e/ou aludem. Também aponta para a tênue fronteira entre filme de ficção e filme documentário, pois partindo da premissa de que todo filme é uma construção ou um conjunto de escolhas empreendido por uma vasta equipe de produção, é preciso ter em mente "qual relação ele [o filme] guarda e expressa em relação ao real que o fez surgir",98.

Assim, Menezes propõe que a relação entre cinema, real e espectador seja entendida em termos de representificação; como algo que torna presente uma forma de construção fílmica diante do espectador no momento da projeção na sala de cinema. O

\footnotetext{
${ }^{96}$ MENEZES, P. O cinema documental como representificação: verdades e mentiras nas relações (im)possíveis entre representação, documentário, filme etnográfico, filme sociológico e conhecimento. In: Escrituras da Imagem. São Paulo: EDUSP/FAPESP. 2004, p. 31.

${ }^{97}$ MENEZES, P. O cinema documental como representificação, op.cit., p.31-33.

${ }^{98}$ MENEZES, P. O cinema documental como representificação, op.cit., p. 25.
} 
momento da projeção é entendido pelo autor como "uma unidade de contrários que permite a construção de sentidos. Sentidos estes que estão na relação, e não no filme em si mesmo"99. Nesta direção, o autor entende que analisar a construção fílmica envolve entender as "relações construídas pela história do filme, entre o que ele mostra e o que ele esconde. Relações elaboradas com a história do filme, articulação de espaços e tempos, articulação de imagens, sons, diálogos e ruídos" ${ }^{\prime 100}$.

É no entrecruzamento entre diferentes articulações do passado no presente, evidenciado no momento da projeção do filme, que confere ao conceito de representificação uma possibilidade rica de apreensão ao se ter em mente essa relação entre filme e espectador - diferente da acepção de representação já esvaziada de sentido devido seu uso comum. Com isto, "a representificação seria a forma de experimentação em relação a alguma coisa, algo que provoca reação e que exige nossa tomada de posição valorativa, relacionando-se com o trabalho de nossas memórias voluntária e involuntária que o filme estimula"101.

Nesse sentido as análises dos filmes de Moore são pensadas em termos de representificação, partindo da relação entre os filmes e a pesquisadora que, pautada em uma perspectiva sociológica, busca entender a construção de significados e interpretações possíveis a partir da forma dos filmes, isto é, da construção de suas narrativas.

Esse caráter construtivo do filme que o coloca num patamar de ficção, inclusive o filme de documentário, é reforçado por Menezes no sentido de que os filmes "dizem mais sobre as formas de se construir o mundo do que sobre este mundo propriamente dito. (...), pois são filmes que escondem em seus próprios nomes os esquemas valorativos que presidem seus esquemas conceituais construtivos, os sistemas relacionais que constituem"102.

Por conseguinte, após a introdução do contexto que situa o objeto de pesquisa dentro dos contornos da alta modernidade, e da apresentação dos conceitos metodológicos referenciais, sigo para a análise dos documentários estruturando o trabalho em dois grandes blocos a fim de dividir os filmes de acordo com temas que os aproximam. Um primeiro bloco intitulado, Ameaças ao american way of life, abrange os

\footnotetext{
${ }^{99}$ MENEZES, P. O cinema documental como representificação: verdades e mentiras nas relações (im)possíveis entre representação, documentário, filme etnográfico, filme sociológico e conhecimento. In: Escrituras da Imagem. São Paulo: EDUSP/FAPESP. 2004, p 44-45.

${ }^{100}$ MENEZES, P. O cinema documental como representificação, op.cit., p.44-45.

${ }^{101}$ MENEZES, P. O cinema documental como representificação, op.cit., p. 44-45.

${ }^{102}$ MENEZES, P. O cinema documental como representificação, op.cit.
} 
filmes: Roger e Eu (1989), The Big One (1997), e Capitalism: a Love Story (2009). O segundo bloco: A industrialização da guerra como fenômeno social - o lado sombrio da modernidade, comporta análises acerca de uma cultura bélica como algo comum entre os estadunidenses construídos nos filmes: Tiros em Columbine (2002) e Fahrenheit 9/11(2004).

Assim, considero que os filmes escolhidos para a análise remetem de modo alusivo, através de suas construções, a processos sociais que dialogam com as teorias acima referidas e, de modo dialético, é possível perceber nuances de como um grupo social específico se constrói dentro de um contexto mais amplo. 


\section{I -Ameaças ao American way of life.}

\section{1 - Roger e Eu: orgulho de ser americano ${ }^{103}$.}

“O filme não deseja exprimir nada além do que ele próprio.”
Maurice Merleau-Ponty ${ }^{104}$

Primeiro filme dirigido pelo estadunidense Michael Moore em 1989, Roger e Eu constrói um olhar crítico acercada situação de trabalhadores nos Estados Unidos a partir do caso da indústria automobilística General Motors, fundada em 1908 na pequena Flint - cidade de origem do cineasta. A narrativa, entendida aqui como um discurso fílmico, ${ }^{105}$ constrói a centralidade da fábrica na vida dos moradores da cidade e a prosperidade conquistada por diversas gerações de trabalhadores que, na segunda metade da década de 1980, sofreriam as consequências negativas de demissões em massa. Essas demissões afetariam quase 30 mil funcionários só na região do Estado do Michigan, onde está situada Flint. Denunciar o saldo social do desemprego e as consequências para a cidade é o foco deste filme documentário, contudo, esta análise busca apreender não apenas qual o discurso do filme, mas também como esse discurso é construído e quais proposições de sentido a narrativa alude em sua relação com a matéria social que a informa.

No início do filme Roger e Eu, uma música alegre semelhante às de sitcoms dos anos $1950^{106}$ é tocada na abertura do filme conferindo um tom de humor à história que

\footnotetext{
${ }^{103}$ I am proud to be an American é título da música escrita por Albert Malotte e interpretada por Pat Boone. Essa música entra no final do filme junto aos créditos e fecha em tom de ironia as críticas que Moore faz aos grupos de empresários. Contudo, o personagem de Moore não consegue eximir-se de seu próprio orgulho de ser americano, como indicam alguns momentos do filme, por exemplo, o saudosismo das cenas iniciais.

${ }^{104} \mathrm{Cf}$. Merleau-Ponty.O cinema e a nova psicologia. In: Xavier, I. (org). "A experiência do cinema: antologia". Rio de Janeiro: Ed. Graal: Embrafilmes, 1983, p.115.

${ }^{105}$ Sobre a narrativa como discurso e, portanto, uma sequência de enunciados que remete necessariamente a um sujeito da enunciação, consultar livros: GAUDREALT, André. A narrativa cinematográfica. Brasília: Edit. UnB, 2009; Xavier, I. O discurso cinematográfico - A opacidade e a transparência. São Paulo: Paz e Terra, 1977, (4 edição, 2008).

${ }^{106}$ Alguns sitcoms dos anos 60 apresentam músicas semelhantes à da abertura do filme como se essas músicas alegres pudessem traduzir o espírito de otimismo e prosperidade que percorriam os EUA nestas décadas, os links seguintes apresentam algumas dessas comédias com músicas orquestradas em tom alegre e festivo, incluindo uma abertura de "I Love Lucy": http://www.youtube.com/watch?v=w5GoNM4J2O8;

http://www.youtube.com/watch? $\mathrm{v}=\mathrm{gK} 41 \mathrm{AExfFD} 0 \&$ feature=related. Outro link apresenta um pouco da história da GM com as mesmas músicas alegres indicando o otimismo em torno daqueles anos de prosperidade para os trabalhadores. http://www.youtube.com/watch?v=Uj6A2Hzg1_M\&NR=1. Acesso em 15/01/2011.
} 
se inicia. Montado sobre um fundo de tela em preto, o título do filme Roger e Eu é escrito em letras de formato arredondado e na cor azul.

Esta abertura em tom divertido, pela associação de letras e músicas alegres, sugere um filme dinâmico, cômico, de inclinação ao entretenimento. Isso também pode tornar o espectador receptivo, no sentido da expectativa em assistir algo que o divirta. Talvez a escolha desta abertura já indique sutilmente o público alvo do filme, formado por pessoas afeitas aos programas populares da televisão, sobretudo os de temas humorísticos como os conhecidos Sitcoms (situation comedy).

Segundo Sean Purdy, as comédias de costumes são populares nos EUA desde a década de 1950, período em que a indústria cultural passa a promover um tipo de entretenimento televisivo que reforçava "atitudes homogêneas brancas e acauteladas em favor do capitalismo, do consumo e da conformidade social". Purdy aponta que em 1962, 90\% das famílias tinham pelo menos uma televisão em casa, e os seriados mais populares eram: Papai sabe tudo, Eu amo Lucy e As aventuras de Ozzie e Harriet programas que glorificavam o American Way of Life e a família nuclear americana ${ }^{107}$.

Como um ideal de vida disseminado nas rádios e no cinema estadunidense do pós-guerra, a ideia de um estilo de vida americano celebrava de modo idealizado os benefícios de se viver nos EUA graças às benesses do capitalismo, em contraposição ao modo de vida dos "ateus comunistas" na URSS. Em seu trabalho acerca do cinema estadunidense do pós-guerra, Alexandre Valim lembra que, "em linhas gerais o American Way of Life representou a crença na superioridade da democracia em moldes estadunidenses, na Providência Divina, no direito à propriedade privada e na livre concorrência econômica"108.

Nesse sentido, o filme de Moore é iniciado com referências aos anos dourados da economia em que desfrutar do estilo de vida americano parecia possível para todos aqueles que o desejassem, bastando apenas ter um trabalho. As cenas iniciais do filme mostram diferentes períodos do que seria a infância do narrador Michael Moore, e a construção de seu personagem é realizada a partir de imagens de vídeo retiradas de arquivo pessoal e fotos de família. Essas imagens reunidas mostram alguns momentos da vida de um menino que brinca com outras crianças, faz caretas diante da câmera, se veste com a fantasia do Popeye para uma festa infantil, ou ainda, segue para a escola no

${ }^{107} C f$. PURDY, Sean. O século Americano. In: KARNAL, L. (org.) História dos Estados Unidos: das origens ao século XXI. São Paulo: Ed. Contexto, 2010, p. 232.

${ }^{108}$ VALIM, Alexandre Busko. Imagens vigiadas: uma história social do cinema no alvorecer da GuerraFria, 1945-1954. Tese (doutorado). Niterói: UFF, 2006, p. 17. 
carro da família. Porém, a voz do narrador diz que ele era um menino "meio estranho", que engatinhou para trás até os dois anos de idade, e seus pais sabiam que ele tinha "algo de errado". Pela primeira vez no filme, e isso será recorrente, é observada a contradição entre o texto, ou aquilo que está sendo dito, e às imagens. Isto ocorre quando Moore afirma que era um menino estranho e que seus pais notaram algo de errado com ele. Contudo, as imagens apresentam um menino aparentemente normal, no sentido de um desenvolvimento físico e intelectual coerente com a idade da criança conforme é indicado pelas sequências. Esse aspecto sugere que quem dá o tom de interpretação das imagens ao espectador é a fala do narrador. E o que Moore se refere como elemento de estranheza por parte de seus familiares, fica subentendido como sua percepção de mundo para construir um discurso de autoridade em relação ao tema que vai tratar.

Para legitimar seu papel de narrador privilegiado desta história, tanto pelo aspecto de um suposto espírito crítico aguçado, aparentemente manifesto na tenra infância, quanto pela sua origem em família de trabalhadores operários, o que pode significar uma visão "por dentro" dos acontecimentos, Moore afirma que aos seis anos de idade já memorizava o discurso de posse do presidente John Kennedy.

Propor uma identificação desde tão cedo a um presidente popular e carismático como foi Kennedy, sugere que o narrador aponta não apenas para sua própria precocidade em decorar discursos enquanto criança, como também remete à sua postura alinhada, num primeiro momento de sua carreira, ao partido democrata daquele país. Além disso, Kennedy foi o primeiro presidente católico eleito nos EUA, mesma religião em que Moore foi educado, o que pode representar outro ponto de identificação com o ex-presidente.

Purdy informa que poucos presidentes foram tão populares quanto John F. Kennedy;

Jovem e bem apessoado, herói de guerra e o primeiro presidente católico, Kennedy foi uma consequência das aspirações liberais não satisfeitas do tempo do New Deal. Seu assassinato inesperado em novembro de 1963 e a sua subsequente mitificação na memória 
coletiva como a "grande esperança liberal" têm mascarado a timidez de sua agenda liberal doméstica $[\ldots]^{109}$.

Desde o início do filme, Michael Moore entra em cena como o narrador de uma história que, não por acaso, se confunde com sua própria história familiar, pois parece que seu "intuito" "110 é aproximar o espectador de sua "intimidade", apresentando sua família, e seu local social. Possivelmente, a construção dessa "familiaridade" com o personagem que se coloca como autoridade no assunto, pode promover diferentes interpretações a respeito do filme, de modo que o seu discurso, acerca de uma suposta "realidade" que contempla, seja recebido de forma pouco mediada tanto pela crítica jornalística quanto pelo público.

Partindo dessas alusões, este trabalho procura desconstruir esse discurso, nem lhe conferindo estatuto de verdade nem o invalidando como farsa ${ }^{111}$. Antes, a proposta envolve apontar aspectos sociais que o filme suscita, contrapondo os temas que constrói e seu possível diálogo com a teoria social, de modo a mediar o discurso fílmico e produzir outro discurso, agora sociológico, acercada obra cinematográfica e sua relação com a sociedade.

Para a construção do discurso fílmico, Michael Moore corporifica um personagem, ou como diria Goffman, uma representação de si mesmo, na tentativa de conferir legitimidade para seu papel de crítico dos acontecimentos que envolvem os

\footnotetext{
${ }^{109}$ PURDY, S. O século americano. In: KARNAL, L. (org.) História dos Estados Unidos: das origens ao século XXI. São Paulo: Ed. Contexto, 2010, p. 236.

${ }^{110}$ Não há, neste trabalho, interesse em discutir as intenções do autor ou cineasta, por isso coloco a palavra intuito entre aspas, visto que o sentido da palavra está mais relacionado ao que pode ser percebido pelo espectador do que por um interesse em verificar as intenções do autor. Neste trabalho a vida pessoal de Michael Moore não é prioridade, e é citada como fonte de informação para sinalizar um contexto através do filme. Antes, o que importa é pensar a construção do seu personagem nos filmes, o que implica interpretar como ele se coloca enquanto construção de si mesmo, ou perceber como ele se comporta em cena para fazer sua crítica social. Em "O que é um autor", Foucault afirma que o conceito de autor faz parte de um momento da "individualização na história das ideias, dos conhecimentos, das literaturas, e também na história da filosofia, e das ciências" (p. 267). Sobre a relação do autor com o texto, Foucault salienta a separação fundamental que deve ser considerada ao estudar obra e autor - neste caso cineasta e filme. A respeitode uma obra, Foucault adverte que esta seja estudada em sua estrutura, em sua forma, observando suas relações internas, e que seria preciso "localizar o espaço assim deixado vago pela desaparição do autor, seguir atentamente a repartição das lacunas e das falhas e espreitar os locais, as funções livres que essa desaparição faz aparecer" IN: FOUCAULT, M. O que é um autor. Ditos e escritos: Estética - literatura e pintura, música e cinema (vol.III). Rio de Janeiro: Forense Universitária, 2001, p. 264-298, (p. 271). Neste sentido, o filme é considerado obra autônoma do seu diretor, que é pensado mais como parte de um todo social do que único responsável pelas escolhas fílmicas.

${ }^{111}$ Como sugere o documentário Manufacturing Dissent (Canadá, 2007), em que os diretores Rick Caine e Debbie Melnyk "perseguem" Michael Moore questionando o modo como ele produz seus filmes, acusando-o de fabricar mentiras e de enriquecer com elas. Site do filme no IMDB. http://www.imdb.com/media/rm251630336/tt0961117
} 
trabalhadores na cidade de Flint, como o desemprego crescente e a queda no padrão de vida $^{112}$. Ele parte de sua vida, de sua família, de sua cidade como se quisesse mostrar que faz parte do problema e seria um membro atuante na sociedade. Isto fica sublinhado na discussão que Moore teve com uma representante da última fábrica da $G M$ a ser fechada em Flint, a mesma onde ocorreu a primeira grande greve em 1936. Neste dia, 1800 empregados seriam demitidos, Moore está no gramado em frente à fábrica com a equipe de filmagem e tenta entrevistar alguns funcionários que estão do lado de dentro da instalação. Ao ser visto por uma pequena janela, um funcionário tenta comentar a situação, mas a porta-voz da fábrica chamada McGee interpela a entrevista e questiona de onde Moore e sua equipe é. Ela diz que não permitiria que estranhos filmassem aquelas cenas de "tristeza familiar". Moore se defende dizendo: - "não somos de fora, somos cidadãos da comunidade." McGee reitera que o interesse de Moore é pessoal e diz: - "vocês não representam ninguém". Essas imagens aparecem quase no fïm do filme de modo a não influenciar o espectador que se desvie da construção que o personagem faz no início do documentário, quando busca se colocar como representante legítimo daquela comunidade, ou pelo menos, dos trabalhadores demitidos naquela região.

Entretanto, após passar o filme inteiro fazendo, aparentemente, o oposto do que McGee o acusa, isto é, buscando representar o grupo dos que ficaram sem trabalho, Moore coloca as imagens da porta-voz da fábrica nas cenas finais de Roger e Eu, como se pontuasse o contrassenso da postura de MacGee que, mesmo com o fechamento das fábricas, obedecia às regras e dava ordens em favor da propriedade privada da $G M$ propriedade essa que será demolida para "limpeza" do local, mas que permanecerá em ruínas e será filmada vinte e um anos depois no documentário Capitalismo: uma história de amor.

Exibindo fotos e imagens de infância, Moore constrói seu personagem como um filho de ex-funcionário da $G M$ e, portanto, oriundo de uma família de trabalhadores, nascido em cidade operária e que, desde a infância, seria uma pessoa diferenciada por

\footnotetext{
${ }^{112}$ A criação deste personagem crítico daquilo que os estadunidenses denominam de "América", renderá a Michael Moore entre outras críticas, uma em forma de filme documentário intitulado "Michael Moore Hates América" (EUA, 2004). Neste filme, o diretor Mike Wilson persegue Moore em busca de uma entrevista que possa confrontar as diferentes opiniões de ambos sobre o sonho americano. Além disso, Wilson afirma no seu filme que Moore mudou o gênero com suas manipulações e estaria milionário à custa de filmes que distorcem a imagem da América, propondo ainda, que Moore disseminaria o sentimento antiamericano em seus filmes. Fonte: http://www.imdb.com/title/tt0411646/ - Acesso em $10 / 02 / 2011$.
} 
acompanhar de modo crítico a situação política no seu país. Moore diz que a $G M$ foi responsável por milhares de postos de trabalho em Flint, empregando várias gerações de cidadãos daquela cidade, incluindo seus avôs, pais, irmãos, irmãs, tios, tias, primos e primas. O pai do narrador/personagem trabalhou 33 anos na esteira de produção de velas de ignição. Toda sua família tinha passado algum momento da vida na fábrica, menos ele. Seu tio Laverne (aparece em foto vestido com a farda da Marinha Americana - U.S NAVY) participou da primeira grande greve em Flint nos finais de 1936 quando os trabalhadores tomaram a fábrica por 44 dias o que gerou a fundação do UAW (United Auto Workers) sindicato dos montadores, reivindicando direitos e o reconhecimento dos dirigentes da fábrica.

As forças armadas norte-americanas, neste caso a marinha, compreendem uma instituição respeitada aos olhos dos estadunidenses. Apresentar um tio como parte dos dois mundos - o da fábrica e o da marinha - reforça, no sentido simbólico dessa construção, a legitimidade do narrador e de sua família como pessoas atentas aos seus papéis sociais e, portanto, "dignas de confiança". Além disso, Moore enfatiza o nascimento do sindicato dos montadores justamente nesse evento que contou com a participação do seu tio, sugerindo a contribuição histórica de sua família para o progresso do país e das conquistas trabalhistas. Isso pode, também, legitimar seu envolvimento pessoal no problema das demissões.

Essa construção familiar empreendida por Moore, em seu personagem crítico, pode ser uma representação idealizada aos moldes do que pensou Goffman. Segundo este autor, "quando o indivíduo se apresenta diante dos outros, seu desempenho tenderá a incorporar e exemplificar os valores oficialmente reconhecidos pela sociedade e até realmente mais do que o comportamento do indivíduo como um todo" ${ }^{\prime 13}$. Nesse sentido, é possível afirmar que Michael Moore reitera os valores estadunidenses para formar seu personagem dentro dos ideais que ressaltam a importância da família, do trabalho, do estudo, e do cumprimento dos papéis sociais e/ou deveres, como por exemplo, servir às forças armadas.

Além disso, ao expor fotos de sua família e outras imagens de infância, Moore explora a ilusão comum que as pessoas têm de acreditar na veracidade das imagens, mesmo que elas apresentem uma coisa pela outra. Acerca do potencial fotográfico para

\footnotetext{
${ }^{113}$ GOFFMAN, E. A representação do eu na vida cotidiana. Petrópolis: Vozes 2009, p. 41.
} 
promover um sentimento de familiaridade e propor noções de "verdade" e "realidade", envolvendo pessoas e lugares que não conhecemos, Paulo Menezes considera que,

Se a pessoa nos é desconhecida, passamos a vê-la com uma intimidade a um só tempo, curiosa e ambígua. A familiaridade com a imagem que nos é mostrada faz com que sintamos uma estranha familiaridade com a pessoa que ali está e que passamos a olhar como se já conhecêssemos há muito tempo. Por isso, quando nos perguntam se conhecemos alguém, às vezes dizemos que sim, que conhecemos de vista ou por fotografia. Entidade misteriosa que faz nos sentirmos perto de alguém que nunca vimos ou termos familiaridade com lugares onde nunca passamos ${ }^{114}$.

A rigor, apresentar as fotos da família não prova que sejam pessoas "boas", "felizes" e "trabalhadoras", como a construção fílmica sugere, mas em razão da crença que as pessoas têm na veracidade das imagens e na familiaridade que esta exposição constrói, as cenas consolidam esse sentido construído pelo filme - de que Moore veio de uma família de trabalhadores que desfrutavam das benesses do capitalismo trabalhando na fábrica da General Motors. Adicionado a isso, essas fotografias conferem um sentido de dignidade para aquelas pessoas, pois como diria Richard Sennett, ao estudar o caráter do trabalhador estadunidense, "o valor do trabalho árduo definiu o ethos do cidadão que possuía respeito próprio. Todavia, a sociedade ocidental teve de esperar a chegada do capitalismo moderno para que a ideia de dignidade do trabalho viesse a se tornar um valor universal"115.

Moore poderia usar qualquer foto do seu tio Laverne, mas preferiu àquela que este está vestido com o uniforme da Marinha de seu país, pois neste momento de representação lhe foi útil citar que teve um tio nas forças armadas. Assim, Moore conjuga alguns valores comuns da sociedade à que se dirige, reforçando a legitimidade da sua posição como narrador e se construindo como membro de uma família que obedece as regras, que participa da sociedade de forma digna e, portanto, merecedora de respeito.

\footnotetext{
${ }^{114}$ MENEZES, Paulo. Cinema: imagem e interpretação. Tempo Social; Revista de Sociologia da USP. São Paulo, 8 (2):83-104, out de 1996, p. 84-85.

${ }^{115}$ SENNETT, Richard. Respeito: a formação do caráter em um mundo desigual. Rio de Janeiro: Record, 2004, p. 74.
} 
Até aqui, Moore procurou mostrar uma suposta "familiaridade" com a linha de montagem e o trabalho operário. Contudo, ele diz que sonhava desde a infância em jamais precisar trabalhar na $G M$, por isso opta pelo jornalismo, e mesmo sem graduar-se fundou o Michigan Voice, um pequeno jornal do qual foi editor chefe por 10 anos. Com isto, Moore estaria inserido naquele grupo de atores que como ressaltou Goffman, "alimentam a impressão de ter motivos ideais para o papel, e que não precisam sofrer quaisquer indignidades, insultos e humilhações, ou fazer "acordos" tácitos para consegui-lo" $" 116$. Afinal, ele teve outras opções de trabalho e não precisou de emprego na GM mas, para legitimar seu personagem, reconstrói sua origem aos moldes dos valores dos trabalhadores da $G M$, que como insiste, empregou grande parte de sua família.

Em seguida, com um estilo de montagem que busca associar aquilo que é narrado com uma imagem de confirmação, seja para ratificar ou ironizar o que foi dito, Moore apresenta imagens de algumas pessoas nascidas em Flint ou nas regiões do Michigan que escaparam do trabalho operário e seguiram outras carreiras mais ou menos promissoras. Interessante notar a escala visual como essas pessoas são apresentadas numa espécie de hierarquia que rompe um pouco com o didatismo das cenas anteriores.

Primeiro aparece uma foto que seria do guitarrista da banda de hard rock Grand Funk Railroad em um momento de aparente inspiração musical - essa banda fez sucesso nos anos 70, descoberta em 1969 no Atlanta Pop Festival, chegando a ser uma grande sensação do rock para os jovens no final dos anos 60 e começo dos anos 70 . Depois, entra uma foto do rosto de Casey Kasem que nasceu em Detroit, Michigan, e é uma personalidade do rádio e dublador americano. Kasem foi graduado na Northwestern High School e Wayne State University e ficou muito popular após ser dublador de personagens de desenhos animados para Hanna Barbera como o Salsicha de Scoob Doo. Em seguida, Michael Moore cita "a mulher que se casou com Zubin Mehta” - mas a imagem apresentada é a do maestro indiano em uma foto que parece ser o ápice da escala valorativa com um zoom na imagem do regente de talento internacionalmente reconhecido pela sua atuação na Orquestra Filarmônica de Israel. Também aparece a foto de um personagem de Don Knotts que, apesar de ter nascido em Morgantown, West Virgínia, foi segundo o site do $\operatorname{IMDB}^{117}$ um ator de personagens

\footnotetext{
${ }^{116}$ GOFFMAN, E. A representação do eu na vida cotidiana. Petrópolis: Vozes 2009, p. 41.

${ }^{117}$ Sobre Don Knotts no IMDB - http://www.imdb.com/name/nm0461455/bio -Acesso em dezembro de 2010 .
} 
lendários nos EUA. Knotts fez muito sucesso na TV de seu país ao interpretar Barney Fife na série humorística The Andy Griffith Show (1960-1968). Por fim, como se representasse a decadência da escala valorativa, a câmera incide sobre a foto daquele que Moore considera, com voz irônica, ser "o mais famoso filho de Flint", Bob Eubanks. Eubanks é um apresentador de televisão e rádio famoso pelo programa Newlywed Game, uma espécie de show em auditório que será ridicularizado no filme, pois como Moore diz: "se até Bob Eubanks tinha conseguido sair de Flint, eu também sairia”.

Embora esteja familiarizando o espectador com sua vida pessoal, antes de confrontar Roger Smith com o problema das demissões, é possível notar que, ao falar do sonho de sair da cidade, Moore reitera valores estadunidenses que dão a perceber alguns contornos morais desta sociedade. Entre os valores historicamente construídos que moldam a peculiaridade americana, Simon Schama destaca a inquietante busca pela "autossuficiência", traduzida por um espírito inquieto do não contentamento passivo com as circunstâncias, a vontade de progredir, a busca pela felicidade garantida constitucionalmente ${ }^{118}$.

Assim, nesse sentido de concretizar o impulso americano de "avançar" ou de "seguir para o Oeste" como sinônimo de superar as barreiras de nascimento, Moore lembra a oportunidade que teve para trabalhar em uma "revista investigativa" de São Francisco, o que significava ascender profissionalmente. Entretanto, como se contrariasse suas "aspirações jornalísticas" a direção da "revista investigativa" pede que ele inicie seu trabalho com uma pesquisa sobre chás! Considerando-se sério demais para falar sobre chás, Moore chega a realizar uma matéria associada a sua cidade natal, publicando a foto de um amigo operário da $G M$ na capa da revista californiana. Segundo indica, essa atitude lhe rendeu uma passagem de volta para Flint.

Para construir visualmente a sua mudança de emprego, Moore inclui a seleção de imagens da época, quando um jornal televisivo local anuncia a sua saída do Michigan Voice. Os planos escolhidos para lembrar a estadia de Moore em São Francisco incluem imagens turísticas como a da ponte Golden Gate e músicas alegres com a câmera passando por ruas de grande concentração humana, indicando um status de centro cosmopolita. Contudo, logo em seguida, como se Moore estivesse se sentindo do outro lado do mundo, as imagens apontam para o bairro de Chinatown para construir

\footnotetext{
${ }^{118} \mathrm{Cf}$. SCHAMA, Simon. Abundância Americana. IN: "O futuro da América: uma história”. São Paulo: Companhia das Letras, 2009, p. 347-411.
} 
a sensação de estranhamento que ele sentiu com a nova vida. Ao ver tantas pessoas nas ruas Moore diz: "São Francisco era o oposto de Flint, todos lá tinham um emprego, mas parecia que ninguém trabalhava. Os cafés estavam cheios às três da tarde".

A economia diversificada da Califórnia e em particular a cidade de São Francisco, pouco tem a ver com a rotina de trabalhadores fabris com a qual Moore estava acostumado em Flint. Embora afirme que nunca quis pertencer ao quadro de funcionários da $G M$, Moore expressa os valores daquela comunidade que cresceu apegada à produção de bens materiais, ao valor do trabalho árduo, ao orgulho de pertencer à maior nação fabricante de automóveis do mundo (pelo menos até 1989), e tudo o que significou a produção e venda de carros e caminhões, símbolos da vida estadunidense e seu ideal de felicidade, este baseado principalmente no acesso ao conforto e ao consumo.

Ao longo da apresentação que faz da $G M$, principalmente dos seus familiares operários, Moore diz com voz orgulhosa "nós fazíamos Cadillacs, Buiks, e rabos de peixe (Fisher bodies), caminhões da GM, Chevrolets, e velas de ignição" - numa espécie de referência ou homenagem ao seu pai. (Grifo nosso). Moore parece orgulharse de sua trajetória nesta "sociedade de consumo" que, segundo o filme indica, coincide com a trajetória da maioria dos moradores da cidade, pois parece que naqueles tempos áureos da fábrica não seria difícil encontrar uma família que não tivesse pelo menos um membro trabalhando na empresa.

A respeito daquilo que se convencionou chamar sociedade de consumo, em referência à cultura do consumo nas sociedades modernas como os Estados Unidos, Jean Baudrillard afirma que "a felicidade constitui a referência absoluta da sociedade de consumo, revelando-se como o equivalente autêntico da salvação" "119. Para este autor a ideia de felicidade pelo consumo é um mito cultivado desde a "Revolução Industrial e as revoluções do século XX" ${ }^{\prime 20}$ nas quais o mito da Igualdade foi transferido para o de Felicidade e, neste sentido, é preciso que a felicidade seja mensurável, isto é "importa que se trate do bem-estar mensurável por objectos e signos, do conforto" ${ }^{\prime 21}$. Assim, para o autor a noção de felicidade distancia-se da ideia de fruição total e interior da pessoa, ou felicidade independente dos signos mensuráveis pelos olhos dos outros e de necessidades de provas materiais através do consumo, felicidade não estaria atrelada à

\footnotetext{
${ }^{119}$ BAUDRILLARD, Jean. A sociedade de consumo. Lisboa: Edições 70. 1995, p. 47.

${ }^{120}$ BAUDRILLARD, J. A sociedade de consumo, op.cit., p. 47.

${ }^{121}$ BAUDRILLARD, J. A sociedade de consumo, op.cit., p. 47.
} 
exigência de igualdade sediada nos princípios individualistas que reconhecem o direito à Felicidade como previa a Declaração dos Direitos do Homem e do Cidadão. Para Baudrillard,

A "Revolução do Bem-Estar" é a herdeira, a testamenteira da Revolução Burguesa ou simplesmente de toda a revolução que erige em princípio a igualdade dos homens sem a poder (ou sem a conseguir) realizar a fundo. O princípio democrático acha-se então transferido de uma igualdade real, das capacidades, responsabilidades e possibilidades sociais, da felicidade (no sentido pleno da palavra) para a igualdade diante do objecto e outros e outros signos evidentes do êxito social e da felicidade ${ }^{122}$.

É imerso nesta cultura do consumo como prova de êxito social, tão celebrada nos EUA, que Moore procura estabelecer elementos que o propiciem fazer a crítica não desse estado de coisas, ou do "sistema", mas da falta de oportunidades que os trabalhadores estariam enfrentando para obter participação "efetiva" nesta sociedade, e esta participação seria conquistada através do consumo. $O$ filme sugere vários signos do bem-estar daquela sociedade, quando Moore apresenta sua família em fotos de festas, em casas agradáveis e repletas de coisas, além de quintais gramados e espaçosos.

Outras imagens indicam que o carro da família seria novo e, em outras, Moore e sua irmã estariam em viagens de férias sempre felizes e bem vestidos. Todos esses indícios conferem um padrão econômico que garantia estabilidade para as famílias de operários que viveram naquele período.

Acerca desta fase próspera da economia americana John Lewis Gaddis enfatiza um aspecto ideológico marcante neste período, o de um "capitalismo que estava dando certo". Para isto, todo esforço do governo em possibilitar aos trabalhadores garantias de acesso ao trabalho e à prosperidade (o American Way of Life) tem como "pano de fundo" os anos da Guerra Fria, em que lutar contra a "opção comunista" estava na ordem do dia. Referindo-se àquilo que Hobsbawn chamou de "Era Dourada" da economia e o salto tecnológico que possibilitou seu avanço ao término da Segunda Guerra Mundial, Gaddis afirma:

\footnotetext{
${ }^{122}$ BAUDRILLARD, Jean. A sociedade de consumo. Lisboa: Edições 70. 1995, p. 48.
} 
A produção de alimentos cresceu mais rapidamente do que o incremento da população. Bens de consumo antes considerados de luxo - automóveis, refrigeradores, telefones, rádios, televisões, máquinas de lavar - tornaram-se bens de uso comum (...) nas terras centrais do trabalho industrial que sentido teria o 'revoltem-se, famintos, acordem' da Internationale (comunista) para operários que agora esperavam ter seus carros e gastar nas praias da Espanha seu dinheiro das férias anuais pagas ${ }^{123}$.

Essas referências históricas indicam o contexto social que o filme situa como um período no qual os trabalhadores de fábricas, como os da família de Moore, viviam e prosperavam desfrutando dos benefícios que o acesso ao trabalho lhes proporcionava. Adiante, o filme dialoga mais diretamente com seu contexto, ano de 1989, quando se observa a dificuldade de manter o ideal de vida americano, porque o acesso ao emprego não estava mais sendo garantido como nos "anos dourados".

Em relação à construção fílmica, este primeiro bloco de análise converge, pelo menos na maior parte, com o primeiro bloco de cenas de Roger e Eu, em que o personagem principal reconstrói sua vida familiar para legitimar a condição de narrador de uma história. Essa história tem como eixo o fechamento da fábrica da General Motors e as milhares de demissões que se seguiram, deixando muitos trabalhadores $\grave{a}$ deriva.

Ao falar da situação dos trabalhadores, a partir da década de 1980, diante do fim da estabilidade de emprego no contexto de "capitalismo flexível", Sennett propõe um novo sentido para a palavra "mudança" com o uso do termo "deriva". Esse termo comporta as mudanças que interferem não apenas no modo como as pessoas "ganham a vida" ao perderem empregos que mantinham por décadas, mas também as afetam ética e emocionalmente, exigindo um "comportamento flexível" no sentido dos trabalhadores se adequarem às transformações. "As condições da nova economia alimentam, ao contrário, a experiência com a deriva no tempo, de lugar em lugar, de emprego em emprego" $" 124$ (grifo meu).

\footnotetext{
${ }^{123}$ GADDIS, John Lewis. História da Guerra Fria. Rio de Janeiro: Nova fronteira, 2006, p. 111.

${ }^{124}$ SENNETT, R.A corrosão do caráter: as consequências pessoais do trabalho no novo capitalismo. Rio de Janeiro: Record, 2005, p. 27.
} 
Até este ponto da película, fica delimitado que as cenas iniciais são construídas para que os espectadores sejam envolvidos pelo personagem principal. A montagem do filme confirma um discurso de autoridade ao narrador Michael Moore. Para isso ele usou fotografias e imagens de arquivo pessoal de modo a veicular uma representação, nos termos de Goffman, de família ajustada à hierarquia daquela sociedade. As opções utilizadas pelo cineasta e sua equipe de produção podem ser facilmente confundidas, pela maioria dos espectadores no momento de representificação ${ }^{125}$, como sendo a própria "realidade" do tema abordado pelo filme.

Para construir a prosperidade na cidade de Flint com a instalação da $G M$, o documentário apresenta um segundo bloco de imagens antigas, muitas em preto e branco, dos incontáveis trabalhadores que seguiam aparentemente felizes, para a linha de montagem nas fábricas. As cenas das comemorações dos 50 anos da $G M$ têm imagens variadas, algumas durante o dia e outras à noite, com desfiles em grandes avenidas da cidade onde se mesclam figuras populares da cultura americana como a Miss America, o senhor e a senhora América (um casal de pessoas jovens e brancas chamadas $M r$ e Mrs USA), banda marcial ou marching band, personagens da televisão como o espadachim Zorro e o Sargento Garcia, ligados aos ícones da empresa como o garoto propaganda da $G M$ na época, o cantor Pat Boone, e outros símbolos que remetem à $G M$, como as pessoas que desfilam vestidas de vela de ignição, e a presença de Harlow Curtis (diretor da $G M$ na época). E ainda, o grupo assistido pela política social da empresa: os meninos de Elks Junior Drill Team que ensaiam de modo pouco sincronizado passos de dança chamados no filme de lively marching.

Em Roger e Eu, os desfiles lotados de público dão o significado da estreita relação entre os moradores da cidade e a General Motors, e colocar juntamente a empresa com personagens do Zorro e Miss America simboliza o quanto a GM também fazia parte da cultura local.

A ênfase que o filme confere às pessoas desfilando vestidas de vela de ignição são cenas que não fazem sentido se tomadas isoladamente, contudo, como pontua Merleau-Ponty, "o sentido de uma imagem depende, então, daquelas que a precedem no correr do filme e a sucessão delas cria uma nova realidade, não equivalente à simples

\footnotetext{
${ }^{125}$ Conforme pontua Menezes, na relação entre filme e espectador no momento da projeção e a construção de sentidos que essa relação (filme/espectador) permite. Cf.O cinema documental como representificação: verdades e mentiras nas relações (im)possíveis entre representação, documentário, filme etnográfico, filme sociológico e conhecimento. In: NOVAES, Sylvia C. [et. al]. (orgs) Escrituras da Imagem. São Paulo: FAPESP. Ed. da Universidade de São Paulo, 2004.
} 
adição dos elementos empregados" ${ }^{126}$. Nesta direção, essas cenas entrariam no filme para valorizar o setor de produção de velas de ignição que foi local de trabalho do pai de Moore e que será ligado às cenas seguintes, de modo que, com isto, o cineasta direciona o filme para aquilo que está ligado à sua história pessoal desconsiderando um pouco os grandes ícones da empresa que fazem parte da cultura nacional como a criação do carro Cadillac símbolo de requinte e qualidade.

Porém, para além das referências pessoais do diretor, é curioso notar, pelos olhos do espectador no século XXI, pessoas desfilando vestidas de vela de ignição. Isto pode ser compreendido, a partir dos estudos de Sennett acerca do trabalho, como tempos em que se podia contar com a estabilidade de emprego, isto é, antes que o "capitalismo flexível" reordenasse aquilo que as pessoas consideravam como uma "carreira". Segundo o autor,

"Carreira", por exemplo, significava originalmente, na língua inglesa, uma estrada para carruagens, e, como acabou sendo aplicada ao trabalho, um canal para as atividades econômicas de alguém durante a vida inteira. O capitalismo flexível bloqueou a estrada reta da carreira, desviando de repente os empregados de um tipo de trabalho para outro $^{127}$.

Com isto, é possível afirmar que ao passar trinta anos na esteira de montagem de velas de ignição, tanto o pai de Moore quanto os demais operários tinham uma carreira e um emprego estável. E não seria de se estranhar que nas paradas comemorativas dos aniversários da $G M$ tivesse um bloco de desfile que homenageasse aquela "carreira" - a fabricação de velas de ignição. Foram tempos em que, devido a associação de longo prazo, as pessoas mantinham laços fortes de lealdade e confiança nas instituições em que trabalhavam e a experiência pessoal era uma narrativa linear, "ano após ano trabalhando em empregos que raras vezes variavam de um dia para outro" ${ }^{\text {128. }}$.

Sennett também sublinha que o capitalismo pós Segunda-Guerra manteve o trabalho em ritmo de estabilidade, sobretudo nas economias avançadas, nas quais era

\footnotetext{
${ }^{126}$ MERLEAU-PONTY. O cinema e a nova psicologia. In: XAVIER I. (org). "A experiência do cinema: antologia”. Rio de Janeiro: Edições Graal: Embrafilmes.1983, (4ª edição, 2008, p. 111).

${ }^{127}$ SENNETT, Richard. A corrosão do caráter: as consequências pessoais do trabalho no novo capitalismo. 10 ${ }^{\text {a }}$ Ed. Rio de Janeiro: Record, 2005, p. 09.

${ }^{128}$ SENNETT, R. A corrosão do caráter: as consequências pessoais do trabalho no novo capitalismo. $10^{\mathrm{a}}$ Ed. Rio de Janeiro: Record, 2005, p. 14.
} 
possível observar "sindicatos fortes, garantias do estado assistencialista e empresas em grande escala [que] combinaram-se e produziram uma era de relativa estabilidade. Esse período de mais ou menos trinta anos definia um passado estável. O mesmo passado que o filme de Moore anuncia em seu início como sendo um tempo ideal, um tempo de prosperidade para sua família e para Flint.

Após as cenas dos desfiles que constroem uma relação estreita entre os moradores da cidade e a General Motors, entra um selo dourado que fazia parte de um filme comemorativo realizado na época do aniversário de 50 anos da montadora na cidade. Este selo encerra o clima de festividade proposto pela abertura do filme para entrar no problema, o que, juntamente com o The End do filme produzido pela $G M$, indica uma nova fase de acontecimentos e o fim daquele ciclo de prosperidade.

A imagem do selo de ouro, no filme comemorativo da GM, remete aos anos que o narrador do filme demonstra sentir saudade, os anos dourados da economia estadunidense. Segundo Hobsbawm, "durante os anos 50, sobretudo nos países "desenvolvidos" cada vez mais prósperos, muita gente sabia que os tempos tinham de fato melhorado, especialmente se suas lembranças alcançavam anos anteriores à Segunda Guerra Mundial" ${ }^{129}$.

Com isto, Roger e Eu busca construir as consequências humanas das rápidas transformações após os trinta anos que marcaram a "Era de Ouro" na economia do país e a perda de estabilidade no emprego. Uma cena colorida mostra um outdoor com a imagem de um carro Buick e o filme sai do contexto idealizado para construir a decadência da cidade como resultado do desemprego. Se até este ponto do filme imperou uma imagem positiva da $G M$ para o progresso material da cidade, os planos seguintes, construídos para responsabilizar a empresa pelo declínio econômico de Flint, darão um tom trágico às centenas de demissões que afetam os trabalhadores e as suas famílias. E essas mudanças levariam a cidade, como insiste o filme, a índices alarmantes de decadência.

Um jornal televisivo da época recupera a notícia anunciada pelo repórter da CBS Dan Hather:

- A General Motors confirmou hoje que fechará fábricas que empregam quase 30 mil trabalhadores.

\footnotetext{
${ }^{129}$ HOBSBAWM, Eric. Era dos extremos: o breve século XX. São Paulo: Cia das Letras, 1995 (2 ${ }^{\mathrm{a}}$ edição, 2003), p. 253.
} 
Outras imagens de manchetes dos jornais da época reforçam o impacto do fechamento das 11 fábricas mais antigas da $G M$ e as centenas de demissões que se seguiram. Ao construir um panorama de demissões, com o uso de imagens e arquivos da época, o filme remete ao que Roger Odin chamou de leitura documentarisante, ${ }^{130}$ como sendo um efeito do posicionamento que o espectador/leitor é levado a ler o filme como documento, como registro da realidade, ou ainda quando o enunciador do filme a câmera, o cinema, a sociedade, o cameraman, o realizador - pode ser entendido como "enunciador real".

Qual imagem que o leitor de um filme é levado a construir sobre o Enunciador?

A partir desta pergunta, Odin qualifica o enunciador como "aquele que é observado na origem da comunicação fílmica". No caso de Roger e Eu, não é difícil o leitor estabelecer Michael Moore como "Enunciador" do filme e seu discurso como realidade.

Em contrapartida de uma leitura documentarizante existe a leitura fictivisante em que o leitor do filme entende o enunciador como um "eu-fictivo", ainda que o filme remeta a questões da "realidade" mais prementes do que um filme de documentário.

No caso de Roger e Eu, as imagens não podem ser confundidas com o discurso que Moore empreende a respeito do tema - trabalho versus capital. Mas, é mais aceitável ao leitor do filme que, diante de imagens "históricas", compreenda o enunciador como "enunciador real". Se o leitor tomar Michael Moore como enunciador real, e o diretor se esforça para construir isso no início do filme, tudo o que for dito até o fim do filme será tomado como enunciado real, encobrindo a caráter construtivo do discurso, ainda que este se valha da utilização de imagens que são "modelos de realidade" tomados para um filme de ficção. Roger Odin, como outros autores já citados, também afirma que todo filme é uma obra de ficção, inclusive o documentário.

Nesta direção, o espectador recebe instruções dadas no próprio filme para lê-lo como um documento, devido seus códigos formais como, por exemplo, as legendas, os créditos, ou mais do que isso, pelas "figuras estilísticas" típicas do documentário. Roger e Eu faz uso dessas "figuras estilísticas" com a utilização de imagens tomadas da época do problema tratado pelo filme, como os jornais escritos e televisivos que noticiavam as demissões. Esses elementos impõem um tipo de leitura ao espectador, a leitura documentarizante.

\footnotetext{
${ }^{130}$ ODIN, Roger e LYANT, J.C. Cinéma et réalites. Saint Etienne: Universidade de Saint-Etienne, 1984, p. 263-277. (Tradução de Samuel Paiva).
} 
Disso decorre que, se o leitor aceitar como documento as imagens de época que anunciam as demissões ocorridas e o fechamento das fábricas da $G M$, todo o discurso empreendido pelo enunciador para justificar essas demissões, estabelecendo o problema e o conflito, poderá ser aceito como verdadeiro.

No caso deste filme as explicações a respeito das demissões em massa não constroem as transformações no trabalho partindo do seu contexto histórico-social, embora as sinalize. Antes, as consequências das demissões são lidas do ponto de vista moral do americano liberal, esse último pensado na direção tratada por Sennett como alguém "generoso no sentido americano de se preocupar com os pobres e agir de maneira correta com as minorias, como os negros e homossexuais" em contraposição ao modo conservador que "detesta os parasitas sociais, (...) encarnados na figura da mãe que vive da previdência e gasta os cheques que recebe do governo em bebida e drogas", e ainda, diferente "do conservadorismo que preserva o passado"131.

Neste cenário de demissões, o filme estabelece dois grupos principais, os operários das fábricas da $G M$ e os empresários - que também podem ser compreendidos na acepção de Marx ao distinguir esses dois grupos em classes de proletários versus burgueses. Considerando o modo conflitante que o filme constrói esses dois grupos principais é possível, num primeiro momento, fazer alusão à luta de classes ${ }^{132}$. Esses dois grupos possuem interesses opostos, pois enquanto o primeiro deseja a manutenção dos empregos nas antigas fábricas, o segundo, "personificado" na figura de Roger Smith, busca ampliar os negócios e tornar a empresa competitiva o que não significa ampliação ou manutenção dos empregos, mas redução de custos e fechamento das fábricas tornadas obsoletas. Alinhando-se ao grupo dos proletários ou operários (como o filme os denomina), sobretudo os demitidos, Moore busca motivos para as demissões e

\footnotetext{
${ }^{131}$ SENNETT, Richard. A corrosão do caráter: as consequências pessoais do trabalho no novo capitalismo. - $10^{\text {a }}$ Ed. Rio de Janeiro: Record, 2005, p. 28-29.

${ }^{132}$ Para conceituar as relações construídas pelo filme como interesses distintos entre operários e burgueses (sintetizado pelo filme na figura de um dos acionistas da $G M$ o presidente da empresa na época: Roger Smith) recorro inicialmente às construções de Marx ao falar da indústria moderna. Em $O$ manifesto do partido comunista podem ser encontradas as distinções básicas entre as classes no contexto de capitalismo industrial, com os termos burguesia e operariado como duas classes dentro do sistema de produção cujos interesses são conflitantes. Segundo seus autores: "A sociedade se divide cada vez mais em dois grandes campos inimigos, em duas classes que se opõem frontalmente: burguesia e proletariado. (...). O lugar da manufatura foi tomado pela indústria gigantesca moderna, o lugar da classe média industrial, pelos milionários da indústria, líderes de todo exército industrial, os burgueses modernos". IN: MARX, Karl. O manifesto do partido comunista. Karl Marx e Friedrich Engels: Rio de Janeiro: Paz e Terra, 1998, p. 10-11. Pela forma como Roger e Eu constrói os dois grupos principais, as noções de Marx auxiliam a distinguir essas duas classes dos desdobramentos que serão apontados por outros autores como Sennett e, conforme o filme indicar, outras "classes da população" podem ser trazidas à tona, conforme Marx exemplifica em $O$ manifesto do partido comunista: baixa classe média, pequenos comerciantes, lojistas, artífices aposentados, artesãos, camponeses, e ainda, a pequena burguesia.
} 
pretende um encontro com Roger Smith na tentativa de levar o presidente da $G M$ até Flint onde poderia ver a situação dos ex-montadores de automóveis.

Michael Moore se coloca como parte dos cidadãos envolvidos no problema da "decadência econômica" de Flint, o que, nos termos da representação em Goffman, pode ser uma apresentação sincera ${ }^{133}$. Um ponto interessante que parece recorrente nos filmes de Moore, e que ele inicia em Roger e Eu, é a escolha de um oponente para construir uma espécie de "debatedor" acerca do problema ${ }^{134}$. Neste filme, o escolhido é Roger Smith que figura na tela em situações como: transações financeiras, acordos com sindicatos, clubes e bairros de pessoas ricas e em convenções com líderes militares.

Toda a construção em torno do personagem de Roger Smith se dá através de discursos ou entrevistas concedidas pelo empresário. As imagens de Smith são alinhavadas com explicações irônicas de Moore acerca das "verdadeiras" intenções da $G M$ que, em última instância, seriam ações voltadas para a busca "gananciosa" de lucros e, portanto, prejudiciais aos operários.

A ideia que comporta o termo ironia, atribuída a algumas proposições de sentido referentes às falas de Michael Moore, é pensada a partir de Linda Hutcheon em sua obra Teoria e Política da Ironia. A partir do ponto de vista político que envolve as construções discursivas interpretadas como irônicas, a autora afirma que analisar o uso da ironia em um discurso é responsabilidade mais do interpretador do que do "autor" da ironia, ou ainda, "é mais com inferência que com implicação, mais com atribuição de ironia que com qualquer intenção "original” de ironizar, não importa quão decisivamente esse intento possa ser provado"135. Nesta direção, a autora aponta que seu foco de estudo é entender a ironia em uso no discurso partindo do princípio que "a

\footnotetext{
${ }^{133}$ Segundo Goffman, o indivíduo ou ator, de modo geral, nutre a crença de que está fazendo algo "em benefício de outros" e, por sua vez, o público pode se sentir convencido pela atuação do ator. “[...] o ator pode estar inteiramente compenetrado de seu próprio número. Pode estar sinceramente convencido de que a impressão de realidade que encena é a verdadeira realidade. Quando seu público está também convencido deste modo a respeito do espetáculo que o ator encena - e esta parece ser a regra geral então, pelo menos no momento, somente o sociólogo ou uma pessoa socialmente descontente terão dúvidas sobre a "realidade" do que é apresentado." GOFFMAN, E. A representação do eu na vida cotidiana. Petrópolis: Vozes 2009, p. 25.

${ }^{134}$ Pode-se adiantar que se em Roger e Eu o "debatedor" é Roger Smith, em Tiros em Columbine será o ator Charlton Heston, e em Fahrenheit 9/11, será o ex-presidente George W Bush. Estas escolhas parecem propor inimigos palpáveis, ou individuais, para questões de ordem histórica e social, como se essas pessoas, arbitrariamente escolhidas, tivessem todo o poder de decisão - independente do grupo a que podem estar envolvidas, representando, ou mesmo, submetidas.

${ }^{135}$ HUTCHEON, Linda. Teoria e política da ironia. Belo Horizonte: Ed. UFMG, 2000, p. 74.
} 
"cena" da ironia é uma cena social e política" cujo funcionamento auxilia a pensar o contexto do discurso ${ }^{136}$.

Assim, é possível notar que atribuir sentidos a partir das falas de Michael Moore como sendo irônicas auxilia a pensar tanto as relações entre as pessoas envolvidas nas falas quanto o contexto das situações e a carga afetiva que as interpretações possíveis promovem no espectador.

Nas sequências do filme, Roger Smith anuncia o fechamento de 11 das montadoras mais antigas da GM. Isso incluiu fábricas nas cidades de Detroit e Pontiac, mas em Flint, conforme anuncia o repórter televisivo, "o efeito é totalmente devastador". A cena da explosão das bases de uma antiga caixa d'água elevada a uns 10 metros de altura do solo, que ostentava a logomarca da empresa, conferem o tom visual devastador em consonância ao anúncio anterior.

Moore diz que "devastador foi pouco", pois não entendia como empresas consideradas lucrativas poderiam demitir. Segundo Moore, a $G M$ era a empresa mais rica do mundo e fecharia fábricas mesmo com faturamento de bilhões de dólares americanos. Uma foto em preto e branco de Roger entra em cena, e parece congelar um momento de distração do empresário, em que ele apareceria sem fazer pose enquanto coçava o canto da cabeça, dando a impressão de que se trata de uma pessoa confusa.

Em outro momento, Roger está sentado em um tipo de auditório ao lado de alguns homens vestidos com uniformes militares que, a julgar pelas credenciais, devem ser de alta patente. Se nas fotos de Moore e sua família prevalecia um clima de idealização com pessoas bem dispostas e sorridentes diante da câmera, as fotos que "personalizariam” Roger serão apresentadas em momentos "duvidosos", dando margem a interpretações negativas a seu respeito.

Na foto em que Roger está com os militares, a música que acompanha a cena e propõe a alusão de sentido é parecida com as dos filmes de gângster, e a voz off de Moore analisa em tom irônico ${ }^{137}$ os planos do presidente da GM.

Segundo sua análise, o "plano genial” de Roger consistia em:

\footnotetext{
${ }^{136}$ HUTCHEON, L. Teoria e política da ironia, op.cit., p. 19.

${ }^{137}$ Como diria Hutcheon, basicamente a ironia pode ser caracterizada em um discurso "como dizendo uma coisa e querendo dizer outra". Além disso, para a autora a ironia tem "arestas", isto é "a ironia tem nervos à flor da pele (...) é um modo de discurso que tem "peso", no sentido de ser assimétrica, desequilibrada em favor do silencioso e do não dito (...) envolve a atribuição de uma atitude avaliadora, até mesmo julgadora e é aí que a dimensão emotiva (...) ou afetiva também entra”. HUTCHEON, Linda. Teoria e política da ironia. Belo Horizonte: Ed. UFMG, 2000, p. 63.
} 
Primeiro feche 11 fábricas nos EUA, então abra 11 fábricas no México onde se paga 70 centavos de dólar por hora de trabalho. Use o dinheiro que economizou no México para comprar outras empresas, de preferência empresas de alta tecnologia e fábricas de armas. Em seguida, diga ao sindicato que está quebrado e lhe darão de volta alguns bilhões em cortes salariais. Então tire dinheiro dos empregados e acabe com seus empregos construindo mais fábricas no exterior. Roger Smith era um verdadeiro gênio.

As cenas que acompanham essa narração intercalam fotos e imagens de noticiários televisivos cuidadosamente planejados para "alinhavar" a assertiva. Primeiro uma música típica de filmes de gângster dos anos 1930 embala a narrativa que passa a "elogiar" o então presidente da GM de ser autor de um plano "brilhante" para as empresas. Em seguida, ao falar do México, aparecem cenas da passagem pela alfândega na fronteira americana com aquele país e toca-se uma música que, pelo ritmo, parece ser mexicana. Para "provar" a compra de empresas de armas é colocada uma imagem de telejornalismo com a manchete do dia: GM buys Hughes Aircraft Company for $\$ 5$ billion e outro corte mostra um avião de caça dos EUA lançando um míssil em direção a um navio, que explode.

As cenas de explosão parecem tentar impressionar o público no sentido de que o empresário deixaria de investir no emprego dos montadores de automóveis transferindo capital para o setor bélico. Talvez as imagens de explosão do navio não causem uma grande sensação em um expectador habituado aos efeitos especiais conhecidos por décadas de cinema Hollywoodiano. Diante disto, o filme parece deixar o "entretenimento" de lado e passa a se concentrar no elemento humano e, portanto, mais dramático do saldo de demissões. Essa mudança de foco, que incide sobre os indivíduos, pode se referir ao EU do título Roger $e E u$, isto é, cada pessoa desempregada.

Em toda a sequência anterior de imagens que reforçam o discurso do narrador colocando-se contra as mudanças na $G M$, uma música que se parece com os ritmos mexicanos não deixou de tocar. A música é finalizada quando reaparece Roger, em entrevista para televisão, dizendo que não demitiria os funcionários, de modo que sua 
fala e as imagens em que ele supostamente "negocia" com a liderança do sindicato denotariam se tratar de um homem mentiroso.

Acerca das transformações no capitalismo, pós-crise energética de 1973, e para contextualizar a situação que pode ter contribuído para o desemprego em massa observado no filme, Sennett afirma que,

O colapso dos acordos monetários de Bretton Woods, depois da crise petrolífera de 1973, levou à diminuição das limitações nacionais aos investimentos; em contrapartida, as corporações trataram de se reformular [como foi o caso da GM] para atender a uma nova clientela internacional de investidores - investidores mais preocupados em obter lucros a curto prazo com preços de ações, do que lucros de longo prazo com dividendos. Da mesma forma, os empregados começaram a cruzar rapidamente as fronteiras. $\mathrm{O}$ mesmo aconteceu com o consumo e as comunicações. Lá pela década de 1990, graças aos avanços do microprocessamento em eletrônica, o velho sonho/pesadelo da automação começou a tornar-se realidade no trabalho manual e no burocrático: finalmente tornava-se mais barato investir em máquinas do que pagar pessoas para trabalhar. ${ }^{138}$

Após Roger Smith declarar o fechamento das fábricas, ganha no filme os contornos da sociedade de risco pensada por Ulrich Beck na introdução deste trabalho. Para Beck na modernidade tardia a produção social de riqueza segue acompanhada da produção dos riscos. No que se refere especificamente às classes sociais, Beck afirma que "o risco de tornar-se desempregado é atualmente consideravelmente maior para quem não tem qualificações do que para os que são altamente qualificados" ${ }^{\text {"139. }}$.

Com isto, é possível considerar que a massa dos trabalhadores demitidos pela $G M$ em Flint é formada de pessoas com menor qualificação e, portanto, facilmente substituídas por outros trabalhadores. A GM migra para o México justamente porque encontraria ali o mesmo tipo de proletário ou operário disposto a trabalhar na montadora de automóveis, só que a custos mais baixos do que os operários estadunidenses.

Assim, ao fechar fábricas antigas, a $G M$ põe à deriva 30 mil proletários cuja estabilidade de emprego estava sendo encerrada. A montadora investiria em novos

\footnotetext{
${ }^{138}$ SENNETT, R. A cultura do novo capitalismo. Rio de Janeiro: Record, 2006, p. 15-16.

${ }^{139}$ BECK, U. Sociedade de risco: rumo a uma outra modernidade. São Paulo: Ed. 34, 2010, p. 41.
} 
mercados, em novas instalações e máquinas - como o braço robótico que o filme mostra na cena do parque temático construído em Flint.

Acerca dessas transformações, Sennett pontua que,

Na operação dos mercados modernos, a demolição de organizações se tornou lucrativa. Embora possa não ser justificável em termos de produtividade, os retornos a curto prazo para os acionistas proporcionam um forte incentivo aos poderes do caos disfarçados pela palavra "reengenharia", que parece convincente. Empresas perfeitamente viáveis são estripadas ou abandonadas, empregados capazes ficam à deriva, em vez de ser recompensados, simplesmente porque a organização deve provar ao mercado que pode $\operatorname{mudar}^{140}$.

Nesse contexto, o filme confere um sentido catastrófico para o fechamento das 11 fábricas mais antigas da GM. Em momentos de confronto, Roger Smith diz para Michael Moore que "a GM não despejou ninguém" - isentando-se de responsabilidade pelas consequências das demissões que são construídas como uma catástrofe, principalmente, entre as famílias mais pobres que aparecerão sendo despejadas de suas casas alugadas.

Nas sequências do filme, Roger Smith é colocado como responsável pelas demissões e, por extensão, à decadência econômica da cidade. Moore diz que não entende como podem demitir se a empresa estava lucrativa. A proposição de sentido que o filme constrói para o espectador é a de que um grupo relativamente pequeno de pessoas agiria de modo consciente em busca de seus interesses pessoais em detrimento de um grupo maior, formado pelos operários prejudicados por não terem poder econômico nem político, pois esses últimos estariam "nas mãos" de burgueses "gananciosos". Na direção da "luta de classes" retomo as considerações de Marx que dão as bases para aquilo que o filme constrói na chave do conflito:

Com a exploração do mercado mundial, a burguesia deu um caráter cosmopolita à produção e ao consumo, em todos os países. Para grande desencanto dos reacionários, tirou de sob os pés da indústria o

\footnotetext{
${ }^{140}$ SENNETT, R. A corrosão do caráter: as consequências pessoais do trabalho no novo capitalismo. Rio de Janeiro: Record, 2005, p. 58-59.
} 
terreno nacional em que esta se levantava: todas as indústrias nacionais, estabelecidas de longa data, foram destruídas ou dia a dia estão-se destruindo. São desalojadas por novas indústrias, cuja introdução passa a ser a questão de vida ou morte para todas as nações civilizadas - indústrias que já não operam com matéria-prima local, e sim com matéria-prima trazida das mais remotas paragens; indústrias cujos produtos são consumidos não apenas em sua terra, mas em todos os quadrantes do globo. Em lugar das antigas necessidades, atendidas pela produção do país, encontramos novas demandas, requerendo, para sua satisfação, produtos de terras e climas distantes. Em lugar da segregação e da auto-suficiência, nacional e local, de antes, temos o intercâmbio em todas as direções, a interdependência universal das nações $^{141}$.

Uma das preocupações expostas no filme é saber o motivo que leva o diretor de uma empresa lucrativa a fechar fábricas, consideradas um importante símbolo nacional, e as transferir para outras nações. Ou, como simplifica Moore, porque dar os empregos americanos aos mexicanos? Como Roger poderia fazer aquilo com seus compatriotas? É nestes termos que o filme apresenta o conflito.

A forma como as cenas são apresentadas não visam promover a empatia entre o espectador e Roger Smith, construído na chave de inimigo dos operários. Quando Moore afirma que as fábricas seriam construídas no México certamente tinha consciência do desconforto que essa afirmação causaria em qualquer cidadão dos Estados Unidos, visto que embora a $G M$ estivesse há muito tempo abrindo fábricas em outros países, - no Brasil a primeira fábrica veio em 1930 - a narrativa prefere referir-se apenas ao México, vizinho historicamente indesejado dos EUA ${ }^{142}$.

\footnotetext{
${ }^{141}$ MARX, K. Escritos Econômicos. IN: FREEDMAN, Robert. (Org - seleção e prefácio) Escritos Econômicos de Marx. Rio de Janeiro: Zahar Ed. 1966, p. 37-38.

${ }^{142}$ Neste sentido, o filme parece remeter às teses do polêmico livro "O choque de civilizações" do professor em Harvard, Samuel P. Huntington. Huntington discorre, em chave negativa, acerca da histórica imigração de latinos (leia-se mexicanos) ao território estadunidense. Para esse autor, os imigrantes mexicanos representam não apenas a transferência de trabalho dos nascidos nos EUA para as mãos-deobra barata, como também significariam uma "ameaça para a cultura norte-americana" (p. 253). A competição dos estadunidenses em relação aos mexicanos é histórica, em 1990 as pesquisas de opinião apresentadas por este autor, afirmaram que $60 \%$ dos estadunidenses opinavam contra a imigração, sobretudo à mexicana. Segundo Huntington, "conquanto as preocupações econômicas e as condições econômicas afetem as atitudes para com a imigração, a oposição que cresce de modo sistemático em tempos bons e ruins sugere que cultura, criminalidade e estilo de vida foram mais importantes para essa mudança de opinião", ele refere-se aos crescentes índices de rejeição do povo estadunidense em relação aos mexicanos como apontaram pesquisas efetuadas de 1965 até início dos anos 1990. Cf.
} 
$\mathrm{Na}$ sequência, o filme alterna cenas em que os discursos de Roger Smith parecem contradizer suas próprias ações. Smith aparece em entrevistas carregadas de positividade em favor dos trabalhadores e, em resposta, o filme coloca cenas opostas às falas do presidente da GM. Após assinar os contratos que, segundo o filme, cortaram horas de trabalho e reduziram salários, Roger concede nova entrevista em que fala sobre os sindicatos:

- Acho que nossos funcionários deram uma nova ênfase e estabilidade no emprego e, certamente, queremos auxiliá-los nisto.

Em seguida, a imagem corta para a saída de alguns operários demitidos e, buscando promover o confronto, Moore pergunta o que eles têm a dizer para Roger Smith. A maioria dos funcionários que aparecem são homens jovens entre 30 e 40 anos de idade, algumas mulheres são vistas em menor número. Alguns dizem que não podem falar o que querem diante das câmeras, indicando um descontentamento que não poderia ser expresso de modo educado.

Outro corte na cena e um homem de camisa branca, gravata e aspecto de quem trabalharia na administração do setor - devido a suas mãos limpas, unhas feitas e anel na mão direita parecido com os anéis de formatura - afirma que aquilo não era o fechamento de uma fábrica e sim a perda de uma linha de produtos. Provavelmente ele tinha em mente a visão da reestruturação do setor que estaria em curso.

Para a caracterização da burguesia local como pessoas ricas e aliadas de Roger Smith, a cena é apresentada de forma didática em um dia ensolarado com uma música instrumental, o que confere um ar requintado ao grupo. Um grupo de homens brancos e jovens aparecem montados em seus cavalos, vestidos com roupas próprias para a prática do Pólo ou Hóquei à cavalo. As imagens mostram que este esporte é, decididamente, uma prática de pessoas com maior poder aquisitivo porque as cenas sugerem um grande aparato para a sua manutenção, como um clube de campo ou uma hípica, baias, cavalos, veterinários, ração, remédios, treinamento, tacos, uniformes, transporte, enfim, uma

HUNTINGTON, S, P. O choque de civilizações. Rio de Janeiro: Objetiva, 1997, págs. 18, 40, 52, 134, 165, 167, 239, 287 e 393. Em resposta ao primeiro texto polêmico de Huntington, Edward Telles afirma que a mão de obra mexicana é benéfica à economia americana e o pequeno impacto negativo incidiria sobre o grupo de americanos com baixa qualificação, esses últimos deveriam entrar em políticas educacionais. Para Telles, "em vez de fazer dos mexicanos um fácil bode expiatório para uma série de problemas americanos, seria preciso avançar na direção de uma "verdadeira democracia participativa". In: TELLES, Edward. Os mexicanos-americanos e a nação americana: resposta ao professor Huntington. Tempo Social: revista de sociologia da USP, v.18, n2, p. 167-184. 
logística sofisticada. Moore informa que essas cenas se passam entre "os mais afortunados de Flint", isto é, na casa de uma das famílias fundadoras da $G M$ e sua tradicional festa inspirada no livro O Grande Gatsby.

A imagem que segue é tomada a partir de uma grande mesa posta no jardim com um cisne em tamanho natural, esculpido em gelo. Bandejas estão repletas de comidas sofisticadas e uma espécie de gourmet prepara pratos quentes para os convidados que estão servindo-se. Em seguida Moore diz, em tom de ironia, que esse grupo não era totalmente insensível à situação dos trabalhadores, pois convidaram algumas pessoas da cidade (negras) para servirem de estátuas vivas no meio da festa. A imagem focaliza o rosto de um jovem negro parado como uma estátua, vestindo terno preto e entre as mesas onde passam os convidados. Na mesma posição está uma jovem, também negra, vestida à moda dos anos 1920, com uma espécie de pele de animal por cima do vestido, mesmo em um dia aparentemente ensolarado.

Dois casais são apresentados numa posição da câmera levemente abaixo dos seus rostos, como se os visse em um patamar elevado. Esse grupo de pessoas aparece elegantemente vestido: os homens estão vestidos à rigor com roupas clássicas, um de smoking e outros de jaquetão; as mulheres com vestidos finos coloridos e chapéus com penas ou com echarpes de penas. Como estão na "Festa do Grande Gatsby" eles usam alguns trajes típicos de grupos ricos dos EUA anos 1920.

Ao entrevistar esse grupo, Moore pergunta o que eles acham da vida em Flint. Eles dizem que a vida em Flint não é tão ruim quanto alguns fazem parecer, pois eles tinham o hóquei e seus filhos faziam balé. Outro homem sem chapéu, diz que ainda tinham empregos na cidade. Um corte na cena mostra outros convidados e Moore entrevista dois homens que estão juntos perguntando o que eles achavam das demissões em massa na cidade. Se as perguntas de Moore aparentam tentar envolver os burgueses nos problemas dos operários demitidos, as respostas soam bastante individualistas, pois não ultrapassam o cotidiano daquelas pessoas de vida estruturada que usufruem de melhores empregos, lazer e momentos culturais, muito longe do drama dos desempregados que o filme explora mais adiante.

Acerca dos riscos específicos de classe, como o filme alude, diria Beck que "os riscos parecem reforçar, e não revogar, a sociedade de classes", pois aqueles que detêm 
mais renda, educação e poder "podem comprar segurança e liberdade em relação ao risco" 143 .

Provavelmente aqueles membros da burguesia de Flint estavam preocupados com a manutenção dos seus negócios dentro desse quadro de "capitalismo flexível", como observado anteriormente por Sennett. Muito embora, Beck alerte para a generalização da distribuição dos riscos da modernização, o que muitas vezes, rompe os termos de classe como o caso de uma catástrofe ecológica.

$\mathrm{Na}$ sequência das entrevistas de Moore com os burgueses, enquanto o cineasta parecia buscar alguma empatia em prol dos demitidos, surge um homem branco, vestido com terno branco, de cabelos claros e olhos azuis (um típico representante dos WASP ${ }^{144}$ ), dizendo que eles começaram uma revolução e que vão até o fim. Moore pergunta que revolução foi essa, e o homem afirma que foi a Revolução Industrial com aço e carros. Essa fala parece uma espécie de reapropriação da história, conhecida como iniciada na Inglaterra com o motor a vapor.

Contudo, nas palavras do entrevistado,

$\neg$ Começamos alguma coisa e agora vamos terminar. Vamos ser os líderes! Começamos uma revolução industrial, uma forma de arte que nunca havia sido criada na história da humanidade. [e quando é questionado que revolução foi essa] Os carros, aço sabe, tudo começou aqui, nós inventamos a roda! Recomeçamos e estamos com tudo!

O depoimento desse membro da burguesia de Flint parece uma apropriação indevida da revolução industrial inglesa. Mas no tocante a construção de sentidos, a fala dos burgueses sugere pouco interesse pela situação dos demitidos, ou ainda, sugere uma postura de quebra com qualquer sentido de comunidade. Talvez Moore estivesse buscando algum senso de comunidade entre aquelas pessoas, no sentido de imaginar que a diretoria da $G M$ e aqueles operários teriam sido uma "grande equipe", e também

\footnotetext{
${ }^{143}$ BECK, U. Sociedade de risco: rumo a uma outra modernidade. São Paulo: Ed. 34, 2010, p. 41.

${ }^{144}$ Também conhecidos como pilgrim fathers, os pais peregrinos são valorizados pelos livros de história oficiais dos EUA. São tidos como os pais desta nação, mas não de toda a nação e sim da parte "WASP" (em inglês, white anglo-saxon protestant - branco, anglo-saxão e protestante). A principal igreja estabelecida por este grupo é a Puritana (protestantes calvinistas) e se consideravam os escolhidos de Deus para criar uma nova sociedade de "eleitos". Cf. KARNAL, Leandro (Et al.) História dos Estados Unidos: das origens ao século XXI. São Paulo: Contexto, 2010.
} 
que todo progresso obtido em décadas de fabricação de automóveis fosse uma conquista não apenas para Flint, mas para toda a região que envolvia as 11 fábricas. Os vídeos antigos usados na abertura do filme aludem para um senso de comunidade através do discurso de um dos antigos membros da direção da fábrica, reconhecendo a importância dos trabalhadores.

Pensando comunidade a partir da construção conceitual de Bauman, esta seria idealizada como um lugar de conforto e aconchego em que as pessoas se sentem seguras entre seus pares. Um lugar em que "nunca somos estranhos entre nós (...) nunca desejamos má sorte uns aos outros, e podemos estar certos de que os outros à nossa volta nos querem bem (...) se tropeçarmos e cairmos, os outros nos ajudarão a ficar de pé outra vez"145. O autor confessa que esse senso de comunidade está mais no imaginário que na "realidade", pois uma vida em comunidade inclina mais para o lado de uma coletividade que requer obediência às regras do que com proteção, ou ainda, pensando nas "comunidades realmente existentes" seria mais uma vida de opressão do que de liberdade ${ }^{146}$.

Essa noção de comunidade, ainda que no sentido ideal, não passa pelo grupo entrevistado por Moore nas cenas anteriores, pois aqueles burgueses dirigem seus negócios dentro de um novo contexto tratado por muitos autores como "globalização" $" 147$. Deste modo, cada vez mais livre das amarras da localidade, aquele grupo burguês e seu "poder desarraigado" se insere no que Bauman chama de "nova assimetria entre a natureza extraterritorial do poder e a contínua territorialidade da "vida como um todo" - (...) capaz de se mudar de repente ou sem aviso, é livre para explorar e abandonar às consequências dessa exploração"”,148.

Segundo Bauman, a "globalização" encerra a expressão "compressão tempo/espaço" e, com isto, diversos parâmetros da condição humana são afetados causando consequências sociais sem precedentes. Acerca das consequências da

\footnotetext{
${ }^{145}$ BAUMAN, Z. Comunidade: a busca por segurança no mundo atual. Rio de Janeiro: Zahar, 2003, p. 8.

${ }^{146} C f$, BAUMAN, Z. Comunidade: a busca por segurança no mundo atual, op.cit., p. 10.

${ }^{147}$ Acerca do conceito de globalização, Bauman o trata como "liberdade do capital" em que os negócios ganham "dimensões planetárias", e todos aqueles que não conseguem seguir o ritmo dessa mobilidade, que desloca tanto as empresas quanto os mercados e, consequentemente, as pessoas, ficam presos às consequências locais. $C f$. BAUMAN, Z. Globalização: as consequências humanas. Rio de Janeiro: Jorge Zahar Ed.,1999. Em uma acepção não muito distante de Bauman, Giddens entende globalização "como expressando aspectos fundamentais do distanciamento tempo e espaço. (...) diz respeito à interseção entre presença e ausência, ao entrelaçamento de eventos e relações sociais "à distância” com contextualidades locais. (...) uma relação continuada entre o distanciamento e a mutabilidade crônica das circunstâncias e compromissos locais". IN: GIDDENS, A. Modernidade e identidade. Rio de Janeiro: Jorge Zahar, 2002, p. 27.

${ }^{148}$ BAUMAN, Z. Globalização: as consequências humanas. Rio de Janeiro: Jorge Zahar Ed.,1999, p. 16.
} 
globalização sobre as classes, diria Bauman que a "liberdade de movimento", dentro desse novo contexto, mobiliza novas hierarquias sociais que rompem definitivamente com qualquer senso de comunidade e de localidade. Segundo o autor,

A mobilidade adquirida por "pessoas que investem" - aquelas com capital, com dinheiro necessário para investir - significa uma nova desconexão do poder face as obrigações, com efeito uma desconexão sem precedentes na sua radical incondicionalidade: obrigações com os empregados, mas também com os jovens e fracos, com as gerações futuras e com a autorreprodução das condições gerais de vida: em suma, liberdade face ao dever de contribuir para a vida cotidiana e a perpetuação da comunidade ${ }^{149}$.

Nas sequências da entrevista na festa do Grande Gatsby, os valores do entrevistado podem ser percebidos no modo como fala acerca de seu grupo social, além das opiniões que emite em relação aos desempregados. Quando Moore pergunta que conselho daria aos que estão passando dificuldades, o entrevistado diz:

$\neg$ Levante cedo e faça alguma coisa. Tenha motivação, ligue o próprio motor, há coisas para fazer!

Esse outro membro da burguesia se exime de qualquer responsabilidade para com os demitidos, suas colocações podem parecer egoístas, mas também apontam para os valores deste grupo social. Esses valores se espalharam pelo conjunto da sociedade com a celebração das promessas materiais da indústria moderna desde 1950 e durante todo o pós-guerra com a propaganda do American Way of Life. A meta políticoeconômica era estimular a produção das empresas e o fortalecimento do mercado consumidor interno que, por conseguinte, incluía a ampliação do poder aquisitivo do cidadão com aumento de salários e consumo de bens supérfluos.

Além disso, um forte ethos puritano permeia os valores dos estadunidenses, ainda que não sigam nenhuma religião. Por isso, pode parecer tão automático para o WASP dizer que os mais pobres devem fazer alguma coisa para progredirem na vida, pois segundo Weber, a base moral da religião puritana é a transformação do mundo.

\footnotetext{
${ }^{149}$ BAUMAN, Z. Globalização: as consequências humanas. Rio de Janeiro: Jorge Zahar Ed.,1999, p. 16.
} 
Em uma parte de seu amplo estudo sobre as religiões, Weber comparou duas religiões antagônicas: o confucionismo e o puritanismo, de modo a diferenciar os tipos de racionalidade que as orientam. Weber entende que se no confucionismo o mundo é a morada dos deuses e as pessoas devem afirmar sua ordem natural, no puritanismo o mundo é um lugar a ser conquistado, dominado racionalmente através da técnica, porque deus entregou este mundo aos homens e ordenou que o dominassem. $\mathrm{O}$ puritanismo coloca deus o mais longe possível dos homens e do mundo (é a transcendência de um deus insondável), os homens retiraram os rituais que no mundo da magia os aproximava de deus, pois, na fé puritana, o homem só pode se aproximar de deus através do trabalho árduo, uma das bases desta fé que está arraigada no pensamento estadunidense. Weber aponta dois critérios básicos para se pensar o nível de racionalização que uma religião representa, e esses critérios se inter-relacionam de várias maneiras: "o primeiro é o grau em que uma religião despojou-se da magia; o outro é o grau de coerência sistemática que imprime à relação entre Deus e o mundo e, em consonância com isso, sua própria relação ética com o mundo" ${ }^{\text {150 }}$.

Nesta acepção de Weber, o protestantismo ascético nas suas várias manifestações, como o puritanismo, representa o grau extremo de racionalização de uma religião. Quando o homem da burguesia de Flint, diz que os mais pobres "devem levantar cedo e fazer alguma coisa, porque existem coisas para serem feitas", ele pode ser interpretado como arrogante, mas estaria reproduzindo um dos valores de seu grupo social.

Weber entende que "o puritanismo imprimia a tudo um cunho objetivo, dissolvia tudo em "empresas" racionais e relações "comerciais" puramente objetivas, e punha o direito e o acordo racionais no lugar da força da tradição, do costume local e do favor pessoal" ${ }^{\prime 151}$.

Conforme aponta Weber e por extensão, na fala do WASP, os ricos entendem sua condição a partir de sua convicção no valor ético da riqueza como um meio de se santificar, como meio de "aperfeiçoamento moral"" 152 e, com isto, para o puritano "o lucro era consequência involuntária mas sintoma importante da própria virtude, mas o

\footnotetext{
${ }^{150}$ WEBER, Max. Confucionismo e puritanismo. IN: COHN, Gabriel. (org). "Weber: Sociologia”. São Paulo: Ática, 1979, p. 151.

${ }^{151}$ WEBER, Max. Confucionismo e puritanismo, op.cit., p. 156.

${ }^{152}$ WEBER, Max. Confucionismo e puritanismo, op.cit., p.156.
} 
dispêndio da riqueza para fins de consumo próprio era muito facilmente submissão idólatra ao mundo" ${ }^{\prime 153}$.

Reconhecendo a atualidade das considerações de Weber acerca da ética no trabalho, Sennett aponta que "qualquer adulto que não é considerado um trabalhador suporta um fardo mais pesado de autojustificação" ${ }^{154}$. Segundo Sennett,

Foi este elemento de "autojustificação" que Max Weber analisou extensivamente. A ética do trabalho de Weber trata do homem ou da mulher "sustentando-se" por meio do trabalho; o que o indivíduo está provendo é seu valor básico; para Weber, as evidências apresentadas são economias e restrições insignificantes, a negação dos prazeres a si mesmo, exercícios de autocontrole - uma espécie de treinamento de aptidão moral através do trabalho. (...) a ética do trabalho é competitiva, requer julgamentos comparativos de valor; aqueles que vencem podem fazer vista grossa aos que perdem ${ }^{155}$.

Enquanto os mais ricos de Flint, apresentados na festa do Grande Gatsby, parecem vangloriar-se da condição de "privilegiados e abençoados" por também se sentirem trabalhadores e terem "revolucionado à história", os mais pobres, defendidos por Moore, poderiam cobrar, dentro da mesma lógica ética, uma postura menos esbanjadora dos ricos. Talvez por isso, o filme faça uma construção dos ricos em cenas de lazer, festas e ocasiões sociais como clubes e restaurantes, para que possa cobrar desses "abençoados" uma postura mais frugal, mais trabalhadora, aos moldes da ética puritana que os orientou (pelo menos em princípio). O filme não mostra os ricos levantando cedo e fazendo alguma coisa, mas prefere construí-los em jogos de Pólo, no Golfe, no clube privé e outros locais considerados de alta classe, numa aparente chave esbanjadora.

Essa construção empreendida pelo filme, com oposição entre ricos e pobres, faz parte da história do cinema e pode ser vista em filmes como Corner In Wheat, dirigido por Griffith em um conjunto de curtas filmados entre 1908 e 1913.

\footnotetext{
${ }^{153}$ WEBER, Max. Confucionismo e puritanismo, op.cit., p. 157.

${ }^{154}$ SENNETT, R. Respeito: a formação do caráter em um mundo desigual. Rio de Janeiro: Record, 2004, p. 76.

${ }^{155}$ SENNETT, R. Respeito: a formação do caráter em um mundo desigual. Rio de Janeiro: Record, 2004, p.77.
} 
Em Corner In Wheat, o rico empresário do trigo Sr. W.J.Hammond planeja adquirir o monopólio da produção dificultando a concorrência de outros empresários através da concentração do produto em seus estoques e a elevação dos preços. Isto prejudica a vida dos pequenos produtores do trigo que mal conseguem comprar os grãos para o plantio, e a dos pequenos comerciantes que têm dificuldades em comprar farinha para a produção de pães. As cenas alternam música instrumental alegre para a construção da vida dos ricos em seus banquetes festivos, e música triste para as filas de pessoas pobres em busca de pão nas pequenas mercearias, cujos produtos além de preços elevados vão se esgotando. Até um fundo social do governo, destinado à alimentação, é prejudicado pelo monopólio do trigo.

Em outra cena, enquanto verifica um silo sendo cheio de trigo, o Sr. Hammond recebe, pelas mãos de um empregado, o comunicado que declara sua liderança no controle do mercado mundial do trigo, além de ser o homem mais rico do mundo. Em meio à comemoração junto aos estoques de trigo, o Sr. Hammond delega ordens para um empregado, ficando sozinho próximo das pequenas aberturas no chão que levam ao interior do silo. Em um momento de distração, o empresário cai dentro do silo e morre sufocado pelos grãos que caem em torrente formando o estoque. Remetendo à "providência divina", a saída para o conflito do filme foi uma punição moralizante para a "ganância" do empresário, devido ao modo como prejudicou as pessoas que vão desde os outros proprietários de campos de trigo até à população local, que como as imagens remetem, estava passando fome em razão do preço elevado do pão.

Ainda na história do cinema, o filme alemão Metrópolis (1927) de Fritz Lang também constrói a oposição entre ricos e pobres. Em uma cidade governada por um rico empresário, muitos operários vivem e trabalham exaustivamente no subsolo sem chances de progredirem na vida, como que condenados à exploração pelo homem e suas máquinas. A saída para o conflito alude ao evangelho da Bíblia cristã com a jovem Maria pregando a chegada de um salvador para o povo. Ao final da narrativa um acordo entre ricos e pobres parece sinalizar um futuro de justiça para os trabalhadores.

Essas construções simbólicas em filmes antigos parecem servir de referências aos filmes de Moore, sobretudo Roger e Eu cuja construção de ricos contra pobres é colocada de forma didática, tanto pelas músicas que dão sentido às cenas quanto pela montagem que coloca os grupos em lados opostos: festa e tristeza, brancos e negros, burgueses e proletariado, empregadores e desempregados, calor e conforto para os ricos, 
frio, chuva e neve para os pobres, mansões em oposição às casas velhas, ostentação em oposição à sobrevivência.

Para concluir, este bloco dos ricos e as representificações possíveis na relação entre filme e espectador, retomo a ideia de que existe um forte ethos puritano permeando a sociedade no filme, vale a pena trazer à tona a conclusão de Max Weber no seu estudo comparativo entre confucionismo e puritanismo:

[...] apenas a ética racional puritana orientada para além do mundo levou às últimas consequências o racionalismo econômico intramundano, justamente porque nada lhe era mais alheio do que exatamente isso, justamente porque para ela o trabalho intramundano não passava de expressão do esforço por uma meta transcendente. Conforme o prometido, o mundo dava-se ao puritano porque unicamente ele tinha-se "empenhado por Deus e sua justiça". Pois é, nisso que reside a diferença fundamental entre essas duas modalidades de "racionalismo". O racionalismo confuciano significava adaptação racional ao mundo. $\mathrm{O}$ racionalismo puritano significava dominação racional do mundo. Tanto o puritano quanto o confuciano eram "sóbrios". Mas a "sobriedade" racional do puritano repousa sobre um poderoso entusiasmo que faltava totalmente ao confuciano, [...] Pois é exatamente nisso que ele [o puritano] procurava a sua dignidade. E porque ele queria ser isso ele era um instrumento útil para transformar e dominar racionalmente o mundo ${ }^{156}$.

A comparação de Weber auxilia a pensar as características dos valores puritanos que permeiam a vida dos estadunidenses e sua busca obstinada de transformar o mundo, como disse um dos entrevistados de Moore: "ligue o próprio motor, existem coisas para serem feitas". Ainda acerca dos valores relacionados ao trabalho árduo e competitivo como fonte de bênçãos e prosperidade, Fernandes e Moraes pontuam outros como a crença no direito de propriedade, livre-concorrência e satisfação das necessidades individuais:

\footnotetext{
${ }^{156}$ WEBER, Max. Confucionismo e puritanismo. IN: COHN, Gabriel. (org). Weber: Sociologia. São
} Paulo: Ática, 1979, p. 157-158, grifos do autor. 
Competiam a profunda crença nos direitos de propriedade, que se aliava aos influentes interesses da indústria, e a também enorme crença na livre concorrência e nas oportunidades da "Terra da liberdade" [...] a tradição de valorizar o individualismo competitivo, acreditavam os intelectuais que os assuntos humanos eram governados por leias naturais imutáveis: o bem geral era mais bem servido com a busca da satisfação dos interesses individuais. $\mathrm{O}$ eventual sofrimento causado seria infinitamente inferior às recompensas trazidas àqueles laboriosos espíritos independentes, que, por meio do trabalho, atingiam a plenitude econômica. A pobreza era quase sempre vista como castigo advindo aos indolentes. ${ }^{157}$

A entrevista com as pessoas ricas, na sequência da festa do Grande Gatsby, termina com algumas mulheres dizendo que Flint era um bom lugar para se viver. Entretanto, as imagens cortam para a primeira cena de despejo do filme, saindo de um panorama clean e ensolarado para um dia cinzento com um pouco de neve no pavimento das ruas de um dos bairros mais pobres da cidade, onde a primeira família de ex-operários será despejada no filme. A narrativa alterna dias ensolarados e agradáveis para construir a vida dos mais ricos e cenas em dias quase sempre frios e/ou nevando para a vida dos pobres. Na relação do filme com o espectador isso pode representificar uma vida agradável e privilegiada para os ricos e outra repleta de dificuldades, ansiedades e desconforto para os pobres - no limite: uma relação de exploração.

Contudo, neste ponto da análise, para delimitar o sistema relacional do grupo de ricos, será continuada a caracterização dos empresários e suas famílias, com as sequências fílmicas que percorrem os bairros "nobres" em dias ensolarados, focalizando mansões requintadas. A música, ao som de cornetas, anuncia essa classe como se fosse parte de alguma "realeza" e Moore segue para o Iate Clube de Gosse Point - em busca de confrontar Roger Smith.

Com seu inseparável boné e um gesto grotesco de manter um palito entre os dentes, Moore entra no clube após filmar a placa onde está escrito - private members only. De modo provocativo, enquanto sua equipe filma tudo, Moore passeia pela recepção observando cada quadro, cada símbolo daquele grupo para incômodo da

${ }^{157}$ FERNANDES, L. E; MORAIS, M, V. Os tempos modernos e os magnatas da indústria. In: KARNAL, L. (org). História dos Estados Unidos: das origens ao século XXI. São Paulo: Contexto, 2010, p.157. 
senhora recepcionista que liga insistentemente para alguém - provavelmente da gerência. Moore faz especulações sobre tudo o que Roger Smith poderia fazer quando está no clube, e a recepcionista informa sobre alguns eventos como "o jantar de caça" em que os sócios degustam carnes exóticas como as de cascavel e jacaré. Em outra ocasião à busca de Roger, Moore está no Detroit Athletic Club e, desta vez, a gerência impaciente pede que ele se retire imediatamente sob o mote: - Este é um clube particular.

Em geral, as cenas em volta do grupo de Roger apresentam os ricos como pessoas arrogantes, insensíveis e excêntricas. Em contraposição, o grupo dos operários é construído como formado por pessoas batalhadoras, humildes, sofridas, injustiçadas, cuja satisfação das necessidades vitais, como emprego, moradia e alimentação, estaria ameaçada devido às demissões.

Outra cena que fecha a configuração do grupo dos ricos de Flint é formada pelas imagens de senhoras que jogam golfe. $O$ filme sugere que são senhoras com mais de 60 anos de idade, elas vestem roupas apropriadas à prática daquele esporte, composta de bermudas, suéteres, chapéus, luvas e tênis. As roupas são coloridas em tons pastéis, com algumas peças em branco, o que confere um ar de requinte e sofisticação àquele grupo que frequenta o Clube de Golfe em um dia ensolarado. Nos depoimentos, algumas senhoras dizem que sentem pena dos desempregados, porém reiteram que: "temos um bom programa de assistência social, então eles é que não querem trabalhar". São quatro senhoras em momentos de "boa tacada", naquele clube luxuoso com carrinhos elétricos que circulam sobre gramados impecáveis e outras instalações confortáveis. Outra senhora concede entrevista e, como se soubesse de antemão qual seria a resposta, Moore pergunta se ela acha que os demitidos são pessoas preguiçosas. Entre uma tacada e outra a resposta é: "sim, muitos deles não se esforçam muito".

Novamente, as cenas conformam um grupo de ricos que parece viver sem se importar com os pobres, trazendo para o espectador uma imagem negativa dos mesmos, e que, por sua vez, são tratados de forma pouco contextualizada em suas trajetórias individuais. Além disso, aquele pequeno grupo é construído como portador da opinião de todos os membros de sua classe, isto é, como se os entrevistados representassem todos os ricos da cidade. Com isto, o filme parece impor ao espectador uma imagem negativa de pessoas que, por serem do grupo burguês, não se importariam com outros grupos, sobretudo se "os outros" são pessoas pobres passando por dificuldades devido a 
fatores subjetivos como a "preguiça" de fazer alguma coisa que transforme suas vidas positivamente.

A respeito do imaginário que associa pobreza à inabilidade individual, aludido pelo filme nas cenas dos ricos emitindo opiniões acerca dos pobres, Leandro Karnal aponta que entre as décadas de 1950 e 1960, momento de grande crescimento econômico vivido nos EUA, algumas reformas sociais foram implementadas pelo então presidente Lyndon Johnson, e reduziram a pobreza em 12\%. Os pobres foram beneficiados com vales alimentação, obras públicas, educação, treinamento ocupacional e moradia. Contudo, conforme aponta Karnal, para Johnson e provavelmente para seus eleitores, a pobreza não era consequência das falhas das instituições econômicas ou da diferença no poder econômico "e sim da carência de habilidades, treinamento e motivação entre os pobres" ${ }^{\prime 58}$. Com isto, as políticas sociais de Johnson foram de pouco impacto em longo prazo, e algumas foram revogadas nos governos de Richard Nixon e Gerald Ford. Porém, o discurso de que a pobreza é fruto da inabilidade e falta de motivação entre os mais pobres vigora anos depois dessas políticas, como é percebido nas falas das senhoras que também são construídas como membros da burguesia de Flint, uma delas chega a dizer que as pessoas desempregadas "deveriam fazer um treinamento qualquer".

Essas sequências do filme, que representificam uma construção dos ricos parecendo não se importar com o infortúnio dos pobres, podem ter um efeito negativo para o espectador que assiste ao filme e se posiciona a favor ou contra esse grupo. Contudo, outra análise mais detida pode sugerir que essas atitudes de "classe burguesa" estão relacionadas com a própria forma de existência desse grupo enquanto classe social.

Segundo Marx, a burguesia simplificou os antagonismos de classe superando antigas formas feudais, porém, nesta acepção, continuam as relações sociais entre "opressores e oprimidos"159. Para o autor, o poder executivo do Estado moderno é apenas "uma comissão para gerir os negócios comuns de toda a burguesia"160.

Talvez por causa desse papel secundário que o Estado exerce em meio à luta de classes, conforme sugeriu Marx, que a intervenção estatal não é construída no filme. Por

\footnotetext{
${ }^{158}$ KARNAL, Leandro (et.al.) História dos Estados Unidos: das origens ao século XXI. São Paulo: Contexto, 2010, p. 237.

${ }^{159}$ MARX, K. Manifesto do partido comunista. In: FREEDMAN, Robert. "Escritos Econômicos de Marx". Rio de Janeiro: Zahar Ed. 1966, p.34-46.

${ }^{160}$ MARX, K. Manifesto do partido comunista, op.cit., p.36.
} 
outro lado, nos EUA a intervenção do Estado não é bem vista por grande parcela da sociedade, apegada aos valores do self made man e do livre mercado. As pessoas esperam oportunidades para progredir na vida, preferindo não depender da "vergonhosa" ajuda estatal. Os poucos momentos que os representantes do Estado aparecem em cena são no grupo de mediação, em que tanto o governador do Michigan quanto o prefeito de Flint aparecem ora do lado dos trabalhadores, ora do lado dos empresários, mas sem a possibilidade de propor alguma mudança significativa para as demissões.

Quanto às transformações porque passou a $G M$, diria Marx que não passam de formas de sobrevivência da classe burguesa, pois:

A burguesia não pode existir sem revolucionar constantemente os instrumentos de produção, e com isso as relações de produção e a totalidade das relações da sociedade. A conservação dos velhos modos de produção de forma inalterada foi, pelo contrário, a primeira condição de existência de todas as classes industriais anteriores. $\mathrm{O}$ revolucionamento constante da produção, perturbação ininterrupta de todas as condições sociais, a incerteza e a agitação duradouras distinguem a época burguesa de todas as épocas anteriores. Todas as relações fixas, congeladas, com seu cortejo de velhos e veneráveis preconceitos e opiniões, são varridas, e todas as relações recémformadas se tornam antiquadas antes que se possam ossificar. Tudo o que é sólido se transforma em ar, tudo o que é sagrado é profanado, e o homem é finalmente obrigado a enfrentar, com sentidos sóbrios, suas condições reais de vida e suas relações com os semelhantes. A necessidade de um mercado em constante expansão para os seus produtos persegue a burguesia por toda parte, evidencia-se em toda parte, estabelece ligações em toda parte ${ }^{161}$.

Todo o movimento de reestruturação da $G M$ (sinalizado pelo filme), a demolição de fábricas antigas, a construção de novas e mais modernas instalações, se estendeu por

\footnotetext{
${ }^{161}$ MARX, K. Manifesto do partido comunista. In: FREEDMAN, Robert. "Escritos Econômicos de Marx”. Rio de Janeiro: Zahar Ed. 1966, p. 37.
} 
mais de 31 países $^{162}$. Além disso, a ampliação dos negócios e serviços alcançou 120 países, a construção da nova sede monumental em Detroit, nos anos 1977, fez parte daquilo que Galbraith chamou de "A síndrome Multinacional". Segundo este autor, para a grande empresa moderna não existem mais fronteiras e "aqueles que gostariam de subdividi-la e confinar suas operações às fronteiras nacionais simplesmente estão lutando contra uma realidade histórica e as circunstâncias da vida"163. Galbraith aponta que "faz parte do credo da livre empresa que a General Motors - e a UGE - constituem a obra definitiva de Deus e do homem. Tudo mais pode ser aperfeiçoado; estas não. [...] insinuar a possibilidade ou necessidade de quaisquer modificações é a heresia moderna"164.

Talvez seja por causa da crença neste símbolo da livre iniciativa estadunidense, que o filme Roger e Eu prefere confrontar a pessoa de Roger Smith ou o grupo que ele sinaliza, ao invés de questionar os mecanismos que sustentam uma empresa multinacional e sua necessidade de expansão. $O$ filme não usa diretamente os termos da "luta de classes", mas alude ao conceito na medida em que constrói dois grupos principais na chave de oposição, indicando o histórico conflito discutido por Karl Marx.

Se for considerada a ideia de livre iniciativa, indicada pela burguesia industrial no filme, fica difícil não entender a decisão, se é que ela coube unicamente a Roger Smith, de demitir 30 mil pessoas e transferir a produção para países como o México, além de direcionar parte do capital da GM para a compra de outras empresas lucrativas como a indústria bélica. As movimentações de empresas, símbolos da antiga estabilidade de emprego, para unidades internacionais é um elemento decisivo para a pauperização da classe operária estadunidense e este tema será ampliado no próximo filme de Moore, The Big One.

$\mathrm{Na} 2^{\circ}$ Guerra Mundial, a indústria de automóvel estadunidense, direcionou parte de sua produção, num celebrado esforço de guerra, para produzir caminhões, tanques de guerra entre outros ${ }^{165}$. A GMC Truck, empresa da GM, produziu 600.000 veículos pesados para utilização dos militares. Além disso, a $G M$ produziu o tanque de guerra M41 até 1951, entre outros artefatos para a guerra do Vietnã e para a polícia dentro do

\footnotetext{
${ }^{162} \mathrm{http}: / /$ www.gm.com/corporate. Atualmente o complexo industrial da GM negocia as marcas: Buick, Cadillac, Chevrolet, GMC, Daewoo, Holden, Isuzu, Jiefang, Opel, Vauxhall e Wuling. Seu maior parceiro comercial tem sido a China.

${ }^{163}$ GALBRAITH, John, Kenneth. A grande empresa multinacional. In: "A era da incerteza: história das ideias econômicas e suas consequências”. São Paulo: Pioneira, 1980, p. 280.

${ }^{164}$ GALBRAITH, John, Kenneth. A grande empresa multinacional, op.cit., p. 281.

${ }^{165}$ Esses dados e referências foram extraídos dos seguintes sites: http://www.army-guide.com; http://www.armyguide.com/eng/product1432.html. (Acesso em 15 de janeiro de 2011).
} 
país como o Cadillac Gage Ranger, uma espécie de carro de combate blindado produzido desde 1979 para o grupo de polícia especial conhecido como Swat. Neste sentido, não seria algo inédito a GM comprar a Hughes Aircraft Company, como prefere induzir a pensar as cenas iniciais de Roger e Eu, pois a participação no setor bélico ja era tradição da empresa.

Acerca da gênese histórica das condições que abriram caminho para o início do modo de produção capitalista, cuja origem estaria associada à ética protestante e o modo como esta orientou a vida burguesa, economicamente racional, contribuindo para a expansão do sistema, Weber concluiu sua obra com a constatação de que aos nascidos nessa engrenagem seria dificil escapar do "cumprimento do dever profissional" ${ }^{166}$, pois se "o puritano queria ser um profissional - nós devemos sê-lo" "167. Nas palavras de Weber,

[...] a ascese, ao se transferir das celas dos mosteiros para a vida profissional, passou a dominar a moralidade intramundana e assim contribuiu [com sua parte] para edificar esse poderoso cosmos da ordem econômica moderna ligado aos pressupostos técnicos e econômicos da produção da máquina, que hoje determina com pressão avassaladora o estilo de vida de todos os indivíduos que nascem dentro dessa engrenagem - não só dos economicamente ativos - e talvez continue a determinar até que cesse de queimar a última porção de combustível fóssil. ${ }^{168}$

Nesse sentido, de acordo com a posição que o indivíduo ou grupo social se encontra no sistema capitalista, com o ritmo cada vez mais voraz de suas engrenagens, as consequências de decisões tomadas e/ou sofridas podem ser cada vez mais desumanas, sem contudo, os indivíduos terem alguma forma de poder para agir de modo diferente sem afetarem a si próprios, pois parece que as contradições desse "estado de coisas" vão muito além dos seus agentes individuais.

Após observar a contribuição da religião para a gênese do sistema capitalista, Weber afirma que, ao adquirir força, o capitalismo não precisaria mais da ética protestante para se sustentar, pois sustenta-se em bases mecânicas, e assim,

${ }^{166}$ WEBER, Max. A ética protestante e o "espírito" do capitalismo. São Paulo: Cia das Letras, 2004, p. 165.

${ }^{167}$ WEBER, Max. A ética protestante e o "espírito" do capitalismo, op.cit., p. 165.

${ }^{168}$ WEBER, Max. A ética protestante e o "espírito” do capitalismo, op.cit., p. 165. 
O capitalismo vitorioso, em todo caso, desde quando se apoia em bases mecânicas, não precisa mais desse arrimo [a ascese protestante]. Também a rósea galhardia de sua risonha herdeira, a Ilustração, parece definitivamente fadada a empalidecer, e a ideia do "dever profissional" ronda nossa vida como um fantasma das crenças religiosas de outrora. A partir do momento em que não se pode remeter diretamente o "cumprimento do dever proficional" aos valores espirituais supremos da cultura - ou, vice-versa, também não se pode mais experimentá-lo subjetivamente como uma simples coerção econômica - aí então o indivíduo de hoje quase sempre renuncia a lhe dar uma interpretação de sentido. ${ }^{169}$

Até este ponto da análise, buscou-se evidenciar a construção que o filme faz da classe burguesa, associada a um grupo de pessoas que convivem em torno da crença comum em favor do empresariado, da livre-concorrência, do direito à propriedade e de herança. Quando Moore segue de carro pelos bairros considerados "nobres" ele diz que Smith é um nome comum por alí, o que denota a representatividade social daquelas famílias que poderiam, sucessivamente, transmitir não apenas um nome destacado naquela sociedade para seus herdeiros, como também suas propriedades e negócios.

A construção dos grupos na chave de classe social terá continuidade com a classe operária ou proletária no próximo ítem. Esta construção revela a voz que emana do filme, ou ainda, o ponto de vista que o narrador do filme se alinha.

Bill Nichols aponta que o filme possui uma voz que dá o tom do discurso proferido pela construção narrativa, esta seria "o meio pelo qual esse ponto de vista ou essa perspectiva singular se dá a conhecer" ${ }^{\prime 170}$.

A voz narrativa em Roger e Eu possui um viés à favor dos operários e suas famílias, ou do proletariado. Contudo, as explicações que essa voz narrativa oferece para o problema, entre os dois principais grupos formados, sintetizam uma questão social muito mais ampla do que a atitude individual de Roger Smith, embora o filme não deixe de sinalizá-las como forma de apontar questões do seu contexto. As atitudes que envolvem o grupo, no qual se encontra Roger Smith, fazem parte do seu próprio

${ }^{169}$ WEBER, Max. A ética protestante e o "espírito" do capitalismo. São Paulo: Cia das Letras, 2004, p. 166.

${ }^{170}$ NICHOLS, Bill. O que dá aos documentários uma voz própria? IN: "Introdução ao documentário". Campinas: Papirus, 2005, p.73. 
meio de sobrevivência, e estaria o empresário agindo mais como capitalista racional do que como um "vilão" contra o proletariado, pois, caso contrário, a própria GM poderia entrar em crise, neste mercado cada vez mais concorrido e transnacional. A crise financeira na $G M$, sinalizada em Roger e Eu, ocorrerá anos mais tarde e será lembrada no último filme de Moore: Capitalism: a love story (2010).

Roger e Eu é um filme que envolve alguns tipos de documentários classificados por Bill Nichols, numa espécie de tipologia norteadora para diferenciar os documentários já produzidos na história do cinema. Esta tipologia de filmes documentários não deve ser tomada como "pura" e sim como um "tipo-ideal" no sentido dado por Weber, porque se tomados isoladamente não designariam nenhum dos filmes de Michael Moore que parecem mesclar alguns desses tipos. Assim, se tomados como "tipo-ideal"171, como constructo metodológico que não encontra um referencial direto na realidade, essas características auxiliam a perceber as escolhas realizadas por Michael Moore e sua equipe de produção.

Nesse sentido, Roger e Eu possui uma estrutura básica de filme expositivo, sem a voz de Deus no sentido tradicional ${ }^{172}$, já que a voz da narração pode ser percebida ou vista como sendo a de Michael Moore, com uma "lógica informativa transmitida verbalmente" ${ }^{\prime 17}$ que é uma característica do filme de tipo expositivo. Suas imagens desempenhariam papel secundário, pois "ilustram, esclarecem, evocam ou contrapõem o que é dito" ${ }^{174}$. Apesar de não ter a característica tradicional da voz de Deus (onisciência e onipresença), o filme coloca seu narrador no lugar da voz de Deus, pois em vários momentos sua narração "toma ares de onisciência" e passa a explicar as intenções de Roger Smith como se as pudesse conhecer. Além disso, o narrador confere voz de autoridade aos seus comentários, não oferecendo ao espectador margem para duvidar do que é dito.

\footnotetext{
${ }^{171} \mathrm{O}$ conceito de tipo-ideal, criado por Weber, refere-se a uma construção metodológica que visa a construção lógica de uma análise social, um tipo ideal de cristianismo, por exemplo, não significa um conceito pelo qual se mede a realidade, e sim um ideal de cristianismo pelo qual se julga a realidade avaliando-a. Um tipo ideal não tem correlato empírico, mas fornece a possibilidade de "interpretação avaliadora" do cristianismo. Nesse sentido, os tipos de documentário de Nichols serão tomados como esquemas lógicos para avaliar os filmes de Moore. Sobre tipo-ideal conferir: WEBER, Max. A "objetividade" do conhecimento nas ciências sociais. IN: COHN, Gabriel. "Weber: sociologia". São Paulo: Ática, 2005 (7 $7^{\mathrm{a}}$ edição), p. 79-127.

${ }^{172}$ Entendida a partir de Bill Nichols como sendo uma "voz masculina profissionalmente treinada, cheia e suave em tom e timbre, que mostrou ser a marca da autenticidade do modo expositivo" também é característica dessa voz que seu orador jamais seja visto. Cf. NICHOLS, Bill. Que tipos de documentários existem? In: Introdução ao documentário. Campinas: Papirus, 2005, p. 142.

${ }^{173}$ NICHOLS, Bill. Que tipos de documentários existem? IN: Introdução ao documentário. Campinas: Papirus, 2005, p. 143.

${ }^{174}$ NICHOLS, B. Que tipos de documentários existem? Op. cit., p.143.
} 
Os comentários de Moore durante o filme, aos moldes do tipo expositivo, "servem para organizar nossa atenção e enfatizar alguns dos muitos significados e interpretações de um fotograma. Portanto, presume-se que o comentário seja de ordem superior à das imagens que o acompanham"175.

Em Roger e Eu, Michael Moore se coloca discretamente como voz de Deus e abertamente como narrador privilegiado desta história, de modo que sua fala soe como "conselho do comentário e vemos imagens como comprovação ou demosntração do que é dito [...]. É o modo ideal para transmitir informações ou mobilizar apoio dentro de uma estrutura preexistente ao filme" ${ }^{, 176}$.

O tipo de documentário expositivo, que estrutura Roger e Eu, "agrupa fragmentos do mundo histórico numa estrutura mais retórica ou argumentativa [...] dirige-se ao espectador diretamente, com legendas ou vozes que propõem uma perspectiva, expõem um argumento ou recontam a história"177. Assim, as cenas de Roger e Eu, apontam para um narrador cujo discurso parte do seu lugar social, sua família, sua infância e é através da posição ocupada nesta sociedade que Moore confere legitimidade à sua narração no filme, a fim de convencer o espectador que "ele sabe do que está falando".

De volta ao filme, dizendo-se disfarçados de uma equipe de TV de Toledo, Moore e sua produção conseguem filmar o último carro sendo montado em uma das fábricas da GM que encerraria as atividades naquele dia. Vários funcionários aparecem em cena, estão vestidos de modo informal, sem uniformes, muitos sorrindo e aparentemente felizes, como se estivessem em mais um dia de trabalho ou de dever cumprido. Porém, outro funcionário alerta que não deveriam se alegrar nem aplaudir o último carro que saiu daquela esteira, porque estavam todos demitidos. Esta fala entra como resposta do filme às cenas de alegria anterior. Diferentemente do funcionário da administração que em seu depoimento parecia ter ciência do estado da empresa, ao dizer que aquilo não era o fechamento de uma fábrica e sim a perda de uma linha de produtos, os funcionários da esteira de produção não pareciam muito conscientes da situação e, curiosamente, celebravam o último dia de trabalho fazendo gestos e sorrindo para as câmeras.

\footnotetext{
${ }^{175}$ NICHOLS, B. Que tipos de documentários existem? Op. cit., p.143.

${ }^{176}$ NICHOLS, B. Que tipos de documentários existem? Op. cit., p. 143.

${ }^{177}$ NICHOLS, B. Que tipos de documentários existem? Op. cit., p. 142.
} 
Se os jornais falavam em números de demitidos e os burgueses pensam na expansão dos negócios, em cifras ou novos investimentos, o filme aproxima a câmera do personagem $E U$ que consta no título e é construído na figura de alguns demitidos apresentados não como números, não como parte do exército industrial de reserva, mas como pessoas com rostos, falas e problemas pessoais.

Robert Kurz aponta que o aumento do "desemprego estrutural de massas"178 é produto do "mercado globalizado" que rompeu as barreiras do chamado "Terceiro Mundo". Isto pode ser visto, ainda que em menor proporção, no mundo ocidental, de forma ainda mais evidente "nos países anglo-saxões, com o seu radical liberalismo econômico de matiz clássico" "179 . Por desemprego estrutural de massa, Kurz entende que se trata de um fenômeno recente na história da modernização, pois anteriormente este era um fenômeno cíclico, cujo "exército industrial de reserva", na visão de Marx, era reconduzido aos postos de trabalho na fase de "recuperação cíclica da conjuntura". Contudo, nas chamadas "crises econômicas" esse exército se amplia em considerável proporção e sem perspectiva de recolocação em novos postos de trabalho.

Os desempregados foram considerados apenas como exército de reserva para a próxima recuperação conjuntural e assim ficavam à disposição para a reabsorção como força de trabalho no movimento de valorização do capital. Isso parece que acabou. De ciclo para ciclo, e totalmente independente de seus altos e baixos, aumentou o desemprego natural ${ }^{180}$.

Nesse sentido, para Kurz, o crescente desemprego de base tornou-se um fenômeno global acrescido de um componente paradoxal: não seria a crise do capital e sim a do trabalho, e o cerne da crise está ligado ao processo de racionalização do qual Roger Smith faria parte no filme Roger e Eu. Nos momentos em que Moore acusa Smith de ser o causador das demissões e dos despejos de muitas pessoas em Flint, o empresário não parece entender o apelo social das perguntas, pois sua visão acerca da $G M$ e dos negócios está ancorada no processo de "racionalização organizacional" de que fala Kurz como sendo,

\footnotetext{
${ }^{178}$ KURZ, Robert. Com todo vapor ao colapso. Juiz de Fora, MG: Editora UFJF - PAZULIN, 2004, p. 203.

${ }^{179}$ KURZ, R. Com todo vapor ao colapso, op.cit., p. 204.

${ }^{180}$ KURZ, R. Com todo vapor ao colapso, op.cit., p. 17.
} 
[...] a automatização de processos de produção, redução de linhas organizacionais, portanto, aquela racionalização organizacional pela qual se racionaliza e elimina tão fortemente a força de trabalho em todo o território; isto causa um aumento de produtividade em tal medida que ultrapassa a capacidade de absorção de trabalho vivo pelo capital em sua valorização, nos processos de produção empresariais. Esta constatação enfrenta a crítica de economistas de todas as orientações. Aumento da produtividade, dizem eles, significa também ampliação dos mercados e, assim, mais cedo ou mais tarde, a superação da crise, portanto, nova prosperidade e em algum momento a redução do desemprego em massa ${ }^{181}$.

Para Kurz, esta ideia dos economistas acerca da redução do desemprego em massa seria uma ilusão de ótica, porque considera apenas a racionalização até o início da microeletrônica, como se as coisas permanecessem da mesma maneira e a racionalização mais atual - que neste filme está associado à racionalização implantada no caso da GM por Roger Smith - situa-se no que o autor chamou de "novo degrau da racionalização organizacional sob o lema da lean production (produção enxuta)"182.

Voltando ao ponto inicial da explicação de Kurz, a produção fordista é considerada como o período que segue a partir da $1^{\mathrm{a}}$ Guerra Mundial e se estende até o final da década de 70. Sua característica básica é a racionalização da produção, ampliando o mercado de trabalho devido à aplicação dos "métodos de racionalização da nova ciência do trabalho" criados por Frederick Taylor e ampliados por Henry Ford. A grande inovação deste processo de trabalho foi à introdução da esteira, "copiada por Ford dos matadouros de Chicago"183. Essas inovações aumentaram a produção de carros, que antes da $1^{\text {a }}$ Guerra era de "6 a 10 mil automóveis por ano" para "248 mil automóveis em 1914," conferindo notoriedade à figura de Henry Ford e ampliação deste modelo de trabalho em "todos os cantos do mundo"184.

Para finalizar a ideia de racionalização da produção de mercadorias no modo de produção capitalista e o crescente desemprego que é seu produto antagônico, Kurtz lembra que até Lênin interessou-se pelos métodos fordistas ao dizer que "nós

\footnotetext{
${ }^{181}$ KURZ, R. Com todo vapor ao colapso. Juiz de Fora, MG: Editora UFJF - PAZULIN, 2004, p. 20.

${ }^{182}$ KURZ, R. Com todo vapor ao colapso, op.cit., p. 25.

${ }^{183}$ KURZ, R. Com todo vapor ao colapso, op.cit., p. 21.

${ }^{184}$ KURZ, R. Com todo vapor ao colapso, op. cit., p. 22.
} 
precisamos adotar este último grito da ciência, da tecnologia e da racionalização ocidentais" $" 185$. Apesar do filme utilizar o caso da GM, Kurz aponta que o modo de produção fordista foi apropriado pela indústria em geral,

[...] a indústria de eletrodomésticos e de entretenimentos eletrônicos, a indústria de alimentos, a distribuição de alimentos e de utilidades domésticas, o que hoje tem como consequência a eliminação das pequenas mercearias pelos grandes supermercados. Também a mecanização e industrialização da agricultura foi fortemente impulsionada: não só os carros ficaram mais baratos mas também os tratores $^{186}$.

Este avanço tecnológico não ampliou a oferta de empregos para atender a demanda crescente. $\mathrm{O}$ trabalho sofreu mudanças significativas que o filme, com seu saudosismo dos anos dourados da economia americana na década de 1950, sinalizou na atualidade das 30 mil demissões em Flint.

Nesse sentido, segundo Richard Sennett:

A automação, outro aspecto da revolução tecnológica, teve uma consequência profunda na pirâmide burocrática: a base de uma instituição já não precisa ser grande. Tanto no trabalho braçal quanto no intelectual, as organizações podem já agora disseminar tarefas rotineiras de maneira eficiente, graças a inovações como os códigos de barras, tecnologias de identificação de voz, os escaneadores de objetos tridimensionais e as micromáquinas que fazem o trabalho dos dedos. [...] A consequência dessa capacidade tecnológica é que a inclusão das massas - o elemento social do capitalismo social - pode ficar para trás. O provável é que fiquem de fora apenas os elementos mais vulneráveis da sociedade, os que desejam trabalhar, mas não dispõem de capacitações especializadas. Naturalmente, as indústrias e escritórios de outros tempos não eram geridos como instituições de caridade. [...] Criar empregos para todos dessa maneira antiga hoje em dia é desafiar ou ignorar a força da moderna tecnologia. ${ }^{187}$

\footnotetext{
${ }^{185}$ KURZ, R. Com todo vapor ao colapso. Juiz de Fora, MG: Editora UFJF - PAZULIN, 2004, p. 22.

${ }^{186}$ KURZ, R. Com todo vapor ao colapso, op. cit., p. 23-24.

${ }^{187}$ SENNETT, R. A cultura do novo capitalismo. Rio de Janeiro: Record, 2006, p. 46.
} 
As constatações dos teóricos escolhidos evidenciam profundas mudanças no mundo do trabalho, nas empresas e consequentemente no capitalismo, de modo a possibilitar a ideia colocada no início deste capítulo, de que Roger e Eu apresenta um conflito de classe que torna cada vez mais improvável a realização do "sonho americano".

Alguns grupos, que serão apresentados no bloco de saídas para a crise, conseguem se mantêr minimamente inseridos no mercado de trabalho porque possuem pelo menos dois membros em setores diferentes da economia, como será visto no caso dos operários que têm companheiras empregadas no setor de serviços.

As cenas, com operárias e operários demitidos, apresentadas nas sequências do filme, os colocam em diferentes escalas hierárquicas, eles falam para as câmeras acerca do seu descontentamento com a situação em que se encontram e responsabilizam Roger Smith pelas demissões.

De todos os entrevistados, uma senhora de visual formal chama atenção pelo modo como se refere ao diretor da $G M$, com um discurso de tom calmo e educado. Questionada sobre o que diria a Roger Smith, ela diz:

$\neg$ Diria a ele que pegasse seus milhões e devolvesse aos trabalhadores. Estou farta desses fat cats. Eu poderia dizer poucas e boas, mas sou uma dama e fui educada como tal, então eu não direi o que realmente sinto, mas poderia usar alguns palavrões para denominar esses fat cats.

Enquanto os demais proferiam palavras de ordem, por exemplo: "fora Roger Smith", ou, "Roger Smith deveria se aposentar", a senhora diz que está cansada desses fat cats. O termo fat cat está relacionado, nos Estados Unidos, aos homens ricos que fazem doações aos políticos ou a um homem de grande poder financeiro. O termo é usado desde os anos de 1920 quando Frank Richardson Kent (1877-1958) um escritor do jornal Baltimore Sun usou o termo num artigo intitulado "Fat Cats and Free Rides ${ }^{\prime 188}$ em seu artigo, datado de 1925, Kent escreveu:

\footnotetext{
${ }^{188}$ Fonte: http://www.barrypopik.com/index.php/new_york_city/entry/fat_cat/. O termo é usado até hoje como pode ser visto no site: http://www.time.com/time/printout/0,8816,877421,00.html.(Acesso em 20 de janeiro de 2011).
} 
Talvez seja importante explicar que Fat Cat é a expressão significativa e reveladora nos círculos políticos elegantes que se refere aos companheiros ricos que entram na política por uma razão ou outra, e cuja reputação e sucesso dependem da generosidade com que eles desembolsam os dólares ${ }^{189}$.

Além do jogo de influência, disputado através do poder conferido pelo dinheiro, este termo estaria associado a um tipo de pessoa que, como um "gato gordo", se "alimenta" de dinheiro a ponto de obter grandes reservas, aludindo ao acúmulo de gordura. A senhora soube colocar de forma elegante um termo de uso antigo no país.

Outro operário do qual Moore toma depoimento no filme é Ben, a mesma pessoa que anos antes tinha sido colocada na capa da revista californiana. Após várias demissões e readmissões Ben estava internado em um tipo de sanatório em decorrência do nível de ansiedade e incerteza a que foi exposto nos últimos anos. Ele conta em seu depoimento como perdeu o controle de si, sofrendo uma espécie de crise nervosa enquanto trabalhava na linha de montagem, abandonando suas funções para dirigir sem rumo pelas ruas da cidade. Relata que ao ligar o rádio e ouvir a música Wouldn't It Be Nice (não seria legal) dos Beach Boys, tentava cantar a letra e se controlar, mas era como "se tivesse uma maçã entalada na garganta".

Para reviver a sensação que Ben sentiu, o filme reproduz para o espectador a música Wouldn't It Be Nice em composição com cenas feitas da perspectiva de uma pessoa que, dentro de um carro em movimento, dirige pelas ruas de Flint em bairros aparentemente abandonados, com casas vazias, danificadas, e muito lixo nos arredores. Esse modo de associar imagem e música cujos sentidos contrastam, aprofunda o efeito de ironia que permeia boa parte do filme, não deixando dúvidas ao espectador que a GM prejudicou os trabalhadores e a cidade. Para reforçar a ideia de decadência geral, o filme inclui imagens de ratos enormes caminhando em meio ao lixo de ruas escuras, e a veiculação disso em um noticiário da TV local, tudo para dar a sensação de que Flint

\footnotetext{
${ }^{189}$ No original: "It ought perhaps to be explained that Fat Cat is the significant and revealing name in political circles for the sleek, rich fellows who enter politics for one reason or another and depend for their standing and success upon the liberality with which they shell out the dollars".

Fonte: http://www.barrypopik.com/index.php/new_york_city/entry/fat_cat/. Acesso em 15 de fevereiro de 2011.
} 
encontra-se em decadência generalizada e, mesmo que aquelas cenas fossem de um lugar específico, acabam por representar toda a cidade.

Acerca do contraste entre o uso de música e cena, Menezes pontua como esse recurso foi observado no filme de Stanley Kubrick Laranja Mecânica (1971) - em uma cena de estupro ao som da ópera La Gazza Ladra, de Rossini. Para o autor, a dramaticidade da cena é atenuada pelo som da ópera e pela expressão tranquila de Alex que destoam das imagens de sua gang arrastando uma moça em uma tentativa de estupro $^{190}$. Posteriormente, outros filmes também usam o recurso de som em contraste com imagens, por exemplo, Lars Von Trier em Dogville (2003) e Manderlay (2005). Ambos os filmes contêm em suas sequências finais, algumas fotos de pessoas em momentos de sofrimento e miséria ao som de The Youngs Americans, de David Bowie. Essas construções parecem acentuar as contradições e os conflitos entre os grupos sociais construídos nesses filmes.

Em mais um momento relacionado aos trabalhadores, o filme apresenta uma nova Big Parade ocorrida na cidade de Flint. Esta Parada é contemporânea às últimas demissões em finais dos anos 1980, no entanto é diferente das ocorridas nos anos dourados da cidade, apresentadas no início do filme. Em meio a um público reduzido e desanimado, a câmera focaliza o rosto de um homem que cochila em sua cadeira na calçada ao invés de assistir o desfile do palhaço Ronald MacDonald's que, segundo Isleide Fontenelle, representa "um símbolo da nova economia global", da "cultura do descartável", do "consumo de massa" e é a logomarca mais reconhecida em todo o mundo $^{191}$.

Moore anuncia que, com 30 mil empregos ao menos, essa parada fez homenagem aos sobreviventes da greve de 1937, um gesto que, segundo o cineasta, parece tão decadente quanto o fechamento das fábricas. A atração dessa parada foi a Miss Michigan, Kaye Lani Rae Rafko, entrevistada por Moore em um momento de total despreparo, pois foi pega de surpresa com perguntas aparentemente difíceis de responder acerca da economia local e do fechamento das fábricas - assuntos

\footnotetext{
${ }^{190}$ MENEZES, P. À meia luz: cinema e sexualidade nos anos 70. São Paulo: Ed. 34, 2001, p. 57.

${ }^{191}$ Segundo a autora, a marca Mc Donald's foi eleita em 1997, pela Interbrand consultoria inglesa, a número um do mundo em termos de reconhecimento, desbancando as duas outras poderosas marcas globais, Coca-Cola e Disney, que ficaram respectivamente, com o segundo e terceiro lugares; os arcos dourados, sua logomarca, já se tornaram mais conhecidos do que a cruz cristã, e são o segundo símbolo mais conhecido do planeta, só perdendo para os jogos olímpicos [...] o clown Ronald McDonald - só perde para Papai Noel em termos de reconhecimento das crianças americanas, conforme pesquisa realizada pela companhia ainda em 1986, p.28. IN: FONTENELLE, Isleide A. $O$ nome da marca: McDonald's, fetichismo e cultura descartável. São Paulo: Boitempo editorial, 2002, p. 25 - 31.
} 
aparentemente distantes do cotidiano de quem vive nos concursos de beleza. Michael Moore pedia um posicionamento da Miss que queria "curtir o momento" de festa. Ao perceber como Rafko se contradiz nas respostas não sabendo se posicionar nem ao lado da $G M$ nem ao lado dos trabalhadores, Moore termina a entrevista deixando que a moça expresse suas expectativas em relação ao próximo concurso, quando ela se tornaria Miss America 1988, pelo estado do Michigan. Apesar deste destaque final o filme não deixou de usar a imagem da Miss como uma pessoa passível de ser interpretada por "fútil" devido sua participação nos tradicionais concursos de beleza.

Acerca da entrevista com a Miss, Bill Nichols aponta que a atuação de Moore implicou em uma questão ética porque fez Rafko parecer uma "boba" diante da câmera. Diante das questões éticas que surgem nos documentários Nichols diz:

A ética torna-se uma medida de como as negociações sobre a natureza da relação entre o cineasta e seu tema têm consequências tanto para aqueles que estão representados no filme como para os espectadores. Os cineastas que têm a intenção de representar pessoas que não conhecem, mas que tipificam ou detêm um conhecimento especial de um problema ou assunto de interesse, correm o risco de explorá-las ${ }^{192}$.

O governador do Michigan, James Blanchard, é, juntamente com a Miss, membro de um terceiro grupo do sistema relacional do filme, chamado aqui de grupo de intermediação, porque não fazem parte nem do grupo dos operários nem dos burgueses. Apesar de sua postura pró-empregos, o governador pouco parece influenciar a decisão dos empresários e, aparentemente, a política naquela região. O governador considera trágicas as demissões em massa, contudo, não acredita que nenhuma mobilização coletiva possa reverter a situação. As participações do governador do Michigan e do prefeito de Flint no filme são insignificantes, isso pode estar associado ao ideal da economia liberal estadunidense que preconiza a participação mínima do Estado nos assuntos econômicos. Portanto, não é ao Estado que o filme se refere como responsável pelas demissões e sim a Roger Smith e, no limite, ao seu grupo social.

Ainda nas cenas da Parada, Moore entrevista Owen Bieber, presidente do UAW, e pergunta se uma nova greve daria fim às demissões. Como o filme constrói o sindicato como uma instituição influenciada por Roger Smith, Bieber é apresentado com

\footnotetext{
${ }^{192}$ NICHOLS, Bill. Introdução ao documentário. Campinas: Papirus, 2005, p. 36.
} 
inclinação para o lado do grupo de Roger, e diz que não acredita no poder de mobilização por greve. A opinião do filme a respeito de Bieber vem na cena seguinte em que um representante do sindicato, um jovem homem negro, é entrevistado por Moore. Este jovem afirma que o sindicato perde força, porque "muitos caras do sindicato são amigos da gerência”.

Em seu modo didático de contraposição de imagens, o filme corta do discurso do trabalhador negro para o discurso inexpressivo de Bieber, em meio às cenas de moças que dançam no desfile. As cenas de moças dançando ao som da fala de Bieber, sobre a possibilidade de crescimento econômico para a cidade apesar do fechamento das fábricas, parecem indicar, em tom de brincadeira, que nenhuma mudança em relação ao trabalho operário estaria no horizonte de Flint. O sentido a que aquelas imagens aludem é que o discurso de Bieber não seria mais sério do que às imagens daquelas moças dançando alegremente.

Assim, nesta sucessão de cenas que compõem o discurso do filme, o jovem negro dá o tom da fala final sobre esta última parada dizendo: "algumas pessoas sabem a hora certa, outras pessoas não". Essa fala do sindicalista pode indicar a "missão" de Michael Moore no filme, mostrar para aqueles que ainda não sabem disso, que é hora de parar, ou ainda, de cruzar os braços e fazer uma nova greve em prol dos empregos perdidos, pois afinal, o filme mostra que ainda existiam fábricas em funcionamento em Detroit e outras localidades dos EUA. Contudo, pode-se pensar, para além dessas questões mais candentes apresentadas pelo filme, que tipo de transformações ocorreram no mundo do trabalho para que as pessoas não se dispusessem mais a fazer grandes greves como a de 1936, ou para que estejam desmotivadas em relação a uma solução coletiva.

Nesta direção, Zygmunt Bauman pode indicar algumas das transformações que ocorreram no mundo do trabalho com aquilo que chamou de ascensão e queda do trabalho. $\mathrm{O}$ autor explica que no dicionário Oxford consta o uso da palavra trabalho (labour), no sentido de esforço físico em busca de satisfação das necessidades materiais de uma comunidade, e isso foi registrado em 1776. Segundo Bauman, o uso inglês da palavra estrutura "a trindade do trabalho" 193 em aproximar o trabalho à identidade do indivíduo e a uma classe, a ligação de trabalho como fonte de bem-estar da sociedade e a autoafirmação do movimento trabalhista. Segundo o autor,

\footnotetext{
${ }^{193}$ BAUMAN, Z. Modernidade líquida. Rio de Janeiro: Zahar, 2001, p. 161.
} 
[...] a proximidade (de fato, a convergência semântica ligada à identidade de destino) entre a significação atribuída ao trabalho (essa labuta "física e mental"), a autoconstituição dos que trabalham numa classe e a política fundada nessa autoconstituição - em outras palavras, a ligação entre definir a labuta física como principal fonte da riqueza e bem-estar da sociedade, e a autoafirmação do movimento trabalhista. Ascenderam juntos e juntos caíram ${ }^{194}$.

Bauman lembra que a sociedade industrial nascida na Grã-Bretanha, teve como característica diferenciadora dos demais países europeus a destruição de seu campesinato e, por extensão, "a ligação "natural" entre terra, trabalho humano e riqueza"195, de modo que a emancipação do trabalho de suas "limitações naturais"196 colocou o trabalhador em uma nova ordem construída por uma forma racional de exploração da força de trabalho. A construção da nova ordem industrial estava localizada em "fábricas gigantescas lotadas de maquinarias volumosas e multidões de operadores de máquinas, ou densas redes de canais, pontes e trilhos" ${ }^{197}$ num ideal construído para "atar capital e trabalho numa união que - como um casamento divino nenhum poder humano poderia, ou tentaria, desatar" ${ }^{\prime 198}$. O estadunidense Henry Ford foi um símbolo desse ideal, ao buscar explorar o máximo da força de trabalho de seus operários, aumentou os salários e desejava que seus operários pudessem ganhar o suficiente para comprar os carros que construíam;

[...] os carros comprados pelos trabalhadores da Ford eram uma fração mínima das vendas totais, enquanto o aumento dos salários pesava nos custos de produção da empresa. A verdadeira razão para o passo heterodoxo era o desejo de Ford de deter a mobilidade irritantemente alta do trabalho. Ele queria atar seus empregados às empresas Ford de uma vez por todas, fazendo com que o dinheiro gasto em sua preparação e treinamento se pagasse muitas vezes, por toda a duração da vida útil dos trabalhadores. E para alcançar tal efeito tinha que imobilizar sua equipe, para mantê-los onde estavam, de preferência

\footnotetext{
${ }^{194}$ BAUMAN, Z. Modernidade líquida. Rio de Janeiro: Zahar, 2001, p.161.

${ }^{195}$ BAUMAN, Z. Modernidade líquida, op.cit., p.163.

${ }^{196}$ BAUMAN, Z. Modernidade líquida, op.cit.

${ }^{197}$ BAUMAN, Z. Modernidade líquida, op.cit., p.165.

${ }^{198}$ BAUMAN, Z. Modernidade líquida, op.cit., p. 166.
} 
até que sua força de trabalho fosse inteiramente utilizada. Tinha que torná-los tão dependentes do emprego em sua fábrica e vendendo seu trabalho a seu dono como ele mesmo dependia de empregá-los e usar seu trabalho para sua própria riqueza e $\operatorname{poder}^{199}$.

Esse histórico do trabalho operário na sociedade industrial possibilita apreender as mudanças drásticas por que passam os operários da $G M$ em Flint, tornados mão de obra tornada obsoleta. Neste contexto de queda do trabalho, a palavra de ordem é a flexibilidade ou o fim da antiga definição de emprego, com a ascensão de novas relações de trabalho caracterizadas "por contratos de curto prazo, ou sem contratos, posições sem cobertura previdenciária, mas com cláusulas "até nova ordem","200, saturando a vida do trabalhador de incertezas.

Ainda com Bauman, podem-se visualizar os desdobramentos de uma ascensão $e$ queda do trabalho nas mudanças observadas entre a passagem de uma "modernidade sólida" ou capitalismo pesado, tempo "do engajamento entre capital e trabalho fortificado pela mutualidade de sua dependência"201, para uma modernidade líquida cuja fluidez abandonou os operários à própria sorte como as cenas que o filme mostrará com os despejos. Conforme o autor ${ }^{202}$, na sociedade industrial ou modernidade sólida, os trabalhadores dependem do emprego para sobrevivência, pois estão afastados da propriedade e dos modos de existência típicos da antiga vida campesina. O capitalista dependia tanto dos trabalhadores como esses dependiam dele, contudo, com os avanços na tecnologia, incremento de máquinas, braços robóticos, e exploração da mão de obra cada vez mais barata, um grande volume de desempregados se formou, principalmente entre aqueles que não conseguem acompanhar o ritmo das mudanças, ou da fluidez da modernidade líquida.

É no conjunto das transformações desse contexto que os moradores de Flint viram a cidade se desenvolver nos anos 1950 e 60, como o filme construiu nas cenas dos antigos desfiles - graças aos benefícios trazidos pela fábrica nos moldes da esteira fordista. Contudo, nos anos finais da década de 1980, esses trabalhadores entraram, definitivamente, em um período de transição, ou como propõe Bauman, para a

\footnotetext{
${ }^{199}$ BAUMAN, Z. Modernidade líquida, Rio de Janeiro: Zahar, 2001, p.166.

${ }^{200}$ BAUMAN, Z. Modernidade líquida, op.cit., p.169.

${ }^{201}$ BAUMAN, Z. Modernidade líquida, op.cit., p. 166.

${ }^{202}$ Cf. BAUMAN, Zigmunt. Modernidade líquida. Rio de Janeiro: Zahar, 2001.
} 
modernidade líquida, em que a rapidez das transformações observadas nas relações de trabalho não absorve a todos, deixando alguns trabalhadores à deriva.

Ainda acerca as mudanças no trabalho, Sennett aponta para

A fragmentação das grandes instituições deixou em estado fragmentário as vidas de muitos indivíduos [...] a vida familiar se viu desorientada pelas exigências do trabalho; a migração tornou-se o verdadeiro ícone da era global, e a palavra de ordem é antes seguir em frente que estabelecer-se. $\mathrm{O}$ desmantelamento das instituições não gerou maior senso comunitário ${ }^{203}$.

Nesta direção, estariam os moradores de Flint em busca de certezas e oportunidades para combater temores e ansiedades decorrentes dessa nova condição de vida fluida em que eles se sentem à deriva. Acerca dos sentimentos que vigoram nesse contexto de aparente falta de mobilização dos moradores de Flint, como insiste o filme, diria Bauman,

Os medos, ansiedades e angústias contemporâneos são feitos para serem sofridos em solidão. Não se somam, não se acumulam numa "causa comum", não têm endereço específico, e muito menos óbvio. Isso priva as posições de solidariedade de seu status antigo de táticas racionais e sugere uma estratégia de vida muito diferente da que levou ao estabelecimento das organizações militantes em defesa da classe trabalhadora. ${ }^{204}$

A busca por novas oportunidades poderia ser o foco dos trabalhadores de Flint, de modo que não estariam estimulados a cruzar os braços ou se mobilizar em favor da manutenção dos antigos empregos, ou ainda, transitar de fábrica em fábrica protestando pelas mudanças no capitalismo global. Ao invés disso, os trabalhadores poderiam estar à procura de novas oportunidades, cada vez mais escassas, e talvez fosse mais importante, como sugeriu Giddens ${ }^{205}$, buscar a "estabilidade no eu interior" do que coletivamente como fizeram os grevistas de Flint em 1936.

\footnotetext{
${ }^{203}$ SENNETT, R. A cultura do novo capitalismo. Rio de Janeiro: Record, 2006, p. 12.

${ }^{204}$ SENNETT, R. A cultura do novo capitalismo. Rio de Janeiro: Record, 2006, p. 170.

${ }^{205}$ GIDDENS, A. As consequências da modernidade. São Paulo: Ed. UNESP, 1991, p. 118.
} 
Esta estabilidade "no eu interior" poderia significar a tomada de decisão individualmente ou, no limite, em família, mas não de forma coletiva, visto que essas pessoas não teriam a quem recorrer em "um mundo de autoridades múltiplas"206. Uma funcionária dos correios de Flint afirma que cadastrou, nos últimos meses, mais de 82 mil mudanças de endereço de pessoas que saíram da cidade. Essas pessoas provavelmente devem ter migrado em busca de novas oportunidades, ou ainda, estariam na direção de uma política para suas próprias vidas, reagindo, assim, contra as condições sociais instáveis e fragmentárias por que passavam em Flint.

Em Roger e Eu, o operário Ben é construído como quem sucumbiu diante das ansiedades geradas em razão das transformações no mundo do trabalho. Ben sofreu com tantas demissões, ao longo de sua "carreira" na fábrica, que não pode sequer concretizar uma ideia de "política-vida" 207 ou a tentativa de gerenciar sua situação, entrando em um estado de ansiedade extrema que o levou para um sanatório psiquiátrico.

Em um diálogo entre Giddens, Beck e Lasch, acerca da modernidade reflexiva e as consequências no cotidiano das pessoas, esse último autor aponta que,

(...) só se atinge a modernidade reflexiva com a crise da família nuclear e a concomitante auto-organização das narrativas de vida; com o declínio da influência das estruturas de classe sobre os agentes - na escolha do comportamento, nos padrões de consumo e na participação nos sindicatos; com o deslocamento da produção limitada por regras pela flexibilidade no trabalho com a nova desconfiança ecológica e crítica à ciência institucionalizada ${ }^{208}$.

Contudo, essas novas demandas sociais não podem ser satisfatoriamente vividas por todos, devido, entre outros fatores, às dificuldades de adaptação de cada pessoa diante das mudanças. O operário Ben, que teve uma crise de ansiedade, é um indicativo da dificuldade de algumas pessoas diante de situações que exigem tomadas de decisão e uma nova "política de vida".

Após a configuração do grupo das pessoas ricas de Flint, composto por burgueses e seu círculo social restrito, sempre em cenas claras, ensolaradas e em

${ }^{206}$ GIDDENS, A. Modernização reflexiva. São Paulo: Ed. UNESP. 1997, p. 108-109.

${ }^{207}$ Cf. GIDDENS, A. Modernidade e identidade. Rio de Janeiro: Zahar, 2002, p. 197.

${ }^{208}$ BECK, Ulrich. Modernização reflexiva: política, tradição e estética na ordem social moderna/ Ulrich Beck, Anthony Giddens, Scott Lash; São Paulo: 2a Ed. UNESP, 2012, p. 175. 
momentos fora do trabalho, o filme caracteriza os trabalhadores em pequenas reuniões nas saídas das fábricas, e em ocasiões que parecem buscar por saídas individuais com as cenas de pessoas que sofrem as consequências mais drásticas do desemprego.

Um homem com uma ferramenta nas mãos caminha sobre a calçada com um pouco de neve. Trata-se do delegado adjunto Fred Ross que executa as ordens judiciais de despejo. O xerife é um homem com aparência latina, diferente das pessoas brancas da festa do Grande Gatsby nas cenas anteriores. Ross veste terno, gravata, capa de chuva, chapéu claro e costuma ser paciente com as pessoas que vai despejar. Ao saber que Fred Ross chega a executar 24 ações de despejo num único dia, Moore afirma que este é um homem com emprego seguro em Flint e, pelas inúmeras cenas de despejo no filme, esta ideia parecerá convincente.

Ross não encontrou as pessoas na primeira casa e, mesmo assim, com a ajuda de dois auxiliares, o despejo é realizado. Essas imagens dão um tom ainda mais dramático às cenas dos despejos, pois, neste caso, a pessoa nem estaria presente para cuidar de suas coisas que são amontoadas na calçada. Pelo menos é essa impressão que o filme causa, não oferecendo outras informações a respeito dos locatários do imóvel que ao retornarem encontrarão a fechadura da porta trocada e um aviso de despejo colado no vidro da casa.

Em outras imagens de despejos, enquanto espera que as pessoas retirem seus pertences das casas e os amontoem na calçada, Fred Ross emite juízos sobre si e sobre os outros. O delegado afirma que já foi operário das fábricas, mas não suportou "o sistema". Mesmo fora da classe operária, Fred Ross solidariza-se com os trabalhadores e se entristece por ter que executar tantas ações de despejo, dizendo que alguém tem que fazer aquele serviço. Corroborando a ideia do filme que constrói a decadência da cidade com tantos desempregados, Ross afirma que com tantas demissões aquela localidade poderia se tornar "barra pesada".

Em outra ação judicial, Ross avalia a situação de uma mulher que seria despejada em três dias se seu "novo marido" não conseguisse dinheiro, pois, para o delegado: - "você não precisa de ajuda para ser pobre", referindo-se à mulher casada com alguém mais pobre do que ela. Apesar de seus comentários em tom moralista, as cenas mostram Ross como um homem tranquilo, paciente e até solidário com a situação dos despejados. Esses últimos são em sua grande maioria pessoas negras, famílias ou grupos numerosos com crianças e poucos pertences retirados das casas, amontoados em velhos carros ou caminhões alugados que os levam para algum abrigo público, porém as 
cenas enfatizam as coisas amontoadas nas calçadas não indicando o destino das pessoas. Ross afirma que algumas famílias tentam alugar trailers para ficar. Nos Estados Unidos, geralmente, lugares com muitos trailers estacionados são conhecidos como parques de reboque, os trailers são alugados por pessoas que estariam abaixo da linha de pobreza porque seus custos são bem menores do que os de uma casa convencional.

Em um dos despejos finais, Ross "protesta" dizendo que "o sistema precisa mudar", sua postura é de quem se solidariza com aquelas pessoas que não conseguiram mais pagar o aluguel. Ross lamenta despejá-los, inclusive diz que alguns eram seus amigos desde os tempos que trabalhou na $G M$ - como montador por 17 anos. Ao final de sua entrevista, Ross justifica que cumprir as ações de despejo era o seu atual trabalho.

As cenas com as pessoas pobres sendo despejadas ocorrem em dias frios, ora com chuva, ora com neve, mas sempre dias nublados e cinzentos. Essas pessoas estão vestidas com roupas velhas, às vezes rasgadas, recolhendo suas coisas de modo súbito e colocando-as na rua sem chance de negociação e sem aviso prévio. Conforme as cenas sugerem, esses desempregados já não podem satisfazer as necessidades mais vitais para sua sobrevivência, sua mão de obra pouco qualificada ou sem qualificação não satisfaz as exigências cada vez mais fluidas e cambiantes do capitalismo em contexto de globalização. Mesmo em um país rico como os Estados Unidos o progresso industrial não absorve a todos e, aos poucos, uma camada de pobres ganha destaque. Marx apontou essa precarização das relações de trabalho ainda nos tempos de crescimento da indústria moderna. Segundo o autor;

O trabalhador moderno, pelo contrário, ao invés de elevar-se com o progresso da indústria, mergulha cada vez mais abaixo das condições de existência de sua própria classe. Torna-se um pobre, e a pobreza se desenvolve mais rapidamente do que a população e a riqueza. E tornase evidente, no caso, que a burguesia já não é mais capaz de ser a classe dominante na sociedade, e de impor suas condições de existência à sociedade como uma lei predominante. É incapaz para governar porque é incompetente para assegurar uma existência aos seus servos escravos, dentro da escravidão, porque não pode impedir 
que eles se afundem numa situação em que tem de ser alimentados por ela, ao invés de alimentá-la ${ }^{209}$.

Além desse aspecto mais geral do movimento do capital, trabalhado por Marx, Sennett aponta, na atualidade, algumas consequências sofridas pelas pessoas, como as mais pobres de Flint. Para Sennett, "só um certo tipo de ser humano é capaz de prosperar em condições sociais instáveis e fragmentárias. Este homem ou mulher ideal tem de enfrentar três desafios:"210

O primeiro desafio apontado pelo autor é com relação ao tempo, em como as pessoas cuidariam das suas relações de curto prazo, e delas mesmas, e ao mesmo tempo estariam migrando de um lugar para outro, mudando de cidade, casa e de emprego. "Quando as instituições já não proporcionam um contexto de longo prazo, o indivíduo pode ser obrigado a improvisar a narrativa de sua própria vida, e mesmo a se virar sem um sentimento constante de si mesmo"211.

O segundo desafio refere-se ao talento dessas pessoas: como descobrir e desenvolver capacidades potenciais em um contexto econômico cujas exigências mudam tão rapidamente. Sobre esse aspecto Sennett afirma que,

Em termos práticos, na economia moderna, a vida útil de muitas capacitações é curta; na tecnologia e nas ciências, assim como em formas mais avançadas de manufatura, os trabalhadores precisam atualmente se reciclar a cada período de oito ou doze anos. O talento também é uma questão de cultura. A ordem social que vem surgindo milita contra o ideal do artesanato, de aprender a fazer bem apenas uma coisa, compromisso que frequentemente pode revelar-se economicamente destrutivo. No lugar do artesanato, a cultura moderna propõe um conceito de meritocracia que antes abre espaço para as habilidades potenciais do que para as realizações passadas ${ }^{212}$.

\footnotetext{
${ }^{209}$ MARX, K. Manifesto do partido comunista. In: FREEDMAN, Robert. "Escritos Econômicos de Marx". Rio de Janeiro: Zahar Ed. 1966, p.45.

${ }^{210}$ SENNETT, R. A cultura do novo capitalismo. Rio de Janeiro: Record, 2006, p. 13.

${ }^{211}$ SENNETT, R. A cultura do novo capitalismo, op.cit., p. 13.

${ }^{212}$ SENNETT, R. A cultura do novo capitalismo, op.cit., p. 14.
} 
Do segundo desafio decorre o terceiro: que vem a ser o desafio de "abrir mão" do passado deixando-o para trás constantemente, de desenvolver uma capacidade de encarar novidades e desafios. Nesse sentido, Sennett reproduz o discurso sintomático dessas mudanças na fala de uma empresária:

A responsável por uma empresa dinâmica declarou recentemente que ninguém tem o emprego garantido em sua organização e, particularmente, que os serviços prestados não significam garantia de perenidade para nenhum empregado. Como reagir a semelhante afirmativa de maneira positiva? Para isso, é necessário um traço de caráter específico, uma personalidade disposta a descartar-se das experiências já vivenciadas. É uma personalidade que mais se assemelha à do consumidor sempre ávido de novidades, descartando bens antigos, embora ainda perfeitamente capazes de ser úteis, que à do proprietário muito zeloso daquilo que já possui ${ }^{213}$.

Nesta direção, é possível afirmar que as pessoas submetidas aos despejos em Flint não conseguem se remodelar neste homem ou mulher ideal, porque para isto é necessário desenvolver uma habilidade especial de se reconstruir constantemente. Nas palavras do autor:

Uma individualidade voltada para o curto prazo, preocupada com as habilidades potenciais e disposta a abrir mão das experiências passadas só pode ser encontrada - para colocar as coisas em termos simpáticos - em seres humanos nada comuns. A maioria das pessoas não é assim, precisando de uma narrativa contínua em suas vidas, orgulhando-se de sua capacitação em algo específico e valorizando as experiências por que passou. Deste modo, o ideal cultural necessário nas novas instituições faz mal a muitos dos que nelas vivem ${ }^{214}$.

\footnotetext{
${ }^{213}$ SENNETT, R. A cultura do novo capitalismo, Rio de Janeiro: Record, 2006, p. 14.

${ }^{214}$ SENNETT, R. A cultura do novo capitalismo, op.cit., p. 15.
} 
Nas sequências, o filme apresenta outros personagens, alguns moram na cidade e outros foram até Flint a fim de apontar saídas para a crise do desemprego. Esse terceiro grupo faz a mediação entre os dois grandes grupos construídos, seus membros emitem opiniões e tomam posição junto às polarizações de classe. Esse grupo apresenta algumas personalidades estadunidenses, como o ex-ator e ex-presidente Ronald Reagan, ou o cantor e ex-garoto propaganda da GM, Pat Boone. Além de rostos conhecidos, outros personagens ganham destaque nas saídas para a crise em Flint, como a mulher que cria coelhos para vender ou o homem que vende o próprio sangue.

Um dos primeiros personagens do grupo de mediação, apresentado no início do filme é o lobista da GM Tom Kay, que concede uma entrevista para Moore em seu escritório. A entrevista é apresentada aos poucos ao longo do filme, de modo a reforçar ideias contraditórias entre o que é narrado pelo personagem e o que é dito através das imagens. Tom Kay, um homem branco, que aparenta estar na faixa dos 60 anos de idade, veste terno escuro, camisa clara e gravata vermelha. Sentado na cadeira de seu escritório, com o corpo levemente inclinado para a direita, estende a mão esquerda sobre a mesa de madeira como se fosse fazer um juramento. Kay fixa o olhar no seu entrevistador e responde pausadamente às perguntas enquanto a câmera fecha um close no seu rosto. Ele diz:

$\neg$ Eu tenho certeza de que Roger Smith tem uma consciência social tão grande e forte como qualquer outro neste país. Só porque é um executivo de automotores não quer dizer que seja desumano. Conversei com muitos, sei com o que se preocupam. Ele se preocupa tanto com essas pessoas quanto você ou quanto eu, e ninguém gosta de ver as pessoas sem emprego ou numa situação difícil.

Moore pergunta se Tom Kay já falou pessoalmente com Roger Smith. Kay parece entrar em contradição e, apesar de afirmar que já falou com Roger Smith, seu tom de voz não parece convincente. Ele afirma, olhando para baixo como se não tivesse muita certeza, que Roger Smith parece ser um homem simpático. A fala de Kay é associada pelo filme às cenas das demissões, de modo que qualquer opinião favorável a Roger Smith será invalidada pelo discurso fílmico, construído com a contraposição direta entre as perguntas que Moore faz a seus entrevistados e as imagens escolhidas 
como resposta. Mais adiante, Kay admitirá que as demissões justificam-se para manter a competitividade da empresa junto ao cenário internacional e que novas empresas, como pequena Helmac Co, inventora do rolo com fita adesiva para limpeza dos fios soltos em roupas de lã, sinalizavam soluções para suprir a demanda por empregos. Parecendo incomodado com o que ouviu, Moore interrompe Kay para, ironicamente, perguntar se o rolo de limpar fiapos das roupas era a saída para o desemprego!

Ao final da entrevista, Kay afirma que a $G M$ não devia nada aos moradores da cidade e que não deveria honrar sua "cidade natal" - como tenta fazer Moore no filme. Para Kay, como uma empresa capitalista, a $G M$ era uma corporação que visava lucros, e "esta é a natureza das corporações que visam lucro", fazer dinheiro. Neste discurso final, Kay parece revelar o que pensa, em contraposição à sua fala inicial de que a $G M$ tinha alguma consciência social - buscando minimizar as provocações de Moore. Em resposta às convicções "equivocadas” de Tom Kay, Moore informará junto aos créditos finais que o lobista também foi demitido e seu escritório fechado.

Ironicamente, Moore passa alguns momentos do filme tentando descobrir se estava "enganado" a respeito de Roger Smith e inicia uma busca pelo presidente da GM para tentar entrevistá-lo. Cenas caleidoscópicas de dedos fazendo ligações, uma mulher, em um filme em preto e branco, operando um antigo aparelho de ramal telefônico, e de outra mão operando um antigo telégrafo, retomam o formato "divertido" do filme que se vale de cenas comuns ao imaginário de um público que possui décadas de cultura cinematográfica.

Quando Moore chega à sede da $G M$ em Detroit, com intuito de que Smith o receba e discutam as demissões, fica aparente um momento de roteirização do filme, contrariando a noção comum de que filme documentário não teria roteiro, e sim imagens realizadas sem planejamento das consequências. Segundo Nichols "alguns documentários utilizam muitas práticas ou convenções que frequentemente associamos à ficção, como, por exemplo, roteirização, encenação, reconstituição, ensaio e interpretação",215.

Nessas cenas, aparentemente planejadas para incomodar o grupo que trabalha junto ao empresário, parece interessante que Moore não seja recebido. Isto para sugerir

${ }^{215}$ NICHOLS, Bill. Introdução ao documentário. Campinas: Papirus, 2005, p, 17. 
que o diretor da $G M$ é inacessível, visto que obter êxito e falar com Roger Smith poderia perder o impacto desejado pelo narrador em realçar sua insistência infrutífera.

Assim, Moore faz seu papel de pessoa obstinada e tenta subir direto ao andar onde estaria o presidente da $G M$, sendo impedido por seguranças e não conseguindo sequer fechar a porta do elevador. Essas tentativas de entrevistá-lo ocorrem pelo menos quatro vezes ao longo do filme, na sede da $G M$, nos restaurantes, clubes, hotéis e eventos que Smith frequenta.

No belo saguão do edifício sede da montadora, Moore é advertido por um funcionário que o lembra de um dos princípios caros àquela nação. Em alto e bom tom o funcionário diz:

\section{$\neg$ Primeiro! Qualquer lugar acima do primeiro nível é propriedade privada! Está fora dos limites!}

Moore diz que veio de Flint e gostaria de falar com Roger acerca das demissões, mas enquanto tenta explicar o que deseja, os planos alternam imagens dos rostos impacientes das diferentes pessoas que formam a equipe de segurança. Alguns funcionários de uniforme começam a transmitir mensagens por rádio e telefone, outro vestindo terno cruza os braços e sacode os joelhos impacientemente como se estivesse supervisionando quanto tempo mais levariam os seguranças para finalizar aquela situação com um grupo de pessoas que, portando câmera e microfone, filmavam a propriedade da $G M$.

Um senhor chamado Herb Slauter tenta convencer Moore a deixar um cartão e marcar uma entrevista futura. Talvez pressupondo que aquilo não aconteceria, Moore começa a puxar vários cartões do bolso, mesmo sabendo que não tinha nenhum cartão de visita e talvez ganhando tempo para que a equipe filmasse mais imagens internas da $G M$. Moore faz um personagem que muitas vezes inclina para um modo de agir tolo ou cômico, propondo ao expectador a impossibilidade de ser recebido pelo presidente da General Motors, mas sua disposição para tentar marcar a entrevista faz dele um "representante" dos trabalhadores demitidos.

Um personagem que entra no grupo de mediação, tomando posição alinhada ao grupo de Roger, é o ex-presidente republicano Ronald Reagan. Eleito o $40^{\circ}$ presidente dos EUA, Reagan cumpriu dois mandatos ao longo dos anos 1981 até 1988 com uma 
agenda marcadamente neoliberal ${ }^{216}$. O vice-presidente de Reagan foi George Herbert Bush, eleito presidente em 1989, cuja trajetória política será retomada por Moore no filme Fahrenheit 9/11, trazendo denúncias em torno da administração do seu filho George Walker Bush. Essas informações fornecem um panorama geral do grupo contra o qual os filmes de Moore se posicionam.

Em sua visita à cidade de Flint, Reagan leva um grupo de trabalhadores demitidos para comer pizza em uma cantina da cidade, a fim de conversarem acerca de alternativas ou novos empregos pelos EUA. Ao som de Connie Francis, com Lucky, Lucky Me, o filme mostra Reagan cumprimentando os desempregados. Moore diz em sua narração que mais uma pessoa com uma "ideia brilhante" chegara à cidade para dizer aos demitidos que, "se eles tentassem, todos iriam trabalhar novamente".

Ao final da visita, três depoimentos são colhidos na pizzaria: o primeiro, de uma mulher dizendo não poder largar tudo o que construiu em Flint, sua casa e sua família, para procurar emprego em outro estado, como sugeriu o ex-presidente. A capacidade de abrir mão do passado, deixando-o constantemente para trás, foi colocada linhas acima por Sennett ${ }^{217}$, como sendo a capacidade de homens e mulheres, nada comuns, de reagirem a condições sociais instáveis e fragmentárias. Talvez essa senhora não estivesse disposta a ceder em relação às novas exigências do mundo do trabalho. Outro depoimento mais otimista foi dado por outra mulher dizendo que "apesar de não termos emprego público", Reagan estava ali para colher opiniões dos desempregados como se fossem importantes. Ao final um homem jovem e bem vestido, disse que gostou das ideias que Reagan passou para eles.

Os depoimentos são apresentados como três opiniões distintas: um em oposição a Reagan (o da primeira mulher), outro sem opinião definida (o da mulher mais jovem), e o terceiro satisfeito e alinhado à proposta política da visita do ex-presidente republicano. Mas o que prevalece, fechando a cena e conferindo um sentido inapropriado àquela visita, é a foto em preto e branco de um trabalhador negro que olha sério para a câmera que o fotografou em suas vestes puídas ao lado de Reagan e seu

\footnotetext{
${ }^{216}$ Segundo Eric Hobsbawm, ao lado d $\mathrm{Sr}^{\mathrm{a}}$ Thatcher na Grã-Bretanha (1979-90), Ronald Reagan representa a ascensão da nova direita política comprometida com formas extremas de "egoísmo comercial e laissez-faire", cujas metas políticas visavam à participação mínima do Estado na economia e o fim do Estado de Bem-estar Social. Além disso, conforme aponta Hobsbawm, para Reagan "o capitalismo assistencialista patrocinado pelo Estado das décadas de 1950 e 1960, não mais escorado, desde 1973, pelo sucesso econômico, sempre havia parecido uma subvariedade de socialismo [...] da qual em sua ótica, a URSS era o lógico produto final.” IN: HOBSBAWM, Eric. Era dos extremos: o breve século XX: 1914 1991. São Paulo: Cia das Letras, 1995, p. 245.

${ }^{217}$ Cf. SENNETT, Richard. A cultura do novo capitalismo. Rio de Janeiro: Record, 2006, p. 15.
} 
sorriso congelado. A foto mostra Reagan, à direita, em sua aparente simpatia forçada. À esquerda uma senhora de expressão "vislumbrada" se inclina para não perder nem um momento da fala do ex-presidente. Ao centro da imagem um trabalhador com a expressão séria olha diretamente para a câmera, sugerindo descrença em relação àquela "figura notória" e seu provável discurso retórico aos trabalhadores ${ }^{218}$.

Ironizando as "boas intenções" de Reagan, Moore diz que de todos aqueles trabalhadores que não teriam seus empregos de volta na $G M$, apenas um conseguiu solucionar seus problemas momentaneamente "pegando emprestado" o dinheiro da caixa registradora na saída da pizzaria. Uma encenação é apresentada a posteriori do dia oficial de visita, com a câmera fazendo o trajeto da suposta pessoa que levara o dinheiro para casa, encerrando assim a canção da americana Connie Francis.

A respeito do "ator mediano de Hollywood" (Reagan), Hobsbawm afirma que se tratou de um governo em que a pobreza e a miséria aumentaram consideravelmente. Mesmo com algum crescimento econômico, e mesmo com a diversificação da indústria e do comércio internacional, o que se viu foi o aumento da pobreza ${ }^{219}$.

\section{Segundo Hobsbawm,}

Quanto à pobreza e miséria, na década de 1980 muitos dos países mais ricos e desenvolvidos se viram outra vez acostumando-se com a visão diária de mendigos nas ruas, e mesmo com o espetáculo mais chocante de desabrigados protegendo-se em vãos de portas e caixas de papelão, quando não eram recolhidos pela polícia. [...] O reaparecimento de miseráveis sem teto era parte do impressionante aumento da desigualdade social e econômica na nova era [...]. Durante as Décadas da Crise, a desigualdade inquestionavelmente aumentou nas "economias de mercado desenvolvidas", principalmente desde que o quase automático aumento nas rendas reais a que as classes

\footnotetext{
${ }^{218}$ Em janeiro de 2011, o diretor Eugene Jareck, conhecido pelos filmes Razões para a Guerra (2005) e The Trials of Henry Kissinger (2002), lançou um interessante documentário, Reagan (EUA, 2011), a respeito de Ronald Reagan, o qual constrói o ex-presidente como uma pessoa fechada e pouco afeita ao contato com o público. Segundo o filme de Jareck, durante seus oito anos de mandato, Reagan estaria mais preocupado em fazer oposição aos soviéticos do que com os problemas sociais dentro dos EUA. No site do IMDB constam informações detalhadas do documentário. http://www.imdb.com/title/tt1822382/ (Acesso em 20 de junho de 2011).

${ }^{219}$ HOBSBAWM, Eric. Era dos extremos: o breve século XX: 1914 - 1991. São Paulo: Cia das Letras, 1995, p. 246.
} 
trabalhadoras se haviam acostumado na Era do Ouro agora chegara ao fim. ${ }^{220}$

Defensores da "liberdade individual", como Reagan, pareciam não se abalar com as injustiças sociais que cresciam no capitalismo de mercado irrestrito. Durante a visita de Reagan à Flint, uma mulher disse que estava tentando viver sozinha com seus filhos, de modo que não poderia deixar tudo e partir. A fala dessa mulher sugere a opinião do filme e também remete às teses de Hobsbawm. Segundo este autor, os políticos do neoliberalismo não se importavam com os problemas individuais, antes, defendiam a não participação do governo nas questões econômico-sociais, pois em sua visão: “o governo não era a solução, mas o problema",221.

Nesse sentido, sob essa ótica neoliberal, grandes indústrias como a GM podiam tomar a "livre iniciativa" de demitir 30 mil pessoas em curto espaço de tempo. $\mathrm{Na}$ proposição de sentido que o filme alude, parece que os 30 mil empregos foram cortados em espaço curto de tempo, porém, o processo pode ter levado alguns anos - o que não deixa de ser significativo.

Na continuidade de seu discurso, o filme parece criticar a população da cidade por não aderir a um protesto contra as demissões em solidariedade aos 30 mil desempregados. Para comprovar esta assertiva, o filme mostra imagens de parte da população se divertindo com a tradicional festa dos "jumentos mergulhadores" ou com a "ilustre" visita do "mais famoso filho de Flint" Bob Eubanks e seu jogo dos recémcasados.

As cenas do jogo dos recém-casados ocorrem em um palco armado em campo aberto, com a plateia sentada em cadeiras ao ar livre. A maioria das pessoas vistas são mulheres que parecem se divertir com risos e aplausos para as piadas do apresentador. Após uma pequena discussão, se Eubanks chamava os seios femininos de breasts ou chest, a cena propõe um sentido ridicularizado ao show e ao modo como as pessoas são expostas em suas intimidades. Eubanks é construído como um apresentador de humor preconceituoso e impróprio para o público familiar. Com isto, o filme sugere que enquanto Moore estaria atrás de Roger Smith buscando satisfações a respeito das demissões, "milhares de pessoas se divertiam".

\footnotetext{
${ }^{220}$ HOBSBAWM, Eric. Era dos extremos: o breve século XX: 1914 - 1991. São Paulo: Cia das Letras, 1995, p. 396-397.

${ }^{221}$ HOBSBAWM, Eric. Era dos extremos: o breve século XX: 1914 - 1991, op.cit., p. 401.
} 
Diante da impossibilidade de se encontrar com Roger e da ausência de adeptos para uma nova grande greve, Moore ironiza outra saída para enfrentar a crise: a religiosa. Segundo a narração, "pelo cachê de 20 mil dólares" o reverendo Robert Schüller veio à Flint "livrar a cidade da praga do desemprego".

$\neg$ Tempos difíceis não duram, mas pessoas fortes sim. Saia da pobreza! Você não sairá da pobreza para a prosperidade até perceber que deve ter a humildade de dizer: "preciso de ajuda”!

Pessoas cantavam hinos de louvor a Deus e na capa dos seus brados estava escrita uma frase bem conhecida nos EUA:

Sim nós podemos! (Yes we can!).

E o reverendo prossegue:

$\neg$ Você conseguirá transformar sua dor em prazer, a tristeza torna-se apenas um escravo. Só porque você tem problemas não é desculpa para ser infeliz.

A visita do reverendo Schüller à Flint, e seus cultos sempre lotados de público, podem parecer uma forma de estimular, através da fé religiosa, as pessoas a reencontrarem nova ocupação e, em consequência, retomarem suas vidas abaladas pelo desemprego. Porém, o filme constrói a saída religiosa como algo improdutivo, ou ainda, descolado da necessidade de ações práticas como parecem ter sido as mobilizações e greves vistas no passado.

O terceiro grupo social configurado pelo filme, ao incluir personagens que não são nem operários nem burgueses, pode remeter à ideia de uma "classe média", porém isso é pouco construído no filme devido sua ênfase no conflito entre operários da $G M \mathrm{e}$ os burgueses. Este terceiro grupo pode ser chamado de grupo de mediação porque entra nas cenas para mediar o conflito, posicionando-se entre os dois principais grupos, ora a favor, ora contra, ou sem opinião definida. São personagens como Pat Boone, Anita Bryant, a cômica vendedora Janet, entre de outros. 
A visita dos antigos símbolos comerciais da $G M$, o cantor Pat Boone que nas propagandas vendia carros e a cantora Anita Bryant que vendia as velas de ignição, ganha destaque no filme com mais tempo em seus depoimentos que os demais personagens.

Com frases de efeito, Anita diz que os trabalhadores devem insistir e "viver um dia de cada vez", ou ainda que eles devam "ir em frente e serem positivos em relação à vida, sem remorsos em relação ao passado, nem pensar no futuro". Focalizando o rosto de Anita como se quisesse captar o vazio de suas palavras, o filme persiste em "ouvi-la" com sua empolgação insistente:

$\neg$ Você tem hoje. Hoje é um novo dia. É uma oportunidade de pensar e ver o lado positivo dentro de si mesmo e de sua comunidade [...]

E Anita termina seu discurso com uma personalidade ícone da política nos anos 80 que, ao lado de Ronald Reagan, era totalmente contra a intervenção do Estado na economia e consequentemente o Estado de bem-estar social, a defensora do individualismo no pior sentido do termo, Margareth Thatcher.

$\neg$ Eu li uma coisa interessante. Margaret Thatcher disse: “Anime-se América, vocês moram num país maravilhoso. É um país livre, tem um presidente ótimo. Nem tudo é perfeito, mas sejam felizes, pois moram num país livre”. Moramos numa sociedade livre. Hoje é um novo dia. É uma oportunidade de fazer alguma coisa. Pelo menos agradeça a deus pelo Sol que brilha e por não estar morrendo de fome. Faça alguma coisa com as suas mãos. Eu não sei.

Quanto mais tempo o filme se estendeu na fala Anita, mais seu discurso tornavase genérico e o corte na cena entra justamente quando ela diz, eu não sei. Enfim, como prefere o filme, ela parece que não sabia do que estava falando.

Pat Boone aconselha a "todos que nasceram no Berço da América” que não devem desistir nem desanimar porque bons períodos produtivos estão para vir. Ele trabalhou como ator nas propagandas televisivas da Chevrolet (marca da GM) e sempre 
que ganhava um novo produto da montadora "sentia que eram grandes produtos!" Com fala articulada, Pat Boone não se deixa levar pelas perguntas de Moore, pois não parece se intimidar com a insistência do entrevistador que requer um posicionamento pró ou contra a GM. Pat Boone não critica nem Roger Smith nem a $G M$, e lamenta não tê-lo conhecido pessoalmente, contudo, o considerava "uma pessoa otimista, um homem capaz”, e termina com um sorriso para Moore após dizer que Roger "não é fraco".

Moore pergunta para Pat Boone "de quem seria a culpa pelas demissões". Boone responde que ninguém, pois "numa sociedade livre, capitalista e democrática as coisas mudam. Existem tendências e transformações. Tenho certeza que a General Motors não deseja fechar uma fábrica nem demitir trabalhadores [...] o mais importante é a forma de agir".

Para Boone diz que muitas pessoas que saíram das fábricas encontraram novas colocações e agradeciam por novas oportunidades como trabalhar por conta própria com os produtos da AMWAY. ${ }^{222}$ Seguindo a pista de Pat Boone, Moore entrevistará uma revendedora dos produtos da Amway e essas cenas são o ponto alto de comicidade em todo o filme.

Janet é uma mulher de aproximadamente 40 anos de idade, que veste um conjunto de calça e terno social feminino na cor bege. Praticante de "atitudes positivas", como as dos manuais de autoajuda, ela também repete palavras motivadoras como fez Anita no bloco anterior. Janet diz: “- se você tem um sonho e for à busca dele, você pode realizá-lo". Moore apresenta Janet como uma das pessoas que seguiram os conselhos de Pat Boone. Apesar de o seu marido trabalhar para a GM, ela tomou iniciativa de ter seu próprio negócio antes que as demissões atingissem sua família. Vendedora de produtos que vão de meias-elásticas a itens de limpeza para casa, Janet se diz apaixonada pela análise das "cores das pessoas", e faz pequenas reuniões com suas

\footnotetext{
${ }^{222}$ AMWAY é uma marca estadunidense de produtos voltados para limpeza doméstica. No site da empresa encontram-se os motes que remetem ao American way of life "embutido" em cada produto. Segundo o site: "Nossa visão é simples: trabalhar todos os dias para ajudar as pessoas a viver melhor. Alcançamos a nossa visão de ajudar as pessoas em todos os lugares para descobrir seu potencial e alcançar seus objetivos por meio da oferta de melhores produtos e oportunidades para o futuro, para partilhar generosamente com a comunidade global. [...] Estes princípios fundamentais estão literalmente esculpidos em pedra, na frente do Centro Mundial de Operações da empresa: Liberdade, Família, Esperança e Recompensa. [...] A Amway sempre apoiará a LIBERDADE fundamental das pessoas em determinar seu próprio futuro, dando-lhes tempo e recursos para proteger e nutrir sua FAMILIA. Além disso, a Amway sempre oferecerá a ESPERANÇA para os indivíduos e a oportunidade de receber RECOMPENSA, na proporção de seus esforços". Grifos da empresa. https://www.amway.com - (Acesso em maio de 2011).
} 
vizinhas em sua própria casa a fim de orientá-las sobre as cores que deveriam dar novo sentido às suas vidas.

Com um discurso aparentemente fabuloso, Janet afirma que " $80 \%$ da população mundial é inverno ou verão", contudo, "negros" (a câmera aponta para uma negra que está no grupo sentado na sala de estar de Janet), “judeus e italianos, a maioria é inverno." Em seguida, Janet demonstra, com auxílio de uma cliente, como faz análise das cores ideais para cada pessoa. Quando Janet começa a sobrepor cortes de tecidos coloridos sobre o colo da pessoa que lhe serve de modelo a cena se torna hilária. Enquanto Janet fala de modo sério, acreditando no seu próprio discurso, outras mulheres que a rodeiam observam a modelo com uma espécie de turbante cor de rosa na cabeça.

As explicações de Janet, acerca da função das cores na personalidade de cada pessoa, propõem a interpretação que ela quer que prevaleça a respeito daquilo que acredita para o cotidiano das pessoas. Janet não legitima seu discurso com algum apoio teórico da psicologia, ou áreas relacionadas, a fim de reforçar suas "conclusões". Contudo, em resposta à crença no poder das cores, as imagens do filme aludem para uma falta de sentido no discurso de Janet. Moore avisa que algum tempo após esta entrevista, Janet o contata desesperada, porque descobriu que havia cometido um erro. Em nova entrevista, a vendedora da Amway afirma ter errado sobre sua própria cor, pois não era outono como previu e sim primavera, uma estação ainda quente só que de cores mais claras! Para consolá-la Moore aceita fazer o teste da cor e a expressão do personagem cômico de Moore torna a cena ainda mais hilária que as anteriores.

Acerca dessas novas formas de consumo, assim como os produtos de Janet e sua ideia com as cores, diria Bauman que "em tempos líquidos"223 as pessoas intensificam formas de consumo, tanto pelas promessas de felicidade que estão embutidas nos produtos quanto para aplacar as incertezas da vida em tempos de novas configurações no trabalho e nas relações humanas, cada vez mais fugazes. Assim, tudo o que venha auxiliar para reforçar as motivações individuais, como a ideia das cores vendida por Janet, seria bem-vindo no mundo dos consumidores.

É possível que, ao associar as cores como fonte de sentido ou estímulo para sua vida e para as de suas clientes, Janet estaria não apenas reproduzindo um modo Amway de ganhar a vida, com sua infinidade de produtos milagrosos, mas também buscando

\footnotetext{
${ }^{223}$ BAUMAN, Z. Modernidade líquida. Rio de Janeiro: Jorge Zahar Ed. 2001.
} 
certezas para seus próprios temores, como a possibilidade de demissão do seu marido que ainda trabalhava na $G M$, e em consequência, que seu padrão de vida não mais celebre o American Way of Life.

O padrão de consumo veiculado pela Amway, na figura de pessoas como Janet, também pode estar relacionado ao conceito de "paixão consumptiva", no sentido de uma paixão que se extingue na própria intensidade, pois "o consumo de bens desempenharia um papel chave na complementação e na legitimação dessas experiências" "224. "As pessoas se libertam quando conseguem transcender espiritualmente aquilo que diretamente sabem, usam ou precisam" e, conforme afirma Sennett, a "paixão consumptiva pode ser outro nome para a liberdade" ${ }^{225}$. Como visto no site da empresa, liberdade e livre iniciativa são motes da Amway; essa nova liberdade mobiliza alguns cidadãos, tanto para o consumo quanto na vida política, um modo de existência voltado para o indivíduo, o que pode enfraquecer qualquer tipo de mobilização coletiva.

Assim, Sennett conclui que esse fenômeno também funciona como "apassivador" do indivíduo que, preso aos papéis de consumidor, espectador e cidadão, acaba afastado da política e segue em direção a um estado cada vez mais passivo dentro da sociedade. É contra essa "passividade" que Moore se coloca ao citar os shows de Bob Eubanks, a gincana dos jumentos mergulhadores, o concurso de Miss America, ou ainda, a preocupação de Janet com as cores que "refletem" sua personalidade. Sennett conclui que a "paixão consumptiva" cultiva a mudança pessoal, mas não o progresso coletivo visto que este dependeria de "relações continuadas e experiências acumuladas" 226 .

Diante da instabilidade que a vida pessoal estaria submetida em Flint, a possibilidade de trabalho com bom rendimento é sugerida por Janet, quando fala de seu salário: “junte-se e nós e descubra!” Em sua representação ${ }^{227}$ de vendedora e consumidora, Janet parece mesmo acreditar no potencial que as cores trouxeram para sua vida.

Em outra sequência com saídas para o desemprego em Flint, o gerente da lanchonete Taco Bell concede entrevista alegando que a rede de fast-food seria uma possibilidade de reinserção no trabalho. Devido a seu ritmo acelerado, este trabalho

\footnotetext{
${ }^{224}$ SENNETT, R. A cultura do novo capitalismo. Rio de Janeiro: Record, 2006, p. 128.

${ }^{225}$ SENNETT, R. A cultura do novo capitalismo, op. cit., p. 144.

${ }^{226}$ SENNETT, R. A cultura do novo capitalismo, op.cit., p. 162.

${ }^{227}$ Representação no sentido dado por Goffman, conforme citado na introdução.
} 
poderia ser mais pesado do que o da linha de montagem de carros, o que, segundo o gerente, incomodava os ex-trabalhadores da $G M$ que não se adaptavam àquele ritmo "desafiante". Em contraposição à fala do gerente, as cenas propõem um sentido nada desafiador para aquele trabalho, com imagens de uma atendente da Taco Bell registrando o pedido de um cliente. Entretanto, deve-se considerar que o dia da semana e horário que as imagens foram gravadas interferem na construção da ideia de um trabalho que não necessita de grande esforço ou habilidade para dar conta de um ritmo intenso. Isso poderia ter outro sentido se as filmagens fossem realizadas em dias e horários de maior movimento da lanchonete.

Outras saídas são apresentadas de modo pouco otimista, como a mulher que vende coelhos para serem pets (animal de estimação) ou meat (comida). A história dessa mulher rendeu outro documentário para a televisão, feito por Moore em 1992, chamado: Pets or Meat: the return to Flint.

Moore vai até a casa desta mulher e pede informações sobre aquela forma de ganhar dinheiro, observando as gaiolas onde os animais estão confinados. Como na primeira visita estava nevando muito, Moore retorna em outro dia mais quente para ver como o animal, com até cinco meses, é abatido no jardim da casa. A mulher aparenta ter 35 anos de idade, veste calça jeans e camiseta, diz que vive do que recebe do seguro social e complementa a renda familiar com a venda dos coelhos, além de criar cães como "dobermann pinchers". Em outro momento, a câmera focaliza o rosto desta mulher um pouco de cima para baixo, provavelmente não a minimizando, mas sugerindo uma posição inferiorizada na escala social configurada pelo documentário. O filme não informa se a mulher já trabalhou na fábrica, contudo a narração lembra que ela teve um irmão demitido pela $G M$.

Em um país como os EUA, uma cidade urbanizada como Flint, ver uma pessoa abater coelhos para comer e vender não foi algo que Moore conseguisse ironizar. Ele parece ter ficado impressionado com aquela mulher e retoma seu caso mais duas vezes num total de três aparições: a segunda vez em um dia mais quente quando ela abate o coelho, e a terceira ao final do filme, quando diz que tem vontade de voltar a estudar para ser ajudante de veterinária. Ao término do filme, Moore informa que metade da cidade também vivia de algum tipo de seguro social, enquanto Roger Smith "se dava um aumento de dois milhões de dólares".

A mulher diz que já havia sido notificada pelas autoridades sanitárias que não poderia abater animais sem condições mínimas de higiene, mas mesmo com receio de 
ser denunciada, abate um coelho na frente da câmera. Primeiro ela bate na cabeça do coelho com uma barra aparentemente metálica, depois o pendura amarrado com sisal no galho baixo de uma árvore. Com a faca ela retira a pele, que junta para fazer casacos, e limpa a carne das vísceras para deixá-la pronta para o cozimento ou fritura. Contudo, as cenas não a mostram cortando a cabeça do coelho, vigorosamente acariciado antes do abate, talvez porque as imagens poderiam chocar ainda mais o espectador urbano não acostumado a ver o processo de abate da carne, costumeiramente comprada em partes no supermercado.

O filme parece ter cuidado em não mostrar a mulher cortando a cabeça do coelho, o que poderia assustar o espectador do cinema e, consequentemente, fazê-lo perder o foco do filme que é a precarização da vida dos trabalhadores nos EUA. Esse tipo de cuidado com o público no cinema documental foi analisado por Menezes no filme Les Maîtres Fous, de Jean Rouch.

Em Les Maîtres Fous, ocorre uma cena que envolve a morte de um animal, um cachorro, que será cozido e comido numa espécie de ritual. Partindo das considerações de John Berger ${ }^{228}$, Menezes acompanha o significado histórico que os animais adquirem para vida humana com a separação entre homem/natureza e homem/animal, para salientar o quão "assustador" pode parecer a morte de um animal em telas urbanas, o que teria motivado o cuidado de Rouch naquele filme, bem como - para esta análise - o cuidado de Moore com a morte do coelho em Roger e Eu.

\section{Segundo Menezes,}

A criação dos zoológicos no fim do XIX marca simbolicamente essa separação que fez com que o lugar a partir de então reservado aos animais fosse as jaulas dos zoológicos, ou, no melhor dos casos, a doçura e a intimidade caseira do Pet, elevado, por isso, à função de "melhor amigo do homem"229.

Para o autor, devido a essa posição de "melhor amigo do homem", as imagens do sacrifício do cachorro poderiam ser excessivamente chocantes, de modo que Rouch, após mostrar o cachorro que seria sacrificado, corta a cena bem no momento que o

\footnotetext{
${ }^{228}$ BERGER, John. Why look at animals. IN: ,About looking. Londres: Writers and Readers, p.1-26. ${ }^{229}$ MENEZES, Paulo. Les Maîtres Fous, de Jean Rouch: questões epistemológicas da relação entre cinema documental e produção do conhecimento. IN: Revista Brasileira de Ciências Sociais. Vol. 22. $\mathrm{n}^{\mathrm{o}}$ 63. São Paulo, fevereiro, 2007, p. 87.
} 
animal olharia para a câmera e, por extensão, para o espectador. Desse modo, estaria o diretor tentando eliminar qualquer "possibilidade de cumplicidade entre o espectador e o cachorro, impedindo com isso que aquele, acostumado com a intimidade do seu "melhor amigo", pudesse sentir no olhar do cão a súplica de quem está condenado ao sacrifício e ao esquartejamento" ${ }^{\text {230 }}$. Mesmo com o corte da imagem na cena da morte do animal, Menezes aponta que uma parcela do público enxergou naquele sacrifício "não apenas um ato ritual, mas, e sobretudo, um ato primitivo de barbárie e selvageria" ${ }^{231}$.

Acerca da morte do coelho em Roger e Eu, o filme não constrói aquela mulher como uma selvagem. Ela foi uma das poucas pessoas que Michael Moore não ironizou. Ao contrário, a edição corta algumas cenas mais dramáticas da morte do animal e enfatiza o depoimento da mulher dizendo que foi "criada para aprender a sobreviver." Moore colabora com suas ideias perguntando se ela achava difícil sobreviver em Flint. A resposta da moça, enquanto limpa as vísceras do coelho a céu aberto, é de que a vida em Flint estava difícil porque "as lojas estavam fechando e as pessoas não tinham dinheiro como antes e não podiam comprar”, e por isso, a carne de coelho, por ser mais barata, era vendida rapidamente. O filme não contrapõe a fala da moça que abate coelhos, ao contrário, reafirma as dificuldades de se viver em Flint mostrando uma matéria da revista Money, datada de agosto de 1987, em que a cidade era ranqueada como o pior lugar para se viver nos EUA.

Mesmo que o filme seja "solidário" com a mulher que sobrevive, diria Menezes que, "quanto mais urbana a plateia, mais essa distância [entre homens e animais] é ressaltada, pois não faz mais parte da tradição urbana "acariciar" a comida antes do jantar, como ainda se pode observar em certas regiões rurais" ${ }^{232}$.

Não menos incomum que as cenas da mulher abatendo coelhos para sobreviver, foram cenas de homens jovens, um negro e outro branco, que aguardavam para vender por um ou dois dólares seu sangue para a Flint Plasma Co. A pedido de Moore, o jovem branco mostrou o braço de onde era extraído seu sangue, e lembrou que o laboratório abre de segunda à sexta. As cenas são rápidas, contudo, o filme pretende construir a ideia de decadência total da cidade, com gente matando animais para comer ao lado de gente vendendo o próprio sangue, em uma alusão "ao mundo cão" que culminará na elevação dos índices de assassinatos e violência nas sequências do filme.

\footnotetext{
${ }^{230}$ MENEZES, P. Les Maîtres Fous, de Jean Rouch, op. cit., p. 87.

${ }^{231}$ MENEZES, P. Les Maîtres Fous, de Jean Rouch, op. cit., p. 88.

${ }^{232}$ MENEZES, P. Les Maîtres Fous, de Jean Rouch, op. cit., p. 88.
} 
Ocorre uma pausa nas cenas que ironizavam as tentativas de saída da crise e, para reforçar o estado de dificuldade econômica vivida pelos moradores em Flint, o filme apresenta a matéria da revista Money, que condena Flint como a pior cidade para se viver nos EUA. Um ato público, com a presença do prefeito e alguns membros da Câmara do Comércio, foi realizado para queimar a revista caluniadora. Entretanto, as cenas seguintes insistem no sentido de que a cidade passava por graves problemas de segurança, mostrando que uma transmissão ao vivo pela $T V A B C$ News sai repentinamente do ar porque o furgão com os equipamentos fora roubado em Flint.

O filme explora o suposto aumento da violência na cidade como produto do desemprego e da consequente crise financeira. Imagens de viaturas policiais sinalizam dias piores com um homem sendo contido a tiro, outras imagens mostram corpos de pessoas assassinadas nas ruas ou quintais das casas abandonadas. O filme também explora sutilmente o aumento das vendas de todo tipo de armas para os cidadãos atemorizados que queriam se proteger. Uma cena dentro da loja de armas sugere a comercialização de um rifle para um homem acompanhado de uma criança pequena (a câmera desce na altura da menina que espera um pouco impaciente, enquanto o homem experimenta o peso do armamento). Esse tema da compra e venda de armas como algo culturalmente incentivado nos EUA, será explorado por Moore em seu terceiro documentário, intitulado Tiros em Columbine (2002).

Dentro da construção de que a cidade se tornara violenta devido ao desemprego, o filme aponta nova saída "equivocada" para a crise econômica, com a construção de uma nova penitenciária que empregou alguns demitidos da GM para trabalhar como carcereiros. Um ex-operário fala com Moore enquanto trabalha dentro da cadeia, no mesmo momento alguns presos começam uma discussão que, para a sorte do entrevistador, ajuda a invalidar o discurso do ex-operário que dizia estar satisfeito com a nova oportunidade, mas seu semblante não corrobora sua fala.

A narração de Moore busca associar a imagem da $G M$ àquele saldo social negativo para a cidade. Entre as cenas da cadeia, a voz off de Moore diz:

$\neg$ Com mais desempregos provocando mais crimes em Flint, a General Motors e o sindicato UAW tiveram uma ideia inovadora. "Ensine os ex-montadores a serem carcereiros e dê a eles empregos nas cadeias lotadas por ex-colegas de trabalho. 
Outro ex-montador da $G M$, agora também carcereiro, afirma que encontrou excolegas de trabalho presos. Isso vem ao encontro dos objetivos do filme em responsabilizar a empresa pela situação dos demitidos, neste caso, os que cometem infrações, supostamente, devido ao empobrecimento.

Embora o filme construa o aumento da violência e criminalidade devido a possível decadência de Flint, um estudo empreendido pelo sociólogo estadunidense Bruce Western, nas três últimas décadas do século XX aponta outras implicações para a questão da punição e o suposto aumento do número de crimes nos Estados Unidos. Apesar de alguns dados apontarem o crescimento nos índices de criminalidade associado às ondas de violência nos finais dos anos 80, para Bruce Western não teria sido a criminalidade que aumentou e sim as ações do governo em favor das políticas do encarceramento, sobretudo dos mais pobres e dos negros. Segundo Western, "as duas últimas décadas do século XX geraram um sistema penal sem precedentes na história americana e também sem comparação com qualquer outra democracia desenvolvida." ${ }^{233} \mathrm{O}$ aumento das prisões gerou consequências profundas para toda uma geração de homens nascidos nos finais da década de 60 e, citando um estudo estatístico realizado por Nils Christie, Western afirma que "o grande aumento do número de reclusos nos Estados Unidos não pode ser justificado como 'causado pelo crime'. Deve-se, ao contrário, às políticas penais" 234 .

[...] O aumento da criminalidade contribuiu para o aparecimento de sentimentos novos de vulnerabilidade entre os ricos, e criou uma abertura política para uma mudança nas políticas criminais que, por fim, levou ao aumento dos índices de encarceramento. [...] Os próprios índices de criminalidade podem não ter levado ao grande aumento do número de reclusos, mas a realidades como medos duradouros e outras ansiedades sociais podem funcionar como o cenário para o aumento do número de prisões. ${ }^{235}$

Nesse sentido, se para Western o crime pode ser entendido como contexto em vez de causa, o discurso de Roger e Eu forneceria um contexto favorável para o

\footnotetext{
${ }^{233}$ WESTERN, Bruce. Punição e desigualdade na América. Coimbra: Edições Almedina. S.A, 2009, p. 58.

${ }^{234}$ WESTERN, Bruce. Punição e desigualdade na América, op.cit., p. 68.

${ }^{235}$ WESTERN, Bruce. Punição e desigualdade na América op.cit., p. 81.
} 
aumento da criminalidade, com um cenário de desemprego, medo, e consequente aumento no número de vendas de armas, além de políticas penais cada vez mais rigorosas com a construção de novos estabelecimentos prisionais. Além disso, Roger $e$ $E u$ sinaliza o tema do terceiro filme desta pesquisa, Tiros em Columbine, com a tese de que a disseminação de sentimentos como o medo fariam parte da cultura dos EUA, e a propagação de ideias que associam práticas violentas aos grupos de pessoas negras e pobres.

Nas sequências de Roger e Eu, têm início uma nova cena de despejo e, desta vez, a câmera focaliza uma criança que deve ter entre três e quatro anos de idade. Enquanto os adultos ajuntam seus poucos pertences na calçada, e em uma caminhonete velha, a câmera focaliza as reações da criança que parece inconformada com aquela situação.

Outros grupos de trabalhadores são entrevistados por Moore, como as mulheres que trabalham no setor de correspondências e afirmam que muitas pessoas estão se mudando de Flint, bem como o rapaz que trabalha com caminhões de mudança. Uma mulher que trabalha com correspondências afirma que aquele setor emitiu $82 \mathrm{mil}$ mudanças de endereço. Outra diz que o marido foi demitido pela GM. Apesar da aparente fuga de pessoas da cidade, essa mulher acredita que tem um emprego seguro e está feliz com a compra de novos equipamentos, sem imaginar que alguns desses equipamentos poderiam substituir seu trabalho - como o caso do robô que Moore mostra numa feira de exposições e que veio substituir a mão de obra de alguns trabalhadores da GM.

Em seu formato didático, o filme utiliza as imagens dos caminhões de mudança para propor que Moore continuou percorrendo o país à procura de Roger Smith. A imagem de um mapa com riscos pontilhados afirma que ele procurou "de Detroit a Chicago", de "Washington, capital, a Nova York." Moore retorna à sede da GM em Detroit e repetem-se as cenas com muitos seguranças tentando barrar a entrada do cineasta.

Após esta tentativa de encontrar Roger, Michael Moore retoma as soluções que a cidade vinha testando para sair crise. Uma das alternativas foi tornar Flint um polo turístico, mas a ideia "equivocada" é apresentada pelo entusiasmado presidente do turismo local que fala dos planos executados para retirar a cidade da depressão. Foi construído um Hotel de luxo - Hyatt Regence - e um centro de convenções - Water Street Pavilion - e, ainda, o parque temático Auto World cujo ápice de atração foi, para 
Moore, a reconstrução do centro da cidade, em miniatura, antes do fechamento das fábricas, e o stand da GM onde um boneco, representando um operário, canta alegremente para o braço robótico que o substitui na linha de montagem. Vídeos promocionais convidavam pessoas que circulavam pelas estradas vicinais para entrarem na cidade e usufruírem de atrações, construídas pelo filme, como pouco atrativas. Felizmente para a narrativa que sugere a falência do local, a resposta sobre o "êxito" dos empreendimentos vem de uma de suas entrevistadas, a senhora Jackie, que entrega os folhetos com informações turísticas. Quando perguntada pelo presidente do turismo o que as pessoas dizem quando chegam ao ponto de informações a inocente Jackie diz:

\section{$\neg$ Primeiro perguntam onde é o banheiro!}

E reitera.

$\neg$ É a pergunta que mais me fazem.

Com esta declaração reveladora, Moore nem precisou se esforçar para mostrar que Flint não seria uma cidade turística porque, segundo sua proposta, aquela era uma cidade de tradição industrial, além disso, não dava para transformar Flint em cidade turística. A funcionária da prefeitura, Maxine Kronic, concede entrevista na rua e fala de como desejou a prosperidade dos centros de entretenimento que não deram certo e, corroborando a proposta de Moore, afirma que não conseguiram transformar Bowery em Palm Beach. A própria Maxine declara nos créditos finais do filme que iria se mudar para a cidade israelense de Tel Aviv em busca de um emprego na área turística e, "em resposta", o filme mostra cenas da Intifada ou guerra de pedras - conflito entre judeus e palestinos naquela localidade. Com isto, o filme aponta que se mudar de Flint não é a melhor saída para os habitantes da cidade.

Focalizando uma pilha de entulhos no chão, e mostrando o hotel fechado ao fundo, Moore encerra esse bloco de saídas para a crise dizendo que o hotel Hyatt faliu e foi colocado à venda, o Water Street Pavillion teve a maioria das lojas fechadas e o Auto World fechou após seis meses da inauguração por falta de visitantes. Para Moore, o insucesso dos empreendimentos deveu-se porque "algumas pessoas não gostam de comemorar a tragédia humana nas férias". Provavelmente, a cidade estava em recessão econômica devido à falta de dinheiro circulando na cidade, com a diminuição dos postos de trabalho e, consequentemente, empobrecidas as pessoas não consomem. 
Nas sequências finais, Moore entra em uma reunião de acionistas da GM e tenta tomar a palavra em público, porém seu microfone é desligado. Duas semanas antes do Natal a $G M$ fecha a fábrica que foi palco da grande greve de dezembro de 1936. Apenas três sindicalistas apareceram para protestar. Outras cenas mostram os moradores saindo da fábrica com flores, e a narração de um repórter local reproduz as palavras de um dos demitidos:

\section{$\neg$ A gente só recebe flores quando morre.}

Ao som dos latidos de cães que compõem o The Singing $\operatorname{Dogs}^{236}$, Moore diz que lamenta por não conseguir levar Roger até Flint. Para finalizar, o filme constrói as cenas dos despejos com alternância do discurso de Natal efetuado por Roger Smith para os trabalhadores da $G M$ em todo o mundo e as pessoas sendo despejadas. A fusão de som e imagens à véspera do Natal dá maior dramaticidade à narrativa.

Enquanto o delegado bate na porta anunciando mais um despejo, jovens celebram com cânticos em outro local onde Roger discursa:

$\neg$ Sabem uma coisa que me impressiona no Natal, é como o Natal é uma experiência que exige tudo de nós. Por algumas semanas do ano nosso mundo se transforma. Temos as luzes, é claro que nos fazem esquecer o frio e a tristeza do inverno.

Corte na cena e a mulher com a família sendo despejada diz:

$\neg$ O maldito pegou a grana e me mandou pro inferno!

Enquanto a mulher anda pela casa desesperada, a voz de Roger continua o discurso:

$\neg$ Elas nos lembram do calor, do companheirismo e da primavera que nunca está longe.

\footnotetext{
${ }^{236}$ Latidos de cães foram arranjados por Carl Weis de modo musical para canção de Natal Jingle Bells.
} 
Outra família de pessoas negras recolhe suas coisas para fora da casa. Alguns ajudantes acompanham o delegado no despejo, uma pessoa troca a fechadura para que a família não consiga retornar para casa. $\mathrm{O}$ dia é frio e mesmo assim aquelas pessoas são despejadas. A voz de Roger prossegue:

$\neg$ Ouvimos os sinos do campo. Sentimos o cheiro das folhas do pinheiro e do peru na mesa. Sonhamos com um Natal com neve, esperando que a natureza nos conceda um momento completo.

Duas crianças são filmadas dentro da casa: uma é bem pequena com cerca de três ou quatro anos de idade e o outro é um pouco maior, talvez com onze anos. A mãe grita com eles para que vistam os casacos. E diz:

$\neg$ Eu paguei o aluguel. Me dá isso!

$\neg$ Eu paguei o aluguel! Eu só devo US\$150!

Roger termina seu discurso:

$\neg$ A dignidade individual e o valor de cada ser humano, mais humanos nos tornaremos. Quero concluir com uma observação que considero de um verdadeiro conhecedor do Natal - Charles Dickens. Ele disse o seguinte: "o Natal sempre significou uma época boa para mim” [...]. Uma época de generosidade, perdão, caridade e agradável e a única época que conheço no longo calendário anual quando homens e mulheres num consenso abrem seus corações livremente. E, apesar de nunca ter caído ouro ou prata no meu bolso, acredito que só tenha me feito bem, e só me fará bem. Deus abençoe o Natal!”Bem senhor Dickens, concordo plenamente! E eu lhes digo: "Deus abençoe o Natal de todos vocês!’”

Pela última vez no filme, Moore se aproxima de Roger após este pronunciamento e diz que filmou a família sendo despejada "um dia antes da noite de 
Natal." Moore quer que Roger vá com ele para Flint ver a situação dos ex-funcionários sendo despejados. Impaciente, como quem sabia do que se tratava e, em sua postura de empresário racional, Roger diz que não pode ir até Flint e que a $G M$ não despejou ninguém. Se o filme insiste em culpar Roger e a $G M$ pelas demissões, o contexto que envolve a narrativa indica mudanças que ocorreram em uma escala bem mais ampliada que os muros da $G M$ em Flint.

Segundo Sennett, três grandes mudanças marcaram o capitalismo no fim do século XX e são mudanças que afetaram a vida de pessoas comuns dentro das instituições. A mudança do poder gerencial para o acionário, com a liberação de capital para investimentos em escala global incentivou investidores privados [como Roger Smith] a buscar novas oportunidades no exterior.

[...] o efeito cumulativo de tão grande liberação de capitais e da pressão por resultados de curto prazo transformou a estrutura das instituições mais atrativas para os investidores recém-investidos de poder. Enormes pressões foram exercidas sobre as empresas, para que fizessem belas aos olhos do primeiro voyeur que passasse; a beleza institucional consistia em demonstrar sinais de mudança e flexibilidade internas, dando pinta de empresa dinâmica, ainda que tivesse funcionando perfeitamente bem na época da estabilidade ${ }^{237}$.

Isso remete à pergunta de Moore no início das demissões: porque empresas consideradas lucrativas estariam demitindo? A responsabilidade recai sobre Roger Smith, construído como um empresário ganancioso e pouco interessado nas pessoas. $\mathrm{O}$ filme sinaliza as mudanças globais com a situação dos mercados, as transformações econômicas, políticas e sociais que ocorriam naquele período. Embora não seja papel do filme discutir os temas que suscita com algum teor sociológico, a construção empenhada é parcial e, portanto, não pode ser lida como "realidade". Ainda assim, o filme dialoga com a matéria social que o informa, o que permite as proposições de sentido aqui colocadas.

Com as mudanças na esfera do poder, Sennett pontua uma segunda grande transformação no capitalismo de fim de século XX. Segundo o autor, os novos

\footnotetext{
${ }^{237}$ SENNETT, R. A cultura do novo capitalismo. Rio de Janeiro: Record, 2006, p. 43.
} 
investidores queriam resultados em curto prazo, pois "a compra e venda de ações num mercado aberto e fluido dava maiores e mais rápidos resultados que o controle de estoques acionários a longo prazo"238. Além da liberalização dos mercados, os grandes fluxos de capital associado ao mercado de ações com seu lucro rápido, Sennett aponta que a terceira grande mudança nesse período de transformações do capitalismo foi o boom tecnológico da década de 1990.

Com o aperfeiçoamento da tecnologia de comunicações a informação pôde ser formulada de maneira intensiva e inequívoca, disseminada em sua versão original por toda uma corporação. O e-mail e seus derivados diminuíram a mediação e a interpretação de ordens e normas transmitidas verbalmente para baixo na cadeia de comando. Graças às novas ferramentas de computação para o mapeamento de insumos e produção nas corporações, tornou-se possível transmitir para cima, de maneira instantânea e sem mediação, informações sobre o desempenho de projetos, vendas e do pessoal. Estima-se que na década de 60, o decurso de tempo para quem uma decisão da direção executiva chegasse a linha de montagem era de cinco meses, intervalo hoje em dia radicalmente reduzido a umas poucas semanas. $\mathrm{Na}$ organização de vendas, o desempenho dos representantes de vendas pode ser mapeado em tempo real em casa, na tela do computador ${ }^{239}$.

Essas três mudanças no perfil do novo capitalismo trouxeram consequências profundas para os trabalhadores de empresas como a GM. O filme Roger e Eu constrói duas classes conflitantes em meio a este contexto estudado pelos teóricos escolhidos para esta análise.

Os anos dourados da economia estadunidense são trazidos pelo filme como um período de pleno emprego e de acesso aos benefícios do consumo. Isso pode aludir a um saudosismo por parte da narrativa de tempos em que a crença na realização do american way of life fosse motivadora dos trabalhadores, que com o passar dos anos se tornam cada vez mais desiludidos com as promessas não cumpridas de prosperidade e felicidade pelo consumo de bens materiais.

\footnotetext{
${ }^{238}$ SENNETT, R. A cultura do novo capitalismo, op.cit., p. 43.

${ }^{239}$ SENNETT, R. A cultura do novo capitalismo, op.cit.,p. 45.
} 
Mesmo nos tempos de aparente prosperidade material ou era do ouro, em que o mercado aquecido mantinha aquela sociedade em uma espécie de isolamento econômico, Hobsbawn lembrou-nos que os primeiros passos da transnacionalização já tinham sido dados e o capitalismo estaria cada vez mais internacional, com trocas comerciais mais intensas entre os países, inclusive os EUA.

A partir de um close na bandeira dos EUA colocada acima da fábrica da GM, a câmera abre a imagem e mostra que metade das instalações daquela fábrica estaria em processo de demolição. Moore finaliza a narração sem perder a ironia com as seguintes palavras:

$\neg$ Conforme nos aproximávamos do fim do século $X X$, os ricos ficavam mais ricos e os pobres mais pobres e quase mais ninguém mais tinha pelos nas roupas graças aos rolos de tirar pelos feitos na minha cidade natal. Era o nascimento de uma nova era.

Corte na cena e a música alegre dos Beach Boys, Wouldn't It Be Nice, abre os créditos finais que continuarão alternando imagens de alguns dos entrevistados ao longo do filme, como Tom Kay que mesmo após defender a $G M$ foi demitido e teve o escritório fechado; o presidente do turismo de Flint que animadamente afirma que a cidade é um bom lugar para morar, criar filhos e ter um bom trabalho; Roxane dizendo que queria ir para Tel Aviv; Bob Eubanks e suas piadas. Contraditoriamente, acariciando um dos coelhos que abate, a mulher diz pausadamente que gostaria de voltar a estudar, pois "há muitos animais que precisam de cuidados". A seguir têm-se: o "diretor" de teatro agradecendo pela equipe de Moore ter acompanhado a agitação dos bastidores dos espetáculos; Pat Boone cantando parabéns para Flint; e parte de uma canção dos anos dourados da vida americana encerra a sucessão de imagens com máquinas demolindo o "sonho americano" simbolizado no filme por meio da fábrica General Motors, em Flint.

Ao som de Pat Boone com a canção I am proud to be an american, o filme aponta, entre outras informações, os dias que o laboratório de doação de sangue funciona - como se aludisse à situação "calamitosa" da cidade, ou ainda, que se a situação piorasse, com aumento da violência e do desemprego, haveria mais pessoas precisando vender sangue e outras precisando recebê-lo. 
Finalmente, os créditos afirmam que "este filme não pode ser exibido na cidade de Flint" e, antes de imaginarmos uma possível censura às criticas dirigidas contra aquela cidade, o motivo apontado foi "porque todos os cinemas fecharam." Contudo, Anita anima a todos com a frase "se você quiser você consegue".

\section{Conclusão}

Em Roger e Eu, foi observada a construção do personagem principal que, partindo do seu local social, sua cidade natal e sua família formada por trabalhadores da indústria, buscou representar, nos termos de Goffman, um personagem idealizado para legitimar seu discurso em favor do trabalho produtivo - aquele que gera riqueza e renda para seu país.

O discurso fílmico construiu a centralidade da fábrica General Motors na cidade de Flint, com uma espécie de memória saudosista dos anos de maior prosperidade da economia americana nos anos 50, considerados por Hobsbawn como "Era do Ouro". Contudo, o filme responsabilizou o diretor da GM (Roger Smith), à época das 30 mil demissões, por uma suposta decadência da cidade. Nesse sentido, o filme constrói um conflito de classes (burguesia versus proletariado) devido à oposição entre ambos os grupos. Michael Moore se coloca como representante dos demitidos e sinaliza as dificuldades que os operários estariam tendo para vivenciarem o celebrado american way of life como modelo de felicidade.

O filme mistura vários tipos de documentários propostos por Bill Nichols, numa estrutura de filme expositivo com momentos de filme participativo. Esses modos de produzir documentário ganham, com a direção de Michael Moore em Roger e Eu, contornos de humor irônico e o uso de referenciais da cultura de massa estadunidense com seus sitcoms, filmes e noticiários mais conhecidos, tudo para criar um discurso que em alguns momentos beira o entretenimento.

O filme pretendeu "documentar" a situação dos trabalhadores e, por extensão, da cidade de Flint. Porém, ao buscar justificativas para os temas que envolvem o trabalho no contexto de alta modernidade e de globalização do modo de produção capitalista, evidencia sua construção e ponto de vista parcial, resumindo questões sociais complexas que envolvem transformações na modernidade na chave de oposição: ricos versus pobres, burgueses versus proletários e de modo implícito, bem versus mal. Os ricos em uma construção negativa ou depreciativa, visualizados em dias claros e ensolarados com seus representantes em momentos de festa ou esporte, e os pobres em 
dias frios acinzentados, com pessoas sendo demitidas após passarem boa parte da vida trabalhando para a $G M$, outros passando dificuldades financeiras, inquietações a respeito do futuro e algumas pessoas sendo despejadas de casas alugadas.

Com a construção de um personagem que narra o filme com voz de autoridade (Michael Moore), Roger e Eu sugere ao espectador fazer aquilo que Roger Odin chamou de leitura documentarizante, pois ao usar imagens de arquivo da época, o filme pode ser lido como documento e seu enunciador, ao se colocar como uma pessoa familiarizada com o trabalho operário, e pelo próprio estilo do filme documentário, pode ser visto como portador de um discurso sobre a realidade.

Após Pat Boone cantar parabéns pelo aniversário da cidade, o filme termina como se sugerisse ao espectador que aquela cidade não tinha nada para comemorar. A economia foi construída como se estivesse em ruínas, milhares de trabalhadores demitidos e desmotivados, e o sonho americano da prosperidade ameaçado. A música final, junto aos créditos, com a letra "orgulho de ser americano" encerra com tom de ironia a construção da cidade, das relações de trabalho, da condição individual do trabalhador estadunidense diante de mudanças para as quais não parecia preparado. Nenhuma saída pareceu viável, restando uma sensação de que o país já viveu dias melhores.

Na sequência deste capítulo analiso o filme The Big One. Produzido oito anos após Roger e Eu, The Big One retoma a persistência do conflito capital e trabalho ampliando o tema para outras grandes corporações que, a exemplo da $G M$, continuam demitindo "para manter a competitividade" - como disse uma das gerentes entrevistadas. Neste filme, a situação dos trabalhadores continua envolvendo demissões, desemprego e pobreza, indicando que o problema de Flint se repete em outras cidades do país radicalizando os efeitos da alta modernidade no cotidiano das pessoas. 


\section{2-The Big One.}

....as obras de arte conferem ao historiador, assim como ao sociólogo,elementos de informação que de outro modo não possuem. Pierre Francastel ${ }^{240}$

Com a afirmação de que "vivemos em tempos doentios", Michael Moore apresenta The Big One, um filme lançado nos EUA em 1998 que amplia a temática trazida por Roger e Eu acerca do desemprego. As representificações ${ }^{241}$ que o filme alude na sua relação com o espectador retomam do conflito na oposição entre capital e trabalho.

Nesse filme, Moore amplia a temática pró-empregos e pró-sindicatos, incluindo em suas críticas algumas das grandes corporações fundadas nos EUA. Essas empresas nacionais teriam crescido tornando-se transnacionais e estariam migrando para outros países em busca de mão-de-obra mais barata e condições mais flexíveis de produção, o que, na visão do filme, torna cada vez mais precária a situação dos trabalhadores nos EUA, prejudicando assim, boa parte da economia interna e ameaçando o american way of life.

Sons de aplausos, a voz de Moore agradecendo as pessoas, enquanto a cartela apresenta as corporações da mídia inglesa Mayfair Entertainment International e a British Broadcasting Corporation Production que, associadas à produtora Dog Eat Dog de Michael Moore, formam o principal grupo produtor do filme. Fazer referência a uma empresa como a BBC, logo na abertura do filme, é o primeiro sinal de legitimação do discurso que se inicia, pois a BBC é uma emissora pública da Inglaterra que desfruta de boa reputação internacional por seus programas e canais de notícias tanto no rádio, quanto na TV, e também na Internet. Além da legitimação que se inicia na abertura do filme, Moore também se vale da popularidade da BBC para apresentar-se ao policial

\footnotetext{
${ }^{240}$ FRANCASTEL, Pierre. A realidade figurativa. São Paulo: Editora Perspectiva. [2ºdição], 1993, p.4.

${ }^{241}$ Conforme afirma seu autor: "o conceito de representificação realça o caráter construtivo do filme, pois nos coloca em presença de relações mais do que na presença de fatos e coisas". In: MENEZES, Paulo. $O$ cinema documental como representificação: verdades e mentiras nas relações (im)possíveis entre representação, documentário, filme etnográfico, filme sociológico e conhecimento. In: Escrituras da Imagem. São Paulo: EDUSP/FAPESP. 2004, p. 21-47.
} 
que irá "prendê-lo" na saída da empresa Leaf mostrando que seu filme é "bem amparado" institucionalmente.

Enquanto promove o lançamento de seu livro "Downsize This! Random Threats from an Unarmed American", Moore forma uma pequena equipe de filmagem e, paralelamente às conferências como escritor, produz este documentário, na tentativa de denunciar as empresas estadunidenses que estariam demitindo funcionários apesar dos lucros crescentes. Em cada cidade visitada Moore entrevista grupos de desempregados, indo aos programas de rádio falar do seu livro, distribuindo cheques simbólicos de US\$ 0,80 para as empresas que se dirigem ao México, e diplomas de demitidor do ano para alguns representantes das empresas que ele consegue encontrar. Incentivar grupos de trabalhadores a se organizar em sindicatos e protestar contra as demissões continua sendo o principal tema do cineasta, que cada vez mais, ganha espaço na mídia como formador de opinião - como indica The Big One, em sucessivas imagens retiradas da TV ou fotos de jornais que anunciam os feitos de Moore em suas viagens pelos EUA.

O filme inicia com Michael Moore em cima de um palco, iluminado por um grande foco de luz, de onde fala para uma plateia formada por pessoas aparentemente receptivas àquela apresentação. Conforme a câmera os focaliza, são vistos rostos de pessoas jovens que emitem sons de risos, pequenos gritos, respostas curtas e aplausos dispersos.

Moore retoma a construção de seu personagem ${ }^{242}$ e sua fachada pessoal composta de calça jeans, camisa, blusão e seu inseparável boné, que troca em algumas ocasiões (são bonés de times estadunidenses, exceção de um da Warner Brothers - que coproduziu Roger e Eu). A respeito de "fachada pessoal", Goffman pontua que o termo refere-se ao que pode ser identificado, de modo mais íntimo, com o próprio ator, e essa "fachada" o acompanha onde quer que vá. Goffman define algumas partes da fachada pessoal em que são incluídos: “os distintivos da função ou da categoria, vestuário, sexo, idade e características raciais, altura e aparência, atitude, padrões de linguagem, expressões faciais, gestos corporais e coisas semelhantes" ${ }^{243}$.

As cenas iniciais indicam que este filme pode ser lido, na tipologia de Nichols para o documentário, como mantendo a estrutura no modo expositivo, visto que desde o

\footnotetext{
${ }^{242}$ No sentido de representação em Goffman, para "referir a toda atividade de um indivíduo que se passa num período caracterizado por sua presença contínua diante de um grupo particular de observadores e que tem sobre estes alguma influência". $C f$. Goffman, E. A representação do eu na vida cotidiana. Petrópolis: Vozes, 2009, p. 29. Pensar na representação que Moore constrói sobre si no filme auxilia a separar o personagem da figura pública cuja atuação social vai além de seus filmes.

${ }^{243}$ Goffman, E. A representação do eu na vida cotidiana. Petrópolis: Vozes, 2009. p. 31.
} 
início The Big One se dirige ao espectador com a voz de Moore expondo sua argumentação de forma objetiva e persuasiva a respeito do tema tratado.

O filme apresenta Michael Moore em momentos de entrevistas em rádios e TVs, de maneira que suas opiniões acerca da crescente falta de emprego constroem o ponto de vista do filme. Nichols expõe outras características do documentário expositivo:

Los textos expositivos toman forma em torno a um comentário dirigido hacia el espectador; las imágenes sirvem como ilustración o contrapunto. [...] La retórica de la argumentación del comentarista desempeña la función de dominante textual, haciendo que el texto avance al servicio de su necesidad de persuasión. [...] El montaje en la modalidad expositiva suele servir para establecer y mantener la continuidad retórica más que la continuidad espacial o temporal ${ }^{244}$.

Ainda sobre a tipologia de Nichols, que se tomada de modo isolado não define um filme em todos os seus aspectos, The Big One apresentará momentos de inclinação para o modo participativo ${ }^{245}$ com Moore se colocando nas situações que expõe; como ocorre quando ele entra em discussão com o representante do governador em Wisconsin para defender os trabalhadores da GM e as mães do Wisconsin. Segundo Nichols, "o documentário participativo dá-nos uma ideia do que é, para o cineasta, estar numa determinada situação e como aquela situação consequentemente se altera" ${ }^{\text {246 }}$. Nesse tipo de documentário o cineasta "torna-se um ator social (quase) como qualquer outro. (Quase como qualquer outro porque o cineasta guarda para si a câmera e, com ela, um certo nível de poder e controle potenciais sobre os acontecimentos.) ${ }^{\text {247 }}$.

Além disso, o filme inclina para o modo participativo através das inúmeras entrevistas que Moore realiza, pois como pontua Nichols: "a entrevista permite que o cineasta se dirija formalmente às pessoas que aparecem no filme em vez de dirigir-se ao público por comentário com voz-over" ${ }^{\prime 24}$. E, como se embaralhasse a tipologia de Nichols, Moore faz as duas coisas: se utiliza principalmente da voz over como uma voz de deus e ainda utiliza entrevistas criando novas situações diante da câmera que, como

\footnotetext{
${ }^{244}$ NICHOLS, Bill. La representación de la realidad: cuestiones y conceptos sobre el documental. Ediciones Paidós Ibérica, S.A: Barcelona, 1991, p. 68.

${ }^{245}$ NICHOLS, Bill. Introdução ao documentário. Campinas, SP: Papirus, 2005, p.153.

${ }^{246}$ NICHOLS, Bill. Introdução ao documentário, op.cit.

${ }^{247}$ NICHOLS, Bill. Introdução ao documentário, op.cit., p.154.

${ }^{248}$ NICHOLS, Bill. Introdução ao documentário, op. cit., p.154.
} 
diria Nichols: "o que vemos é o que podemos ver apenas quando a câmera, ou o cineasta, está lá em nosso lugar [...] vemos como o cineasta e as pessoas que representam seu tema negociam um relacionamento [...]"249.

Como ocorre em Roger e Eu, em The Big One, o discurso é valorado de princípios morais em favor de um grupo social específico - neste caso, o dos trabalhadores assalariados. Segundo Goffman, "na medida em que uma representação ressalta os valores oficiais comuns da sociedade em que se processa, podemos considerá-la, à maneira de Durkheim e Radcliffe-Brown, como uma cerimônia, um rejuvenescimento e reafirmação expressivos dos valores morais da comunidade ${ }^{\text {} 250}$.

Para isso, o filme se vale de casos particulares, de pequenos grupos de trabalhadores em momentos de dificuldades, da imagem de mães desempregadas, enfatizando mulheres trabalhadoras que buscam uma vida melhor para os filhos, com ou sem maridos, como se a instituição família valorizasse ainda mais alguns dos trabalhadores, que além de buscar manutenção pessoal estariam sobrecarregados de responsabilidades em relação aos seus dependentes.

Os valores morais de Moore e o grupo social do qual ele participa, colocados desde a abertura de Roger e Eu, com ênfase na família, e na realização da sociedade de consumo através do trabalho produtivo ${ }^{251}$, voltam a compor o discurso do filme The Big One. Esses valores vão sendo cuidadosamente colocados nos momentos em que o personagem principal se apresenta para a plateia, realiza entrevistas, ou ainda, quando Moore toma parte no confronto com representantes do governo ou com o empresário da Nike, que é o ponto alto do filme.

Moore aparece muitas vezes no filme proferindo uma espécie de palestra, o que algumas vezes se confunde com uma comédia stand $u p^{252}$, pois além das denúncias

\footnotetext{
${ }^{249}$ NICHOLS, Bill. Introdução ao documentário. Campinas, SP: Papirus, 2005, p. 155.

${ }^{250}$ GOFFMAN, E. A representação do eu na vida cotidiana. Petrópolis: Vozes, 2009, p. 41. Reafirmar os valores caros ao grupo social, favorece a aceitação do personagem Michael Moore no discurso fílmico.

${ }^{251}$ Digo trabalho produtivo no sentido de capital empregado na produção de mercadorias e gerador de empregos, não no sentido de capital financeiro em que dinheiro gera dinheiro sem passar pelo trabalhador. Antunes aponta que após o ciclo expansionista do pós-guerra iniciou-se a "desregulamentação dos capitais produtivos" com a "forte expansão e liberalização dos capitais financeiros" (p.32). ANTUNES, Ricardo. Os sentidos do trabalho: ensaio sobre a afirmação e a negação do trabalho. São Paulo: Boitempo editorial, 2002. Este tema permeia boa parte do filme e voltará outras vezes neste trabalho.

${ }^{252}$ Comédia stand up é um tipo de show originado nos EUA em que o comediante faz um monólogo humorístico com assuntos que foram notícia em seu lugar social (país, cidade, ou um assunto que tenha destaque mundial). O comediante usa o palco sozinho e sem nenhum recurso extra, além de uma mesinha de apoio para água, ele apresenta suas piadas buscando entreter a plateia por um período de 40 a 60 minutos. Esse tipo de comédia era usado para animar a plateia antes de um grande show ou nos seus intervalos, depois ganhou status de show único devido o sucesso de mestres de cerimônia como Jack
} 
sobre a precariedade do trabalho e as constantes demissões em massa, ele se vale de uma maneira cômica de agir, fazendo piadas, cantando, inventando histórias, interpretando situações, lendo trechos do seu livro, e tudo que promova risos e aplausos por parte do público.

Ao tratar do momento de representação do indivíduo e o esforço que este empreende para controlar a interação com o público a que se dirige, Goffman aponta, além da fachada pessoal, o termo maneira para sinalizar:

[...] os estímulos que funcionam no momento para nos informar sobre o papel de interação que o ator espera desempenhar na situação que se aproxima. Assim, uma maneira arrogante, agressiva pode dar a impressão de que o ator espera ser a pessoa que iniciará a interação verbal e dirigirá o curso dela. Uma maneira humilde escusatória pode dar a impressão de que o ator espera seguir o comando de outros, ou pelo menos que pode ser levado a proceder assim ${ }^{253}$.

Algumas vezes, Moore muda a maneira como se dirige ao público e, tomando ares de revolta, chega a falar mal de algumas empresas dizendo que não as suporta mais, como fez após ver a situação das mães subsidiadas que queriam trabalhar, e esta reação cessa momentaneamente os risos da plateia.

Em outros momentos do filme, Moore fala de sua infância na escola católica e de como as "irmãs" vigiavam os alunos para não cometerem atos considerados indecentes pela escola, o que configura no filme, um momento de livre combinação do "real" e do imaginário, ou do vivido e da idealização ${ }^{254}$ do vivido.

O filme é iniciado com Moore falando para a plateia (o grupo que ele está começando a construir será tratado à parte). Ele recebe aplausos e entra a animada

Benny, Fred Allen, Bob Hope, e outros mais contemporâneos como, Billy Cristal e Jerry Seinfeld e outros. Cf. http://www.clubedacomedia.com.br. Acesso em junho de 2011. Um artigo publicado em setembro de 1997 na Barnes and Noble Review cita que Moore é comparado ao famoso comediante estadunidense Will Rogers em relação à abordagem humorística que Moore faz da política social. http://search.barnesandnoble.com/Downsize-This/Michael-Moore/e/9780060977337. Acesso em junho de 2011.

${ }^{253}$ GOFFMAN, E. A representação do eu na vida cotidiana. Petrópolis: Vozes, 2009, p. 31.

${ }^{254}$ Conforme aponta Goffman, no momento da representação é comum que os atores tenham a tendência de "oferecer a seus observadores uma impressão que é idealizada de várias maneiras diferentes". In: Goffman, E. A representação do eu na vida cotidiana. Petrópolis: Vozes, 2009, p. 40. Moore relata momentos do seu passado na escola católica, mas, nunca se saberá ao certo qual "coeficiente de realidade" daquilo que ele diz, antes, interessam os efeitos do que ele diz sobre a plateia que o aplaude num gesto de aceitação do que é dito. 
música Panic em Detroit, de David Bowie. A câmera afasta a imagem inicial do rosto de Moore e centraliza em nova imagem com ele ao centro, sob o foco de luz, com um banquinho de madeira ao seu lado - que serve de aparador de água e copo. Também aparecem nesta imagem: outra câmera que faz as filmagens de Moore em sua palestra, além da sombra do público que o prestigia naquele momento. Esta cena confere um tom de celebridade ao personagem que usará este rótulo para satirizar a si mesmo durante o filme. Em seguida, uma cartela com letras brancas em tamanho gigante, apresenta separadamente cada palavra que dá nome ao filme e depois as reapresenta juntas, ocupando a totalidade da tela de fundo preto para darem de forma literal o nome do filme: The Big One.

A ideia de grandiosidade permeará todo o filme, que inicia sua construção apresentando as credenciais de uma empresa do porte da $\mathrm{BBC}$, depois, contraditoriamente, parte para o conflito com outras grandes corporações: (Hershey's, Johnson Control, Nike, Procter \& Gamble, Pillbury, Manpower, K-Mart), e seus movimentos de globalização econômica que interferem na vida de milhares de trabalhadores $^{255}$. Downsize This!, teve os direitos de distribuição comprados pela Random House, uma gigante do setor editorial, que colocará seu autor em turnê por 47 cidades em 50 dias pelo The Big One - como Moore chamará os EUA no filme - um país de dimensões e, como indica o filme, pretensões econômicas, gigantes.

Depois do título, uma nova cartela confere outro crédito comum aos filmes de mainstrean, que é o nome do diretor tornado celebridade: "um filme de Michael Moore." Neste momento de sua carreira como cineasta e escritor, Michael Moore já é bem conhecido do público estadunidense pelo seu filme Roger e Eu (1989), por dois episódios de um documentário curto feito para TV, o primeiro chamado: Two Mikes don't make a right (1992), e o segundo chamado Pets or meats: the return to Flint (1992); por duas temporadas do programa TV Nation (1994-1995) e por seu filme de ficção Canadian Bacon (1995) $)^{256}$. Em 1997, Moore lançou The Big One $e^{257}$ e mais dois

\footnotetext{
${ }^{255}$ Segundo Antunes, a precarização da força humana de trabalho é crescente dentro de um quadro de competição intercapitalista (sinalizado em The Big One com as Corporações), com o desenvolvimento tecnológico, e expansão dos capitais produtivos e financeiros. $C f$. ANTUNES, Ricardo. Os sentidos do trabalho: ensaio sobre a afirmação e a negação do trabalho. São Paulo: Boitempo editorial, 2002, p. 33.

${ }^{256}$ Comédia que satiriza um hipotético conflito dos EUA contra o Canadá para reanimar a supostamente falida economia estadunidense, já que os russos não estariam interessados em uma nova guerra fria. http://www.imdb.com/title/tt0109370/. (Acesso em maio de 2011).

${ }^{257}$ Traduzido pelo site do IMDB no Brasil como "Cortando custos" esse filme não foi distribuído no Brasil. A respeito do seu lançamento, The Big One estreou primeiro no Canadá em setembro de 1997, na Alemanha em fevereiro de 1998 para depois ser apresentado nos EUA - em 10 de abril de 1998. http://www.imdb.com/title/tt0124295/. (Acesso em maio de 2011).
} 
volumes de vídeos documentários sobre o programa TV Nation. Além disso, a atuação de Moore como defensor de mudanças na situação dos trabalhadores tem repercutido cada vez mais entre crítica estadunidense, rendendo inúmeros artigos na mídia ${ }^{258}$. Em 1998, ao falar de The Big One "como um filme inteligente, mas não muito diferente de Roger e Eu", o crítico de cinema Roger Ebert chama Moore de "o proletário de boné de beisebol" que estaria a "nadar contra a corrente" enquanto faz sua "guerrilha" pela situação dos trabalhadores demitidos nos EUA e contra os fat cats $^{259}$.

É interessante notar a leitura que a crítica estadunidense faz a respeito da posição pró-sindicato, defendida por Moore, como uma tendência política mais à esquerda. Entretanto, Moore parece "conservador" em muitos momentos do filme, orgulhoso da posição que seu país ocupa na economia mundial, com suas grandes corporações, desde que isso não afete os empregos e o consumo interno. Em outros termos, Moore não é contra as empresas e sim contra os cortes de empregos em seu país, e ainda, contra a precarização das relações de trabalho entre os empresários e trabalhadores, devido ao enfraquecimento dos sindicatos e a consequente diminuição do poder de negociação por melhores salários e direitos. Em alguns momentos as declarações do cineasta soarão preconceituosas em relação a alguns personagens apresentados no filme, como o caso do jovem ex-presidiário que será analisado mais adiante.

Ebert, também afirma que se o Michael Moore de Roger e Eu foi um "outsider", o Moore de The Big One é "celebridade" reconhecida em todos os locais por onde passa $^{260}$. Alguns artigos associam Moore como defensor dos trabalhadores, como foi publicado pela livraria The Barnes \& Noble ao chamá-lo de "porta voz do trabalho americano" 261 .

Se o crítico de cinema Roger Ebert equaliza valorativamente Roger e Eu e The Big One, esta análise segue a contrapelo desta ideia evidenciando uma construção visual bastante frágil em The Big One, pois muitas cenas celebram mais a figura do narrador e a divulgação de seu "best seller", do que o grupo dos trabalhadores mal construído no filme. Isto implica que, ao associar a filmagem de um filme documentário com uma

\footnotetext{
${ }^{258}$ No site da produtora de Moore, Dog Eat Dog, existe uma lista de artigos escritos nos EUA sobre o filme The Big One. http://www.dogeatdogfilms.com/press.html. (Acesso em maio de 2011).

${ }^{259} \mathrm{Cf}$. http://rogerebert.suntimes.com/apps/pbcs.dll/article?AID=/19980410/REVIEWS/804100301/1023. (Acesso em maio de 2011).

${ }^{260} C f$. http://rogerebert.suntimes.com/apps/pbcs.dll/article?AID=/19980410/REVIEWS/804100301/1023. (Acesso em 03 de maio de 2011).

${ }^{261} \mathrm{http}: / /$ search.barnesandnoble.com/Downsize-This/Michael-Moore/e/9780060977337. Acesso em maio de 2011.
} 
turnê promocional, a produção de The Big One não repete a mesma qualidade observada na montagem das cenas e na construção da narrativa de Roger e Eu.

Neste sentido, ao invés de focalizar a causa dos trabalhadores estadunidenses (que foi a proposta inicial do documentário), The Big One parece celebrar a popularidade de Moore em cenas que é reconhecido pelas aeromoças, nas livrarias e palestras onde recebe um número razoável de público, ou mostrando que o livro (Downsize This!) chegou ao topo dos 10 mais vendidos na lista do jornal The New York Times, além de outras situações que serão sinalizadas nesta análise ${ }^{262}$.

Contudo, Moore também recebeu duras críticas veiculadas em importantes canais de notícias como o jornal The New York Times ${ }^{263}$ cuja matéria publicada em $1^{\circ}$ de fevereiro de 1990 por Richard Bernstein faz um balanço do que a crítica estadunidense já teria escrito a respeito do filme Roger e Eu. Bernstein aponta afirmações de nomes conhecidos, como Pauline Kael entre outros, que acusam Moore de "manipulação de sequências de eventos" para causar "impacto emocional e político", e que Roger e Eu é "tendencioso e enganoso" com um "estilo de humor negro" cuja proposta seria o "entretenimento".

Além disso, Bernstein aponta que, "para os detratores de Michael Moore", as mesmas qualidades que fizeram Roger e Eu um filme de sucesso, como "os elementos de irreverência, sátira e ridicularização" são os mesmos motivos que tornam o filme enganoso, visto que a sátira depende de parcialidade e exagero para a "deformação do mundo real”. O mesmo artigo cita uma declaração de Michael Moore, afirmando que é sim parcial nos seus filmes e que usa de uma "comedic license" para "contar os fatos".

Embora The Big One remeta às criticas sofridas pelo cineasta, não é foco deste trabalho fazer o levantamento e estudar críticas realizadas em torno da pessoa Michael Moore $^{264}$. Antes, este trabalho incide sobre os filmes e, dentro de cada filme, a

\footnotetext{
${ }^{262}$ Este filme teve quatro prêmios dentro dos EUA: em 1997 no Aspen Film Fest ganhou por "audiência de documentário favorito", em 1998 ganhou como melhor documentário pelo Boston Society of Film Critics Awards, em 1997 ganhou o prêmio People choice award como filme documentário pelo Denver International Film Festival, em 1999 ganhou o prêmio KCFCC de melhor documentário pelo Kansas City Film Critics Circle Awards, em 1999 ganhou como melhor documentário no Online Film Critics Society Awards. Fonte das premiações: http://www.imdb.com/title/tt0124295/awards e http://www.dogeatdogfilms.com/tbo.html. (Acesso em 03 de maio de 2011).

${ }^{263}$ Cf.http://www.nytimes.com/1990/02/01/movies/roger-and-me-documentary-satire-or-both.html. (Acesso em 03 de maio de 2011).

${ }^{264}$ Um trabalho em torno da execução e recepção dos filmes de Moore foi realizado por Cristiane Maria Toledo com o título: "O fenômeno Michael Moore na crise do imperialismo norte-americano". Em seu trabalho, a pesquisadora da FFLCH-USP fez extenso levantamento das críticas publicadas em torno dos filmes de Moore desde Roger e Eu até Tiros em Columbine, incluindo os programas feitos para a
} 
construção do seu personagem principal. Em comparação com a representação que Moore construiu de si mesmo em Roger e Eu, e com os debates produzidos a partir do seu primeiro filme, as críticas negativas parecem ter produzido algum efeito na representação que o personagem Michael Moore faz em The Big One.

Neste segundo filme, o personagem é construído de modo diferente do Moore de Roger e Eu, sem, contudo, perder o objetivo de legitimação do seu discurso, só que desta vez, se coloca de modo mais irônico que no filme anterior, fazendo contraposições entre supostas "verdades" e "mentiras" acerca de sua biografia. Moore se constrói como narrador privilegiado, porém não mais se auto elogia como fez no filme anterior, adotando uma postura irônica de quem não se coloca diretamente como o mais indicado para narrar essa história, ao mesmo tempo em que não deixa de fazê-lo. Ele parece tentar rebater as críticas da mídia na postura "humilde" que adota e, enquanto isso, o filme fará o oposto, construindo Moore como pessoa qualificada, e engajada para narrar o filme e apoiar a causa dos trabalhadores contra o desemprego.

A construção do personagem Michael Moore, visando à legitimação do seu discurso ocorre, principalmente, nas cenas iniciais do filme, mas também se estende por diversos momentos que serão realocados neste primeiro bloco de análise.

Colocada na calçada, a câmera filma de baixo para cima, Moore caminhando pelas ruas e dizendo que estaria sem trabalho. Sua fala soa esquisita:

$\neg$ Estou sem trabalho. E fiz como a maioria nessa situação. Escrevi um livro: "Downsize This! Ameaças aleatórias de um cidadão desarmado".

Desta fala podem-se imaginar duas proposições: ou Moore deprecia escritores como sendo pessoas desocupadas, ou ele sugere sua própria genialidade dizendo em chave irônica que como todo mundo que fica sem emprego (o que era cada vez mais comum) ele escreveu um livro (o que não é comum para desempregados). Isto também pode sugerir que todos os desempregados deveriam refletir acerca do desemprego crescente no país.

Escrever um livro a respeito do desemprego representa, na construção desse personagem, afirmar que ele tem condições de discorrer acerca da situação. E para

televisão e os livros do cineasta/escritor de modo a avaliar a reverberação da produção de Moore tanto nos EUA quanto no Brasil. 
enfatizar que seu livro é bom, Moore diz que os direitos editoriais foram comprados pela Random House, o que é "confirmado" através de imagem filmada de baixo para cima valorizando seu prédio monumental.

A pedido da editora, Moore faria uma turnê de divulgação que inicialmente seria em 4 ou 5 cidades (foram em 47 !). Na representação de seu "despreparo" para o papel de narrador desta história, Moore diz:

ᄀ eu respondi: “Claro, com muito prazer!”. Especialmente considerando que jamais havia pisado na universidade e que no colégio fui reprovado em inglês.

Enquanto Moore fala de si, o filme mostra foto em preto e branco de um jovem com alguns colegas. E ele continua:

$\neg$ Gostava da ideia de entrar no jogo da fama. Já via em minhas mãos o Pulitzer e o Nobel. E sendo convidado ao show de Jerry Springer.

Enquanto exagera para satirizar a importância de seu livro que poderia concorrer a prêmios importantes como o Pulitzer e o Nobel, Moore cita que também poderia ser convidado para participar do show de Jerry Springer ${ }^{265}$. Esse programa de auditório apresenta pessoas que supostamente estariam com problemas familiares ou defendendo posições que não são "politicamente corretas". O programa leva essas pessoas para debaterem seus problemas no palco e o auge do show ocorre em torno dos confrontos com brigas, no sentido literal do termo, além de insultos em frente às câmeras (como evidenciam as imagens do filme sobre o show).

Enquanto em Roger e Eu, Moore construiu sua família de modo idealizado, apresentando fotos de seus parentes em cenas do cotidiano harmônico, próspero e feliz; em The Big One, o cineasta sugere que participaria de um programa de auditório que apresenta famílias em problemas de relacionamento. Isso também pode significar que Moore gostaria de ser tão popular como aquele show televisivo. Embora Moore pareça

\footnotetext{
${ }^{265}$ Alguns sites americanos informam reportagens que consideram o show de Jerry Springer como "trash televisivo". Norman Solomon do portal crítico de mídia Albion Monitor, reafirma a popularidade do show de Springer, contudo diz que se trata de "uma apresentação diária de violência e abuso verbal". http://www.albionmonitor.com/9805a/copyright/ns-springer.html. (Acesso em 12 de julho de 2011).
} 
mais "humilde", o filme o constrói como uma figura importante nos EUA, mostrando que foi convidado para participar do renomado programa de Larry King na $C N N$ cujo formato jornalístico recebe personalidades do cenário político, econômico e cultural, e se distancia muito do show de Jerry Springer em termos de reconhecimento pela crítica.

$\mathrm{Na}$ construção de um personagem, que utiliza a "crítica como forma de resistência" ${ }^{266}$, Moore mostra matéria publicada no jornal dizendo que a Casa Branca não gostou de sua brincadeira. Ele fez uma doação simbólica de cem dólares para, o então presidente, Bill Clinton em nome de um grupo fictício de "plantadores de haxixe". Também aparece no filme o porta voz da presidência Mike McCurry dizendo que o cineasta seria uma pessoa perigosa. O filme aponta para alguns efeitos do trabalho de Moore, pois parece que até o presidente Bill Clinton estaria incomodado com a forma que o cineasta produzia suas "provas" a fim de criticar a suposta corrupção ou ganância entre políticos.

Nesse sentido, Michael Moore ganhou cada vez mais notoriedade como crítico da sociedade americana. No documentário canadense Corporation (2003), cerca de 40 pessoas renomadas e de diferentes posições políticas são entrevistas se posicionando a favor ou contra as corporações. Michael Moore participa com seus depoimentos distribuídos em cinco momentos do filme. Sua fala tem tanta importância que Corporation é encerrado com Moore dizendo que usa as brechas das grandes corporações que o financiam, como a Warner Brothers, para falar contra essas mesmas corporações, porque sabe que incomoda os políticos e os empresários. Assim, esta seria sua contribuição para "mudar o mundo". Nas palavras de Moore,

"Chega a ser irônico que eu seja capaz de fazer tudo isso, e ainda estar no esquema [mainstream]. Estou nas Tvs, sou distribuído pelos estúdios de grandes grupos. Porque eles me divulgam se sou contra tudo o que representam? Eu gasto o dinheiro deles para criticar suas crenças. Bem, é porque eles não acreditam em nada. Eles me divulgam porque sabem que milhões de pessoas querem ver meu filme, ver o programa na TV e eles vão faturar. Eu consigo divulgar o meu trabalho porque aproveito esta incrível falha do capitalismo. A

\footnotetext{
${ }^{266}$ AMADO, Ana. Michael Moore e uma narrativa do mal. In: MOURÃO, Maria Dora \& LABAKI, Amir. São Paulo: Cosac Naify, 2005, p. 219.
} 
falha da cobiça. O ditado diz que o rico venderá a corda para se enforcar se ele achar que lucrará com isso. Eu sou a corda. Espero. Sou parte da corda. Eles também acham que quando as pessoas assistirem a este filme, acham que elas verão o filme e não farão nada porque fizeram um bom trabalho entorpecendo suas mentes tornandoas idiotas e eles jamais farão nada, não deixarão o sofá para tomar uma ação política. Eles estão convencidos disso. Eu acho o oposto. Estou convencido de que alguns deixarão o cinema sairão do sofá e farão algo para retomar o mundo,"267.

The Big One, produzido alguns anos antes de The Corporation, propõe um Michael Moore em uma postura mais "humilde" ou menos valorativa do que o narrador que se colocava como um pequeno gênio desde os seis anos de idade em Roger e Eu. Contudo, Moore parece brincar com esse papel de si que é mais ou menos enaltecido pelo filme conforme muda a situação. Um desses momentos ocorre na cena dentro do avião em que Moore brinca que ele ficaria ali na frente (primeira classe), enquanto os integrantes de sua equipe iriam para trás da cortina junto da classe turística, ou econômica, e suas dezenas de poltronas apertadas. Depois o filme mostra os membros da equipe bem no fundo do avião. Outra cena na livraria Library, cujo auditório está tomado pelo público, Moore satiriza sua imagem no livro falando sobre sua "manicure digital" e ressalta que já são 19 cidades! As imagens corroboram o sucesso da turnê ao mostrar a pilha de livros que Moore deve autografar diante de uma fila de compradores. Mesmo no estacionamento da livraria seu autógrafo era solicitado, indicando notoriedade ao cineasta/escritor.

Os intervalos que representam o deslocamento da equipe de filmagens pelas cidades são sinalizados sempre de modo didático pelo filme, com a imagem de aviões (pelo menos 5 vezes), em aeroportos, e outras da equipe se deslocando de van pelas estradas. Como a cena em que toca a música Hightway Junkie da banda The Yayhoo para apontar mais uma viagem do grupo dentro de uma espécie de furgão.

Em sua primeira viagem à cidade de St. Louis, Moore afirma que ninguém sabia que faria esse filme. Enfatizando a logística requerida para o auxiliar na distribuição do livro, o diretor cita a quantidade de representantes da editora (4 no total), ou, como prefere chamar de "escoltas", contratadas para fazerem com que cumpra sua agenda

${ }^{267}$ Fala de Michael Moore no final do documentário The Corporation (Canadá, 2003). 
durante as visitas. Com esse aparato ao redor, Moore diz que agora todos saberiam dos seus feitos e proezas.

Moore parece reclamar que não importava em qual cidade, sempre concedia umas 20 entrevistas que faziam as mesmas 20 perguntas. Apesar de parecer entediado, sua fala sinaliza que por onde passava era considerado o porta-voz dos trabalhadores e respondia sempre perguntas relacionadas aos problemas que envolviam pessoas demitidas, como ele cita a respeito do caso Whitewater que também resultou em demissões ${ }^{268}$.

Ao chegar à loja Media Play com som de música animada, Moore brinca de se comportar como celebridade pedindo que não tirem fotos. Apesar de dizer que estava em Rockfort, uma das piores cidades eleitas pela Money para se viver nos EUA, ele registra a grandiosidade daquela loja como um "complexo enorme" onde se vendiam livros, CDs, vídeos. O filme propõe que os livros de Moore estariam sendo popularizados ao serem posicionados no meio de vários símbolos da cultura americana dos anos 90, como o boneco ET do filme de Spielberg, do escritor Stephen King, do cantor Michael Bolton, Tina Turner, e até da personagem Pocahontas, da Disney. Além disso, a livraria estava na mesma rua em que morava Rick Neilson, guitarrista dos Cheap Trick, a quem Moore queria insistentemente visitar.

Para sinalizar as diferenças entre o que é dito a respeito de Moore e o que ocorreria na repercussão de sua carreira, (como se o filme pretendesse rebater as críticas recebidas pelo diretor de Roger e Eu), é apresentado um momento em que a roteirização do filme aparece mais claramente. Isso ocorre quando Moore e a gerente da loja Media Play, Ann Patty, parecem brincar de dizer “mentiras e verdades”. Ele pergunta algumas vezes para Patty se Rick Neilson estava na cidade, e ela sempre responde que não está, mas o filme mostra Moore indo até a casa do guitarrista visitá-lo, onde ambos tocam e cantam juntos. Depois ele pergunta acerca dos números das vendas de seu livro, e Patty diz que só $3 \%$ das pessoas que entram na fila, ou o escutam, compram o livro. Patty também diz que a loja concorrente, Barnes \& Noble, não tinha o livro de Moore para vender, e ele vai até a $B \& N$ filmar os vendedores com pilhas de seus livros sendo colocados à venda. Pelo modo como Patty dá risadas e se atrapalha nas falas é possível

\footnotetext{
${ }^{268}$ Polêmica envolvendo o casal Bill Clinton e Hilary Clinton, quando ele foi governador do Arkansas e teria usado sua influência para que membros do governo concedessem empréstimos para seus sócios em uma imobiliária. O casal foi inocentado por falta de provas, contudo o caso repercutiu por vários anos. $C f:$ http://www.tsf.pt/PaginaInicial/Interior.aspx?content_id=779252. (Acesso em 19 de junho de 2011). http://www1.folha.uol.com.br/folha/mundo/ult94u8729.shtml. (Acesso em 19 de junho de 2011). http://edant.clarin.com/diario/1997/08/23/i-03501d.htm. (Acesso em 19 de junho de 2011).
} 
que esteja fingindo mentir. Em seu didatismo característico, como se quisesse reforçar aquela cena para o público espectador, Moore ainda faz Patty repetir todas as falas que tinha dito para entrarem as cenas que o filme provará o contrário. Ele quer saber a fonte de Patty acerca daquelas cifras, e ela diz que é da Random House. Depois, o filme mostra Moore conversando com Doug France, representante da Random House, reafirmando o sucesso de vendas do livro. Segundo Doug, de cem pessoas que entraram na loja, cem livros foram vendidos: "Se trata de um recorde de vendas".

A vendedora da $B \& N$ faz a afirmação que Moore quer reforçar para o público do filme, dizendo:

$\neg$ Parece que as calúnias se espalham.

Com esta fala, o filme sugere que toda a representação de "humildade", que Moore vinha fazendo de si, parece contradizer a imagem valorativa construída em The Big One.

Em Milwaukee, o filme mostra o depoimento da "media escort" responsável por conduzir Moore aos compromissos agendados. É Mary Gielow dizendo que Milwaukee não era como as grandes cidades que gostavam de receber "celebridades, estrelas de cinema, ou gente que se acha o bonzão" antes, ali eles preferiam acolher "pessoas mais reflexivas, novelistas ou escritores como Michael - que está fazendo uma turnê interessantíssima". Além disso, ela usa palavras de efeito como "impactante" e "jamais tinha visto nada igual".

Mary Gielow é uma mulher que parece ser "firme" com Moore. Ela se veste de modo impecável, tem uma postura decidida e prefere não se envolver nos momentos em que Moore promove confrontos, seja com os representantes da empresa Johnson Controls, seja com os representantes do governador de Wisconsin, de quem se diz amiga. Assim, seu depoimento elogioso ao trabalho de Moore ganha um teor crítico consistente, visto que Gielow não se colocava como fã do cineasta, e, mesmo assim, o filme retoma suas falas em outros momentos, quando qualifica o trabalho "interessantíssimo" do cineasta. Diferente da postura neutra adotada pela outra "escolta" Elaine Blay que só aparece uma vez no filme. Também teve uma terceira mulher, Diane Mitchell-Urman, que em uma postura amigável, declarou-se fã de Michael Moore logo no momento que o conheceu pessoalmente, de modo que não ofereceu nenhuma oposição e, portanto, sua opinião de fã seria menos representativa do que a de Mary 
Gielow que, dentre todas as quatro "escoltas", foi a que ganhou mais tempo na execução do filme.

"Media escort" é um termo utilizado para nomear a função das três mulheres que dirigem a agenda de Moore em relação aos compromissos assumidos junto à Random House. Ao conversar com o único "escolta" masculino que o acompanha na turnê, Moore pergunta como seria outro nome para "escort" e o homem, talvez atento à "brincadeira" responde: - Gigolô! (observando o significado de escort também usado para "acompanhante" no sentido de prostituta, ele referia a si próprio, então, como o gigolô). Essa cena aparentemente insignificante, confere o sentido inapropriado para a palavra "escort" em relação às três mulheres. Assim, fica registrado no filme um momento preconceituoso e antiético de Michael Moore em relação às três mulheres que o acompanharam durante sua turnê. Além disso, ao encontrar Garrisson Keillor na livraria, Moore pede conselhos em como o outro escritor de "sucesso" lidava com as "escort". Em resposta, Keillor o adverte: "não pense, não se envolva, tome duchas frias e vá para a igreja". Mantendo o tom do seu preconceito em torno das "escort" até o fim do filme, Moore ainda lembra que pediu conselho ao guitarrista Rick Neilson sobre como se livrar da "escort", porque era seu aniversário de casamento e sua esposa viria visitá-lo. O filme chega a apresentar uma situação, encenada ou não, na qual Moore seguia os conselhos do guitarrista, pedindo para Diane Mitchell-Urman que fosse buscar cigarros fora da livraria. Após sair para cumprir sua tarefa de auxiliar do escritor, a escort é acusada por Moore de "assédio" ao segurança da livraria que a impede, momentaneamente, de voltar para o interior da loja, deixando-a constrangida.

Apesar do tom de brincadeira que envolve as cenas, o filme perde o foco em relação à situação dos trabalhadores e o problema do desemprego, para ocupar o tempo de realização com situações secundárias e, ainda, carregadas de preconceito como foi o duplo sentido conferido às "media escort" contratadas pela Random House. Em The Big One, Moore parece tão centrado em sua própria turnê promocional que, em alguns momentos, parece ter esquecido que também estava fazendo um filme documentário, como ele coloca nas cenas iniciais.

Nas sequências do filme, fica cada vez mais delineada a construção em torno de Moore e não dos trabalhadores. O filme enfatiza que o livro de Moore chegou ao topo da lista de livros mais vendidos anunciados pelo New York Times. Em outro momento, Moore está diante de uma plateia de estudantes da Universidade de Havard reconhecida tanto por sua produção intelectual na área do direito quanto por sua posição 
política não muito afeita aos "esquerdistas". Vale lembrar que Harvard foi o local de trabalho, em 1996, de ícones da direita estadunidense como, por exemplo, Samuel Huntington, cujo livro "Choque de civilizações" se distancia muito do debate crítico proposto nos filmes de Moore.

Após legitimar Michael Moore como narrador privilegiado, o filme constrói dois grupos sociais como personagens em conflito: de um lado estariam os políticos aliados aos empresários e suas corporações construídos como um grande grupo burguês, e de outro, Moore com os trabalhadores demitidos, os que ganham pouco, e as pessoas que vivem de subsídios como as mães de Wisconsin. Esse segundo grupo é construído como defensor do trabalho, e o filme retoma de modo muito frágil uma alusão ao conflito de classes que foi construído em Roger e Eu.

Um terceiro grupo mediador comporta as pessoas que não participam do conflito, mas que de alguma forma auxiliam na apresentação dos eventos em torno dos grupos principais. Entre os personagens do grupo de mediação estão os dois radialistas que apresentam o livro de Moore, os repórteres locais que o acompanham nos confrontos, além dos cinco representantes da Random House, (um de vendas, as três mulheres e o único escolta homem que tem uma passagem muito rápida pelo filme), e os vendedores das demais livrarias, (como a gerente Ann Patty - embora esses também sejam trabalhadores eles não participam do conflito proposto pelo filme indicando uma construção frágil em torno da figura do trabalhador). Além disso, entra no grupo de mediação o policial que supostamente prende Moore, o segurança externo da Leav, e o guitarrista a quem Moore visitou. Também aparece em cena um jovem ex-presidiário que ganhará espaço com um tratamento preconceituoso do filme - sua construção se dará mais adiante. The Big One também apresenta, nas sequências iniciais, os membros da equipe de produção dos filmes Moore: Tia Lessin como produtora, Jim Czarnecki como produtor, Brian Danitz e Chris Smith como diretores de fotografia.

O desafio construído pelo filme envolve alguns políticos, problemas econômicos e o saldo social, sinalizando as transformações no sistema capitalista com a globalização da economia e as profundas mudanças no cotidiano dos trabalhadores estadunidenses. Os conceitos que balizam essas transformações serão analisados junto aos respectivos grupos. Os principais enfrentamentos do filme ocorrem entre Moore e os empresários, com as entrevistas e tentativas de entrevistas, além de alguns protestos públicos com grupos de trabalhadores, como por exemplo, os da Leaf e outros que são mostrados rapidamente no fim do filme. Algumas cenas de cortes rápidos, lembrando um vídeo 
clip devido o acompanhamento da música We Will Rock You - propõem a construção de um desconforto gerado pelas manifestações dos grupos pró-empregos e pró-sindicatos em cada confronto com seus "opositores". Assim, os aspectos que envolvem o problema da falta de empregos, as relações conflituosas entre os grupos construídos, o confronto, e a possibilidade de saídas para a crise, caracterizam os sistemas relacionais no filme.

Os dois primeiros grupos que movimentam o conflito do filme, na oposição capital versus trabalho, são construídos com interesses incompatíveis, pois enquanto os trabalhadores querem manter seus empregos, os empresários estariam interessados, como diz uma representante da Johnson Controls, em se manter competitivos.

Para sugerir que alguns políticos, pertencentes ao primeiro grupo, seriam pessoas ávidas por dinheiro, Moore mostra comprovantes de doações em nome de "grupos realmente desprezíveis." Ele doou US\$ 100 para alguns políticos de diferentes legendas - democratas, republicanos e partidos independentes $\neg$ para dizer que, apesar dos grupos de colaboradores serem opostos à plataforma política do beneficiado, todos os cheques foram aceitos sem questionamento, isso porque eram automaticamente aceitos pelos sistemas computadorizados dos partidos. Os grupos "desprezíveis" criados por Moore foram: Fiéis de Satan com Dole, que doaram US\$100 dólares para Bob Dole - senador republicano pelo Kansas; o grupo Cultivadores de Haxixe dos Estados Unidos doou a mesma quantia para o então presidente democrata, e defensor antidrogas, Bill Clinton; o grupo Pró-aborto por Buchanan doaram outros US\$100 para o republicano antiaborto Pat Buchanan ${ }^{269}$; e o quarto grupo Pedófilos pelo livre-comércio que doou US\$ 100 dólares para Ross Perot, um empresário texano, conhecido como um dos mais ricos empresários do mundo que concorreu duas vezes à presidência dos Estados Unidos filiado a um partido independente - sua biografia não autorizada intitulada Citizen Perot pode ser vista nas prateleiras das livrarias visitadas por Moore.

\footnotetext{
${ }^{269}$ Para o público estadunidense talvez Pat Buchanan seja figura bem conhecida, mas para situar o público brasileiro, seguem algumas informações sobre este político: nascido em Washington DC, foi conselheiro sênior de três ex-presidentes estadunidenses: Richard Nixon, Gerald Ford e Ronald Reagan; Buchanan é conhecido também por sua posição política polêmica em favor da direita republicana ultraconservadora, ligada à igreja católica. Cf.http://www.buchanan.org/. Acesso em junho de 2011. Buchanan também é criador do site www.theamericancause.org (acesso em junho de 2011), em que publica artigos sobre suas opiniões em favor da América e sobre "o declínio da civilização ocidental" devido à imigração de não europeus para os EUA. O grupo The Anti-Defamation League, que se posiciona contra o racismo e o anti-semitismo, afirma que Pat Buchanan é um comentarista político racista, antissemita, anti-Israel e xenófobo. Ainda possui um programa semanal pela TV NBC chamado Mc Laughlin Group. Cf.http://www.adl.org/special_reports/buchanan_own_words/buchanan_intro.asp. (Acesso em 05 de junho de 2011).
} 
Além do então presidente Bill Clinton, que recebe um cheque de US\$100, doado pelo grupo pró-haxixe, outra figura política que o filme constrói em tom de humor é um dos concorrentes de Clinton naquelas eleições, o milionário Steve Forbes - filho do criador da revista Forbes. Conhecida por enumerar as pessoas mais ricas do mundo e seus negócios de sucesso.

Moore chama a atenção de sua plateia para observarem como Forbes não pisca quando está na televisão, e, após consultar um médico para se certificar que seres humanos piscam a cada 20 segundos, o cineasta diz em tom de constatação que Forbes deve ser algum alienígena, levando a plateia às gargalhadas. Moore chega a visitar o comitê de Forbes em Iowa para ver se ele era mesmo um "alienígena", mas como não o encontrou, fez sua entrevista bem humorada com um rapaz chamado Chip Carter, perguntando para onde iria a nave mãe após Iowa. As cenas da entrevista são apresentadas na conferência que Moore profere na Hoover High School, como se servissem para "comprovar" suas suspeitas, mas para além do humor, as imagens de Forbes na TV reforçam a construção negativa que o filme afirma através da depreciação dos políticos, sobretudo dos políticos conservadores como Steve Forbes e Tommy Thompson, que são mais depreciados do que o democrata Bill Clinton ${ }^{270}$. Sobre Thompson, Moore sugere que ele possa ter "traumas de infância para querer se vingar do povo de Wisconsin”, cortando subsídios de mães desempregadas. O governador pode ter cortado subsídios de diferentes cidadãos, porém o filme enfatiza a causa das mães.

Associados ao grupo dos políticos estariam os empresários, entre os quais o filme começa citando o fabricante de cigarros R.J.Reynolds como doador de "um milhão de dólares aos republicanos e meio milhão aos democratas”. Isto pode implicar que aos fat cats não importaria o grupo político e sim os benefícios que uma relação com esses grupos podem trazer.

Os políticos e os empresários, que perpassam The Big One, podem ser analisados no mesmo grupo do sistema relacional se pensados no contexto histórico e social trabalhado por Ulrich Beck como globalização. Primeiramente Beck entende a globalização (da economia, dos mercados, da concorrência por postos de trabalho, da

\footnotetext{
${ }^{270}$ Em um dos episódios do seu programa para TV The Awful Truth Moore "sai em defesa" de Clinton na ocasião que o congresso propõe um processo de impeachment contra o político, devido acusações de envolvimento sexual do então presidente com a estagiária Mônica Lewinsky. No programa humorístico, Moore reúne um grupo de atores para encenarem o histórico caso das Bruxas de Salém, em que garotas assustadas acusavam as pessoas de bruxaria e os acusados eram condenados à morte em processos da Santa Inquisição. Conforme o episódio constrói, Moore estaria mostrando ao público que uma questão privada, como a traição no casamento, estava sendo tratada publicamente e deveria dizer respeito aos envolvidos no problema: Clinton, Hillary e Mônica.
} 
produção, de mercados e serviços, das finanças, da informação, do estilo de vida) como um processo de "dissolução da modernidade" 271 que aponta para a "exclusão da política do quadro categorial do Estado nacional"272.

Segundo Beck, "a questão da globalização na virada para o século XXI representa, para as empresas que fazem negócios transnacionais, o mesmo que a questão das classes sociais representava para o movimento dos trabalhadores no século XIX" 273 . Isto quer dizer que, se o movimento dos trabalhadores representou, naquele período, o poder de oposição, as corporações atuam sem oposição transnacional. Livres da política de regulação do Bem Estar Social, afrouxada por anos de liberalismo econômico - desde Reagan e Thatcher - os empresários e suas associações conquistam "o pleno domínio do poder de negociação"274.

The Big One sugere uma parceria entre empresários e suas corporações que recebem subsídios do governo para crescerem, expandirem e manterem a concorrência internacional. Acerca desta suposta aliança pró-capital transnacional, Beck afirma que no contexto de globalização dos mercados e capitais (produtivos e financeiros), "o trabalho pode e deve ser reduzido para que cresçam os lucros" e "quem incentiva o crescimento da economia, produz desemprego no final" ${ }^{275}$, isto é, os próprios governos autorizam e incentivam a precarização do trabalho.

Nesta direção, The Big One apresenta alguns sintomas dessas transformações, porém, o modo como o filme constrói o problema e aponta as soluções é parecido com o que o cineasta fez em Roger e Eu, pois mostra Michael Moore perguntando aos empresários se os lucros obtidos já não seriam suficientes, uma espécie de cobrança moral. Moore insiste em saber quais motivos para mais lucros, de modo que a base da explicação do problema é situada em chave de explicação individual, desvinculando a macro-economia dos atores sociais (as instituições) e antes, vinculando as mudanças às aspirações individuais dos empresários, na condição de fat cats, e dos políticos na condição de interessados por dinheiro.

Quanto às empresas, essas são construídas na chave do interesse individual de seus diretores e acionistas sobre o interesse coletivo dos inúmeros trabalhadores que demitiam. O filme destaca que muitas dessas empresas recebem ajudas fiscais e

\footnotetext{
${ }^{271} \mathrm{BECK}, \mathrm{U}$. O que é globalização: equívocos do globalismo respostas à globalização. São Paulo: Paz e Terra, 1999, p. 25. (Grifos do autor).

${ }^{272}$ BECK, U. O que é globalização, op.cit., p. 13.

${ }^{273}$ BECK, U. O que é globalização, op. cit., p. 14.

${ }^{274}$ BECK, U. O que é globalização, op. cit.

${ }^{275}$ BECK, U. O que é globalização, op.cit., p.15.
} 
dinheiro do governo para incentivar os negócios a prosperarem, mas os negócios estariam lucrando muito longe dos contribuintes. Exemplo disso é colocado quando Moore fala para a rádio $K M O X$ em St Louis, dizendo que o Mc Donalds teria recebido um milhão de dólares só para promover em Singapura seus Chicken McNuggets. Ou quando diz que a indústria de alimentos Pillsbury recebe US\$11 milhões para que seu mascote faça "uma turnê por países do $3^{\circ}$ mundo." De modo geral, Moore enfatiza que o governo dos EUA concede 70 bilhões em "apoio social" às empresas, ou "três vezes mais que o pressuposto das ajudas sociais" aos cidadãos desempregados.

Em Milwauke, a música country toca no rádio do carro enquanto Mary Gielow dirige levando Moore para uma emissora de TV. Em suas participações junto à mídia local, Michael Moore retoma as relações conflituosas entre patrões e sindicatos, o que, segundo o entrevistado, passavam anos discutindo sem sucesso em uma relação de forças desiguais. $\mathrm{Na}$ mesma cidade, ocorre outro confronto com o grupo dos empresários. Desta vez é com representantes da empresa Johnson Controls que provê a indústria de automóvel (inclusive a $G M$ ) com peças de motor, revestimentos e suspensões. Esta empresa anunciou o fechamento de sua fábrica sede em Milwauke para reabri-la no México. Moore segue em direção à empresa para entregar tanto um cheque simbólico pelos US\$ 0,80 que eles pagariam para os funcionários no México, quanto o certificado de "demitidor do ano." Em uma cena ensaiada que mais parecia um ataque surpresa, dois cameramen entram com Moore na empresa, enquanto um terceiro, entrevista Mary Gielow que fica comportadamente distante do confronto dentro de seu carro.

O confronto na Johnson Control é um pouco tenso. Bev Jacowski recebe Moore de modo pouco amigável e diz que aquele não era um bom momento. Em seguida aparece outra mulher que, parecendo ter posição hierárquica superior a de Jacowski na empresa, atende Moore e sua equipe com simpatia. Apesar da urbanidade, essa mulher altera seu semblante, como que decepcionada pelo "presente" que Moore lhe trazia - o cheque de 0,80 centavos por hora de trabalho que a empresa pagaria aos mexicanos. Ela percebeu que não se tratava de uma visita amigável do cineasta e sim uma provocação, ou um confronto acerca das demissões promovidas pela Johnson Control. Nesse momento, a câmera faz um rápido corte para o rosto de Moore, desviando a imagem no instante que a mulher altera o semblante com a situação desconfortável.

Em seguida, já recomposta e parecendo diplomática, a representante responde as provocações de Moore em tom formal, porém mantendo alguma simpatia. Em outro 
momento ela firma o tom de voz e diz que a empresa não passava por dificuldades, mas se despedia de Milwauke para manter-se competitiva. A representante da empresa tenta sair do confronto, mas Moore sabe aproveitar cada momento a mais de filmagem e tenta continuar sua fala para valorizar a tensão criada na cena. Enquanto isso, a câmera focaliza outros empregados agitados pela visita inesperada de Michael Moore. A representante se atrapalha um pouco no modo firme que vinha mantendo a conversa, pedindo que o funcionário Jack a ajude, mas Moore termina por colocar ambos em momentos difíceis apelando para a situação dos desempregados que não deveriam estar preparados para as demissões. Como a representante diz que os funcionários saberiam mais da situação da empresa do que Moore, ele vai ao encontro de Ed, um desses funcionários, e o entrevista para saber o que faria a respeito das demissões.

Moore chega a acompanhar Ed até a Manpower, outra grande corporação do setor de recursos humanos e um símbolo do desmonte do Estado de Bem-estar Social, pois esta empresa contrata pessoas para trabalhar por hora sem nenhum tipo de estabilidade ou seguro social, terceirizando o trabalho de outras empresas. Ed termina seu depoimento falando da desindustrialização da cidade de Milwauke.

Em Cincinnati, Moore visita a Procter \& Gamble para saber a razão pela qual a empresa vinha demitindo cerca de 13 mil pessoas desde 1993, apesar dos lucros estarem na casa dos 6 bilhões de dólares. Ele é recebido por duas pessoas, um homem e uma mulher que se apresentam como representantes da empresa. Em outro momento, um segurança barra a passagem para o corredor que levaria ao escritório e possivelmente à diretoria. Em tom de voz firme e formal, a mulher logo responde que a empresa queria seguir no mercado sendo competitiva, e as demissões foram para manter a empresa saudável e lucrativa. Moore valoriza a fala dizendo que seis bilhões são lucros enormes, e a mulher diz que não são enormes, além daquelas cifras representarem um período maior do que o mencionado. Talvez Moore não tenha a dimensão do que aqueles lucros, aparentemente enormes, representavam para aquela empresa que é uma das maiores do país - fabricante de inúmeros produtos de higiene pessoal e para limpeza doméstica.

Moore pergunta por que aquele grupo não dividia os lucros para beneficiar o país. A mulher tenta responder as perguntas, mas fica sem falar quando Moore faz essas colocações, e a câmera focaliza mais suas mudanças de expressão facial do que as do homem que a acompanha, explorando, assim, o desconforto causado pelo conflito.

Moore também pergunta se eles acham que deveria existir uma lei que os impedisse de demitir se tivessem lucros. Como a dupla de representantes já se mostrava 
bastante incomodada, Moore os presenteia com o diploma "demitidor do ano" e tenta cumprimentá-los, mas a mulher se nega a apertar sua mão. Mesmo assim, o "cineasta participativo" não sai de cena sem antes brincar sobre a eficiência de um dos produtos da empresa, o sabão para roupas Tide. Apesar de tensos, os representantes encontram fôlego para falar do produto e se colocam à disposição para futuras entrevistas.

Um programa de rádio na $\mathrm{BBC}$ rende momentos de descontração com o radialista promovendo o livro "Downzise This!” e a equipe de rádio interagindo com Moore em piadas que envolvem os símbolos da nação estadunidense como o hino oficial, as cores da bandeira, a águia americana, entre outros elementos que são satirizados. Moore diz que não há nada de mais em querer melhorar sua marca, tratando os EUA como uma grande corporação.

Na cidade de Portland, no Oregon, ocorre o momento que fez de The Big One um filme conhecido do público, devido o confronto "amigável", porém comprometedor entre o dono da marca de artigos esportivos Nike, Phillip Knight e Michael Moore. Enquanto concede entrevista na rádio local, uma ligação entra ao vivo e um homem convida Moore para ir até a matriz da Nike para uma entrevista com Knight.

É possível imaginar que, conhecendo a construção realizada em torno de Roger Smith pelo filme Roger e Eu, o empresário da Nike, rotulado no livro de Moore como seu "bandido empresarial favorito", estivesse preocupado em desconstruir a imagem depreciativa que o livro faz dele. Também é citado, em The Big One, que a esposa de Knight presenteou-o com o livro “Downzise This!” Por isso, Knight poderia estar recebendo Michael Moore para colocar o seu ponto de vista sobre as fábricas da Nike na Indonésia, ao invés de silenciar diante da construção negativa que o cineasta/escritor vinha realizando.

Apesar da disposição de Knight para conversar com Moore, recebendo-o na sede da Nike, o filme o colocou numa situação complicada, favorecendo a propagação de um discurso anti-Nike $e^{276}$ dentro e fora dos EUA, sobretudo, através de protestos e fóruns de discussão via Internet. A maioria dos sites que protestam contra os produtos da Nike, o faz alegando diversos abusos nas condições que os trabalhadores seriam submetidos. Palavras como "trabalho escravo" e "império norte-americano" são comumente encontradas nesses sítios. Entre os inúmeros sites, uns extintos e outros em atividade,

\footnotetext{
${ }^{276}$ No site oficial do filme existe uma lista de grupos criados com o intuito de disseminar campanhas antiNike. Além disso, um tópico especial chamado Mike e Nike apresenta toda a reverberação da polêmica e as tentativas de Knight em justificar suas ações em fábricas que ele nunca visitou na Indonésia. http://www.dogeatdogfilms.com/mikenike.html. (Acesso em 28 de maio de 2011).
} 
destacam-se o angelfire $^{277}$ no qual constam acusações de que a Nike explora a mão de obra barata da Indonésia e coloca a empresa norte-americana "como uma das mais malignas do mundo". Além disso, outra questão colocada pelos portais anti-Nike se valem da elevada diferença observada entre os custos da produção em comparação aos gastos com marketing e publicidade, o que, geralmente, envolve um ídolo multimilionário do esporte norte-americano e mundial.

Para os defensores do trabalho, esse desequilíbrio entre o que é pago aos trabalhadores pelas horas despendidas na confecção dos produtos, e o que é gasto com um único atleta ou pequeno grupo de atletas para a propaganda da marca "funciona de forma insana" 278 .

Naomi Klein pontua que, a partir dos anos 1980, devido à recessão econômica observada naquela década, surgiu o consenso que as "corporações estavam inchadas, superdimensionadas; elas possuíam demais, empregavam gente demais"279. Graças às liberalizações ocorridas na produção, com o aumento da concorrência, e reformas nas leis trabalhistas, as corporações (como a Nike), entenderam que "produzir bens era apenas um aspecto incidental de suas operações" ${ }^{280}$ e após transferirem à produção para terceiros, no exterior, essas empresas passam a se dedicar mais "às imagens de suas marcas" ${ }^{, 281}$. Com isto, o principal trabalho não era a produção e sim o marketing. Segundo Klein:

Essa fórmula, desnecessário dizer, mostrou-se imensamente lucrativa, e seu sucesso levou as empresas a uma corrida pela ausência de peso: quem possuísse menos, tivesse o menor número de empregados na folha de pagamentos e produzisse as mais poderosas imagens, em vez de produtos, ganharia a corrida ${ }^{282}$.

\footnotetext{
Record, 2008, p. 40.

${ }^{279}$ KLEIN, Naomi. Sem Logo, op.cit., p. 28.

${ }^{280}$ KLEIN, Naomi. Sem Logo, op.cit., p. 28.

${ }^{281}$ KLEIN, Naomi. Sem Logo, op.cit., p. 28.

${ }^{282}$ KLEIN, Naomi. Sem Logo, op.cit., p. 28.
}

${ }^{277} \mathrm{http}: / /$ www.angelfire.com/art/antinike/. (Acesso em 01 de julho de 2011).

${ }^{278}$ Alguns números desses gastos com publicidade são colocados no livro Sem Logo de Naomi Klein. Segundo a autora, "só em 1991, a Reebok aumentou seus gastos com publicidade em 71,9 por cento, enquanto a Nike injetou 24,6 por cento a mais em seu já estratosférico orçamento de publicidade, levando o gasto total da empresa em marketing a assombrosos US\$ 250 milhões por ano" (p. 40). Segundo Klein, esses vendedores de tênis estavam projetando "sacos de ar cada vez mais intrincados e pseudocientíficos, aumentando os preços com a contratação de atletas de elite por colossais acordos de patrocínio". In: KLEIN, Naomi. Sem Logo: a tirania das marcas em um planeta vendido. $6^{\mathrm{a}}$ edição. Rio de Janeiro: 
Isso significa que essas corporações parecem gigantes, e o são em relação aos $\operatorname{lucros}^{283}$, porém, em termos de produção, essas empresas têm 'encolhido' seu peso produtivo. "Sua grandeza aparente é simplesmente o caminho mais eficaz para alcançar sua verdadeira meta: livrar-se do mundo das coisas", porque, para essas empresas, mais importante do que fabricar coisas é "fortalecer a imagem das marcas" e "disseminar o conceito da marca" 284 .

Assim, na visão de Klein, as marcas buscaram se tornar "acessórios culturais e filosóficos de estilo de vida" ${ }^{\text {285 }}$ e, para isso, tudo passou a significar publicidade para as marcas. "Estranhos léxicos para descrever os funcionários (parceiros, associados, jogadores do time, membros da tripulação, CEO superstar, atenção fanática à coerência do design, uma propensão à construção de monumentos e declarações de missão no estilo da Nova Era"286. Com essas transformações, fazer os produtos deixou de ser importante para as empresas, que à exemplo da Nike, transferem sua produção para outros países. A partir de então, os verdadeiros produtos são as marcas, o conceito ou estilo de vida que incorporam, entendidos pelas empresas de marketing como "agentes de significado, em vez de fabricantes de produtos" 287 .

Não é nesse registro, pelo menos inicialmente, que Michael Moore dirige as perguntas que faz a Knight. Se for considerada a acusação colocada pelos sites, de que as estrelas do esporte levariam um cachê que supriria centenas de trabalhadores mal pagos na Indonésia, The Big One não entra no mérito da questão, nem para "cobrar" das estrelas do esporte, alguns dos quais representam times que o cineasta ostenta em seus bonés, que na mesma lógica de "justiça" com a qual o filme confronta as corporações, os lucros fossem divididos entre os trabalhadores da linha de produção. Antes, o filme prefere focalizar em questões éticas da política interna da Indonésia que, a época do filme, invadiu a ilha do Timor Leste (ex-colônia portuguesa e católica) alegando que o país faria parte do arquipélago Indonésio e, portanto, deveria estar sujeito à política e religião islâmica oficial entre os indonésios.

\footnotetext{
${ }^{283}$ Klein pontua que essa 'manobra' funcionou bem, pois "nos seis anos anteriores a 1993, a Nike passou de uma empresa de US\$ 750 milhões para uma empresa de US\$ 4 bilhões [...] com lucros 900 por cento superiores aos que tinha quando começou”. In: KLEIN, Naomi. Sem Logo: a tirania das marcas em um planeta vendido. $6^{\mathrm{a}}$ edição. Rio de Janeiro: Record, 2008, p. 40

${ }^{284}$ KLEIN, Naomi. Sem Logo: a tirania das marcas em um planeta vendido. 6 a edição. Rio de Janeiro: Record, 2008, p. 28.

${ }^{285}$ KLEIN, Naomi. Sem Logo, op.cit., p. 40.

${ }^{286}$ KLEIN, Naomi. Sem Logo, op.cit.

${ }^{287}$ KLEIN, Naomi. Sem Logo, op.cit., p. 45.
} 
Nesse sentido, Moore "denuncia" que Knight estaria "favorecendo" o fortalecimento da economia de um país acusado de violação dos direitos humanos, e, pela exploração de mão de obra de crianças com menos de $14 \operatorname{anos}^{288}$.

Através da análise das sequências deste confronto no filme, é possível considerar uma exploração visual frágil daquilo que foi construído como abuso, independente da veracidade dessa afirmação. Para configuração da cena, e a proposição do sentido de exploração e abuso aos direitos humanos, as imagens partem de uma foto do livro "Downsize This!" com uma pequena ficha do "bandido empresarial" Phillip Knight, $\mathrm{CEO}^{289}$ da Nike. Nessa sequência de entrada, o empresário é responsabilizado pelo sentido que o filme atribuirá às imagens seguintes, e a cena corta para uma placa afixada em uma das fábricas da Nike na Indonésia, com seu lema comercial que se refere a algo como "apenas faça", "Just Do It".

Em seguida, o filme mostra rapidamente um ambiente aparentemente organizado com o chão limpo e mulheres trabalhando em linha de produção como em qualquer outra fábrica. Outro corte, e são focalizados pés descalços sob a bancada de trabalho, como se andar descalço fosse sinal de exploração, sem considerar que aquelas pessoas poderiam estar descalças por um costume ou condição anterior ao trabalho fabril, visto que são habitantesde um país muito pobre, e, talvez, isso estivesse relacionado ao clima quente da região ou ao calor dentro do galpão. Talvez não tivesse sentido para as mulheres estarem de uniformes e descalças se aquilo não fosse "secundário" para o fator produção. Algumas mulheres aparecem com camisas padronizadas o que sugere o uso de algum uniforme.

Entretanto, para o olhar americano (no sentido amplo do termo) é um contrassenso observar que em uma fábrica de tênis as pessoas trabalham descalças. Isso também pode indicar uma falta de adequação e de treinamento desses trabalhadores à estrutura industrial, visto que esse tipo de produção é relativamente recente na Indonésia, tanto que, após as denúncias de irregularidades, a Nike passará a oferecer programas de treinamento e adequação (conforme informam alguns artigos posteriores ao filme publicados pela revista TIME).

\footnotetext{
${ }^{288}$ A Revista TIME publicou matéria, em 12 de maio de 1998, sobre a questão colocada no filme de Michael Moore denunciando a exploração do trabalho de crianças com 14 anos nas fábricas da Nike na Indonésia. O título da matéria foi "Nike Vows No More Child Labor", e cita que a empresa, talvez num gesto de reconhecimento dos valores estadunidenses para com as crianças, se comprometia a aumentar a idade mínima de seus funcionários para 18 anos de idade. Fonte:

http://www.time.com/time/nation/article/0,8599,11132,00.html. (Acesso em 29 de julho de 2011).

${ }^{289}$ Sigla do inglês americano para Chief Executive Officer. Equivale ao antigo título de presidente da empresa.
} 
A narração alerta que aquela fábrica na Indonésia emprega mulheres adolescentes, pagando US\$ 0,40 por hora e, após focalizar os pés descalços, a imagem mostra o rosto de uma mulher que, a primeira vista, não parece uma adolescente. Contudo, para reforçar o sentido proposto, outra mulher tem o rosto focalizado e, esta sim parece mais jovem, porém, não é possível avaliar sua idade pela imagem, restando ao espectador, acreditar naquilo que a narrativa constrói. Outro corte e, um grupo de militares em marcha entra em cena para corroborar o argumento fílmico de que a Nike teria apoio do governo indonésio cujo "o regime militar invadira o Timor Leste provocando genocídio". Outro corte, e a cena volta para a imagem dentro da fábrica no momento que Moore reforça que a Nike "não fabrica nada nos EUA".

Para encerrar essa sequência em que foi construída a responsabilidade de Knight acerca da exploração da mão de obra barata na Indonésia e o apoio ao "regime opressivo", o filme mostra trabalhadores estadunidenses protestando em Portland, diante da sede da Nike. Antes dessa sequência de imagens, Moore pontuou que a Nike era "a maior fabricante de calçados do mundo", independentemente dessa afirmação ser verdadeira ou não, foi dita justamente para reforçar o sentido de grandeza atribuído pelo filme para aquela corporação. Isso indica que, nesse momento, o filme não se coloca contra a Nike como empresa, e sim, enaltece sua importância para os EUA. Não se trata apenas de um discurso acerca da exploração das trabalhadoras indonésias, visto que ao terminar a sequência cortando a imagem para os americanos em Portland, o filme volta a propor a manutenção dos empregos em solo estadunidense.

Não há discussão a respeito dos gastos com a publicidade ${ }^{290}$ produzida dentro dos EUA, afinal o american wayof life segue embutido nos produtos e o marketing empresarial veicula o modo de ser americano nos produtos da Nike, vendidos para diferentes partes do globo. O filme se vale de um discurso em prol dos direitos civis

\footnotetext{
${ }^{290}$ No blog "Mundo das Marcas" consta a história da empresa Nike e algumas das propagandas que fizeram sua história. Entre os milionários e renomados atletas que participaram de seus vídeos publicitários, podem ser encontrados: Michael Jordan jogador de basquete pelo Chicago Bulls, que assinou uma linha de produtos como o tênis Nike Air Jordan. O jogador de golfe Tiger Woods. Entre as estrelas do futebol internacional constam nomes dos brasileiros: Ronaldo "fenômeno", Ronaldinho gaúcho, e Roberto Carlos. Outros como: Thierry Henry, Francesco Totti, Luis Figo e Hernan Crespo. Na lista de celebridades do esporte também consta o nome do corredor Carl Lewis, o velocista Michael Johnson, os tenistas André Agassi e Pete Sampras, outro astro do basquete LeBron James, e a tenista Maria Sharapova. Todos assinaram contratos milionários com a Nike. Esses dados corroboram as críticas de que a empresa explora a mão-de-obra em países asiáticos faturando milhões de dólares e investe mais em publicidade do que na base da cadeia produtiva e seus trabalhadores anônimos. Fonte site:

http://webcache.googleusercontent.com/search?q=cache:TEGuGy31YrQJ:mundodasmarcas.blogspot.com /2006/05/nike-just-do-it.html+atletas+e+propagandas+Nike \&cd=8\&hl=ptBR\&ct=clnk\&gl=br\&source=www.google.com.br. (Acesso em 28 de julho de 2011).
} 
para justificar que o povo da Indonésia não deveria ser "explorado" pela empresa, não levando em conta qualquer tipo de benefício que essas pessoas teriam com aquele trabalho. Talvez o filme sugerisse que, antes de serem exploradas pela Nike, aquelas pessoas continuassem sem trabalho e sofressem as consequências disso dentro de seu país, como é o que supostamente estaria ocorrendo entre os trabalhadores americanos.

Nesses termos, que parecem nacionalistas, o filme indica que os estadunidenses não poderiam ficar sem trabalho,considerando o padrão americano em termos de piso salarial. Contudo, os indonésios e outros povos "oprimidos" poderiam ficar sem trabalho porque se trabalharem para as corporações seriam "explorados". Adicione-se a isso a proposição, em termos de moral estadunidense, de que as adolescentes indonésias não poderiam trabalhar, como se a vida de uma adolescente nascida na Indonésia pudesse ser igualada a vida dos adolescentes nascidos nos EUA - e todo discurso de família burguesa que se preocupa com a formação dos filhos, com a carreira profissional, com o preparo para a vida adulta, de forma muito diferente do que deve ser a vida dos Indonésios.

Convidado para ir até a Nike falar com o empresário, Moore tentou em tom amigável convencer Knight a "abandonar o trabalho infantil" na Indonésia e a pagar estadunidenses para fazer seus produtos. Contudo, ciente dos riscos que corre ao não se manter competitivo, Knight recusa a oferta alegando que se tiverem opção melhor os americanos não querem fabricar seus tênis.

Knight recebe Moore com uma simpatia incomum se forem considerados todos os representantes de empresas e o próprio Roger Smith do primeiro filme. O CEO da Nike veste calça jeans, camiseta e um paletó simples. Sempre sorridente ele afirma para Moore que os estadunidenses não querem fabricar tênis. Nesta direção, é possível imaginar que Knight se refira não só ao trabalhador estadunidense e sim ao país de maneira geral, pois para o empresário racional, vários fatores contam para a produção, como por exemplo, a carga de impostos. Os custos de produção da Nike dentro dos EUA certamente seriam bem maiores do que em outros países, visto que na condição de um país com estrutura industrial desenvolvida, existe legislação estruturada em torno dos direitos trabalhistas, além de organizações sindicais - como foi colocado desde Roger e Eu ao citar o sindicato dos montadores. Mesmo que os sindicatos estejam enfraquecidos, como pontuam os filmes de Moore, ainda influenciam nas relações de produção, conferindo alguns direitos aos trabalhadores. Provavelmente, o mesmo não ocorre em países com um histórico de industrialização recente como a Indonésia. 
Knight estaria preocupado em manter-se competitivo e que sua marca ganhasse cada vez mais o mercado de produtos esportivos. Nas suas palavras:

“Meu objetivo não é dinheiro. Já não corro atrás do dinheiro. $O$ que eu quero, antes de ir para o céu, é criar a melhor empresa que posso. Eu acredito numa coisa muito simples e já sofri as consequências. Eu creio que os estadunidenses não querem fabricar tênis."

Moore faz brincadeiras e se dispõe a reunir em Flint vários candidatos para fabricar tênis dentro dos EUA. Novamente recebido por Knight, Moore mostra seu vídeo com depoimentos de pessoas que estariam desempregadas.

Contudo, a exibição do vídeo não fez o dono da Nike mudar de ideia. Ele alega que estaria ajudando um país subdesenvolvido a melhorar de condições através do comércio, mas sua fala remete à fórmula que as grandes corporações se utilizam para progredir, num contexto de globalização dos mercados com a liberação dos fluxos de capitais pelos governos, processo tratado por Beck no início deste trabalho.

Enquanto a câmera focaliza o rosto de Knight, Moore lhe fala dos números do genocídio cometido pelo regime militar na Indonésia. E, parecendo estar ciente da "fama de esquerdista" de Moore, Knight diz que, embora não o agradem, esses números também foram vistos na revolução cultural chinesa. Novamente Moore apela para a riqueza pessoal do entrevistado perguntando quanto seria o suficiente para que ele parasse de buscar o lucro. Knight alega que não se trata de buscar lucros, pois ele "já não corria mais atrás do dinheiro" e sim de construir a melhor empresa na terra, reforçando sua "paixão" pela Nike. Uma paixão auto-consumptiva diferente da proposta original, em razão de se revelar no produtor de mercadorias e não no consumidor, mesmo assim, Knight estaria buscando a satisfação de seus desejos, o que coaduna com o conceito de Sennett.

Quanto ao vídeo produzido por Moore, mesmo com tomadas fechadas, as imagens revelam um número não muito expressivo de pessoas se candidatando a uma vaga de emprego na Nike. Knight afirmou, na entrevista em Portland, que uma filial da Nike em Flint poderia pagar não mais que cinco dólares por hora de trabalho na produção de tênis, isso se a marca tivesse condições favoráveis para a instalação. Em outros termos, isso quer dizer que a Nike buscaria, hipoteticamente, em solo americano 
os incentivos que uma corporação encontra em países em desenvolvimento, como por exemplo, isenção fiscal ou menores impostos, um terreno bem localizado ou as instalações de pequenas confecções, insumos baratos e mão de obra terceirizada. Em outro momento, talvez melhor preparado, Knight encerra o assunto dizendo que Flint não figura entre suas prioridades. O resultado prático das entrevistas foi o acordo de doarem cada um, Moore e Knight, a quantia de US\$ 10 mil para as escolas de Flint.

A repercussão desta discussão entre Michael Moore e o dono da Nike foi colocada no filme The Corporation. Naquele filme, são mostradas declarações de Moore acerca da responsabilidade de Knight e suas decisões que afetariam as vidas de centenas de pessoas. Em seu depoimento no filme canadense, Moore diz:

"Como a maioria das empresas é administrada por brancos ricos, eles não têm contato com a maioria do mundo, pois a maioria do planeta não é constituída de brancos ricos, mas sim de pessoas de outras raças. Elas são a maioria. As mulheres são a maioria, os pobres e os empregados pobres compõem a maioria deste planeta. As decisões que eles tomam não são baseadas na realidade que existe na maior parte do mundo." 291

Em seguida, o filme The Corporation faz um corte na imagem de Moore para mostrar a cena antiga em que este pergunta para Knight quanto dinheiro seria o suficiente. Em seguida, The Corporation retoma o depoimento de Moore dizendo que, ao comprar as passagens de avião para ele e Knight, estava pronto para ouvir que o CEO da Nike iria acompanhá-lo até as fábricas na Indonésia. Moore se diz surpreso ao saber que Knight nunca tinha ido à Indonésia e afirma que após finalizar The Big One, recebeu uma ligação do dono da Nike dizendo que "talvez eu possa ir com você até as fábricas... vou assistir ao Austrália Open de tênis". Moore termina seu depoimento em The Corporation rindo da situação.

A título de informação, e de pontuar como o confronto entre Moore e Knight repercutiu. A discussão construída em The Big One acerca da exploração do trabalho na Indonésia ainda repercute. A revista TIME tem publicado diversos artigos ao longo dos últimos 10 anos corroborando as críticas iniciadas no filme de Moore contra a empresa,

${ }^{291}$ The Corporation. Dir: Mark Achbar; Jennifer Abbott; Joel Bakan, (Canadá, 2003). 
e também pontuando de como a Nike tentaria, desde então, contornar a situação dos funcionários terceirizados na Indonésia. Segundo artigo publicado com o título "Nike Faces New Worker Abuse Claims"292 a Nike buscou melhorar as condições de trabalho em suas empresas, após constatar alguns dos abusos sofridos pelas funcionárias por parte dos chefes de produção. Representantes foram enviados às empresas visando adequar a produção às "normas de conduta" estabelecidas por Knight. Segundo o artigo, algumas fábricas na Indonésia chegaram a barrar os representantes da empresa nas auditorias sobre as condições de trabalho. Alguns funcionários ouvidos relatam que, além de agressões verbais, sofrem agressões físicas caso cometam algum erro na produção dos calçados.

É possível imaginar que, não apenas a forma de exploração que faz parte da reestruturação produtiva no capitalismo está em pauta no problema construído em torno da Nike, mas também, que a política local de países com histórico de violação dos direitos humanos reproduz a mesma conduta abusiva dentro da linha de produção das corporações instaladas no país. Assim, se os habitantes desses países em desenvolvimento não desfrutam de condições dignas de existência em virtude da política local, é possível imaginar que dentro da hierarquia social, que inclui o trabalho, essas pessoas também não encontram condições pautadas por relações sindicais entre empregadores e empregados, como ocorre em maior ou menor escala nos países com histórico de desenvolvimento industrial.

O mesmo artigo da revista TIME relata que, depois da China e do Vietnã, as 14 fábricas na Indonésia formam o terceiro maior bloco de transferência para mão de obra mais barata na cadeia produtiva da Nike. Em sua defesa, representantes da empresa alegam que estão desenvolvendo programas para ensinar gestores "sensibilidade cultural e habilidades de liderança", e que estão monitorando "de perto" as fábricas. Contudo, os observadores internacionais acreditam que muito ainda poderia ser feito.

De volta as sequências de The Big One, após uma breve entrevista com duas aeromoças ${ }^{293}$ que mal se lembram em qual ano tiveram aumento salarial, o filme inicia

\footnotetext{
${ }^{292}$ Fontes dos artigos: http://www.time.com/time/world/article/0,8599,2082979,00.html. (Acesso em30 de julho de 2011).

${ }^{293}$ Moore abordará o tema da precariedade do trabalho na aviação estadunidense em seu último filme, Capitalism a Love Story (2010), citando a queda de um avião em Búffalo, no estado de Nova Iorque, em fevereiro de 2009 que vitimou 49 pessoas, e o pouso espetacular no rio Hudson por outro piloto que virou símbolo da precariedade do setor nos http://www1.folha.uol.com.br/folha/mundo/ult94u503350.shtml. (Acesso em 05 de agosto de 2011) Sobre o acidente em Buffalo, o filme de Moore cita que conteúdo da "caixa-preta" teria revelado que os pilotos discutiam seus baixos salários no momento de distração que levou ao acidente.
} 
a construção desse grupo a partir da cidade de Centralia, no estado do Illinois, onde os operários da Leaf fabricavam barras de doces há mais de 60 anos. Ironicamente, Moore escolhe a marca do doce chamado "dia de pagamento"para iniciar sua fala sobre as demissões nos EUA.

Imagens mostram a fachada da fábrica, alguns trabalhadores na esteira de embalagens, e um corte passa para a ocasião da campanha eleitoral em que Bill Clinton visita Centralia para discursar contra George Bush - seu oponente quando tentava a reeleição em $1996^{294}$. O discurso de Clinton reafirma alguns valores arraigados entre os estadunidenses, como o trabalho e o respeito às regras. Em seu discurso Clinton diz:

$\neg O$ Estado de onde venho está cheio de lugares como Centralia, lugares de gente honesta e trabalhadora que respeita as regras e que foi esquecida na América de George Bush. Pois quero dizer algo: tudo isso pode mudar. Nós podemos fazer melhor! É um escândalo desperdiçar assim o potencial desta comunidade em nosso país.

Embora o discurso de Clinton pareça favorável aos trabalhadores e ao potencial produtivo da cidade, o que o filme mostra em seguida, em sua forma de alternar imagens para reforçar sua continuidade retórica, é que a Leaf fecha suas portas, demite centenas de estadunidenses para reabrir a fábrica no México, pagando oitenta centavos de dólar por hora - como diria Clinton, "desperdiçando o potencial daquela comunidade". Nesta construção visual, a fala de Clinton é esvaziada de qualquer sentido.

No estacionamento da fábrica, Moore entrevista um pequeno grupo de trabalhadores demitidos. Eles falam dos anos que trabalharam ali, alguns chegando a permanecer por 50 anos naquela fábrica e, mesmo assim, todos estavam demitidos. Moore questiona se eles nunca fizeram protestos ou greves anteriores àquele dia, e os

\footnotetext{
${ }^{294}$ O governo do democrata Bill Clinton percorreu os anos de 1993 até 2001. Foi precedido pela administração do republicano George H.W Bush (pai), e sucedido em 2001 por George W. Bush (filho). Vencedor das eleições com 41\% dos votos, Clinton concorreu em 1992 com o candidato a reeleição George H.W Bush, que ficou em segundo lugar com 37\% dos votos, e o milionário Ross Perot (partido independente), que ficou em terceiro lugar nas urnas com $19 \%$ dos votos. $C f$. http://www.whitehouse.gov/about/presidents/ (acesso em 05 de agosto de 2011).
} 
ex-funcionários respondiam, como que mostrando sua dedicação, que nunca protestaram nem fizeram greve contra a empresa. Esta postura dos desempregados, orgulhosos de nunca se oporem à empresa, remetem a fala de Clinton acerca do valor que envolve a obediência às regras e o trabalho árduo, indicando uma sociedade pouco afeita à contestação, independente da legitimidade de suas regras.

A maioria dos trabalhadores daquele grupo usa bonés, estão debaixo do sol em um dia aparentemente quente, vestem-se de modo simples com calças jeans e camisetas, são homens e mulheres jovens, ou em idade produtiva entre 30 e 50 anos, poucos são mais velhos que isso. A ênfase dos empregados da Leaf é que mesmo com lucros superiores a 20 milhões de dólares a empresa demitiu a todos e se mudaria da cidade. Um funcionário, parecendo mais revoltado, diz que eles "vão afundar como todos os desempregados desse país. Aumentarão os suicídios, os divórcios, pessoas passam a bater nos seus filhos. Você pode ficar louco sem um salário, ou passa a receber U\$5,00 a hora. É duro!’. Essa fala final remete às consequências observadas na vida de Ben, exoperário da GM, conforme construiu Roger e Eu.

Conforme aponta Beck, as transnacionais tiveram seu caminho aberto "sem revolução, sem mudanças legislativas ou constitucionais e apenas com o curso normal, por assim dizer, do business as usual ${ }^{, 295}$. Com isto, as empresas podem exportar, sem nenhum controle por parte dos Estados, seus postos de trabalho (como a fábrica do doce Pay Day fez no filme) para lugares que oferecem os menores custos de produção, os menores impostos e a mão-de-obra mais barata, como é o caso do México (apresentado desde Roger e Eu). Ainda segundo o autor, as empresas podem "punir" os Estados nacionais se estes se tornarem "caros" ao não oferecerem condições favoráveis para os investimentos, visto que as empresas "podem escolher de modo autônomo seus locais de investimento, produção, recolhimento de impostos e de sede na selva da produção global e confrontá-las uma a uma", como fariam as empresas apresentadas em The Big One.

Nas sequências do filme, se os trabalhadores estadunidenses reclamam que não estavam conseguindo viver com um salário de U\$ 5,00/h (insuficiente para viver aos moldes do sonho americano de consumo), a Pay Day iria pagar 80 centavos de dólar para os mexicanos! Com isto, o filme mostra que não existiria mais proteção dos empregos internos quando o assunto é maximizar os lucros. A fábrica era lucrativa

\footnotetext{
${ }^{295} \mathrm{BECK}$, U. O que é globalização: equívocos do globalismo respostas à globalização. São Paulo: Paz e Terra, 1999, p. 17. (Grifos do autor).
} 
mesmo em Centralia, mas queria crescer e a mudança para outro país representa cortar os custos da produção e lucrar ainda mais.

Segurando um cartaz com uma barra do doce Pay Day em forma de caixão, uma mulher olha para a câmera e diz que não pode comprar uma casa com um salário de U\$5,00 por hora. Ciente de que o dinheiro movimenta vários setores da cidade, outro ex-funcionário diz que se os trabalhadores tiverem de viver cada vez mais com salários mínimos como fariam "para comprar carros e casas?" Também diz que aquela situação se tornaria uma "bola de neve" para a cidade, pois afetaria os construtores, os pedreiros, enfim, os demais setores desaquecidos pela recessão, pelo menos em pequena escala como teria ocorrido em Flint com a saída da GM da cidade no filme Roger e Eu. O diretor da Pay Day aceitou conversar com Moore sem ser filmado. A câmera fica ligada no corredor e mostra Moore na porta da sala, comendo uma barra do doce, enquanto questiona o diretor da empresa. Vale a pena destacar as falas da entrevista:

$\neg$ Qual sua mensagem aos operários que trabalham duro, fazem as coisas bem, e que, graças a eles, a empresa vai bem, e ganham como recompensa o desemprego? (diz Moore).

$\neg$ Se a fábrica tivesse tido um rendimento melhor, mais lucros, as demissões poderiam ter sido ainda mais rápidas. (diretor da Pay Day).

$\neg$ Você diz que, se os operários tivessem gerado mais lucros, seriam demitidos mais rapidamente? Se os operários tivessem trabalhado mal, se as vendas tivessem sido menores, então eles poderiam continuar na fábrica?(Moore).

$\neg$ Exato! (diretor da Pay Day).

$\neg$ Isto é loucura! (Moore).

Do modo como o filme constrói os diálogos, sempre muito curtos e pouco explicativos, acaba prevalecendo a proposição de que as demissões são “ loucura”, ou ainda, que sejam manobras insensatas devido a ganância de alguns empresários. Entretanto, este diálogo sinaliza como a globalização dos mercados teria força para desmontar as economias locais, pois a maioria das empresas que oferecem alguma explicação a respeitodas razões para a mudança de cidade utilizam as palavras: "manterse competitivo". Essas empresas se inserem naquilo que os teóricos da economia 
chamam de "reestruturação da produção e do trabalho"296. Antunes explica como a globalização do capitalismo contemporâneo reorientou estrategicamente toda a produção das empresas que pretendem permanecer competitivas no mercado, cada vez mais globalizado, através de um padrão de acumulação considerado mais flexível, se comparado aos moldes da produção no fordismo. Segundo o autor;

Tentando reter seus traços constitutivos mais gerais, é possível dizer que o padrão de acumulação flexível articula um conjunto de elementos de continuidade e de descontinuidade que acabam por conformar algo relativamente distinto do padrão taylorista/fordista de acumulação. Ele se fundamenta num padrão produtivo organizacional e tecnologicamente avançado, resultado da introdução de técnicas de gestão da força de trabalho próprias da fase informacional, bem como da introdução ampliada dos computadores no processo produtivo e de serviços. Desenvolve-se em uma estrutura produtiva mais flexível, recorrendo frequentemente à desconcentração produtiva, às empresas terceirizadas, etc. Utiliza-se de novas técnicas de gestão da força de trabalho, do trabalho em equipe, das "células de produção", dos "times de trabalho", dos grupos "semi-autônomos", além de requerer, ao menos no plano discursivo, o "envolvimento participativo" dos trabalhadores, em verdade uma participação manipuladora e que preserva, na essência, as condições do trabalho alienado e estranhado. O "trabalho polivalente", "multifuncional", "qualificado", combinado com uma estrutura mais horizontalizada e integrada entre diversas empresas, inclusive nas empresas terceirizadas, tem como finalidade a redução do tempo de trabalho ${ }^{297}$.

Assim, empresas como a Leaf puderam se beneficiar dos lucros obtidos para incrementar a produção. Neste contexto de capitalismo globalizado, crescer também significa cortar custos e, consequentemente, demitir funcionários, pois com as novas possibilidades oferecidas pela tecnologia, não só pelas novas máquinas que fazem o trabalho de vários funcionários, mas também pela maior eficiência administrativa, com

\footnotetext{
${ }^{296}$ ANTUNES, Ricardo. Os sentidos do trabalho: ensaio sobre a afirmação e negação do trabalho. São Paulo: Boitempo editorial. 1999, (6 ${ }^{\mathbf{a}}$ edição), 2002, p. 31.

${ }^{297}$ ANTUNES, Ricardo. Os sentidos do trabalho, op. cit., p. 52.
} 
as comunicações instantâneas que possibilitaram maior integração entre setores das empresas, o que propiciou a "intensificação das condições de exploração da força de trabalho",298.

Beck aponta que, para as empresas que fazem negócios transnacionais, a globalização na virada para o século XXI representa a mesma importância que as classes sociais para o movimento trabalhista no século XIX, com a essencial diferença de que "enquanto o movimento dos trabalhadores atuava como poder de oposição, as empresas globais atuam até este momento sem oposição (transnacional)" ${ }^{299}$. Neste sentido, a oposição do pequeno grupo de trabalhadores de Centrália não faria um efeito transnacional, porque se este pequeno grupo quer seus empregos de volta existem outros grupos além das fronteiras da cidade e do país dispostos em receber a Leaf e outras empresas a custos reduzidos.

Nas sequências do filme, funcionários protestam em clima de desânimo contra as demissões, pois parecem não acreditar na possibilidade de mudança para aquela situação. Com algumas palavras de ordem, pedem para que a empresa fique em Centrália e afirmam que precisam dos empregos, fazendo um enterro simbólico da Leaf. Entretanto, nada disso fez a empresa permanecer em Centralia. Depois, Moore será informado por sua equipe que a Hershey's, gigante no setor alimentício, tinha comprado a marca Pay Day naqueles dias de demissão em massa. Na visita à sede da empresa Leaf em Centrália, Moore tenta entrar para falar com os executivos e "presenteá-los" com cheques simbólicos, mas é rapidamente posto para fora da propriedade e terá que se explicar para o policial que o aguarda do lado de fora.

De volta à divulgação do seu livro, Moore reaparece nas sessões de autógrafos em grandes livrarias como a Media Play, na supostamente empobrecida, cidade de Rockford. A revista Money daquele ano colocou a cidade de Rockford (em Illinois) em $300^{\circ}$, isto é, o último lugar no ranking das piores cidades para se viver nos EUA. Em sessão de autógrafos, Moore diz ao público que foi até ali porque como aconteceu com Flint, também citada como pior cidade para se viver pela Money de 1988, ninguém visitava Rockford. Para dar uma ideia da suposta pobreza em que vive Rockford, o filme mostra uma placa no início da fila formada para se chegar a Michael Moore, com os dizeres: "pague seu livro antes de pegar autógrafo!”.

\footnotetext{
${ }^{298}$ ANTUNES, R. Os sentidos do trabalho: ensaio sobre a afirmação e negação do trabalho. São Paulo: Boitempo editorial. 1999, (6a edição), 2002, p. 53.

${ }^{299}$ BECK, U. O que é globalização: equívocos do globalismo respostas à globalização. São Paulo: Paz e Terra, 1999, p. 14.
} 
Moore alterna momentos em que fala para o público, fazendo piadas de si mesmo, como quando fala da capa do seu livro e sua "manicure digital". O filme também inclui momentos menos irônicos, como foi o encontro de Moore com uma trabalhadora que aguardava na fila para pegar um autógrafo. Ela mostra-se emocionada ao ver Moore, pois, como disse, tinha sido demitida naquele dia - ela vendia carros para sobreviver com um salário mínimo. Moore escreve um autógrafo especial para a mulher, dizendo que tinha sido cortada mas não fora do jogo, e que não estava sozinha, pois em várias cidades havia pessoas na mesma situação de desemprego. Em seguida, Moore concede entrevista para a mídia de Rockford e a repórter pergunta o que ele, que veio também de uma das piores cidades para se viver nos EUA, teria a dizer para os moradores. Moore amplia o discurso sobre o desemprego para todas as cidades do país dizendo:

$\neg$ Já passei em vinte cidades, e todo o país conhece os efeitos das demissões. As empresas ficam mais ricas enquanto demitem as pessoas.

Enquanto Moore fala com a repórter, as imagens alternam para as pessoas dentro da livraria que observam alguns televisores ligados na loja transmitindo imagens de momentos em que trabalhadores protestam, supostamente, contra o desemprego pelas ruas em cidades dos EUA.

$\mathrm{Na}$ cidade de Iowa, Moore entra em uma lanchonete e entrevista pessoas que faziam algum tipo de refeição naquele momento. Aparentemente desanimado, um homem diz que trabalha muito mais atualmente do que há vinte anos e, mesmo tendo filhos crescidos, sentia que precisava trabalhar muito para viver. Além de conversar com os trabalhadores acerca da situação financeira em que se encontravam, Moore pergunta o que eles achavam da corrida presidencial daquele ano com Clinton e Dole, porém as pessoas naquele local não estavam interessadas em política e diziam que não se importavam com os candidatos, pois nenhum dos dois era uma boa opção. Ao falar de sua situação, uma mulher ganha maior tempo na cena. Ela diz que possui dois empregos, é casada, e mesmo assim mal consegue sustentar os dois filhos. Além disso, ela se queixa do pouco tempo que lhe sobra livre para conviver com a família. A câmera focaliza seu rosto na altura em que ela está, sentada, enquanto ela responde às perguntas dizendo: 
$\neg$ Tenho de pagar o aluguel, a luz, a água, o gás, e as roupas para os filhos. Não sobra nada!

Ela diz que divide a maior parte do seu dia entre dois empregos, um pela manhã e outro de noite, e com isto, mal vê os filhos nos finais de semana quando não está trabalhando. Acerca das eleições ela é taxativa: - Não vote!

De volta para a estrada, Moore comenta com sua equipe como é deprimente ver a baixa participação do eleitorado naquelas eleições. Eles fazem uma pausa no $M c$ Donalds para o lanche e criticam a qualidade da comida, mas não deixam de comprar ali.

Um novo momento com o grupo dos trabalhadores é construído pelo filme. Moore se encontra com um pequeno grupo de funcionários da Borders Bookstore, e é informado sobre as condições difíceis que enfrentavam para trabalhar, com baixos salários e com um seguro saúde ineficiente. Por isso, aquele grupo queria apoio de Moore para a formação de um sindicato. Segundo os jovens funcionários, a Borders teria enviado apenas membros da gerência para negociar os livros de Moore, evitando o contato dos trabalhadores do "baixo escalão" com as ideias do escritor/cineasta. Mais adiante o filme anuncia que, em 18 de novembro de 1996, a Borders cancelou a leitura de Downsize This. Uma matéria publicada no jornal entra em cena para confirmar a notícia e Moore alega que o cancelamento deveu-se por causa do seu apoio ao sindicato. A nova geração de trabalhadores da Borders, que aparecem ansiosos para se sindicalizarem, encerram as sequências finais do filme, em uma espécie de mensagem pró-sindicatos. $\mathrm{O}$ filme encerra com aquele pequeno grupo comemorando a abertura de um novo sindicato, mas as cenas mal construídas são bem diferentes das mobilizações do UAW vistas em Roger e $E u$, nos anos de 1930. A construçãofrágildaqueles jovens pode não convencer o espectador acercada legitimidade daquela ação e seu significado pró-sindicato.

Entretanto, para enfatizar a importância da organização sindical, Moore diz em entrevista a uma rádio local que foi da dedicação dos sindicalistas da grande greve de Flint em 1930, da qual participou seu tio Laverne, que surgiram os direitos sociais, e regulamentações diversas no país. Moore retoma este mesmo discurso no filme Capitalismo: uma história de amor. 
Outro momento de construção dos trabalhadores ocorre com o problema das mães subsidiadas. Do mesmo modo como foi construído em Roger e Eu, em The Big Oneas pessoas negras também estariam nas condições mais difíceis de sobrevivência nos EUA. A cena se passa dentro do Congresso de Wisconsin, onde Moore e dois locutores da rádio local WJJO seguem um pequeno grupo de mulheres negras que entram no edifício público munidas de vassouras, rodos, panos e esfregões. Elas queriam limpar o local no sentido de realizar um protesto simbólico contra aquilo que entendiam tercheiro de dinheiro sujo. Moore enfatiza que os subsídios das mães foram cortados pelo governador republicano Thommy Thompson na gestão do presidente democrata Bill Clinton. O grupo é recebido por Kevin Keane, secretário de imprensa do governo, que oferece encaminhá-las para uma agência de emprego oferecendo trabalho por um salário mínimo de US\$ 6,00/h. Keane alega que ao trabalharem, em vez de continuarem dependentes de subsídios, as mulheres teriam US\$ 5.000,00 a mais por ano. Elas protestam que fora dos subsídios não recebem seguro social, seguro médico, nem dental, e que seus filhos, levados ao protesto, não estariam contemplados. Num gesto, aparentemente defensivo, Keane indica que elas sigam para uma agência de empregos. Neste momento Moore está calado observando o confronto entre as mulheres e Keane. Como ocorre em todas as cenas de confronto, a câmera focaliza rostos sérios e incomodados das pessoas que acompanham a defesa do governo.

Subindo o tom da voz, uma das mulheres diz que já se inscreveu em agências de empregos, passou por entrevistas, fez os cursinhos, e continua sem emprego, porém não se alegra de viver dos subsídios. Moore entra no confronto mostrando para Keane uma foto do governador Thompson entregando um cheque de subsídios para Roger Smith da General Motors. Ao defender o governador, Kevin perde a paciência dizendo que Moore e seu grupo não criam empregos. Moore cita que o grupo defendido por Keane, tem demitido cada vez mais pessoas como fizeram na GM. Sem sua maneira costumeira, pautada por um tom de voz calmo, Moore diz:

\section{$\neg$ Parem de presentear com dinheiro livre as Corporações!}

Ao não apresentar a resposta de Keane, que se defendia das acusações sem perder o tom firme de voz e com o corpo inclinado para cima de Moore, a cena prefere cortar para as mulheres que iniciam a limpeza simbólica do local. Com palavras de ordem, a mais nova diz que elas querem trabalhar. Outra, olhando para a câmera, diz 
que tem quatro filhos que também é estudante, e seu filho mais novo ainda fará um ano de idade (ela está com ele nos braços). Apesar de seu esforço pessoal, ela afirma que não consegue ultrapassar a linha da pobreza.

A mulher mais nova, apontando para os dizeres dentro do congresso, diz:

$\neg$ Vê? Aí diz “justiça”.

$\neg$ Onde está a minha? Onde está minha justiça?

Sem ampliar o discurso para a história deste grupo "minoritário" nos EUA, o filme mostra casos isolados para se referir ao todo social, contudo, uma breve retrospectiva histórica informa que, até pouco tempo atrás, as pessoas negras lutavam por direitos civis ${ }^{300}$, por reconhecimento da condição de pessoas. As mães de Wisconsin parecem ainda lutar contra a segregação formal em que vivem, com a falta de estudo, de condições de moradia, de saúde, ou de uma educação que poderia ajudá-las e planejar a maternidade, enfim, são vários aspectos sociais que ainda segregam essas pessoas a uma existência inferiorizada.

Acerca da situação das mães que tiveram seus subsídios cortados pelo governador Tommy Thompson, Baumam oferece uma explicação que as contextualiza nos tempos de modernidade líquida ${ }^{301}$, com o fim da indústria fordista e aumentoda massa empobrecida de trabalhadores, não sendo mais vistos como "os reservistas da indústria" ${ }^{302}$. Segundo o autor

Hoje, o gasto com os pobres não é um "investimento racional". Eles são uma dependência perpétua, e não um recurso em potencial. As chances de seu "retorno às fileiras" da indústria são fracas, ao mesmo tempo, os novos exércitos profissionais, pequenos e esmerados, não têm necessidade de buchas de canhão. O "problema do pobre", outrora considerado questão social, tem sido em grande medida redefinido como uma questão de lei e ordem. Há uma clara tendência à "criminalização" da pobreza, como comprova a substituição da

\footnotetext{
${ }^{300}$ Segundo Purdy, por décadas os negros estadunidenses são inundados com o discurso oficial sobre liberdade e prosperidade, mas poucos conseguiram desfrutar plenamente do progresso econômico e social veiculados desde o final da Segunda Guerra e, desde o início dos anos 60, com o movimento negro por direitos civis. Até então o que os negros conheceram foi "segregação formal e informal, linchamento e violência policial, discriminação no emprego, na educação e nos serviços públicos, falta de direitos políticos, pobreza extrema". PURDY, S. O século americano. IN: História dos Estados Unidos: das origens ao século XXI. São Paulo: Contexto, 2010, p. 243.

${ }^{301}$ Conceito de Bauman tratado desde a análise do filme Roger e $E u$, refere-se às transformações ocorridas na modernidade sólida que cedeu espaço para mudanças cuja rapidez e transitoriedade às assemelhariam ao poder de conformação dos líquidos.

${ }^{302}$ Cf. BAUMAN, Z. Vida a crédito. Rio de Janeiro: Zahar, 2010, p. 50.
} 
"subclasse" por termos como classe "baixa", "trabalhadora" ou "destituída". (em oposição a esses termos, "subclasse” insinua uma categoria "abaixo", que está do lado de fora, não das outras classes, mas do sistema de classes como tal, isto é da sociedade $)^{303}$.

Desta afirmação de Baumam, pode-se depreender não apenas a conotação dramática que as cenas das mães de Wisconsin constroem, bem como não é difícil imaginar que tipo de inserção elas, e futuramente seus filhos, obterão nesta sociedade cujos "incluídos" estão cada vez mais no grupo dos "novos exércitos profissionais pequenos e esmerados" $" 304$. Tanto pelo protesto como por suas habilidades apresentadas no filme, elas evidenciam um tipo de qualificação para o trabalho braçal que historicamente é depreciado no país e, com o incremento do setor com máquinas e terceirização dos prestadores de serviço, é improvável que consigam sair deste ciclo ou da linha da pobreza como citou uma das mães. Contudo, elas ainda receberam por algum tempo um tipo de subsídio, agora cortado pelo governador que prefere as admitir sem repassar alguns benefícios sociais como o seguro saúde. Nesta direção, Baumam completa:

O que hoje se chama de "Estado de bem-estar" é apenas uma geringonça para combater o resíduo de indivíduos sem capacidade de garantir sua própria sobrevivência por falta de recursos adequados. Trata-se de agências para registrar, separar e excluir essas pessoas - e mantê-las excluídas e isoladas da parte "normal" da sociedade. Essas agências administram algo como um gueto sem paredes, um campo de prisioneiros sem arame farpado (embora densamente contido por torres de vigia! $)^{305}$.

Assim, o momento de protesto daquelas mães é breve no filme, pois não tiveram muito tempo para exercitar a limpeza simbólica e rapidamente saíram do lugar que, pela suntuosidade, parece ter sido criado como lugar de passagem, repleto de seguranças prontos para retirar qualquer intruso de cena.

\footnotetext{
${ }^{303}$ BAUMAN, Z. Vida a crédito. Rio de Janeiro: Zahar, 2010, p. 52.

${ }^{304}$ BAUMAN, Z. Vida a crédito, op.cit., p. 52.

${ }^{305}$ BAUMAN, Z. Vida a crédito, op.cit., p. 53.
} 
As sequências com o jovem branco de 20 anos, que trabalhou para a empresa aérea TWA enquanto estava preso, são curiosas, tanto pelo comportamento construído como antissocial do jovem que beira uma encenação combinada, quanto pela depreciação que Moore faz dele, alertando os consumidores que ao comparem suas passagens pela TWA poderiam estar passando seus dados pessoais para ladrões e assassinos. Moore diz que encontrou o jovem no Mall of America, conhecido como o maior Shopping Center dos EUA, e que ao ver o rapaz que se sobressai no público pelas tatuagens, por usar uma espécie de coleira no pescoço, além de seus cabelos arrepiados, foi perguntar se ele havia votado nas últimas eleições ${ }^{306}$. Bastante solícito, pelo menos em princípio, o rapaz responde as perguntas e conta que esteve na prisão em Ventura onde trabalhava para a empresa TWA.

Ao ver que presidiários preenchiam empregos que, segundo o que parece ser seu ponto de vista, deveriam ser ocupados por trabalhadores livres, Moore perde o foco no problema da exploração do trabalho e passa a construir aquele rapaz como um potencial assassino. Para isso, faz perguntas que provocam atitudes mais ofensivas do jovem e, provavelmente, inexperiente rapaz. Nesse sentido, o filme apresenta imagens de presos que, mesmo dentro de celas, fariam o trabalho de telefonistas, atendendo clientes da TWA e, consequentemente, tendo acesso aos seus dados cadastrais - como se ao entrarem em contato com aquelas informações pudessem, ao sair da cadeia, promover algum tipo de crime contra os clientes da empresa.

O filme corta para as interpretações que Moore oferecia acerca daquela situação para sua plateia em um dos shows realizados após a entrevista. As cenas buscam confirmar as suspeitas de Moore, e o modo como os cortes são alternados entre Moore fazendo os comentários para a plateia, e o jovem contando sua experiência, promovem uma representificação que sugere uma leitura negativa tanto do rapaz como de todos os homens presos que apareciam nas imagens.

O rapaz parece mudar sua maneira na representação que faz de si mesmo, e em tom de agressividade olha para a câmera e para a equipe dizendo é um "assassino em potencial", que não se importava com ninguém e que poderia matar o próprio Moore. Contudo, como ocorreu com a gerente Patty no Media Play, esse rapaz se atrapalha nas palavras, o que denota alguma incerteza acerca do que está falando. Não é difícil

\footnotetext{
${ }^{306}$ Moore realizou em 2008 um documentário para a televisão chamadoSlacker Uprising tratando desta questão dos jovens que deveriam ser conscientizados da necessidade de participação nas eleições pelo voto.
} 
imaginar que Moore pediu-lhe uma encenação, para confirmar diante de sua plateia, a hipótese de que a exploração do trabalho nas prisões traria insegurança aos usuários que, na condição de desavisados, não imaginam quem se encontra do outro lado da linha nos serviços de chamadas telefônicas.

Moore cita outras corporações que exploram esse tipo de trabalho de prisioneiros, como a fabricante de bolas de golfe, Spaulding, a Microsoft com os empacotadores de softwares, as confecções de Eddie Bauer, ou os telefonistas da $A T \& T$. Assim, o filme não conjuga valores fora da moral familiar e do trabalho árduo, talvez por isso não tenha construído o rapaz, jovem e solteiro, de forma mais "complacente" como fez Roger e Eu ao falar dos ex-montadores presos, cujo "peso" das responsabilidades familiares talvez os tenha impelido a praticar algum tipo de ilegalidade - como foi construído pelo filme.

Como gosta de apresentar o problema em fórmulas generalizantes, Moore diz:

$\neg$ Fechamos as fábricas e mandamos todo mundo embora, e alguns cometem crimes porque estavam desempregados. Então, vamos readmiti-los na fábrica que agora é uma cadeia. Eles podem fazer seu antigo trabalho para o qual estavam capacitados a US\$2,00/h e, assim, a empresa obterá enormes lucros. Uma ideia genial, não é verdade?

Ao citar aqueles que cometem crimes porque estavam desempregados, Moore remete à uma construção de Roger e Eu em que ex-montadores da GMsão apresentados ou presos ou como carcereiros recém contratados. A plateia se diverte e aplaude as generalizações do discurso de Moore. Após falar dos presidiários em chave depreciativa, o filme encerra sua frágil construção colocando esses últimos no grupo dos trabalhadores. 


\section{Conclusão}

The Big One tratou de modo frágil, em relação ao filme anterior (Roger e Eu), o tema capital versus trabalho, apresentando dois grupos em conflito devido interesses opostos e, aparentemente, irreconciliáveis: trabalhadores demitidos e grandes corporações. Se, em Roger e $E u$, o discurso incide sobre uma empresa e se mostra a favor de um grande grupo de demitidos, em The Big One, o tema do desemprego é ampliado e incorpora outras grandes corporações estadunidenses. A ênfase do filme aponta para as transformações do trabalho nas corporações, a internacionalização da produção e dos mercados, sintetizados pelo caso da Nike. Os políticos são construídos como alinhados aos interesses das corporações e seus lucros crescentes, ambos formam o grupo dos ricos (a mesma formula dualista vista em Roger e Eu: ricos versus pobres).

As cenas retomam o formato didático dos filmes de Moore, como por exemplo, alguns cortes de imagens de avião cruzando o céu para indicar que ele mudou de cidade. Em outras cenas, o filme parece preencher seu tempo com os momentos de comédia stand up encenados pelo próprio Michael Moore. A maioria das imagens apresentou dias claros, com músicas animadas e uma equipe de filmagens bastante descontraída. Nada aqui remete às cenas dramáticas dos despejos em Roger e Eu. Ao contrário, vários momentos de descontração percorrem o filme no mesmo clima de lançamento que teve o livro Downsize This! e o sucesso de vendas do seu cidadão desarmado.

O filme constrói os políticos como um grupo corruptível, e os empresários como um grupo ganancioso, ambos, unidos pelo vínculo financeiro em uma suposta aliança que apresenta riqueza e política como duas faces da mesma moeda. Essa afirmação é alinhavada nas cenas da multidão que acompanha nas ruas os quadros de apuração das eleições presidenciais entre Bill Clinton e Bob Dole. Moore pergunta para umas pessoas como pode $1 \%$ dos mais ricos serem donos dos dois maiores partidos do país, e, como se essa pergunta fosse "subversiva", o filme mostra policiais que caminham em direção à câmera colocando a mão na lente, como se estivessem censurando o "cineasta engajado" que caminha tranquilamente em mais um momento de roteirização evidente.

Os trabalhadores são construídos com pouca ênfase, se comparados ao que foi visto em Roger e Eu, porém com predomínio dos valores familiares, a condição do trabalho feminino com a mãe que ganha mais espaço nas cenas da lanchonete, ou com as mães de Wisconsin. O ex-presidiário não faz parte dos valores apresentados pela película, como o grupo de trabalhadores que precisam sustentar família, por isto pode 
ter sido construído em chave bastante depreciativa, como um assassino em potencial que representaria uma ameaça à sociedade ainda dentro da cadeia.

Em um dos seus momentos de atuação no palco, Moore diz que têm lido a Constituição dos EUA e que não encontrou a palavra acionista, (a plateia o aplaude). Diz ainda, com tom de simplicidade, que leu a palavra povo, mas não a palavra acionista e, reivindicando valores do Estado de Bem-estar social com toda a regulamentação que este comporta, afirma que os EUA vivem em uma democracia e podem estabelecer as leis que quiserem, pois, "enquanto não sejam contrárias à Constituição, não há problemas!"

Encerrar o filme mostrando um pequeno grupo de jovens felizes por terem formado um sindicato, pode ser indicativo de que The Big One se dirige a esta faixa etária de trabalhadores. Isso porque os trabalhadores jovens dependerão de muitos anos de trabalho para sobreviver, ao mesmo tempo em que sofrerão cada vez mais com as mudanças ocorridas em razão da globalização e suas consequências para as economias locais. Ao terminar com a mesma cena de abertura, a câmera focaliza Michael Moore parecendo indignado com aquilo que chama de "nossa História”, também afirma que o país possui "um só partido, uma só empresa” e que existia "um império do mal para cair". É possível imaginar que as colocações de Moore se referem ao grupo dos ricos que detêm poder político e econômico no país e, conforme o próximo filme analisado constrói, esse império se refere ao capitalismo na sua atual face de mercado financeiro.

Em seguida, para fechar o primeiro eixo temático deste trabalho, com os filmes que constroem ameaças ao padrão de vida desejado pelos trabalhadores, adiciono a este capítulo a análise de Capitalismo: uma história de amor. Este filme apresenta a crise financeira que levou muitos trabalhadores à falência pessoal nos EUA em 2008 e retoma imagens de Roger e Eu para construir os anos iniciais do problema. 


\section{3-Capitalismo: uma história de amor.}

"Não se trata de reconstituir objetos dotados
de uma realidade em si e permanente, mas pôr
em evidência os princípios de uma conduta
própria ao homem no quadro e limites de seus
poderes e de seus conhecimentos, num certo
momento de sua história e num determinado
círculo de civilização"
Pierre Francastel

A partir de um filme antigo, a imagem inicial de Capitalismo: uma história de amor retoma a construção irônica que caracteriza os filmes de Moore logo nas primeiras cenas. De costas para um fundo de tela vermelho vivo, um homem de expressão séria faz um elogio e um alerta de que o conteúdo daquele filme, "um dos mais incomuns jamais feitos", é inadequado para cardíacos ou pessoas sensíveis. Ao invés de promover a desistência por parte do espectador, essa abertura mais parece aguçar a curiosidade em torno daquilo que será apresentado. Outra sugestão possível, percebida a partir da visão geral do filme, é a de que a cor vermelha remeta à histórica oposição estadunidense em relação ao comunismo, no sentido de que, ao criticar o rumo que tomou o sistema capitalista, o filme antevê uma possível interpretação que o "classifique" como "apologia ao comunismo".

Nos filmes de Michael Moore a ironia aparece como estratégia discursiva. Tanto nesta abertura, alertando acerca de conteúdo impróprio para pessoas sensíveis,quanto em Tiros em Columbine, quando Charlton Heston aparece dizendo que o espectador irá gostar das cenas que serão apresentadas, o que se diz é oposto do que se quer dizer. Sabendo-se de antemão que Michael Moore produz filmes críticos a alguns grupos sociais, fica subentendida a postura irônica do enunciador que diz uma coisa quando quer dizer outra. Se no contexto original a antiga imagem de advertência não encontra efeito irônico, na atualidade dos filmes de Moore, bem conhecido pela repercussão de suas obras anteriores, o alerta inicial pode ser lido como tendo um tom de ironia ${ }^{308}$, pois

\footnotetext{
${ }^{307}$ Acerca da Sociologia da Arte e a problemática do imaginário. IN: FRANCASTEL, Pierre. A realidade figurativa. São Paulo: Ed. Perspectiva 1993, p. 17.

${ }_{308}$ Conforme Hutcheon, o contexto, as atitudes e expectativas, tanto do ironista quando do interpretador, são fatores condicionantes para o significado daquilo que é atribuído como tendo um sentido de ironia.
} 
não parece que o cineasta deseje o esvaziamento do público na sessão de seu filme, muito menos logo no começo.

Para início da construção crítica ao sistema capitalista, ou pelo menos aos rumos que tomou nas últimas três décadas, entra em alto som a música de Iggy Pop (Louie Louie $^{309}$ ) para, a partir da alternância de imagens que parecem tomadas por câmeras de segurança, montar uma espécie de vídeo-clip em que pessoas armadas assaltam bancos. Enquanto a letra da música diz que "o mundo comunista está desmoronando, os capitalistas estão só quebrando corações e o dinheiro é a razão de ser", são vistos: homens de todos os tipos assaltando bancos, os créditos do filme em cartelas de fundo preto com letras brancas e, após um dos assaltantes beijar um maço de dinheiro, entra o título do filme em letras brancas e fundo vermelho vivo: Capitalismo: uma história de amor. Essa abertura anuncia a tônica do filme, uma crítica ao capitalismo financeiro no contexto da crise mundial que afetou os EUA em finais de 2008. O filme também constrói como o Estado "socorreu" as instituições financeiras enquanto famílias literalmente faliam, perdendo empregos e suas casas hipotecadas.

Os assaltantes dos bancos sugerem pessoas endividadas e desesperadas que, devido ao desemprego, poderiam cometer crimes (uma sugestão também construída em Roger e Eu). Outra leitura possível configura aquelas pessoas como sendo o "povo" tomando de volta uma parte do "resgate" dos bancos e das grandes corporações.

Após essa sequência, uma nova alternância de imagens apresenta um pequeno filme dentro do filme, fazendo uma breve comparação entre a decadência e queda do Império Romano com a atualidade político-econômica dos Estados Unidos, aludindo assim, à queda do atual "império" nos mesmos moldes de seu similar na antiguidade. Neste pequeno filme, a voz de Deus, seguindo o modo expositivo ${ }^{310}$ de narração

Segundo a autora "o significado irônico possui três características semânticas principais: ele é relacional, inclusivo e diferencial” (pág, 89-90), isto é, "a ironia é uma estratégia discursiva que depende do contexto e da identidade e da posição de ambos o ironista e o público" (274). HUTCHEON, Linda. Teoria e política da ironia. Belo Horizonte: Ed. UFMG, 2000. Assim, se o público conhece Michael Moore como um diretor de filmes cuja construção se propõe ao mesmo tempo crítica e bem humorada, é possível que também relacione algumas de suas construções com o sentido de ironia, pois conforme aponta Hutcheon"o interpretador como agente desempenha um ato - atribui tanto sentidos quanto motivos - e o faz numa situação e num contexto particulares, para um propósito particular e por meios particulares. Atribuir ironia envolve, assim, inferências tanto semânticas quanto avaliadoras”. Hutcheon, L. 2000. $O p$. cit., pág. 29.

${ }^{30}$ http://letras.mus.br/iggy-pop/151533/traducao.html (Acesso em 10 de junho de 2013)

${ }^{310}$ Conforme tratou Bill Nichols: "Este modo agrupa fragmentos do mundo histórico numa estrutura mais retórica ou argumentativa... dirige-se ao espectador diretamente, com legendas ou vozes que propõem uma perspectiva, expõem um argumento ou recontam a história. Os filmes desse modo adotam o comentário com voz de Deus (o orador é ouvido, jamais visto), (...) ou utilizam o comentário com voz de autoridade”. NICHOLS, Bill. Introdução ao documentário. Campinas, SP: Papirus, 2005, p. 142. 
documentária, reforça a comparação entre os dois "impérios": o romano e o estadunidense. As imagens da fábrica da Nike na Indonésia (as mesmas sequências que Moore explorou no seu segundo filme The Big One) sugerem um paralelo entre o trabalho escravo na antiga Roma e as atuais relações de trabalho promovidas por grandes corporações. Uma espécie de fosso que separa ricos de pobres entra na comparação entre os dois impérios, só que na atualidade dos EUA os trabalhadores com pouca qualificação seriam explorados pelas cadeias de fast-food, como Roger e Eu anunciou com os ex-montadores de automóveis que encontraram ocupação na rede Taco Bells. Favelas no antigo império e o aumento dos sem-teto nos EUA também servem de comparação para a construção da decadência. Outra comparação empreendida pelo filme estaria na indústria do entretenimento, que aparece como distração para os cidadãos não sentirem o peso das suas vidas cada vez mais desvalorizadas pelo sistema econômico que o filme busca criticar: o capitalismo. Para isso, são dispostas de forma alternada imagens de espetáculos da mídia americana (show de música, jogos, corridas de carro) que remetem às formas de "entretenimento" típicas da época de Trajano, como por exemplo, as corridas de cavalo e as lutas entre gladiadores que ganharam atualidade com combates popularizados nos EUA como o UFC (Ultimate Fithing Championship) e suas lutas de MMA (Mixed Martial Arts).

Acerca da política, as comparações sugerem que nos EUA, tal como em Roma, inicialmente o povo tinha o poder de escolher seus governantes, porém, com o passar do tempo, um grupo assumiu o poder e passou a governar acima da lei - semelhante à figura do antigo imperador. O filme sugere essa figura com a imagem de Dick Cheney $^{311}$, um empresário de longa trajetória política nos EUA, cujo cargo mais importante foi o de vice-presidente nos dois mandatos de George Bush (2001-2009). Além disso, Cheney foi membro da Câmara dos Representantes dos EUA pelo Wyoming durante todo o governo Reagan - governo esse construído pelo filme como um “divisor de águas” na economia do país.

A narração ainda questiona porque um Império com um sistema jurídico bem idealizado tolerava a contradição de ferir as leis do seu próprio sistema. As imagens relacionam supostos abusos praticados no império romano com as formas de tortura cometidas pelos EUA na prisão de Abu-Ghraib, sediada em Baghdad, na guerra contra o Iraque (tema também explorado por Moore no filme Fahrenheit 9/11 e pelo filme

\footnotetext{
${ }^{311}$ Informações biográficas de Dick Cheney encontradas em: http://www.biography.com/people/dickcheney-9246063 (Acesso em 17 de julho de 2013).
} 
documentário Procedimento Operacional Padrão de Errol Morris). Para finalizar este trecho do pequeno filme dentro do filme, esta primeira voice over que narra a comparação entre Roma antiga e os EUA na atualidade, associa que o comportamento irresponsável por parte dos governantes teria sido uma das razões da decadência e queda do império romano.

Com a frase: "Hoje, todas as estradas levam a Washington"312, Bauman diz que são comuns algumas associações do "Império Americano" com o Império Romano, principalmente se a ideia de império for relacionada a poderio econômico e bélico. $\mathrm{Na}$ direção do que Capitalismo: uma história de amor constrói, Bauman concorda, baseado em outros autores, que a semelhança entre o "Império Americano" e o Império Romano ocorre na fase de decadência deste último. Os EUA estariam no limite do poderio militar, com seu orçamento altíssimo e cada vez mais difícil de sustentar, e de sua economia em desaceleração, o que sinaliza a possibilidade de decadência do "aspirante a Império Global” ${ }^{313}$. Segundo o autor;

Parece que os Estados Unidos entraram numa fase de dominação mundial exclusiva que está perigosamente próxima da exaustão de seu potencial expansivo. A pax americana pode se expandir em termos territoriais bem além dos limites da pax romana, contudo sua expectativa de vida dificilmente será medida em séculos. Como tudo em nosso mundo líquido moderno "negativamente globalizado", os mecanismos demolidores e autodestrutivos instalados em todo império de que se tem notícia operam mais depressa agora e precisam de muito menos tempo para completar seu ciclo ${ }^{314}$.

É possível pensar que, conforme indica a fala de Bauman, o filme constrói um ciclo de decadência para a economia dos EUA a partir do governo Reagan até o governo Bush, além de aludir à decadência com os gastos para promoção da guerra contra o Iraque - conforme sugestão do pequeno filme que compara os impérios ${ }^{315}$. Nas sequências, o filme passa a se desenrolar em torno das figuras que Moore constrói como

\footnotetext{
${ }^{312}$ BAUMAN, Z. A ética é possível num mundo de consumidores? Rio de Janeiro: Zahar, 2011, p, 234241.

${ }^{313}$ BAUMAN, Z. A ética é possível num mundo de consumidores? Op. cit., p. 241.

${ }^{314}$ BAUMAN, Z. A ética é possível num mundo de consumidores? Op.cit.

${ }^{315} \mathrm{O}$ filme Fahrenheit $9 / 11$ construiu, de modo mais detido, os gastos exorbitantes com a guerra contra o Iraque, propondo também a irresponsabilidade dos governantes em relação ao gasto de dinheiro público.
} 
sendo os responsáveis pelos principais problemas nos Estados Unidos: membros do Partido Republicano no governo e Senado, juntamente com seus aliados que seriam os empresários de grandes corporações. Conforme o filme enfatiza, alguns republicanos também são empresários, como o próprio Dick Cheney também citado em Fahrenheit 9/11 como CEO da empresa de serviços para petrolíferas Halliburton - o que sugere a aliança entre empresários e membros do governo para benefício do grupo dos ricos, em detrimento da maioria da população construída como pobre.

Após esta breve introdução com um filme dentro do filme, o que se parece configurar é um eixo temático que envolverá a construção da decadência política e econômica da nação estadunidense, associada na abertura ao Império Romano. Em seguida, a voz de Michael Moore passará a narrar uma história de amor que os seus concidadãos, cientes ou não, nutrem pelo sistema capitalista, de modo que "despercebidos" do caráter histórico e, portanto, não natural da atual economia, o tratam como algo inexorável, mesmo que leve muitos à falência pessoal.

Para sinalizar que a política não parece fazer parte da preocupação pública, Moore se pergunta como as futuras civilizações veriam a sua sociedade, ou ainda, por que tipo de referência histórica eles seriam lembrados. Para isso, entra em cena um breve vídeo, campeão de acessos no site do Youtube desde meados de maio de 2008, com vários gatos conseguindo dar descarga no vaso sanitário. De modo cômico o filme sinaliza algumas das coisas que "entretêm" muitos estadunidenses enquanto "ladrões" roubam o país. A referência aos pequenos vídeos do site Youtube, que ganham milhares de acessos em poucos dias, também sugere tempos do "poder" do entretenimento no cotidiano em prejuízo aos assuntos político-econômicos.

Em seguida, o filme aponta para algumas consequências enfrentadas por muitos estadunidenses, devido à crise econômica que afetou a crença na estrutura financeira do país em 2008, com as hipotecas e as pessoas perdendo suas casas para os especuladores imobiliários - esses últimos amparados legalmente pelas contradições das leis e do governo.

Uma família de Lexington, na Carolina do Norte, filma, em nove de fevereiro de 2009, a ação de despejo executada por policiais em cumprimento de uma ordem judicial. Aparecem na imagem cerca de sete viaturas que chegam para retirar os moradores da casa. Os membros da família gravam seus rostos e dizem seus nomes para o público, em seguida, com o barulho da porta sendo arrombada, os moradores se referem aquela situação como: "isto que vocês estão vendo é a América”, o que sugere 
um país rigoroso no cumprimento das leis, ainda que não pareçam mais tão justas aos olhos dos seus cidadãos.

Essas pessoas remetem aos inúmeros casos de estadunidenses que, cedendo aos diferentes apelos comerciais de agências financeiras, contraíram empréstimos e refinanciaram as próprias casas, muitas das quais estavam quitadas há algum tempo, porém eram vistas como capital de giro pelos grupos especuladores. Com o endividamento, o aumento dos juros, e a precarização das condições de trabalho nos EUA, muitas dessas famílias não conseguiram manter os pagamentos em dia e sofreram execuções de suas hipotecas.

De certo modo, ocorre em Capitalismo: uma história de amor a repetição em maior escala de problemas apresentados em Roger e Eu. Entretanto, se no primeiro filme a crise se limitava aos ex-trabalhadores da General Motors, sobretudo pobres, negros e famílias numerosas de Flint, no último a crise percorre diferentes pontos do país atingindo também a "classe média", tradicionalmente formada por pessoas brancas, com emprego, e famílias pequenas.

Com uma música triste a cena corta para novas ações de despejo que ocorrem em diferentes locais dos EUA, começando pela cidade de Detroit no Michigan. A exemplo da família anterior, que filmou o próprio despejo em sinal de resistência pacífica, outras pessoas aparecem em novas cenas resistindo de forma mais exasperada contra os agentes das ações de despejo. Diferentemente da família anterior, aqui a maioria do grupo é composto por pessoas negras em famílias numerosas de modo que a resistência toma corpo rapidamente com maior quantidade de pessoas incluindo crianças e adolescentes que aparecem criticando todos os que cooperam com aquelas ações construídas como injustas e, assim, corroboram a opinião expressa pelo filme de que o ônus da crise financeira afetava principalmente as pessoas pobres. Alguns moradores expulsos de suas casas contam suas histórias pessoais para a câmera com destaque para o senhor que reside há 41 anos no imóvel.

Nesse sentido, junto com o problema dos despejos o filme apresenta a ideia de resistência popular como forma de reação. Talvez esse provável "incentivo à desordem" tenha rendido ao DVD do filme, pelo menos no Brasil, a censura de não recomendado para menores de 18 anos!

Outro homem, morador da cidade de Peoria em Illinois, será despejado de sua propriedade rural e afirma que aqueles dias dão a sensação de que haverá algum tipo de rebelião entre o povo que não tem nada e as pessoas que têm tudo. Esse depoimento 
entra em consonância com a dualidade construída nos filmes de Moore, em que existem dois grandes grupos em conflito. O morador de Peoria e sua família ganham um bom espaço no filme para contarem suas histórias pessoais, aparecendo tanto em cenas iniciais quanto nas finais. São construídos como pessoas trabalhadoras e honestas que se desfazem de móveis e objetos pessoais para entregarem a propriedade limpa para o banco. A câmera focaliza um crucifixo pendurado na parede caracterizando aquelas pessoas como cristãs e também se detém no morador separando as armas da família, algumas pistolas e espingardas, que remetem ao costume dos estadunidenses em manter armas em suas propriedades.

Após as cenas dos despejos e as pessoas inconformadas, o filme passa a dar explicações sobre o sistema capitalista. Segundo a narração de Moore:

"O capitalismo é isto, um sistema que dá e tira. Tira na maior parte das vezes. A única coisa que não sabíamos era quando a revolta ia começar de novo."

Em seguida o senhor construído como um trabalhador diz que tentou de tudo, menos roubar um banco, mas poderia mudar de ideia, o que o filme sugere em sua abertura nas cenas dos assaltos a bancos cometidos por diferentes tipos de pessoas.

$\mathrm{Na}$ sequência, o filme aponta para a configuração do grupo que lucra com a crise. Começando por uma escala valorativa dentro desse "grupo dos ricos" Moore apresenta Peter Zalewski, um jovem corretor em plena ascensão que se ocupa no ramo imobiliário da Flórida. Peter ostenta o aumento dos seus lucros pessoais através da compra de um símbolo de consumo entre as pessoas ricas: o seu segundo sedan de luxo Hyundai Sonata. Ele conta um pouco do modo como trabalha comprando propriedades de pessoas endividadas ou despejadas pelos bancos e as revende com grande margem de lucro.

Michael Moore diz que o próprio Peter denomina sua imobiliária como um "abutre dos imóveis", representando outros especuladores que lucram em cima das ações de despejos ou com o infortúnio dos outros. Peter se isenta de responsabilidade com as "mazelas" individuais dos endividados, alegando que "os abutres não matam, eles fazem a limpeza", também mostra como pesquisa, em sites de bancos na internet, os imóveis que serão executados judicialmente por atraso nas hipotecas. Peter analisa uma casa à venda por U\$355 mil, cujos moradores pagaram U\$840 mil, um exemplo da crise das hipotecas pela qual passavam alguns os moradores daquela região. Parece que 
esses exemplos de vendas por falência familiar vinham se espalhando pelo país, enquanto no contexto de crise financeira os lucros de Peter pareciam estar em curva ascendente.

Para construir uma explicação didática acerca do que "entende" por capitalismo e mercado nas bases da livre-concorrência, o filme apresenta imagens em preto e branco que remetem aos antigos seriados da televisão estadunidense - o que explora o enraizamento cultural das séries no imaginário social, conforme discute Esquenazi em seu livro acerca das séries televisivas ${ }^{316}$. Apenas pela visualização das imagens não é possível afirmar se o filme é antigo ou se é uma construção recente por câmera digital com uma "roupagem" antiga, contudo, segue o aspecto pedagógico que permeia a construção de outros filmes de Moore, propondo o debate acerca de um tema em questão, como se esse formato fosse ao encontro de uma antiga preferência do espectador estadunidense há tempos afeito a esses programas. Em Roger e Eu são vistas cenas de I Love Lucy e Papai sabe tudo, que remetem ao American Way of Life, e em Fahrenheit 9/11 cenas de Dragnet e Bonanza, para ironizar a atuação política de Bush.

Nesta direção, que utiliza trechos de filmes antigos para a construção de um tema específico, Capitalismo: uma história de amor propõe uma crítica ao capitalismo na sua "face" de mercado financeiro, que lucra principalmente com ações. Neste pequeno filme, aparecem algumas das crenças estadunidenses acerca desse modo de produção e seus benefícios. Frases como: "nos deu o maior padrão de vida do mundo", "somos livres para ter lucros, nos virar ou fracassar", "sistema de livre iniciativa"; e palavras como: negócios, lucro, competição, também indicam outras características do livre mercado.

Em busca de explicações acerca das assertivas trazidas pelo pequeno filme anterior, Moore reencontra um amigo chamado Wally Shawn, que entre as "credenciais" de dramaturgo e ator também é apresentado como quem estudou história, política e economia básica, "legitimando" seu discurso de autoridade junto ao espectador. No aconchego de um restaurante em um dia aparentemente frio, os dois amigos conversam acerca da livre iniciativa e dos mercados. Entre rostos sérios e

\footnotetext{
${ }^{316}$ Conforme o autor as séries televisivas estão enraizadas no imaginário social do estadunidense e desempenham um papel importante na disseminação de ideias e valores sociais. Em geral, a matéria prima das séries são os problemas e os debates vigentes na sociedade de modo que "a televisão prossegue uma longa tradição da cultura popular norte-americana, que desde suas origens foi um instrumento essencial da expressão das ideias tanto de esquerda como de direita, como se diz na Europa, ou tanto liberais como conservadoras, como se diz nos Estados Unidos". IN: ESQUENAZI, Jean-Pierre. As séries televisivas. Lisboa: Edições Texto \& Grafia, Ltda. 2011, p. 157.
} 
explicações simplificadas, eles também falam de como funciona a concorrência entre os mercados e de como a demanda incentiva a produção, isto é, o mercado passaria a produzir as mercadorias mais procuradas e não as mais necessárias.

Para iniciar uma explicação que remeta à crise das hipotecas nos EUA, Moore retoma cenas de sua infância em Flint. Usando imagens do mesmo vídeo que apresentou sua família em Roger e Eu, o cineasta fala do tempo em que apenas o emprego na General Motors era suficiente para seu pai pagar a hipoteca da casa e sustentar a família. Em outro momento, Moore cita que sua mãe trabalhava sem precisar e enfatiza que o pai quitou a hipoteca da casa antes que ele terminasse a pré-escola, também lembra que eles trocavam de carro a cada três anos, faziam viagens pelo país nas férias anuais, e de modo geral tinham uma vida boa. Neste filme, que parece dialogar com Roger e Eu, Moore retoma os anos dourados da economia, em que os trabalhadores tinham estabilidade de emprego e uma renda que possibilitava realizar os sonhos de vida nos moldes do self made man. Enquanto as imagens mostram um menino abrindo presentes e se divertindo com algumas coisas em uma infância aparentemente tranquila, o próprio Moore afirma que se aquilo era o capitalismo, ele e os outros adoravam.

Em seguida, o filme passa a construir que, nos anos mais prósperos da economia americana, a diferença entre os mais ricos e os pobres seria menor devido à cobrança diferenciada de impostos. Moore afirma que mesmo com a cobrança de impostos (na casa dos 90\%!) os mais ricos ainda viviam como Bogie e Bacall (o casal de atores Humphrey Bogart e Lauren Bacall), isto é, os mais ricos teriam uma vida semelhante à das estrelas de cinema. Embora o filme pareça exagerar em sua construção visual mostrando os ricos em cenas de lazer e festas suntuosas para contrapô-los aos trabalhadores que buscavam o padrão de vida de "classe média", o que fica reforçado para o espectador é que mesmo pagando muitos impostos os ricos viviam muito bem e os assalariados não eram depauperados, pois o Estado utilizava o dinheiro dos impostos em infraestrutura para as cidades, e também com educação e saúde gratuitos. Inclusive Moore diz que eles, os EUA, mandaram "um cara para a Lua" - como se a pesquisa aeroespacial tivesse mais a ver com dinheiro sobrando em caixa do que com a Guerrafria que permeava aquele contexto.

Segundo Edgard Morin, é comum encontrar entre os produtos da indústria cultural, dentre os quais ele destaca o cinema de Hollywood, construções que pretendem eliminar tudo o que possa ser de difícil assimilação para o espectador. Segundo o autor, “a tendência à simplificação muitas vezes está em pé de igualdade com a tendência ao 
maniqueísmo"317, de modo a assegurar o antagonismo entre o bem e o mal, bem como os traços simpáticos e antipáticos que propõem para o espectador o apego aos heróis e a repulsa pelos maus.

Nesta direção, os filmes de Michael Moore, cuja inserção em Hollywood é um diferencial dentro das convenções que caracterizam o gênero, se valem dos mecanismos da indústria cultural ou, mais especificamente, do cinema de mainstream, recorrendo a simplificações e construções dualistas, reforçando o sentido "crítico" de suas construções, e exigindo do espectador, que em geral não seria afeito às contradições, uma tomada de posição valorativa. A proposta de Moore não se prende em ponderações, porém busca, nos limites de um filme, uma linguagem de assimilação fácil que se adéqua ao público alvo do filme - o "estadunidense médio".

É comum recorrer ao termo "homem médio" ou "estadunidense médio" para indicar uma faixa de público difícil de distinguir, mas que parece acomodar a controversa ideia de "classe média", que o filme também busca caracterizar. No que se refere ao espectador, inserido nesse grupo, geralmente citado como "o homem médio", diria Morin "que se trata do homem imaginário, que em toda a parte responde às imagens pela identificação ou projeção (...) dispõe de um tronco comum de razão perceptiva, de possibilidades de decifração, de inteligência”. Para o autor este homem se apoia na tendência da cultura de massas à universalidade, partindo de elementos culturais próprios da civilização moderna (civilização americana). "É por isso que o homem universal não é apenas o homem comum a todos os homens. É o homem novo que desenvolve uma civilização nova que tende à universalidade" ${ }^{318}$.

O que para Morin, remete a uma corrente cultural dominante, vai de encontro, a meu ver, com o cinema de Hollywood e suas características emprestadas aos filmes de Moore, de modo que os termos "cidadão médio" e "classe média" encontram identificação do espectador ao qual o filme se dirige.

De volta às sequências, com imagens antigas, provavelmente fins de 1960, época em que o apelo ao consumo dava passos iniciais, o filme inicia a construção daquilo que denomina de "classe média" ou o grande grupo que se opõe ao dos ricos. A proposta inicial de "classe média" remete ao padrão econômico observado nas imagens da infância de Moore, quando o Estado supria as necessidades básicas através de escolas,

\footnotetext{
${ }^{317}$ MORIN, Edgar. Cultura de massas no século XX: neurose. Rio de Janeiro: Forense Universitária, 1962 , p. 55.

${ }^{318}$ MORIN, Edgar. Cultura de massas no século XX: neurose, op.cit., 1962, p. 44-45.
} 
hospitais e direitos trabalhistas, garantindo um padrão de "vida decente". Além disso, Moore afirma que as pessoas tinham poupança, poucas dívidas e aposentadoria garantida para um futuro de lazer, como sugere a imagem de um homem que joga boliche ou do outro que, tranquilamente, se refresca em uma piscina ao sol.

Essa ideia do lazer é uma aspiração coletiva, sedimentada na cultura de massa ${ }^{319}$ e suas possibilidades de felicidade através do consumo. Conforme discute Morin, a ideia do lazer moderno ${ }^{320}$, que antes era privilégio das classes dominantes, é decorrente da organização do trabalho burocrático e industrial, que obrigou-se a fornecer não apenas um tempo de repouso, ou de recuperação física e mental, como também um de consumo. O lazer moderno estaria atrelado à cultura de massas, no sentido do indivíduo se interessar tanto pela satisfação das necessidades que gerem o bem-estar material da família, quanto as imateriais como o amor e a felicidade. Segundo o autor;

... a ética do lazer, que desabrocha em detrimento da ética do trabalho e ao lado de outras éticas vacilantes, toma corpo e se estrutura na cultura de massa. Esta não faz outra coisa senão mobilizar o lazer (através dos espetáculos, das competições da televisão, do rádio, da leitura de jornais e revistas); ela orienta a busca da saúde individual durante o lazer e, ainda mais, ela acultua o lazer que se torna o estilo de $\operatorname{vida}^{321}$.

Nessa direção, Moore recorre aos símbolos próprios da cultura de massa que orientam tanto a vida prática quanto a vida imaginária, possibilitando projeções e identificações específicas entre os espectadores. As cenas seguintes, que constroem a relação de amor do estadunidense com o capitalismo, estão impregnadas de símbolos da cultura de massa conforme discutida por Morin.

\footnotetext{
${ }^{319} \mathrm{Na}$ acepção dada por Morin, "o termo cultura de massa, como os termos sociedade industrial ou sociedade de massa (mass-society) do qual ele é o equivalente cultural, privilegia excessivamente um dos núcleos da vida social; as sociedades modernas podem ser consideradas não só industriais e maciças, mas também técnicas, burocráticas, capitalistas, de classes, burguesas, individualistas (...) podemos adiantar que uma cultura constitui um corpo complexo de normas, símbolos, mitos e imagens que penetram o indivíduo em sua intimidade, estruturam os instintos, orientam as emoções. (...) Uma cultura fornece pontos de apoio imaginários à vida prática, pontos de apoio práticos à vida imaginária; ela alimenta o ser semi-real, semi-imaginário, que cada um secreta no interior de si (sua alma), o ser semi-real, semiimaginário que cada um secreta no exterior de si e no qual se envolve (sua personalidade)." IN: MORIN, Edgar. Cultura de massas no século XX: neurose. Rio de Janeiro: Forense Universitária, 1962, p. 14 - 15. ${ }^{320} C f$. Morin, E. Cultura de massas no século XX: neurose, op.cit., p. 68.

${ }^{321}$ MORIN, E. Cultura de massas no século XX: neurose, op. cit., p. 69.
} 
Em seguida, indicando a decadência dos EUA, a narração de Moore passará a criticar o que acabou de construir, associando o padrão de vida que orientou a crença popular no american way of life como algo alicerçado na exploração e estagnação de outras economias ocidentais, inclusive através da guerra ou força bélica- um meio de conquista comum aos impérios como foi construído na associação inicial ao império romano em sua fase de decadência. Para isso, a narração afirma que a indústria estadunidense não tinha concorrência, porque esta última estava reduzida a escombros, e a imagem corrobora o que foi dito com aviões lançando bombas sobre alguma cidade que também deveria ter indústrias, provavelmente o Japão. Outra imagem mostra pessoas empurrando um pequeno vagão com escombros, provavelmente na Alemanha. Com o tom irônico da voz de Moore, ressaltando o contrassenso do sistema capitalista a partir de imagens que contradizem os princípios da livre-concorrência, o filme mostra cenas de destruição que provavelmente são da época da Segunda Guerra Mundial. Moore diz que aquelas eram as condições da indústria automobilística na Alemanha e no Japão. A narração também afirma que os estadunidenses não se importavam com os inconvenientes do período, e as cenas apontam para a guerra do Vietnã e os distúrbios civis que percorriam o país naquele momento - provavelmente em finais dos anos de 1960 e início de 1970 como as imagens já coloridas indicam. Entre cenas de destruição da "concorrência", que manteve a "livre-iniciativa" em solo americano, são citados também os progressos tecnológicos da indústria estadunidense tanto na área bélica quanto no cotidiano doméstico da "classe média", com o boom de novidades oferecidas pelo mercado.

Uma sequência de imagens rápidas ao som do segundo movimento da $9^{a}$ Sinfonia de Beethoven, chamado Molto Vivace - Presto, e seu ritmo acelerado dá o tom da euforia consumista que envolvia muitos estadunidenses nos anos 60. Entre as novas criações americanas como os tanques de guerra e os itens de consumo oferecidos às massas, o filme cita: alimentos industrializados que lotavam as prateleiras dos supermercados, carros, batedeiras, fornos elétricos, aspiradores de pó, televisores e outras coisas que faziam as donas de casa nos comerciais televisivos mais felizes, as crianças sorridentes, homens desfrutando do esporte, cinema, parques de diversões entre outras novas possibilidades, surgidas dessa "relação de amor" que o filme constrói entre o sistema capitalista e os estadunidenses no início dos $70^{322}$.

\footnotetext{
${ }^{322}$ Momento em que a Era do Ouro atinge seu auge. Cf. HOBSBAWM, Eric. Era dos extremos: o breve século XX: 1914 - 1991. São Paulo: Cia das Letras, 1995, p. 270.
} 
Esta exaltação das mercadorias e das possibilidades de consumo vão de encontro ao discurso de Jean Baudrillard acerca da sociedade de consumo, cujo representante por excelência são os Estados Unidos. Segundo o autor, "vivemos o tempo dos objectos"323 que ditam o próprio ritmo de produção, em conformidade com sua sucessão permanente. Nessa direção,

O amontoamento, a profusão revela-se evidentemente como o traço descritivo mais evidente. Os grandes armazéns, com a exuberância de conservas, vestidos, bens alimentares e de confecção constituem como que a paisagem primária e o lugar geométrico da abundância (...). No amontoamento, há algo mais que a soma dos produtos: a evidência do excedente, a negação mágica e definitiva da rareza, a presunção materna e luxuosa da terra da promissão. (...) E semelhante discurso metonímico, repetitivo, da matéria a consumir, da mercadoria, transforma-se, graças à grande metáfora colectiva e por meio do próprio excesso, na imagem do dom, da prodigalidade inesgotável e espetacular, que é peculiar à festa ${ }^{324}$.

Neste sentido, as imagens anteriores, construídas como que para "mergulhar" o espectador na euforia do consumo que percorria os EUA nas décadas pós-segunda guerra $^{325}$, dentro do ritmo não menos eufórico do Squerzo -Molto Vivace na $9^{\text {a }}$ Sinfonia, conferem o tom triunfante do capitalismo nos EUA daquele período. Como a narração de Moore enfatiza e as imagens constroem, o país ia bem, as famílias poderiam atingir um padrão médio de vida, que significava: emprego digno e estável, salário justo, conforto e uma estrutura social básica garantida pelo Estado. Neste cenário, a regulação das diferenças sociais entre os ricos e os pobres se dava, conforme o filme, através da cobrança de impostos e da intervenção do Estado na economia.

Acerca das mudanças na economia e, sobretudo, nas consequências sociais que marcam o contexto referido pelo filme, as discussões de Boltanski e Chiapello na obra O novo espírito do capitalismo oferecem um panorama das transformações no sistema

\footnotetext{
${ }^{323}$ BAUDRILLARD, Jean. A sociedade de consumo. Lisboa: Edições 70. 1995, p. 14.

${ }^{324}$ BAUDRILLARD, Jean. A sociedade de consumo, op.cit., p.15.

${ }^{325}$ Conforme pontua Hobsbawm, "A guerra, com suas demandas de alta tecnologia, preparou vários processos revolucionários para posterior uso civil" numa espécie de "terremoto tecnológico" que transformou a vida cotidiana no mundo rico, e alcançou até os pobres com o amplo acesso aos aparelhos como o rádio. IN: HOBSBAWM, Eric. Era dos extremos: o breve século XX: 1914 - 1991. São Paulo: Cia das Letras, 1995, p. 260.
} 
capitalista desde o pós-guerra. Os autores se debruçam principalmente nas mudanças visualizadas no capitalismo a partir da França, contudo, suas discussões retomam e se referem a todos os países capitalistas do Ocidente como os Estados Unidos. De modo geral, os autores pontuam que as mudanças no capitalismo, como a reestruturação dos mercados em sua expansão internacional, as novas relações que marcam a precarização do trabalho em diversos países, são transformações que abalaram o compromisso estabelecido no pós-guerra em torno da ascensão das "classes médias" e dos “executivos" visando afastar esses grupos do comunismo ${ }^{326}$.

Conforme tratou Sean Purdy, o crescimento dos EUA, após a breve recessão observada no período pós-guerra, marcou o país naquele período como a "sociedade do consumo", e esse "imperativo" foi considerado o principal direito da cidadania, independente se suas promessas eram cumpridas ou não. Esse "imperativo" movia a recente indústria da propaganda e marketing, disseminando a ideia de liberdade ao consumo e a livre expansão do mercado estadunidense. Assim, "a busca por autonomia econômica e soberania política foi substituída, nas mentes de muitas pessoas, pelas possibilidades de consumo como elemento essencial de felicidade e cidadania”, ${ }^{327}$.

As considerações teóricas, que dialogam com o filme nesta análise, auxiliam a compreender com que memória coletiva os filmes de Moore dialogam. A respeito da força que o crescimento econômico nos EUA teve naqueles anos, os quais Michael Moore se remete constantemente, diria Purdy:

Os números eram impressionantes: a produção industrial cresceu $60 \%$, a renda per capita aumentou em um terço, o desemprego e a inflação caíram. Avanços tecnológicos nos processos de produção na indústria automobilística (linha de montagem e mecanização), de comunicações (radio e telefone), eletrônicos e plásticos (eletrodomésticos e outros bens de consumo) criaram produtos inovadores a preços cada vez mais acessíveis. Circulavam entre as massas produtos antes restritos aos ricos - carros, luz elétrica, gramofone, rádio, cinema, aspirador de pó, geladeira e telefone -, o

\footnotetext{
${ }^{326} C f$. BOLTANSKI, Luc; CHIAPELLO, Ève. O novo espírito do capitalismo. São Paulo: Editora WMF Martins Fontes, 2009, p. 26.

${ }^{327}$ PURDY, Sean. O século Americano. In: KARNAL, L. (org.) História dos EstadosUnidos: das origens ao século XXI. São Paulo: Ed. Contexto, 2010, p. 198.
} 
"jeito americano de viver" (american way of life) tornou-se o slogan exaltado do período ${ }^{328}$.

Nesta direção, as cenas de euforia com as novas possibilidades abertas pelo crescimento econômico dos EUA, conforme construíram as imagens anteriores, referem-se aos tempos em que o confronto das ideologias, capitalismo versus comunismo, orientava as ações do governo estadunidense, em prol do liberalismo econômico e a busca da plena inserção dos grupos sociais no american way of life. Michael Moore vivenciou aqueles dias de ascensão econômica em seu país e, ao perceber o declínio da oportunidade de inserção dos trabalhadores nos ideais de "classe média”, vem questionando, desde Roger e Eu, as relações entre os grupos sociais, denominando-os, de "modo prático", como ricos versus pobres.

Em seguida, Capitalismo: uma história de amor passa a construir as mudanças no sistema, que parece "sair do controle", conforme indica, em tom preocupante, a cena do pronunciamento oficial do então presidente Jimmy Carter, advertindo os estadunidenses acerca do consumo desenfreado.

Com isto, o filme sinaliza que aquele ciclo de prosperidade para os trabalhadores poderia estar no fim. Se o presidente Carter indicava a presença do Estado na regulação da economia, alertando acerca daquele modo de vida que parecia não sustentar-se por muito tempo, o filme aponta que a "solução" veio com Ronald Reagan e sua conhecida agenda neoliberal $^{329}$. Na prática, isso significou o afastamento do Estado no controle da economia, deixando que a "livre-concorrência" regulasse o capitalismo.

\footnotetext{
${ }^{328}$ PURDY, Sean. O século Americano, op. cit., p. 198.

${ }^{329} \mathrm{Na}$ introdução do livro de Noam Chomsky "O lucro ou as pessoas: neoliberalismo e ordem global", Robert W. McChesney afirma que "o neoliberalismo é o paradigma econômico e político que (...) consiste em um conjunto de políticas e processos que permitem a um número relativamente pequeno de interesses particulares controlar a maior parte possível da vida social com o objetivo de maximizar seus benefícios individuais". (pág, 07). Na mesma obra, o próprio Chomsky diz que o neoliberalismo é ao mesmo tempo algo novo e que também baseia-se em ideias liberais clássicas [como as de Adam Smith]. Também é conhecido como Consenso de Washington: "um conjunto de princípios orientados para o mercado, traçados pelo governo dos Estados Unidos e pelas instituições financeiras internacionais que ele controla" (pág, 21). Entre as principais medidas desta política são destacadas: "liberalização do mercado e do sistema financeiro, fixação dos preços pelo mercado, fim da inflação e privatização" (p. 22).

IN: CHOMSKY, Noan. O lucro ou as pessoas: neoliberalismo e ordem global. Rio de Janeiro: Bertand Brasil, 2010, págs. 21-22. Na mesma direção, acerca do que considerou como manobra da nova direita nos EUA a partir de 1980, Sean Purdy destaca que as "políticas neoliberais" representaram a "retirada do Estado da regulação da economia e cortes nos programas sociais (...) voltados para a população carente". Para o autor, os cortes nas políticas sociais "caminharam ao lado de acordos de livre comércio negociados em nível internacional para abolir restrições à expansão de mercados internacionais". Neste panorama neoliberal, "as corporações aproveitaram-se das recessões, das pressões da competição global e das políticas conservadoras para abater o custo de seus negócios, resultando num ataque frontal aos direitos trabalhistas e aos sindicatos". PURDY, Sean. O século Americano. In: KARNAL, L. (org.) História dos
} 
Em uma sequência bem humorada com imagens e músicas que retomam filmes de faroeste, Moore sugere "a disposição" com que Reagan chegou ao governo, trazendo cenas do ex-ator nos tempos que trabalhava para os estúdios de Hollywood. Para isso, a cena constrói Reagan como um novo xerife para o país. Imagens capturadas dos antigos filmes sugerem seu modo peculiar de lidar com o descontentamento popular - em referência ao novo cargo de Reagan como presidente dos EUA, isto é, como um homem "linha dura" intolerante com os trabalhadores descontentes e com as mulheres que exigiam igualdade de direitos.

Ao seu modo irônico, Michael Moore costuma construir uma "identidade" para as pessoas, que "representam" os grupos que o cineasta faz oposição, com o uso de cenas retiradas de filmes antigos. Essas construções geralmente incluem filmes de faroeste, como fez em Fahrenheit 9/11 para a "coalizão dos dispostos" com George Bush e seu grupo.

Acerca da importância da construção fílmica para formas não oficiais de memória coletiva do país, Robert Burgoyne afirma que, ao longo de sua história, as produções de Hollywood ganharam a função de um "contador de histórias", cuja licença dramática permitiu o uso da ficção para articular "um campo imaginário no qual as cifras da identificação nacional são exibidas e projetadas". Conforme pontua o autor,

Os conceitos de realidade social construídos em filmes de Hollywood servem claramente como discursos legitimadores na vida da nação, uma função que é especialmente visível na maneira pela qual o passado nacional é representado em filmes norte-americanos que representam a tendência geral da produção ${ }^{330}$.

Nesse sentido, o cinema de Hollywood, com seu sistema de gêneros, constrói "segmentos sociais" que encontram a identificação de muitos espectadores, devido seus discursos legitimadores da vida da nação. Segundo Burgoyne, "nos Estados Unidos do

EstadosUnidos: das origens ao século XXI. São Paulo: Ed. Contexto, 2010, p. 258. Assim, antes de propor uma digressão acerca da conjuntura econômica que caracteriza o neoliberalismo, recorro a essas duas definições básicas para sinalizar que essas medidas são geralmente lidas como sendo prejudiciais aos trabalhadores estadunidenses, pois enfraqueceram os sindicatos, desregulamentaram o mercado e os bancos, e também flexibilizaram as relações de trabalho, prejudicando direitos historicamente conquistados. Nessa direção, a partir do governo de Ronald Reagan, o filme constrói algumas consequências desse conjunto de medidas, chamadas de política neoliberal, enfatizando os principais danos sofridos pelos trabalhadores até chegar ao contexto da crise de 2008-2009, sugerindo a decadência político-econômica do país.

${ }^{330}$ BURGOYNE, Robert. A nação do filme. Brasília: Editora Universidade de Brasília, 2002, p. 19. 
século $\mathrm{XX}$, as formas de narrativa que moldaram a identidade nacional de maneira mais profunda são defensavelmente o filme de faroeste e o filme de guerra",331.

Assim, ciente ou não desta "ferramenta" de memória coletiva, Michael Moore constrói personagens transferindo a carga simbólica de filmes antigos para $\mathrm{o}$ personagem em questão no seu filme. No caso de Reagan ficou até mais fácil, pois o exator tinha participação em filmes de faroeste e em filmes de guerra. No caso de George Bush, o cineasta faz deliberadamente montagens com o rosto do ex-presidente sobrepostas em rostos de outros personagens do cinema de faroeste - tudo para propor sentidos específicos ao espectador.

De volta as sequências de Capitalismo: uma história de amor, para construir Reagan como um membro importante do grupo rico denominado "Wall Street" (que inclui bancos e empresas), são apresentas imagens antigas do tempo em que Reagan, então ator de Hollywood (não do mesmo nível de Booguie e Bacall), também fazia comerciais televisivos para produtos das grandes corporações, como a gigante General Eletric. Assim, do mesmo modo que George Bush foi construído não como um líder político voltado para os interesses sociais, e sim como membro do grupo de políticos que gerenciava o país em Fahrenheit 9/11, também Reagan é construído como um "porta-voz dos bancos e corporações", escolhido para ocupar o cargo mais importante da nação: o de presidente dos EUA. Segundo a narração "onisciente" de Moore:

"Os bancos e empresas tinham um plano simples: transformar os Estados Unidos para que servissem a eles"

Em seguida, as imagens "comprovam" as afirmações anteriores, mostrando que Reagan foi eleito. Outra imagem mostra Reagan dentro do prédio da bolsa de valores sob a afirmação que "os Estados Unidos corporativos e Wall Street estavam no controle total". Nesse momento, uma música semelhante a que tocou em cenas de Fahrenheit 9/11 quando o grupo de Bush era construído dando forma aos planos de guerra contra o Iraque, também é tocada nas imagens que constroem o grupo que estaria orientando a presidência de Reagan. Don (Donald) Reagan presidente do Merrill Lynch, um banco de investidores que atua mundialmente no ramo de ações, aparece ao lado de Reagan e

\footnotetext{
${ }^{331}$ BURGOYNE, Robert. A nação do filme. Brasília: Editora Universidade de Brasília, 2002, p. 19-20.
} 
assume a "posição chave" de Secretário do Tesouro e posteriormente Ministro da Casa Civil, o que segundo Moore, favoreceu os ricos com cortes nos impostos.

Para acentuar que Don Reagan orientava Ronald Reagan, o filme mostra o presidente sendo interrompido e apressado em seu discurso pelo Secretário do Tesouro. Imagens em close no rosto de Don Reagan e cenas colocando-o ao lado do presidente, constroem o grupo que estava no poder naquele momento: as grandes corporações do mercado financeiro. Nessa direção, Moore afirma que o país passaria a ser dirigido como uma corporação, o que remete ao contexto de neoliberalismo o qual Reagan nos Estados Unidos e Margaret Thatcher na Inglaterra foram os principais expoentes na década de 80 .

A frase de Reagan: "Vamos soltar o touro" significa a não intervenção do Estado na economia, o que traria lucro para as grandes corporações e seus negócios transnacionais, porém prejudicaria as pequenas empresas de cidades locais como tratou o segundo filme de Moore, The Big One, com o caso da empresa Leaf que faliu e foi incorporada em 1996 ao grupo Herchey’s. Vários dilemas dos trabalhadores, apresentados nos filmes anteriores de Moore, voltam com enfoque ampliado em Capitalismo: uma história de amor, sinalizando pontos de fixação ${ }^{332}$ entre as películas.

As ações neoliberais de Reagan lhe valeram a reeleição quatro anos depois do primeiro mandato, e o filme aponta para imagens da campanha que mostrava pessoas felizes e confiantes de que dias melhores e prósperos viriam. Contudo, no seu formato didático, o filme retoma a imagem usada em Roger e Eu de uma caixa d'água com o logotipo da $G M$ sendo implodida e indo ao chão. Isso para sinalizar que aquela fé popular em dias melhores não se concretizaria, e com isto o filme passa a construir o desmantelamento da antiga indústria nacional, responsável pelos empregos e estabilidade econômica observados nas imagens da infância de Moore.

Para construir um sentido épico às transformações na economia introduzidas por Ronald Reagan, o filme insere junto das sequências de imagens a música da cantata cênica de Carl Orff - Carmina Burana (O Fortuna) ${ }^{333}$. Conforme a música da cantata invoca em sua letra à Deusa Fortuna, a imagem congela em uma foto de Reagan na Casa Branca e inicia uma montagem com números e gráficos informando os lucros e as demissões simultaneamente gerados pelas grandes corporações como General Motors,

${ }^{332}$ Conceito tratado desde o início deste trabalho que se refere, de modo geral, à insistência de temas em uma mesma amostra de filmes. Cf. SORLIN, Pierre. Sociologia del cine: la apertura para la historia de mañana. México: Fundo de cultura econômica, 1985.

${ }^{333} \mathrm{http}: / /$ letras.mus.br/carmina-burana/884204/traducao.html (acesso em 01 de julho de 2013). 
$A T \& T$, General Eletric, entre outras empresas que, além do grande volume de demissões, também fragilizaram os sindicatos, congelaram salários e aumentaram a produtividade entre os funcionários que ainda tinham emprego, isto é, um cenário de reestruturação do capitalismo discutido nas análises de Roger e Eu e de The Big One.

A estrutura dos impostos observada pelo filme nos tempos de prosperidade inverteu-se, agora os ricos pagavam menos impostos e os trabalhadores pareciam assumir a carga mais pesada do desenvolvimento nos moldes neoliberais. Nesse panorama, os ricos são apresentados como pessoas brancas elegantemente vestidas em meio a festas requintadas, e os pobres "trabalhando duro" como o soldador e outros homens em obras pesadas.

A narrativa apresenta uma nova modalidade de mercado financeiro, que viria culminar na atual crise das hipotecas discutida pelo filme: a concessão de empréstimos aos trabalhadores. O filme constrói gráficos que remetem ao aumento crescente do endividamento dos trabalhadores os quais, consequentemente, sem salários adequados para arcar com os empréstimos contraídos, começam a engrossar as estatísticas de falência pessoal, o que, por sua vez, contribuiu para o aumento do número de prisões em 355\%! Como foi construído em Roger e Eu, no atual filme Capitalismo: uma história de amor também existe uma associação entre desemprego e aumento da criminalidade.

Entre outras consequências, o filme aponta para o aumento nas vendas de antidepressivos, o que garantiu lucros para a indústria farmacêutica e para as seguradoras que trabalhavam com seguro-saúde - tema explorado pelo documentário SICKO de 2007. A imagem do rosto de Ronald Reagan esteve presente em todos os gráficos que informavam os números dessas transformações, e, se a roda da fortuna pudesse ter sido invocada como sugeriu a música, estaria agora apontando sua boa sorte para o grupo dos ricos que, segundo o filme, lucraram: o mercado de ações e os CEOs daquelas corporações citadas.

A imagem antiga de um ônibus azul, e uma voz noticiando que metade da cidade de Flint recebia ajuda do governo (seguro social), compõe a nova sequência de cenas que ganham um tom de melancolia ao som das notas musicais de um piano. Michael Moore comenta que aquelas imagens são dos anos 1989, em que realizou seu primeiro filme Roger e Eu, após os oito anos de mandato de Ronald Reagan o que, conforme os filmes seguintes também constroem, resultou no aprofundamento das desigualdades sociais no país. 
Algumas cenas do primeiro filme são reapresentadas, inclusive à do lobista da GM Tom Kay alegando que as mudanças eram para manter a empresa competitiva no mercado. Contudo, a narração de Moore enfatiza que as empresas iam bem e mesmo com os lucros a GM quase foi à falência, como as cenas de Capitalismo: uma história de amor puderam remeter. Uma manchete no jornal The Detroit News, datada em 01 de junho de 2009, mostra que a velha GM estava falindo e precisava de ajuda do Governo Federal. Michael Moore diz que a falência se estendia a muitas cidades, algumas não tão pequenas como Flint e são citadas e mostradas fotos de regiões empobrecidas pelo desemprego em massa: Boston, Massachusetts; Bellington, Washington; Anderson, Indiana; Sacramento na Califórnia. Interessante destacar que, na narração de Moore, o filme retoma cenas de Flint e em seguida mostra a manchete do Jornal Detroit News anunciando a falência da GM. Acontecimentos separados por um período de 20 anos são unidos na narrativa como se fossem partes de um mesmo processo de "decadência" da empresa.

Novamente dialogando com Roger e Eu, Michael Moore cita um breve filme cujo tom de paródia incide sobre a cidade de Cleveland, destacando seus problemas com a decadência industrial como se fossem atrações turísticas. O breve filme "promocional" cita que em Cleveland uma casa poderia ser adquirida pelo preço de um videocassete, porém eles ainda eram felizes por não serem como Detroit - outra grande cidade que passou por um rápido processo de desindustrialização e falência geral.

Ainda neste diálogo com Roger e Eu, em Capitalismo: uma história de amor, Michael Moore segue até a nova sede mundial da GM, construída em 1977, em um conjunto de edifícios espelhados que formam o GM Renaissance Center, situados na cidade de Detroit. Impedido novamente de entrar na sede, para falar com seu novo $C E O$, Moore revive cenas de Roger e Eu com alguns seguranças barrando a equipe de filmagens. Ao som de uma música cômica, o cineasta diz que há vinte anos tenta entrar naquele prédio e é impedido.

Em nova sequência de imagens, para contextualizar a situação econômica da $G M$, Moore cita que as principais indústrias concorrentes, situadas na Alemanha e no Japão, reconstruíram suas indústrias produzindo automóveis mais seguros e econômicos que os americanos. As imagens apresentam cenas das indústrias: Volkswagen, Mercedes-Benz, Lexus (uma divisão de luxo da Toyota), e outra japonesa, Honda. Além das imagens dos trabalhadores, que montavam os carros em instalações aparentemente repletas de alta tecnologia, Moore diz que nesses países os sindicatos têm poder de 
contratar e demitir membros da diretoria, o que sugere um equilíbrio entre a modernização das empresas e a organização dos trabalhadores em sindicatos. Moore insiste que os líderes políticos desses países não destruíram a "classe média".

Acerca do termo "classe média", Bolstanski e Chiapello afirmam que, a partir da década de 70, as pesquisas a respeito desta classe foram deixando o "campo de representação" e, nos anos 80, muitos analistas acreditaram que as classes já não existiam. Debruçados no caso europeu, os autores indicam que a "consciência de classe enfraqueceu", e o principal motivo observado foi o aumento da inserção dos trabalhadores na "classe média", arrefecendo a antiga oposição entre as classes burguesa versus operária. Segundo os autores:

A elevação do nível de vida dos operários depois do pós-guerra, seu acesso ao consumo de certos bens, tais como automóvel ou televisão, a melhoria do conforto das habitações, assim como o decréscimo regular do efetivo operário a partir de 1975, tudo isso abriu caminho para a teoria da absorção de todas as classes (da classe operária em particular) por uma ampla classe média. As pesquisas transmitem a ideia de que a consciência de classe se enfraqueceu [... e] possibilita mostrar o aumento do sentimento de não pertencer a uma classe, e "os que dizem pertencer a uma classe social" referem-se cada vez mais "à classe média, o que pode de certa maneira ser interpretado como a negação da consciência de classe, pois não há mais oposição a outra classe" ${ }^{, 334}$.

Essas considerações encontram paralelo nos Estados Unidos com a formação de uma grande "classe média", cujo acesso ao consumo arrefeceu a participação política sempre incentivada nos filmes de Moore.

Segundo Bauman "o consumidor é inimigo do cidadão",335. Para o autor, os países ricos do planeta apresentam os maiores índices de desinteresse ou apatia política, o que pode representar uma ameaça à democracia. Nas palavras do autor;

A política democrática não pode sobreviver muito tempo à passividade dos cidadãos produzida pela ignorância e a indiferença

\footnotetext{
${ }^{334}$ BOLTANSKI, Luc; CHIAPELLO, Ève. O novo espírito do capitalismo. São Paulo: Editora WMF Martins Fontes, 2009, p. 316 - 317.

${ }^{335}$ BAUMAN, Z. A ética é possível num mundo de consumidores? Rio de Janeiro: Zahar, 2011, p. 195.
} 
política. As liberdades dos cidadãos não são propriedades adquiridas de uma vez por todas; essas propriedades não estão seguras quando fechadas em caixas-fortes de banco. Elas são plantadas e enraizadas no solo sociopolítico, que precisa ser diariamente fertilizado ou regado, e que secará, ficará quebradiço, se não for assistido diariamente pelas ações informadas de um público educado e comprometido. Não apenas as habilidades técnicas precisam ser continuamente atualizadas, não apenas a educação deve centrar no emprego, elas devem ser vitalícias. O mesmo é exigido, e com ainda maior urgência, da educação para a cidadania ${ }^{336}$.

Com a construção de dois grandes grupos antagônicos denominados de ricos contra pobres, Moore parece propor a construção de uma "consciência social" que considere o conflito de interesses entre esses grupos. Em Roger e Eu a divisão entre a classe operária versus a classe burguesa ficou delimitada, contudo, em Capitalismo: uma história de amor a "classe média" parece remeter mais a um padrão de vida socialmente desejado por um amplo grupo do que a uma classe social delimitada. Esse grande grupo denominado de "pobres" envolve desde as pessoas muito pobres que são despejadas de suas casas até os trabalhadores que atingiram o padrão de vida confortável, mas que ou estão ameaçados, ou perderam o acesso ao estilo americano de vida. Todos os que estão fora do círculo lucrativo do mercado financeiro e dos altos cargos das grandes corporações entram no grupo dos "pobres".

Os filmes de Moore ainda propõem a renovação da participação popular no cenário político, no caso de Capitalismo: uma história de amor, o cineasta retoma o incentivo à participação popular através do voto eleitoral, o que constrói o poder da "democracia".

Voltando para a construção da pauperização da "classe média" estadunidense, o filme segue para o cenário de desindustrialização de Flint, Michael Moore entrevista seu próprio pai e relembra alguns momentos dos 33 anos e meio em que trabalhou na fábrica mais antiga da $G M$ - quando o ideal de "classe média" parecia possível aos trabalhadores. Conforme o filme constrói, esse ideal de "classe média" nos EUA é caracterizado como tempos que os estadunidenses tinham oferta de emprego estável,

\footnotetext{
${ }^{336}$ BAUMAN, Z. A ética é possível num mundo de consumidores? Rio de Janeiro: Zahar, 2011, p. 195.
} 
sindicatos estruturados, e uma renda familiar que possibilitasse a inclusão social via consumo de bens - isso com o amparo do Estado regulando a equidade social.

Uma espécie de "exemplo" de resistência às demissões em massa é exibida pelo filme, com o caso dos trabalhadores da indústria Republic Windows \& Doors em Chicago, Illinois. Os funcionários, diante do anúncio do fechamento da fábrica, ocuparam de modo organizado e pacífico as instalações, pouco antes do Natal de 2008, recebendo apoio da comunidade local e acompanhamento da mídia. Outro apoio aos demitidos veio do Bispo de Chicago, James Wilkolwski, que, sendo filho de um metalúrgico, aparece nas cenas finais do filme retomando a admiração construída por Moore aos membros da Igreja Católica. Moore sinaliza a atuação da Igreja no apoio aos direitos civis com as cenas de Martin Luther King na Marcha de Selma, e com as imagens dos padres entrevistados acerca do sistema capitalista.

Na construção deste grupo, ao som de uma música triste, a câmera focaliza os rostos dos funcionários que prestam algum depoimento, sobretudo os mais emocionados ou os mais combativos, conferindo um sentido de injustiça a favor daquelas pessoas aparentemente honestas e trabalhadoras. O caso desta fábrica de portas e janelas é retomado nas sequências finais do filme, como que para fixar ao espectador modelos de conduta diante das demissões, sobretudo para aqueles funcionários que eram demitidos sem receber os direitos trabalhistas, como foi em princípio o caso da Republic Windows \& Doors.

Para reforçar ao espectador o sentido dramático das cenas de falência pessoal, devido ao mau gerenciamento dos políticos estadunidenses na economia que, ao contrário dos alemães e japoneses, pareciam não se importar em "destruir a classe média”, o filme alterna as cenas que constroem os trabalhadores resistindo às demissões com imagens da descontração de Bush, ao som animado da música Zambesi, no último ano de seu segundo mandato como presidente dos EUA. A narração de Moore afirma que "enquanto a economia entrava em colapso", o presidente resolveu falar bem do capitalismo. As imagens seguintes apresentam recortes de discursos em que Bush faz elogios ao mercado, enquanto a narração questiona e descontextualiza suas palavras: ganância, exploração e fracasso.

Entre a fala de Bush acerca da liberdade de escolha do modo de viver e das oportunidades oferecidas pelo capitalismo, o filme coloca a câmera novamente focalizando rostos de estadunidenses cuja situação econômica "segue na contramão" das 
palavras do presidente. Pat Andrews, uma senhora, ainda procura no jornal de classificados a oportunidade de emprego tão celebrada por Bush em seus discursos.

Semelhante ao caso do xerife Fred Ross, que em Roger e Eu foi construído como uma pessoa de emprego estável em Flint por executar diariamente inúmeras ações de despejo, em Capitalismo: uma história de amor, Don Rendem, morador da Califórnia, vê seu pequeno negócio de confecção de placas aumentar o faturamento em $50 \%$ devido a um único tipo de placa: a que sinalizava as execuções por hipotecas. Enquanto isso o filme traz novos recortes, com cenas dos discursos de Bush falando das benesses do livre comércio, e suas assertivas são imediatamente contraditas pela narrativa com imagens de pessoas desempregadas.

A cidade Wilkes Barre, na Pensilvânia, entra em cena para ilustrar que até a prisão se tornou uma espécie de negócio, com jovens sendo presos por motivos simples. A maioria dos adolescentes entrevistados no filme são construídos como inofensivos. $\mathrm{O}$ reformatório seria um negócio rentável, porque o juiz Mark Ciavarella descobriu um modo de lucrar com aquelas prisões, contratando uma corporação para lidar com os "delinquentes" a custos altos para o governo local, que pagava aluguel pela nova infraestrutura terceirizada. Se como indica a narração de Moore, no capitalismo "tempo é dinheiro", quanto mais tempo os "6.500 jovens", "injustamente condenados", permaneciam presos, mais o reformatório lucrava. Para finalizar essa construção, o filme mostra que os juízes, e os demais responsáveis pelos lucros naquele reformatório, foram punidos. Contudo, aquele caso era um exemplo, conforme pontua Moore, do que se pode esperar quando uma entidade do governo vira uma empresa.

Após o caso das prisões dos adolescentes, pela primeira vez Michael Moore diz que "o capitalismo derrotou a democracia", e o filme seguirá com esta assertiva até o seu final, no sentido de que as instituições criadas pelo governo não deveriam se tornar empresas capitalistas, ou ainda, como as cenas dos anos Reagan construíram, as instituições não deveriam receber uma administração corporativa, pois conforme visto no caso do reformatório juvenil, as pessoas seriam cada vez mais usadas e lesadas em favor de lucros privados.

Com uma "música de ninar" ao fundo da cena, indicando o sonho, momentaneamente interrompido, de um jovem piloto também preso na Pensilvânia, o filme segue para outro setor na economia estadunidense que parecia em crise: o da aviação civil. 
Corte na cena e entra o caso do capitão e piloto Sullenberger, que ganhou notoriedade ao conseguir pousar um Airbus no rio Hudson, salvando cerca de 150 pessoas do que seria mais um desastre aéreo nos EUA. O filme aponta que, transformado em celebridade por seu ato de heroísmo, "Sully" ganhou atenção e honras num cenário de espetacularização ${ }^{337}$ do seu feito, cuja notícia vendeu como mercadoria, mas quando se valeu dos holofotes para criticar no Congresso a situação dos pilotos da aviação comercial dos EUA, as luzes se apagaram.

Se na definição de Debord o espetáculo é a afirmação da aparência, e "aparece como uma enorme positividade, indiscutível e inacessível" não dizendo nada além de "o que aparece é bom, o que é bom aparece ${ }^{, 338}$, o ato de Sullenberger em salvar vidas foi uma grande celebração daquilo que pareceu bom do ato na sua aparência imediata, sem considerar as causas do acidente ou o contexto que envolve aquela profissão. Apesar de tudo o que "Sully" viveu, a "realidade" por trás da vida de um piloto de Airbus, cuja profissão faz parte do cenário das mudanças promovidas pelo neoliberalismo econômico, obliterou a positividade da aparência de seu feito, pousar o Airbus em um rio, salvando dezenas vidas.

Em seguida, o filme "comprova" a crise financeira no setor apresentando depoimentos de pilotos. Alguns deles complementam a pouca renda na aviação com ocupações incomuns para a profissão, como passear com cachorros, ser garçonete em um café, ou vender plasma por dinheiro (algo também visto em Roger e Eu). Alguns pilotos mais empobrecidos chegam a receber auxílio alimentação, o que deixa Moore indignado com a situação econômica daqueles que comandam aviões a 9 mil pés de altura! Um piloto antigo da United Airlines diz que com o enfraquecimento dos sindicatos e com as terceirizações, as companhias aéreas apostavam no lucro com qualidade baixa. Moore completa a construção da crise nesse setor lembrando um acidente ocorrido em 12 de fevereiro de 2009 na cidade de Buffalo, quando um avião caiu inesperadamente, sem alerta de pane, vitimando cerca de 50 pessoas. A explicação de Moore, enquanto o filme mostra imagens do incêndio que se seguiu após a queda, é que os pilotos discutiam acerca de seus salários, descuidando de manobras importantes

${ }^{337}$ Conforme a definição seminal de Guy Debord, "O conceito de espetáculo unifica e explica uma grande diversidade de fenômenos aparentes. Suas diversidades e contrastes são as aparências dessa aparência organizada socialmente, que deve ser reconhecida em sua verdade geral. Considerado de acordo com seus próprios termos, o espetáculo é a afirmação da aparência e a afirmação de toda vida humana - isto é, social - como simples aparência. Mas a crítica que atinge a verdade do espetáculo o descobre como negação visível da vida; como negação da vida que se tornou visível”. IN: DEBORD, Guy. A sociedade do espetáculo. Rio de Janeiro: Contraponto, 1997, p. 16.

${ }^{338}$ DEBORD, Guy. A sociedade do espetáculo, op. cit., p.16-17. 
no momento de aproximação do aeroporto, distante 8 quilômetros do local do acidente. Moore lamenta que um piloto responsável por tantas vidas ganhe menos que um gerente do Taco Bell (rede de fast food que empregou alguns ex-montadores da GM conforme explorou o filme Roger e Eu).

$\mathrm{O}$ caso dos pilotos indicou outro problema que deixou de ser responsabilidade do Estado e se tornou uma empresa: a educação. Os pilotos entrevistados obtiveram empréstimos a juros altos, denominados de crédito estudantil.

Seguindo a dinâmica do filme, que é a de um assunto relacionado a outro, após as imagens do avião carbonizado em Buffalo, Moore diz que "no capitalismo tudo é permitido", até mesmo lucrar com a morte de um funcionário. Para legitimar essa afirmação, o filme apresenta casos de funcionários que deram, com suas mortes, lucro aos empregadores, através de seguros de vida feitos sem conhecimento dos funcionários e de seus familiares.

Irma Johnson, que perdeu o marido com câncer, e Paul Smith, que perdeu a esposa asmática, tomaram conhecimento que os empregadores de seus cônjuges tinham sido beneficiados com seguros de vida sigilosos. A câmera, entre as cenas das entrevistas, focaliza rostos que ainda choram suas perdas, passeia pelos cômodos das casas de cada um dos dois entrevistados, mostrando os seus filhos órfãos, fotos de família, vídeos pessoais, diferentes lembranças de anos de vida em comum, de modo a oferecer ao espectador do filme familiaridade e empatia pelos dois casos.

O advogado Michael D. Myers, que investigava o caso do marido de Irma Johnson, concede entrevista explicando como funcionavam aquelas apólices de seguro corporativas em nome de funcionários, e que era desejável para as empregadoras que os segurados morressem, principalmente os mais jovens, pois aquelas pessoas valiam mais mortas do que vivas. Enquanto as empresas lucravam, as famílias tinham que arcar com os custos hospitalares e funeral. $\mathrm{O}$ advogado ainda alerta que milhões de estadunidenses não sabem que têm cobertura dessas apólices, chamadas de "seguro do camponês morto".

Com uma música triste o filme apresenta fotocópias de documentos com nomes de empresas que se valiam daquela prática, enquanto o advogado explica alguns casos que vieram à tona, devido a um documento relatando a insatisfação de uma empresa com o retorno do "investimento", pois a mortalidade estava abaixo da prevista. Entre as corporações citadas estão: Bank of America, Citibank, Wal-Mart, Winn-Dixie, Proctor \& Gamble, McDonnell Douglas, Hershey's, Nestlé, AT\&T, Southwestern Bell, 
Ameritech, American Express. Enfim, todas grandes corporações, algumas das quais o próprio Moore conhecia bem de outros confrontos, como visto com representantes da Procter \& Gamble, ou da Hershey's comprando a empresa de doces Leaf em The Big One.

Novo corte nas sequências, e Moore passa a construir uma espécie de comparação entre o capitalismo e o mal, entrevistando diferentes autoridades religiosas, de modo a relacionar o modo de produção e o mercado de consumo como práticas relacionadas ao pecado. Em seu costume de se colocar como parte do grupo que defende, Moore recorre ao padre que realizou seu casamento em Flint, Dick Preston. O padre alerta que o capitalismo é um mal ao bem comum, contrário à compaixão e contrário a todas as religiões, e precisa ser eliminado. Moore aproveita essa palavra final (eliminado) e ironiza que, por "soar algo forte", prefere consultar outras autoridades religiosas em busca de uma opinião "mais equilibrada". O padre Peter Dougherty, que casou uma das irmãs de Moore, é consultado, e suas colocações parecem mais "fortes" do que as do padre anterior, pois refere-se ao sistema capitalista com os dizeres: "imoral", "obsceno", "escandaloso", "mal radical".

Assim, recorrendo ao superior daqueles dois padres, Moore entrevista o bispo da Arquidiocese de Detroit, Thomas Gumbleton, o qual afirma que "o capitalismo não estaria mais provendo o bem-estar das pessoas". Esta fala não é rebatida pela narrativa de Moore como algo "forte", sugerindo uma opinião fílmica de que o "bom capitalismo" teria um papel a desempenhar: prover o bem-estar social. O Bispo consulta a Bíblia no evangelho de São Lucas e lê uma advertência que se alinha às construções dos dois grupos principais e antagônicos no filme:

"Abençoados sejam os pobres. Ai de vós, ricos."

A próxima construção do filme é no sentido de entender como o "povo" aceita o sistema capitalista há tanto tempo. O padre Peter Dougherty acredita que as pessoas são enganadas pelo poder daquilo que chama de "propaganda ideológica" do sistema capitalista e sua capacidade de enganar as próprias vítimas.

Como um assunto faz ligação ao assunto seguinte, o filme passará a construir a "propaganda ideológica" do sistema capitalista e como sua ideologia mantêm as pessoas na expectativa de alcançar seus benefícios, apresentando cenas de outro filme antigo em 
preto e branco, e mostrando um homem jovem fazendo uma declaração que parece ir de encontro à crença comum em relação ao capitalismo:

\section{Sabemos que o capitalismo americano é moralmente certo porque seus} principais elementos, propriedade privada, motivo de lucro, e mercado competitivo, são benéficos e bons. São compatíveis com as leis de Deus e os ensinamentos da bíblia.

Em seguida, o filme passa a "desmistificar" essa fala, ou ainda, a desconstruí-la, como se essa afirmação estivesse arraigada ao imaginário social. Michael Moore, colocando-se como "exemplo" de quem cresceu sujeito à mesma "propaganda ideológica" em favor do capitalismo, diz que também acreditou que competição e o lucro estivessem de acordo com as leis de Deus. Apelando para a moral cristã, que permeia os valores estadunidenses independente das práticas religiosas individuais, o filme busca associar o capitalismo ao mal através de sua simbologia comum - cores escuras, homens que parecem enganar outras pessoas, voz distorcida. Para isso entram: música de suspense, cenas de filmes antigos, imagens escuras em preto e branco cujos personagens sugerem práticas de hipnose no sentido de levar pessoas a graus de inconsciência, como se no sistema capitalista as pessoas estivessem entorpecidas ou hipnotizadas.

Um homem com capa preta e cartola, em uma construção típica de um "vampiro", tenta hipnotizar um jovem. Em outra cena, uma espiral hipnótica gira diante de uma mulher observada por outro homem e por uma face que aparece à esquerda dentro de um espelho - o que sugere uma espécie de gênio do mal. Em outra imagem um homem parece hipnotizar uma mulher deitada em uma cama, como se estivesse em um consultório de psicólogo. Enquanto isso, a voz masculina diz que os princípios do capitalismo baseados no lucro e na livre concorrência "são compatíveis com as leis de Deus e os ensinamentos da Bíblia”. Esses dizeres são repetidos 5 vezes, conforme o filme acrescenta cenas de suspense e terror à sua construção do mal e do engano das pessoas. A cada repetição a voz fica mais distorcida em referência à voz do "diabo" ou do mal.

Na última cena que remete à hipnose, outro homem tenta hipnotizar uma mulher de modo que essa construção do mal ocorre principalmente em mulheres, crianças e adolescentes, apresentados como inocentes. A cena seguinte, em um antigo grupo escolar, sugere que a educação formal também seria uma forma de doutrinar antigas e 
futuras gerações à lealdade ao sistema - o que vai de encontro à tese do padre Peter de que as "vítimas" do capitalismo o legitimam e o defendem.

Como que "absolvendo" aos que chama de "bons americanos", a voz de Moore também afirma que dívida, despejo e exploração são resultados da antiga fé de que aquele sistema "é compatível com as leis de Deus e os ensinamentos da bíblia". Ao som de música de um órgão de igreja e com cenas de sua adolescência católica, Moore parece justificar sua escolha de consultar a opinião de padres e um bispo acerca do capitalismo, afirmando que eram seus ídolos de infância, pois tinham se posicionado em favor dos pobres e minorias oprimidas, como na Marcha de Selma e dos que tentaram parar a guerra dedicando suas vidas aos pobres.

A marcha de Selma ${ }^{339}$ fez parte do movimento em prol dos direitos civis, simbolizado naquele período por Martin Luther King. Em 7 de março de 1965, grupos de negros iam se avolumando para cruzar uma ponte desde a cidade de Selma, cujo governo era racista, até Montgomery em prol do fim da segregação eleitoral, a qual impedia pessoas negras de votarem. O primeiro grupo a fazer a tentativa foi duramente reprimido, o que resultou em mais de 140 feridos. Alguns dias depois Martin Luther King levou uma marcha simbólica até a ponte novamente, sem, contudo, poder seguir pelas ruas, pois era ilegal. Após conseguir apoio jurídico para seguir com a marcha, outra grande mobilização partiu de Selma em 21 de março chegando à Montgomery no dia 25 , obtendo a adesão de cerca de 25 mil pessoas, entre elas muitas autoridades locais e eclesiásticos. Essa marcha fez com que presidente Lyndon Johnson assinasse uma nova Lei dos Direitos de Voto de 1965, liberando o voto dos negros em eleições.

Valendo-se de algumas máximas bíblicas ensinadas pelos seus padres preferidos, Moore narra alguns trechos desses ensinamentos, mostrando imagens contrastantes entre pobres e ricos, e se pergunta como sua nação seria julgada em relação ao tratamento que dispensou aos mais pobres, e que "não há ninguém mais importante para Deus do que os pobres". Cenas com moradores de ruas reforçam, de acordo com as referências bíblicas, a existência de muitos pobres para serem "cuidados" nos EUA.

Em seguida, com a câmera apontando para um morador de rua em um ponto muito próximo da Casa Branca, Moore diz que muita gente cooptou as ideias de Jesus para seus interesses pessoais, de modo a "vender" a ideia de que Jesus veio "criar um paraíso na Terra para os ricos". As imagens mostram o interior do prédio da bolsa de

\footnotetext{
${ }^{339}$ Fonte site do Governo dos EUA. http://www.nps.gov/nr/travel/civilrights/al4.htm (acesso em 25 de junho de 2013).
} 
valores e George Bush entre dezenas de corretores, o que sinaliza não a presença de um Estado regulador, mas do favorecimento político entre os ricos. Essas imagens também remetem à ideia final da narrativa construída em The Big One de que existia nos EUA apenas um partido: o do negócio.

Moore diz que não encontrou na Bíblia nenhuma indicação de que Jesus tenha se tornado capitalista. Contudo, o filme apresenta, com trechos de filmes sobre a vida do ícone do cristianismo, uma pequena interpretação de um Jesus que não prega o evangelho, e sim o capitalismo, de modo que alguns dos principais diálogos entre Jesus e seus seguidores se referem aos ditames do capitalismo, como por exemplo: maximizar os lucros, desregular o setor bancário, não curar doenças pré-existentes e cobrar pelos milagres. Moore diz que não acredita que Jesus veio para essa finalidade, mas curiosamente os ricos "o chamam de seu". Para corroborar a tese acerca da apropriação da imagem de Jesus e a deturpação de seus ensinamentos pelos ricos, a cena volta para o mercado financeiro, com a abertura da bolsa de valores de Nova Iorque, e o vicepresidente do banco de investimento UBS, o ex-senador Phil Gramm, dizendo que ali era como um "templo" do capitalismo estadunidense.

Para enfatizar que o imaginário estadunidense estaria acostumado com a associação do capitalismo ao cristianismo, o filme parte para imagens dos noticiários de televisão. Nessas imagens, alguns apresentadores comentam que, mesmo com a Guerra do Iraque, a economia estadunidense ia muito bem, e por extensão a economia mundial também estava bem, o que deveria ser um "milagre divino", ou devido às vitórias do capitalismo globalizado, ou ambos.

Moore retorna ao Bispo de Detroit, relatando o que viu em Wall Street, e ouve a opinião de que Jesus não faria parte do capitalismo. Tomando essas palavras como "verdadeiras", o filme volta à suas construções críticas ao capitalismo, alertando contra o poder das grandes corporações no sistema.

Em relação às grandes corporações, Michael Moore apresenta um memorando, criado em 2005 e 2006, para os três principais investidores do grupo Citibank, "revelando planos do para controlar o mundo", isto é, um prospecto acerca da situação econômica e geral do país. Novamente a narração de Moore ganha ares de onisciência, narrando as "intenções" das corporações. Nesse memorando, a análise conclui que os EUA teriam se tornado uma plutonomia, isto é, uma sociedade criada e gerenciada por $1 \%$ da população, o que coincide com a construção fílmica do grupo dos ricos e sua hierarquia própria. Segundo a narração de Moore, “comprovada" pela imagem com 
realces coloridos sobre trechos do texto filmado, esse grupo de ricos, que também inclui a instituição bancária, teria mais dinheiro do que os 95\% restantes da população, o que, segundo o memorando, representaria uma nova aristocracia.

Enquanto as imagens caracterizam esse grupo dos ricos em um teatro muito grande, no qual pelo requinte sugere uma noite de ópera, Michael Moore volta ao memorando para dizer que a única coisa que ameaça aquele grupo é a "sociedade exigindo uma parcela mais justa da riqueza". Isso também poderia representar uma "revolta dos camponeses", lembrando como eram chamados os empregados mortos assegurados pelas corporações. Moore diz que o próprio memorando alertava que o voto popular seria uma manifestação de poder, o que, verdadeiro ou não, incide diretamente naquilo que o cineasta tem falado em seus filmes - a força do voto popular como fator preponderante para alguma mudança política e econômica no país. Ainda narrando os termos do memorando, o cineasta diz que o Citibank declara que os $95 \%$ tolerava sua própria situação porque sonhava em ser como aquele $1 \%$ mais rico.

A imagem de mansões à beira mar é rapidamente cortada para um cão de pequeno porte, que salta insistentemente em direção a um prato sobre uma mesa, o esforço do pequeno animal o mantém visualizando o "doce", porém, é impossível que o alcance. Segundo a narrativa, assim seria com os $95 \%$ restantes da população, que acredita no "sonho americano", um ideal capitalista que alimenta a expectativa de se tornarem ricos. Quanto aos ricos, o filme se refere a esse grupo com a imagem de um cão grande e treinado, que abocanha, num único movimento, um biscoito equilibrado no focinho. Nesta construção, os ricos não estariam dispostos a dividir a riqueza com o grande grupo dos pobres.

O colunista e membro da redação do The Wall Street Journal, Stephen Moore, entra em cena para dizer que entende a "democracia como dois lobos e uma ovelha decidindo o que comer". Moore alerta que esse jornal é a "bíblia empresarial" diária da América - o que dá relevância aquele depoimento diante de toda a construção anterior acerca do sistema associado ao mal. Para Stephen, o voto não mudaria a condição econômica das pessoas, porque existem eleições populares em países pobres que nem por isso deixam essa condição. Contudo, segundo o jornalista, o capitalismo torna as pessoas livres para fazerem o que quiserem de suas vidas, o que também não significa que serão bem sucedidas, visto que a Constituição dos EUA não garante à felicidade. 
No seu costume de conferir as indicações dos seus entrevistados, Moore segue até Washington para ler se no texto original da Constituição dos EUA existia a palavra capitalismo, porém encontrou e sublinhou para o espectador os termos: "nós o povo".

O que Moore constrói na cena em que vai reler o texto original da Constituição dos Estados Unidos, é que os cidadãos teriam sido "convencidos" durante anos de educação formal e pela ideologia (american way of life) que "democracia" e capitalismo seriam indissociáveis.

É possível imaginar que essa indissociação seja muito comum, visto que a democracia moderna e o capitalismo ganham relevo no período moderno.

Assim, o filme buscaria desconstruir instituições que seriam comumente associadas entre si: o cristianismo, o capitalismo e a democracia moderna. A meu ver, é relevante destacar que a mensagem principal no filme é que o sistema capitalista adquiriu força a ponto de sobrepujar as outras instâncias sociais, de modo que tudo teria se tornado lucrativo, inclusive aquilo que moralmente deveria ser exceção - como a morte das pessoas.

Moore conduz sua narração sublinhando para o espectador palavras como: "união", "promoção do bem-estar geral", "democracia". Palavras que, segundo a construção fílmica, colidem com os princípios do capitalismo que é o "lucro" e a "livreconcorrência".

Em seguida, o filme apresenta o que parece uma alternativa para o "gerenciamento do capitalismo", que não entra em conflito com os princípios da democracia e, portanto, do bem comum. O "modelo" de empresa democrática é trazido ao filme com o caso da Isthmus Engineering, em Wisconsin, na qual todos os funcionários são donos do negócio, com direito a voto e participação nas decisões da empresa, que projeta e produz robôs para indústrias. A câmera apresenta rostos de trabalhadores tranquilos, em um ambiente muito limpo repleto de alta tecnologia em meio às máquinas criadas para produção industrial. A narração de Moore enfatiza que a atitude dos membros daquela empresa é um ato patriótico, em oposição à crítica do cineasta acerca das grandes corporações, que fragmentam e destroem a indústria nacional, transferindo capital para outros países.

Outro exemplo vem da Califórnia, na fábrica de pães que funciona como uma cooperativa, em que os trabalhadores ganham três vezes mais que um piloto inicial na American Eagle. Enquanto as imagens mostram pessoas trabalhando em instalações apropriadas, os discursos dos entrevistados nas duas empresas enfatizam o salário justo, 
uma vida confortável e sem exageros, conforme aponta um funcionário da fábrica de pães que, em seu depoimento, questiona porque as pessoas precisam ser ricas ou quantos carros precisam ter.

Voltando as suas construções que remetem ao passado, o filme mostra outras pessoas que ofereceram seu trabalho sem se preocupar com enriquecimento. Imagens em preto e branco apresentam uma manchete de jornal anunciando a descoberta da vacina de Salk, eficaz contra a poliomielite. O médico e pesquisador Salk é descrito por Moore como alguém que poderia ter enriquecido se vendesse a fórmula da vacina para uma indústria farmacêutica, entretanto preferiu não requerer a patente, cedendo sua descoberta para o bem universal. Após exibir parte de uma entrevista do Dr. Salk, dizendo que não se poderia patentear o Sol e o mesmo valia para sua vacina, a narração de Moore diz que "os tempos mudaram muito".

Nas sequências, o professor William Black, da Faculdade do Missouri em Kansas City, diz que atualmente os pesquisadores de diferentes áreas, como matemática e ciências, vão para Wall Street ganhar dinheiro, ou para as grandes corporações. Moore culpa as dívidas contraídas pelos estudantes, com os altos juros para os créditos estudantis, como motivador da busca por retorno financeiro rápido logo após a faculdade. Trabalhar para os bancos representaria, segundo o professor William, uma atividade menos produtiva e mais destrutiva para os jovens talentos, que estariam contribuindo para "tornar o mundo pior". Em razão dessa assertiva do professor William, Michael Moore segue até a bolsa de valores de Nova Iorque para tentar entender o conceito de "derivativo" ou de "troca de crédito de inadimplência", que devido sua complexidade parecem criações dos "talentos desviados para o mercado financeiro". Independente de uma boa explicação, o cineasta parece mostrar que esses termos servem mais para "camuflar" as diferentes frentes pelas quais as empresas lucram, do que definir o conceito daquelas operações.

Para entender o que são os "instrumentos financeiros complexos", Moore entrevista Marcus Haupt, que foi vice-presidente do Lehman Brothers, um banco de investimentos que marcou a crise financeira nos EUA em 2008.

O filme constrói para o espectador, com a aparente dificuldade de especialistas, como Marcus Haupt e Prof. Kenneth Rogoff, em explicarem o que são os derivativos, que existem modos de confundir e complicar as ações econômicas, a fim de que grande parte da população não compreenda como os lucros são gerados. 
Moore sugere que derivativos e suas fórmulas complicadas não passam de "esquemas de apostas" de um grande "cassino" chamado Wall Street, feitos propositalmente para não serem entendidos, pois assim os agentes do mercado financeiro "podem matar e sair impunes", como no caso das hipotecas e das falências pessoais que marcaram a crise de 2008.

Um corte na cena dos derivativos, com a foto de capa da Revista Time, apresenta três homens que formariam um "comitê" para "salvar o mundo". O primeiro membro desse comitê era o economista Alan Greespan, que também foi presidente da Reserva Federal dos EUA e aparece em imagem sendo condecorado por George Bush. Para deslegitimar a credibilidade do famoso economista para o espectador, o filme apresenta a especialista em direito de falência e professora em Harvard, Elizabeth Warren, uma mulher de aspecto visual formal, de voz suave e postura educada, que concede entrevista no que parece um escritório com uma estante de livros à sua direita - aspectos visuais que no filme legitimam a professora como pessoa séria e de opinião confiável.

Warren afirma que, por ser considerado "o homem mais inteligente da face da terra", Greespan encontrou legitimidade para seu discurso de incentivo às pessoas em "capitalizarem o valor de suas casas", o que segundo a professora era o mesmo que dizer "hipoteque sua casa". Segundo Warren, muitos americanos de mais idade que tinham casas próprias quitadas também fizeram a hipoteca e, não conseguindo pagar as prestações, perdendo tudo. Esse exemplo vai de encontro aos casos de despejos que abrem o filme.

Em seguida, o filme constrói como as pessoas teriam sido incentivadas ao endividamento. Para manter o mercado aquecido, economistas como Greespan formularam um plano de incentivo às hipotecas como forma de investimento familiar. Muitas pessoas cederam aos apelos da mídia, algumas estavam em situação econômica relativamente estável, e utilizaram o financiamento como meio de capitalizarem, sem considerar os riscos "embutidos" nas taxas de juros, como foi o caso do morador de Peoria que disse não conseguir pagar a hipoteca devido aos reajustes excessivos.

Conforme o filme constrói, incentivar pessoas que desconhecem os mecanismos do mercado ao endividamento pode trazer camuflado um grande risco de perderem seus "negócios", e foi o que aconteceu com a chamada "bolha imobiliária” em 2007 - 
$2008^{340}$, quando uma espécie de "efeito em cascata" da queda das ações asiáticas, repercutiu no mercado financeiro mundial. Quando a crise das bolsas atingiu o mercado financeiro dos Estados Unidos, trouxe mudanças rápidas nos juros e muitas pessoas não conseguiram mais pagar as prestações de suas hipotecas, perdendo suas casas.

Com uma música alegre e antiga, parecida com a da abertura de Roger e Eu, uma espécie de comercial televisivo é apresentado pelo filme, a narração de Moore enfatiza que os donos dos imóveis seriam convencidos que estavam sentados em uma "mina de ouro", pois se investissem o valor de suas casas na forma de empréstimos bancários, poderiam lucrar reinvestindo o dinheiro no mercado de ações. Pilhas de barras de ouro e uma mulher nadando em dinheiro são imagens que reforçam a sensação de um grande negócio lucrativo. Recortes de comerciais dessas propostas de refinanciamento imobiliário são mostrados nas sequências em cenas de pessoas alegres pela nova forma de investimento, contudo a voz de Moore narra a proposta de modo cômico, sobretudo nos itens que se referem aos contratos e os juros embutidos nas transações, que seriam a garantia do banco para tomar as casas dos inadimplentes.

Um corte seco na imagem apresenta um dia frio e nublado. Uma música fúnebre anuncia que aquele "negócio" não seria bom para seu principal público: as pessoas que não tinham noções de economia, de mercado financeiro, bolsa de valores, ações, enfim, dos movimentos internacionais do capitalismo e da forma como isso afeta o cotidiano dos pequenos investidores. O ex-regulador dos bancos William Black volta em cena para explicar uma foto em capa de revista que sinaliza as mudanças nas regulamentações das poupanças e hipotecas, isto é, as regulamentações que "freiam" os bancos e "protegem" minimamente os cidadãos de contratos abusivos. Um relatório anual da FDIC (Federal Deposit Insurance Corporation) é apresentado como decisivo para os cortes nas regulamentações. Black comenta a foto em que quatro homens estão diante de uma pilha de papéis brancos com cerca de meio metro de altura. Um deles chama-se John Gilleran, chefe da agência que regula poupanças e empréstimos, e está segurando uma serra elétrica em direção aos papéis, enquanto é auxiliado por quatro homens, que portam outras ferramentas manuais de corte, e são chamados de os "três dos maiores lobistas do setor bancário". O quarto homem no canto direito da foto é o vice-diretor da Corporação Federal de Depósitos de Seguro.

\footnotetext{
${ }^{340}$ Fonte de notícias vinculadas na época que explicam a crise nos EUA em decorrência da crise no mercado financeiro mundial: http://g1.globo.com/Noticias/Economia_Negocios/0,,MUL111829356,00.html (acesso em 10 de julho de 2013).
} 
Importante destacar que o excesso de informações complicadas envolvendo o mercado financeiro, aliado ao discurso de autoridade dos entrevistados, pode tornar o filme entediante para o espectador. Porém a forma dinâmica do filme contribui para que os grupos sejam bem delimitados e rapidamente compreendidos pelo público.

Novamente, o filme retoma as propagandas televisivas que incentivam as famílias ao endividamento, porém nesta segunda exibição dos comerciais são apresentadas imagens com a narração de Moore alertando que aquelas propagandas se assemelham à "mesma lábia que a máfia passa em seu bairro". Para reforçar essa construção que aproxima os bancos da máfia, uma voz parecida com a do personagem Don Corleone do filme "O poderoso chefão" e trechos da música de Nino Rota Godfather Love Theme são sobrepostas à fala da mulher no comercial original, o que associa os dois discursos que levam ao endividamento: o do banco e o da máfia.

Fotos de antigos mafiosos que tiveram notoriedade nos EUA são apresentadas, com Moore citando nomes de grandes bancos como o Countrywide, Citibank, Wells Fargo e Chase. Cenas de filmes antigos "lembrando" como os mafiosos cobravam as dívidas são colocadas antes das imagens que retomam o drama da família Hacker, despejada em Peoria no Illinois. Para Moore aquelas cenas de despejo e humilhação familiar são cenas de um roubo, o cineasta também se espanta ao ver que o Citibank contratou serviços de remessa dos avisos de despejos "em uma das cidades mais desesperadas dos Estados unidos": Flint, no Michigan.

Os filmes de Moore costumam repetir cenas para que os espectadores não se esqueçam das construções e dos sentidos que lhe são propostos. A construção que associa máfia com bancos e mostra pessoas sendo despejadas, reforça ao espectador que o estadunidense estava sendo "vítima" de ações criminosas.

Outro corte na cena e Bob Feinberg, um ex-funcionário que cuidava dos empréstimos especiais da Countrywide (uma grande empresa de hipotecas), concede entrevista revelando que para algumas pessoas mais ricas, geralmente políticos e amigos de Ângelo Mozilo (CEO do Countrywide), poderiam contrair empréstimos a juros baixos, diferente das taxas cobradas das famílias de menor renda, foco principal da agência, mostradas nos comerciais com pessoas negras ${ }^{341}$. Entre os ricos beneficiados com juros baixos, cortes de taxas e outros benefícios do Countrywide, foram citados

\footnotetext{
${ }^{341}$ Essas hipotecas de maior risco ou de segunda linha, porque são concedidas às pessoas de menor renda ou de histórico de crédito ruim e, portanto, oferecem as próprias casas como garantia, são os chamados subprimes.Fonte: $<$ http://www.ipea.gov.br/desafios/index.php?option=com_content\&view=article\&id=21 56: catid=28\&Itemid=23> (Acesso em 12 de julho de 2013).
} 
nomes como o do embaixador Richard Holbrooke, que aparece em foto ao lado do expresidente Bill Clinton; uma mulher chamada Donna Shalala, que aparece em foto ao lado do ex-presidente George Bush; pessoas do Capitólio, outros que trabalhavam na regulamentação do mercado de hipotecas, outros membros de Wall Street; o presidente da Fanne Mae, Jim Johnson; Alphonso Jackson, secretário do HUD, é mostrado em foto com Bush passando a mão em sua cabeça e o Senador Conrad do Comitê de Finanças.

Essas pessoas são construídas como influentes na política e economia do país, recebendo facilitações em negócios que eles próprios deveriam regular. Inclusive o Senador Christopher Dodd (presidente do Comitê de Bancos e Habitação do Senado), que falava na televisão contra os "empréstimos predatórios", foi denunciado por Bob Feinberg como um beneficiário dos "favores" do Ângelo. Com fotos "comprometedoras", closes nos rostos que o espectador precisava conhecer e diferentes tipos de documentos e denunciantes, o filme constrói uma teia de relações entre pessoas influentes, conduzindo a política e economia do país em favor de poucos e em detrimento de muitos; de modo "prático": os ricos contra os pobres. As revelações de Bob Feinberg denunciam um esquema de "troca de favores".

Nesta direção, ao som de uma música de suspense, o filme retoma imagens de audiências do Senado nos anos 80, nas quais aparece Bill Black, então regulador de bancos, denunciando "escândalos de empréstimos". Alinhado ao grupo de Moore, que representa a população lesada pelos "empréstimos predatórios", Black denunciou ainda nos anos 80 Charles Keating e foi ameaçado de morte. Segundo Black até o FBI denunciou uma "epidemia de fraude de hipoteca pelos bancos", mas devido os atentados contra os EUA em 11 de setembro de 2001 muitos agentes foram transferidos para as novas investigações, deixando o caso das hipotecas de lado, o que segundo o entrevistado, configurou "a maior onda de crimes de colarinho branco da história do país". Black ressalta que a maioria das fraudes foram cometidas "por quem controla a organização", isto é, os próprios presidentes das organizações que saíram ilesos dos processos. Como que "traduzindo" para o espectador o significado das declarações de Black, o filme retoma cenas de desenhos animados e filmes antigos com pessoas nadando em dinheiro, construindo a sensação de impunidade dos CEOs.

Com a aproximação da nova eleição presidencial, que marcaria a posse do primeiro presidente negro dos Estados Unidos, Barack Obama, a narração alerta que os ricos estariam temerosos que seu "roubo à nação" terminasse. Novas cenas antigas, com pessoas roubando lojas, ilustram o que o Moore chama de "novo golpe dos ricos 
sobre os pobres". Parecendo uma síntese dos seus filmes anteriores, Moore também cita os atentados do 11 de setembro como um bom pretexto para que "os ricos" mantivessem sua influencia sobre "os pobres". Entre imagens antigas de pessoas apavoradas e multidões correndo nas ruas, Moore retoma a tese do medo sugerida em Fahrenheit 9/11. Segundo sua narração:

\section{Como o "11 de setembro" mostrou nada funciona mais no país dos valentes do que o velho medo.}

Para retomar sua "ideia" de que o medo ajuda a manter os estadunidenses longes dos problemas importantes, como a desregulamentação dos bancos, e os mantêm presos à antiga paranoia ${ }^{342}$, o filme faz uma breve montagem (ironizada por Moore como digna de ganhar um Oscar) de um discurso alarmante de George Bush ${ }^{343}$. Conforme o presidente "discursa" o fundo do cenário que remete ao interior da casa branca é "varrido" como que por um furacão. Dizeres como: crise financeira, queda na bolsa de valores, redução de aposentadorias, execuções de hipotecas, queda no valor dos imóveis, perda de empregos, entre outras coisas, ganham o tom humorado das construções de Moore, contudo remetem aos problemas tratados pelo filme Capitalismo: uma história de amor, bem como dialogam com todos os filmes tratados anteriormente pelo cineasta.

Em seguida, Moore "comprova" a legitimidade de suas construções com imagens das reportagens televisivas veiculadas em 15 de setembro de 2008, que geralmente entram nos seus filmes como sinalizadores que "orientam" a opinião pública e, portanto, o seu espectador. Ao som impactante da música "Mars" from the Planets orquestrada pela Royal Scottish National Orchestra, o filme apresenta uma cena curta de diferentes canais de TV anunciando os temores presentes no discurso de Bush.

Após um corte brusco na cena, Michael Moore e William Black retomam as medidas do governo que deram vazão à crise financeira - semelhante a uma rachadura em uma barragem, conforme a alegoria que usaram para explicar o descontrole do

\footnotetext{
${ }^{342}$ Tal como foi explorada no filme Tiros em Columbine com o desenho produzido pelos criadores de South Park para construir o antigo costume dos estadunidenses em portar armas devido o medo paranoico dos outros (negros, estrangeiros, criminosos, etc).

${ }^{343}$ Analisei os principais discursos à nação do presidente Bush em 2008 e 2009 e não encontrei nenhum discurso exatamente igual ao que o filme sugere, portanto, acredito que seja uma montagem. Os discursos oficiais de George W. Bush podem ser conferidos em: http://millercenter.org/president/speeches\#gwbush (acesso em 10 de julho de 2013).
} 
capitalismo representado nas instituições financeiras. Imagens e sons alternam as explicações de Black, a câmera aproxima e distancia o foco de imagens das pessoas que trabalham no mercado de ações, são vistos rostos preocupados, olhares pensativos, pessoas inquietas, outras visivelmente assustadas com as grandes perdas que se avolumaram nos mercados de ações naquele período. Na televisão, os repórteres anunciam as perdas dos principais grupos envolvidos: Chase, Bank of America, Citibank, Fannie Mae, Freddie Mac, Lehman Brothers, Merril Lynch, AIG - grandes instituições financeiras dos EUA. Algumas dessas empresas negociavam títulos do governo e pediram concordata, ou entraram em falência. Grandes corporações como a General Eletric, Boeing, American Express, são anunciadas com grandes quedas nas ações.

Contudo, conforme o filme indica, associando a bolsa de valores a um cassino, os mais ricos sofrem menos com os danos das flutuações de mercado global. Black também afirma que manipulações e fraudes, chamadas de "crimes do colarinho branco", também teriam sido cometidos e não foram investigados.

Embora Moore acredite que o capitalismo estaria "ruindo" sobre si mesmo, William Black afirma que muitos enriqueceram com a crise nos mercados de ações, sobretudo os presidentes dos grandes bancos. E as imagens apresentam nomes desses empresários e das instituições em que trabalham, para "comprovar" que, enquanto os pobres perdiam tudo, os ricos ainda lucravam. Grandes CEOs como: Vikran Pandit do Citigroup, Lloyd Blankfein da Goldman Sachs, Ken Lewis do Bank of America, são citados como os principais beneficiados com a crise, pois foram as instituições que concentraram as negociações do chamado subprime nos $\mathrm{EUA}^{344}$ e receberam o resgate posterior.

Assim, conforme as hipotecas não eram pagas, toda a cadeia de pagamentos nos investimentos internacionais também era atingida, criando uma onda de insolvência e falências, o que gerou quedas nas ações das principais bolsas de valores do mundo, uma espécie de efeito em cascata que "pôs em xeque" a capacidade de auto-regulação dos mercados - o que contraria o neoliberalismo. Conforme o filme construiu, desde Ronald

\footnotetext{
${ }^{344} C f$. BORÇA JR; TORRES FILHO. Analisando a Crise do Subprime. IN: Revista do BNDES, Rio de Janeiro, V 15, N. 30, p. 129-159, Dez, 2008.

<http://www.bndes.gov.br/SiteBNDES/export/sites/default/bndes_pt/Galerias/Arquivos/conhecimento/re vista/rev3005.pdf> (acesso em 10 de julho de 2013). Outros termos mencionados na Crise financeira de 2007-08 podem ser entendidos em: <http://g1.globo.com/Noticias/Economia_Negocios/0,,MUL7826349356,00VEJA+O+SIGNIFICADO+DOS+TERMOS+MENCIONADOS+NA+CRISE+DOS+EUA.html> ( acesso em 13 de julho de 2013).
} 
Reagan, de 1981 até 1988, o "touro" está solto, isto é, o Estado passou a intervir cada vez menos na economia.

De volta a sua entrevista, Black cita que membros do congresso, como por exemplo, os congressistas Rubin e Summers, foram trabalhar em instituições financeiras. $\mathrm{O}$ filme rapidamente corta para a narração de Michael Moore, apresentando a trajetória empresarial dos ex-congressistas de modo a "comprovar" as afirmações de Black. Embora William Black seja o especialista no tema das fraudes, sua participação limita-se a sinalizar os "causadores dos problemas", enquanto Moore não abre mão de narrar, a seu modo, a explicação mais ampla para o espectador, o que inclui a seleção de imagens de filmes antigos e fotos de corretores aturdidos com as quedas nos pregões de todo mundo.

Conforme o filme constrói, é possível perceber que algumas instituições entraram em concordata e outras foram "socorridas" pela maior intervenção do Estado que se viu nos últimos 30 anos, porém os CEOs dessas instituições não faliram como ocorreu com as pessoas pobres que tiveram hipotecas executadas, ao contrário, enriqueceram. Isso porque, tanto as manobras jurídicas, quanto o peso dessas instituições no cenário internacional, foram decisivas para mudanças inéditas no setor, como por exemplo, o auxílio do FED aos bancos de investimentos que não tinham direito à sua cobertura. Além disso, bancos comerciais também obtiveram o direito de mesclar suas transações financeiras com investimentos e seguros - algo que não ocorria antes, pois bancos comerciais (que recebem depósitos de pessoa física e jurídica) e bancos de investimento (que operam no mercado de ações e gerenciam investimentos) tinham funções definidas não podendo mesclar os negócios como as novas regras permitiram.

Moore narra ao espectador que o ex-secretário do tesouro, na gestão de Clinton entre 1995-1999, Robert Rubin saiu do Congresso para trabalhar como alto executivo do Citigroup e da Goldman Sachs (instituições diretamente envolvidas na crise porque concentravam investimentos no mercado imobiliário de subprimes). Rubin aparece na capa da revista Time juntamente com o "gênio" do mercado financeiro, Alan Greespan.

Moore cita algumas fusões, como a do Citigroup com o Travelers Group, criando o maior banco do mundo. Imagens do prédio do Citigroup, captadas no nível da calçada e subindo em direção ao topo do prédio, dão o tom de imponência da Instituição no mercado. Em seguida Black sugere a ideia, mas é Moore quem explica acerca do enriquecimento individual de Summers, outro ex-congressista que, de secretário do 
tesouro, se tornou consultor de investimentos oferecendo palestras por até US\$ 100 mil! Inclusive Moore cita que Summers ganhou muito dinheiro oferecendo consultoria para fundos de hedge, que são fundos de alto risco, isto é, fundos de caráter especulativo.

Tim Geithner, Secretário do Tesouro desde 2009, também é citado por Black por cometer erros de forma proposital, quando trabalhava no governo, para favorecer os empresários. Geithner deveria usar sua autoridade regulatória para proteger a economia, mas "sua atuação desastrosa" tornou os CEOs e seu grupo muito mais rico.

O que interessa ao espectador nessas construções é que, ao invés de protegerem a economia do país, essas pessoas davam os golpes de "colarinho branco", usando as informações privilegiadas que obtinham em seus cargos no Tesouro, e depois vendendo as informações nas instituições mais especulativas do mercado financeiro, o que gerou enriquecimento pessoal dos CEOs, em detrimento dos pequenos investidores e dos endividados que representam grande parcela da "classe média" estadunidense.

Moore constrói que essas pessoas estão no grupo dos ricos e exploram os pobres há várias décadas. Imagens do Capitólio, filmadas em diferentes períodos de um dia, são apresentadas de modo acelerado ao espectador, o que confere um sentido de passagem do tempo. Enquanto isso, a narração enfatiza que ali estariam os ricos com seus planos de explorar a nação. O modo "insolente" com que fariam isso seria através do pacote de auxílio a essas instituições; aprovado rapidamente pelo Tesouro americano no total de US\$ 700 bilhões para "sanear" o sistema financeiro, isto é, "para salvar os bancos" com dinheiro do povo.

Moore segue até o Capitólio para falar com alguns congressistas construídos como honestos, que nas entrevistas alegam que foram convencidos da necessidade de aprovar aquele pacote de mudanças cuja votação ocorreu às pressas em um final de semana, ou seja, grandes transformações, em tempo recorde, sem possibilidade de reflexão ou consulta pública. Moore constrói que aquelas decisões foram tomadas pelo mesmo grupo de ricos que prejudicou a nação.

O democrata Baron Hill fala com Moore sobre o caráter emergencial daquelas decisões, que o "pegou de surpresa" com "um resgate multimilionário das instituições financeiras". Outro democrata, Elijah Cummings, é entrevistado dizendo que os congressistas foram pressionados a votar em favor daquele resgate, pois, caso contrário, e economia entraria em colapso. A democrata Marcy Kaptur desconfia que aquelas mudanças em tempo de eleição, quando o congresso "fica mais nervoso", não eram normais. Essas três opiniões de membros do Partido Democrata, desconfiados da lisura 
daquele pacote em favor das instituições financeiras, formam o ponto de vista do filme e constroem negativamente a pressa do grupo dos ricos em aprovar aquele pacote, que salvaria suas instituições.

Em seguida o filme retoma o grupo dos ricos, mostrando membros do partido republicano com a administração de George Bush, responsabilizado pela pressa em transferir dinheiro do Tesouro em favor dos especuladores e suas instituições "falidas". O filme "comprova" suas assertivas mostrando fotos dos grandes investidores, o que sugere suas presenças na reunião que determinaria o valor retirado do governo para injetar liquidez nas corporações. Lloyd Blankfein, CEO da Goldman Sachs, está entre os investidores que receberam apoio do governo, representado na figura do Secretário do Tesouro Henry Paulson, que segundo Moore, também foi ex-presidente da Goldman Sachs.

Essas redes de relações entre empresários que têm acesso ao poder político, estruturam o grupo dos ricos contra o grupo dos pobres. O grupo dos pobres é formado em sua maioria pelos trabalhadores, que desejam o padrão de vida de "classe média", mas cujo acesso ao poder só é possível por meio do voto, justamente o que o filme busca valorizar como saída para esse grupo.

Para o filme, o departamento do tesouro seria "uma divisão da Wall Street", porque seus representantes também tinham interesses na Goldman Sachs, visto que eram ex-funcionários daquele banco. Em um fundo de tela preta, o filme coloca todos os nomes de funcionários da Goldman Sachs que estavam ou estiveram em cargos importantes no Tesouro, tanto na administração de Bill Clinton quanto na de George Bush. Moore narra novamente os nomes das instituições bancárias que especularam no mercado imobiliário e tiveram prejuízos cobertos pelo governo. As imagens apresentam as fachadas dessas empresas de modo a fixar para o espectador os nomes das instituições, seus principais CEOs, e suas respectivas ligações no governo. O filme se torna repetitivo no que se refere a essas instituições, como se tentasse convencer o espectador daquele grupo "em oposição" e suas responsabilidades diante da nação.

Alguns congressistas são apresentados protestando contra aquele pacote de medidas e seu resgate bilionário. Outros parecem com medo das mudanças preferindo aceitar aquele pacote de ajuda aos bancos como um "mal necessário". Em seu depoimento, a democrata Marcy Kaptur acredita que a proximidade das eleições ajudou a pressionar os congressistas pela aprovação das medidas, sobretudo com a velha arma da disseminação do medo, neste caso, medo de uma crise econômica generalizada. Em 
outro momento, o filme mostra a congressista protestando efusivamente contra aquelas decisões, tomadas sem discussão de comitês e sem consulta pública. Outro congressista também protesta contra o medo inflado na sociedade pelos especuladores de Wall Street. E mais um membro do Congresso também protesta, questionando porque o governo não auxiliou as famílias que perderam tudo com aquelas especulações promovidas pelos bancos e agencias de investimentos.

Todos os depoentes acima parecem unânimes em relação à aliança entre a Goldman Sachs e o governo dos EUA, e seus discursos de autoridade propõem uma tomada de posição por parte do espectador, que dificilmente ficará contra essa aliança entre bancos e governo, pois o filme a constrói como prejudicial ao grupo dos pobres.

O filme responsabiliza Bush mostrando o presidente discursando em favor do "resgate" das instituições financeiras, algumas das quais eram privadas e chegaram a ser estatizadas, como a Fannie Mae e Freddie Mac.

Moore enfatiza a pressão popular para o Congresso não aprovar o "pacote de medidas" que auxiliavam os bancos. Apesar do sucesso inicial da participação popular, lembrado pelo filme como um dos temores do memorando do Citigroup, o "resgate" foi aprovado com apoio de democratas e republicanos. Para Moore, o Congresso "traiu" o povo e aquelas medidas seria uma espécie de "golpe de estado financeiro". Todos os três democratas entrevistados concordam que a "democracia", isto é, o povo, não estava no poder dos EUA naquele momento.

Elisabeth Warren (Presidente do Comitê Congressual do Resgate) retorna ao filme para dizer que não sabe onde foi parar o dinheiro usado para o resgate, ou "socorro financeiro" dos bancos, até porque, conforme alegou, a política do Tesouro era não questionar os usos do dinheiro cedido aos bancos. O filme "responde" onde foi parar o dinheiro através de canais que noticiam as novas aquisições dos grupos financeiros, como um novo jato comprado pelo Citigroup, ou o bônus cedido pela Goldman Sachs, ou ainda as reuniões da maior seguradora dos EUA, AIG (American Interegional Group), em resorts de alto luxo. As cenas alternam entre o rosto confuso de Elisabeth Warren, que deveria saber onde foi usado o dinheiro emprestado, e a mídia anunciando alguns usos possíveis do que mais pareceu um "prêmio" para aquelas instituições. Warren diz que Moore deveria perguntar para o secretário Paulson onde foi parar o dinheiro, e o som de uma ligação mostra que foi isso que o cineasta, sem sucesso, fez. 
As sequências apresentam uma espécie de dramatização cômica, para encenar a tentativa de Moore em pegar aquele dinheiro de volta. Em um antigo caminhão blindado, também conhecido como "carro-forte", o cineasta se dirige para as instituições que obtiveram o resgate do governo e pede que devolvam o dinheiro do povo americano. Novamente o filme enfatiza os nomes das empresas filmando as fachadas de seus edifícios: Goldman Sachs, Citigroup, Morgan Stanley, AIG.

Moore ironiza, oferecendo sacolas marcadas com um sinal de cifrão (\$) para colocarem o dinheiro. As encenações deixam os seguranças das empresas em alerta para deter Moore antes que entre nos prédios. Até um policial aparece em cena para barrar Moore e não consegue conter o riso diante do cineasta, que já se tornou uma figura pública nos EUA. A música jazz de Louis Prima anima as sequências em que Moore "tenta" pegar o dinheiro de volta e confere um tom de comédia as cenas, pois parece que não levam mais o cineasta a sério, alguns porteiros parecem representar um papel junto ao do cineasta na sua tentativa de invadir um prédio e ser contido. Após esta imagem a encenação com tons de comicidade termina.

As sequências que encaminham o filme para o final retomam o depoimento do amigo de Moore, o ator Wally Shawn, dizendo que é possível que o povo se rebele contra os ricos e seus "jogos de azar" que prejudicaram os mais pobres. Independente de essa ideia corresponder a alguma "realidade", ela propõe um posicionamento para o espectador do filme. Em seguida, o filme corta a imagem para alguns protestos populares em frente às principais instituições financeiras envolvidas. Entre palavras de protesto e cartazes diversos, as pessoas pedem que os trabalhadores também sejam "resgatados" de suas falências pessoais.

Apesar das tomadas fechadas deixarem transparecer que a "multidão" dos descontentes não era tão grande, Moore afirma que "era incomum ver americanos se voltando contra os ricos", pois a crença de que todos seriam ricos parecia forte entre o povo.

As cenas seguintes parecem apostar na esperança de que Barack Obama represente a mudança para aquele cenário de crise. Imagens da corrida eleitoral mostram um grande público optando, não apenas pelo primeiro presidente negro em um país de histórico racista, mas também pela saída dos republicanos e seu grupo do poder - o que mostra o ponto de vista deste e de todos os filmes de Moore: libelos contra os republicanos dos EUA.

Com uma multidão à sua volta Obama diz: 
Estamos prontos para levar o país em uma direção fundamentalmente diferente.

\section{É o que está acontecendo com os Estados Unidos agora.}

A mudança está acontecendo nos Estados Unidos.

Em seguida em tom de exclamação Michael Moore diz que não era isso o que Wall Street queria. E ainda arremata: "E se ele ganhar? O que aconteceria com seu estilo de vida?" O filme construiu os empresários do mercado de ações como responsáveis pela crise financeira e pelas consequências desastrosas para os trabalhadores. Se Obama tinha "intenção" de representar a mudança, o filme propõe que poderia ser cooptado por Wall Street através de inúmeras doações recebidas de corporações, como a Goldman Sachs, Citigroup, JP Morgan Chase, entre outros.

Em um momento de conversa com eleitores, Obama diz:

Se a economia é boa para as pessoas de baixo para cima, pode ser boa para todos. Acho que espalhar a riqueza é bom para todos.

Imediatamente o filme corta cena para os principais adversários de Obama naquele pleito, os republicanos: Senador John McCain e a ex-governadora do Alaska Sarah Palin. Ambos sugerem que as propostas de Obama significam "socialismo" - uma palavra temida nos EUA desde os tempos de Guerra-Fria.

Diante de uma breve cena do Exército Vermelho nos tempos de Rússia Comunista, com os acenos de Stálin e desfiles civis ovacionando seus líderes, o filme inclui a fala de eleitores que "demonstram" o temor de estadunidense e sua visão de sociedade socialista. Também ocorrem cortes para cenas do líder comunista chinês Mao Tsé-Tung. Até o ex-governador da Califórnia, o ator Arnold Schwarzenegger aparece em imagem declarando que saiu da Europa "porque o socialismo destruiu oportunidades lá”. Apesar dessas declarações que sugerem o medo de alguns eleitores em relação ao que consideram socialismo, o filme aponta que aquelas declarações não surtiram efeito e Obama subiu nas pesquisas.

Na tentativa de "desmistificar" o medo que o termo socialismo parece causar nas pessoas, o filme aponta para um Senador socialista no país: Bernard Sanders do Partido Independente. E o próprio Moore "desvaloriza-o" dizendo que se tratava de uma pessoa do "estado gay de Vermont", o que indica mais um "medo" ou preconceito a ser 
desmistificado. Com a câmera atrás de Moore, focalizando o entrevistado, Bernie Sanders afirma que ser "socialista democrata" nos EUA significa crer "que a função do governo é representar os trabalhadores e a classe média em vez de só os ricos e poderosos. Uma coisa que fizemos aqui foi ficarmos religiosos na idolatria da ganância”. Em seguida, um corte na imagem tomada à direita e atrás de Sanders, focaliza Moore concordando com Sanders que diz:

“colocamos nas capas de revistas gente que ganhou bilhões de dólares. Ignoramos os policiais, bombeiros, professores, enfermeiras que todos os dias fazem tanto em melhorar as vidas das pessoas. Temos que mudar nossos sistemas de valores”.

A fala de Sanders sugere que "ter dinheiro" é estimulado e valorizado culturalmente, o que vai de encontro à fala de Jimmy Carter, no início do filme, na qual este alertava que as pessoas não valorizavam mais "ser", e sim “ter".

O filme não somente valoriza as opiniões que são dadas acerca do tema construído, como também o foco da câmera nas expressões faciais de Michael Moore, isto é, se o cineasta concorda ou não com aquelas assertivas, reforçando sua imagem de formador de opinião.

Em seguida, ao mostrar gráficos de pesquisas de opinião acerca do capitalismo e do socialismo, a narração sinaliza que as novas gerações não temiam o socialismo como as anteriores.

Outro corte e a cena começa com letras no canto direito da tela, indicando local e data de onde era feita a tomada do que seria um registro histórico: Detroit, Michigan, 10:59, 11:00. Era noite de apuração dos votos da eleição presidencial, em 04 de novembro de 2008, uma mulher negra está sentada em um chão acarpetado, em um local fechado, acompanhada de outras pessoas também negras. Ela falava da economia e se declarava investidora no mercado de ações, algo comum mesmo entre os estadunidenses não ricos, antes que terminasse sua declaração, uma voz surge do fundo daquele "salão" anunciando a histórica vitória de Barack Obama.

Enquanto a câmera focaliza as reações da mulher, uma música orquestrada e lenta acompanha suas emoções antes da imagem expandir para as demais pessoas que comemoram a decisão oficial do pleito. Entre rostos alegres e outros que choram, Moore enfatiza que aquele resultado não parecia possível dois anos atrás e que naquele momento "o país estava eletrificado por sua vitória”. As imagens percorrem ruas onde 
as pessoas vibram com aquela vitória, são vistos principalmente pessoas negras e de feições latinas, o que pode significar que as minorias do país se sentiam representadas por aquele novo presidente.

Construindo e incentivando tomadas de posição para o espectador, o filme aponta pessoas que decidiram "violar a lei" e protestar, como o Xerife de Detroit, Warren Evans, que resolveu impedir as execuções de hipotecas no Condado de Wayne por entender que "o livre mercado" traiu o país. O filme mostra o xerife discursando contra os bancos, Moore narra que se tratava de ato de "subversão" de uma lei, isto é, se o defensor da lei poderia entender a injustiça, o espectador estaria autorizado a "subverter-se" também. Em seguida, Moore entrevista o xerife acerca do "mercado livre".

Acha que o mercado livre traiu Detroit? (Pergunta Moore).

Acho que o mercado livre traiu o país. (Responde o xerife).

A imagem corta para uma bandeira estadunidense tremulando com as pontas de seu tecido em farrapos, o que pode remeter ao estado das pessoas mais pobres, nas margens do tecido social, que não resistem aos imperativos do "mercado livre". Enquanto o xerife fala que "o livre mercado traiu o país", a câmera passeia por bairros "destruídos devido às execuções de hipotecas", janelas velhas com vidros quebrados remetem ao abandono e prédios inteiros vazios sugerem uma grave recessão econômica. Isso porque, como o filme constrói, o "mercado livre" teria retirado o capital produtivo do país com a globalização econômica.

A globalização dos mercados remete a discussão de Bauman acerca da globalização e suas consequências. Para o autor abriu-se uma divisão entre Estado e economia, pois devido à compressão tempo/espaço, o capital se movimentou com velocidade de modo que o Estado não podia mais controlar suas riquezas. Parece ser esse "descontrole das riquezas" do país que o filme de Moore construiu. Na abertura do filme ocorre uma comparação entre os Estados Unidos e o Império Romano, sobretudo no período de decadência, porém a comparação com um Império remete a tempos que o país tinha adquirido bens e riqueza, como sugerem os anos pós-guerra. Contudo, após o "Touro ser solto" nos anos Reagan com a promoção do "livre mercado", os capitais foram saindo do país e cidades como Detroit e Flint, e tantas outras citadas nos filmes de Moore, ganharam notoriedade devido à decadência econômica. 
Sinalizando a fuga das riquezas de um país, diria Bauman que,

"A economia" - o capital, que significa dinheiro e outros recursos necessários para fazer as coisas, para fazer mais dinheiro e mais coisas - move-se rápido; rápido o bastante para se manter permanentemente um passo adiante de qualquer Estado (territorial, como sempre) que possa conter e redirecionar suas viagens. Neste caso, pelo menos, a redução do tempo de viagem a zero produz uma nova qualidade: uma total aniquilação das restrições espaciais, ou melhor, a total "superação da gravidade". O que quer que se mova a uma velocidade aproximada à do sinal eletrônico é praticamente livre de restrições relacionadas ao território de onde partiu, ao qual se dirige ou que $\operatorname{atravessa}^{345}$.

Nesse sentido, o filme Capitalismo: uma história de amor sugere que um país rico como os Estados Unidos estaria sujeito à decadência econômica e social, devido a regras de "livre mercado" que sua ideologia incentivou, porém que não pôde controlar. Assim que outros mercados se tornaram competitivos, como as indústrias internacionais de automóveis citadas no filme, cidade inteiras como Detroit, e a própria economia estadunidense, sentiram o impacto da competitividade dos mercados internacionais.

Segundo Michael Mann, "o neoliberalismo tende a favorecer os ricos. Os programas de ajuste estrutural aumentam o desemprego e ampliam a distância entre ricos e pobres nos países mais pobres" 346 . O autor também concorda que "os programas adotados nas décadas de 1980 e 1990 ampliaram a desigualdade na maior parte do continente" ${ }^{, 347}$. Nessa direção, o que o filme de Moore reforça é que as consequências econômicas do neoliberalismo, comumente vistas em países pobres, também atingiram os EUA.

Inclusive nas cenas finais de Capitalismo: uma história de amor o xerife Warren compara algumas cidades estadunidenses com outras do "terceiro mundo", talvez no sentido de que os EUA passavam por um processo de aprofundamento da desigualdade social e o arrefecimento da crença no self made man, devido à falta de oportunidades.

\footnotetext{
${ }^{345}$ BAUMAN, Z. Globalização: as consequências humanas. Rio de Janeiro: Jorge Zahar Ed., 1999, p. 63. ${ }^{346}$ MANN, Michael. O império da incoerência. Rio de Janeiro: Record, 2006, p. 91.

${ }^{347}$ MANN, Michael. O império da incoerência, op. cit., p. 91.
} 
A sugestão do xerife Warren Evans de que "só nos resta fazer uma revolução" é construída pelo filme com atitudes "em locais improváveis", como Miami na Flórida (um estado de histórico político alinhado ao partido republicano). Naquele Estado, Moore narra e apresenta imagens do caso da família Trody, composta de um casal e três crianças pequenas que, após terem sido despejados da casa que era deles há 22 anos, foram "morar" na traseira de um caminhão. A vizinhança do casal despejado, formada em sua maioria por pessoas negras e pobres, assim como os Trody, se une para fazer a devolução da casa para aquela família. Em um ato de protesto, o grupo que se nomeia como "famílias de baixa renda lutando juntas" recebe apoio de algumas emissoras de TV e do próprio Michael Moore para devolverem a casa da família Trody. A comunidade ajuda o casal a retomar posse da casa tirando a placa do banco com o anúncio de vende-se e colocando os poucos pertences de volta para seu interior.

O filme mostra a reação do banco que envia um representante para lembrá-los que aquele ato era ilegal. Uma breve discussão entre alguns moradores, indignados com a desvalorização de todas as casas do bairro, e o representante do banco, defendendo a oportunidade de revender a casa para outras pessoas, marca o tempo de espera pela chegada das nove viaturas policiais. Os ânimos se exaltam, as pessoas discutem e Moore analisa aquilo como um momento de resistência. Dois adolescentes também afirmam que moravam no caminhão e que não tinham para onde ir, outras pessoas protestam enquanto a câmera filma o rosto do representante do banco, como se pudesse captar em algum instante empatia ou sentimento de injustiça por parte daquele homem, que também se insere no grupo que vinha lucrando com a crise das hipotecas.

A câmera filma os policiais conversando com o representante do banco, enquanto as pessoas ainda resistem cantando músicas que celebram suas raízes naquele local. Em seguida, tanto o representante do banco quanto os policiais vão embora, sinalizando que aquelas pessoas poderiam, pelo menos por algum período, ficar com a casa. A comunidade vibra com aquela vitória inicial, e a cena imediatamente corta para imagem gravada no Congresso com a democrata Marcy Kaptur incentivando o mesmo tipo de resistência das cenas anteriores a outros moradores de todo o país. Kaptur diz para as pessoas que não saiam de suas casas, e se saírem que as invadam novamente, porque Wall Street não tinha os documentos comprobatórios das hipotecas. Moore se impressiona com um membro do congresso incentivando a rebelião. Enquanto isso, o filme mostra mais pessoas desalojadas com suas coisas espalhadas na rua, assim como foi visto em Roger e Eu com os despejos em Flint. 
A cena com a democrata, uma representante eleita e, portanto, uma autoridade legal, sinaliza a legitimação daquilo que o filme construiu como uma sucessão de crimes do "colarinho branco", devido a transações financeiras complicadas baseadas em equações que nem os especialistas de Harvard conseguiam explicar. Nesse esquema lucrativo uma parcela expressiva de pessoas pobres, construídas como "baixa renda" e outros membros da "classe média", sucumbiu diante de sucessivos aumentos dos juros que regulavam os acordos hipotecários, como a família de Peoria em Illinois.

O caso dos trabalhadores da Republic Windows \& Doors é retomado como outro "exemplo" de resistência, e o modo como um segmento da mídia apoiou o grupo, ressaltando que o cidadão estadunidense estaria pagando o resgate aos bancos, reforça o que o filme construiu desde o princípio com a ideia de ladrões. Assim, os bancos configuram no filme como um grupo de ladrões que roubam as riquezas da nação, ou uma parte do dinheiro do contribuinte que estava no Federal Reserv.

E a pergunta de uma das funcionárias da fábrica de portas e janelas, criticando o Bank of America, pode promover a reflexão do espectador do filme. Ela diz:

“Para que fazer um resgate se não há empregos?”

Diante dessa pergunta, cuja resposta não parece difícil ao espectador, o filme retoma cenas da Republic Windows \& Doors para, através da fala do Bispo James Wilkowski, reforçar a saída para o que foi construído como negativo no sistema capitalista e nos rumos que a economia de livre mercado se encontrava. O incentivo principal do bispo foi:

\section{... é justo desafiar o que é injusto.}

E a cena seguinte aposta na esperança democrata, com Barack Obama defendendo os trabalhadores da fábrica de portas e janelas, além de confirmar que aquilo que eles estavam passando era um reflexo do que ocorria com a economia em todo o país. Outros políticos e cidadãos apoiavam a causa da fábrica, que foi tida pela mídia como "exemplo de resistência" aos problemas na economia do país. Após seis dias de ocupação, o grupo recebeu seus direitos trabalhistas que estavam retidos pelo Bank of America com o fechamento da fábrica. 
Para Michael Moore aquilo poderia ser o começo de uma revolta de trabalhadores contra Wall Street. Imagens buscam confirmar que pequenos grupos de protesto se espalhavam pelo país. Os discursos em prol da luta dos trabalhadores, diante da crise financeira de 2008, promovem um momento de aparente nostalgia em Michael Moore, pois o cineasta retoma imagens antigas para lembrar momentos da primeira fábrica da GM em Flint, onde seu tio Laverne, que aparece em foto no filme Roger e Eu, e outros trabalhadores, resistiram e lutaram por direitos trabalhistas em uma histórica greve promovida pelos montadores de automóveis em 1936. Aquela ocupação, que durou 44 dias, foi reprimida pela polícia local, porém contou com apoio da guarda nacional e do presidente Roosevelt. Moore também diz que aquela greve organizada pelo sindicato venceu, pela primeira vez, uma grande corporação, e atribui a construção da "classe média" estadunidense às conquistas daquele grupo.

Partindo de um discurso do ex-presidente Franklin D. Roosevelt, o filme deixa sua principal mensagem ao espectador, um país ideal, em que os trabalhadores possuem direitos e onde o sonho americano é possível. As imagens de famílias, atentas ao redor do rádio para ouvir o discurso anual do presidente, e milhares de pessoas nas ruas na ocasião de sua morte, pouco antes do fim da $2^{a}$ guerra em 1945, constrói a popularidade daquele presidente democrata.

Em seu discurso, Roosevelt propõe uma nova convenção de Direitos para a Constituição em que segurança e prosperidade fossem um direito estendido a todos, independente de raça, credo, ou condição social. De modo geral, entre os ideais de Roosevelt são citados: emprego e renda justa para prover uma "vida decente" aos trabalhadores rurais e urbanos, moradia, atendimento médico, saúde, educação e seguridade social. Direitos para que "os homens de negócios" negociem "livres da concorrência desleal e do domínio por monopólios domésticos ou estrangeiros".

Esses ideais do governo Roosevelt são os mesmos que o filme propõe ao espectador, a possibilidade de viver o american dream, um sonho de liberdade e prosperidade, conseguida através da garantia de oportunidades para todos os trabalhadores.

Michael Moore lamenta que aqueles direitos não entraram em vigor, e com as imagens antigas das pessoas chorando no funeral do presidente Roosevelt o cineasta cita novamente os direitos ao trabalho, salário, saúde, educação, moradia e seguridade social, que também são temas das discussões de seus filmes. Moore compara de modo 
generalizado que "o povo da Europa" e do "Japão" conseguiu esses direitos com auxílio financeiro de membros do governo Roosevelt, para a reconstrução após a $2^{\mathrm{a}}$ Guerra.

Por fim, o cineasta retoma imagens da cidade de New Orleans, após a passagem do furacão Katrina, para exemplificar como as pessoas mais pobres do país eram tratadas pelo governo, lembrando novamente os nomes de bancos e seus dirigentes que tinham sido beneficiados com resgate financeiro.

Uma tela negra e a declaração de que "Eu me recuso a viver num país assim" marcam o posicionamento de Michael Moore no fim do filme. Ele segue para Wall Street a fim de fazer uma prisão "simbólica" dos bancos e seus CEOs, estendendo, em volta dos prédios das corporações, uma faixa utilizada pela polícia em "cena de crime". Isso encerra a construção fílmica de que aquele grupo dos ricos promoveu um grande "roubo ao país". Alguns símbolos financeiros de Wall Street são delimitados como cena de crime: JP Morgan \& Chase Co, Citibank, Merryl Linch, entre outros nomes. Essas instituições financeiras foram utilizadas para caracterizar o capitalismo como um "mal que não pode ser regulado" e "precisa ser eliminado". Em seu discurso final Moore diz:

Vivemos no país mais rico do mundo. Todos merecemos um emprego decente, assistência de saúde, boa educação e uma casa para morar. Todos merecemos o sonho de FDR. É um crime que não tenhamos, e nunca vamos ter se continuarmos um sistema que enriquece alguns à custa da maioria. O capitalismo é um mal, e não se pode regulamentar o mal. Você tem que eliminá-lo e substituí-lo por algo que seja para o bem de todos. Isso se chama democracia.

Enquanto Moore termina de cercar a "cena do crime", as imagens sugerem a chegada da polícia, mais pelo incômodo que ele causava no local do que para auxiliá-lo em sua prisão. $\mathrm{O}$ cineasta termina o filme diante de um prédio com uma bandeira estadunidense gigante e declara que, como cidadão, tinha o direito de prender as pessoas que trabalhavam naquele prédio - que pelas imagens parece ser a Bolsa de Valores de Nova Iorque. Novamente com a tela preta Moore declara que não poderia mais fazer aquilo sozinho e pede a todos os espectadores do filme que se unam a ele.

Embora tenha construído em todo o filme que a saída para os problemas decorrentes do capitalismo se concentram no termo "democracia", e o poder de voto, além de não ter citado nenhum "ismo" como "comunismo" ou "socialismo" em 
contraposição ao "capitalismo", o filme termina com duas músicas diferentes que, embora possam ser lidas como críticas ao capitalismo seguem caminhos paralelos.

A primeira música L'Internationale ${ }^{348}$, conhecida como um hino comunista, é apresentada em sua versão inglesa navoz de Tony Babino, sendo esta a versão mais americanizada da letra. Muitas das outras versões são cantadas em coro, o que reforça seu sentido de grupo, e na versão de Babino, além de ser um canto individual, tem como arranjo musical o jazz estadunidense, o que a descaracteriza do seu "sentido socialista". Acredito que o filme utiliza esta música não para propor o regime socialista aos estadunidenses, mas para sugerir a união dos trabalhadores e sua organização em sindicatos, ideia recorrente nos filmes de Moore.

A segunda música, "Jesus Christ" de Merle Haggard ${ }^{349}$, também pode ser lida como uma crítica ao capitalismo, representado na figura dos ricos, pois a letra recomenda em diferentes situações que os ricos distribuam suas riquezas entre os

\footnotetext{
${ }^{348}$ No filme entra a música The Internationale na versão inglesa conforme a letra abaixo: Arise you starvelings from yours slumbers! Arise you prisoners of want! For reason in revolt now thunders. And a better age shall dawn. Now away with all your superstitions. Servile masses arise! arise! We'll change forthwith the old conditions. And spurn the dust to win the prize. Then come comrades rally! And the last fight let us face. The Internationale unites the human race! Then come comrades rally! And the last fight let us face. The Internationale unites the human race! No saviors from on high deliver. No trust we have in prince or peer; Our own right hand the chains must shiver. Chains of hatred, greed and fear. Ere the thieves will out with their booty

And to all give a happier lot. Each at his forge must do his duty. And strike the iron while it's hot! Then come comrades rally! And the last fight let us face. The Internationale unites the human race! No more deluded by reaction. On tyrants only we'll make war! The soldiers too will take strike action, They'll break ranks and fight no more! And if those cannibals keep trying. To sacrifice us to their pride. They soon shall hear the bullets flying. We'll shoot the generals on our own side. So comrades, come rally. And the last fight let us face. The Internationale, Unites the human race. So comrades, come rally, And the last fight let us face. The Internationale, Unites the human race.

Fonte: http://www.antiwarsongs.org/canzone.php?lang=en\&id=2003\&infos=1. (internationale em 98 idiomas). (Acesso em 19 de julho de 2013).

${ }^{349}$ Conforme a letra original:

Jesus Christ was a man that traveled through the land. A carpenter true and brave He said to the rich give your goods to the poor. And they laid Jesus Christ in the grave He went to the sick and he went to the poor. And he went to the hungry and the lame And he said that the meek would inherit the whole world. And they laid Jesus Christ in the grave. One day Jesus stopped at a rich man's door. What must I do to be saved.

Take all you own and give it to the poor. And they laid Jesus Christ in the grave.

When the love of the poor shall one day turn to hate. When the patience of the workers give away.

Would be better for the rich if they never been born. So they laid Jesus Christ in the grave.

When Jesus came to town all the working folks around. Believed what he did say.

But bankers and preachers nailed him to the cross. And they laid Jesus Christ in the grave.

Well the people held their breath when they heard about his death. And everybody wondered why. Was the landlord and soldiers lawmen there had hired. That nailed Jesus Christ in the sky. We would lay Jesus Christ in the grave Lord. We would lay Jesus Christ in the grave. And if Jesus preached today like he preached in Galilee. We would lay Jesus Christ in his grave. Fonte: http://letras.mus.br/merle-haggard/1841134/traducao.html. (Acesso em 20 de julho de 2013).
} 
pobres. Outra alusão possível é que esta música coloca Jesus ao lado do grupo dos pobres enquanto os ricos o crucificaram.

Ambas as músicas que embalam os créditos do filme, falam contra os ricos e poderosos. Enquanto a primeira música convoca os trabalhadores para saírem das superstições e se unirem em prol de uma revolução da Internacional (socialista), a segunda música remete aos ensinamentos de Jesus, valorizando os pobres e repreendendo a "ganância dos ricos". Assim, antes de unir os dois discursos, o filme pode indicar valores encontrados nesses dois caminhos e sugerir alternativas aos "males do capitalismo”. As duas músicas, uma socialista e outra cristã, unidas no final do filme, podem sugerir duas frentes de ataque contra o capitalismo financeiro.

\section{Conclusão}

Nas cenas iniciais de Capitalismo: uma história de amor um pequeno filme dentro do filme compara a decadência do Império Romano com a dos EUA. Essa ideia de decadência permeia boa parte do filme, principalmente nas cenas que constroem, a partir do governo de Reagan, a emergência de um grupo de ricos que toma importantes posições de poder no Congresso e as mantêm por décadas. Esse grupo de ricos é formado por empresários e políticos que associados em torno de interesses comuns (enriquecimento pessoal) governam acima da lei ou por "decreto", como foram a ações do governo de George Bush e seu "pacote de resgate" aos bancos. A predominância dos interesses desse grupo dos ricos e suas ações, que resultam na desregulamentação da economia ou a "soltura do touro", com Reagan, sinalizam a decadência do império econômico estadunidense cujo sistema, antes do neoliberalismo, formou o desejado padrão de vida "classe média".

Em contraposição aos ricos, o filme constrói um grande grupo de "pobres", que engloba tanto os mais depauperados pelo sistema, como os vistos na condição de semteto, os desempregados e os subempregados, até os membros da "classe média" em dificuldades de manter o padrão de vida, considerado como básico entre os trabalhadores que há décadas acreditavam, no então ameaçado, american way of life.

Para reforçar suas construções, o filme estrutura a narrativa não apenas no discurso de autoridade das pessoas entrevistadas, (autoridades democratas, especialistas em mercado, advogados, e "vítimas" do capitalismo), mas também em um confronto de 
imagens que buscam "comprovar" visualmente as assertivas do seu diretor. Assim, tudo o que é dito pelo diretor é imediatamente "comprovado" com imagens de documentos, de noticiários, de vídeos de época e até mesmo em pequenas construções que utilizam filmes antigos e seriados. Todas as cenas contam com acompanhamento musical, de modo a construir e reforçar sentidos de tristeza, de comicidade e da própria ironia de Moore, que diz uma coisa quando quer dizer outra.

Embora sinalize que, se não mudarem os rumos do capitalismo financeiro o país pode encontrar a mesma decadência do seu antecessor antigo, Capitalismo: uma história de amor não aponta para a decadência como um fim definitivo aos EUA, pois também sinaliza saídas construídas a partir de modelos de resistência:

1 - os trabalhadores que resistem as demissões sem receber os direitos trabalhistas na Republic Windows \& Doors.

2 - os moradores que tiveram hipotecas executadas e invadiram suas próprias casas.

3 - os empresários que preferem o regime de cooperativa, propiciando participação de lucros entre todos os empregados, ao invés de concentrarem os lucros entre os membros da diretoria.

4 - o poder do voto e da pressão popular nas ações e decisões de membros do Congresso, Senado e do governo em geral, num esforço de que a democracia sobrepuja as influências do capitalismo.

5 - a união e organização dos trabalhadores em sindicatos de classe.

6 - a regulamentação dos bancos e do mercado financeiro.

7 - a taxação dos mais ricos e o Estado como regulador da economia, promovendo equidade social e igualdade de oportunidades.

8 - A implementação da II Declaração de Direitos idealizadas no governo Roosevelt.

9 - O fortalecimento da democracia em relação às influências do capitalismo.

Nesta direção, o filme não se coloca contra o sistema capitalista, nem sugere a saída pelo socialismo, porém se coloca contra os rumos do capitalismo financeiro com as desregulamentações da economia e da política neoliberal que dificulta qualquer ação em prol de equidade social. 
O filme de Moore propõe a busca pelo fim das desigualdades sociais, e uma vida mais digna aos trabalhadores. Também propõe que o Estado volte, como nos tempos de Roosevelt, à regulação da economia, pois não acredita na auto regulação dos mercados, o que historicamente favorece as grandes corporações em detrimento das pequenas indústrias, essas últimas construídas como fontes de emprego e renda para cidades como Flint.

Assim, Capitalismo: uma história de amor construiu o neoliberalismo na economia americana, iniciada com Reagan em 1981, como uma atividade de grupos de pessoas que puderam associar dinheiro e poder político em favor próprio. Para isso, o filme aponta nomes, rostos e documentos comprobatórios que revelam esquemas e facilitações que mantiveram esse grupo de pessoas cada vez mais ricas por cerca de 3 décadas, enquanto os trabalhadores iam sendo pauperizados - o que reduziu a "classe média”, construída como a classe social símbolo dos EUA desde os anos dourados.

A proposta geral do filme é a união e luta dos trabalhadores em prol da reconstrução dos ideais de classe média, através da democracia ou participação popular nas decisões comuns, isto é, para o bem geral de um Estado social idealizado no New Deal escrito pelo ex-presidente Franklin D. Roosevelt. 


\section{II - A industrialização da guerra como fenômeno social: o lado sombrio da modernidade.}

\section{4-Tiros em Columbine: paixão e morte por armas de fogo.}

"A árvore da liberdade deve ser refrescada de tempos em tempos com o sangue de patriotas e tiranos" Thomas Jefferson. ${ }^{350}$

A primeira cena de Tiros em Columbine apresenta diversos personagens que retornarão nas sequências posteriores, como se uma síntese visual da história fosse colocada desde o início do documentário. Sem oferecer alguma informação prévia acerca do que construirá como "realidade", em torno dos atentados ocorridos em uma escola secundária dos EUA, uma imagem em preto e branco apresenta uma das "faces" do problema que será configurado pelo filme: o grupo favorável ao livre porte de armas e de munição, pessoalizado na figura do ator Charlton Heston - presidente da Associação Nacional do Rifle (ANR) à época de Tiros em Columbine.

A aparição de Heston, elogiando o filme que se inicia (o próprio filme Tiros em Columbine conforme a montagem estabelece), sugere, não sem ironia ${ }^{351}$, que muitas das

\footnotetext{
${ }^{350}$ Dizeres na camiseta vestida por Thimoty McVeigh no dia que foi preso após explodir grande parte de um prédio federal em Oklahoma. In: GALVÂO, Walnice Nogueira. Sombras \& sons: recortes sobre cinema e música contemporânea. São Paulo: Lazuli Editora: Companhia Editora Nacional, 2010, p. 121125.

${ }^{351}$ Acerca do conceito de ironia, o trabalho de Vladimir Jankélévitch "L’ironie ou La Bonne conscience" é seminal ao oferecer um panorama do conceito nos primórdios da filosofia grega e também na literatura romântica, especialmente com a poesia alemã. De modo geral, na vertente grega, ironia significa interrogação, auxiliando no conhecimento como estabelecido pela ironia socrática.Cf: JANKÉLÉVITCH, Vladimir. L'ironie ou La Bonne Conscience. Paris: Presses Universitaires de France. 1950. A meu ver, o tratamento empenhado por Jankélévitch está mais ligado às questões filosóficas que envolvem a ironia socrática e a romântica (como, por exemplo, Kant, Schlegel e Novalis) com as inquietações do indivíduo acerca da vida, das ciências e da possibilidade de conhecimento dos mesmos. Em outra direção, mais aproximada da minha leitura em relação ao objeto de pesquisa, a acepção de ironia que utilizo neste trabalho está mais ligada a um significado que diferencia aquilo que se diz do se quer significar, como um jogo de palavras. Neste sentido, utilizo o trabalho, já citado na análise do filme Roger e Eu, de Linda Hutcheon, "Teoria e política da ironia" (2000), pois além da atualidade dos inúmeros exemplos que a autora utiliza, retirados das artes visuais como o cinema, os usos do conceito referem-se não a ironia socrática ou romântica, e sim a ironia como prática e estratégia discursiva, como a ironia verbal e
} 
cenas desagradáveis que virão nas sequências são de responsabilidade, pelo menos em parte, dos membros desta antiga associação.

De aparência jovem, com tom de voz otimista, e vestido em trajes militares, Heston afirma:

“Com certeza você achará muito interessante. Daremos uma olhada.”

Antes de considerar as imagens iniciais de Tiros em Columbine, vale lembrar sua importância como portadoras de significados que comumente são desconhecidos do público, e que podem oferecer pistas sobre a narrativa fílmica. Nesse sentido, Menezes aponta que:

É quase uma tradição, tratando-se de cinema, que as primeiras imagens que nos são mostradas em um filme sejam as de uma série de letreiros onde o nome dos atores, do diretor e do produtor sejam-nos dados a conhecer. Em alguns filmes, entretanto, o diretor aproveita este espaço para também introduzir-nos a alguma outra coisa, que não raras vezes passa despercebida do público ${ }^{352}$.

No filme documental também é possível seguir esta linha de raciocínio. As cenas iniciais de Tiros em Columbine poderiam ser consideradas como imagens aleatórias que propõem a sensaçãode mais um dia tranquilo nos EUA, como aponta a narração irônica. Antes, essas imagens são lidas aqui como uma tentativa de relacionar pessoas aparentemente desconexas, mas que, contudo, vivenciaram experiências promovidas por um meio comum (armas de fogo) e, por este motivo, estariam conectadas a uma ampla ordem de coisas que o filme tentará delinear como a cultura do medo e, em consequência, a busca por proteção através de armas de fogo.

Belas imagens do início de mais um dia nos Estados Unidos, com o nascer do sol em céu aberto, visto com a câmera posicionada ao nível do espelho d'água, mostrando o obelisco, construído como um memorial a George Washington, e parte do conjunto de prédios do Capitólio - sede do Congresso. Uma música, aparentemente estrutural do discurso que ocorrem num contexto denominado de "cena", o que, por sua vez, é social e político. Cf: HUTCHEON, Linda. Teoria e política da ironia.Belo Horizonte: Ed. UFMG, 2000.

${ }^{352}$ MENEZES, Paulo. À meia luz: cinema e sexualidade nos anos 70. São Paulo: Editora 34, 2001, p. 15. 
antiga, embala a narrativa de Moore quando ele situa o espectador no dia 20 de abril de 1999, sem informar que nesse dia ocorreu o ataque de jovens armados contra seus colegas na escola Columbine. Em seguida, a partir do que parece ser um sobrevoo que, a julgar pela velocidade baixa talvez seja de um helicóptero ou de um avião de pequeno porte, é vista uma cidade aparentemente típica do interior do país com casas térreas e uma igreja puritana, que orientou as origens de muitos valores daquela nação. A mesma sequência corta a imagem para um campo onde um fazendeiro dirige seu trator em um dia de trabalho. O filme não informa ainda, embora o faça depois, que o fazendeiro é James Nichols, irmão de Terry Nichols - que participou com Timothy McVeigh dos atentados contra um edifício na cidade de Oklahoma em 19 de abril de 1995, vitimando 168 pessoas. A título de informação, na data de realização do filme ambos estavam condenados, Terry Nichols com prisão perpétua e McVeigh à pena de morte. James Nichols será entrevistado no filme e suas considerações polêmicas ganham mais espaço no documentário, como será analisado.

Ainda nesta sequência de abertura, aparece um senhor entregador de leite que permanece no anonimato e, em seguida a imagem corta para um local com escombros de edificações e carros retorcidos onde, segundo Moore, seria mais um lugar de nome difícil bombardeado pelo presidente dos EUA (na época o democrata Bill Clinton). Novo corte brusco e o filme mostra outra cidade, Fargo na Dakota do Norte, para se referir, em tomada fechada, que Kerry McWilliam tinha feito sua caminhada diária, sem dizer que se trata de um homem cego, que ganha espaço no filme para apresentar sua dedicação aos treinos de tiro ao alvo e sua paixão por rifles.

Na continuação desta abertura, a senhora Hughes encaminha pequenos alunos para mais um dia de aula em uma escola do Michigan. Mais adiante, essa senhora será entrevistada sobre o dia que teve uma de suas alunas, de apenas seis anos de idade, morta a tiro por um colega de seis anos dentro da sala de aula. $\mathrm{O}$ áudio da ligação original que esta diretora fez, pedindo socorro médico para a menina baleada, acrescentará a sensação de realismo ao espectador que assiste ao filme $\mathrm{e}^{353}$.

Um corte para as montanhas do Colorado, as mesmas que abrem os desenhos

\footnotetext{
${ }^{353}$ Realismo no sentido atribuído por Jacques Aumont como sendo "um conjunto de regras sociais, com vistas a gerir a relação entre a representação e o real de modo satisfatório para a sociedade que formula essas regras" IN: AUMONT, Jacques. A Imagem. Campinas, SP: Papirus, 1993, p. 106. Recontar a história da morte da menina baleada na escola, inserindo o áudio original da ligação da professora pedindo socorro médico, confere realismo às cenas e pode requerer do espectador um conjunto de valores como empatia, tristeza pela morte prematura da criança, solidariedade, responsabilidade, e até compaixão pela outra criança que atirou, pois o filme não culpa o garoto, mas apresenta um conjunto de fatores (abandono, pobreza, revolta) que poderiam influenciar a conduta do atirador de seis anos.
} 
animados do South Park $^{354}$ e são parte do cenário natural de Littleton, cidade onde está situada a escola Columbine e a fábrica de mísseis Lockheed Martin - que segundo Moore, é a maior produtora de armas para destruição em massa do mundo. A voz de Michael Moore cita que naquele dia, "um dia típico nos Estados Unidos da América", "dois garotos foram jogar boliche às 6 horas da manhã" - embora jogar boliche a essa hora da manhã não pareça algo comum, não é informado ao espectador que se tratavam dos adolescentes Eric Harris e Dylan Klebold, que sairiam do boliche em direção à escola Columbine para cometerem os assassinatos.

Em outro momento do filme, Moore cita que investigações posteriores aos crimes, informam que os garotos estiveram no Boliche naquela manhã para jogarem uma partida, antes de irem para a escola. Para finalizar essa rápida abertura do filme que dura pouco mais de um minuto, entra a imagem de uma mulher que parece modelo fotográfico, vestida com trajes de banho, posando com um Rifle M16 (arma do exército americano) - o que será posteriormente esclarecido como um ensaio fotográfico para mais um dos calendários criados pela milícia do Michigan.

Ao entrevistar o grupo de milicianos, onde Nichols e McVeigh treinaram antes do atentado em Oklahoma, Moore conta que os milicianos vendem uma espécie de calendário com mulheres seminuas portando armas diversas, a fim de reverter os lucros para o grupo manter seus equipamentos e treinos. Também aparece a Estátua da Liberdade, símbolo dos Estados Unidos, fechando a construção da cena de abertura com a aparição de alguns personagens que falarão de suas histórias particulares, envolvendo experiências com armas de fogo ou momentos de violência gerados pelo uso desse tipo de arma. O filme apresentará as opiniões desses personagens a respeito do porte de armas e munições, evidenciando a facilidade para a aquisição dos mesmos como mercadorias comuns, e insinua uma cultura do medo, como responsável pela sensação de assombro entre os cidadãos estadunidenses e a consequente paranoia de autodefesa.

Acerca das histórias individuais, amplamente usadas nos filmes de Moore, diria Bauman,

\footnotetext{
${ }^{354}$ Os criadores do desenho South Park nasceram em Littleton, a mesma cidade na qual Eric Harris (um dos autores dos disparos na escola de Columbine) morou por algum tempo. Harris era filho de piloto da aeronáutica e morava com seus pais numa base militar na cidade. Os criadores de South Park criam um pequeno desenho, a pedido da produção de Moore, com alguns personagens parecidos com os do desenho original, construindo uma "história do medo" nos EUA, com um povo paranoico em torno da ideia de autodefesa.
} 
[...] as condições sob as quais os humanos constroem sua existência individual e que decidem o alcance e as consequências de suas escolhas se retiram (ou são removidas) para além dos limites de sua influência consciente, enquanto as referências a elas são riscadas ou deportadas para o cenário nebuloso e raras vezes explorado das histórias que os indivíduos contam de suas vidas, em seus esforços para inventar ou descobrir sua lógica e remodelá-los em sinais convertíveis de comunicação interpessoal ${ }^{355}$.

Neste sentido, pode-se pensar que ao contar histórias individuais sobre ocorrências que resultam em pessoas mortas ou feridas por armas de fogo, e as consequentes sequelas físicas e emocionais, o filme parece empreender uma tentativa de "des-individualizar" essas histórias que poderiam ser anunciadas ao público como atitudes isoladas e, portanto, contribuir para naturalizá-las. O filme pode unir vidas contadas e histórias vividas por seus personagens como uma tentativa de estabelecer conexões entre os eventos ocorridos, e como se repetem na história do país sem que as pessoas percebam.

Neste caso, Tiros em Columbine parece sinalizar que a violência por armas de fogo não estaria somente visível nos centros das cidades onde a população é maior e heterogênea em suas origens, ou nos guetos, geralmente associados a bairros de negros ou latinos. Além disso, ocorrências envolvendo o uso de armas de fogo estariam acontecendo com mais frequência nos subúrbios, como por exemplo, os da cidade de Littleton no Colorado. Isso pode significar que esse tipo de violência alcançou uma localidade tradicionalmente conhecida pela segurança, pela maioria de moradores brancos, com casas grandes, bem equipadas e amplos jardins. Embora seja possível encontrar famílias de pessoas negras habitando algumas casas nos subúrbios, como apresentou com irreverência o seriado The Fresh Prince of Bel-Air ${ }^{356}$, essas localidades foram criadas e vendidas, por muitos anos, exclusivamente para famílias de estadunidenses brancos.

Importante assinalar que é bem diferente o significado do termo subúrbio nos

\footnotetext{
${ }^{355}$ BAUMAN, Z. A sociedade dos individualizada: vidas contadas e histórias vividas. Trad. José Gradel. - Rio de Janeiro: Jorge Zahar Ed., 2008, p. 13.

${ }^{356}$ Seriado produzido pela rede de televisão estadunidense NBC, The Fresh Prince of Bel-Air, esteve no ar entre os anos de 1990 até 1996, fazendo grande sucesso e apresentando o ator Will Smith que seria revelação no cinema em filmes como "MIB- homens de preto", "Eu, Robô", "Eu sou a lenda" entre outros blockbusters de grande sucesso deHollywood. Fonte: http://www.imdb.com/title/tt0098800/ (acesso em abril de 2012). O seriado é em torno da vida de Will, um jovem negro e pobre que passa uns tempos na casa do seu tio, um juiz de direito, cuja família de pessoas negras representa a possibilidade transpor as "barreiras de classe" através do estudo e do trabalho.
} 
EUA do seu termo correlato em cidades não estadunidenses como, por exemplo, o Rio de Janeiro, onde os subúrbios significam localidades pobres, longe dos grandes centros e cujos moradores são, em grande parte, pessoas de pouco poder aquisitivo, isto é, o oposto de morador de um subúrbio estadunidense. A melhor correlação da ideia de subúrbio estadunidense aplicada ao Rio de Janeiro estaria em casas de condomínio fechado, por exemplo, na Barra da Tijuca.

A respeito da caracterização dos subúrbios como bairros de brancos, Purdy informa que as regiões suburbanas dos EUA receberam incentivos do governo federal desde o pós-segunda guerra. Muitas empresas se instalaram nos arredores dessas regiões, sobretudo no Sul, Sudoeste e Oeste do país “onde o conservadorismo reinava em políticas locais e no empresariado e onde os sindicatos e movimentos sociais não eram tão fortes ${ }^{\text {} 357}$. Com o beneficiamento público voltado para maioria branca nos subúrbios, e o deslocamento dos negros para os guetos também isolados de áreas centrais, revitalizadas para abrigar núcleos comerciais e instituições estudantis ou de saúde, o autor afirma que uma espécie de apartheid racial marcou as cidades nos anos 70.

Enfim, a reestruturação industrial e a política federal acabaram criando um verdadeiro "apartheid racial" nas metrópoles americanas a partir dos anos 1970, com, de um lado, subúrbios brancos mais prósperos cujos residentes se preocupavam em reduzir os impostos e valorizar os seus imóveis, e, de outro, pobres bairros negros e latino americanos nos centros da cidade, cujos residentes se tornavam cada vez mais dependentes da ajuda estatal ${ }^{358}$.

Nesta perspectiva, o que Tiros em Columbine poderia indicar é que não se deve encarar as ocorrências violentas com armas de fogo, sobretudo nos subúrbios, como algo banal ou corriqueiro. Conforme o contexto do filme indica, a violência por meio de armas de fogo não estaria restrita aos bairros de pobres e/ou negros (uma associação feita pelo programa Cops que o filme também cita) podendo também ocorrer entre os brancos nos seus subúrbios, cada vez menos, seguros. Em outro registro, o próprio Michael Moore, ao contar suas memórias de infância, sinaliza a diferença entre a vida no subúrbio e no centro, deixando claro que existia um acordo tácito entre os moradores

\footnotetext{
${ }^{357}$ KARNAL, L. História dos Estados Unidos: das origens ao século XXI. São Paulo: Ed. Contexto, 2010, p. 237.

${ }^{358}$ KARNAL, L. História dos Estados Unidos: das origens ao século XXI. op. cit., p. 238.
} 
e corretores de imóveis para que não vendessem suas casas para famílias de pessoas negras - mesmo que essas estivessem emergindo financeiramente e pudessem pagar por moradia no subúrbio ${ }^{359}$.

De volta ao filme, as cenas iniciais apresentam pessoas aparentemente comuns, mas que estão de diferentes formas envolvidas na narrativa e em ocorrências com armas de fogo. Comuns no sentido de que não são famosos, nem atores, não trabalham ou têm influênciano governo, não são pertencentes às camadas altas da hierarquia social e, por serem assim, podem transmitir para o espectador a sensação de que este último também poderia ser uma pessoa com a vida a ser contada, caso não considerem, como quer o filme, a necessidade de buscar saídas para os dilemas históricos que propiciam a repetição, ano após ano, de ocorrências de mortes por armas de fogo.

Acerca do tipo de documentário que pode ser observado em Tiros em Columbine, alguns dos principais envolvidos no problema do filme são inseridos em uma lógica narrativa que se refere ao modo de documentário expositivo, conforme a tipologia estabelecida por Bill Nichols, visto que o filme se dirige ao espectador diretamente, com a voz de Moore expondo sua argumentação de forma objetiva e persuasiva a respeito do mundo histórico ${ }^{360}$.

Nesse sentido, as diferentes imagens usadas no filme, independente do contexto em que foram retiradas, formam uma narrativa coerente a respeito de um assunto, neste caso, os possíveis motivadores dos altos índices de mortes ocorridas por armas de fogo nos EUA. A voz de Moore entra como "voz de deus", embora destoe um pouco da característica básica da voz de deus em filmes expositivos, cujo narrador onisciente não é identificado. Moore pode ser visto e ouvido em todo o filme narrando com autoridade e impondo explicações valorativas acerca dos assuntos tratados.

Ainda com Bill Nichols,

Os documentários expositivos dependem muito de uma lógica informativa transmitida verbalmente [...]. O comentário é geralmente apresentado como distinto das imagens que o acompanham. Ele provém de um lugar ignorado, mas associado à objetividade ou onisciência. $\mathrm{Na}$ verdade, o comentário representa a perspectiva ou o argumento do filme. Seguimos o conselho do comentário e vemos as

\footnotetext{
${ }^{359} \mathrm{Cf}$. MOORE, Michael. Adoro problemas: historias da minha vida. São Paulo: Lua de papel, 2001.

${ }^{360} \mathrm{Cf}$. NICHOLS, Bill. Introdução ao documentário. Campinas, SP: Papirus, 2005, p. 142.
} 
imagens como comprovação ou demonstração do que é dito. ${ }^{361}$

A narração e intervenções de Moore constroem o ponto de vista do filme, como também o tempo de participação dos demais personagens e o modo como suas falas são apresentadas na continuidade retórica de todo o discurso. Alguns personagens ganham mais tempo para expressar o que pensam, de acordo com a proposição de sentido que o filme constrói em cada cena, como por exemplo, o tempo que ganha o fazendeiro Nichols e os milicianos na construção de grupos cuja opinião parece radical em favor ao uso de armas por civis. Em contraposição, o tempo é menor para o depoimento da senhora Hughes ou as meninas que falam dos colegas da escola Columbine, porque são construídas como vítimas da violência - da qual parecem não conseguir entender as motivações e muito menos falar a respeito; é para essas pessoas construídas como vítimas, que o filme se coloca como uma espécie de porta-voz ou de defesa.

Segundo a abertura do filme, 20 de abril de 1999 teria sido um dia típico nos Estados Unidos. Um dia em que todos se levantam para realizar suas atividades cotidianas e, sem se darem conta, estariam ligados a questões que envolvem tragédias como a da escola Columbine - causadoras de comoção nacional. É como se o filme, antes de culpar o indivíduo pelas imperfeições das fórmulas da vida ${ }^{362}$, procurasse conquistar a empatia no espectador pelas histórias dos seus personagens "não atores" e, portanto, lidos do ponto de vista da "realidade" ou da enunciação do real de que falou Roger $\operatorname{Odin}^{363}$.

Na tentativa de coletivizar o problema em torno do uso de armas de fogo, primeiramente o filme aproxima o espectador dos dramas vividos pelos seus entrevistados para, depois de construir o problema e os grupos envolvidos, exigir do espectador uma posição no debate. Esse foi o filme pelo qual Moore foi aplaudido, por uma plateia em pé, na premiação do Oscar de melhor filme documentárioem2003, o que confere a grande popularidade deste documentário entre o público estadunidense.

Nesse sentido, é possível sugerir que o filme ganhou muitas posições a favor do desarmamento por enfrentar um tema que gerou comoção nacional, talvez a mesma

\footnotetext{
${ }^{361}$ NICHOLS, Bill. Introdução ao documentário.op. cit., p. 143-144.

${ }^{362}$ Segundo Bauman, A sociedade dos indivíduos os culpa "pelas imperfeições das fórmulas de vida produzidas culturalmente e da desigualdade de sua distribuição produzida socialmente sobre os mesmos homens e mulheres para os quais as fórmulas são produzidas e os recursos necessários para dispô-las são fornecidos." BAUMAN. Asociedade individualizada: vidas contadas e histórias vividas. Rio de Janeiro: Jorge Zahar editor, 2008, p.12.

${ }^{363}$ ODIN, Roger. Film documentaire, lecture documentarizante. In: ODIN, R; LYANT, J.C. "Cinéma et réalites". Saint Etienne, 1984, p. 263-277.
} 
sensação revivida pelo espectador do filme, visto que, como pontua Aumont,

[o] espectador jamais tem, com as imagens que olha, uma relação abstrata, "pura", separada de toda realidade concreta. Ao contrário, a visão efetiva das imagens realiza-se em um contexto multiplamente determinado: contexto social, contexto institucional, contexto técnico, contexto ideológico ${ }^{364}$.

Com isto, é possível afirmar que Tiros em Columbine ganhou prêmios populares nos EUA por, entre outras coisas, propiciar ao espectador reviver um momento de comoção nacional em torno de ocorrências relativamente recentes do contexto social, como parecem ter sido os atentados em Oklahoma e em Columbine, o que teria gerado mais empatia do que se fossem vidas estrangeiras.

Colocado no centro do debate sobre o porte de armas nos EUA, do espectador será exigida uma posição diante das cenas assistidas, pois o filme indica que cada pessoa, tão comum quanto os envolvidos nas histórias do filme, teria a possibilidade tanto de contribuir para atos de violência com armas de fogo, quanto para sofrer a repetição daquelas histórias, visto que o filme constrói o uso de armas como algo disseminado nos EUA.

$\mathrm{Na}$ continuação das primeiras cenas de Tiros em Columbine, como fez nos documentários anteriores, Moore se coloca como parte integrante do problema apresentado e constrói, nas sequências, a naturalidade com que as armas de fogo são historicamente usadas no cotidiano dos americanos. Ele mesmo se coloca como participante desta cultura, afirmando que cresceu com armas de brinquedo e, ainda adolescente, já praticava tiros com armas de fogo pela Associação Nacional de Rifle, inclusive sendo diplomado como atirador - o que busca comprovar por meio de fotos da época.

Neste segundo bloco de cenas, que construirão a cultura do uso de armas de fogo no país, Moore está no banco North Country para abrir uma conta e, conforme o anúncio da promoção para abertura de poupança, ganhar uma arma. As imagens se passam no interior do banco, com atendentes mulheres vestidas com camiseta azul com o símbolo daquela instituição que, além de banco, também é revendedor licenciado de

\footnotetext{
${ }^{364}$ AUMONT. Jacques. A imagem. Campinas, SP: Papirus, 1993, p. 09.
} 
armas. Parece um banco comum e seu interior é limpo e organizado. A atendente explica o procedimento para abrir a conta, pois eram oferecidos vários tipos de contas bancárias, não apenas a que se ganha uma arma. Assim, é possível pensar que um sentido proposto pelo filme, neste momento, é de que a compra de armas seria algo comum naquele país, e que estaria associada a outros tipos de aquisições como em uma compra de produtos combinados $^{365}$. Abrir uma conta e levar um rifle não seria menos comum do que comprar um hambúrguer e levar a munição de brinde. (Glassner exemplifica esses tipos de compra combinada ao falar de uma promoção realizada na loja Burguer King no seu livro sobre "A cultura do medo"366).

A atendente do banco informa: "você faz um depósito e nós lhe damos uma arma". Embora o filme use essa "promoção" como se fosse algo simples, não significa que tenha sido tão simples assim, pois o dono da nova arma passaria por todos os registros e verificações da idoneidade dos seus dados, e teria o registro da arma em seu nome no cadastro da compra, como se estivesse adquirindo a arma em um estabelecimento exclusivo.

Ao preencher a ficha, Moore parece não saber marcar no item raça se ele é branco ou caucasiano, valorizando a cena para, talvez, enfatizar que o banco utiliza um cadastro classificatório para seus clientes ou ainda para reforçar a construção que associará durante todo o filme, pessoas da cor branca ao uso de armas de fogo. Ou até mesmo para sugerir que poderia ser um banco com algum tipo de discriminação racial como algumas das que presenciou em sua adolescência, em diferentes instituições estadunidenses $^{367}$.

Nesse sentido, as repetições em torno da "cor branca" constroem uma associação do uso de armas de fogo como uma "cultura de brancos", assim como o jogo do boliche - a contrapelo do que faz o seriado televisivo Cops que associa, em grande parte, o uso de armas de fogo com saldo violento às pessoas de cor negra, o que é reforçado pela

\footnotetext{
${ }^{365} \mathrm{~A}$ indústria de armas é bem estruturada nos EUA, e como os carros da GM (tema explorado em Roger e $E u$ ), as armas também têm um mercado consumidor interno, legalizado e incentivado. Disso decorre pensar até que ponto seria interessante para a economia interna restringir a compra de armas de fogo e munições, o que provavelmente é um mercado lucrativo dentro e fora dos EUA.

${ }^{366}$ GLASSNER, Barry. Cultura do medo. São Paulo: Francis, 2003.

${ }^{367}$ Ao falar de sua adolescência, Mike cita o desconforto de seu pai quando quis associar-se ao ELKS clube que só admitia caucasianos como sócios. Apesar de preencherem o requisito "brancos de pele" a família de Moore não aceita a regra e prefere se associar a outro clube de golfe. IN: Adoro Problemas: Histórias da minha vida. São Paulo: Lua de Papel, 2011, p.155.
} 
música Bad Boys na versão do grupo Inner Circle ${ }^{368}$. Isso também pode remeter ao período histórico em que aos negros era proibido o porte de armas, e evidenciar o valor que os americanos conferem aos seus cidadãos descendentes de europeus (sobretudo os ingleses) - ambas as proposições são reforçadas no filme pelo desenho animado que entra no documentário: "Uma breve história dos Estados Unidos".

No caso de Moore, ele é descendente de Irlandeses (católicos) e, pelo menos no filme, não teve nenhum impedimento para abrir a conta bancária, sendo bem tratado pelos funcionários em todas as cenas ${ }^{369}$. Muito embora, o historiador Simon Schama lembra que os irlandeses católicos fizeram parte dos grupos preteridos pelas "peneiras da imigração",370.

Talvez percebendo que Moore estava valorizando a cena sobre o item raça, a atendente do banco diz, sorrindo, que aquilo não era tão importante assim. Outros itens do cadastro são citados por Moore, como por exemplo, se a pessoa teria algum tipo de deficiência mental, ou envolvimento criminal. Essas perguntas parecem absurdas, visto que não é difícil imaginar se as pessoas têm consciência de sua condição mental, ou se, caso tivessem, poderiam facilmente mentir diante de um simples cadastro, embora os estadunidenses levem as informações cadastrais muito a sério. Essas declarações parecem proteger o banco caso a pessoa faça uso inadequado da arma, pois, ao preencher e assinar o cadastro, o usuário estaria declarando ter algum discernimento do modo de uso daquele produto, além da ausência de antecedentes criminais.

Independentemente do tempo decorrido entre a abertura da conta e a aquisição da nova arma, o filme abrevia esse tempo unindo na cena seu personagem principal entrando no banco para abrir a conta e já saindo com a arma em punho, como se fosse um troféu. Isso pode transferir ao espectador a sensação de que a arma foi retirada do banco no mesmo dia em que o novo correntista preencheu seus dados cadastrais e, mesmo que não seja bem assim, isso constrói a naturalidade com que se adquire uma arma nos EUA. Vestido com a mesma roupa em todas as imagens produzidas dentro do North Country, como se fossem realizadas no mesmo dia, Michael Moore valoriza o momento do ganho da arma, experimentando seus mecanismos sem munição ainda

\footnotetext{
${ }^{368}$ Embora a música seja bem conhecida nas vozes de Bob Marley e, em outra regravação, por Will Smith o áudio da série Cops utiliza a versão do grupo jamaicano Inner Circle. http://www.imdb.com/title/tt0096563/ (Acesso em seis de abril de 2013).

${ }^{369}$ Moore conta esses detalhes de sua vida particularno livro: Adoro Problemas: Histórias da minha vida. São Paulo: Lua de Papel, 2011.

${ }^{370} C f$. SCHAMA, Simon. O que é um americano? In: O futuro da América: uma história. São Paulo: Companhia das Letras, 2009, p. 255-344.
} 
dentro da agência bancária e, ironizando acerca da possibilidade de uso ilegal para a arma, pergunta para os funcionários que o acompanham:

"Acha que é perigoso distribuir armas num banco?"

Ainda em relação à saída de Moore do North Country, com a arma em punho, essas cenas foram as que mais renderam críticas ao filme, porque no tempo cotidiano ou "na realidade", não se entra em uma agência bancária e sai com a arma em mãos. Muito foi dito a respeito dessas imagens, e acusações de manipulação renderam um filme também "documentário" chamado Manufacturing Dissent, em que os autores tentaram invalidar toda a suposta "realidade" com que o filme de Moore trabalha, apontando a cena do banco como uma fraude ${ }^{371}$.

Independente desses últimos debates, pouco interessantes, que o filme promoveu, a cena na agência bancária pode indicar que Moore procurou sugerir como a compra de armas é algo comum nos EUA, a ponto de fazer parte de promoção comercial. Esta naturalidade em usar armas será novamente indicada na cena dentro da barbearia. Enquanto corta o cabelo, Moore compra munição e a manipula dentro do estabelecimento. Tudo isso sugere que a aquisição de armas de fogo e munição seria algo corriqueiro, como a compra de qualquer produto, ou ainda, que seria algo economicamente facilitado e culturalmente aceito. Em outros momentos do filme, Moore responsabilizará redes de supermercados, como o $K$-Mart, pela venda irrestrita de munições em seus hipermercados. Em um momento de protesto, um dos jovens baleados em Columbine comprará todas as caixas de munições da mesma bala $9 \mathrm{~mm}$ que tem alojada em seu corpo e as levará para o escritório central do K-Mart.

Acerca da construção do tempo no filme, diria Carrière que "o cinema joga com o tempo de tantas e tão variadas formas que seria possível escrever um livro apenas sobre esse tópico"372. Se, "todo meio de comunicação adapta o tempo [e] nos filmes o tempo custa mais caro que nos outros lugares"373, ou ainda, se o cinema é "ele próprio

\footnotetext{
${ }^{371}$ Dentre as inúmeras fontes disponíveis na Internet: http://cinema.terra.com.br/noticias/0,,OI109003EI1176,00-Revista+acusa+Michael+Moore+de+forjar+cena.html (acesso em fevereiro de 2012). http://www1.folha.uol.com.br/folha/ilustrada/ult90u69786.shtml (acesso em fevereiro de 2012).Link com mais informações sobre o filme Manufacturing Dissent - http://www.imdb.com/title/tt0961117/ (acesso em fevereiro de 2012).

${ }^{372}$ CARRIÈRE, Jean-Claude. A linguagem secreta do cinema. Rio de Janeiro: Nova Fronteira, 2006, p. 99.

${ }^{373}$ CARRIÈRE, Jean-Claude. A linguagem secreta do cinema, op. cit., p. 99.
} 
um tempo-dentro-de-um-tempo",374, não é difícil imaginar como seria inviável que um filme como Tiros em Columbine acompanhasse, através de imagens, todo o processo de compra de uma arma via promoção bancária - a proposta do filme não é copiar o "real cronológico" é sugerir o "real", ou ainda, lembrar que as coisas acontecem de uma forma, por que acontecem assim e que consequências isso traz para aquela sociedade discutida no filme. A respeito da filmagem do tempo no cinema - e isso também explica porque Moore filmou sua entrada e saída do banco com a arma em punho reduzindo o tempo cronológico - diria Carrière que é muito difícil situar o leitor no tempo durante o filme sem se valer de alguns clichês ultrapassados, como filmar a data em um calendário, ou o sol nascendo, por exemplo. Transmitir ao espectador a ideia de dia e noite já teria algumas complicações, mas a do dia seguinte é tão mais complicada que ajuda a pensar porque Moore entra e sai da agência com a mesma roupa com a mesma luz do dia e com a arma em punho. Talvez porque ele quisesse transmitir mais uma noção sobre como as coisas funcionam. Sobre isso diria Carrière;

A ideia de dia seguinte é sempre muito difícil de transmitir, porque no cinema os dias e as noites não se movem em uma sequência regular como na vida. Eles nem chegam perto de uma tal sequência. Existem até dias fílmicos e noites fílmicas, que dividem o tempo de uma maneira única, que pertencem exclusivamente ao cinema. É possível, por exemplo, se mover de um interior - sala de jantar - dia para um exterior - campo de batalha - dia, e então ordenar as cenas que se sucedem na filmagem de forma que similarmente se sucedem na suposta realidade da história. O tempo da narração e o tempo do filme são desta forma, confundidos. Ambas as cenas se passam no mesmo dia. [...] Como num jogo, a sequência do tempo no cinema obedece a certas regras secretas e até a certos truques, que ninguém está ansioso para revelar. Infeliz o filme que permite às plateias ver o que o faz funcionar, que meticulosamente sinaliza e servilmente observa a passagem do tempo. Este laborioso servilismo é instantaneamente percebido, provocando um evidente desconforto nos espectadores, mesmo que eles não saibam exatamente por quê. ${ }^{375}$

\footnotetext{
${ }^{374}$ CARRIÈRE, Jean-Claude. A linguagem secreta do cinema. Rio de Janeiro: Nova Fronteira, 2006, p. 111.

${ }^{375}$ CARRIÈRE, Jean-Claude. A linguagem secreta do cinema, op. cit., p. 104-105.
} 
Com isto, discutir se Moore está ou não forjando uma "realidade" no filme, com a aquisição da arma no banco, é atestar o desconhecimento de regras triviais do cinema que são válidas para todos os gêneros, inclusive para o de documentário. E diria Menezes, “o cinema não fala diretamente do real, não é uma reprodução mais que perfeita deste real, e sim uma construção a partir dele e que dele se distingue" ${ }^{376}$.

Contudo, no âmbito das discussões em torno do cinema de não ficção, diria Michael Renov,

[...] o domínio da não ficção foi tipicamente estimulado por uma preocupação com a objetividade, uma crença em que aquilo que era visto e ouvido deveria manter sua integridade como uma parte plausível do mundo social. De que outra maneira persuadir os espectadores a investir na crença, produzir a "evidência visível" e até mesmo induzir a ação social? Hoje em dia há muitos motivos para se desconfiar dessa esperada neutralidade ${ }^{377}$.

Até porque, se o cinema documentário for pensado a partir da máxima de Grierson, que sintetiza o gênero como "tratamento criativo da realidade"378, a pretensa neutralidade, que os críticos de Moore tanto exigem, sequer existiu nos primórdios do documentário. Mesmo os pioneiros do documentário, como Robert Flaherty e seu filme Nanook of the North (1922), as encenações e mediações estavam presentes na construção do filme.

Para Menezes, "o surgimento do cinema documental é também o surgimento da falsificação documental" ${ }^{379}$. O autor discute detidamente as construções do documentário de Flaherty e afirma que o que se vê é Nanook interpretando ele mesmo, isto é, um personagem encenando um modo de vida tradicional que o esquimó já não vivia mais. Essa encenação envolveu a construção de cenários com iglus gigantes adaptados para entrar a luz que permitiria as filmagens, uma foca previamente morta para a encenação de sua caçada, além do cuidado de se retirar os sinais da "sociedade

\footnotetext{
${ }^{376}$ MENEZES, P. Cinema: imagem e interpretação. In: Tempo Social: Revista de Sociologia. USP, São Paulo, 8(2): 83-104, outubro de 1996, p. 89, (83-104).

${ }^{377}$ RENOV, Michael. Investigando o sujeito: uma introdução. In:MOURÃO, Maria Dora \& LABAKI, Amir (Orgs). Cinema do real. São Paulo: Cosac Naify, 2005, p. 244-245.

${ }^{378}$ RENOV, M. Investigando o sujeito: uma introdução. Op. cit., p. 16.

${ }^{379}$ MENEZES, P. Representificação: as relações (im)possíveis entre cinema documental e conhecimento. Rev. bras. Ci. Soc., São Paulo, v. 18, n. 51, fev. 2003. Disponível em <http://www.scielo.br/scielo.php?script=sci_arttext\&pid=S010269092003000100007\&lng=pt\&nrm=iso> Acesso em 20 abr. 2013, p. 93.
} 
industrial", que aparecem apenas na cena em que o esquimó conhece o que é um disco de vitrola e a do óleo de rícino ${ }^{380}$.

Esses elementos sinalizam que, mesmo em um filme reconhecidamente fundador do gênero, é possível discutir a construção do "real" e as proposições de sentido que aludem ao espectador, de modo que, se a "realidade" da coisa filmada não se confunde com a "realidade" do filme, importa mais saber quais sentidos e valorações o filme sugere na sua relação com o espectador do que com a "realidade" daquilo que foi filmado, o que, segundo Menezes, também incorre em uma posição valorativa, visto que para os pais fundadores da sociologia a realidade seria diversa ${ }^{381}$. Assim, antes de preocupar-se com a "realidade" das construções de Moore, importa saber quais sentidos são propostos e quais valorações o filme destaca na sociedade que constrói, além de quais tomadas de posição pode "despertar" no momento da relação com o público espectador.

Michael Moore imprime uma boa dose de criatividade no tratamento dos seus filmes, com a representação ${ }^{382}$ de seu personagem que se assemelha a um estadunidense médio (camada social que seus filmes parecem buscar atingir), para construir uma "realidade" em torno de alguns temas dos EUA. Realidade essa com carregadas doses de autobiografia do cineasta, como quando enfatiza sua vida pessoal, história familiar, trabalho operário, catolicismo, política liberal, entre outras opções

\footnotetext{
${ }^{380}$ MENEZES, P. Representificação: as relações (im)possíveis entre cinema documental e conhecimento.op. cit., p. 93.

${ }^{381}$ Acerca das diferentes noções do "real" discutidas pelos três pais fundadores da sociologia, Menezes pontua que, em Durkheim "se os fatos sociais estão inscritos no real é somente por meio do método que delimita com ele uma relação de objetividade que se pode eliminar do trajeto as pessoalidades indesejáveis que nos impedem de descobrir as verdadeiras causas dos fenômenos sociais. (...) Tanto para Weber quanto para Marx, o método aparece como a única possibilidade de se constituir um real apreensível ao conhecimento. Para o primeiro, o mundo como se apresenta é um caos, composto por uma infinidade de fenômenos que se sucedem e se superpõem incessantemente, não sendo, portanto passível de ser conhecido e menos ainda compreendido sem o recorte direcionado e intencional do investigador, que seleciona para compreender o mundo que se apresenta sempre como uma configuração de possibilidades. Para o segundo, o visível nada mais é do que formas de manifestação que no seu incessante aparecer e desaparecer, na sua constante mutação, elidem os processos que as fazem aparecer como tais, não se permitindo que se compreendam como são os processos de reprodução do capital, e os processos de exploração aí inscritos, compreensíveis apenas e tão somente pelo processo de pensamento." MENEZES, Paulo. Representificação: as relações (im)possíveis entre cinema documental e conhecimento.Rev. bras. Ci. Soc., São Paulo, v. 18, n. 51, fev. 2003. Disponível em<http://www.scielo.br/scielo.php?script=sci_arttext\&pid=S010269092003000100007\&lng=pt\&nrm=is o> Acesso em 17 abr. 2013, pág. 90. Nesta direção é importante destacar que, nas ciências sociais, antes de se discutir o "real" deve-se partir de um pressuposto teórico-metodológico acerca deste mesmo "real" a fim de situar qual "ponto de vista" este olhar incide sobre uma suposta "realidade".

${ }^{382}$ Cf.GOFFMAN, E. A representação do eu na vida cotidiana. Petrópolis: Vozes 2009.
} 
particularizadas que atravessama narrativa, sobretudo, porque Moore se coloca como parte do grupo social que sofre com os problemas e como quem quer a mudança, neste caso, da cultura do uso de armas.

Renov considera, a partir de Brian Winston (e sua visão de que o documentário é uma mediação da realidade), que caso o documentário não tenha essa mediação, tornase jornalismo. Sobretudo o jornalismo pretensamente neutro que se preocupa em "mostrar a realidade" - como se isso fosse possível. Pensando em pontuar a discussão a respeito dos limites entre o documentário e a ficção, Renov diz:

Quando os próprios cineastas ressaltam que o trabalho do seu documentário é a evidência, eles estão defendendo um conceito ideologicamente poderoso, porém com uma noção ingênua de objetividade. Estão encorajando o público em sua ingenuidade. Mais que isso, no entanto, quando assumem essa posição, estão realmente pondo em risco o conceito de documentário como "tratamento criativo"; a única coisa que torna os documentários diferentes das outras formas audiovisuais de não ficção ${ }^{383}$.

Esta discussão envolve questões do cinema direto, de não intervenção naquilo que é filmado, mas acabam se estendendo aos demais filmes, pois o imaginário social está impregnado da ideia de que o filme documentário aborda a "realidade" de forma não mediada o que, em tese, segundo esses autores, aproximaria o documentário do jornalismo, visto que a preocupação inicial de Grierson era distinguir os documentários dos cinejornais, filmes científicos, etc, passando do plano da "descrição do material natural para arranjos, rearranjos e a remodelação criativa do mundo natural" ${ }^{384}$. Para Winston, Grierson "via o documentarista como um artista, como uma pessoa que mediava a filmagem do mundo real para iluminar a condição humana através de seus próprios insights" ${ }^{385}$.

\footnotetext{
${ }^{383}$ WINSTON, Brian. A maldição do "jornalístico" na era digital. In: Cinema do Real. MOURÃO, Maria Dora \& LABAKI, Amir (orgs). O cinema do real. São Paulo: Cosac Naify, 2005, p. 21.

${ }^{384}$ WINSTON, Brian. A maldição do "jornalístico" na era digital. Op. cit., p. 22.

${ }^{385}$ WINSTON, Brian. A maldição do "jornalístico" na era digital. Op. cit., p. 22.
} 
Segundo Calvin Pryluck, muitas pessoas que trabalham com documentários reconhecem o problema da ética como desconcertante ${ }^{386}$. Esses problemas são sinalizados após a exibição dos filmes com as entrevistas e os debates suscitados.

A análise de Tiros em Columbine sugere alguns "problemas éticos", tanto pela cena em que Moore supostamente ganha uma arma após abrir a conta no banco, tanto nas tomadas com o ator Charlton Heston, cujos debates promovidos acusam um tratamento "desrespeitoso" com o "mítico" ator de Hollywood, que consentiu uma entrevista em sua casa. O que fica registrado no imaginário do espectador é aquilo que o filme constrói e não as entrevistas extra-filme em que o diretor tenta explicar suas intenções, como se as pudesse controlar.

Acerca dos problemas éticos, que envolvem muito mais do que moralidade, Pryluck diria que "Suposições éticas têm consequências estéticas, e suposições estéticas têm consequências éticas" ${ }^{387}$. As consequências emergem das questões que envolvem consentimento, e privacidade. No momento da filmagem, geralmente a pessoa está sob a coerção da câmera, como por exemplo, os doentes filmados por Wiseman num Hospital. Isso sugere a possibilidade de que a pessoa filmada não tenha noção dos usos que a produção do filme fará daquelas cenas ou fotos. Pryluck cita: Wiseman com um filme de idosos e doentes em uma clínica, também cita os vendedores de bíblias filmados pelos irmãos Maysles e os trabalhos de Leacock. Se por um lado, esses trabalhos apresentam o ônus das questões éticas acerca dos limites dos usos das imagens, mesmo que autorizadas pelas pessoas envolvidas, por outro lado, possuem um lado "positivo" ao trazer à tona aspectos que teriam permanecido invisíveis ao público.

Pryluck enfatiza que alguns produtores de filmes, como Marcel Ophuls, têm consciência do problema ético que podem trazer com seus documentários. "Como um produtor de filmes, você está sempre... explorando. É parte da vida moderna"388. Ophuls percebe "problemas e depressões" pessoais na exploração profissional da "grande urgência das pessoas em se comunicar por causa da solidão, da insegurança, de complexos enrustidos" ${ }^{389}$. Contudo, ele explica, "o meu maior problema era convencer as pessoas a serem entrevistadas... Se você tem dons razoáveis, como falar rápido ou

\footnotetext{
${ }^{386}$ PRYLUCK, Calvin. Ultimately We Are All Outsiders: The Ethics of Documentary Filming. In: ROSENTHAL, A; CORNER, J. New Challenges for Documentary. Manchester University Press, 2005, p. 256, (tradução minha).

${ }^{387}$ PRYLUCK, Calvin. Ultimately We Are All Outsiders: The Ethics of Documentary Filming. In: ROSENTHAL, A; CORNER, J. New Challenges for Documentary. Manchester University Press, 2005, p. 256, (tradução minha).

${ }^{388}$ PRYLUCK, C. Ultimately We Are All Outsider, op. cit., p. 257.

${ }^{389}$ PRYLUCK, C. Ultimately We Are All Outsiders, op. cit.
} 
diplomacia, ou se você parecer razoavelmente sincero, você será capaz de obter cooperação... É um jogo de enganar, de certo modo" 390 .

Neste sentido, o que as discussões apontadas por Pryluck enfatizam é que todos somos intrusos quando usamos um equipamento de filmagem para captar cenas de pessoas e colocar essas imagens nas telas para o julgamento do público em geral. Essas discussões remetem às cenas em que Moore entrevista Charlton Heston e serão retomadas quando a análise avançar até essas imagens.

Embora Michael Moore não faça cinema direto, seus trabalhos também podem remeter às considerações éticas de Pryluck. Como foram as cenas em que Moore "refaz o percurso" da aquisição da arma, abrindo a conta em um banco, não informando que está resumindo, encenando, ou ainda, recriando o processo de "ganhar a arma". Assim, é possível que a crítica em geral entenda as encenações de Moore como um problema ético, visto que este sugere ao público uma "facilidade desmedida" na obtenção da arma, o que não ocorreria na prática. Contudo, o que importa ao espectador no momento de exibição do filme é a construção da facilidade e da rapidez com que se pode adquirir uma arma nos EUA.

Ainda a respeito das questões éticas no documentário, Jay Ruby discute em "A ética da produção da imagem" alguns problemas citados por Pryluck, como a questão do consentimento do entrevistado e as implicações éticas que lhe são decorrentes. Ruby questiona o que significa "consentimento informado" quando uma família é questionada por uma equipe de televisão interessada em filmar sua vida e transmitir o conteúdo em uma série para rede nacional, ou ainda, se é possível pensar em algum equilíbrio entre o direito do público de ser informado com o direito de privacidade do indivíduo ${ }^{391}$.

Essas questões nos servem de alerta não apenas no sentido de discutir os limites “éticos” do documentário, mas na direção de perceber e reforçar o seu caráter construtivo e, portanto, ideológico em torno de um determinado tema ou assunto. Talvez importe mais pensar os limites daquilo que o filme trata como "realidade", do que em impor limites à sua exibição e conteúdo.

Ruby preocupa-se com as expectativas morais da sociedade em torno do diretor do filme e a consequente ambivalência que alguns profissionais sentem em relação à sua

\footnotetext{
${ }^{390}$ PRYLUCK, C. Ultimately We Are All Outsiders: The Ethics of Documentary Filming. In: ROSENTHAL, A; CORNER, J. New Challenges for Documentary. Manchester University Press, 2005, p. 257-258. (Tradução minha).

${ }^{391}$ RUBY, Jay. The Ethics of Imagemaking; or, “They're Going to Put Me in the Movies. They're Going to Make a Big Star Out of Me...". In: ROSENTHAL, A; CORNER, J. New Challenges for Documentary. Manchester University Press, 2005, p. 308. (Tradução minha).
} 
própria base ética. Para o autor, essas preocupações têm relação com a natureza das imagens e à sensação de que podemos ser mais confundidos do que informados por elas. Isso porque os argumentos dos profissionais (artistas, jornalistas, entre outros), acerca dos usos que fazem das imagens, não estariam convencendo o público, preso mais às impressões sugeridas do que às intenções dos autores. Assim, "a base moral sobre a qual os produtores de imagens confiaram é instável, se não esfacelada"392.

Nessa direção, o autor reforça a necessidade de se compreender a "decisão de usar a imagem de outrem e onde nossas responsabilidades se encontram"393. A partir da descentralização das tecnologias produtoras e distribuidoras de imagem, e a popularização dos equipamentos para a sua produção, o autor lembra a ideia de Andy Warhol de que todos podem ter seus 15 minutos de fama, e, com isso, as imagens estariam sendo mais discutidas e também desmistificadas entre os espectadores.

Assim, para Ruby muitos trabalhos que desfrutaram dias de popularidade “acrítica", envolvendo usos de imagens de pessoas na tentativa de "informar" o público acerca do "real", estariam hoje com os dias contados. Alguns exemplos sugeridos envolvem: tirar fotos de pessoas em localidades distantes, geralmente pobres e com vida muito diferente do padrão encontrado na América, teriam deixado de ser um direito do artista; reconstruir eventos históricos com personagens ficcionais e não ser considerado eticamente responsável, teria também acabado com a popularidade dos docudramas televisivos. Também estaria com os "dias contados" a crença na responsabilidade ética primeira de um jornalista, bem como no interesse do repórter de que o direito do público em saber seria mais importante do que o direito individual de privacidade. Outros exemplos são citados pelo autor, contudo todos confluem para o aspecto ético dos usos das imagens a partir das reações e de discussões valorativas que promovem no espectador. De tão habituado com essas práticas, alguns espectadores já sinalizam o fim da ingênua confiança na objetividade da câmera.

Embora seja mais provável que a maioria das pessoas ainda creditem "realidade" e "verdade" nas imagens, Ruby pontua que

\footnotetext{
${ }^{392}$ RUBY, Jay. The Ethics of Imagemaking; or, "They're Going to Put Me in the Movies. They're Going to Make a Big Star Out of Me...". In: ROSENTHAL, A; CORNER, J. New Challenges for Documentary. Manchester University Press, 2005, p. 309. (Tradução minha).

${ }^{393}$ RUBY, Jay. The Ethics of Imagemaking; or, “They're Going to Put Me in the Movies. They're Going to Make a Big Star Out of Me...”.Op. cit. (Tradução minha).
} 
"nós estamos começando a entender a imagem tecnologicamente produzida como uma construção - como o ato interpretativo de alguém que tem uma cultura, uma ideologia, e frequentemente um ponto de vista consciente, todos os quais fazem com que a imagem carregueum certo tipo de conhecimento de um modo particular. Os que fazem as imagens nos mostram suas visões de mundo, quer eles queiram ou não"394.

Nesse sentido, é possível imaginar o desconforto causado no público espectador de Tiros em Columbine, em boa parte ciente do processo de aquisição de uma arma nos EUA, ao ver Michael Moore entrar no banco, preencher uma ficha simples, omitir a necessidade do depósito em dinheiro para participar da promoção bancária, abrir uma conta e levar uma arma. Tudo isso foi realizado no mesmo dia e, pela luz da entrada e saída do banco, ocorreu em pouco tempo. Para Ruby isso incorreria em um problema ético visto que o cineasta,

... tem a obrigação moral de revelar o esconderijo - para nunca dar a impressão de produzir um espelho objetivo através do qual o mundo pode ver sua "verdadeira" imagem (...). Enquanto nossas imagens do mundo continuarem a ser vendidas a outros como a imagem do mundo, estaremos sendo anti-éticos ${ }^{395}$.

Assim, para Ruby a imagem seria polissêmica ao potencializar uma variedade de significados socialmente gerados. Entretanto, essa ideia de polissemia das imagens entra em confronto com a metodologia de Sorlin e seu pressuposto de que o sentido da imagem está na relação com o espectador e não na imagem em si. Talvez a polissemia coubesse mais na ideia de inúmeras possibilidades de relações que o espectador pode estabelecer com a imagem, ao invés de sentidos que partam unilateralmente dessas últimas. Deste modo, as considerações de Ruby auxiliam não apenas a pensar o teor dos possíveis debates em torno de "manipulação da realidade", como também para reforçar a noção do caráter construtivo das imagens.

\footnotetext{
${ }^{394}$ RUBY, Jay. The Ethics of Imagemaking; or, “They're Going to Put Me in the Movies. They' re Going to Make a Big Star Out of Me...", op.cit., p. 309. (Tradução minha).

${ }^{395}$ RUBY, Jay. The Ethics of Imagemaking; or, “They're Going to Put Me in the Movies. They're Going to Make a Big Star Out of Me...”, op.cit., p. 310. (Tradução minha).
} 
Moore não nega que trata seus temas com auxílio de uma licença de comédia, ou com o humor irônico que lhe é peculiar - o que marca seu tratamento criativo da "realidade" com os temas que seus filmes evocam.

Conforme aponta Winston, existe a queixa de que "os documentários são entretenimento" ${ }^{\text {396 }}$. Isso também pode ser lido como indicador da ideia comum de que o filme documentário é algo sério porque fala da "realidade". Talvez por quebrar alguns padrões do gênero, sem deixar a pretensão de tratar da "realidade", os filmes de Moore trouxeram o documentário para o gosto popular ao mesmo tempo em que sofreram críticas de distorção da "realidade".

Para finalizar esse panorama de discussões em torno de ética no filme de documentário, a contribuição de Bill Nichols parece englobar outros fatores de modo a oferecer uma noção ampla em relação aos autores anteriores. Para o autor, ética, política e ideologia são conceitos distintos, porém envolvem a mesma problemática, visto que conduta ética envolve motivação política e vice-versa. Com isto, toda construção social dentro dos filmes apresenta um discurso ideológico ${ }^{397}$. Esta proposição de Nichols é retomada na análise do filme Fahrenheit 9/11 com a construção empreendida contra o governo de George Bush. Isso exemplifica que determinada construção acerca dos grupos nos filmes, se em chave positivada ou não, forma um discurso ideológico acerca dos mesmos.

De volta as sequências de Tiros em Columbine, após sugerir a facilidade para comprar armas no país, o filme faz novo corte nas cenas e, ao som da música Take The Skinheads Bowling, imagens em preto e branco de pessoas jogando boliche apresentam os créditos iniciais do filme com as empresas: Alliance Atlantis e United Artists, a Salter Street Films VIF2 Production, e, a produtora de Moore, Dog Eat Dog Films. O jogo de boliche é outro símbolo da cultura (branca) estadunidense que permeia a construção valorativa do filme.

O nome do filme é Bowling for Columbine e a tradução brasileira é Tiros em Columbine. O título original pode remeter a vários significados, pois se no jogo de boliche vence quem derruba o máximo de pinos possíveis, os atiradores que entraram armados na escola Columbine seguiram a mesma lógica do jogo, isto é, "derrubar" o maior número possível de pessoas. O título do filme também pode remeter à palavra

\footnotetext{
${ }^{396}$ WINSTON, Brian. A maldição do "jornalístico" na era digital. In: Cinema do Real. MOURÃO, Maria Dora \& LABAKI, Amir (orgs). O cinema do real. São Paulo: Cosac Naify, 2005, p. 23.

${ }^{397}$ NICHOLS, Bill. La representación de la realidad: cuestiones y conceptos sobre el documental. Ediciones Paidós Ibérica, S.A: Barcelona, 1991, pág. 144.
} 
bullying, termo designado aos atos violentos, físicos ou psicológicos, sofridos por alunos dentro das escolas. Segundo o filme, os atiradores da Escola Columbine sofriam algum tipo de bullying por parte de seus colegas, até pelo modo reservado como se comportavam, e algumas alunas os descreveram no filme como "pessoas estranhas",398.

As imagens antigas em preto e branco de pessoas jogando Boliche podem indicar o quanto esse jogo faz parte da cultura, sobretudo dos brancos, e pode ser mais um atrativo para o público do filme, algo que gostem de assistir, ou mais um símbolo reconhecível para a maioria dos espectadores, assim como a comédia stand up uma forma de cultura de entretenimento típica dos EUA. A associação de cenas de boliche e armas de fogo, como partes integrantes da infância americana, dão o tom de práticas comuns nos EUA. O filme também parece questionar a cultura das armas de brinquedo, como algo prejudicial para as crianças e adolescentes.

Michael Moore ironiza que o boliche não teria sido citado pelos especialistas como algo nocivo para os jovens, sobretudo quando foi incluído nas aulas extras da escola - aulas essas caracterizadas pelo filme como não importantes. Apesar da ideia acerca da influência do boliche na vida dos estudantes não estar bem construída pelo filme, um sentido interessante propõe que o uso das armas de brinquedo, associado aos treinos com pinos de boliche, sugere uma iniciação precoce ao artefato bélico, e a facilidade com que essas crianças encontram armas na adolescência pode favorecer que desavenças juvenis, antes resolvidas com uns "socos e pontapés" na saída da escola ou com brigas entre vizinhos sejam, cada vez mais, resolvidas à bala ${ }^{399}$.

\footnotetext{
${ }^{398}$ Considero a questão do bullying, como é tratada por profissionais da pedagogia, psicologia e educação em geral, algo pouco construído no filme Tiros em Columbine e não entrarei nos méritos deste debate porque Tiros em Columbine toca em questões mais amplas do que o comportamento estudantil, trata do uso de armas como algo cultural e não como específico de alunos em fase escolar e suas dificuldades de convivência. Um filme estadunidense que associa o bullying entre adolescentes às ocorrências que envolvem mortes por armas de fogo como os atentados ocorridos na Escola Columbine, foi Elefante (2003). Inspirado na tragédia que marcou a Escola Columbine no Colorado, o filme Elefante constrói de um modo frágil o cotidiano de alunos em uma escola secundária de Portland, no Oregon. Classificado no IMDB como sendo do gênero drama e ganhador da Palma de Ouro em Cannes de 2003, Elefante sugere a importância de se discutir um tema que, semelhante a um elefante dentro de uma sala, não poderia mais ser ignorado. Contudo, o filme apresenta construções fracas envolvendo bullying, problemas familiares e homossexualidade entre dois alunos a fim de "justificar" os atentados que eles cometem contra vários colegas de escola. O "pano de fundo" comum tanto em Tiros em Columbine quanto em Elefante é a facilidade com que os alunos conseguem as armas para cometerem os assassinatos. Sobre o filme consultar: http://www.imdb.com/title/tt0363589/ (acesso em 06/04/13).

${ }^{399}$ Ao contar suas memórias, Moore informa o público, sobretudo ao não estadunidense, como era a vida típica de classe trabalhadora nos EUA dos anos 60 e 70, os costumes, os valores, a vida escolar, o trabalho e os sonhos de consumo. Ele conta que foi levado por seu pai para aprender boxe na Associação Cristã de Moços porque, apesar de ser bom de tiro, ele era ruim de briga e tinha apanhado de um vizinho na rua. $C f$. MOORE, Michael. Adoro Problemas: histórias da minha vida. São Paulo: Lua de Papel, 2011.
} 
Embora o filme apresente alguns elementos da cultura americana, como o boliche e o tiro com arma de fogo, unidos como jogos de lazer ou práticas comuns, ao mesmo tempo sinaliza implicações sociais bem distintas entre ambos, porque é evidente que o jogo de boliche não possui o poder de destruição encontrado em armas de fogo e, como sugere o filme, praticar tiro, que estaria sendo tratado como um jogo qualquer, seria uma prática questionável porque se mostra cada vez mais perigosa devido aos elevados índices de mortes que as estatísticas apontam. Adicionam-se a isso as facilidades do bem estruturado mercado de armas em uma sociedade de desigualdades e contrastes como o problema racial, a diminuição do emprego entre os trabalhadores, e um medo incomum infundido pelos meios de comunicação - como o filme sugere. Esses elementos unidos na narrativa parecem uma "fórmula" para a ocorrência de acontecimentos motivados por frustrações (sejam estas contra colegas de escola ou contra o governo) que levariam ao uso desmedido de armas de fogo, cada vez mais potentes, em uma sociedade, além de desigual, intolerante para comaqueles que chama de "perdedores" (no sentido de fracassados) ou "losers". Esse pensamento comum em torno do medo do fracasso será exposto pelo criador do desenho South Park quando ele fala do período que estudou em Littleton.

As cenas seguintes são de comerciais televisivos, em que crianças brincam com armas que imitam o som das originais. Esses comerciais antigos, em preto e branco, entram no filme para "atestar" que ter e brincar com armas fez parte da "educação" de crianças por várias gerações, como uma espécie de iniciação do uso desses artefatos para a vida adulta. Esta aprendizagem do uso das armas de fogo, consentida e incentivada pela família, além da regularidade com que são comercializadas no país, são construídas pelo filme como facilitadores para a ocorrência de assassinatos entre os jovens, como foi na escola Columbine.

Novamente colocando-se como parte do grupo social que deseja a mudança daquele estado de coisas, até porque se coloca como membro atuante da comunidade, Moore utiliza imagens de sua infância nas quais ele também se divertia com pequenas armas de brinquedo. Um vídeo de arquivo pessoal mostra Michael e sua irmã correndo pelos gramados de sua casa, e a narração de Moore diz que "mal podia esperar para sair atirando pela vizinhança". Esta fala, aparentemente ingênua, pode sugerir que esse tipo de brincadeira infantil ganha uma dimensão trágica quando algumas dessas crianças crescem e não dissociam o ato de brincar com armas de plástico das práticas "adultas" de operar armas de fogo. 
Também é possível inferir que em um país considerado "um gigante militar" 400 , com tradição em guerra e o maior orçamento empregado para fins bélicos do mundo, possa ser interessante que futuros recrutas tenham afinidade com armas e estejam despertos para a competição desde cedo, mais um fator para a tolerância em torno de armas. Além disso, ainda resta pensar que outra questão em torno de armas de fogo nos EUA é a proteção individual e familiar, e o uso do termo "legítima defesa" é levado às últimas consequências.

Moore conta que quando estava na adolescência já atirava bem e ganhou reconhecimento de atirador pela Associação Nacional de Rifle. Ele mostra uma foto segurando um troféu para provar sua afirmação. E, como se precisasse insistir junto ao espectador, mostra também a imagem do diploma cedido pela National Rifle Association Junior. Em sua narração, Moore diz que cresceu no Michigan, o "paraíso dos amantes de armas". Isso tudo parece reforçar o sentido da cena para a construção de uma cultura pró-armas na vida de um cidadão comum nos EUA, sobretudo os que vivem no interior do país. A cena é construída com acréscimo de uma música antiga que confere um aspecto de costume ou tradição familiar.

Ao tratar da importância do som, e isso se refere a todas as músicas no filme, Michel Chion chama de "valor acrescentado" ao "valor expressivo e informativo com que um som enriquece uma determinada imagem" e que funciona na sincronia som/imagem pela "relação imediata e necessária entre qualquer coisa que se vê e qualquer coisa que se ouve". Para este autor, o som no filme geralmente é lido como algo que reforça o sentido de uma imagem como se a informação decorresse naturalmente da imagem. Contudo, o som cria o sentido da imagem: “[...] a impressão eminentemente injusta, de que o som é inútil e de que reforça um sentido que, na verdade, ele dá e cria, seja por inteiro, seja pela sua própria diferença com aquilo que se vê" 401 .

Nesse sentido, o "valor acrescentado" do som e das músicas é constantemente analisado neste trabalho, até porque os filmes dirigidos por Moore estão repletos de músicas que constroem sentidos nas narrativas.

A forma como Moore dirige o filme, sua preocupação em reforçar o sentido da cultura de armas para seu espectador, remete ao que Carrière pontua acercada evolução

\footnotetext{
${ }^{400} C f$. MANN, Michael. "O império da incoerência”. Rio de Janeiro: Record, 2006, pág. 31.

${ }^{401}$ CHION, Michel. A Audiovisão: som e imagem no cinema. Lisboa: Edições Texto \& Grafia, 2011, p. 12.
} 
da linguagem cinematográfica. Para Carrière, "os cineastas perceberam que a memória de imagens pode, às vezes, ser mais forte e duradoura do que palavras e frases" Talvez, ciente disto, Moore enfatize suas mensagens ao espectador através de fotos, e imagens que algumas vezes são repetidas nos filmes e ainda acompanhadas de sons e músicas que configuram o sentido da cena e, portanto, a construção do "real". Carrière afirma que a imagem prevalece porque possui uma espécie de "poder" de acalentar e paralisar o espectador, e alerta para "o perigo de que repetidas imagens do mundo venham, em última análise, a tomar o lugar do mundo" 403 .

Tiros em Columbine faz justamente esse percurso de análise da cultura de armas e seus efeitos entre os grupos em conflito, como se pudesse apreender a "realidade".

O possível sentido que o filme alude a partir dessas imagens, que compreendem o início da história, é a de que Moore é um narrador legítimo, que entende do assunto, pois busca comprovar que tem uma história pessoal no uso de armas, também foi criado dentro dos costumes do seu país e, mesmo que tenha sido um adepto desta cultura, seu personagem questionará este costume e as implicações atuais. Assim, embora reafirme os costumes em torno dos usos de armas de fogo, apresentando sua vida familiar como exemplo, Moore se coloca como alguém capaz de repensar essas práticas que, conforme o filme constrói, tornaram-se cada vez mais prejudiciais para alguns grupos sociais, atingindo lugares considerados seguros como os subúrbios. De membro atirador da ANR, ele passa a criticar esse grupo e apontar a necessidade de rever esses costumes.

Acerca do esforço fílmico em reforçar para o espectador um ponto de vista específico, Carrière também fala do poder de persuasão que possuem as imagens fílmicas, mas que podem, ao mesmo tempo, convencer e decepcionar, ainda que se trate da "suposta honestidade objetiva do documentário". Com isto, o autor afirma que o poder das imagens pode parecer mais forte nos filmes de ficção do que no documentário “como se a realidade "verdadeira' fosse mais difícil de transmitir que a artificial" 404.

Ciente ou não deste processo de "fuga da realidade", Moore repete várias vezes o sentido de suas mensagens para que a ambiguidade do real não atrapalhe o que é proposto pelo discurso do filme. Ele se coloca como um bom atirador, o que pode ser mal interpretado por uma parcela do público, mas ao mesmo tempo está fazendo a crítica aos efeitos prejudiciais que incorrem no costume de usar armas de fogo,

\footnotetext{
${ }^{402}$ CARRIÈRE, Jean-Claude. A linguagem secreta do cinema. Rio de Janeiro: nova Fronteira, 2006, p. 22.

${ }^{403}$ CARRIÈRE, Jean-Claude. A linguagem secreta do cinema. op. cit., p. 100.

${ }^{404}$ CARRIÈRE, Jean-Claude. A linguagem secreta do cinema. op. cit., p.51.
} 
sobretudo, por pessoas que, como o filme indica, vivem sob uma rotina de medos de ataques, além de todo um contexto político-social de "vida líquida" ${ }^{405}$,com a diminuição do papel do Estado nas instituições e as incertezas nas relações de trabalho devido à reestruturação produtiva do capitalismo - temas tratados desde Roger e $E u^{406}$. Nesse sentido, o filme associará a crescente desigualdade social e falência do núcleo familiar como mais um ponto importante para o aumento dos números de mortes por armas de fogo no país.

Assim, como fez em Roger e Eu, elegendo o diretor da GM, Roger Smith, e em The Big One, com Philip Knight (ambos escolhidos como alvos das polêmicas tratadas nos filmes), no filme Tiros em Columbine o escolhido para personalizar o grupo em oposição é Charlton Heston - premiado ator de cinema e presidente de honra da Associação Nacional do Rifle na época do filme. Para valorar o sentido desta escolha, em seguida ocorre um rápido jogo de cena que propõe o início de um duelo entre Heston e Moore.

Após apresentar Charlton Heston, o filme rapidamente alterna imagens do ator e de Moore, indicando que são pessoas nascidas em um Estado onde se costuma caçar. Ambos estão no que parece ser uma floresta em dia frio, nublado e esfumaçado. Moore veste capa e boné laranja e aponta um rifle em direção oposta à imagem que mostra Heston apontando outra arma. Também armado com uma espingarda, Heston está vestido com capa marrom e chapéu cinza em um cenário também de floresta com neve. Em seguida, as cenas cortam rapidamente para cada um deles atirando em direção ao que seria supostamente o outro, porém ambos errando os tiros. Por conseguinte, caberá ao espectador seguir o filme até o fim para ter pelo menos um "balanço" daquele "duelo". A oposição construída pelo filme entre os personagens pode ser conferida nas direções opostas dos atiradores nas imagens e também nas cores das roupas que são diferentes. É como se imageticamente eles fossem colocados em posições opostas, tanto no suposto duelo quanto pelas suas posições políticas em torno do tema tratado no filme, com Heston a favor do porte de armas, sobretudo pelos cidadãos brancos, e com Moore contra o porte e a livre aquisição de munições por qualquer civil.

\footnotetext{
${ }^{405} C f$. BAUMAN. Zygmunt. Modernidade líquida. Tradução de Plínio Dentzien. Rio de Janeiro: Zahar, 2001.

${ }^{406}$ Esses temas remetem ao conceito depontos de fixação devido ao modo como permeiam os filmes analisados: a persistência do desemprego, a questão do medo, a violação dos direitos civis, ou até mesmo a própria dualidade com que os filmes são construídos já implicam em pontos de fixação (a persistência de dois lados opostos e inconciliáveis, a ausência de outros pontos de vista, a construção didática e repetitiva). $C f$. SORLIN. Pierre. Sociologia del cine: la apertura para la historia de mañana. México: Fundo de Cultura Econômica. 1985, p. 195-197.
} 
Após apresentar Michael Moore como narrador crítico e conhecedor do problema, eleger seu debatedor ou personalizar ${ }^{407}$ um grupo opositor na narrativa (Charlton Heston) para tematizar uma cultura pró-armas, o filme inicia um terceiro bloco, citando alguns usos de armas e suas consequências para a vida americana. A naturalização do uso de armas nos EUA toma ares de paródia com o humorista Chris Rock $^{408}$, conhecido por seus shows de comédia stand up. Na cena Chris Rock diz para sua plateia:

Não precisam controlar armas. Precisam controlar a munição! Acho que uma bala deveria custar 5 mil dólares! 5 mil por uma bala! Sabem por quê? Se uma bala custasse US\$ 5 mil, não matariam pessoas inocentes. Quando alguém levasse um tiro, diriam: ele deve ter merecido. Caramba! Meteram US\$ 50 mil em balas no rabo dele! Todos iriam pensar antes de atirar, se a bala custasse US\$ 5 mil.

E Chris interpreta uma discussão:

Cara, eu estouraria seus miolos se tivesse grana! Vou procurar outro emprego, começar a guardar dinheiro e vou te matar! Reze para que eu não possa pagar em prestações!

A plateia no show de Chris Rock se diverte com a "solução" para o uso das armas de fogo no país e, provavelmente, o público do filme. Se Carrière pontua o tédio como um elemento capaz de promover a crítica no espectador em relação ao filme assistido, os filmes de Moore parecem tentar evitar que qualquer nível de tédio invada seu espectador.

\footnotetext{
${ }^{407}$ Segundo Guy Gauthier "A personalização é levada ao extremo quando o diretor torna-se ele próprio uma estrela e "desce" do comentário, que mantém uma presença reservada do autor, mostrando sua imagem com mais ou menos complacência. Para o autor, Michael Moore se tornou uma espécie de "vedete do filme político" ao propor, com seus filmes, "todas as características do documentário americano de luta (personalização, virulência, não conformismo, pesquisa do espetacular, engajamento social e político)". In: GAUTHIER, Guy. O documentário: um outro cinema. Campinas, SP: Papirus, 2011, p. 331.

${ }^{408}$ Conhecido no Brasil como criador da série "Todo mundo odeia o Cris" exibida entre 17 e $18 \mathrm{hs}$ pela TV Record.
} 
Em Tiros em Columbine, a forma como a história é contada muda a todo o momento, ora aparecem cenas sem muito sentido como foram as iniciais e os personagens ainda desconhecidos, depois entram imagens animadas do jogo de boliche e da história de vida do irônico Moore. Em seguida entram artistas da televisão que "emprestam" sua popularidade a alguns temas do filme (como as piadas de Chris Rock), até chegar ao núcleo duro do filme que seriam as imagens captadas pelo circuito interno de segurança da escola, que registraram alguns momentos dos atentados em Columbine e que são alinhavadas com o áudio das chamadas telefônicas pedindo socorro - o que torna as sequências ainda mais dramáticas. Esse enredo é alternado como se promovesse no espectador uma montanha russa de sentimentos, de modo que este não tenha tempo para sentir aquilo que Carrière chamou de o velho e bom tédio,

Esta fascinante força da imagem tem obviamente seus limites. Podemos estar entorpecidos, mas as sentinelas cochilando dentro de nós ainda estão lá. Dentre elas, a principal é o tédio, o velho e bom tédio, esta nossa maravilhosa capacidade de perder o interesse, de instintivamente recusar a mediocridade que nos é oferecida. [...] De fato, como é possível nos persuadir, depois que o tédio se instala, de que não estamos entediados? Uma tarefa das mais difíceis, pois o tédio, o vigilante, que não deve satisfação ao cérebro, é inteiramente confiável e está constantemente em guarda ${ }^{409}$.

Assim, alternando imagens e sons, de modo que o tédio não tome conta do espectador e, consequentemente, implique na perda do interesse, o filme articula as cenas rapidamente e, em seguida, aponta para um grupo de pessoas que parecem compartilhar dos ideais de Charlton $\operatorname{Heston}^{410}$ ao seguirem a tradição da NRA e formarem uma milícia bem conhecida nos EUA - a Milícia do Michigan ${ }^{411}$.

Os milicianos treinam tiro em um campo com uma pequena barreira de terra no fundo e alguns pinos de boliche servindo de alvo. Para introduzir a sua explicação para

\footnotetext{
${ }^{409}$ CARRIÈRE, Jean-Claude. A linguagem secreta do cinema. Rio de Janeiro: Nova Fronteira, 2006, p. 67.

${ }^{410} \mathrm{Na}$ condição de membro honorário e vitalício, Heston foi presidente a RNA em 1998. Sobre sua atuação política dos EUA, em 1980 Heston trocou seu registro no Partido Democrata para o Partido Republicano e foi um dos defensores das campanhas de Ronald Reagan e dos Bush. Fonte: http://www.imdb.com/name/nm0000032/bio (Acesso em 20 de fevereiro de 2012).

${ }^{411}$ No site da organização, são disponibilizados treinamentos para os cidadãos americanos (brancos ou negros - excetuam-se os estrangeiros) interessados em defesa pessoal, do território, da Constituição e do "american way of life". Cf. http://www.michiganmilitia.com/ (acesso em 20 de fevereiro de 2012).
} 
aquelas imagens, Moore diz que se tratava de um local "não muito longe de onde eu e Charlton Heston crescemos". O local é chamado de campo de treinamento da Milícia do Michigan. Um atirador do grupo, que se veste com roupas semelhantes às fardas do exército (verdes como as da guerra do Vietnã), explica que utilizam as "garrafas" de boliche porque além de pequenas também representam os órgãos vitais de uma pessoa. Talvez essa relação entre boliche e as armas, apresentada pelos milicianos, seja a mais plausível de todo o filme, diferente da forma desconexa que as cenas de abertura introduziram as pessoas jogando boliche.

De outro modo, também é possível pensar que a junção do jogo de boliche aos clubes de tiro signifique uma associação de costumes típicos dos estadunidenses brancos, que, por sua vez, são construídos como paranoicos por autodefesa. Assim, o filme se contrapõe à ideia aparentemente "comum" de que a violência por meio de armas de fogo é predominante entre os negros, conforme as imagens retiradas de jornais televisivos e trazidas para o documentário sugerem - tanto na associação entre violência e abelhas africanas, quanto no seriado Cops, e ainda, com os inúmeros suspeitos negros que os jornais noticiam nas imagens trazidas para o documentário. Com isto, fica reforçado o sentido, proposto pelo filme, de que tanto o jogo de boliche quanto os clubes de tiro, as milícias, a NRA, e as facilidades de se comprar e usar armas de fogo seriam costumes de brancos. De modo geral, o filme não reforça o preconceito social contra os negros, embora indique relações de teor racista entre os grupos - outro ponto de fixação entre os filmes de Moore.

Enquanto as imagens apresentam os milicianos treinando tiro, a voz de Moore narra que aquele grupo ficou famoso em 19 de abril de 1995, quando dois de seus participantes, Timothy McVeigh e Terry Nichols, foram acusados de explodir um prédio federal em Oklahoma City, matando 168 pessoas. Durante a entrevista, integrantes do grupo miliciano alegam que não tinham ligação com os responsáveis pelo atentado em Oklahoma, e que o interesse da milícia era seguir uma "tradição americana", a qual preza que cada civil tenha uma arma para sua proteção. Enquanto tenta ajustar o cinto por cima de sua farda um miliciano diz:

É responsabilidade nossa estar armado. Se você não estiver armado, você não é responsável. Quem vai defender seus filhos e sua família? Os policiais? O governo federal? 
Os milicianos estariam alinhados aos valores defendidos por Charlton Heston e, simbolicamente, a um grande grupo construído pelo filme como sendo majoritariamente formado por pessoas brancas, principalmente homens. Os milicianos se dizem pessoas comuns, com empregos comuns, e responsáveis por sua própria segurança. Também alegam um sentimento de descrença nas ações do governo, o que os motivou a assumir a defesa de suas famílias, de sua integridade física e da propriedade privada.

A respeito das milícias dos EUA, Galvão informa que as ideias desses grupos os situam no grande grupo denominado como direita americana. Entre algumas características desses grupos a autora cita:

São essas ideias que distinguem a direita americana de outras. Primeiramente, a fervorosa defesa da Constituição e dos direitos civis, expressos na prerrogativa de comprar e portar todo tipo de armamento. Nessa concepção, a liberdade é garantida pelo conjunto de cidadãos armados: um homem desarmado é presa fácil da tirania. Em segundo lugar, a desconfiança, e resistência sem tréguas, ao governo e ao aparelho de Estado, a cujos serviços secretos atribuem uma conspiração em andamento para privá-los das armas. Acreditamse perseguidos pelo FBI e pela CIA, mas odeiam acima de tudo a ATF, Agência Federal do Tabaco, Álcool e Armas de Fogo, com filial no edifício dinamitado em Oklahoma City. E em terceiro, porque se concebem como legítimos herdeiros do espírito libertário que norteou a Guerra da Independência, quando os dominadores ingleses foram expulsos. Temendo o totalitarismo, recusam-se a pagar impostos, a ter um número de inscrição na previdência social e a cadastrar-se seja para o que for, numa afirmação de individualismo ${ }^{412}$.

Talvez para o espectador estadunidense o papel das milícias no país seja conhecido, e é bem diferente da definição de uma milícia, por exemplo, no Brasil. Entretanto, para o espectador não estadunidense as informações de Galvão auxiliam a perceber como os entrevistados de Moore seguem na direção das características expressas na citação anterior.

\footnotetext{
${ }^{412}$ GALVÂO, Walnice Nogueira. Sombras \& sons: recortes sobre cinema e música contemporânea. São Paulo: Lazuli editora: Companhia Editora Nacional, 2010, p. 123.
} 
Nas sequências do filme com a participação da Milícia do Michigan, Moore e um miliciano comentam as fotos de um calendário datado de 2002 em que aparecem mulheres chamadas de "Militia Babes". O calendário, que é vendido para angariar fundos para a milícia, contém fotos de mulheres com poucas peças de roupa e em poses que pretendem parecer "sensuais", mostrando também que elas exibem diferentes tipos de armas de fogo.

Acerca do imaginário social em torno da "receita hollywoodiana" que relaciona "a girl and a gun", Edgar Morin cita que imagens de mulheres portando armas são conhecidas do público estadunidense e sua cultura em torno do revólver, num simbolismo que remete aos "instintos reprimidos" e aos "desejos censurados". Conforme o autor:

Uma moça e um revólver. O erotismo, o amor, a felicidade, de um lado. De outro, a agressão, o homicídio, a aventura. Esses dois temas emaranhados, uns, portadores dos valores femininos, outros, dos valores viris, são, contudo, valores diferentes. Os temas aventurosos e homicidas não podem realizar-se na vida; eles tendem a se distribuir pejorativamente. Os temas amorosos interferem nas experiências vividas; eles tendem a se distribuir identificativamente. Os temas "femininos" constituem a polaridade positiva da cultura de massa, os temas "viris", a polaridade negativa ${ }^{413}$.

Aspectos, como o descrito acima, das construções "cristalizadas" em filmes de Hollywood permeiam o imaginário social estadunidense e podem ser vistos nos documentários de Moore tanto nos ícones da cultura pop, que são trazidos desde Roger $e E u$, quanto nos recortes de cenas retiradas da história do cinema e inseridas nos documentários para a construção das narrativas.

O calendário produzido pela Milícia do Michigan foi sinalizado na abertura de Tiros em Columbine entre as imagens que formam a cena síntese do filme. Ao final das sequências que propunham mais um "dia tranquilo" nos EUA, uma mulher em trajes de banho aparece com uma arma que se parece um fuzil M-16, isso pouco antes da Estátua da Liberdade, de modo que mais uma simbologia da história do cinema, (a girl and a gun), perpassa o documentário. Ao associar essas construções fílmicas ao imaginário

\footnotetext{
${ }^{413}$ MORIN, Edgar. Cultura de massas no século XX: Neurose. Rio de Janeiro: Forense Universitária,
} 1997, p. 110. 
social, diria Morin, "a cultura de massa nos entorpece, nos embebeda com barulhos e fúrias. Mas ela não nos curou de nossas fúrias fundamentais. Ela as distrai, ela as projeta em filmes e notícias sensacionalistas" ${ }^{414}$. Essa constatação de Morin vem de encontro aos problemas apresentados no filme, como se essa sociedade tão afeita ao cinema Hollywoodiano não soubesse mais distinguir "real" e imaginário.

Nesta direção, é possível pensar que desde os filmes de westerns até os atuais blockbusters, Hollywood propõe ao imaginário social histórias repletas de tiros, explosões e "dias de fúria" - semelhantes ao dos adolescentes assassinos de Columbine. Contudo, Tiros em Columbine parece construir um alerta de que cenas de fúria estariam como que "saltando" das telas de ficção para invadir o cotidiano das pessoas, deixando muitas vítimas pelo caminho.

De volta ao grupo de milicianos construídos em Tiros, uma mulher jovem e vestida com farda militar falará de sua participação no grupo. Nesta entrevista alguns membros da milícia estão com mulheres e crianças, numa espécie de apologia à proteção familiar como um bem acima de tudo. Enquanto a mulher fala do seu treinamento e preparo para se defender de possíveis inimigos, a câmera focaliza o rosto de um menino também fardado, que aparenta ter uns 12 anos de idade, mostrando ainda uma menina muito pequena, talvez de três anos de idade que parece filha da miliciana. A proposição de sentido que o filme pode sugerir é a de que tipo de adultos se tornarão essas crianças vivendo em meio a uma rotina de treinamentos, uso de armas e da possibilidade de "ataques inimigos", ou ainda constrói a naturalização do uso de armas de fogo. Segundo as cenas sugerem, é possível imaginar que velhas e novas gerações de estadunidenses convivem com revólveres, fuzis, espingardas e pistolas como se armas fossem "utensílios domésticos", o que sugere a banalização do manuseio dissociada dos riscos que possuem.

Interessante notar a diferença entre o que é construído pelo documentário Tiros em Columbine e como os milicianos receberam a visita de Moore para as filmagens utilizadas no filme. Em uma espécie de "arquivo de campo" com relatos dos principais treinamentos do grupo, consta um datado de 18-19 de novembro de 2000, chamado Militia \& Me,comentando rapidamente a visita de Moore ${ }^{415}$. Naquele dia os milicianos

\footnotetext{
${ }^{414}$ MORIN, Edgar. Cultura de massas no século XX: Neurose. op. cit., p. 118.

${ }^{415}$ http://www.michiganmilitia.com/fieldreports/nov2000/militiaandme.htm. (Acesso em 05 de fevereiro de 2012). Nos diversos relatos de treinamentos constam fotos em que se pode observar a presença de muitas crianças e adolescentes entre os grupos de milicianos, ao ponto de serem chamados de Junior
} 
treinaram tiros de longa distância, operações com máscara de gás e ficaram acampados para treinar "sobrevivência ao ar livre". A nota do grupo publicada no site informa que naquele dia estiveram presentes sete adultos e três crianças, outros milicianos não participaram das filmagens porque estavam aproveitando a recém-aberta temporada de caça. Ao final da nota, os milicianos dizem que Moore fez muitas perguntas, parecendo querer irritá-los e os fazer passar por idiotas, porém, na concepção do grupo, o cineasta não poderia entender que o bem estar de uma família valia todo aquele esforço.

Nas sequências de Tiros, novamente a cena corta para a mulher que fala da participação nos treinos da milícia e da sua necessidade de autodefesa, caso sinta algum risco ou sofra uma agressão. Enquanto ela fala, a câmera mostra sua filha pequena brincando dentro de uma barraca que abriga o grupo naquela noite. Eles se mostram bem equipados e é possível enxergar armas entre aquelas pessoas. Outra imagem focaliza o rosto de um garoto junto com um adulto segurando o que parece ser um rifle. O menino tem um olhar cansado e também está vestido com fardas. Ao focalizar essas duas crianças o filme leva a pensar que aquele grupo de milicianos estaria formando novas gerações de pessoas a favor do uso pessoal de armas e, em nova proposição de sentido, isso pode representar a perpetuação dos problemas decorrentes do uso de armas de fogo, sobretudo por civis jovens como foi o caso da Escola Columbine.

Embora o filme pareça relacionar a influência dos treinos das milícias e dos clubes de tiro com a possibilidade de "formar" pessoas violentas, outros aspectos sociais incorrem na formação das novas gerações, o que poderia diminuir o peso de uma única influência como a familiar, também observada na Milícia do Michigan. Do modo aparentemente isolado que o filme apresenta os milicianos, fechados em grupos familiares, organizados em uma espécie de disciplina militar e com o objetivo "paranoico" de autodefesa, o espectador poderia pensar que aquelas crianças podem reproduzir esses costumes de forma "mecânica", visto que estariam crescendo acostumados com diferentes tipos de armas.

Entretanto, a educação e a formação do indivíduo moderno não cabem exclusivamente ao grupo familiar. No sentido da educação das novas gerações, Durkheim aponta em "A educação moral" que o ideal para os jovens seria uma "educação puramente racionalista" ${ }^{416}$, isto é, na direção de uma formação plural e laica

Militia Corps. Cf. http://www.michiganmilitia.com/JMC2011/JMCAug2011.htm (Acesso em 05 de fevereiro de 2012).

${ }^{416}$ DURKHEIM, Emile. La Educación Moral. Buenos Aires:Editorial Losada, S.A, 1974, p. 11. 
que não parte unicamente da família, mas também da escola (pública), sendo livre de influências religiosas, embora cultive valores éticos que também podem ser encontrados nas religiões. A educação racionalista pensada por Durkheim se apoia na autoridade da razão e não na autoridade religiosa, o que, em tese, parece contrariar alguns princípios morais dos estadunidenses que acreditam na "Providência Divina" e no papel moral que a religião cristã exerce no país, como foi apontado em Roger e Eu.

Contudo, como a instituição escolar emerge em um contexto de modernidade com a racionalização não apenas da produção material como também da formação das futuras gerações de profissionais, a ideia durkheimiana de educação racionalista auxilia a compreender que o papel da educação não estaria restrito, ou pelo menos não deveria estar, ao contexto familiar. No caso das crianças e adolescentes que entram em contato com os clubes de tiro, não é possível afirmar que isso seja algo necessariamente deletério em suas vidas, pois o próprio Michael Moore pode ser tomado como "exemplo" de quem cresceu dentro desse costume e foi capaz de produzir um filme propondo repensar esta cultura.

De modo geral, Durkheim associa três influências básicas para a formação moral de uma pessoa:

Familia, patria, humanidad representan distintas fases de nuestra evolución social y moral, que se han preparado unas a otras y, por consiguiente, los grupos correspondientes pueden superponerse sin excluirse. Así como cada uno de ellos representa su papel en la continuidad del desarrollo histórico, se complementan recíprocamente en el presente; cada uno tiene su función. La familia envuelve al individuo de manera distinta que la patria y responde a otras necesidades morales. No es necesario hacer una elección exclusiva entre ellos. El hombre es moralmente completo sólo cuando se somete a esta triple acción ${ }^{417}$.

Assim, da mesma forma que Moore participou da cultura pró-armas e, mesmo assim, propõe questionar os efeitos nocivos que isto implica, as crianças que convivem com as milícias podem receber outras influências em sua formação, de modo que também possam confrontar valores herdados.

\footnotetext{
${ }^{417}$ DURKHEIM, E. La Educación Moral. Buenos Aires: Editorial Losada, S.A, 1974, p. 76.
} 
$\mathrm{Na}$ sequência do filme, apesar de um miliciano alegar que eles não são extremistas ou racistas, a transmissão de valores entre grupos predominantemente brancos e a defesa desses valores com o auxílio de armas, sugere que os inimigos dos milicianos podem ser, inclusive, as minorias de seu país - sobretudo se for considerada a crescente desigualdade social já sinalizada em Roger e Eu e em The Big One, com o empobrecimento de muitos trabalhadores desempregados e a forma como estes filmes aliam declínio econômico e aumento dos índices de violência.

Tiros em Columbine sugere que as milícias não seriam "lugar" para pessoas não brancas porque, após apresentar esses grupos armados e sua preocupação com autodefesa, o filme segue para as imagens da repressão policial aos negros. O filme denuncia relações de preconceito racial evidenciando que os negros são tratados como perigosos em alguns canais de TV. Para isso, são lembradas matérias “jornalísticas" que buscam naturalizar uma relação entre negro e criminalidade assim como seriam as "perigosas" abelhas africanas em relação às "pacíficas" abelhas europeias, e também ao programa televisivo Cops, em que a maioria, senão a totalidade dos "criminosos" são pessoas de pele negra. Com isto, o filme remete à questão racial como uma espécie de componente dos motivos para o medo e violência nos EUA - algo que a entrevista com Charlton Heston irá corroborar.

Contudo, no site do grupo, os milicianos reafirmam que não são racistas e como se quisessem provar isto, incluem algumas mulheres negras em seus calendários "Militia Babes" "18. Apesar do discurso em relação à tolerância de negros na milícia, é possível notar, nas diversas fotos de treinamentos, que a maioria dos milicianos do Michigan são homens e mulheres brancos - a presença de negros é muito reduzida ou quase inexistente. Isso pode sugerir que além do discurso aparentemente liberal (o que na política dos EUA quer dizer pró-minorias), algum “detalhe” desta tradição, talvez sua suposta aproximação com a antiga KKK, não parece torná-la atrativa para os negros. E ainda, por se tratar de um grupo que busca um padrão de vida típico da antiga referência de "classe média" 419 , seus membros devem ser pessoas dispostas a gastar com

\footnotetext{
${ }^{418} \mathrm{http}$ //michiganmilitia.com/friends/gallery/gallery2.htm. (Acesso em 12 de fevereiro de 2012).

${ }^{419}$ Pensada neste ponto a partir de Giddens no sentido de englobar um grupo de trabalhadores denominados white-collar como sendo os não manuais e não proprietários. $\mathrm{O}$ aumento relativo deste tipo de trabalhador se deu nos Estados Unidos, "recentemente aclamado como a primeira sociedade de classe média". GIDDENS, A. "O crescimento da nova classe média". IN: GIDDENS, A. A estrutura de classes das sociedades avançadas. Rio de Janeiro: Zahar Editores, 1975, p. 217. O autor também relaciona os trabalhadores de "colarinho branco", como o miliciano de Tiros que disse trabalhar como corretor de imóveis, às "ocupações de escritório e de vendas (...), trabalho profissional e técnico" além de outras
} 
equipamentos e tudo o que envolve a participação nos eventos das milícias, algo que parecem ter um custo econômico considerável.

Nesse sentido, como foi construído em The Big One, pessoas negras teriam mais dificuldades para sair da linha da pobreza, o que as distancia muito da possibilidade de "brincar de Comandos em Ação", a menos que forem literalmente para a Guerra, como construirá o documentário Fahrenheit $9 / 11^{420}$.

Um dos entrevistados da milícia do Michigan disse que eles moram no subúrbio, localizando-os socialmente como pessoas que ainda desfrutam das possibilidades de conforto e consumo idealizados pelo "american way of life" (o mesmo ideal compartilhado pelos personagens de Roger e Eu e The Big One). Além do afastamento dos centros urbanos, outra característica dos subúrbios são as casas construídas em série, cuja proposta das imobiliárias era a de reproduzir a vida pacata do campo com o conforto da cidade. Os subúrbios foram símbolo do governo de Eisenhower e Nixon quando tudo funcionava ou parecia funcionar perfeitamente na vida do "average american”, isto é, o americano médio, temente a Deus, defensor da tradição, avesso a grandes novidades urbanas ${ }^{421}$.

Em relação à vida dos milicianos e a temporada de caça que também é um costume motivador para a prática de tiro, Mike Davis afirma que devido o avanço das cidades para áreas repletas de animais, inúmeros casos de mortes envolvendo pessoas atacadas por ursos, leões, pumas ou panteras, contribuíram para instalar um sentimento de histeria entre populações locais, e isso alimentou o constante desejo para o porte de armas também entre os habitantes das periferias selvagens ${ }^{422}$.

Conforme Davis;

A aparição inesperada de vida selvagem de grande porte nos quintais da cidade é às vezes interessante, mas, com mais frequência, assustadora. Coiotes e pumas, em particular, tornaram-se símbolos da desordem urbana. [...]. O subúrbio ideal é vizinho à natureza, mas sem

ocupações não manuais. In: Giddens, A. A estrutura de classes das sociedades avançadas. op. cit., p. 215- 219.

${ }^{420}$ Em alusão ao depoimento de um soldado negro no filme Fahrenheit 9/11, e a forma como enxergava ir para à guerra, o que lhe parece uma "imposição" do Senado Americano, isto é, a única opção de trabalho oferecida aos pobres e aos negros.

${ }^{421} C f$. TOTA, Antônio Pedro. Os americanos. São Paulo: Contexto, 2009, p. 198.

${ }^{422} C f$. DAVIS, Mike. Comedores de carne humana da Sierra madre. In: Ecologia do medo. Rio de Janeiro: Record, 2001, p. 189-199. 
envolvimento direto com ela. Criaturas selvagens não são mais bemvindas dentro dos limites de um loteamento do que as humanas ${ }^{423}$.

E cabe ressaltar que esta relação dos moradores do subúrbio com a vida selvagem criou uma interessante comparação usada pelos "suburbanos" em sua relação com os habitantes do centro, visto pejorativamente como um lugar degradado. Segundo aponta Davis;

De fato, na mente da maioria dos moradores dos subúrbios, a indisciplina reinante no centro da cidade está figurativamente reproduzida em sua periferia. Não é de surpreender que os predadores [ele fala dos animais] sejam criminalizados como invasores de propriedades e associados a serial killers e gangues de estupradores. De modo recíproco, a classe inferior urbana é permanentemente animalizada como "predadores", "juventude selvagem" e "alcateias de lobos" na wilderness urbana ${ }^{424}$.

Assim, conforme pontua Davis, as contradições sociais ganhariam interpretações espelhadas às da natureza, ou ainda às relações entre homens e animais. Essas referências são trazidas por Tiros em Columbine, principalmente, através das reportagens televisivas e dos inúmeros especialistas que tentarão explicar o comportamento dos jovens assassinos na Escola.

Acerca da vida tranquila e idealizada, como era proposta pelos vendedores e moradores de casas nos subúrbios, os milicianos podem representar a luta incessante pela manutenção desse ideário, sem perceber que, talvez, na prática, essa tranquilidade nunca tenha existido. Se no período da Guerra-Fria temia-se o "avanço dos comunistas ateus", na narrativa de Tiros é possível imaginar o surgimento de novos "inimigos", como por exemplo, as mudanças impostas pela globalização dos mercados e as transformações no mundo do trabalho - essas últimas exploradas pelos dois filmes iniciais de Moore que apontaram, principalmente, ameaças ao american way of life.

\footnotetext{
${ }^{423}$ DAVIS, Mike. Comedores de carne humana da Sierra madre, op. cit., p. 199.

${ }^{424}$ DAVIS, Mike. Comedores de carne humana da Sierra madre. In: "Ecologia do medo". Rio de Janeiro: Record, 2001, p. 199. Lembrando que conforme pontua Davis, wilderness seria usado para sinalizar uma "região selvagem e desabitada", mas o autor prefere esse termo ao uso de wild (selvagem), p. 196.
} 
Anthony Giddens afirma que, ao contrário do que comumente se pensa, a globalização é um fenômeno que afeta o cotidiano das pessoas, seus costumes, valores e toda a forma como conduzem suas vidas. Conforme pontua o autor,

Es un error pensar que la globalización sólo concierne a los grandes sistemas, como el orden financiero mundial. La globalización no tiene que ver sólo con lo que hay "ahí fuera", remoto y alejado del individuo. Es también un fenómeno de "aquí dentro", que influye en los aspectos íntimos y personales de nuestras vidas. El debate sobre valores familiares que se desarrolla en muchos países puede parecer muy apartado de las influencias globalizadoras. No lo está. ${ }^{425}$

Para Giddens, as noções de nação, família, trabalho, tradição, natureza não são iguais ao que eram no passado ${ }^{426}$.Nesse sentido, é possível imaginar que os milicianos buscam manter-se aos moldes da "modernidade pesada" conforme propõe Bauman em seu livro: "Modernidade Líquida".

Acerca dos valores dos milicianos e sua preocupação em defendê-los, diante da liquidez da vida na atual modernidade, diria Bauman que esses grupos parecem querer o ordenamento em meio ao caos. Segundo o autor, quando as coisas não estão na ordem que as pessoas esperam, elas passam a se preocupar com a ordem. Por sua vez, se as coisas estão fora de ordem, as pessoas acreditam que devem tomar atitudes para colocar as coisas novamente em ordem. Na modernidade pesada, as pessoas sentiam seu presente e futuro mais ou menos em ordem, pois a coesão da sociedade fechada era mais ou menos definida a partir do local de nascimento e origem social da pessoa. Com a fluidez do capitalismo moderno, a temida mudança pode ser imposta pela falta de estabilidade no emprego, a desatualização dos saberes, ou ainda pela necessidade de mais anos de formação profissional.

A estabilidade de um grupo social também pode ruir em razão da abertura do mercado para a mão de obra mais barata (e a consequente migração de grupos humanos e suas culturas), ou com o fechamento de uma fábrica que empregou gerações de pessoas em uma localidade. De modo geral, perder o trabalho em uma sociedade

${ }^{425}$ GIDDENS, A. Un mundo desbocado: Los efectos de la globalización en nuestras vidas. Madrid: Grupo Santillana de Ediciones, S.A., 2000, p. 24-25.

${ }^{426} \mathrm{Cf}$. GIDDENS, A. Un mundo desbocado: Los efectos de la globalización en nuestras vidas. Madrid: Grupo Santillana de Ediciones, S.A., 2000, p. 31. 
capitalista significa também perder a dignidade. Conforme pontua Sennett, "a sociedade ocidental teve de esperar a chegada do capitalismo moderno para que a ideia da dignidade do trabalho viesse a se tornar um valor universal" ${ }^{427}$. E esse valor permeia todos os filmes de Michael Moore.

Ao conceder entrevistas os milicianos se queixam do governo, falam de suas profissões (um desenhista, um corretor de imóveis, um motorista de caminhão, um desempregado). Com exceção de um que está desempregado, as profissões dos demais milicianos os estratificam na "classe média", o que historicamente nos EUA foi sinal estabilidade social. Quando falam dos tipos de armas que possuem em suas casas, os milicianos qualificam suas moradias situando-as no subúrbio, localidade típica daqueles que se refugiam dos grandes centros, que preferem habitar em comunidade com uma vizinhança fixa, branca e que compartilhe dos seus valores. O filme mostra outras comunidades de subúrbio, como em Littleton, e a "paranoia" de vigilância entre os moradores que chegam a colocar avisos na fachada das casas para que os "outros" saibam que aquela comunidade se vigia mutuamente.

Acerca da vida no subúrbio, e a segregação racial que isto implicava nos EUA, Michael Moore conta que quando morava em Davison, Flint contava com 50 mil negros e os corretores de imóveis tinham um acordo tácito para impedirem que famílias negras saíssem de Flint para morarem em Davison. Ele também afirma que e a maioria das famílias nunca vendiam suas casas para uma família negra, e, segundo o cineastaescritor: "isso manteve as coisas agradáveis, pacatas e brancas por décadas"

Nessa direção, Tiros em Columbine sugere que para os estadunidenses, uma casa no subúrbio representaria a consagração do american way of life, sinal de prosperidade e de ter atingido um patamar mínimo de felicidade. Após 1960,

Os subúrbios, construídos em ritmo alucinante, mudaram a paisagem do país: de costa a costa, longas e arborizadas ruas, casas assobradadas com cercas de madeira e um carro na garagem se multiplicavam, consolidando a emergência de uma enorme classe média. [...] Todavia, a propagação dessa sociedade afluente não era livre de problemas. Sob o verniz da riqueza e prosperidade, a classe média americana suprimia suas contradições com equivalente

\footnotetext{
${ }^{427}$ SENNETT, R. Respeito: a formação do caráter em um mundo desigual. Rio de Janeiro: Record, 2004, p. 76.

${ }^{428}$ MOORE, M. Adoro problemas: histórias da minha vida. São Paulo: Lua de Papel, 2011, p. 126.
} 
disposição. Uma vez que o fator determinante da unidade nacional era a luta contra o comunismo, não é de surpreender o surgimento de um clima de repúdio e paranoia a tudo que se afastasse do "ideal americano", entenda-se, um ideal de conformismo ${ }^{429}$.

Os milicianos parecem pessoas afeitas à crença em uma sociedade idealizada, como fora sugerido na abertura de Roger e Eu, cultivando valores acerca do trabalho e da felicidade via consumo, através da segurança trazida pela estabilidade econômica. Não é de se estranhar que estejam cada vez mais assustados com as transformações por que passa esta sociedade no capitalismo flexível, na fluidez dos valores e na corrosão do caráter de que tratou Sennett. Deve ter sido difícil para os estadunidenses acreditarem que o atentado ao prédio federal em Oklahoma tivesse partido de um jovem, veterano de guerra e miliciano como Timothy McVeigh ${ }^{430}$.

Como informa Walnice Galvão, McVeigh constituía um membro exemplar da direita americana. Filho de operários da "classe média" cresceu perfeitamente integrado na comunidade de Lockport. Sem ficha policial, nem multas de trânsito, e de comportamento disciplinado, o herói de guerra recebeu diversas condecorações por sua atuação na Guerra do Golfo, em 1991. Ao final da guerra, McVeigh ficou desempregado e o "posto" de segurança particular não agradava o soldado exemplar que preferiu - como se tivesse escolha diante da fluidez trabalho - ficar à deriva, participando apenas de uma Milícia na qual encontraria terreno fértil para expressar suas ideias e planejar um atentado contra o governo federal. Após os atentados e toda repercussão midiática que promoveu, diferentes especialistas tentavam "explicar" McVeigh. Alguns defendiam a tese de insanidade mental, como se "insanidade" fosse preferível à racionalidade e os objetivos que não pouparam muitas vidas humanas. Nesse sentido, Galvão afirma que os laudos médicos não indicaram qualquer alteração no comportamento psiquiátrico do acusado ${ }^{431}$.

\footnotetext{
${ }^{429}$ TOTA, A, P. Os americanos. São Paulo: Contexto, 2009, p. 190-191.

${ }^{430} \mathrm{Em}$ um primeiro momento, os árabes foram acusados pelos ataques ao prédio em Oklahoma, contudo McVeigh foi detido algumas horas depois por fugir da cidade em um carro sem placas. Mais tarde foi confirmada sua participação nos crimes, pois mesmo tendo suas partes arremessadas à longa distância, o número do eixo do caminhão Ryder (um veículo muito comum usado para entregas) permaneceu intacto. Cf. GALVÂO, Walnice Nogueira. Sombras \& sons: recortes sobre cinema e música contemporânea. São Paulo: Lazuli Editora: Companhia Editora Nacional, 2010, p. 121- 125.

${ }^{431}$ GALVÂO, W. N. Sombras \& sons. op.cit. p.121- 125.
} 
Mc Veigh foi herói de guerra treinado para defender os EUA, e partícipe do orgulho de ser americano ${ }^{432}$. Foi capaz de precisar os detalhes de um atentado que derrubou grande parte de um prédio repleto de escritórios do governo federal, o qual abrigava três instituições em desacordo com suas crenças, o FBI, a CIA e a ATF.

Talvez McVeigh não seja apenas exemplo do radicalismo direitista nos EUA, como pensou Galvão ${ }^{433}$, mas também, como tratou Sennett ${ }^{434}$, de corrosão do caráter em uma sociedade de valores fluidos, cambiantes e que atravessa o fim das estabilidades observadas na modernidade pesada, como define Bauman ${ }^{435}$.

Para Sennett, "Talvez o aspecto da flexibilidade que mais confusão causa seja seu impacto sobre o caráter pessoal [...] é o valor ético que atribuímos aos nossos próprios desejos e às nossas relações com os outros" ${ }^{436}$.

Talvez McVeigh represente o caráter contraditório entre alguns estadunidenses, o que parece, nos termos de Durkheim viver diante da anomia social ${ }^{437}$ e o afrouxamento dos laços de solidariedade que seriam a base da coesão social nas sociedades industriais.

Nas cenas que constroem a milícia é possível imaginar que, na tentativa de organizar sentimentos como medo e insegurança diante das transformações sociais, aquele grupo parece buscar algo que ofereça coesão, como a observação de uma disciplina militar, o treinamento constante, a socialização de ideais entre suas famílias, a sensação de indissociação promovida pelo fardamento. E ainda, os milicianos parecem saudosistas de modos de vida alinhados aos tempos de modernidade pesada, em que de rígidos padrões sociais mantinham os indivíduos em rotina e, portanto, em ordem.

Nesta direção, os milicianos mantém a solidariedade entre seu grupo valendo-se da observância das leis, sobretudo àquelas que asseguram os direitos relacionados aos valores correspondentes à sua ideologia, como a proteção da propriedade privada, a segurança pessoal e familiar, além do direito à autonomia e, consequentemente, a busca

\footnotetext{
${ }^{432} \mathrm{O}$ documentário Carrier: mais um dia no paraíso - (EUA, 2008) - indica que, além do treinamento com os artefatos bélicos, os militares são psicologicamente insuflados a reverenciar o modo americano de vida com todos os seus direitos intrínsecos, sobretudo o da felicidade através do consumo.

${ }^{433}$ GALVÂO, W. N. Sombras \& sons, op.cit., p. 121- 125.

${ }^{434}$ SENNETT, R. A corrosão do caráter: as consequências pessoais do trabalho no novo capitalismo. $10^{\mathrm{a}}$ Ed. - Rio de Janeiro: Record, 2005.

${ }^{435} C f$. BAUMAN, Z. Modernidade líquida. Rio de Janeiro: Jorge Zahar Ed. 2001.

${ }^{436}$ SENNETT, R. A corrosão do caráter, op cit., p. 10.

${ }^{437}$ Conforme pontua o autor, quando a divisão do trabalho não produz ou mantém laços de solidariedade, a sociedade pode entrar em um estado de anomia ou desorganização, o que pode ser caracterizado pelo desregramento das atividades humanas e a consequente perda dos laços sociais que mantêm os indivíduos unidos e em ordem. DURKHEIM, E. A divisão do trabalho anômica. In: Da divisão do trabalho social. São Paulo: Martins Fontes, 1999, p. 367 - 416.
} 
pela felicidade. Esses grupos se valem da complexidade das leis estadunidenses, do direito restitutivo e das formas jurídicas típicas das sociedades avançadas - dado o seu grau de complexidade com tribunais de toda espécie, para nutrir a forma de solidariedade orgânica.

Ao falar das formas de solidariedade, Durkheim conceitua a solidariedade orgânica como formas de relações sociais reguladas pelo "direito cooperativo com sanções restitutivas e a solidariedade que elas exprimem resultam da divisão do trabalho social" $" 438$.

Os membros da Milícia do Michigan se valem do direito ao porte de armas e do dever de portá-las para uso pessoal como uma forma de cidadania. Assim, em sua particularidade, os milicianos ganham destaque na narrativa ao serem construídos como um grupo significativo cujos ideais anseiam a manutenção de um padrão de vida e da coesão em torno de valores comuns que visam à perpetuação da crença em torno do american way of life. Independentemente do grau de inserção que os indivíduos conseguem obter nesta sociedade, o mais importante é o aspecto simbólico que o modo de vida estadunidense ocupa no imaginário social, promovendo formas de solidariedade, e a luta diária em torno de um ideal de vida.

Nesse sentido, embora a solidariedade orgânica seja uma solidariedade pautada na diferenciação e não na similitude (como a forma mecânica ${ }^{439}$ ), a regulação social via direito civil estabelece uma relação jurídica entre pessoas e coisas, como o direito à propriedade privada. Nas palavras de Durkheim,

Em resumo, as regras relativas aos direitos reais e às relações pessoais que se estabelecem em sua ocasião formam um sistema definido que tem por função, não ligar as diferentes partes da sociedade umas às outras, mas, ao contrário, pôr umas fora das outras, assinalar nitidamente as barreiras que se separam. (...) A primeira condição para

\footnotetext{
${ }^{438}$ DURKHEIM, E. A divisão do trabalho anômica. In: Da divisão do trabalho social. São Paulo: Martins Fontes, 1999, p. $367-416$.

${ }^{439}$ Conforme Durkheim, "o vínculo de solidariedade social a que corresponde o direito repressivo é aquele cuja ruptura constitui o crime" (pág, 39). Nessa forma de solidariedade a consciência coletiva define quais formas de crime são passíveis de pena e, nesses casos, a penalidade não passa pela restituição do bem ou da quebra de uma regra e sim no sofrimento do agente da ação criminosa. Nessa forma de solidariedade, "o crime ofende sentimentos bastante gerais e enérgicos", (pág, 51). Importante destacar que nessa forma de solidariedade social a natureza do ato criminoso é definida pelo grupo, podendo variar entre as diferentes sociedades primitivas ou de organização mais simples. In: DURKHEIM, E. Solidariedade Mecânica ou por similitudes. In: Da divisão do trabalho social. São Paulo: Martins Fontes, 1999 , p. $39-83$.
} 
que um todo seja coerente é que as partes que o compõem não se choquem em movimentos discordantes. (...) Com efeito, os direitos dos indivíduos, tanto sobre si mesmos como sobre as coisas, só podem ser determinados graças a compromissos e a concessões mútuas, pois tudo o que é concedido a uns é necessariamente abandonado pelos $\operatorname{outros}^{440}$.

Consequentemente isso une os membros do grupo, como o caso dos milicianos, mantendo a coesão em torno dos valores da inviolabilidade de suas residências, do seu patrimônio e da segurança de suas famílias - tudo através do porte e direito ao uso de armas de fogo como prevê a constituição dos EUA.

Apesar de o filme sugerir um clima de paranoia entre o grupo de milicianos, Moore não fez perguntas complicadas para aquelas pessoas, não buscou nenhum confronto direto com eles, não os "culpou" por encherem suas casas de armas, não sugeriu que seus filhos as usem contra os colegas de escola, nem os colocou "contra a parede", como fará com Charlton Heston. A postura de Moore diante dos milicianos parece curiosa, e porque não, contraditória, já que vem de um diretor conhecido por sua destreza em usar as falas de seus entrevistados contra eles mesmos ${ }^{441}$.

De modo geral, os seguintes fatores podem contribuir para a perda da solidariedade social e da ordem que a caracteriza: as crescentes incertezas da globalização dos mercados, o esmaecimento das fronteiras culturais e regionais, a flexibilização das relações de trabalho, a exigência de novos saberes, a constante perda dos antigos postos de trabalho (questões tratadas em Roger e Eu e The Big One), a necessidade de migrar em busca de oportunidades e conviver com a chegada de imigrantes, o aumento das desigualdades sociais e os crescentes índices de criminalidade. Segundo Bauman,

Por causa de suas conexões insípidas, porém íntimas, com o estado da incerteza, a "impureza" das classificações, a nebulosidade e a

\footnotetext{
${ }^{440}$ DURKHEIM, E. A solidariedade devida à divisão do trabalho ou orgânica. In: Da divisão do trabalho social. São Paulo: Martins Fontes, 1999, p. 95.

${ }^{441}$ Como ele fez com a Miss Michigan e com alguns artistas da GM em Roger e Eu, com o lobista da GM ou como fez com Knight em The Big One.
} 
porosidade das fronteiras são fontes constantes de medo e agressividade inseparáveis dos esforços de criar e manter a ordem ${ }^{442}$.

Assim, é possível afirmar que os milicianos buscam a ordem para sua comunidade moradora do subúrbio, querem a manutenção dos seus trabalhos, querem se proteger de tudo o que consideram fora dos padrões, como as diferenças entre classes sociais (pobres), de cor da pele ou religião (o não cristão). Enquanto os centros ficam ocupados por imigrantes de diversas origens e afro-americanos, o subúrbio é o refúgio da classe média branca, cristã e de valores conservadores, preocupada com a manutenção do seu padrão de vida, com a inviolabilidade de suas residências bem equipadas, além da integridade física e moral de seus membros.

Acerca das rápidas transformações que marcam a sociedade no filme, diria Bauman,

No mundo que se globaliza, a ordem se transforma no índice de falta de poder e subordinação. A nova estrutura de poder global é operada pelas posições entre a mobilidade e sedentarismo, contingência e rotina, rarefação e densidade de imposições. É como se o longo trecho da história que começou com o triunfo dos sedentários sobre os nômades estivesse chegando ao final ${ }^{443}$.

O papel das milícias em Tiros em Columbine pode, também, estar associado a esta dificuldade em lidar com as mudanças, a perda de antigos modos de vida, a necessidade de transformação diante das novíssimas demandas do capitalismo globalizado, que abre e fecha rapidamente as empresas, interfere na estabilidade de centenas de postos de trabalho, impossibilita a fruição do american way of life e, em consequência, promove o declínio da "classe média". Com isto, parece que os milicianos estão dispostos a se organizar e batalhar, literalmente, pelo direito de levarem uma vida "simples" - dentro dos padrões da felicidade americana.

Outro ponto explorado pelo filme, que também vai ao encontro dos interesses dos milicianos por sugerir um clima de "paranoia social", é o histórico de segregação

\footnotetext{
${ }^{442}$ BAUMAN, Z. A sociedade individualizada: vidas contadas e histórias vividas. Rio de Janeiro: Jorge Zahar Ed., 2008, p. 47.

${ }^{443}$ BAUMAN, Z. A sociedade individualizada: vidas contadas e histórias vividas. Rio de Janeiro: Jorge Zahar Ed., 2008, p. 49.
} 
racial do país. Para isso, o documentário explora o tema do medo pela frequência com que esse sentimento é incentivado através das notícias na televisão. As imagens de alguns noticiários "alertam" a população a respeito dos temores de invasão das abelhas africanas cujo comportamento "agressivo" pode matar uma pessoa rapidamente, o oposto do que fariam as dóceis abelhas europeias. Associando esta ideia ao programa televisivo de ação policial conhecido por Cops, o filme faz alusão a uma parcela do imaginário social que enxerga na pessoa de pele negra um perigo em potencial contra os valores dos grupos brancos. O criador do programa Cops é entrevistado e diz que não enxerga outra fórmula para audiência fora deste formato de programa - em que pessoas negras são filmadas em perseguições e capturas policiais, de preferência, espetaculares $^{444}$.

Nas sequências, ainda no bloco das consequências de uma cultura pró-armas, o filme apresenta de modo mais detido o caso de James Nichols. James foi acusado de contribuir para o atentado, porque chegou a fazer pequenas bombas em sua fazenda com seu irmão e McVeigh. Nichols é proprietário de uma fazenda onde planta alimentos orgânicos e, para defender suas terras, também possui uma arma municiada conforme mostrará para Moore, assustando o diretor ${ }^{445}$.

James fala abertamente contra o governo, por "explorar e escravizar as pessoas", talvez se referindo à carga de impostos. O filme se demora nas falas de James, seu discurso radical o alinha ao grupo de milicianos e ao tipo de cidadão que não acredita no Estado, enxergando o governo como explorador do povo.

A origem histórica desse discurso, dos milicianos e o de James Nichols, pode ter raízes no tempo em que os EUA lutavam para ser uma federação diante da presença incômoda da Inglaterra e da França disputando territórios na América, o que alimentou a formação de milícias de civis para proteção do território e auxílio do governo.

\footnotetext{
${ }^{444}$ O TV Show Cops é uma espécie de reality ou programa de não ficção, veiculado nas noites de sábado desde 1988 pelo canal FOX. Cops apresenta ocorrências policiais nos EUA com imagens "flagrantes" de perseguições e capturas de supostos infratores da lei, construídos conforme a música tema do filme como Bad Boys. Ao privilegiar imagens de negros em situações que envolvem ocorrência policial, o seriado constrói de forma pejorativa essas pessoas como criminosos em potencial. Algumas imagens deste programa podem ser conferidas em: http://www.youtube.com/user/copstv (acesso em 25 de março de 2012).

${ }^{445}$ Em uma entrevista fora do filme apresentada nos extras do DVD de Tiros em Columbine, Moore diz que a cena que eles estão no quarto do fazendeiro, quando foram conferir se existia uma pistola carregada embaixo do travesseiro, foi um momento tenso para a equipe, pois o homem que parecia tranquilo nas entrevistas teve um momento de aparente desequilíbrio psicológico, brincando de colocar a arma contra a própria cabeça na frente do cineasta, que ficou imobilizado.
} 
Conforme pontua Schama, as milícias nos EUA existem desde antes da Guerra da Independência quando cidadãos comuns se uniam para proteger família, terras e seus vilarejos. As milícias são consideradas exércitos de voluntários desde os tempos de George Washington e também representam um ponto de preocupação para os governos, pois podem tanto auxiliar na defesa do país quanto se rebelar por questões internas como a "rebelião do uísque" de $1791^{446}$.

Nas sequências do filme, a imagem mostra James enquanto fala ostensivamente contra o governo. A câmera focaliza seu rosto mais à esquerda da tela, ignorando uma pilha de papéis que estão no balcão atrás do entrevistado o que pode denotar alguma desorganização. Nichols é um homem de discurso firme e o modo como concede sua entrevista, carregada de gestos e olhos bem abertos, sugere um ar ameaçador ou, talvez, até algum desequilíbrio mental. Essa ideia de que o fazendeiro seria uma pessoa desequilibrada será corroborada pelo filme na última fala de James. Contudo, antes de fechar esse bloco de consequências dos usos de armas de fogo, com pessoas mais alinhadas à Charlton Heston e, portanto, a favor do armamento, o filme inclui a entrevista de dois jovens em busca de informações a respeito dos assassinos da escola Columbine.

Um corte na imagem de James Nichols e um jovem de olhar cansado com um lenço na cabeça, fala sobre sua cidade Oscoda:

\section{"O defeito de Oscoda é produzir lunáticos."}

Moore informa o espectador dizendo que Oscoda é uma cidade de Michigan situada do outro lado da fazenda de James. No momento em que Moore inicia sua narrativa sobre os personagens de Oscoda, o filme toca uma música de piano que deixa a cena melancólica preparando o espectador para os acontecimentos mais trágicos que irá contar.

O jovem de lenço na cabeça se chama Brent e seu amigo chama-se DJ. Ambos conheceram pouco da história dos atiradores de Columbine. Um dos atiradores em Columbine chamava-se Eric Harris, e viveu parte de sua infância na Base Aérea de Oscoda, pois seu pai (Wayne Harris) era piloto e serviu na Guerra do Golfo. O filme informa que da base aérea de Oscoda teriam partido $20 \%$ das bombas lançadas na

\footnotetext{
${ }^{446}$ SCHAMA, Simon. O futuro da América: uma história. São Paulo: Companhia das Letras, 2009, p. 62.
} 
guerra do Golfo. Passar uma parte da vida morando em uma base aérea pode indicar que Harris era acostumado com a rotina militar e tudo o que isso envolve, como o conhecimento de armas e munição. A narrativa parece sugerir que ser filho de um combatente de guerra contribuiria para que Harris ficasse muito tempo sem a presença paterna, o que, segundo uma das teses do filme acerca dos jovens, traria algum prejuízo para a formação emocional dos adolescentes.

Entrevistados separadamente, mas colocados simultaneamente no filme, o que os aproxima na construção dos seus "perfis", Brent está fumando e jogando sinuca dentro de um bar, e DJ diverte-se em um espaço com jogos eletrônicos e fliperama. Brent e DJ são construídos como garotos que utilizam seu tempo em jogo de sinuca ou jogos eletrônicos. Eles poderiam ter sido entrevistados em qualquer outro lugar, mas ali, diante dos jogos eletrônicos, com Brent fumando e DJ com a aba do seu boné virada para trás, ambos ganham ares de "bad boys". Essa imagem de "garotos problema" também pode ser percebida devido ao aparente descompromisso com valores, como os estudos e a carreira profissional, pois os jovens estão em momentos de lazer e as imagens favorecem pensar que aqueles momentos ocupam boa parte do tempo deles independente se vivem ou não todo o tempo deste modo. Talvez para justificar aqueles modos de vida, ambos associam Oscoda como um lugar sem oportunidades. Brent afirma que foi expulso da escola por apontar uma arma para outro garoto, e o ar despreocupado com que descreve seus atos indicam a sua própria construção como um bad boy.

A aparente imaturidade de DJ fez dele um alvo mais fácil para as perguntas de Moore, perguntas essas que parecem construir o jovem "rebelde" como um perigo potencial diante das câmeras, ou ainda, como um dos "alunos que seriam uma ameaça após Columbine". DJ afirma que chegou a ser o segundo nome na lista dos suspeitos ao atentado em Columbine devido a um pedido de transferência, além disso, tinha "O livro de receitas do Anarquista", com o qual aprendeu a fazer até Napalm. Ainda sobre sua "periculosidade", DJ diz que teria sido uma criança-problema e na escola se envolvia em confusões, o que, em uma cidade pequena lhe rendeu fama rapidamente. Também diz que ficara chateado de não ser o primeiro da lista e, portanto, o melhor.

Em seguida, a cena corta para DJ atirando em um inimigo virtual no videogame, e retoma para seu depoimento acerca de já ter feito bombas pequenas. A câmera focaliza o rosto de DJ como se buscasse captar a subjetividade do entrevistado. Moore repete várias vezes que o rapaz era o segundo na lista de suspeitos sobre o ocorrido em 
Columbine. Toda a construção em torno de DJ, com a ênfase nas falas a respeito de fabricar pequenas bombas, do tempo utilizado com jogos e lazer, e o discreto sorriso que o jovem mantém no rosto ao falar de si, pode ser lida muito mais como a idealização de sua participação no grupo de jovens de Oscoda do que com a “delinquência em potencial", sugerida pela ambiguidade das imagens.

A falta de reconhecimento, mesmo que seja por um assunto que envolveu mortes, possivelmente afeta a baixa autoestima de DJ, cujo semblante mais leve que o de Brent, não indica, pelo menos à primeira vista, se tratar de uma pessoa perigosa e sim de um adolescente com pouca expectativa diante do futuro em uma sociedade incerta, cuja insegurança em relação à própria reprodução da vida tornou-se um sentimento comum. Esse sentimento de insegurança e precariedade pode afetar com mais intensidade pessoas jovens como DJ. Conforme tratou Bauman, acerca do fim das estruturas sociais pesadas que mantinham o indivíduo em um destino mais ou menos determinado:

A "precariedade", essa nova garantia de submissão, é maior porque abandonou as pessoas aos seus próprios recursos, lamentavelmente inadequados quando se trata de "controlar" sua condição atual, um controle forte o bastante para encorajar pensamentos para mudar o futuro. O descomprometimento é o mais atrativo e praticado jogo da cidade hoje em dia $^{447}$.

Os jovens de Oscoda, sobretudo DJ, parecem inclinados a quebrar regras e antigos padrões de comportamento e, mesmo que isso não melhore suas condições materiais e intelectuais, mostram disposição para mudança.

Para Sennett, essa nova configuração social, que transformou principalmente o mundo do trabalho e como as pessoas organizam suas vidas, também trouxe a cultura do risco ou do arriscar-se diante do novo ou do desconhecido. Em uma sociedade moderna como os EUA "não se mexer é tomado como sinal de fracasso, parecendo a estabilidade quase uma morte em vida" ${ }^{448}$. Nesse sentido, pode-se pensar que a suposta tranquilidade de Oscoda, diante da efervescência das grandes cidades do país, torna esta pequena cidade um local onde os jovens se sintam pelo menos desmotivados.

\footnotetext{
${ }^{447}$ BAUMAN, Z. A sociedade dos individualizada: vidas contadas e histórias vividas. Rio de Janeiro: Jorge Zahar Ed., 2008, p. 20.

${ }^{448}$ SENNETT, R. A corrosão do caráter. Rio de Janeiro: Editora Record, 2005, p.102.
} 
DJ diz que gostaria de sair daquela cidade e ir para o Colorado, o que pode significar a tentativa de seguir a diante em desapego às antigas estruturas como a família de origem e o local de nascimento, para seguir o fluxo de mudanças que as novas configurações sociais exigem como a "mobilidade e flexibilidade" 449 . Com a mudança de Oscoda, e tudo o que aquela cidade representa [controle, limitação, falta de oportunidades], DJ talvez não saísse do lugar na escala social, contudo, pondo-se em movimento, possa suspender a sua realidade e trocar o sentimento de incerteza pela esperança de que alguma coisa nova aconteça na sua vida.

Nas sequências do filme, este pequeno grupo de adolescentes estadunidenses construídos como "problemáticos", será contraposto a outro pequeno grupo de adolescentes "problemáticos" do Canadá. Com a diferença que os canadenses resolviam seus conflitos de modo diferente, "jogando ovos" ou fazendo provocações verbais como alega um dos entrevistados. É como se o breve depoimento dos jovens canadenses pudesse atestar que sua forma de resolver os conflitos fosse mesmo "tão inocente" quanto o filme tenta indicar.

De outro modo, é possível sugerir que a diferença significativa entre os jovens estadunidenses e os canadenses é que nos primeiros a cultura do sucesso é impositiva desde o ambiente familiar e escolar, estendendo-se ao conjunto da sociedade. A pressão em torno do sucesso individual pode gerar formas de expressão mais "rebeldes", como Brent e DJ. Quanto ao grupo canadense, este não sofreria o peso do american way of life e a necessidade de sucesso que este modo de vida impõe. É possível imaginar que para os valores estadunidenses, de sucesso material e felicidade individual, os jovens canadenses não convencem e se enquadram mais como losers do que como "pacíficos". Isso sugere uma construção fílmica muito frágil dos jovens "problemáticos" entre os dois países, de modo que não importa apenas saber como os canadenses lidam com armas de fogo e com diferenças pessoais e sim quais os tipos de pressões sociais eles sofrem.

O filme também parece veicular as teses colocadas no livro de Glassner acercados temores que a sociedade disseminou a respeito dos jovens. A cena com DJ dizendo que sabe fazer bombas, treinando atirar no videogame, e afirmando que a cidade o deprime, parece indicar a fórmula de um "predador em potencial", como citou Glassner $^{450}$ em razão das manchetes dos jornais que, contrariando as estatísticas,

\footnotetext{
${ }^{449}$ SENNETT, R. A corrosão do caráter.op. cit., p. 102.

${ }^{450}$ GLASSNER, Barry. Cultura do medo. São Paulo: Francis, 2003, p 73-104.
} 
"previam" novos atos violentos cometidos por jovens em solo americano. Nesse sentido específico, Moore parece seguir a contrapelo do livro de Glassner e sua crítica às teses veiculadas na mídia em torno dos "jovens predadores" $" 51$, imagem que o filme parece construir dos adolescentes entrevistados - pelo menos os de Oscoda.

$\mathrm{O}$ depoimento de DJ também remete ao conceito de representação ${ }^{452} \mathrm{de}$ Goffman, ou ainda a Bill Nichols, quando este último fala dos entrevistados em documentários. Ambos os autores concordam que ao serem entrevistadas as pessoas alternam níveis de representação diante das câmeras - e, no caso da adolescência, período em que os jovens comumente tentam se auto afirmar, não é difícil observar um esforço ainda maior de representação, como é percebido em DJ.

Michael Moore, por sua vez, sabe como provocar seu entrevistado de modo que este fale mais do que deve. E, como que "facilitando" a construção que o filme faz, com Moore e suas provocações ao ego do jovem, DJ parece estar representando um personagem potencialmente perigoso diante da câmera, que não parece condizer com sua simpatia inicial. Diferente de Brent, que já tinha a experiência de ter sido preso e “estava limpo" a respeito o uso de drogas, e, talvez por dizer que não conhecia pessoalmente os garotos de Columbine, não teve tanto espaço no filme para a construção de um "jovem problema" - como facilitou DJ.

Perigoso ou não, Brent parece conhecer muito mais do mundo do crime e sistema prisional estadunidense do que o inexperiente DJ, até porque Brent já teria sofrido as consequências da rígida legislação estadunidense, que também será citada no filme com as políticas de tolerância zero aos jovens que tentarem novos atos "violentos".

Para terminar essa sequência que constrói pessoas no grupo de Heston, porque se colocam a favor do uso de armas de fogo, e que poderiam se tratar de pessoas

\footnotetext{
${ }^{451}$ Sobre essa relação em considerar os desajustados como animais, Davis aponta que "é desnecessário dizer que a política da vida selvagem quase sempre apresenta um aspecto duplo. Por um lado, refere-se à formação de atitude dos homens para com os animais; por outro, diz respeito aos conflitos de classe ou étnicos refletidos pelo papel simbólico desempenhado pela vida selvagem na distinção dos universos éticos de grupos sociais concorrentes." In: DAVIS, Mike. Ecologia do medo. Rio de Janeiro: Record, 2001, p. 199.

${ }^{452}$ Segundo Erving Goffman, quando um indivíduo se apresenta diante de outros, busca controlar a impressão que estes irão ter a seu respeito, bem como a da situação social apresentada. Para isto, como se fosse um ator e estivesse num teatro, o indivíduo representa um personagem de si mesmo, a fim de marcar uma boa impressão e evitar, assim, que lhe apliquem "estereótipos" (p.11), ou seja, que o indivíduo não seja compreendido fora do modo que deseja ser. "Assim, quando uma pessoa chega à presença de outras, existe, em geral, alguma razão que a leva a atuar de forma a transmitir a elas a impressão que lhe interessa transmitir." IN: GOFFMAN, E. A representação do eu na vida cotidiana. Petrópolis: Vozes 2009, p. 15.
} 
inconsequentes, o filme volta ao depoimento de James Nichols. Nichols defende seu direito ao porte de armas, o que é protegido pela constituição americana na segunda emenda. ${ }^{453}$ Ambos discutem acerca de qual tipo de revólver envolve a palavra“arma”, e Moore diz que o termo arma envolve até "armas nucleares!". E James se empolga dizendo que "deveríamos poder ter tudo", até plutônio na fazenda como provoca o entrevistador. James concorda que no caso de armas nucleares deveria haver restrições e a câmera encerra a participação do fazendeiro quando, se excluindo do grupo que critica, olha para Moore e diz:

"Bem, tem muito louco por aí!"

Ao som dos Beatles cantando "felicidade é uma arma quente"o filme constrói a última fala de James Nichols com imagens que dão o tom de relação insana entre algumas pessoas e as armas de fogo - a ironia das cenas propõe o contrassenso daquela paixão. Entram imagens de pessoas em parques de diversões, crianças atirando em alvos cuja feição física remete ao árabe, pessoas sorrindo em lojas de armas, em treinamentos militares, mulheres seminuas atirando com armas poderosas, numa espécie de satisfação libidinal promovida pelo uso de armas de fogo. Para configurar uma espécie de "auge do absurdo", o filme mostra que até um homem cego poderia conseguir diploma de atirador, como informam as imagens recortadas de jornal televisivo falando de Kerry McWilliam - um dos personagens anônimos das cenas iniciais do filme. McWilliam aparece atirando e falando de sua "paixão" por rifles.

As cenas são montadas lembrando um vídeo-clip, devido aos cortes bruscos das imagens, do que poderiam ser os "loucos" citados por James Nichols: são flagrantes de violência obtidos em diferentes épocas, com pessoas matando outras pessoas, ou até mesmo se matando em frente das câmeras, como se o filme começasse a mostrar o "lado McWilliam" da sociedade americana. Assim, é reforçado o sentido deletério de uma cultura pró-armas entre pessoas como Thimoth McVeight, James e Terry Nichols, DJ, Brent, o cego Kerry McWilliam, Charlton Heston entre outros.

Nas sequências, como se iniciasse um IV bloco de cenas, o filme se aproxima cada vez mais do local onde ocorreram as mortes na escola Columbine. Entram entrevistas com moradores da cidade dizendo que é um bom lugar para se viver - o

${ }^{453} \mathrm{O}$ texto da segunda emenda diz: "Sendo necessária à segurança de um Estado livre a existência de uma milícia bem organizada, o direito do povo de possuir e usar armas não poderá ser impedido." Fonte: http://www.mspc.eng.br/temdiv/const_usa01.shtml\#eme_2.(Acesso em 17 de janeiro de 2012). 
ideal de todo subúrbio. Imagens de um vídeo promocional de Littleton são usadas no filme, porém, antes de reforçarem a sensação de que ali seria um bom lugar para se viver, as cenas sugerem um"clima bélico"instalado naquela cidade, a qual abriga uma filial das maiores indústrias de armas dos EUA - a Lockheed Martin.

Neste contexto, as cenas sugerem que os problemas resultantes nas mortes em Columbine seriam negligenciados por uma população que banaliza o uso de armas, ou ainda, cuja indústria bélica possui um papel importante para a economia do país. É como se, mesmo habitando ao lado de uma grande indústria bélica e perto de uma base aérea, os moradores de Littleton viviam como se aquilo tudo fosse comum e sem implicações para seus habitantes. Para Paul Virilio, "mesmo quando não empregados, os armamentos são elementos ativos na conquista ideológica" ${ }^{454}$.

Mesmo que Virilio se refira as imagens no cinema com filmes de guerra, há que se concordar que Littleton é construída pelo filme como um lugar onde a "ideologia", ou, como prefiro chamar, cultura bélica, ganha contornos mais definidos. É como se o filme sugerisse que viver nesse lugar, onde se fabricam e transportam armas de destruição em massa, favorecesse a aceitação e reprodução da cultura bélica e, consequentemente, da paranoia americana: em torno da proteção do território, da intervenção militar em outros países, e tudo o que justifique o seu contraditório ideal de democracia.

Sobre a ideia de democracia que os estadunidenses apregoam pelo mundo, Mann cita que "como todos os imperialistas, os norte-americanos são os donos da verdade. Os políticos professam ideais impecáveis de liberdade, democracia e direitos humanos para o mundo e prometem-lhe fartura material. Dizem que concretizaram este "Sonho Americano" nos EUA e que agora vão levá-lo ao mundo",455.

Acentuando as contradições sociais, Moore não deixa de construir que sua sociedade apregoa liberdade, igualdade de oportunidades e justiça. Entretanto, o que propõe com seus filmes é desnudar o lado "hipócrita" dos EUA, cujas práticas, muitas vezes, destoam desses valores - como quando ele cita todo um histórico de preconceito, intolerância e racismo contra os negros, cujos direitos civis são conquista recente.

Tiros em Columbine também sugere que desde a fundação, o país mantém um uso indiscriminado de armas. Para isso, os criadores de South Park realizam um desenho especial a pedido de Moore em que personagens animados incorporam valores

\footnotetext{
${ }^{454}$ VIRILIO, Paul. Guerra e cinema: logística da percepção. São Paulo: Boitempo, 2005, p. 25.

${ }^{455}$ MANN, Michael. O império da incoerência. Rio de Janeiro: Record, 2006, p. 139.
} 
da Associação Nacional do Rifle e da Ku Klux Klan. Se depender das construções críticas dos filmes de Moore, o Sonho Americano não foi vivido nem mesmo pelo seu povo.

Outro entrevistado que reforça a ideia de contradição construída pelo filme é Denny Fennell, consultor de segurança em Denver, que se emociona ao falar das mortes em Columbine. A participação de Fennell, acercados produtos de segurança que vende, é ironizada por Moore que se aproveita do momento para perguntar onde estaria o ladrão em uma cidade tão tranquila. Em contraposição à Fennell, e ao sentimento de paranoia que ele ajudaria a promover, o filme segue para o Canadá a fim de construir como os "cidadãos armados do Canadá" não sofrem do mesmo sentimento de medo generalizado e, por isso, não trancavam as portas nem usavam suas milhares de armas para autodefesa, razão pela qual o número de mortes por armas de fogo no Canadá seria pouco significativo se comparado aos EUA.

Em outro momento do filme, Moore entrevista um membro da indústria de mísseis Lockheed Martin, em Littleton no Colorado. Filmado em pé, diante de um grande míssil em processo de montagem, Evan McCollum, relações públicas da empresa, fala da importância da fábrica para a cidade de Littleton - empregando cerca de cinco mil pessoas da região. Para McCollum, as mortes na escola Columbine representam "um microcosmo do que acontece pelo mundo", e os jovens estariam movidos por sentimentos como raiva e revolta. Por isso, a empresa teria doado cerca de US\$ 100 mil para implantação, nas escolas locais, de um "programa de treinamento de controle da raiva." Moore questiona se os motivos que promovem raiva nos jovens não ocorrem porque seus pais trabalham em uma fabricante de armas de destruição em massa. O representante da Lockhead Martin diz que não vê conexão entre a fabricante de mísseis e as mortes em Columbine, pois acredita que os mísseis protegem os EUA dos seus "inimigos". Assim, mais uma vez, a presença ostensiva de um sentimento de medo e a banalização do uso de armas passam desapercebidos pelos personagens do filme, que não conseguem relacionar os eventos com mortes por armas de fogo à cultura pró-armas - como constrói o filme.

Partindo de um ponto de vista que valoriza a vida humana independente da sua nacionalidade, o filme pode indicar que a fala do representante comercial constrói a opinião de um grupo que "se importa" apenas com os estadunidenses, em detrimento das pessoas de outras nacionalidades - as quais prefere chamar de "inimigos". As perguntas de Moore, a respeito das mortes em massa, não parecem distinguir a 
nacionalidade das mortes. Como faz na maioria dos filmes, Moore questiona a utilidade de uma fábrica que leva destruição em massa para outros lugares, dizimando vidas como ocorreu, em menor escala, na escola Columbine, e contraditoriamente, o representante da indústria nega que os EUA utilizem aquelas armas para agressão, e sim para se defender. McCollum diz:

... os mísseis foram projetados e criados para nos defender de alguém que de alguma forma nos agredisse. [...] Não nos irritamos com alguém e só por estarmos bravos bombardeamos, atiramos ou lançamos mísseis nos outros.

Como se "desmentisse" a fala de McCollum, o filme inicia uma sequência de antigas imagens de guerras e intervenções estadunidenses em outros países. Ao som da música What a wonderful world, de Louis Armstrong, as imagens remetem a um período histórico em que os EUA interviu militarmente em países "não alinhados aos seus ideais de democracia".

A construção irônica da cena, em que se diz uma coisa para dizer outra, opõe a letra de Armstrong que fala de um mundo maravilhoso, feliz e colorido, com imagens de um mundo em preto e branco, repletas de conflitos, dor e mortes. Enquanto a música fala de pessoas amigas que se cumprimentam com apertos de mão, o filme mostra pessoas resolvendo conflitos através do uso de armas de fogo, gerando destruição e morte. Nestas cenas, aparecem imagens que dão referência a conflitos ideológicos nos anos da Guerra-fria. Enquanto várias fotos e imagens são apresentadas, a narração de Moore atribui golpes de Estado, "assassinatos" a lideres políticos, treinamentos e concessão de armamento para grupos paramilitares, mortes em massa, e diversas intervenções que ferem os direitos humanos como sendo responsabilidade dos Estados Unidos. Nessas sequências que constroem a intervenção militar dos EUA pelo mundo, as assertivas da narração são "comprovadas" por meio de imagens, além da construção irônica através da música de Armstrong a respeito de um mundo maravilhoso.

Com isto, as imagens constroem que, muito mais do que um "ideal de democracia", as intervenções dos EUA pelo mundo sugerem o país mais como um grande fornecedor de armas para os conflitos humanos, do que um "guardião" dos "direitos-civis" e/ou da "liberdade" - conforme alegam alguns políticos em discursos pró-guerras. O ápice da ideia de intervenção militar como um grande negócio comercial 
foi construído de forma mais detida por Michael Moore no próximo filme analisado: Fahrenheit 9/11.

Acerca do modo estadunidense de "defender" o país de supostas agressões externas, o filme cita que em 1998 Bill Clinton bombardeia uma "fábrica de armas" no Sudão, o que, posteriormente, se revelou tratar de uma fábrica de aspirinas. Assim, a contrapelo da canção de Armstrong, o mundo construído em Tiros em Columbine não teria nada de maravilhoso, pelo contrário, ali as crianças estariam morrendo de modo cada vez mais violento e prematuro. Ao longo da música de Armstrong, o filme reforça sua construção irônica com imagens de tanques de guerra, aviões a jato, bombardeios, tiroteios, incêndios e muitas armas em uso. Neste ponto do filme, as cenas são impactantes com imagens de pessoas mortas e corpos em decomposição. Após Armstrong dizer que este mundo é maravilhoso, a imagem flagrante do segundo avião colidindo com a segunda torre do WTC termina este conjunto de imagens, quando entra o audio dos gritos dos civis americanos naquele dia que chamou a atenção do mundo. Esse acontecimento terá tratamento especial no documentário Fahrenheit 9/11 que será analisado na sequência da amostra fílmica desta pesquisa.

Neste final de imagens acercadas intervenções militares dos EUA, o filme sugere que o "onze de setembro" foi uma resposta possível às inúmeras intervenções militares que, em dado momento da história, encontram um grupo capaz de responder senão à altura do poder bélico estadunidense, pelo menos com criatividade sem precedentes na história mundial.

$\mathrm{Na}$ montanha russa de sentimentos promovida por Tiros em Columbine, um corte na imagem e uma cena alegre se inicia com dia ensolarado e uma música tranquila, "levando" o espectador de volta para o sul Denver, na cidade de Littleton, para retomar o orgulho americano de construir armas de guerra como o Bombardeiro B52 - protagonista do maior bombardeio no Vietnã, mais precisamente na noite de Natal de 1972. Observando a tradição do "espírito do Natal", os estadunidenses celebram a data com discursos de paz e fraternidade, mas parece que este valor só ganha sentido dentro de solo estadunidense. Além da Lockheed Martin, o filme informa que as terras de Denver abrigam uma fábrica de plutônio e as instalações do NORAD (North American Aerospace Defense Command). Essas imagens sugerem um clima bélico em toda aquela região que inclui a escola Columbine, como se o filme quisesse conectar os atentados ocorridos na escola com a "ideologia" que paira na região, não isentando 
aquela cultura pró-armas como incentivadora dos índices de violência que percorrem o país.

Uma cartela preta com a data 20 de abril de 1999 prepara o espectador para as cenas que dão nome ao filme. Sons de tiros e imagens de videogame se confundem com imagens do bombardeio realizado naquele mesmo dia, em que os EUA promoveram um grande ataque na guerra do Kosovo. Novas imagens da destruição de um vilarejo residencial e mais pilhas de corpos, indicam o contrassenso do discurso do democrata Bill Clinton. Naquele dia, Clinton falava em favor de uma guerra contra "o mecanismo de repressão sérvio" e a tentativa de minimizar o sofrimento dos civis, enquanto as imagens ironizam a "precisão" do bombardeio em que foram destruídos um hospital e uma escola primária com muitas pessoas dentro das instalações.

Outra cartela preta com letras brancas indica que uma hora após os EUA aniquilarem mais civis, em nova intervenção militar, dois jovens da cidade de Littleton põem em prática seu próprio conhecimento, culturalmente incentivado, de lidar com armas de fogo. Contudo, agora o alvo é formado pelos próprios estadunidenses brancos e moradores dos subúrbios, sendo que o que tornam as imagens ainda mais tristes e comoventes é que se trata de adolescentes - indicando o saldo negativo dessa cultura pró-armas.

Um corte na cena mostra Clinton falando à nação após receber a notícia dos assassinatos em Columbine. $\mathrm{O}$ tom de seu discurso parece menos firme do que o anterior, acerca da guerra no Kosovo, agora o presidente pede que o povo reze pelas vítimas da escola Columbine. $\mathrm{O}$ apelo à moral cristã confere um sentido diferenciado quando a morte envolve vidas estadunidenses, como se um sentimento de empatia e luto pudesse ser convocado entre os concidadãos.

Outro corte na cena, o áudio original dos pedidos de socorro e as imagens em preto e branco do circuito interno de segurança "transportam" o espectador "para dentro" da escola Columbine. Enquanto algumas imagens apresentam o nome da escola e as instalações com a visita de Moore acompanhado de um aluno sobrevivente, diferentes vozes de alunos pedindo socorro para as autoridades ou nas entrevistas com os repórteres, além de uma música triste, anunciam os momentos dramáticos do filme. Tristes porque ferem os sentimentos do espectador americano, agora a cultura bélica passa a "punir" sua própria gente. As imagens são lentas, a escola limpa e organizada após o ocorrido é apresentada em detalhes, como se antes de assistir as crianças em pânico o espectador fosse convidado a entrar no clima da escola, e pensar que ao invés 
de um cenário de assassinatos ali deveria ser lugar de formação, crescimento intelectual e motivação para os alunos. As vozes e a música melancólica ainda preparam o espectador como se o colocasse no clima de lamentação do filme.

As imagens dos atentados, captadas pelo circuito interno de segurança da escola, mostram alguns momentos do ataque. Essas imagens foram veiculadas pelas TVs de todo o país e também utilizadas no filme Tiros em Columbine, exibem o que parece ser uma tentativa dos alunos de se protegerem, abaixados entre as mesas da biblioteca. Enquanto apresenta essas imagens, o filme coloca outro áudio junto às mesmas: tratamse dos gritos de pânico da professora que pede ajuda à polícia e tem sua ligação também gravada. Interessante notar que o documentário construiu novas cenas juntando imagens de uma fonte e adicionando som de outra, de modo que, quando unidos, os momentos distintos oferecem a sensação de "realidade" dos ataques e, mesmo sendo uma construção, transmitem essa impressão ao espectador como se o transportasse para os instantes em que ocorrem as mortes na escola.

São momentos em que o espectador é "levado para dentro" dos atentados, como se pudesse reviver o que sentiram aquelas pessoas. Apesar dos debates em torno da manipulação da "realidade" serem citados em relação aos filmes de Moore, é válido notar que após construir a cultura pró-armas nos EUA, o diretor parece promover a empatia do espectador pelas vítimas deste estado de coisas, isto é, da facilidade em comprar uma arma e usá-la de modo irresponsável.

Assim, o esforço do filme parece ser uma tentativa de aproximar o espectador dos momentos vividos pelas pessoas que estavam na escola naquele exato momento. Através da relação entre o espectador e as imagens, o filme requer uma tomada de decisão valorativa por parte do espectador e, a considerar os apelos emocionais que propõe, esta decisão seria incentivada no sentido de repensar, dificultar e até mesmo abolir a cultura pró-armas nos EUA.

Nos momentos de maior desespero dos alunos sob os ataques, o filme mostra as imagens captadas pelo circuito interno de segurança do prédio em que muitos jovens aparentemente apavorados tentam se esconder dos atiradores. Ouvem-se mais tiros e as imagens dos alunos tentando sair da biblioteca. Os atiradores dispunham até de granadas que são arremessadas contra um professor ou funcionário adulto, que tenta escapar atirando-se no chão. Enquanto isso, o áudio mostra o interesse da mídia em transmitir ao vivo aqueles acontecimentos antes mesmo de terminarem. $\mathrm{O}$ áudio de uma ligação sobre a transmissão dos ataques ao vivo pela Fox News indica que o frisson 
causado entre alguns membros da mídia parece atrapalhar as ligações daqueles que ainda pediam socorro, e dos pais desesperados à procura dos filhos que ainda estavam na escola. Esse interesse ávido da mídia, construída como sensacionalista, preenche o bloco seguinte do filme.

Ainda sob os ataques na escola Columbine, a voz do militar e pai de Eric Harris pode ser ouvida em uma ligação para a polícia dizendo que seu filho poderia estar envolvido nos ataques, porque pertencia a "máfia do casaco". O som da música triste aumenta e o filme propõe com suas imagens "captar" a dor das famílias, com as câmeras focalizando rostos de mães, pais, e familiares abraçando os sobreviventes momentos após a invasão da polícia na escola.

A voz de Moore narra que antes de suicidarem, Eric Harris e Dylan Klebold haviam matado doze alunos e um professor. A polícia apurou que durante o ataque foram disparadas cerca de 900 balas por armas de fogo, e muitos alunos estariam feridos naquilo que se tornou um caso de repercussão nacional, rendendo centenas de entrevistas e programas que buscavam responder a pergunta colocada pelo fabricante de armas McCollum:

\section{"Por que crianças fariam isso?"}

O último depoimento que encerra este bloco sobre o uso indiscriminado de armas de fogo é de uma garota sobrevivente do massacre. Ela conta que o atirador matou uma menina que estava ao seu lado na biblioteca, e também matou um menino negro -"só porque ele era negro". Ao final do filme outros sobreviventes de Columbine (um deles ficou paraplégico) falarão das consequências do massacre para suas vidas, e Moore também responsabilizará a rede de lojas K-Mart pela venda de munições aos atiradores da escola. A insistência de Moore em expor negativamente a loja, e o apoio de alguns membros da mídia, favorecem as negociações de modo que a rede de lojas $K$ Mart se dispõe a não vender mais armas e munições.

Após construir o drama na escola Columbine e as sequelas que ainda ferem seus sobreviventes, o filme volta o olhar para o grupo inicialmente construído como oponente, e as sequências apontarão para Charlton Heston. Como se fosse o único modo possível para alcançar e mobilizar os afetos do seu espectador, (que parece ter dificuldade de pensar para além dos dualismos), o filme trabalha na chave do conflito entre posições inconciliáveis e, se Moore entra como condutor do grupo que pretende 
refletir acerca dos dilemas que envolvem o uso de armas de fogo, Heston é construído do lado oposto, ou do ponto de vista dos intolerantes, dos inconsequentes, ou ainda, dos não pacifistas.

De volta às sequências logo após as mortes na escola Columbine, a imagem corta para Charlton Heston defendendo o uso de armas em uma de suas conferências pelo país. Nesse ponto, o filme presume que a intolerância contra os negros alimentaria e necessidade dos brancos em proteger-se e, consequentemente, contribui para a cultura pró-armas. Verdadeira ou não, essa suposição sinaliza tensões históricas entre negros e brancos nos EUA. E um roteiro de intolerância racial será explorado nas sequências que tratam detidamente de Heston.

Dez dias após a tragédia em Columbine, Heston viajou para Denver para um encontro pró-armas pela NRA. As imagens de um senhor branco com olhar obstinado segurando um rifle configura a imagem que o filme registra do ator de Hollywood. Enquanto Heston discursa, colocando-se contra os apelos do prefeito de Denver (um homem negro) que pedia o cancelamento do evento, devido ao luto na cidade, o filme sobrepõe imagens dos pais enlutados protestando com faixas e cartazes contra aquela reunião pró-armas. Como um confronto de imagens e ideias, o filme alterna cenas do discurso de Heston e do grupo que protesta contra as armas de fogo, porque perderam filhos e amigos na escola. Emocionado, o pai de um dos garotos mortos chamado Daniel discursa:

“Tem algo errado neste país, quando uma criança pode pegar uma arma com tanta facilidade e atirar no meio da face de outra criança, como aconteceu com meu filho. Alguma coisa está errada. Mas chegou a hora de entender que uma arma Thec-9, semiautomática de 30 disparos como aquela que matou o meu filho, não é usada para matar cervos. Não tem utilidade! Está na hora de resolver este problema."

O filme se detém no discurso daquele pai, mostrando a multidão que acompanha o protesto e que aplaude cada palavra proferida contra o uso de armas. É com este ponto de vista que o filme se alinha. Em contraposição, o filme também mostra imagens do discurso de Heston e sua apologia às armas. Com isto, Tiros emColumbine promove um 
debate entre os dois grandes grupos opostos. A fala de Heston, que remete à época da formação da nação, declara em tom solene;

"Temos trabalho a fazer, corações a apaziguar. Derrotar o mal e unir um país. Podemos ter diferenças, sim”.

Conforme o filme sugere, Heston parecia desprezar a gravidade do ocorrido em Columbine envolvendo mortes por armas de fogo. Heston ainda diz:

"E novamente sofreremos tragédias indescritíveis. Mas quando o sol se puser em Denver esta tarde e eternamente, que seja sempre: "Nós, o povo seguros num país livre e lar dos corajosos”. Eu pretendo fazer minha parte. Obrigado”.

Nas sequências, Moore discute a apologia ao uso de armas, realizada por Heston dias depois das mortes em Columbine, com Matt Stone, um dos criadores do desenho animado South Park (Trey Parker foi seu sócio na criação). Juntos eles não apenas reprovam a visita do presidente de honra da NRA, como também comentam a respeito de como os jovens seriam pressionados pelos próprios familiares a serem pessoas de sucesso, como se fossem uma "vitrine" da realização do sonho americano.

Durante a entrevista o filme alterna imagens do desenho animado e o modo irônico que os personagens coloridos criticam sua "cidade calma nas montanhas ... repletas de caipiras brancos" (Colorado). Como o filme construiu com os jovens, aparentemente, sem perspectivas de futuro como Brent e DJ.

Um corte na cena, a imagem volta para o rosto de Matt que conta um pouco de suas lembranças de adolescente na escola Columbine e no subúrbio "dolorosamente normal" de Littleton. Para Matt, a vida escolar se resume a uma grande pressão pelo sucesso e, de série em série, os alunos ouviriam que se não conquistassem o sucesso terminariam adultos pobres e solitários, pois o que mais ouviam na escola é: "se fracassar agora, será um fracassado para sempre”. Isso remete novamente à Brent e DJ em Oscoda, pois aqueles dois jovens também sofriam as mesmas pressões sociais em torno do sucesso.

Ao falar acercadas novas formas de organização da vida e do trabalho na atualidade do capitalismo flexível, Sennett lembra que, sobretudo para os mais jovens, a 
probabilidade do fracasso é um temor incessante, como um fenômeno psicológico comum. A ideia do loser é forte na cultura estadunidense.

Diante de alguma coisa conflituosa, a atenção da pessoa fica pregada mais em suas circunstâncias imediatas que numa visão de perspectiva. [...] Quando falta a crença em que se pode fazer alguma coisa para resolver o problema, o pensamento a longo prazo é suspenso como inútil. [...]. "Nunca chegar a parte alguma", "sempre na casa um", diante de um sucesso aparentemente sem sentido, ou da impossibilidade de recompensa pelo esforço: em todos esses estados emocionais, o tempo parece parar; a pessoa nessa labuta torna-se prisioneira do presente, fixada em dilemas do presente ${ }^{456}$.

Matt conta que Eric Dylan e Harrys Klebold eram depreciados na escola. Talvez não vendo perspectiva de futuro esses adolescentes teriam resolvido se vingar dos "causadores" dos seus problemas no presente. Sem perspectiva de futuro em uma sociedade competitiva e punitiva, como os filmes analisados constroem os EUA, aqueles jovens se armam, treinam, divertem-se com a ideia de vingança e partem para solucionar o "problema", matando alguns desafetos na escola e suicidando, cada um com um tiro na própria cabeça.

Após a fala de Matt, o filme tenta explorar o universo adolescente, adicionando algumas imagens de vídeos feitos pelos próprios alunos em momentos que mais parecem construir a descontração entre os jovens do que um potencial agressivo.

Uma música de tom sombrio toca junto a cenas de meninos e meninas em um cotidiano escolar aparentemente comum, não para construir os "futuros predadores sociais" como são ironizados no livro de Glasnner, mas para sugerir como a pressão em torno da vida dos adolescentes, sobretudo após Columbine, estaria ampliada devido a formas intensas de controle. Como diz a narração de Moore:

"Ficou um saco ser estudante nos EUA"

Revistas, detectores de metais, obrigação do uso de uniforme escolar, e toda uma política de "tolerância zero" seriam instaurados pelas escolas para inibir qualquer tipo

\footnotetext{
${ }^{456}$ SENNETT, Richard. A corrosão do caráter. Rio de Janeiro: Editora Record, 2005, p. 106-107.
} 
de "delinquência" sendo que a definição de crime inclui até gestos que sugiram o porte de "armas", agora redefinidas para objetos como um cortador de unhas, ou qualquer tipo de brincadeira que pareça ou remeta aos ataques em Columbine. Para construir o contrassenso que a sociedade teria mergulhado, o filme alterna imagens de crianças brincando nas escolas, parques e quintais com o áudio das reportagens que comentam as novas medidas disciplinadoras e as consequências de sua não-observação. Interessante notar que em contraposição às imagens das crianças que parecem estar sendo militarizadas ao frequentarem os grupos de milicianos, o filme mostra crianças com uniforme dos escoteiros, o que poderia sugerir uma alternativa de vida coletiva e defensora de valores em torno da cooperação, da amizade e de valores familiares pregados pelas milícias, sem, contudo, disparar tiros.

Entretanto, após as mortes em Columbine, qualquer atitude que pareça agressiva, ou característica que fuja do lugar comum, seria vista como irregular, como por exemplo, um aluno suspenso em razão da cor dos seus cabelos (azuis), ou ainda, roupas que sugiram alguma postura contra os valores morais e políticos dos EUA, como a menina que vestia uma camiseta com símbolos anarquistas.

Em seguida, o filme apresenta em chave irônica o sensacionalismo empreendido pela mídia americana, com centenas de repórteres se dirigindo até a escola para noticiarem os ocorridos e explorarem o drama dos envolvidos. Segundo o livro de Glassner $^{457}$, essas matérias serviriam para disseminar o pânico entre a população. E as semanas seguintes, pós Columbine, seriam marcadas por "pseudo-especialistas" e “caçadores de tendências" emitindo seus pareceres acercados possíveis motivos para a existência de "jovens predadores".

Algumas motivações que levariam os jovens a cometerem crimes são citadas pelo filme, porque foram amplamente noticiadas pela mídia televisiva. Entre os "motivos" citados estariam: raiva, subcultura metaleira, ausência dos pais, filmes violentos, videogames, televisão, desenhos, entretenimento, Satã, sociedade, armas de brinquedo, drogas, o roqueiro Marylin Manson e o desenho South Park.

Entre os motivos "geradores" de atos violentos, alguns entrevistados nos programas de televisão sugeriram a "influência nociva" do cantor Marylin Manson. Diferente de Charlton Heston, Manson cancelou as cinco aparições previstas na região de Littleton em respeito às vítimas de Columbine. Moore entrevista Manson dois anos

${ }^{457}$ Cf. GLASSNER, Barry. Cultura do medo. São Paulo: Francis, 2003. 
após as mortes na escola Columbine, e parece concordar com as opiniões coerentes do roqueiro. Apesar de não declarar admiração pelo trabalho de Manson, como fez pela banda Grand Funk Railroad em Roger e Eu, e por Rick Neilson em The Big One, Moore entrevista o roqueiro como se o filme sugerisse um enfrentamento, e, consequentemente, a desmistificação daquele indivíduo tão temido pelo "americano médio".

Manson materializaria diferentes temores dos estadunidenses com opiniões na contramão dos valores puritanos em torno da família, do trabalho e do "ajustamento" social. Moore e Manson concordam que mais poder do que as músicas do roqueiro tiveram as bombas lançadas na guerra do Kosovo, cujo maior bombardeio americano foi justamente no dia do ataque à escola Columbine. Manson acredita na influência do que chama de "campanha de medo e consumo" na mente dos adolescentes, algo que os mantêm "na adrenalina" em busca das novidades oferecidas pelo mercado, e sua música lhes oferece uma fuga para aquela ordem de coisas.

Moore concordava com o roqueiro na maioria de suas assertivas acerca dos jovens, e este gesto mais parece neutralizar a importância daquela figura demonizada pela mídia, do que ressaltar sua "influência negativa" para com os jovens. Tanto que, na tentativa de anular esse tipo de música da lista de "perigos", o filme remete aos grupos roqueiros em diferentes países como os punks ingleses, os góticos e outros adeptos da "música metaleira" que vivem em países com baixo índice de mortes por armas de fogo. Como que "absolvendo" Manson nas sequências do filme, Moore faz uma comparação entre a popularidade do roqueiro tanto nos EUA quanto em outros países, mostrando que o cantor tinha muitos fãs em países com baixo índice de mortes por armas de fogo.

Contrariando os motivos assinalados pelos "caçadores de tendências" na mídia televisiva, o filme questiona se filmes violentos, videogames, histórico de guerras, entre outras coisas também não são encontrados em outros países. E conclui que o número de mortes anuais - apresentados no começo deste texto - é irrisório se comparados aos EUA.

Ao final da entrevista, Manson diz que não diria nada aos jovens, antes ouviria o que eles têm a dizer e, seguindo sua pista, o filme corta a imagem para duas meninas que falam sobre seus ex-colegas, os atiradores de Columbine.

$\mathrm{Na}$ montanha russa de sentimentos promovidos pelo filme, um corte nas indagações de Moore e seus entrevistados acerca dos motivos da violência, entra em cena outro escolhido pelos especialistas: o desenho animado South Park. 
A pedido de Moore, os criadores de South Park fizeram um episódio especial em que criam uma história bélica para os EUA. Com feições semelhantes aos dos personagens do desenho original, os personagens do desenho sobre as armas, reconstroem a história dos EUA com a narração de uma bala de revólver. Os temores sofridos pelos pais peregrinos desde a fuga da Europa, o medo que resulta no extermínio das populações indígenas no "novo mundo", a caça às bruxas promovida pelo medo que os peregrinos, supostamente, tinham entre si. A independência dos ingleses e a lei permitindo o porte de armas a todos os homens brancos, a perseguição e escravização dos negros, a criação da Klu Klux Klan após a libertação dos escravos, e a NRA (Associação Nacional do Rifle) entrando no lugar da KKK após esta ser considerada ilegal. E ainda, a criação dos subúrbios como um lugar próprio para famílias de brancos, e como estas famílias viveriam, até a atualidade do filme, dispostas a se protegerem de todos os seus temores.

O filme busca seguir diferentes motivações sociais para o aumento das mortes relacionadas com armas de fogo. Contudo, antes de serem os causadores isolados dos números de mortes, esses "motivos" não parecem comprovar muita coisa, embora, expressam preconceitos disseminados entre a população estadunidense - tanto os preconceitos raciais quanto os relacionados ao termo loser.

Como que aderisse à tese do medo, iniciada com Glassner, o filme sugeriu um clima de pânico instaurado entre os estadunidenses, inclusive com participação do presidente Bush e seus alertas acercada possibilidade de um ataque terrorista contra o povo. Esta citação ao governo Bush indica o tema do próximo filme de Moore que também será analisado na sequência deste trabalho: Fahrenheit 9/11.

Sem descobrir motivos isolados que expliquem os números envolvendo mortes por armas de fogo, Moore entrevista o próprio Glassner, cujo livro "Cultura do Medo", serviu de pistas para muitos momentos do documentário. Glassner conta que, apesar do índice de violência diminuir, os noticiários divulgam alguns casos com tanta intensidade que a violência parece crescente. E o aumento do medo alimenta a procura por armas e por outros itens de segurança como travas nas portas, cadeados e grades.

Comparações entre EUA e Canadá também buscam construir diferenças significativas entre a cultura de ambos os países, reforçando uma espécie de "inclinação bélica" dos estadunidenses "apaixonados" por armas de fogo. A principal comparação apontada no filme é que, apesar de serem ávidos consumidores dos produtos de entretenimento americano e de possuírem milhares de armas em seu país, os canadenses 
não viviam atemorizados como os americanos. Pelo contrário, a vida de um canadense seguiria aparentemente tranquila, sem os "ataques" constantes de uma "mídia paranoica", além de possuírem maior equidade social e baixos níveis de assassinatos. Parece que no Canadá não vigoram valores como o self-made man, nem o do loser, e a participação do Estado seria maior na vida dos cidadãos com a garantia de direitos sociais, como atendimento de saúde gratuito, assistência à moradia e previdência social.

De volta aos EUA, Moore cita o empobrecimento da antiga "classe média", crescida nos tempos da esteira fordista, como mais um item na lista dos motivos para os conflitos armados e os crescentes índices de criminalidade. Usando Flint como exemplo da relação entre pobreza e criminalidade, o filme relembra Roger e Eu ao retomar imagens dos bairros decadentes, sob a neve de mais um dia cinzento e gelado, além de lembrar que a maior fábrica de automóveis do país, a $G M$, tinha fechado uma de suas maiores instalações, desempregando boa parte dos moradores da cidade.

As razões que contribuíram para o menino de seis anos de idade ter atirado na colega de classe, também ganharam atenção do filme. Motivos como: abandono do pai, miséria, despejo, a mãe sozinha criando dois filhos, sobrecarregada por uma extenuante jornada de trabalho, e uma arma carregada na casa de um tio, seriam os elementos que envolveram a vida do pequeno atirador. Da mesma forma que procurou ajudar as mães do Wisconsin no filme The Big One, Moore procura entrevistar autoridades de Flint e coloca em dúvida a utilidade do programa social que mantinha a mãe do menino em um trabalho longe de casa, impossibilitando-a de cuidar dos filhos menores.

O confronto final e mais significativo do filme ocorre quando Charlton Heston recebe Moore para entrevista na casa do ator. Moore faz perguntas a respeito do porte de armas, e qual a visão de Heston acerca dos motivos que contribuiriam para o elevado índice de mortes por armas de fogo. Heston indica que a diversidade racial do país seria um motivo para os confrontos, deixando transparecer o seu preconceito em relação à população negra e imigrante. Quando Heston é acusado por Moore de, como integrante do grupo promotor do porte de armas, ter contribuído para a morte da menina na escola da diretora Hughes (apresentada nas imagens iniciais do filme), o ex-ator se levanta e sai de cena, deixando Moore "falando sozinho". 


\section{Conclusão}

Conforme apontei no início desta análise de Tiros em Columbine, as cenas com Heston podem remeter aos problemas éticos citados por Pryluck, dizendo que "quando usamos pessoas numa sequência, nós a colocamos em risco sem informá-las suficiente sobre os riscos em potencial" ${ }^{\natural 58}$. Ciente ou não deste processo, Moore coloca Heston "contra a parede" com perguntas que instigam o ator a evidenciar os próprios preconceitos raciais e, antes que falasse muito mais do que devia, o ator simplesmente sai de cena. No filme, Heston pessoaliza o grupo defensor do direito ao porte e uso de armas de fogo, consequentemente, pode ser lido como um inconsequente diante das mortes que avolumam as estatísticas no país.

Na saída da casa do ator, Moore coloca a foto da menina morta a tiro dentro da sala de aula por um colega de classe. Esse gesto simbólico pode ser interpretado como antiético em relação à pessoa de Heston, porém, também pode ser lido como um gesto de cariz ideológico que culpabiliza todos os defensores da cultura bélica pelas mortes ocasionadas por armas de fogo nas mãos de civis.

No final do filme, ao som de Joey Ramone cantando "What a wonderful world", Moore aponta para o tema de seu próximo documentário, Fahrenheit 9/11, sugerindo que a "política de autodefesa" dos EUA aprofunda a histórica sensação de medo e pânico entre a população. O governo de George W Bush, eleito seu próximo "interlocutor", promoveria a sensação de medo, sobretudo contra os árabes e muçulmanos, em favor de "jogos de guerra", que por sua vez alimentam a economia do país, gerando lucros como nenhuma outra empresa. Para Michael Moore uma população em pânico não deveria portar armas, muito menos munição.

Tiros em Columbine foi o terceiro documentário produzido por Michael Moore para o cinema, custou 4 milhões de dólares e rendeu cerca de 58 milhões em todo o mundo $^{459}$. O filme também ganhou muitos prêmios, entre os quais são destacados: o Academy Awards (Oscar) de melhor documentário em 2003, prêmio do 55 Aniversário de Cannes em 2002 e o Prêmio César da Academia de Cinematografia Francesa como o melhor filme estrangeiro em $2003^{460}$. Também foi indicado à Palma de Ouro em Cannes 2002 e ganhou prêmios de melhor audiência para filme documentário no Bergen

\footnotetext{
${ }^{458}$ PRYLUCK, Calvin. Ultimately We Are All Outsiders: The Ethics of Documentary Filming. In: ROSENTHAL, A; CORNER, J. New Challenges for Documentary. Manchester University Press, 2005, pág, 258. (Tradução minha).
} 
International Film Festival de 2002, no Atlantic Film Festival de 2002, no Amsterdam International Documentary Film Festival também em 2002, e na Mostra Internacional de Cinema de São Paulo em 2002.

O filme explora os possíveis motivos que resultariam nos crescentes números de mortes causadas por armas de fogo nos EUA, o que, no ano de sua produção, estaria em torno de 11.127 mortes. Segundo dados trazidos pelo filme, esses números seriam superiores aos dos principais países industrializados juntos: Alemanha (381), França (255), Canadá (165), Reino Unido (68), Austrália (65) e Japão (39).

Embora a narrativa tenha como eixo central os atentados praticados por dois adolescentes na Escola Secundária Columbine, não se atém apenas ao ocorrido - que resultou em 13 mortes e dezenas de feridos. Tiros em Columbine construiu a paixão dos estadunidenses por armas de fogo, procurando os motivos que levariam a uma cultura pró-armas, se existe razões históricas, a influência do Estado, da economia e da mídia jornalística na "mentalidade" dos cidadãos. O filme relaciona essa cultura como prática comum entre pessoas brancas, que a partir de um ideal de "classe média”, seriam os maiores consumidores de armas no país e, consequentemente, os mantenedores da ameaça envolvendo armas de fogo.

Independente do êxito em responder as questões que se propõe, o filme apresenta alguns aspectos sociais dessa cultura e, por outro lado, o crescente descontentamento quando seus efeitos negativos afetam os próprios estadunidenses. Também constrói como legitimam seu potencial bélico, historicamente usado contra outros países, e como conjugam seus valores, sobretudo os ligados a moral cristã, a família e aos direitos de civis dos brancos, quando eles próprios são vítimas de sua força destrutiva. Interessante destacar que Tiros em Columbine sinaliza a questão do racismo nos EUA, e tem o cuidado de construir o problema das mortes por armas de fogo como uma cultura de brancos.

O porte de armas de fogo para uso pessoal, ganha diferentes contornos de acordo com o grupo apresentado: jovens com dificuldades de convívio escolar e familiar que, se antes brigavam na rua após saírem da escola, agora passariam a resolver seus problemas à bala; milicianos descontentes com o governo, famílias preocupadas em proteger o patrimônio pessoal, empresas fabricantes de armas e comerciantes que

\footnotetext{
${ }^{459}$ Fonte: http://www.boxofficemojo.com/movies/?id=bowlingforcolumbine.htm. Acesso em 18/07/2010.

${ }^{460}$ As premiações podem ser conferidas no site: http://www.imdb.com/name/nm0601619/awards. Acesso em 21/07/2010.
} 
vendem armas e munições livremente, e até pessoas como Thimoty MacVeigh que foi capaz de explodir parte de um prédio público que abrigava, além de escritórios do governo, uma escola infantil.

As comparações que Moore faz com outros países, acerca dos índices de mortes por armas de fogo, desconsideram as peculiaridades históricas de cada nação, pois é possível imaginar que apesar do passado nazista e as implicações nacionalistas que envolvem esse período naquele país, a Alemanha não se transformou em uma indústria da guerra como os EUA. Devido suas inúmeras intervenções na política interna de outros países, e do seu parque industrial voltado para fabricação e exportação de todo tipo de artefato bélico, os EUA perpetuam seu histórico de envolvimento em guerras por motivos aparentemente econômicos, como o próprio Moore construirá no documentário Fahrenheit 9/11.

Na sequência deste trabalho, analiso o filme Fahrenheit $9 / 11$ e seu dialogo com Tiros em Columbine devido à persistência do problema em torno do mercado de armas e da cultura belicista que "emana" dos EUA. Se em Tiros, o foco da narrativa se deu em torno dos problemas internos e consequentes dos usos de armas de fogo por uma população civil "amedrontada", Fahrenheit 9/11 amplia a questão bélica construindo a indústria das armas e a da guerra como fontes altamente rentáveis entre os que detêm seu poder, em uma das faces mais sombrias da alta modernidade e da sociedade de risco. 


\title{
5-Fahrenheit 9/11: o medo como arma de guerra.
}

\author{
"A democracia periga quando está sendo \\ negligenciado o seu princípio essencial: o \\ predomínio do bem comum sobre os interesses \\ de indivíduos particulares". \\ Anatol Rosenfeld ${ }^{461}$.
}

Fogos de artifício em celebração à vitória do candidato Al Gore abrem as cenas do documentário Fahrenheit 9/11. O início do filme retoma os momentos da disputa por votos nas eleições presidenciais dos Estados Unidos, em finais do ano 2000. Na ocasião, o candidato pelo partido democrata $\mathrm{Al}$ Gore, e vice-presidente dos EUA no segundo mandato de Bill Clinton, parecia estar vencendo com a maioria dos votos populares. A narração em off de Michael Moore questiona se aquele resultado foi um sonho ou um milagre, como se, para manter os membros do partido republicano longe do poder fosse preciso mais do que eleições populares.

Para construir aquilo que sugere como fraude eleitoral, o filme toma emprestadas algumas imagens dos canais de televisão à época da disputa dos votos. A música country acelerada marca não apenas o tom da corrida presidencial, como também confere uma espécie de tema western que permeará toda a construção do grupo que tem George Bush, na época governador do Texas, como membro principal.

As pesquisas indicavam que $\mathrm{Al}$ Gore ganharia em várias regiões do país, inclusive na Flórida, estado responsabilizado pela a derrota do democrata. O canal Fox News é citado como ponto fundamental para que outras emissoras não insistissem nos resultados das pesquisas e seguissem a opinião da emissora conservadora que dava vitória na Flórida para George Bush. Assim, o filme inicia com referências à Flórida por considerar que aquele Estado, governado pelo irmão do candidato republicano e com apoio da Fox (que naquele momento tinha um primo de Bush, John Ellis, tomando decisões na emissora), teria sido a base daquilo que será construído como uma eleição

\footnotetext{
${ }^{461}$ ROSENFELD, Anatol. A Crise da Democracia. In: Texto e contexto II. São Paulo: Perspectiva/Edusp/; Campinas: Ed. Unicamp, 1993, p. 205 - 216.
} 
fraudulenta, visto que a diferença entre o candidato eleito e Al Gore foi mínima - cerca de 05 votos dos colegiados na contagem oficial ${ }^{462}$.

Deste modo, ainda nos momentos iniciais, o filme constrói um sistema relacional que, como ocorre em todos os documentários de Michael Moore, define dois grupos em lados opostos: o de Michael Moore narrando o filme e se posicionando ao lado dos democratas como Al Gore e seus eleitores; e outro "liderado" por George Bush, seu pai, e membros do partido republicano que estavam em posições de poder na época do filme, além de empresários estadunidenses e árabes que atuam no ramo petrolífero. Os membros desse segundo grupo são construídos como pessoas poderosas que prosperam suas empresas a partir das facilidades obtidas com o acesso ao poder político e econômico, dentro e fora do país.

Nesse momento da análise, a construção dos sistemas relacionais ainda é incipiente, mas indica a construção comum nos filmes de Moore com o uso de uma linguagem de assimilação fácil caracterizada por dualismos: bem versus mal, ricos contra pobres, republicanos contra democratas. Contudo, como o próprio filme indica, os membros desses grupos podem migrar de posição visto que muitos trabalhadores estadunidenses amedrontados poderiam mudar para o lado de Bush, ao ver nesse grupo uma forte coalizão contra o "terrorismo", como foram denominadas as ações ocorridas nos EUA no dia 11 de setembro de 2001. Coalizão essa que o filme de Moore irá desqualificar.

Para configurar o início da tese de fraude naquelas eleições, o filme insere imagens do dia da posse de Bush, um dia frio e chuvoso, quando centenas de pessoas contrariadas protestavam atirando ovos e mostrando cartazes, tumultuando o desfile da comitiva e dando trabalho para os inúmeros seguranças.

Aos que não compreendem o formato das eleições estadunidenses, Michael $\mathrm{Mann}^{463}$ aponta que naquele ano o comparecimento popular às urnas foi pequeno e Bush foi eleito com menos de um quarto dos votos de cidadãos americanos em condições de votar. Segundo o autor, o que privilegiou Bush, naquelas eleições, foram

\footnotetext{
${ }^{462} \mathrm{http}: / /$ www.archives.gov/federal-register/electoral-college/votes/2000.html (Acesso em 25 de maio de 2013).

${ }^{463} \mathrm{Cf}$. MANN, Michael. O império da incoerência: a natureza do poder americano. Rio de Janeiro: Record, 2006, p. 19.
} 
os votos decisivos dos delegados por Estado, e o número desses delegados depende do índice populacional em cada Estado ${ }^{464}$.

Fontes oficiais do governo dos EUA fornecem o número exato de delegados por Estado. Nas eleições de 2000, se Nova Iorque elege 33 delegados, Dakota do Sul elege apenas 3, e graças aos delegados do Texas ${ }^{465}$ (32) e da Flórida (25), governada naquele momento por Jeb Bush, George Bush foi eleito presidente dos EUA em 2000 e reeleito em $2004^{466}$.

Bush venceu com apoio dos delegados de 30 Estados, somando 271 votos. Apesar de contar com os votos dos populosos Estados da Califórnia e Nova Iorque, Al Gore venceu em 21 Estados recebendo 266 votos dos delegados ${ }^{467}$. Os Estados mais populosos possuem maior número de delegados que são indicados pelos partidos locais e votam, em geral, segundo a escolha popular em cada Estado. O voto popular escolhe um candidato entre os partidos que estão na disputa e os Delegados devem ou não, de acordo com a legislação estadual, repassar essa escolha popular no dia da eleição presidencial. Alguns Estados não obrigam seus colegiados a seguirem o voto popular, no geral o que decide a eleição é o voto dos Delegados. O voto popular pressiona a decisão, mas não tem o mesmo poder que o voto em eleições diretas como, por exemplo, no Brasil.

Pela lei americana são necessários 270 votos para ganhar a eleição (metade +1 dos 538 votos possíveis), e os estadunidenses prezam pelo cumprimento de suas leis. Assim, George Walker Bush tomou posse do cargo, mesmo sob protestos e acusações de fraude, pois embora tenha ganhado as eleições pelos votos dos Delegados Colegiados teria perdido na soma dos votos populares. Contudo, esse tipo de impasse não é inédito

\footnotetext{
${ }^{464} \mathrm{Um}$ panorama dos votos nessas eleições pode ser visto no site: http://www1.folha.uol.com.br/folha/mundo/2000_eua_eleicoesfinal.html. (Acesso em 28 de agosto de 2011). Outro site também confere as mesmas regras: http://noticias.terra.com.br/mundo/estadosunidos/eleicoes/entenda-como-funciona-a-eleicao-presidencial-nos-estadosunidos, 2e59b5b66d9da310VgnCLD200000bbcceb0aRCRD.html (Acesso em 20 de maio de 2013).

${ }^{465}$ Alguns Estados possuem legislação específica que obriga o Delegado a seguir a escolha do candidato eleito pelo voto popular, já o Texas está entre os poucos Estados que não existe esse tipo de legislação. Assim se a população elege um candidato o delegado pode, arbitrariamente, votar em outro candidato, isso sem contar que o voto nos EUA não é obrigatório e isso faz com que a participação popular seja reduzida. http://www.archives.gov/federal-register/electoral-college/electors.html\#restrictions (Acesso em 21 de maio de 2013).

${ }^{466} \mathrm{http}: / / \mathrm{www}$. archives.gov/federal-register/electoral-college/allocation.html (Acesso em 21 de maio de 2013).

${ }^{467} \mathrm{http} / / / \mathrm{www}$. archives.gov/federal-register/electoral-college/votes/2000.html (Acesso em 21 de maio de 2013).
} 
nas eleições estadunidenses cujo voto decisivo é indireto, isto é, não corresponde à soma dos votos populares ${ }^{468}$.

Em Fahrenheit 9/11 amúsica acelerada termina e o filme apresenta uma longa sequência de imagens com o próprio Al Gore, na condição de presidente do Senado naquele momento, anunciando a vitória de George Bush. As imagens gravadas da sessão histórica no Senado marcam o início de um segundo momento de Fahrenheit 9/11, ainda no primeiro bloco do filme quando é configurada a tese de fraude eleitoral e a construção de um presidente para ocupar a posição. O filme mostra que Bush, após tomar posse do cargo, saiu de férias - contrariando a ideia comum de que quem assume um cargo começa a trabalhar. Isso pode sugerir que a meta de Bush era "simplesmente" conquistar o poder sem um "compromisso" com a nação, mas também pode significar que o país não é governado apenas por uma pessoa, isto é, um grupo estava no poder.

Diante da síntese que comporta a abertura do filme, é possível afirmar que os sentidos propostos nesse bloco de Fahrenheit 9/11 aludem, com as cenas da "vitória" de Al Gore mesmo após a derrota oficial, uma mensagem direcionada ao espectador estadunidense de que existiria alternativa para a sequência de acontecimentos que o filme construirá a partir da vitória de Bush, com a chegada de uma nova guerra e a política interna entregue aos membros do partido republicano cujos interesses políticos se confundem com os pessoais. Para registrar o otimismo com a opção democrata, a narração de Moore ressalta alguns ícones do entretenimento do país como o ator Ben Affleck, o renomado Robert De Niro do filme Taxi Driver, além do não menos conhecido cantor Stevie Wonder, que acompanham Al Gore no palanque e representariam papéis de aliados para a continuidade dos democratas no poder.

Como é recorrente em seus filmes, Moore se vale de símbolos da cultura e do entretenimento dos EUA para auxiliar a construção da narrativa de Fahrenheit 9/11. Conforme indicam seus filmes anteriores: Roger e Eu, The Big One e Tiros em Columbine, parece difícil atingir o público estadunidense se não for pela via do entretenimento à qual estão acostumados e pela qual reconhecem os símbolos de sua nação.

Neste filme serão lembrados antigos seriados como Bonanza e Dragnet, esse último muito conhecido durante toda a década de 1950, além da alusão aos filmes de

\footnotetext{
${ }^{468} \mathrm{http}$ ///noticias.terra.com.br/mundo/estados-unidos/eleicoes/entenda-como-funciona-a-eleicaopresidencial-nos-estadosunidos, 2e59b5b66d9da310VgnCLD200000bbcceb0aRCRD.html (Acesso em 20 de maio de 2013).
} 
faroeste para construir, em chave humorística, a coalizão de Bush. Outro ícone do entretenimento estadunidense utilizado foi o seriado The Greatest American Hero, veiculado nos anos 80 , cuja música Believe It Or Not anima as sequências em que George Bush visita militares no USS Abraham Lincoln, para proferir seu famoso discurso de "Missão cumprida" poucos meses após o início da guerra. As imagens de rostos sorridentes dos tripulantes daquele navio de guerra, após tantas mortes nas sequências anteriores, e a música de $O$ Herói Americano conferem o mesmo tom fictício do herói trapalhão do seriado ao presidente George Bush.

Após indicar que a saída para os problemas do país estaria no poder do voto, através de maior participação popular em eleições, o filme toca uma música triste como se lamentasse a derrota do grupo aliado à Al Gore. A cena corta para uma sessão conjunta da Câmara dos Deputados e do Senado em que representantes do eleitorado afro-americano protestavam acerca da possibilidade de fraudes e de privação dos direitos civis naquela eleição. Moore reitera que nenhum membro do Senado assinou apoio às impugnações propostas pelos representantes dos afro-americanos e, como se explicasse ao espectador em uma linguagem bastante simples, o narrador diz que, a cada um, "eram dadas ordens de sentar e se calar". Segundo Moore, os oito meses seguintes serviram para reafirmar a ilegitimidade daquelas eleições devido às dificuldades que Bush teria em eleger juízes e aprovar leis, até mesmo entre os republicanos no Senado.

Se considerarmos a tipologia de Bill Nichols acercados tipos de documentários existentes, a estrutura de Fahrenheit 9/11 segue os demais filmes de Moore com modo expositivo. Neste filme, o diretor retoma a narração como voz de Deus em uma "lógica informativa transmitida verbalmente" ${ }^{\$ 69}$ que é uma característica do filme expositivo, e mais, suas imagens desempenhariam papel secundário, pois "ilustram, esclarecem, evocam ou contrapõem o que é dito" ${ }^{\natural 70}$. Subvertendo a característica clássica da voz de Deus (onisciência e onipresença), Moore se coloca no lugar dessa voz, pois em vários momentos sua narrativa "toma ares de onisciência" e passa a explicar as intenções de George Bush como se as pudesse conhecer. A cena de Bush na escola primária recebendo a notícia dos atentados ao World Trade Center e a fala de Moore narrando os pensamentos do presidente, compõem um dos vários momentos em que a narrativa como voz de Deus é percebida no filme.

\footnotetext{
${ }^{469}$ NICHOLS, Bill. Introdução ao documentário. Campinas: Papirus, 2005, p.143.

${ }^{470}$ NICHOLS, Bill. Introdução ao documentário, op. cit.
} 
Além disso, o documentário constrói, a partir de recortes de imagens com declarações do candidato, que Bush tinha certeza da vitória na Flórida, como se aquele Estado governado por seu irmão Jeb Bush fosse o foco da fraude eleitoral. O filme também aponta alguns parentes e amigos de Bush em cargos de poder decisório naquele momento, como um primo na emissora Fox (para atuar na "guerra" televisiva acerca da campanha presidencial), e outras pessoas próximas, como a chefe de campanha que também acumulava o cargo de fiscal de votos, uma empresa encarregada de "fiscalizar" quem estava ou não em condições de legais de votar, o advogado e também exsecretário de estado James Baker (para rebater as alegações de ilegitimidade) e membros da Suprema Corte como aliados da família Bush para votarem "corretamente" a favor do candidato - que também é filho do ex-presidente George Herbert Walker Bush.

Entre as diversas imagens antigas inseridas no filme, existe uma em que o próprio Bush declara que ter o pai na presidência o beneficiava nos negócios e no acesso às pessoas importantes. Tudo isso para dar concretude à ideia do filme de que George Bush e seu grupo trapacearam naquelas eleições.

Através da ironia e do didatismo próprio de seus filmes, que visam orientar a construção de sentidos para os espectadores por meio de imagens e sons, Moore utiliza a música Vacation para sugerir algo como a indolência com que o presidente teria lidado com a desaprovação popular nos primeiros meses de mandato. Bush é construído como uma pessoa individualista e hedonista, que pouco se importa com a opinião popular. Mais adiante, o filme cita Bush como desertor da Guarda Aérea Nacional do Texas, como quem fugia dos exames médicos pelo suposto uso de cocaína, e que desde 1972 mantinha relações empresariais com um amigo dos tempos da Guarda chamado James R. Bath, o qual viria a ser administrador financeiro dos Bin Laden no Texas.

As sequências, aparentemente montadas a partir das filmagens de algum cinegrafista que acompanhava a comitiva presidencial, situam Bush em meio aos discursos oficiais que, a rigor, deveriam priorizar os interesses da nação. Contudo, Bush aparece fazendo olhares engraçados para os jornalistas, concedendo entrevistas acerca de assuntos de segurança nacional em momentos de lazer e descontração, como por exemplo, na pesca, no jogo de golfe, em sua fazenda no Texas, ou junto ao seu irmão governador da Flórida. Em uma das situações, após errar uma tacada de golfe,George Bush diz: 
"Se eu jogar sempre bem, o povo dirá que não trabalho."

Ao mesmo tempo em que o filme constrói George Bush como um homem despreparado para o cargo de presidente dos EUA, e cujas ações trariam grande dano ao país, também constrói Michael Moore como quem fala "a verdade". Isso porque, o filme retoma uma ocasião em que Moore seguia os passos de Bush nas convenções do partido e parecia incomodar o candidato com sua presença. Assim, como parte da legitimação do personagem que se constrói contra Bush, Moore apresenta uma rápida imagem em um dia de convenção política, quando Bush o adverte a comportar-se e arrumar "um trabalho de verdade".

Ora, se Moore coloca-se como denunciante dos abusos de poder cometidos pelo então presidente e seu grupo, nada mais representativo do que sinalizar para o público espectador o quanto seu trabalho de "cineasta investigativo" incomoda Bush que, por sua vez, "se mostrava" pouco disposto ao trabalho, visto que passou um bom tempo de férias em pleno mandato - como o filme insiste em "provar" com uma afirmação baseada em notícia do jornal Washington Post.

Moore responde, ironicamente, que quem entende de trabalho é Bush, e as sequências que sempre buscam "comprovar" o que é sugerido pela narração, apontam para momentos construídos como insignificantes, com o presidente servindo pratos ou retornando aos momentos de lazer e seus depoimentos acerca das coisas que gostava de fazer em seu rancho no Texas - uma alusão de que não era esse o papel de um presidente comprometido com o povo nem com os problemas do país, sobretudo quando faltava cerca de um mês para o dia 11 de setembro de 2001. Inclusive a música que pode ser ouvida no documentário, acompanhando alguns depoimentos de Bush, se parece com as mesmas de desenhos infantis antigos, sugerindo que uma pessoa despreparada, ou pouco séria, estava no cargo mais importante do país.

Na sequência, começa um segundo bloco de imagens que parecem dar início ao problema configurado pelo filme, ou ainda, às consequências desastrosas da tomada daquele grupo de republicanos ou "privilegiados" ao poder, e o modo como se mantêm nesta posição diante de uma "nação amedrontada". Uma música melancólica, parecida com o som de violão, entre imagens que constroem os principais membros do grupo dos "privilegiados", imprime o sentido de que dias piores estavam por vir. 
Neste ponto do filme, com pouco mais de 10 minutos rodados, aparecem junto aos créditos de produção os principais envolvidos no grupo de Bush. Importante notar que enquanto os rostos dos participantes do grupo aparecem, uma das falas remete aos elementos que serão trabalhados pelo filme: segurança nacional, guerra contra o Iraque, atentados "terroristas" no dia 11 de setembro de 2001. Os membros desse grupo aparecem inicialmente atrás das câmeras, em momentos de preparo para entrarem em transmissões nacionais com seus discursos oficiais. O sentido que essas imagens podem aludir é que o conteúdo dos discursos desses políticos seriam tão "maquiados" quanto seus rostos antes das apresentações oficiais, ou ainda, que suas posturas fossem tão "sérias" quanto as observadas nos momentos em que a câmera da Casa Branca estaria também sendo preparada para as tomadas oficiais, isso porque tanto Bush quanto Paul Wolfowitz, entre outros, aparecem rindo antes dos discursos oficiais - discursos cujas decisões anunciadas mudariam a vida de milhões de pessoas e, literalmente exterminaria a vida de outras.

Entre os principais membros do grupo de Bush, aparecem nesta abertura o experiente secretário de defesa Donald Rumsfeld que já tinha trabalhado com o expresidente George H. Bush, o vice-presidente Dick Cheney, a conselheira de segurança nacional Condoleezza Rice, e Paul Wolfowitz (um dos arquitetos da guerra no Iraque e ex-presidente do Banco Mundial) ${ }^{471}$. Também entra no grupo, o Secretário de Estado e militar Colin Powell e outros nomes menos conhecidos do público fora dos EUA, como o então Senador John Ashcroft que brinca com a equipe dizendo que quer parecer mais jovem nas imagens.

Antes de configurar um discurso afastado da construção do filme ou uma longa digressão, as informações trazidas por Mann para este texto auxiliam o público fora dos EUA a entender a posição desses atores no jogo do poder, pois se para o espectador estadunidense é mais fácil ter algum referencial acerca da maioria desses políticos, para outros públicos não há, salvo raras exceções, alguma noção de quem são aquelas pessoas.

Após a apresentação desse grupo, centrado na figura de George Bush, que, segundo o filme, construiu uma relação perigosa com outros grupos fora dos EUA, entra em cena uma tela preta cujo áudio original retorna ao dia 11 de setembro de 2001, ocasião do maior ataque empreendido contra os Estados Unidos - desde Pearl Harbor

\footnotetext{
${ }^{471}$ MANN, Michael. O império da incoerência: a natureza do poder americano. Rio de Janeiro: Record, 2006, p. 10.
} 
em 1941. Em meio à ausência de imagens é possível ouvir gritos, choros, explosões, pedidos de socorro, som de turbina de avião e objetos caindo.

Segundo Chevalier e Gheerbrant, de acordo com a simbologia das cores, no Ocidente o preto é a cor do luto, da perda, do pessimismo, da aflição, da infelicidade e da morte. "O preto absorve a luz e não a restitui. Evoca, antes de tudo, o caos, o nada, o céu noturno, as trevas terrestres da noite, o mal, a angústia, o inconsciente e a Morte" ${ }^{\text {472 }}$.

Se a cor preta representa o luto, e este a perda e a dor devido à ausência de alguém, aquela tela escura e os ruídos ouvidos anunciam um período escuro aos estadunidenses. Além da referência às vidas perdidas devido ao ataque, a tela preta indica que outros dias não menos sombrios e dolorosos viriam, principalmente, para pessoas que viviam distantes dos EUA cuja riqueza econômica (ouro negro) era alvo dos interesses do grupo político construído na abertura do segundo bloco de imagens.

A tela preta com os sons e ruídos trazidos do local dos atentados ativa o imaginário do espectador. Se a cor preta e seus significados fazem parte da linguagem cotidiana, o espectador pode recorrer à própria memória das imagens das torres ruindo em 2001 e reconstruir, segundo suas próprias emoções, aqueles momentos de aflição e de infelicidade. "Na sua influência sobre o psiquismo, o Preto dá uma impressão de opacidade, de espessura, de peso. É assim que um fardo pintado de preto parecerá mais pesado que um fardo pintado de branco (...) ${ }^{, 473}$.

Nesse sentido, é possível perceber que a tela preta, ao ativar o imaginário, recorra do espectador um exercício de empatia ainda maior do que se o filme reproduzisse as imagens exaustivamente televisionadas do impacto dos aviões e do colapso das torres. Os ruídos e os gritos que o filme apresenta parecem colocar o espectador no nível da rua em meio às pessoas que vivenciaram aquele dia.

Em outra direção, a tela escura também pode significar o estopim acerca daquilo que o filme constrói como argumento essencial para que o grupo de Bush consiga pôr em prática um antigo plano de guerra contra Saddam Hussein. Esse suposto plano seria configurado, segundo o filme, não apenas para atender os interesses econômicos em relação ao petróleo, mas também auxiliaria na tentativa de mascarar históricas relações entre dois fortes grupos no mesmo lado dos "privilegiados": os estadunidenses com a família Bush e os sauditas com a família Bin Laden (embora boa parte dos sauditas que

\footnotetext{
${ }^{472}$ CHEVALIER, Jean; GHEERBRANT, Alain. Dicionário dos Símbolos. $22^{\mathrm{a}}$ ed. Rio de Janeiro: José Olympio, 2008, p. 742.

${ }^{473}$ CHEVALIER, Jean; GHEERBRANT, Alain. Dicionário dos Símbolos, op. cit., p. 743.
} 
aparecem nas imagens não são membros da família Bin Laden). Por sua vez, Osama bin Laden seria responsável pelo apoio financeiro à grupos árabes de cunho fundamentalista islâmico como o al Qaeda. A tela preta pode remeter não somente às perdas humanas e materiais daquele dia, mas também às perdas muito maiores que estavam por vir com a guerra - esta última contra uma nação cuja riqueza material jorra de um óleo também preto e muito cobiçado entre as nações ocidentais.

Os ataques conhecidos como 11 de setembro ficaram com este nome devido à sua repercussão mundial e espetacularização sem precedentes na história. Naquele dia, um grupo formado por homens, cuja maioria era saudita, sequestrou aviões comerciais de passageiros e, após desviar suas rotas, efetuou ataques suicidas colidindo dois aviões, um para cada uma das duas torres que formavam o complexo de edifícios do World Trade Center- WTC em Nova Iorque. Um terceiro avião foi desviado para colidir contra parte do prédio do Pentágono na cidade de Arlington em Virgínia, e um quarto avião teria caído em um campo na região da Pensilvânia, porque se supõe que os passageiros teriam reagido ao ataque antes deste avião atingir seu alvo.

Para falar específicamente da repercussão dos ataques na mídia televisiva, aponto as considerações de Zizek acerca dos dias seguintes à queda das torres. Para Zizek foram dias de intensa repetição das imagens do colapso nas redes de televisão, como se o espetáculo do "real" fosse mais uma ficção Hollywoodiana.

Para a grande maioria do público as explosões do WTC aconteceram na tela dos televisores, e a imagem exaustivamente repetida das pessoas correndo aterrorizadas em direção às câmeras seguidas pela nuvem de poeira da torre derrubada foi enquadrada de forma a lembrar as tomadas espetaculares dos filmes de catástrofe, um efeito especial que superou todos os outros, pois como bem sabia Jeremy Bentham - a realidade é a melhor aparência de si mesma ${ }^{474}$.

Nesta direção, T. J. Clark relembra Guy Debord em seu famoso aforismo: "o espetáculo é o Capital em um grau tal de acumulação que se torna imagem" ${ }^{475}$ para discutir que "o espetáculo é um exercício de poder social. Violenta os atores humanos

\footnotetext{
${ }^{474}$ ZIZEK, Slavoj. Bem-vindo ao deserto do real! cinco ensaios sobre o 11 de setembro e datas relacionadas.São Paulo: Boitempo editorial, 2003, p. 25.

${ }^{475}$ CLARK, T. J. O Estado do Espetáculo. In: "Modernismos: ensaios sobre política, história e teoria da arte”. São Paulo: Cosac Naify, 2007, p. 314.
} 
tanto quanto a disciplina da linha de produção. O espetáculo provém do cano de uma arma de fogo" 476 . Para o autor, a crença de que uma imagem vale mais do que mil palavras pareceu fazer parte dos planos dos "pilotos mártires" que, possivelmente, sabiam que derrubar as torres não poderia barrar os circuitos do Capital. Contudo, o ataque significou um gesto poderoso ao destruir literalmente o WTC diante das câmeras e seu poder de fabricar emoções. Nas palavras do autor, no dia 11 de setembro o Estado americano foi derrotado espetacularmente;

No dia 11 de setembro, o Estado americano foi ferido em cheio no coração, e ainda vemos quase quatro anos depois, golpeando às cegas a cara de uma imagem que não consegue exorcizar, e tentando desesperadamente fazer com que a derrota se converta em termos aos quais possa responder ${ }^{477}$.

Clark concorda com as análises que qualificam os atentados como gestos simbólicos desesperados, ou ainda, como um "protesto" de negação ao capitalismo. Porém, na prática, os ataques não surtiram efeito contra o sistema nem abalaram "os

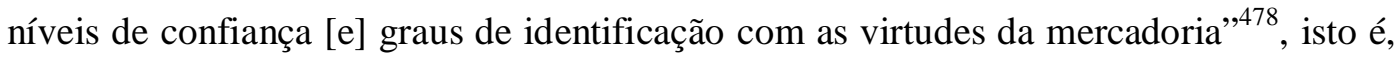
o capitalismo em si, e mais do que isso, a crença na sua eficácia não foram abalados.

Ainda assim, o "terror" como pontua Clark, pode apoderar-se da máquina das imagens e perpetuar aqueles instantes de derrota. Imagens que o próprio governo tentou proibir de serem veiculadas foram amplamente divulgadas pelas televisões em todo o mundo e, posteriormente, utilizadas pela indústria cultural na forma de filmes ${ }^{479}$.

A contrapelo da onda sensacionalista que invadiu as redes de televisão de todo o mundo, Fahrenheit 9/11 não mostra as imagens dos aviões colidindo contra as torres. Porém, o efeito da tela escura com o som do impacto e das explosões, os ruídos dos

\footnotetext{
${ }^{476}$ CLARK, T. J. O Estado do Espetáculo. In: "Modernismos: ensaios sobre política, história e teoria da arte". São Paulo: Cosac Naify, 2007, p. 311.

${ }^{477}$ CLARK, T. J. O Estado do Espetáculo, op.cit., p. 313.

${ }^{478}$ CLARK, T. J. O Estado do Espetáculo, op.cit., p. 314.

${ }^{479}$ Vários filmes fizeram algum tipo de referência aos ataques contra as torres gêmeas do WTC no 11 de setembro, entre os quais destaca-se o premiado " 11 de setembro" produzido pelo francês Alain Brigand em 2002. Neste filme 11 diretores renomados como: Samira Makhmalbaf (Irã), Claude Lelouch (França), Youssef Chahine (Egito), Danis Tanovic (Bosnia-Herzegovina), Idrissa Ouedraogo (Burkina Faso), Ken Loach (Reino Unido), Alejandro González Iñárritu (México), Amos Gitaï (Israel), Mira Nair (India), Sean Penn (Estados Unidos) e Shohei Imamura (Japão), contam pequenas histórias que remetem e promovem discussões acerca dos atentados. Fonte: http://www.imdb.com/title/tt0328802/?ref_=fn_tt_tt_1. (Acesso em 23 de maio de 2013). Outros 41 títulos de filmes fazem menção ou trazem histórias que citam ou discutem os atentados no dia 11 de setembro; a lista completa pode ser acessada no site do IMDB: http://www.imdb.com/list/5gorsyrby-g/?ref_=tt_rls_2. (Acesso em 23 de maio de 2013).
} 
destroços e o desespero das pessoas, não é menos chocante para o espectador, até então, acostumado com uma espécie de "compulsão à repetição" das imagens televisionadas. Para Zizek, é possível supor que os próprios agentes dos atentados não o fizeram apenas pelo dano material, mas também pelo seu efeito espetacular, pois "tínhamos de ver tudo aquilo vezes sem conta; as mesmas imagens eram repetidas ad nauseam, e a estranha satisfação que elas nos davam era a jouissance em estado puro"480.

Contudo, em outra linha de raciocínio, para falar da influência de acontecimentos distantes no cotidiano das pessoas, Giddens aponta que essas repercussões midiáticas que lhe são decorrentes fazem parte das influências em um contexto de alta modernidade, período também marcado pelo papel central dos meios de comunicação na organização das relações sociais. Segundo Giddens;

Com o desenvolvimento da comunicação de massa, particularmente a comunicação eletrônica, a interpenetração do auto-desenvolvimento e do desenvolvimento dos sistemas sociais, chegando até os sistemas globais, se torna cada vez mais pronunciada. O "mundo" em que agora vivemos, assim, é em certos aspectos profundos, muito diferente daquele habitado pelos homens em períodos anteriores da história. (...) Um universo de atividade social em que a mídia eletrônica tem um papel central e constitutivo $(. . .)^{481}$.

Nesse sentido, é possível imaginar que todo tipo de "evento", ainda que de diferente magnitude, como foi, por exemplo, o dia 11 de setembro de 2001, ganha uma repercussão de grande impacto no cotidiano e na auto identidade de pessoas, que, continuamente, são mobilizadas a tomar posicionamento e decisão em relação aos acontecimentos mundiais. Nesta direção, o filme Fahrenheit $9 / 11$ faz parte deste contexto de alta modernidade, e também reverbera tanto os atentados do 11 de setembro de 2001 enquanto "recorte" histórico, quanto o seu debate posterior que traz influências na vida cotidiana.

Acerca do filme como um "recorte" histórico, diria Nichols que;

\footnotetext{
${ }^{480}$ ZIZEK, Slavoj. Bem vindo ao deserto do real! cinco ensaios sobre o 11 de setembro e datas relacionadas. São Paulo: Boitempo editorial, 2003, p. 26.

${ }^{481}$ GIDDENS, A.Modernidade e identidade. Rio de Janeiro: Jorge Zahar, 2002, p. 12.
} 
El documental nos permite acceder a una construcción histórica común. En vez de a un mundo, nos permite acceder al mundo. En el mundo siempre hay cuestiones de vida o muerte no muy lejos de nosotros. La historia mata. Aunque nuestra entrada en el mundo se produce a través de redes de significación como el lenguaje, las prácticas culturales, rituales sociales, sistemas políticos y económicos, nuestra relación con este mundo también puede ser directa e inmediata (...). Se producen prácticas materiales que no son entera o totalmente discursivas, aunque sus significados y valor social lo sean ${ }^{482}$.

Assim, antes de um "registro do real" o filme apresenta uma construção partindo de elementos do "real", os atentados ocorridos em 11 de setembro de 2001, com valores e relações simbólicas que permeiam ou atravessam a "realidade" mesmo que esta comporte diferentes acepções teóricas. Com isto, o filme mais dialoga com o "real" do que o "retrata" - no sentido simples do termo.

Embora Fahrenheit 9/11 inclua os atentados ao WTC como estopim para a explosão da guerra, o filme não trata exclusivamente da guerra contra o Iraque e a conhecida barbárie "eletrônica" das guerras contemporâneas, além da falsa "precisão cirúrgica" sobre os alvos inimigos. Não aponta apenas para o poderio bélico dos EUA reconhecido mundialmente como um "gigante militar" da perpetuação da exploração entre grupos humanos através de uma arma simbólica e não menos poderosa como o medo e, neste caso, mais especificamente o medo da morte. Conforme o filme segue em sua construção do "real", o grupo de Bush seria formado por pessoas que usam o acesso ao poder político em benefício de seus negócios particulares e asseguram sua posição na estrutura social através de mecanismos de controle social relacionados ao medo. Medo da morte, medo de "ataques terroristas", medo de perder familiares, medo de perder o emprego, a casa e a estabilidade financeira, a paz, o sossego, a "liberdade".

É possível imaginar que o filme inicia com a questão das eleições, não apenas para denunciar uma suposta fraude eleitoral, como também, para indicar que a possibilidade de mudança ou de reação a essa ordem de coisas, sobretudo em uma

\footnotetext{
${ }^{482}$ NICHOLS, Bill. La representación de la realidad: cuestiones y conceptos sobre el documental. Ediciones Paidós Ibérica, S.A: Barcelona, 1991, p. 152.

${ }^{483} C f$. MANN, Michael. O império da incoerência: a natureza do poder americano. Rio de Janeiro: Record, 2006, p.31.
} 
sociedade democrática, ocorre através do voto. O poder do eleitor que não votou em Bush pode ser notado mesmo em meio às denúncias de fraude, visto que o partido republicano obteve vitória com uma margem pequena de diferença, como se, com maior engajamento do eleitorado, a vitória de Al Gore poderia ter sido um sonho realizado e, consequentemente, a guerra, com seu saldo devastador para uns e milionário para outros, teria sido evitada.

Acerca do medo da morte, o filme segue a linha de pensamento construído em seu antecessor, Tiros em Columbine, ao sugerir que o medo é um sentimento historicamente cultivado entre os próprios estadunidenses, diariamente "bombardeados" com notícias alarmantes veiculadas pela mídia, bem como pelo próprio grupo político que está na Casa Branca - os mesmos rostos que se preparam na abertura do segundo bloco de imagens.

A representificação do dia 11 de setembro constrói a relação do espectador com o momento dos atentados a partir da tela preta e dos ruídos captados nos primeiros instantes da colisão entre aviões e edifícios. Essas cenas ganham um sentido trágico com a música orquestral Cantus in Memory of Benjamin Britten. Com um tom marcadamente fúnebre, a música constrói a sensação de dor e de lamento pelas vidas que estavam sendo ceifadas, enquanto aquelas imagens eram gravadas por testemunhas dos atentados. Entre o som orquestrado é possível reconhecer o toque de um sino, e a câmera filma rostos apreensivos olhando para o topo das torres que ainda não tinham ruído. $\mathrm{O}$ dia escurece em meio à nuvem de poeira e de cinzas, chove papel picado e materiais em destroços, pessoas correm, outros choram. Sentimentos como apreensão e medo estariam visíveis nos rostos das pessoas que vivenciaram aqueles ataques. A construção das cenas é lenta, a música está alta, de modo a reforçar o caráter trágico daquele episódio histórico.

As imagens reunidas pelo filme com flagrantes dos primeiros momentos do ataque remetem ao que Michel Chion chama de "efeito empático", no sentido de a música criar no cinema uma emoção específica relativamente à situação mostrada.

Numa das formas, a música exprime diretamente a sua participação na emoção da cena, dando o ritmo, o tom e o fraseado adaptados, isto evidentemente em função dos códigos culturais da tristeza, da alegria, da emoção e do movimento. Podemos então falar de música empática 
(do termo empatia: faculdade de partilhar os sentimentos dos outros) $)^{484}$.

Após a tela preta, as imagens retornam aos flagrantes de indignação que envolve as testemunhas do choque entre aviões e prédios. Através das feições de surpresa ou espanto, a "realidade" parecia ficção, não se sabia ao certo o que estava acontecendo, nem como as autoridades do país haviam permitido que um ataque daquela proporção pudesse acontecer com êxito. A música triste ainda não terminou e filmando os pequenos cartazes que foram afixados na tentativa de identificar os desaparecidos na tragédia, Moore conta que entre os três mil mortos também estava seu amigo Bill Weems, passageiro em um dos aviões sequestrados e atirados contra as torres. Moore aproxima a câmera da história familiar dos mortos, também se colocando como quem perdeu alguém querido e enfatizando que Bill Weems também tinha esposa e filha. Uma moça procura por um parente desaparecido dizendo que ele tem dois filhos pequenos, outras pessoas levam flores e fazem suas homenagens nas proximidades do local dos ataques. Como a tela preta sugeria, o país entrava em luto.

A partir desse dia, 11 de setembro de 2001, o filme passa a construir com mais detalhes uma histórica relação entre a família Bush e os sauditas enfatizando o grupo empresarial dos Bin Laden. Dando relevo a não reação do presidente diante da notícia dos ataques, a narrativa relaciona o passado político dos Bush (pai e filho) e de seus aliados, como Donald Rumsfeld, como parte das responsabilidades políticas que resultaram no "11 de setembro" e, consequentemente, na guerra contra o Iraque. Uma guerra que, como sugere a narração, parecia uma espécie de antigo plano esperando o momento certo para sair da gaveta, visto que Bush (o pai), na época presidente dos EUA, liderou a coalizão militar que travou a guerra do Golfo Pérsico, em agosto de 1990, justamente contra o Iraque, país invasor do Kwait - outra liderança mundial na produção de petróleo.

Para reforçar o sentido de facilitação aos membros da família Bin Laden em deixar o país após os atentados, com o bloqueio do espaço aéreo, o filme focaliza aviões parados em diferentes pontos do país de modo a enfatizar o incômodo gerado entre todos os passageiros que estavam impedidos de seguir viagem, ironizando que até o astro da música Ricky Martin estaria entre os lesados.

\footnotetext{
${ }^{484}$ CHION, Michel. A audiovisão: som e imagem no cinema. Lisboa: Texto \& Grafia, Ltda. 2011. p.14.
} 
No sentido de comprovar as assertivas da narrativa, entram entrevistas com especialistas e outros pesquisadores das relações entre sauditas e os Bush, como Craig Unger autor de House of Bush, House of Saud. Em vários trechos apresentados separadamente, Unger afirma que os sauditas obtiveram todo apoio do governo para saírem do país. Outras fontes de jornal também são usadas para legitimar o discurso fílmico e até uma suposta lista oficial de passageiros daqueles voos em 13 de setembro é focalizada na tela. Inclusive, o próprio embaixador da Arábia Saudita nos EUA, Bandar Bin, afirma em entrevista para a televisão que obteve ajuda do FBI para retirar muitos sauditas do país após o dia 11 de setembro de 2001.

O conhecido programa de entrevistas de Larry King também é utilizado como fonte de informação para a construção de Osama Bin Laden como líder dos atentados e cuja família mantinha antigas relações empresariais com os Bush, além de outros negócios "na América".

Nesta entrevista, após ajeitar os óculos apenas com o dedo médio (gesto internacionalmente conhecido como sinal de escárnio) como quem, inconscientemente, não se importava com o ocorrido nem com os grupos em questão, o príncipe Bandar Bin lembra a antiga aliança formada entre os EUA e os sauditas para apoiar o grupo de Bin Laden à época do mujahedin no combate à invasão soviética ${ }^{485}$.

Moore costuma inserir trechos de seriados nos seus documentários, principalmente quando busca oferecer alguma explicação didática para aquilo que constrói ao seu público. Nesse sentido, em Fahrenheit 9/11, são utilizados trechos do antigo seriado policial Dragnet em que investigadores importunam familiares de seus suspeitos. Ao estudar a importância histórica das séries televisivas Esquenazi informa que é profundamente arraigado entre os estadunidenses o gosto popular pelo

\footnotetext{
${ }^{485}$ Em estudo realizado para compreender os atentados do "11 de setembro de 2001 " dez anos depois, o que quer dizer, com algum distanciamento histórico após a comoção das perdas humanas e afastado das 'teorias de conspiração' tão comuns nos EUA, o professor da Universidade Lusíada de Lisboa, Vasco Rato (que lecionou como professor convidado de ciência política e relações internacionais na Universidade de Georgetown - em Washington, DC - de 2007 a 2009) pesquisou a fundação do grupo alQaeda por Abdullah Azzam e Osama Bin Laden em 1988 para a defesa da fé islâmica puritana e fundamentalista, o que significa um entendimento literal do Corão e da Suna (livro com exemplos de conduta deixados pelo profeta Maomé). A propósito da conhecida aliança contra os soviéticos, Vasco Rato é contrário ao mito de que Bin Laden era uma criação da CIA desde 1980 e 1983. Segundo este autor, "Os mujahedin eram financiados pelos Estados Unidos e pela Arábia Saudita com o compromisso saudita de atribuir um montante igual àquele que era concedido pelos americanos. Mas essas contribuições, tal como as armas fornecidas à resistência afegã, não eram distribuídas diretamente aos sete grupos que compunham o movimento mujahedin. Bin Laden distribuía algumas ajudas, principalmente fundos doados por cidadãos da região do Golfo Pérsico, mas eram os serviços de inteligência sauditas e paquistaneses que estavam incumbidos de fazer a distribuição de armas. Osama era muitas coisas, mas nunca terá sido uma marioneta da CIA, muito menos sua criação". RATO, Vasco. Compreender o 11 de setembro dez anos depois. São Paulo: Edit. Babel, 2011, p. 42.
} 
entretenimento e pela ficção, e seriados como I Love Lucy e Dragnet são alguns dos primeiros grandes sucessos deste segmento.

Acerca da recepção do conteúdo das séries televisivas, Esquenazi aponta que,

Nos Estados Unidos, dado que uma produção é portadora de ideias, valores e princípios americanos, é vista com seriedade e atenção, mesmo que se destine inicialmente ao prazer. Não é de admirar que a representação que propõe possa ser analisada sob o ângulo do seu rigor, da sua pertinência ou da sua receptividade. Como vimos desde o início do nosso percurso, as séries não são exceção à regra ${ }^{486}$.

Assim, é possível supor que as séries televisivas possuam um caráter pedagógico que auxilia as construções da narrativa em propor ao espectador um modo de ser, de enxergar e pensar determinado assunto. Ao citar o conhecido seriado Dragnet, o filme lembra seu leitor da antiga forma de agir dos seus "genuínos" investigadores, ou ainda, como é que "nós" fazíamos antigamente em um caso desses. E desta forma, fica bem marcado o sentido de contrassenso do atual governo em ajudar os suspeitos a deixar o país, ao invés de detê-los e pedir explicações em busca de um possível envolvimento com Osama Bin Laden.

O Senador Byron Dorgan também aparece em entrevista, de modo que seu depoimento legitima a proposição do filme de que a família Bin Laden foi cuidadosamente retirada dos EUA, enquanto centenas de outras pessoas de origem árabe eram presas e fichadas em todo o país, mesmo que não tivessem a mínima ligação com o principal suspeito dos atentados.

O agente aposentado do FBI, Jack Cloonan, conversa com Michael Moore e, ao modo do agente de Dragnet, Cloonan também diz que agiria segundo o antigo costume policial de investigar todos os suspeitos com perguntas além de "fichar" cada um dos familiares de Bin Laden.

Na sequência, Moore ainda faz uma pequena comparação desta situação com os atentados praticados por Thimoty McVeight em Oklahoma, perguntando ao público como seria a reação das pessoas se o ex-presidente Bill Clinton tivesse ajudado os familiares do suspeito a se retirar da cidade ou do país. A resposta da narrativa vem com uma breve imagem que faz alusão de "caça às bruxas" com um homem segurando uma

${ }^{486}$ ESQUENAZI, Jean-Pierre. As séries televisivas. Lisboa: Edições Texto \& Grafia, Ltda. 2011, p. 159. 
tocha acesa. Quem conhece o trabalho de Michael Moore na televisão, com os programas TV Nation e The Awful Truth, pode reconhecer, neste exemplo comparativo, algumas das encenações com atores que aqueles programas faziam em episódios curtos para tratar temas da política interna relevantes naquele momento.

Enquanto constrói uma antiga ligação entre os negócios dos Bush com os Bin Laden, o filme retoma a suposta amizade entre George Bush e James R. Bath desde os tempos da Guarda Nacional do Texas, o que coincidiu com o período em que o pai de Bush era chefe da CIA. Na condição de empresário do ramo aéreo, James Bath teria iniciado negócios com os Bin Laden ao mesmo tempo em que Bush iniciava no setor de poços de petróleo no Texas - começo dos anos 70.

Com fotos e gravações de imagens antigas, somados aos depoimentos do repórter investigativo James Moore, o filme sublinha que, apesar da aparente "incompetência" na exploração de petróleo, as empresas de George Bush (filho) recebiam financiamento de grupos sauditas (sob a mediação de James Bath), isto porque, conforme a narrativa estrutura e comprova com fotocópias de documentos e depoimentos de especialistas, o que estava em negociação não era petróleo, e sim informações privilegiadas acerca de negócios nos EUA. George Bush aparece em um desses vídeos dizendo que tinha acesso irrestrito ao seu pai, presidente dos EUA naquele momento, e que este privilégio o beneficiava. Esse recorte trazido para o filme constrói o significado de que Bush já tinha acesso ao poder político do país e, portanto, se beneficiava de informações privilegiadas para a condução dos seus negócios.

A partir das declarações de Bush extraídas de vídeo antigo, das imagens de arquivo, documentos fotocopiados e fotos diversas, reunidos pelo filme, o sentido que alude ao espectador é o de que uma grande teia de relações envolvia a empresa de Bush, Harken Energy Corp. Segundo o filme, a Harken Energy Corp também contava com financiamento saudita, de modo que essa estrutura de poder "blindava" as empresas até contra os rigorosos controles fiscais do mercado estadunidense - em razão de alguns processos que envolveram as empresas de Bush em negociações aparentemente ilegais, conforme o filme explora ao citar um processo aberto pela Comissão de Valores Imobiliários.

Nesta teia de relações envolvendo os membros do grupo de Bush, construído como bem financiado e que se mantém em diferentes níveis de acesso ao poder por décadas, o filme cita o apoio favorável de Robert Jordan à Bush, na época do processo movido pela Comissão de Valores Imobiliários. Posteriormente, quando Bush é eleito 
presidente, Jordan foi nomeado embaixador americano na Arábia Saudita. Nesta construção de relações com mútuos favores, Farenheit 9/11 ainda cita que o pai de Bush foi nomeado consultor do Carlyle Group e, para "comprovar", aparecem imagens de diferentes encontros entre o ex-presidente e lideranças sauditas.

Dan Briody, do "The Halliburton Agenda", entra em cena como outro escritor de caráter investigativo que auxilia na legitimação das acusações contra o grupo de Bush, de modo que a tese do filme, balizada por um discurso de autoridade, ganhe cada vez mais consistência ou "veracidade" a partir dos depoimentos de especialistas nos assuntos que envolvem a família Bush.

Assim, o sentido que o filme propõe é que tanto as empresas petrolíferas dos Bush quanto os investimentos na indústria bélica pelos sauditas, via Carlyle Group, lucrariam com as mortes do dia 11 de setembrode 2001, fornecendo muitos dos principais equipamentos para a posterior guerra contra o Iraque, além de movimentações milionárias na bolsa de valores com a venda de ações em um mercado aquecido. Ao citar tantos nomes em ligações empresariais, de lisura duvidosa, o filme tece uma estrutura de relações entre grandes corporações estadunidenses e sauditas cujos interesses comerciais são favorecidos por influência política em detrimento dos interesses da nação, sobretudo, a estadunidense.

Nesta suposição, Fahrenheit 9/11 utiliza a alegre música Shine Happy People 487 para finalizar o que construiu como uma amistosa rede de relações empresariais entre os sauditas que investiam nas empresas dos Bush há pelo menos três décadas. Enquanto o filme apresenta imagens de George Bush (pai) realizando encontros e reuniões com grupos de empresários árabes, a música do grupo R.E.M constrói o sentido das cenas ao falar de pessoas ilustres e alegres que sorriem e dão as mãos, numa espécie de relação baseada em amizade, amor, e felicidade em que o ouro e a prata reluzem - uma alusão fílmica ao caráter econômico-comercial que move essas relações.

\footnotetext{
${ }^{487}$ Segue a letra original da música: Shiny happy people laughing. Meet me in the crowd. People, people. Throw your love around. Love me love me. Take it into town. Happy, happy. Put it in the ground. Where the flowers grow.Gold and silver shine.Shiny happy people holding hands. Shiny happy people holding hands.Shiny happy people laughing. Everyone around love them, love them. Put it in your hands. Take it take it. There's no time to cry. Happy, happy. Put it in your heart. Where tomorrow shines. Gold and silver shine.Shiny happy people holding hands. Shiny happy people holding hands. Shiny happy people laughing. Fonte: http://musica.com.br/artistas/rem/m/shiny-happy-people/traducao.html (acesso 15 de maio de 2013). Assim, conforme discute Michel Chion em “A audiovisão", o som não reforça o sentido da cena, ao contrário, "ele dá e cria, seja por inteiro, seja pela sua própria diferença com aquilo que se vê". IN: CHION, Michel. A audiovisão: som e imagem no cinema. Lisboa: Texto \& Grafia, Ltda. 2011, p, 12.
} 
Esta construção sugere que, de modo nada ético ou, muito menos patriótico, antes de cuidar dos interesses da nação, os Bush (pai e filho) estariam mais preocupados com os lucros advindos da realeza saudita, essa última construída no filme como chefe de "um regime infrator dos direitos humanos", o que foi "comprovado" com uma cena forte, tomada à distância, da execução de dois homens conforme as leis sauditas decapitação pela espada.

Acerca dessa construção em relação aos sauditas, vale lembrar que a cena da decapitação pela espada que os desqualifica como "infratores dos direitos humanos", não é menos forte do que uma cena de execução em algumas das cadeias estadunidenses em seus diferentes métodos aplicados ao longo da história: cadeira elétrica, injeção letal ou nas formas mais antigas e cada vez menos utilizadas como a câmara de gás, enforcamento e até o fuzilamento ${ }^{488}$. O filme fala dos "costumes" de outras nações como se outras práticas de execução de indivíduos condenados à morte não pudessem ser encontradas nos EUA.

Nesse panorama de lucrativos negócios entre multinacionais, facilitados pela influência política, adiciona-se a postura aparentemente negligente de George Bush no que concerne às investigações pós o 11 de setembro de 2001-como se o presidente temesse que descobrissem mais detalhes das relações entre sua família e amigos com os Bin Laden. Enquanto uma entrevista para a televisão coloca Bush alegando apoio às investigações da Comissão pós 11 de setembro, outra, em seguida, parece desmenti-lo com falas dos membros da mesma Comissão alegando falta de acesso ao material necessário para compor um relatório dos atentados. Logo em seguida, o filme aponta para os parentes das vítimas que esperavam, através dos possíveis esclarecimentos obtidos pela comissão, um alívio para a dor da perda dos seus entes queridos. Com isto, o filme valoriza o papel da comissão que tenta investigar os atentados e coloca Bush sob suspeita de prejudicar o processo.

Outra informação, com a qual o filme trabalha sua tese da falta de ética dos dois presidentes estadunidenses, refere-se à nacionalidade dos 19 terroristas militantes da alQaeda envolvidos no ataque suicida: 15 eram sauditas, dois oriundos dos Emirados Árabes Unidos, um era egípcio e o outro era libanês ${ }^{489}$. As pequenas fotos com os rostos

\footnotetext{
${ }^{488}$ Fonte: http://www.time.com/time/magazine/article/0,9171,1699855-2,00.html (Acesso em 10 de maio de 2013).

${ }^{489} \mathrm{O}$ filme sublinha apenas que dos 19 terroristas 15 eram sauditas. As demais informações acerca da nacionalidade dos membros do grupo podem ser conferidas em: RATO, Vasco. Compreender o 11 de setembrodez anos depois. São Paulo: Edit. Babel, 2011, p. 86.
} 
dos suspeitos foram divulgadas em Fahrenheit 9/11, de modo que podem contribuir para que, no imaginário social, todo indivíduo de feição árabe ganhe status de "terrorista" conforme Bush e seu grupo denominaram os grupos suspeitos pelos atentados.

Apesar de o filme não ter obrigação de dar conta de um suposto "real", até porque não é espelho desse mesmo "real", e sim, a construção de outra "realidade" que, por sua vez, dialoga com diferentes teses acerca do "real", não é fácil desconsiderar que a narrativa de Fahrenheit $9 / 11$ equaliza diferenças históricas entre os grupos muçulmanos.

Acerca da história dos povos árabes, Albert Hourani aponta para a falta de coesão entre os muçulmanos enquanto grupo religioso. Vivendo atualmente em diferentes graus de ocidentalização, os muçulmanos ou seguidores do Islã dividem-se basicamente em dois ramos originais, diferenciados principalmente, pelo modo como escolheram os sucessores de Maomé e pela interpretação do Corão (livro sagrado do Islã) e da Suna (uma espécie de biografia idealizada com exemplos de conduta do Profeta). O primeiro ramo é formado pela maioria sunita (cerca de $80 \%$ dos seguidores) que preferem a interpretação literal do Corão e da Suna ${ }^{490}$. Esse ramo escolhe os sucessores do Profeta através do mérito devocional, ao entender que qualquer fiel eleito pelo conselho estaria habilitado à sucessão. Entre os sunitas existem nuances doutrinárias que vão desde os moderados até os ultraconservadores e extremistas como os talibãs. O segundo ramo é formado pelos xiitas, considerados radicais ao preferirem como sucessor os membros da linhagem familiar do Profeta (como foi seu genro e primo $\mathrm{Ali}^{491}$ ). Os xiitas divergem dos sunitas tanto na interpretação do Corão (metafórica) quanto nos registros acerca da vida do Profeta $^{492}$. Ainda é possível encontrar sub-ramos entre os dois principais grupos de fé islâmica, o que os tornam ainda mais complexos do que a generalização apresentada nos limites de um filme. Essa generalização não prejudica o eixo narrativo do filme em torno do grupo de Bush,

\footnotetext{
${ }^{490}$ Talvez isso nos ajude a pensar porque uma sociedade modernizada como a saudita (de poder sunita) aparece no filme em formas antigas de execução de pessoas consideradas "infratoras da lei", como visto na imagemda decapitação por espada.

${ }^{491}$ Ali ibn Abi Talib (656-61), era coraixita, um antigo convertido à fé no Islã, primo de Maomé e casado com sua filha Fátima. Após disputas para se manter no poder, foi assassinado na sua cidade Kufa. HOURANI, Albert Habib. "A sucessão de Maomé”.In: Uma história dos povos árabes. São Paulo: Companhia das Letras, 1994, p. 39-44.Os xiitas também são conhecidos como seguidores de Ali. Hourani, A. Op. cit, p. 56.

${ }^{492} C f$. HOURANI, Albert Habib. A formação de uma sociedade. In: Uma história dos povos árabes. São Paulo: Companhia das Letras, 1994, p. 57- 75.
} 
porém não é possível afirmar que o filme ofereça algum tipo de "conhecimento" acerca dos povos árabes.

Assim, Fahrenheit $9 / 11$ pode contribuir para uma visão simplista dos árabes porque os trata de forma ampla, como se entre esse grupo não existisse divergências na leitura do Corão, na sucessão do Profeta Maomé, ou acerca da ocidentalização ou modernização do mundo, esta última representaria, para a al-Qaeda de Osama Bin Laden, a decadência da fé genuína.

Segundo Vasco Rato, autor que discute mais detidamente o grupo envolvido nos ataques às Torres, é a "fé genuína" do ano 622-630 período do retorno de Maomé para Meca que os islamitas jihadistas da al-Qaeda querem reproduzir nos tempos modernos, daí decorre o ódio ao Ocidente considerado materialista, seja este ateu (com os comunistas soviéticos) seja cristão (com os EUA e aliados, incluindo os não cristãos como os judeus) ou ainda de outra fé que não esteja enraizada nas tradições islâmicas ${ }^{493}$.

Acerca do significado do termo Jihad, Hourani afirma que se trata de um preceito aos seguidores do "caminho de Deus". O significado dessa ordenança poderia variar entre um sentido mais amplo e mais preciso que compreende em "combater pela expansão das fronteiras do Islã ${ }^{\text {"494 }}$. O preceito também ganhou sentido de defesa das fronteiras, conforme o autor;

A jihad, guerra contra os que ameaçavam a comunidade, fossem eles infiéis hostis de fora ou não-muçulmanos de dentro que rompessem seu acordo de proteção, era em geral encarada como uma obrigação praticamente equivalente a um dos Pilares. (...) Após a grande expansão do Islã nos primeiros séculos, e com o início do contraataque da Europa Ocidental, a jihad tendeu a ser encarada mais em termos de defesa que de expansão ${ }^{495}$.

Assim, a acepção do termo jihad leva à compreensão de que tipo de valor teve para a fé de grupos muçulmanos os ataques contra os EUA. Ainda com a construção fílmica em torno dos grupos árabes, sobretudo os sauditas, esses são majoritariamente uma nação de fé islâmica (sunita). Existem, de um lado, os mais ocidentalizados que

\footnotetext{
${ }^{493}$ RATO, Vasco. Compreender o 11 de setembrodez anos depois. São Paulo: Edit. Babel, 2011, p. 32.

${ }^{494}$ HOURANI, Albert Habib. A formação de uma sociedade. In: Uma história dos povos árabes. São Paulo: Companhia das Letras, 1994, p. 82.

${ }^{495}$ HOURANI, Albert Habib. op. cit., 1994, p. 164.
} 
estão no mundo dos negócios, sobretudo no que concerne ao capitalismo globalizado e, portanto, mais alinhados à modernidade alta ${ }^{496}$, e de outro lado extremo, pessoas que não colocam sua fé no progresso, como os 19 jihadistas que tomaram os aviões sequestrando-os numa forma de luta contra aquilo que consideravam apostasia da fé genuína. Apostasia esta, que eles observaram tanto entre os próprios sauditas quanto naqueles que consideram o foco do seu problema - os "materialistas" ${ }^{497}$ Estados Unidos - fornecedores de apoio financeiro e bélico a outro inimigo dos muçulmanos: o Estado de Israel. Curiosamente Osama Bin Laden ou as lideranças do seu grupo teriam escolhido os jihadistas mais ocidentalizados (que falavam inglês e fizeram cursos como a escola de pilotagem nos EUA) para a ação suicida.

De volta ao filme, Fahrenheit 9/11 não se posiciona contra Saddam Hussein e enfatiza que as armas químicas, motivadoras para a guerra, nunca foram encontradas pela coalizão de Bush. Utilizando imagens retiradas de programas de televisão, cujos repórteres aparecem preocupados com a repetição de um novo Vietnã (diante da resistência dos iraquianos), o filme constrói um "real" acerca dos árabes equalizando suas diferenças talvez como estratégia para manter o foco na ideia da guerra como algo que favorece economicamente o grupo de Bush. O filme está mais voltado em "confrontar" Bush do que construir outros personagens. Com isto, a participação árabe no filme também é polarizada entre os dois grupos principais: ou como os financiadores sauditas no grupo de Bush, ou como os iraquianos que sofrem com os ataques da guerra e ficam mais próximos do grupo de Michael Moore.

O filme associa Osama Bin $\operatorname{Laden}^{498}$ e a al-Qaeda aos sauditas que, por sua vez, são construídos como antigos aliados dos Bush. Essas ligações colocam essas pessoas como participantes das responsabilidades que resultaram nos ataques no dia 11 de setembro de 2001. Desta forma, é possível afirmar que o filme se posiciona abertamente

\footnotetext{
${ }^{496}$ Conforme aponta Giddens na introdução deste trabalho, o conceito de modernidade alta marca um período pós-tradicional em que a difusão das instituições modernas por meio da globalização alcançou diferentes regiões do globo [como o mundo árabe saudita] promovendo a radicalização dos efeitos da modernidade e a expansão de suas instituições alterando as relações cotidianas. GIDDENS, Anthony. Modernidade e identidade. Rio de Janeiro: Zahar, 2002, p. 09-16.

497، $P$ or conseguinte, em décadas mais recentes, a luta contra os regimes seculares/ modernizadores do mundo muçulmano, aos quais são atribuídas responsabilidades pela decadência do mundo islâmico, sobressaiu como um elemento crítico da narrativa jihadista. Dado que o jihadismo é uma entre as várias interpretações possíveis da experiência islâmica (...)”. RATO, Vasco. Compreender o 11 de setembrodez. anos depois. São Paulo: Ed. Babel, 2011, p. 33.

${ }^{498}$ Conforme aponta Vasco Rato, Osama Bin Laden seria dissidente tanto da sua própria família Bin Laden, quanto da família real saudita. RATO, Vasco. Anos de Exílio. IN: "Compreender o 11 de setembro dez anos depois". São Paulo: Ed. Babel, 2011, p. 53-67.
} 
contra George Bush em uma construção ideológica que, como um discurso político, construiu motivações que requerem do espectador um posicionamento.

Entre os inúmeros posicionamentos que o filme poderia sugerir, o mais importante propõe a não reeleição de Bush e, a julgar pelo resultado das eleições em 2004, o cinema de documentário não possui um discurso tão persuasivo quanto um pensamento singelo poderia imaginar, visto que Bush não apenas foi reeleito como o foi de modo a não dar margem a acusações de fraude como no pleito anterior ${ }^{499}$.

A construção em torno do grupo de Bush em Fahrenheit 9/11 remete às discussões acerca de ética no cinema de documentário e no modo como Bill Nichols trata essas discussões relacionando ética com política e ideologia. Segundo o autor;

Considero que la ética va a la par de la política (y la ideología) ya que estos términos representan la misma problemática dentro de marcos conceptuales diferentes. La conducta ética, en otro nivel, puede considerarse como una conducta de motivación política y viceversa; tanto la ética como la política se pueden ver como ejemplos de discurso ideológico dirigido a la constitución de formas apropiadas de subjetividad para un modo determinado de organización social ${ }^{500}$.

Assim, a conduta ética ou ideológica da narrativa em Fahrenheit 9/11, possivelmente seria a de direcionar um acirrado discurso fílmico contra Bush e seu grupo, a fim de evitar a reeleição do presidente em 2004. Mesmo que o filme não tenha esse "poder", seu diretor é figura pública no país e alvo de debates em torno de suas obras.

Para Bill Nichols, os discursos ideológicos buscariam não apenas afetar a conduta individual como também apresentam uma rede de relações sociais que dão textura a uma economia e cultura determinadas. Assim, para o autor, tanto a política da ética quanto a ética da política,

(...) son discursos ideológicos no solo en el sentido de que buscan afectar a la conducta individual por medio de la retórica, sino en el sentido más básico de que establecen y mantienen un "entramado de

\footnotetext{
${ }^{499}$ Fonte: http://usatoday30.usatoday.com/news/politicselections/vote2004/president.htm (acesso em 17 de maio de 2013).

${ }^{500}$ NICHOLS, Bill. La representación de la realidad: cuestiones y conceptos sobre el documental. Ediciones Paidós Ibérica, S.A: Barcelona, 1991, pág. 144.
} 
relaciones sociales" específico que forma el tejido y la textura de una economía cultural determinada ${ }^{501}$.

Nesta direção, Fahrenheit 9/11 pode ser considerado como um dos filmes de discurso ou posicionamento político mais evidente em relação aos seus predecessores. Dois grupos de opiniões, partidos e interesses divergentes são construídos e o grupo de Bush é alvo das críticas do filme do começo ao fim, numa forma objetiva cuja retórica fala para um grupo específico dos EUA "representado" tanto por Michael Moore como pelos personagens estadunidenses que ganham relevo na narrativa - como será o caso de Lila Lipscomb vista nas sequências finais desta análise. Assim as questões éticas que os filmes de Moore suscitam podem ser respondidas como questões ideológicas ou de um posicionamento valorativo em relação ao grupo divergente do grupo no qual Moore se apoia em seus filmes.

Na sequência das imagens que mostram a logística em torno da guerra com as empresas estadunidenses a cargo dos membros do grupo de Bush, a tese da narrativa que também permite um diálogo com o contexto de alta modernidade, é a da exploração de seres humanos através do medo, em um sistema capitalista globalizado no qual a indústria da guerra assumiu o "lado sombrio" da modernidade, fazendo parte das transformações rápidas atreladas à industrialização.

Segundo Giddens, a conexão da organização e inovação industriais com o poder militar põe em relevo o "lado sombrio" da modernidade tornando o mundo atual mais perigoso devido aos possíveis conflitos gerados em um contexto de estados-nação que possuem armas cada vez mais destrutivas e, por sua vez, afetam a crença no "progresso"

Ao seu modo, Fahrenheit 9/11 aponta para relações entre grupos de empresários num contexto de capitalismo globalizado cujo avanço sistemático por todas as regiões do planeta estaria solapando os localismos e culturas regionais, bem como religiões (como o islamismo) e tudo que não aderisse à lógica do mercado.

O filme dialoga com as teses de que, amparados pela comoção nacional devido às três mil pessoas mortas de uma só vez em solo americano, os chamados "guerreiros

\footnotetext{
${ }^{501}$ NICHOLS, Bill. La representación de la realidad: cuestiones y conceptos sobre el documental. Ediciones Paidós Ibérica, S.A: Barcelona, 1991.

${ }^{502}$ GIDDENS, A. As consequências da modernidade. São Paulo: Ed. UNESP, 1991, p. 18-19.
} 
de escritório" ${ }^{, 503}$ associaram o nome de Saddam Hussein, ditador de um país com uma das maiores reservas de petróleo do mundo, aos atentados contra os EUA.

Mann chama Bush de "guerreiro de escritório" ou "matador de escrivaninha" porque este "nunca chegara a ver a ação militar nem suas terríveis consequências", deliberando, a partir da segurança de sua sala, ordens que resultariam em milhares de mortes. Ainda que a afirmação de Mann seja coerente, Fahrenheit 9/11 indica uma estrutura de poder que delimita e separa os que planejam a guerra daqueles que vão à guerra. Assim, os que tomam decisões em prol da guerra também poupariam seus filhos e, em certa medida, suas próprias vidas de um conflito bélico, enquanto os mais pobres, fora dos círculos de decisão política, seriam enviados à guerra correndo todos os riscos que isso implica.

George Bush se coloca como "o presidente da guerra" mesmo após "deixar Bin Laden escapar", e mobiliza a poderosa infraestrutura de guerra dos EUA para um conflito, aparentemente, iniciado por seu pai em 1991 na chamada Guerra do Golfo Pérsico. Nova entrevista de "comprovação" das teses do filme entra com Richard Clark, um agente de segurança nacional na época do 11 de setembro, alegando que antes de irem atacar as bases da al-Qaeda no Afeganistão, foi-lhe ordenado que indicasse Sadam Hussein como responsável pelos atentados - como se um antigo plano de guerra estivesse saindo da gaveta.

Fahrenheit 9/11 ironiza Bush em sua "fraca" resposta ao al-Qaeda no Afeganistão, montando um pequeno filme típico do "gênero de western", ou ainda, parecido com o seriado Bonanza $a^{504}$, dentro do documentário, associando nomes dos aliados de Bush à cowboys que, segundo Moore, deram dois meses de vantagem ao grupo de Osama em fuga - o mesmo acusado da autoria de outros atentados anteriores como contra o navio USS Cole e embaixadas americanas na África. Em outro momento do filme, e de forma humorada, o grupo de Bush será ridicularizado com sua "coalition of the willing" que apresenta de modo estereotipado os aliados de Bush na guerra contra o Iraque: a República de Palau, a República da Costa Rica, a República da Islândia, Romênia, Holanda, Afeganistão e o Reino do Marrocos que não estava na coalizão, mas

\footnotetext{
${ }^{503}$ Mann chama Bush de "guerreiro de escritório" ou "matador de escrivaninha" porque este "nunca chegara a ver a ação militar nem suas terríveis consequências", antes, Bush dava, a partir da segurança de sua sala, ordens que resultariam em milhares de mortes. $C f$. MANN, Michael. O império da incoerência: a natureza do poder americano. Rio de Janeiro: Record, 2006, p. 13.

${ }^{504}$ Famoso seriado veiculado pela rede de televisão NBC, Bonanza esteve no ar entre os anos de 1959 até 1973. Narra a história de um personagem viúvo que cuida dos três filhos e do seu rancho em Nevada. Fonte: http://www.imdb.com/title/tt0052451/ (18 de maio de 2013).
} 
ofereceu macacos para serem usados como detonadores de minas terrestres - uma crueldade contra os animais.

O filme reforça novamente a tese de facilitação entre os grupos aliados de Bush, como a Halliburton de Dick Cheney ${ }^{505}$, ou a Unocal do ex-consultor Hamid Karzai, em lucrativas relações comerciais também no Afeganistão para a construção de um gasoduto. Karzai teria sido empossado por Bush como presidente do Afeganistão após a retirada dos talibãs do poder - cuja imagem e música sintonizada aos filmes de gângster conferem um tom humorístico à cena, construindo os talibãs como fugitivos que não ofereciam riscos para os grandes interesses dos grupos supracitados.

Após a construção das relações comerciais entre os Bush e os sauditas, o filme inicia um terceiro bloco cujo personagem principal é o povo dos EUA. Neste bloco, que faz uma longa pausa na narrativa acerca da guerra contra o Iraque, o filme constrói como Bush e seus aliados mantinham o povo "ocupado" ou alheio aos interesses daquele grupo com o uso de uma arma já sinalizada no documentário Tiros em Columbine: o medo. Um congressista democrata, membro do Senado e psiquiatra, Jim McDermott concede várias entrevistas a Moore, dizendo que o povo era tratado pelo governo Bush como um cão treinado recebendo ordens confusas.

A seguinte fala de Bush, concedida à imprensa que o acompanhava em outro momento de lazer pós o 11 de setembro, entra como ilustração daquilo que o congressista assinalou como informações truncadas cujos conteúdos não se relacionam:

"Precisamos deter o terror.

Apelo para as nações que lutem para deter esses terroristas assassinos.

Obrigado.

Agora, vejam esta tacada."

Sob o lema veiculado na televisão: "Guerra contra o Terror", o filme propõe que os inimigos dos estadunidenses seriam seus próprios governantes, visto que antes de

\footnotetext{
${ }^{505}$ A título de informação, Mann afirma que a Halliburton, que teve como presidente-executivo o vicepresidente dos EUA Dick Cheney, é a maior fabricante de equipamento petrolífero tendo, inclusive, fechado negócios em 1998 com Saddam Hussein. Essas informações reforçam a tese do filme de que um dos grandes motivos da invasão do Iraque foi por este país ter a segunda maior reserva de petróleo do mundo (11\% da reserva mundial de maior qualidade) e não a al-Qaeda. Além disso, as sanções econômicas impostas ao Iraque pelos EUA e aliados impedem o país de explorar suas próprias jazidas. Também é conhecido que tanto a família Bush quanto membros do partido republicano se beneficiam do dinheiro obtido em negócios com petróleo. $C f$. MANN, Michael. O império da incoerência: a natureza do poder americano. Rio de Janeiro: Record, 2006, p. 282.
} 
encontrar Osama Bin Laden, preferiram voltar-se contra o povo, utilizando as armas do medo e da sensação de ameaça permanente para a implantação de um confuso controle institucional observado, principalmente, nos aeroportos. Ironicamente chamados por Moore de "imprensa independente", jornalistas anunciam na televisão tudo o que pudesse gerar pânico entre a população, como alertas de possíveis“ataques terroristas” que variavam entre as cores laranja e vermelha, desde que nunca atingissem a tranquilidade dos limites azul e verde.

Enquanto constrói que o governo Bush “investiu” bilhões de dólares retirados do orçamento do país com gastos militares, Fahrenheit 9/11 aponta para importantes trechos de fronteiras precariamente patrulhados. Isso sugere que, enquanto o governo aplica recursos em questões externas, muita coisa deveria ser feita dentro do país. Em outro momento, o filme aponta para grupos de moradores em pequenas cidades curiosamente vigiados pela CIA - como se um "espírito de terrorismo" pairasse sobre a população trazendo desconfiança generalizada.

Neste contexto de vigilância crescente, outras proibições são criadas para o controle, como a restrição para o transporte de líquidos em aeroportos em contraste com o uso liberado de fósforos e isqueiros. O filme perde tempo em longa entrevista de uma mãe que foi parada pelas autoridades por descumprir a norma de não levar líquidos a bordo. Ela portava leite materno para seu bebê e teve que prová-lo para certificarem que não era um "líquido ilegal", conforme encenou para a câmera. Até o setor de segurança privada parece lucrar com engenhocas em nome da segurança individual.

Assim, com pequenas histórias individuais (de uma mãe com seu bebê, até patrulheiros solitários), o filme constrói que, cada vez mais, os estadunidenses se tornavam reféns em seu próprio país e, através do Decreto Patriota, novas formas de controle social foram instauradas com direito a buscas que vão dos registros médicos e financeiros, passando pela internet, telefonia, até empréstimos de livros. Isso tudo porque meses antes do dia 11 de setembro algumas autoridades estadunidenses cortaram financiamentos e pararam investigações do FBI, justamente acerca de membros da alQaeda que atuavam dentro dos EUA. Com isto, o filme ironiza como o FBI passou a importunar cidadãos aparentemente inofensivos como o grupo de moradores em Fresno ou o aposentado Barry Reingold, que fez críticas ao governo Bush durante suas aulas de musculação em uma academia de Oakland. É como se o governo estivesse mais preocupado com os indivíduos que não sentiam medo, o que poderia os tornar "menos controláveis", do que com a possibilidade de novos ataques "terroristas" contra o país. 
Um quarto bloco fílmico é iniciado a partir de um corte na imagem da, aparentemente tranquila, costa do Oregon para bombas em um navio de guerra. Neste novo segmento da narrativa, o filme aumenta o foco na guerra contra o Iraque. As imagens mais fortes da guerra propõem o sentido da insanidade de mais um conflito envolvendo os EUA contra um país em evidente desvantagem bélica.

Destacando o lado "humanista" do filme, é possível perceber que entre os interesses do grupo de empresários, construídos como a base de George Bush, e a riqueza mineral nas terras de Saddam Hussein, estavam duas populações envolvidas: de um lado, tropas americanas, formadas em sua maioria por jovens pobres enviados para a guerra, (o que inclui suas famílias - amedrontadas diante de um inimigo novo e desconhecido); e de outro, toda a população civil do Iraque construída como pessoas tranquilas que levavam a vida de modo não muito diferente de uma família pobre na América.

Coincidindo com a tese de Mann que chama Bush e seus aliados de "guerreiros de escritório" ${ }^{, 506}$, o filme monta nova sequência de cenas que preparam o espectador para o saldo mais negativo das eleições presidenciais que abrem Fahrenheit 9/11. Bush aparece impecavelmente vestido em um terno preto, falando a partir da Casa Branca. Ao mesmo tempo, as imagens cortam para tropas, provavelmente ordenadas em algum porta-aviões no Golfo Pérsico preparando mísseis e bombas diversas. O áudio de duas contagens regressivas, uma direto da Casa Branca, e outra do comando do navio de guerra, unem os dois momentos distintos em uma narrativa que responsabiliza o presidente George Bush pela sequência de mortes que ocorrerão tanto entre os soldados quanto aos civis iraquianos.

Antes que o espectador associe as duas contagens regressivas nas cenas anteriores, e esteja preparado para assistir a algumas explosões, semelhantes às de filmes de ação produzidos por Hollywood, o filme propõe um momento de empatia pela população que será bombardeada.

Para isso, Fahrenheit 9/11 focaliza o letreiro de uma sorveteria no Iraque onde se lê: ice cream. Numa possível alusão de que, ao adotar na fachada de um ponto comercial a referência ao sorvete em língua inglesa, aquele povo não parecia ser antiestadunidense, o filme contrapões essas imagens ao áudio do discurso de Bush dizendo que, "sob seu comando, as tropas atacarão alvos militares a fim de libertar o povo do

\footnotetext{
${ }^{506} \mathrm{Cf}$. MANN, Michael. O império da incoerência: a natureza do poder americano. Rio de Janeiro: Record, 2006, p. 13.
} 
Iraque". As cenas mostrando civis nas ruas não sugerem que o exército dos EUA encontraria um inimigo ou exército à sua altura. Aquelas imagens sugerem mais o início de um período de violação aos direitos humanos do que uma "coalizão contra o terror".

Gravadas em março de 2003, as imagens apresentam um pouco do cotidiano em Bagdá antes da guerra, que começaria em 19 de março de 2003. Foram filmadas imagens de uma cidade movimentada, com pessoas sorridentes nas ruas; alguns estabelecimentos comerciais como bares e restaurantesaparecem limpos e organizados, como se pudessem ser encontrados em qualquer cidade pequena, senão nos EUA certamente na América Latina. Outras imagens mostram muitos carros no que parece ser um congestionamento comum em grandes cidades, o que aproxima o espectador do cotidiano daquelas pessoas. Outro corte, e o filme aponta um grupo familiar que se diverte em uma festa de casamento não muito diferente de um casamento burguês realizado na América. Nota-se que a noiva está de vestido branco com véu e grinalda, seus familiares também seguem um estilo de roupa ocidental com os homens vestidos de terno e as mulheres em vestidos elegantes. Essa imagem parece aproximar dois povos tão distantes geograficamente, fazendo com que todos pareçam ter os mesmos ideais de uma vida familiar comum. De volta às ruas, aparece uma espécie de parque de diversões repleto de crianças iraquianas, com roda gigante e outros brinquedos encontrados em qualquer cidade pequena dos EUA. Mulheres em trajes típicos sorriem para as câmeras não dando nenhuma impressão de se tratarem de pessoas oprimidas ou que desejem alguma libertação. Mesmo nos locais aparentemente mais pobres, como as cenas de prédios pequenos que se assemelham a conjuntos habitacionais, são filmados rostos tranquilos de pessoas que vivem em um país pobre, porém, continuam seus afazeres diários sem demonstrar problemas diferentes dos que podem ser encontrados em regiões das grandes cidades.

Enquanto a voz de Bush discursa a respeito de um povo oprimido, em um país cujo líder ameaça o mundo com armas de destruição em massa, a imagem que fecha as cenas, construindo o cotidiano em Bagdá, é de uma criança pequena que desliza despreocupadamente sobre um escorregador comum de parque, e, antes que esta chegue ao solo, a imagem corta abruptamente para a explosão de uma bomba de grande proporção no que parece ser a primeira noite dos bombardeios naquela cidade.

A partir desta imagem, o filme aponta para as primeiras horas de guerra no Iraque. Navios de combate acionam mísseis, supostamente para aquela cidade que acaba de ser apresentada ao espectador. Essa construção fílmica pode suscitar a 
necessidade de se imaginar o porquê dos EUA atacarem um povo que, à primeira vista, parece tão próximo da maioria dos americanos pobres, o que reforça a ideia de contrassenso daquela guerra.

Após imagens de crianças se divertindo dias antes no pequeno parque de diversões, com a chegada da guerra, o filme imediatamente corta para a imagem de uma criança muito pequena, morta e ensanguentada, sendo colocada por um homem na carroceria aberta de um carro que passava pelas ruas recolhendo cadáveres. A imagem é forte, as cenas seguintes trazem o saldo trágico da guerra - destruição e mortes. É como se aquela criança morta fosse uma daquelas que brincavam há poucos instantes no parque de diversões e pelas quais já era possível sentir alguma empatia.

A maioria das sequências que remete aos horrores da guerra, construída como injustificada, é composta por imagens de mulheres e crianças em cenas de morte e/ou desespero, reforçando a fragilidade dessas pessoas e sua desvantagem em relação à invasão do exército estadunidense no Iraque.

Os extras do filme informam que no primeiro mês de guerra os EUA e a Inglaterra lançaram 30 mil bombas e mísseis no Iraque, também fizeram mais de 50 "ataques cirúrgicos" a "alvos essenciais".Como se os espectadores estadunidenses do filme estivessem acostumados ao conteúdo desses discursos de precisão cirúrgica, Fahrenheit 9/11 aponta a câmera para a dor dos civis iraquianos justamente para contradizer tais discursos.

O número total de civis iraquianos mortos é desconhecido, mas passaria dos 150 mil. Entre os soldados americanos as baixas seriam bem inferiores, porém Moore informa que esses números não seriam divulgados para evitar maior descontentamento entre a população que mantém uma histórica relação de admiração e respeito por seus combatentes.

Um dos iraquianos que aparece na cena do início da guerra recolhendo corpos dos civis mortos, diz uma frase bastante significativa, que pode indicar a capacidade de resistência daquele povo mesmo diante de um oponente tão forte. Em tom de juramento ele diz:

\section{"Quem não teme a morte, não morrerá."}

Esta fala sinaliza que, para os muçulmanos, a morte é vista de um modo diferente do ocidental, neste caso, dos estadunidenses. Embora sejam o lado mais fraco 
e as maiores baixas da guerra, os muçulmanos apresentam uma coragem própria diante da morte.

Conforme indica Mann, algumas lideranças de grupos muçulmanos alegam que em caso de jihad, ou guerra santa contra os infiéis, estariam preparados para o sacrifício. "Nada temos (...) a não ser a arma do martírio. É fácil e só nos custa nossas vidas (...) as bombas humanas não podem ser derrotadas, nem mesmo pelas bombas nucleares" "507. A partir dessas declarações é possível inferir que os "novos" inimigos dos EUA lidam de modo diferente com o medo e com a morte.

Ainda acerca do medo da morte, mas em uma lógica sintonizada ao modo de vida estadunidense, diria Paul Virilio;

A guerra não pode jamais ser separada do espetáculo mágico, porque sua principal finalidade é justamente a produção deste espetáculo: abater o adversário é menos capturá-lo do que cativá-lo, é infligir lhe, antes da morte, o pavor da morte ${ }^{508}$.

Segundo o filme, o pavor da morte poderia ser observado nos rostos assustados dos estadunidenses de Rappahannock à Tappahannock que, por sua vez, tentavam interpretar os alertas de possíveis atentados contra aquelas cidades. Ou ainda entre aqueles que faziam vigília diante da Casa Branca e, segundo Moore, pediam a seu líder que os protegesse. Se o medo da morte não fosse tão comum entre os estadunidenses não haveriam tantos negócios voltados para a segurança pessoal, como o filme sugere.

Segundo os estudos de Vasco Rato, acerca dos fatores que culminaram no 11 de setembro, uma das maiores constatações de Osama Bin Laden, desde que criou o grupo jihadista da al-Qaeda, é que os estadunidenses tem medo da morte, ou ainda, que lhes faltam a "coragem e capacidade de sacrifício" "509 observadas entre os jihadistas. Isso porque desde o Vietnã, onde o exército americano não conseguiu êxito diante de um exército de camponeses, a população passou a rejeitar veementemente a morte dos seus soldados em guerras, e nenhum presidente desconhecia a dificuldade de seguir com uma guerra sem o consentimento da opinião pública.

\footnotetext{
${ }^{507}$ MANN, Michael. O império da incoerência: a natureza do poder americano. Rio de Janeiro: Record, 2006, p. 65.

${ }^{508}$ VIRILIO, Paul. Guerra e Cinema: a logística da percepção. São Paulo: Boitempo, 2005, p. 09.

${ }^{509}$ RATO, Vasco. Compreender o 11 de setembrodez anos depois. São Paulo: Ed. Babel, 2011, p. 64.
} 
Nesse sentido, conforme o filme indica, Bush passa um bom tempo tentando convencer a opinião pública da necessidade da guerra e o filme parodia esse discurso sem se dar conta de seu significado na estratégia de infligir o medo de novos ataques. É possível admitir que o filme subestime a inteligência de Bush, como se essa só fosse legítima se estivesse sintonizada com o bem comum.

Para a construção da guerra como algo insano e a exploração do trabalho das tropas, não para libertar o Iraque, mas para os lucros que jorrariam dos poços de petróleo, o filme trata a guerra como um grande negócio extremamente lucrativo. Dentro desta 'economia de guerra' são formados grupos bem distintos. Em primeiro plano, dois grandes grupos opostos: um formado pelos guerreiros de escritório estadunidenses e seus sócios sauditas focados no ouro negro iraquiano; outro, a partir do apoio fictício de Saddam Hussein aos "terroristas" reunidos na figura de Osama Bin Laden, que contaria também, com apoio do governo talibã do Paquistão, cuja antiga jihad islâmica ou guerra santa contra o ocidente (infiéis) foi o estopim para a concretização dos planos de guerra iniciados com a Guerra do Golfo.

Nesse esquema lucrativo, a força de trabalho explorada pelos "privilegiados estadunidenses" são as tropas e este grupo ganha destaque no filme. Caracterizados como imaturos e mal preparados para o trabalho na guerra, o grupo dos soldados levados ao Iraque é, em sua maioria, composto por jovens que se alistavam no serviço militar por falta de opção de trabalho nos EUA. Michael Moore explora essa condição como fator predominante para o alistamento, partindo de sua cidade Flint no Michigan empobrecida com a desindustrialização apontada desde seu primeiro filme Roger e Eu. O modo "fantasioso" como os recrutadores "caçam" potenciais soldados nas ruas de todo o país também é construído pelo filme. Essas construções dos jovens soldados como sendo, predominantemente, pessoas pobres reforça o sentido de que os ricos planejam a guerra e os pobres vão para a guerra.

Em uma das cenas com militares falando sobre o início da invasão, um combatente, aparentemente mais velho, diz que o grande número de baixas civis no Iraque era devido às dificuldades dos militares diante do combate, pois "chegaram atirando em tudo o que se mexia". Essa declaração inicial é tomada pelo filme para o início da construção da imaturidade e despreparo da grande maioria dos soldados estadunidenses, os mesmos jovens pobres convencidos por "patriotas mal informadas" como Lila Lipscomb, uma senhora que se torna símbolo de ‘cidadão médio’ dos EUA, 
ou seja, os trabalhadores que acreditam nos seus líderes e nos valores do país, entre os quais predomina a "liberdade".

Ao focalizar rostos que mal têm barba, o filme aponta para os soldados construindo-os como se confundissem o trabalho na guerra com entretenimento. Eles seguem para o combate, que alguns associam a brincar de Comandos Em Ação ${ }^{510}$, ao som de ritmos chamados por eles mesmos de heavy metal. Essa música seria tocada dentro dos jipes e tanques de guerra, como a música Fire Water Burn e Bodies (Let The Bodies Hit The Floor)reproduzidas pelo filme junto a cenas de civis mortos ou feridos, sobretudo, crianças. Esse conjunto de cenas torna presente a crueldade da guerra e pode promover no espectador momentos de empatia pelos jovens soldados, visto que esses também são construídos como vítimas de maus líderes.

Ao tomar os depoimentos dos soldados, o filme busca reconstruir a visão que eles tinham do conflito, como o percebiam e o que acreditavam estar fazendo ali. Para transmitir ao público essa visão, e defender a ideia daqueles soldados como imaturos e despreparados para a guerra, o filme apresenta um momento curto em que ocorre uma quebra no ritmo da narrativa para cenas mais rápidas, parecidas com um vídeo-clip - o que reforça a ideia de entretenimento como um recurso muito usado nos filmes de Moore.

Nesse momento, ao som da música "Let The Bodies Hit The Floor" são adicionadas as imagens de momentos dramáticos das vítimas da guerra, como a de um funeral muçulmano e a de um pai desesperado que tenta socorrer uma criança ferida desacordada. Enquanto isso, outro soldado americano informa qual sua música preferida para o combate: o rock "The Roof Is On Fire" "511. Esta música parece acrescentar mais crueldade às cenas, pois enquanto o rapaz fala de seu desejo de queimar Bagdá e acabar com Saddan, o filme sugere a frieza do exército estadunidense como se este

\footnotetext{
${ }^{510}$ Como depõe um soldado apresentado nos créditos do filme: ele diz que a Corte dos EUA lhe deu duas opções: ou ir para a cadeia, ou ir para a guerra - sintetizando as poucas opções que restariam aos jovens pobres.

${ }^{511}$ Ambas as músicas possuem letras agressivas, cujos conteúdos "celebram" mortes violentas. $\mathrm{Na}$ primeira: "Let The Bodies Hit The Floor" os dizeres repetitivos falam em "deixar os corpos baterem no chão" numa alusão ao ato de atirar em pessoas com as armas de fogo e ver seus corpos caírem no chão. Fonte: http://letras.mus.br/drowning-pool/11816/traducao.html (Acesso em 28 de maio de 2013). Na segunda música: "The Roof Is On Fire", os dizeres da letra apelam para que "deixem o filho da puta queimar" de forma ainda mais agressiva que a primeira letra e o filme enfatiza essa fala filmando o soldado cantando para a câmera e em seguida apresentando crianças queimadas após os bombardeios no Iraque. Fonte da letra: http://www.vagalume.com.br/bloodhound-gang/the-roof-is-on-fire-traducao.html (Acesso em 28 de maio de 2013).
} 
desconhecesse que, entre aquele poderio bélico desmedido para uma guerra urbana e Saddan Husseim, estariam milhares de civis desarmados.

No sentido de propor essa sensação incômoda ao espectador, representificando um ataque do lado mais forte contra um povo aparentemente indefeso, o filme apresenta as músicas citadas pelos soldados associadas ao saldo trágico dos combates. Ouvir a letra da música com os dizeres "Burn motherfucker" e ver as imagens de mulheres muçulmanas vestidas com seus véus tradicionais, desesperadas ao ver suas vidas sendo destruídas, pode causar uma forte sensação no espectador de violação dos direitos humanos por parte do exército dos EUA. Ainda nessas sequências, a câmera corta para o perfil de um jovem soldado sorridente diante das colunas de fogo que aquelas bombas promoviam. Os risos do jovem seriam sintoma da incoerência de um país em que diversão e guerra eram incentivadas desde a infância como propôs Tiros em Columbine.

As músicas indicadas pelos próprios soldados no front são incômodas porque, segundo Michel Chion, teriam um sentido anempático. Conforme apontei em outro momento, este autor discute o valor acrescentado pela música à imagem de modo que ambas construam um sentido no filme. Se na queda das torres gêmeas o filme acrescentou valor à cena com a música Cantus in Memory of Benjamin Britten, o que conferiu de modo empático dor e tristeza às imagens, nesse momento, com The Roof Is On Fire, o filme faz o contrário sem perder o efeito de promover incômodo.

Talvez pareça que assistir cenas de guerra ao som de heavy metal sugira um gesto de indiferença do filme em relação às mortes e ao sofrimento observado nas imagens, no entanto, essa música anempática também reforça o efeito de emoção pelas vítimas no sentido de que as imagens sugerem o oposto dos dizeres nas letras das músicas.

Nesta direção, retomando Chion e sua discussão acerca das duas formas de a música criar no cinema uma emoção específica relativamente à situação mostrada: uma seria o efeito empático em que a música e as imagens partilham um sentimento comum,

$\mathrm{Na}$ outra, pelo contrário, a música manifesta uma indiferença ostensiva relativamente à situação, desenrolando-se de maneira igual, impávida e inexorável, como um texto escrito - e é sobre esse próprio fundo de "indiferença" que se desenrola a cena, o que tem por efeito 
não a suspensão da emoção mas, pelo contrário, o seu reforço, inscrevendo-a num fundo cósmico"512.

A imagem em close no braço despedaçado de uma criança sendo atendida por médicos, no que parece ser uma sala de cirurgia, é um dos momentos mais fortes do filme no sentido de apelar para a comoção do espectador com o sofrimento de mulheres e crianças. E a partir deste ponto, entram vozes de soldados mais "reflexivos" acerca do que vinham promovendo naquela região, falando que eles mesmos pediram reforços como Napalm e depois encontraram mulheres e crianças queimadas, (algumas dessas pessoas são mostradas no filme). Outro soldado depõe a respeito das dificuldades daquela luta urbana com tanques de guerra, onde ao invés de um exército em oposição eles só enxergavam civis e não sabiam quem era inimigo e quem não era. Afinal eles estavam ali para libertar aquele povo do antigo regime, entretanto, as cenas parecem insistir que eles estavam exterminando aquele mesmo povo - conforme as imagens iniciais no bloco que fala da guerra sugeriram.

Em sua narração, Michael Moore culpa o presidente Bush de enviar soldados tão jovens para a guerra, e que os abusos praticados refletiam o "comportamento imoral do presidente". Outras cenas mostram os soldados fazendo piadas e fotografando alguns prisioneiros encapuzados. Esse tipo de atitude militar diante da guerra foi discutido mais detidamente pelo documentário de Errol Morris - Procedimento Operacional Padrão (EUA, 2008) - em que soldados americanos tiram fotos dos momentos em que cometem abusos contra os iraquianos presos em Abu Ghraib o que levou à prisão somente os envolvidos que apareciam nas fotos.

Contudo, em um segundo momento, Fahrenheit 9/11 amplia a história dos soldados, mostrando jovens assustados com os horrores da guerra, cantando ao som do violão em homenagens aos seus mortos, declarando a saudade que sentiam de suas famílias e de sua terra natal, e, em outros momentos, criticando o governo (o que eram proibidos de fazer), as razões para a guerra e lamentando a demora em terminar o conflito. Alguns veteranos feridos e com diferentes traumas de guerra são construídos também como vítimas através de seus depoimentos não menos trágicos. Os próprios soldados parecem não entender o que fazem no Iraque, e muito menos porque seriam odiados pelo povo que foram "libertar", o que indica a crença de que estariam fazendo a

${ }^{512}$ CHION, Michel. A audiovisão: som e imagem no cinema. Lisboa: Texto \& Grafia, Ltda. 2011, p. 1415. 
coisa certa em nome da pátria.

O filme também remete à histórica memória militar como parte da cultura dos estadunidenses, o que os mantêm em constante apoio às tropas e reverência aos seus combatentes que sucumbem em guerras ${ }^{513}$.

Michael Moore cita os esforços da "mídia pró-guerra" que, apesar de citar o crescente índice de mortos, insiste em não revelar o número exato de soldados mortos e também a atitude do governo de não permitir filmagens dos caixões com os corpos. Em contraposição, o filme apresenta imagens de caixões cobertos por bandeiras dos EUA em reverência aos militares mortos naquele combate, e aqui, diferentemente das cenas que tratavam do lado iraquiano o filme parece mais "respeitoso" tocando apenas algumas notas de uma música melancólica em uma imagem de maior duração.

Nas sequências finais do documentário, enquanto Donald Humsfeld discursa acerca das supostas armas químicas, nunca encontradas, e a respeito da "humanidade" com que as tropas tratam os civis no Iraque, as cenas novamente contrapõem, apresentando homens, crianças e mulheres mortas, mutilados, ou gravemente feridos.

A cantora Britney Spears também aparece em cena, através de uma entrevista provavelmente retirada da televisão, mascando chicletes em uma postura pouco séria, aconselhando a todos que confiem nas ações do presidente. A imagem parece uma sugestão fílmica da opinião pouco fundamentada de uma figura pública que falaria em consonância com todos que consentem e legitimam as ações do presidente Bush. Talvez Britney tenha sido escolhida pela sua popularidade como cantora Pop, pois se o filme utiliza ícones da mídia para fazer "oposição" também os usa para sinalizar o esvaziamento crítico dos mesmos.

Em seu modo didático de fazer filmes, Moore narra que toda a confiança depositada pela nação nas ações do presidente se deu ao custo de um bom período de convencimento e do uso de uma arma simbólica como o medo, incutido na população com tantos alertas de "ataque terrorista". Com a construção de imagens e falas alternadas, tanto de Bush quanto de seus aliados, o filme retoma o processo de convencimento do eleitorado da necessidade daquela guerra. Ao mesmo tempo Moore

\footnotetext{
${ }^{513}$ Conforme aponta o historiador Simon Schama, os Estados Unidos destinaram dois dias específicos de memória militar: o primeiro, celebrado na terceira segunda-feira de maio, chama-se Memorial Day ou Dia da Memória dos Mortos em Combate, criado desde o fim da Guerra Civil para homenagear a memória daqueles que morreram em guerras; o segundo, criado em 1919, é o dia dos veteranos celebrado em 11 de novembro. SCHAMA, Simon. O futuro da América: uma história. São Paulo: Companhia das Letras, 2009 , p. 43.
} 
retoma imagens do início do governo de Bush, antes do 11 de setembro, quando a guerra não estava no horizonte e o discurso político não apontava para a capacidade de Saddam em produzir armas de destruição em massa. Nesse sentido, o filme reafirma sua tese de guerra lucrativa, de povo amedrontado e da responsabilidade de Bush e seu grupo diante do quadro apresentado.

Para configurar simbolicamente a grande parte do povo estadunidense a quem o filme se dirige, constituída por trabalhadores assalariados e pessoas suscetíveis ao medo e às manipulações de líderes como Bush, o filme concede um tempo significativo de sua realização à história familiar de Lila Lipscomb. Lila é mãe do jovem sargento Michael Pedersen, morto em combate no Iraque. E não por acaso, Lila ganha espaço no fim do filme, talvez porque as mensagens finais são menos esquecidas pelo público.

Lila ganha destaque no filme pela contradição que viveu ao devotar anos de suavida ao serviço social na cidade de Flint, convencendo garotos pobres a servirem no exército em troca da possibilidade de terem dinheiro para pagar a faculdade e chance de conhecerem o mundo, através de viagens em treinamento e/ou combate. Traída por suas convicções, Lila enxerga a própria ignorância, como prefere dizer, após perder seu filho de 23 anos na guerra do Iraque e, a partir disso, ao lado de Moore, ela engrossa o coro dos críticos ao governo Bush.

Como pessoa pobre que conquistou posições de destaque junto à sociedade em Flint, Lila considera que sua família, formada por vários ex-combatentes, seria "a espinha dorsal da América", como todos os que tiveram parentes defendendo o país em guerras. Isso remete ao orgulho cultivado entre os cidadãos para lutar pelo país e a admiração que nutrem pelos ex-combatentes em razão do modo honroso como se referem aos mesmos.

Aparentemente, Lila desconhecia os motivos da guerra do Iraque ao dizer que não sabia nada a respeito daquele país, mas que odiava os contestadores, pois não suportava ouvir protestos contra a guerra após enviar seu filho para lá. Depois de seu filho Michael Pedersen morrer dentro de um helicóptero Black Hawk abatido, Lila diz compreender que os protestos não eram contra os soldados e sim contra a lógica da guerra.

A história de Lila confere ao documentário contornos de melodrama, quando sua dor vem à tona ao ler as cartas que recebia do seu filho enquanto servia no Iraque, ou quando, após a morte de Pedersen, ela segue para Washington com Moore. Diante da Casa Branca, Lila observa uma senhora estrangeira, que também perdeu filhos, fazendo 
um protesto solitário contra a guerra; ambas as mães ouvem de uma estadunidense que tudo aquilo é encenação e que deveriam culpar a al-Qaeda pelas mortes de seus filhos.

Para lembrar que o "lado oposto" não envia seus filhos para a guerra, o filme aponta novamente para Bush dizendo que não faz ideia do que seria perder um filho, no seu caso, uma de suas duas filhas.

Segundo Silvia Oroz, a partir de uma estrutura formal e ideológica de cariz conservador e moralizante, o melodrama cinematográfico desenvolve-se num esquema binário dos núcleos de conflito da tragédia, entre os quais destaco: paixão/dever, bem/mal, amor/poder, ou ainda, amor/pecado, inferioridade/periculosidade. Essas oposições buscariam "induzir" no espectador sentimentos de piedade ou tristeza. Segundo a autora,

O melodrama desenvolve os mitos da sociedade judaico-cristã e patriarcal, e, através dessa forma cultural, o público confirma a ideia de mundo assimilada. Significa que a necessidade do espectador, no sentido de reafirmação de seus valores, não é frustrada. Dessa maneira, a ausência de novos valores ou, ainda, de outros valores faz com que o espectador não entre em crise com aqueles já assimilados. Suas referências continuam de pé ${ }^{514}$.

Segundo Oroz "todo mito é uma história/fábula em si mesmo e expressa regras de conduta de um grupo social" ${ }^{15}$. A autora discute o cinema de melodrama na sua versão latino-americana, contudo, algumas de suas construções acerca do sofrimento da mãe nesses filmes incorrem no modo como Moore usa a história de Lila em Fahrenheit 9/11.

A dor de uma mãe que perde seu filho na guerra não estaria muito distante da ideia de que o "amor-sacrifício filial erige a figura da mãe como síntese de que qualquer

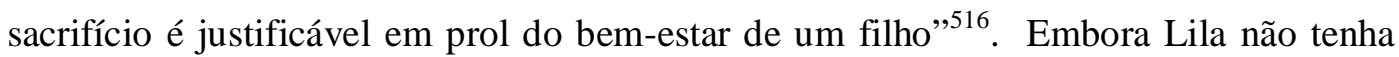
mais a presença física de seu filho, sua vida sofreu mudanças significativas, pois agora ela deixou as antigas convicções de lado e "migrou" do grupo de George Bush para o grupo de Moore tomando um posicionamento público contra a guerra. Ainda com

\footnotetext{
${ }^{514}$ OROZ, Silvia. Melodrama: o cinema de lágrimas da América Latina. Rio de Janeiro: Funarte, 1999, p. 46-47.

${ }^{515}$ OROZ, Silvia. Melodrama: o cinema de lágrimas da América Latina, op. cit., p. 60-61.

${ }^{516}$ OROZ, Silvia. Melodrama: o cinema de lágrimas da América Latina, op. cit., p. 64.
} 
Oroz, "a mãe é uma figura mítica na sociedade judaico-cristã, cuja iconografia remete à Virgem Maria, com toda a sua bateria de resignação e sofrimento" ${ }^{\text {"517 }}$. Nessa direção, Lila encarna o símbolo do sofrimento em Fahrenheit 9/11 porque "ofereceu" seu filho em sacrifício na guerra contra o Iraque, e por todos os valores sociais que acreditava defender naquele confronto pós-11 de setembro.

Segundo Ismail Xavier, "o melodrama tem sido o reduto por excelência de cenários de vitimização" ${ }^{\text {518 }}$.Configurando essa afirmação de Xavier, o filme se detém na vida de Lila construindo-a como vítima do governo. Ainda que sua a dor seja genuína, a forma como o filme monta e apresenta seus personagens remete à fórmula do melodrama, pois marca o lado inocente (Lila, seu filho e sua família) e o vilão (Bush, seu grupo e a guerra) e atribui traços de caráter a cada grupo, um bom e outro mal.

Tanto o "presidente da guerra", quanto Lila, como quem encaminha os jovens para o exército, tinham suas próprias convicções. Guardadas as proporções de poder decisório acerca da vida dos jovens, ambas as personagens possuem ambiguidades dentro de seu grupo de atuação, que o filme soluciona rapidamente. Isso porque o filme aponta para uma dificuldade em lidar com ambiguidades, de modo que as polarizações parecem ser mais "digeríveis" pelo público. Portanto, Bush vai sendo construído como o lado que atuaria de modo consciente em prol do seu grupo e em detrimento dos grupos prejudicados, enquanto Lila não teria noção da sua participação na logística da guerra. O que reforça a sensação de melodrama, nesta forma de organização dos personagens no filme, é aquilo que Xavier considera como uma "pedagogia que requer a resolução das ambiguidades mesmo que tudo se apoie no terreno por excelência das incertezas: o mundo da imagem"

Acerca da narrativa melodramática, que pode se alinhar tanto à esquerda quanto à direita contrariando ou favorecendo o poder político constituído, Xavier pontua que é a fórmula da polarização moral, a qual pretende definir os termos do jogo, que importa, muito mais até do que o conteúdo desta polarização. Esta construção pode ser visualizada na história de Lila em Fahrenheit 9/11, ao retomar aquilo que o gênero do melodrama tem por tradição: "abriga e ao mesmo tempo simplifica as questões em

\footnotetext{
${ }^{517}$ OROZ, Silvia. Melodrama: o cinema de lágrimas da América Latina. op. cit., p. 75.

${ }^{518}$ XAVIER, Ismail. Melodrama ou a sedução moral negociada. In: “O olhar e a cena”. São Paulo: Cosac \& Naify, 2003, p. 85 - 99.

${ }^{519}$ XAVIER, Ismail. Melodrama ou a sedução moral negociada, op.cit., p. 95.
} 
pauta na sociedade, trabalhando a experiência dos injustiçados em termos de uma diatribe moral dirigida aos homens de má vontade" ${ }^{, 520}$.

Para terminar essa caracterização do melodrama indicada por Xavier como algo típico do cinema Hollywoodiano, que Moore parece explorar com a história de Lila, vale lembrar que:

Em termos retóricos, isto significa que é essencial, na composição do drama, colocar os autênticos do "nosso" lado e os hipócritas do lado oposto, regra geral posta em prática nas várias faixas do espectro ideológico, pois todos no melodrama procuram identificar os seus valores sociais com a celebração da espontaneidade e o ataque à dissimulação. A virtude de caráter de um personagem sanciona a sua posição política, a hipocrisia o desautoriza. E a hipótese de legibilidade do que se dá ao olhar garante a nossa percepção da diferença entre uma coisa e outra ${ }^{521}$.

Fahrenheit 9/11 apresenta grupos complexos, cita muitos nomes e impõe diferentes discursos de autoridade, contudo, se detém naquilo que parece mais didático, de melhor assimilação e identificação entre a população de um país com tradição em guerras e reverência aos seus veteranos: uma mãe que perde um jovem filho na guerra.

Enquanto Lila é um personagem que expõe sua vida, sua família, sua simplicidade passível de engano e posterior vitimização, Bush é construído ora como um presidente desqualificado para o cargo, ora como um "vilão supremo", conhecedor e maquinador de "planos de guerra", forte o suficiente para levar um grande grupo poderoso consigo. Apesar de ser caracterizado como o "mal triunfante" e líder de seu grupo, Bush não estava sozinho, pois foi eleito por pessoas que compartilham de suas crenças - a despeito do quão prejudicial ao próprio país e aos estrangeiros essas convicções possam ser. Dentro da lógica sugerida pelo filme,

(...) o mal triunfante pode também confortar, notadamente quando se encarna numa figura de bode expiatório cuja culpa nos purifica, pois ela reúne em si todos os sinais da iniquidade. Exibindo as marcas que permitem o reconhecimento do pecado como sua origem, o mal não é senão teatro do mal, razão por que seu agente deve ser

\footnotetext{
${ }^{520}$ XAVIER, Ismail. Melodrama ou a sedução moral negociada. In: "O olhar e a cena”. São Paulo: Cosac \& Naify, 2003, p. 93.

${ }^{521}$ XAVIER, Ismail. Melodrama ou a sedução moral negociada, op. cit., p. 95.
} 
deliberado, conspirador e caprichoso; e o bem não é senão teatro do bem, razão por que seu agente deve ser autêntico, "naturalmente" prestativo, de bom senso. ${ }^{522}$

Independente de uma suposta "verdade", o que seria impossível conhecer totalmente, o filme configura seus grupos dentro desta lógica assinalada por Xavier com escalas de valores delimitadas e contradições anuladas. Lila Lipscomb, os jovens soldados, e o povo americano são construídos como honestos, trabalhadores, prestativos, valorosos, amedrontados, patriotas, passíveis de serem enganados - como alerta a senhora idosa no final do filme. Osama, os sauditas, Bush e seu grupo políticosão construídos como desleais, ambiciosos, conspiradores, maus em sua essência, corruptos, avessos ao trabalho árduo, ricos, e todo o tipo de vilania que o melodrama comporta.

O povo do Iraque e a queda das torres gêmeas ofereceriam o espetáculo a “jouissance em estado puro" de que falou Zizek ${ }^{523}$, e que alimenta a audiência nas TVs de todo mundo.

Susan Sontag alerta criticamente para a crença de que "se o horror pudesse ser apresentado de forma bastante nítida, a maioria das pessoas finalmente aprenderia toda a indignidade e a insanidade da guerra" ${ }^{424}$.

Parecendo compartilhar da crença comum, observada nas discussões acerca da veiculação das imagens de guerra com Sontag, o filme remete ao lado sombrio da modernidade, com os horrores de um conflito bélico, no sentido de propor ao espectador um posicionamento acerca de tudo o que assistiu.

A respeito dos soldados como pobres e filhos de trabalhadores, o filme constrói que os ricos poupam seus filhos dos mecanismos de exploração utilizados em relação aos pobres. Moore até confronta alguns parlamentares pedindo que alistem seus filhos no exército em tempos de guerra, num modo de verificar as reações dessas pessoas.

O filme termina com o discurso de Bush para aqueles que, amigavelmente, nomeia de "minha base", a elite estadunidense visivelmente formada pelos WASP americanos (sigla para branco, anglo-saxão e protestante). A mensagem que o filme alude, cuidadosamente confeccionada para transmitir essa sensação, é a construção dos

\footnotetext{
${ }^{522}$ XAVIER, Ismail. Melodrama ou a sedução moral negociada. In: "O olhar e a cena”. São Paulo: Cosac \& Naify, 2003, p. 96.

${ }_{223}$ ZIZEK, Slavoj. Bem vindo ao deserto do real! São Paulo: Boitempo editorial, 2003, p. 26.

${ }^{524}$ SONTAG, Susan. Diante da dor dos outros. São Paulo: Cia das Letras, 2003, p. 17.
} 
representantes do grupo de privilegiados lucrando através da guerra, como se esta fosse uma negociação comercial qualquer, isto é, ganhariam dinheiro através da morte de inocentes de ambos os lados, e também seriam responsáveis pelo ônus econômico imposto ao país com o desvio dos recursos de áreas sociais para o conflito - como por exemplo, a área que cuida dos veteranos de guerra, esses últimos colocados como preteridos pelo atual governo.

Empresas como a Unocal, a Halliburton, a Microsoft, a DHL, entre outras, são citadas em cenas de uma reunião promovida em nome da "reconstrução do Iraque" que, segundo o filme, dão o tom dos motivos para a guerra. Em resposta àquela reunião cheia de depoimentos otimistas, que sob o mote de apoio às tropas visavam os lucros que iriam "jorrar junto do petróleo", o filme coloca algumas senhoras questionando as razões para a guerra e dizendo que se sentiam enganadas. Essa fala das senhoras soa como um alerta, pois o filme as apresenta como pessoas comuns, no sentido de não serem especialistas no assunto, para falarem diretamente ao espectador. Um perfil de "pessoa de bem" é configurado na imagem daquelas senhoras, como pessoas que tem família, patriotas que não negam seu apoio ao governo, que mandam seus filhos e netos para a guerra, nutrem bons sentimentos em relação aos veteranos e aos mortos em guerras, enfim, à grande maioria dos EUA, ou como diria uma senhora na fala final: "o coitado do povo".

Diante da dor de Lila Lipscomb, símbolo máximo eleito pelo filme como pessoa enganada pelo governo dos republicanos, e de todas as mortes que a guerra resultou, o filme termina com Moore citandoGeorge Orwell:

A questão não é se a guerra é real ou não. A vitória não é possível. A guerra não é para ser ganha. É para ser eternizada. A sociedade hierárquica é possível nas bases da pobreza e ignorância [...] por princípio a guerra é planejada para manter a sociedade à beira da fome. A guerra é a fúria dos governantes contra suas próprias ideologias. E o objetivo não é a vitória sobre a Eurásia ou a Ásia Oriental, mas manter a própria estrutura da sociedade intacta.

Essa fala de Moore é entremeada pelos mesmos rostos que abriram o grupo de Bush, construídos pelo filme como arquitetos da guerra e como parte daqueles que 
buscam perpetuar as bases de exploração do homem pelo homem também pela arma simbólica, e não menos poderosa, conhecida como o medo. É como se o filme relembrasse ao espectador o nomeque ele deveria evitar votar na próxima eleição para presidente dos EUA.

Todavia, apesar das discussões que promoveu e das tomadas de decisão que propõe Fahrenhei 9/11 não parece ter abalado a figura política de George Bush a ponto de alterar o resultado das eleições de 2004. Talvez porque o cinema teria mais um "papel" de diálogo com o social, de propor sentidos, reforçar valores do que produzi-los enquanto "realidade social", ou, para usar um conceito de Durkheim, um filme não tem a força de promover uma espécie de "fato social" 525 em torno dos temas que trata.

Se como diria Durkheim, "a vida social apresenta-se ao indivíduo sob o aspecto da coerção" 526 visto que a "coerção é a característica de todo fato social" se as representações sociais possuem uma superioridade intelectual e moral sobre os indivíduos, não caberia aos limites de um filme alterar algum tipo de coerção cuja força e significado funcionam independente das consciências individuais.

Conforme Durkheim,

(...) a maior parte de nossas ideias e de nossas tendências não é elaborada por nós, mas nos vem de fora, elas só podem penetrar em nós impondo-se; eis tudo o que significa nossa definição (... regras jurídicas, morais, dogmas religiosos, sistemas financeiros, etc.) consistem todos em crenças e em práticas constituídas, poder-se-ia supor, com base no que precede, que só há fato social onde há $\operatorname{organização~definida~}^{528}$.

Valores sociais em torno da "defesa da pátria", da "liberdade", da "democracia", de "apoio às tropas", entre outros modos de ser e pensar dos estadunidenses, mobilizou um grande apoio em torno do presidente e de seu grupo após o 11 de setembro. Talvez

\footnotetext{
${ }^{525}$ Segundo Durkheim "é fato social toda maneira de fazer, fixada ou não, suscetível de exercer sobre um indivíduo uma coerção exterior; ou ainda, toda maneira de fazer que é geral na extensão de uma sociedade dada e, ao mesmo tempo, possui uma existência própria, independente de suas manifestações individuais. In: DURKHEIM, Émile. As regras do método sociológico. São Paulo: Martins Fontes, 1999, p, 13.

${ }^{526}$ DURKHEIM, E. As regras do método sociológico, op.cit., 1999, p, 125.

${ }^{527}$ DURKHEIM, E. As regras do método sociológico, op. cit., 1999, p. 124.

${ }^{528}$ DURKHEIM, E. As regras do método sociológico, op.cit., 1999, p. 04.
} 
personagens como Lila Lipscomb não saibam explicar conceitualmente o significado dos valores que acreditam, mas os defendem porque os têm internalizado há gerações.

A guerra foi construída como absurda pelo filme, num provável gesto de consciência individual do seu realizador, da equipe e até daqueles que tomam partido dessa construção, contudo, como o próprio filme aponta, um grupo que tinha o poder de decisão pensava diferente e buscou apoio para promover a guerra, explorando, talvez, aquilo que Durkheim chamaria de "movimentos de entusiasmo ou de devoção" após o 11 de setembro. Nas palavras do autor,

Assim, numa assembleia, os grandes movimentos de entusiasmo ou de devoção que se produzem não têm por lugar de origem nenhuma consciência particular. Eles nos vêm, a cada um de nós, de fora e são capazes de nos arrebatar contra a nossa vontade. (...) Que um indivíduo tente se opor a uma dessas manifestações coletivas: os sentimentos que ele nega se voltarão contra ele. (...) Somos então vítimas de uma ilusão que nos faz crer que elaboramos, nós mesmos, o que se impôs a nós de fora ${ }^{529}$.

A coerção dos "sentimentos coletivos" mobilizados após o 11 de setembro também podem apontar para o comportamento dos jovens soldados na Guerra do Iraque conforme o filme construiu como "comportamento imoral". Acerca desses sentimentos expressos pelas condutas dos jovens a coerção do grupo pode colaborar espontaneamente para a emoção comum,

É assim que indivíduos perfeitamente inofensivos na maior parte do tempo podem ser levados a atos de atrocidade quando reunidos em multidão. Ora, o que dizemos dessas explosões passageiras aplica-se identicamente aos movimentos de opinião, mais duráveis, que se produzem a todo instante a nosso redor, seja em toda a extensão da sociedade, seja em círculos mais restritos, sobre assuntos religiosos, literários, artísticos, etc ${ }^{530}$.

\footnotetext{
${ }^{529}$ DURKHEIM, E. As regras do método sociológico. São Paulo: Martins Fontes, 1999, p. 05.

${ }^{530}$ DURKHEIM, E. As regras do método sociológico, op.cit., p. 05.
} 
Neste quadro de construções coletivas, como propõem as imagens de Fahrenheit 9/11, independente dos motivos e dos protestos, a guerra aconteceu, o presidente recebeu apoio e como lembram os dizeres de George Orwell no fim do filme "a sociedade hierárquica" mantém as suas bases. Essas bases são socialmente construídas em cima de valores, crenças e práticas sociais que constituem "um estado do grupo, que se repete nos indivíduos porque se impõe a eles" ${ }^{\text {"531. }}$.

\section{Conclusão}

Estreando nos cinemas em 2004, Fahrenheit9/11 é um documentário estadunidense cuja ácida crítica, aliada à "comedic license" de Michael Moore, incide sobre o governo do republicano George Bush. Esse documentário foi orçado em 6 milhões e rendeu a inédita quantia, para esse tipo de produção, de 222 milhões de dólares em todo o mundo. ${ }^{532}$ Foi o segundo documentário produzido na história do cinema premiado com a Palma de Ouro em Cannes em 2004. ${ }^{533}$

Neste momento de sua carreira como cineasta e escritor crítico de sua sociedade, Michael Moore é bem conhecido do público estadunidense pelo seu filme Roger e Eu (1989), por dois episódios de um documentário curto feito para TV, o primeiro chamado: Two Mikes don't make a right (1992), e o segundo chamado Pets or meats: the return to Flint (1992); por duas temporadas do programa TV Nation (1994-1995) e por seu filme de ficção Canadian Bacon (1995). ${ }^{534} \mathrm{Em} \mathrm{1997,} \mathrm{Moore} \mathrm{lançou} \mathrm{The} \mathrm{Big}$ One e mais dois volumes de vídeos documentários sobre o programa TV Nation. Além disso, a atuação de Moore como defensor dos trabalhadores repercute cada vez mais entre a crítica estadunidense, rendendo inúmeros artigos na mídia ${ }^{535}$.

\footnotetext{
${ }^{531}$ DURKHEIM, E. As regras do método sociológico. São Paulo: Martins Fontes, 1999, p. 09.

${ }^{532}$ Fonte: http://www.boxofficemojo.com/movies/?id=fahrenheit911.htm. Esses valores foram coletados pelo site até o dia 20 de maio de 2007. (Acesso em 18/01/2010).

${ }^{533} \mathrm{O}$ primeiro a receber esse Prêmio foi The Silent World de Jacques Cousteau e Louis Malle em 1956. Fonte: http://www.imdb.com/title/tt0361596/awards. (Acesso em 02 de fevereiro de 2010).

${ }^{534}$ Trata-se de uma comédia sobre um hipotético conflito dos EUA contra o Canadá para reanimar a supostamente falida economia estadunidense, já que os russos não estariam interessados em uma nova guerra fria. http://www.imdb.com/title/tt0109370/. Acesso em maio de 2011.

${ }^{535}$ No site da produtora de Moore, Dog Eat Dog, existe uma lista de artigos escritos nos EUA sobre o filme The Big One. Este filme enfatizou o problema da exploração dos trabalhadores pelas corporações estadunidenses e ficou conhecido pela entrevista que Moore teve com Phillip Knight dono da empresa Nike.http://www.dogeatdogfilms.com/press.html. Acesso em maio de 2011.
} 
Em 2003, Moore ganhou ainda mais notoriedade e entrou definitivamente para o mainstream com o premiado filme Tiros em Columbine ${ }^{536}$, ao propor um retrospecto da história bélica dos EUA para chegar aos atentados praticados por estudantes na escola secundária Columbine no Colorado em 1999. Tiros em Columbine já adiantava a ideia de que uma histórica cultura do medo manteria a população dos EUA refém de si mesma, e isto levaria a alarmantes índices de mortalidade por armas de fogo, superior aos principais países ocidentais juntos, como o filme procurou evidenciar. Se a ideia da cultura do medo favorecia a cultura armamentista dentro do país, também favoreceria, segundo Fahrenheit 9/11, a aprovação da guerra contra países que supostamente abrigam grupos considerados "terroristas" como o al-Qaeda. O filme aponta para a questão do medo como um sentimento generalizado entre os estadunidenses. Curioso que em relação à ação suicida dos jihadistas, teria Osama Bin Laden usado a "tese do medo" a seu favor, visto que os muçulmanos não teriam, diante de uma guerra santa, medo da morte.

Assim, a temática do medo perpassa ambos os filmes caracterizando um ponto de fixação ${ }^{537}$ entre as películas.

Os filmes de Moore se valem dos mecanismos de construção e símbolos da cultura de massa - arraigados no imaginário do seu público - para transmitir uma espécie de "crítica social" e alertar para a necessidade de reflexão acerca dos temas que aborda. No caso de Fahrenheit 9/11 o discurso fílmico, e também ideológico, se posiciona diretamente contra Bush e seu grupo de aliados no partido republicano numa espécie de "desconstrução" da legitimidade política das eleições de 2000.

Embora não problematizem de modo acentuado ou respondam as teses que constroem acerca do medo generalizado entre os estadunidenses, esse sentimento é citado nos filmes de Moore, de modo a configurar um interessante diálogo com a matéria social (medo de perder o emprego, de não viver de acordo com os padrões sociais, de sofrer violência, de ataques "terroristas", entre outros), indicando uma questão simbólica que orienta muitas ações, e por que não, alguns dos principais valores daquela sociedade.

\footnotetext{
${ }^{536}$ Esse documentário custou 4 milhões de dólares e rendeu 58 milhões em todo o mundo ${ }^{536}$, ganhou prêmios como o Academy Awards de melhor documentário em 2003, prêmio do $55^{\circ}$ Aniversário de Cannes em 2002 e o Prêmio César da Academia de Cinematografia Francesa como o melhor filme estrangeiro em $2003^{536}$. Também foi indicado à Palma de Ouro em Cannes 2002 e ganhou três prêmios de melhor audiência em filme documentário no Bergen International Film Festival de 2002, no Atlantic Film Festival de 2002 e no Amsterdam International Documentary Film Festival também em 2002.

${ }^{537}$ Cf. SORLIN, Pierre. Sociologia del cine: la apertura para la historia de mañana. México: Fundo de cultura econômica, 1985, p. 195- 197.
} 


\section{III - Conclusão.}

"O real, o percebido e o imaginário estão presentes mas nenhum é exclusivo"

Pierre Francastel ${ }^{538}$

A investigação em detalhe dos cinco filmes de Michael Moore buscou analisar como esses documentários constroem seu referencial de "realidade" dentro de um contexto específico com o qual dialoga. Nessa direção, a construção social da "realidade" nos filmes de Moore estrutura-se a partir do ponto de vista do "cidadão médio", portador de valores cristãos, em torno da família e do trabalho, cuja crença fundamental visa alcançar o padrão de vida aos moldes do american way of life.

Em termos de teoria do cinema de documentário, a principal forma de produção da "realidade" dos filmes estudados concentra-se no modo expositivo, conforme apresentado na tipologia de Bill Nichols. No modo expositivo prevalece uma lógica informativa transmitida verbalmente na voz de Michael Moore, fazendo o papel de voz de Deus. O diretor se coloca como autoridade em relação aos temas que narra, construindo em cada filme sua própria legitimidade. Moore "subverte" algumas características do modo expositivo, porém não perde essa estrutura na construção de seus filmes. Além disso, os filmes apresentam de forma secundária momentos cuja "representação" inclina para o modo participativo, sobretudo quando o cineasta/personagem se coloca diretamente nos confrontos, inclui entrevistas com personagens envolvidos nas situações, além de especialistas e seus inúmeros discursos de autoridade.

Os principais temas tratados pelos filmes foram as transformações no mundo do trabalho dentro de um contexto de alta modernidade, cuja sociedade de risco envolve não apenas as transformações no capitalismo que afetam o cotidiano das pessoas, como também a construção de uma "disposição" bélica dos EUA que se tornou altamente lucrativa a despeito das implicações e consequências sociais que ocasiona.

Michael Moore constrói um personagem que defende os trabalhadores e as pessoas que buscam o padrão de vida do "americano médio" formando um grande grupo de oposição aos ricos e aos políticos republicanos - esses últimos formando outro

${ }^{538}$ FRANCASTEL, P. Realidade Figurativa. São Paulo: Perspectiva, 1993, p.88. 
grupo geralmente caracterizado pelo poder financeiro e acesso ao poder político. Sua origem social como filho de operários é amplamente citada em seus filmes, a fim de legitimar seu discurso de autoridade pela causa dos trabalhadores e na ênfase da organização sindical.

Os filmes de Moore trabalham com uma carga enorme de informação, citam muitos nomes e constroem seus personagens com diversas referências visuais, como se buscasse de uma forma rápida e didática apresentar temas de complexidade histórica: racismo, armas de fogo, oferta de trabalho e precarização da mão de obra, crescimento da desigualdade social, mudanças na economia, conflitos entre grupos e valores sociais.

Acerca dos pontos de fixação conforme aponta a metodologia de Sorlin, descrita na introdução, alguns temas permeiam os cinco filmes e unem os discursos em torno da perda dos ideais do "american way of life" devido à crescente impossibilidade de os trabalhadores atingirem um padrão mínimo de conforto, isto é, do empobrecimento massivo dos trabalhadores e a perda do padrão de vida aos moldes estadunidenses. Outro ponto recorrente entre os filmes são as disputas entre os grupos ricos e seus “interesses pessoais" contra os pobres "condenados" à sobrevivência.

A questão do trabalho, em Roger e Eu, dialoga diretamente com Capitalismo: uma história de amor, este último eivado de citações acerca de seu antecessor "clássico". Os efeitos negativos da globalização da produção e dos mercados são sinalizados em Roger e Eu e suas consequências aprofundadas em Capitalismo: uma historia de amor, cuja ênfase no mercado acionário e a diminuição de postos de trabalho nos EUA causam ainda mais danos com a crise financeira de 2008 - favorecendo a proposta fílmica de se repensar os "rumos" da economia estadunidense em relação aos trabalhadores.

The Big One entra como elemento acessório entre os dois filmes anteriores, ao pormenorizar o problema das grandes corporações estadunidenses e o deslocamento dos postos de trabalho. Esses três filmes formaram o primeiro bloco de análise com questões acerca do trabalho no sistema capitalista, as transformações em torno da flexibilização das relações de trabalho e a globalização da produção que transportou milhares de empregos para outras regiões afetando muitas cidades nos EUA.

Os problemas construídos no primeiro bloco de filmes apontam para o enfraquecimento da crença comum em torno do ideal de vida estadunidense conhecido como american way of life. Isso ocorre em razão das dificuldades enfrentadas pelos 
trabalhadores para alcançar o padrão de vida da antiga "classe média", caracterizada por empregos estáveis, pelo acesso ao consumo e ao conforto da vida nos subúrbios.

Embora os filmes, não sugiram soluções em curto prazo, enfatizam os rumos sombrios que o sistema capitalista vem tomando nos EUA, a ponto de transformar vidas humanas em fator de lucro, seja nas guerras que o país promove, no consumo desenfreado de armas de fogo, nas formas de exploração do trabalho cujos lucros são garantidos até em caso de morte do trabalhador - como apontado em Capitalismo: uma história de amor.

O segundo bloco de filmes, com Tiros em Columbine e Fahrenheit 9/11, constrói a paixão estadunidense por armas de fogo e como isso culminou em uma indústria bélica altamente rentável, não para o país, mas para grupos ricos com acesso ao poder político. Tiros em Columbine questiona o antigo costume do porte de armas de fogo entre a população civil, esta última transformada em "operários de guerra" para as lucrativas ações militares fora do país, conforme sugere Fahrenheit 9/11.

Devido a atualidade dos temas tratados, a popularidade dos filmes de Moore sugere um público imerso em tempos líquidos, cuja crescente inquietação em torno das mudanças no presente e das incertezas em relação ao futuro, parece "saltar das telas" e propor a redefinição da própria "realidade" para aqueles que buscam uma política de vida.

Acerca da forma dos filmes, muitas vezes rápida como um vídeo-clip, não é por acaso que Moore levou o cinema documentário aos holofotes de Hollywood, visto que seus filmes incorporam fórmulas desta indústria como, por exemplo, melodrama, além do uso constante de músicas para construir sentidos e propor sentimentos do espectador. Um retrospecto na história do cinema documental pode sinalizar como os filmes de Moore se distinguem dos anteriores em razão de seu dinamismo, e como influenciam a geração de filmes posteriores que, cada vez mais, lotam as salas de cinema em todo o mundo.

Os filmes de Moore trabalham com a história estadunidense, porém como se trata de uma história recente, como as mortes em Columbine e a queda das Torres Gêmeas, a memória popular em torno dessas questões também é recente. Isso resultou em acusações de fraude, manipulações, reinterpretações, entre outros debates acalorados em torno da produção do autor. Contudo, o cineasta soube explorar seus temas dentro de recursos visuais bem aceitos e conhecidos do público, como a própria história do cinema estadunidense, os seriados televisivos, noticiários de jornal, desenhos animados, 
programas de TV e de auditório que compõem a bem estruturada cultura visual dos EUA.

Como "realidade" construída, os filmes de Moore convencem e entretém seu público, atendendo demandas do espectador ávido por modelos de política-vida em exemplos de como as pessoas enfrentam problemas sociais de modo, cada vez mais, individual.

\section{IV - Referências bibliográficas.}

AMADO, Ana. Michael Moore e uma narrativa do mal. In: MOURÃO, Maria Dora \& LABAKI, Amir. Cinema do Real. São Paulo: Cosac Naify, 2005.

ANTUNES, Ricardo. Os sentidos do trabalho: ensaio sobre a afirmação e a negação do trabalho. São Paulo: Boitempo editorial, 2002.

AUMONT, Jacques. A Imagem. Campinas, SP: Papirus, 1993.

BAUDRILLARD, Jean. A sociedade de consumo. Lisboa: Edições 70. 1995.

BAUMAN, Zygmunt. Globalização: as consequências humanas. Tradução de Marcus Penchel. - Rio de Janeiro: Jorge Zahar Ed., 1999.

. Modernidade líquida. Tradução de Plínio Dentzien. Rio de Janeiro: Zahar, 2001.

Comunidade: a busca por segurança no mundo atual. Rio de Janeiro: Zahar, 2003.

A sociedade individualizada: vidas contadas e histórias vividas. Rio de Janeiro: Jorge Zahar editor, 2008.

. Vida a crédito. Rio de Janeiro: Zahar, 2010.

. A ética é possível num mundo de consumidores? Tradução de Alexandre Werneck. - Rio de Janeiro: Zahar, 2011.

BECK, Ulrich. Modernização reflexiva: política, tradição e estética na ordem social moderna/ Ulrich Beck, Anthony Giddens, Scott Lash; tradução de Magda Lopes; revisão técnica de Cibele Saliba Rizek. - [2ºd.]. -São Paulo: Ed. UNESP, 2012. [1 ${ }^{\mathrm{a}} \mathrm{ed}$. 1995].

.O que é globalização: equívocos do globalismo respostas à globalização. São Paulo: Paz e Terra, 1999. 
. Sociedade de risco: rumo a uma outra modernidade. [tradução de Sebastião Nascimento] - São Paulo: Ed. 34, 2010.

BERGER, John. Why look at animals. In: About looking. Londres: Writers and Readers.

BOLTANSKI, Luc; CHIAPELLO, Ève. O novo espírito do capitalismo. Trad. Ivone C. Benedetti; revisão técnica Brasílio Sallum Jr. - São Paulo: Editora WMF Martins Fontes, 2009.

BORÇA JR; TORRES FILHO. Analisando a Crise do Subprime. IN: Revista do BNDES, Rio de Janeiro, V. 15, N. 30, pág.129-159, Dez, 2008. Disponível em: <http://www.bndes.gov.br/SiteBNDES/export/sites/default/bndes_pt/Galerias/Arquivos/ conhecimento/revista/rev3005.pdf> (acesso em 10 de julho de 2013).

BURGOYNE, Robert. A nação do filme. Tradução de René Loncan. Brasília: Editora Universidade de Brasília, 2002.

CARRIÈRE, Jean-Claude. A linguagem secreta do cinema. Rio de Janeiro: nova Fronteira, 2006.

CHEVALIER, Jean; GHEERBRANT, Alain. Dicionário dos Símbolos. Trad. Vera da Costa e Silva ... [et. al]. 22ª ed. Rio de Janeiro: José Olympio, 2008, pág 740-744.

CHION, Michel. A audiovisão: som e imagem no cinema. Trad. Pedro Elói Duarte, Lisboa: Texto \& Grafia, Ltda. 2011. Coleção Mí-Me-Sis, 2008.

CHOMSKY, Noan. O lucro ou as pessoas: neoliberalismo e ordem global. Tradução de Pedro Jorgensen Jr. $6^{\text {a }}$ ed - Rio de Janeiro: Bertand Brasil, 2010.

CLARK, T. J. O Estado do Espetáculo. In: "Modernismos: ensaios sobre política, história e teoria da arte”. Tradução de Vera Pereira. São Paulo: Cosac Naify, 2007.

COHN, Gabriel. Weber: sociologia. São Paulo: Ática, 2005, (7ª edição).

DAVIS, Mike. Ecologia do medo. Trad. de Aluizio Pestana da Costa. Rio de Janeiro: Record, 2001.

DEBORD, Guy. A sociedade do espetáculo. Tradução Estela dos Santos Abreu. - Rio de Janeiro: Contraponto, 1997.

DI TELLA, Andrés. O documentário e eu. In: MOURÃO, Maria Dora \& LABAKI, Amir (Orgs). O cinema do real. São Paulo: Cosac Naify, 2005, pág. 69-75.

DURKHEIM, Émile. As regras do método sociológico. Tradução de Paulo Neves. São Paulo: Martins Fontes, 1999.

La Educación Moral. Tradução de Maria Luisa Navarro. Buenos Aires: Editorial Losada, S.A, 1974.

Da divisão do trabalho social. Tradução de Eduardo Brandão. - $2^{\mathrm{a}}$ ed. São Paulo: Martins Fontes, 1999. 
. O Suicídio: estudo de sociologia. Tradução de Monica Stahel. - São Paulo:

Martins Fontes, 2000.

ESQUENAZI, Jean-Pierre. As séries televisivas. Tradução de Pedro Elói Duarte. Lisboa: Edições Texto \& Grafia, Ltda. Coleção Mi Me Sis, 2011.

FERNANDES, I.E; MORAIS, M, V. Os tempos modernos e os magnatas da indústria. In: KARNAL, L. (org). História dos Estados Unidos: das origens ao século XXI. São Paulo: Contexto, 2010.

FRANCASTEL. Pierre. A realidade figurativa. São Paulo: Perspectiva, $2^{a}$ edição, 1993.

FONTENELLE, I, A. O nome da marca: McDonald's, fetichismo e cultura descartável. São Paulo: Boitempo editorial. 2002.

FOUCAULT, M. O que é um autor. Ditos e escritos: Estética - literatura e pintura, música e cinema (vol.III). Rio de Janeiro: Forense Universitária, 2001, p. 264-298.

GADDIS, John Lewis. História da Guerra Fria. Rio de Janeiro: Nova fronteira, 2006.

GALBRAITH, J, K. A grande empresa multinacional. In: A era da incerteza: história das ideias econômicas e suas consequências. São Paulo: Pioneira, 1980.

GALVÂO, Walnice Nogueira. Sombras \& sons: recortes sobre cinema e música contemporânea. São Paulo: Lazuli editora: Companhia Editora Nacional, 2010.

GAUDREALT, André. A narrativa cinematográfica. Brasília: Edit. UnB, 2009.

GAUTHIER, Guy. O documentário: um outro cinema. Tradução de Eloisa Araújo Ribeiro. - Campinas, SP: Papirus, 2011. (Coleção Campo Imagético).

GLASSNER, Barry. Cultura do medo. [trad. Laura Knapp]. - São Paulo: Francis, 2003.

GIDDENS, A. A estrutura de classes das sociedades avançadas. Tradução de Márcia Bandeira de Mello Leite Nunes. Rio de Janeiro: Zahar Editores, 1975.

. As consequências da modernidade. São Paulo: Ed. UNESP, 1991.

. A vida em uma sociedade pós-tradicional. IN: BECK, U. Modernização reflexiva. São Paulo: Ed. UNESP, 1997, p. 89-166.

. Un mundo desbocado: Los efectos de la globalización en nuestras vidas. Madrid: Grupo Santillana de Ediciones, S.A., 2000.

Modernidade e identidade. Tradução de Plínio Dentzien. Rio de Janeiro: Jorge Zahar, 2002.

GLASSNER, Barry. Cultura do medo. [tradução de Laura Knapp]. - São Paulo: Francis, 2003. 
GOFFMAN, E. A representação do eu na vida cotidiana. Petrópolis: Vozes 2009.

HOBSBAWM, Eric. Era dos extremos: o breve século XX: 1914 - 1991. Trad. Marcos Santarrita - São Paulo: Cia das Letras, 1995.

HOURANI, Albert Habib. Uma história dos povos árabes. Tradução de Marcos Santarrita. - São Paulo: Companhia das Letras, 1994.

HUNTINGTON, Samuel, P. O choque de civilizações. Rio de Janeiro: Objetiva, 1997.

HUTCHEON, Linda. Teoria e política da ironia. Tradução de Júlio Jeha - Belo Horizonte: Ed. UFMG, 2000.

JAMESON, Fredric. Espaço e imagem: teorias do pós-moderno e outros ensaios. Rio de Janeiro: Ed. UFRJ, 1994.

\section{0.}

. Pós-modernismo: a lógica do capitalismo tardio. São Paulo: Ed. Ática,

JANKÉLÉVITCH, Vladimir. L'ironie ou La Bonne Conscience. Paris: Presses Universitaires de France. 1950.

KARNAL, Leandro. (org.) História dos Estados Unidos: das origens ao século XXI. São Paulo: Ed. Contexto, 2010.

KLEIN, Naomi. Sem Logo: a tirania das marcas em um planeta vendido. [trad. Ryta Vinagre] $6^{\text {a }}$ edição. Rio de Janeiro: Record, 2008.

. A doutrina do choque: a ascensão do capitalismo de desastre. [trad. Vânia Cury] - Rio de Janeiro: Nova Fronteira, 2008.

KURZ, Robert. Com todo vapor ao colapso. Juiz de Fora, MG: Editora UFJF PAZULIN, 2004.

LASCH, Christopher. Refúgio num mundo sem coração: A família: santuário ou instituição sitiada? - tradução de Ítalo Tronca e Lúcia Szmrecsanyi - Rio de Janeiro: Paz e Terra, 1991. [edição 1997].

LYOTARD, Jean-Françóis. A condição pós-moderna. São Paulo: Ed. José Olympio, 1985.

MANN, Michael. O império da incoerência. [trad. Maria Beatriz de Medina]. Rio de Janeiro: Record, 2006.

MARX, Karl. O Capital: crítica da economia política. Livro I. 19ª Ed. Rio de Janeiro: Civilização Brasileira, 2002, págs. 452-453.

. O manifesto do partido comunista. Karl Marx e Friedrich Engels: Rio de Janeiro: Paz e Terra, 1998.

. Manifesto do partido comunista. In: FREEDMAN, Robert. (Org. - seleção e prefácio) Escritos Econômicos de Marx. Rio de Janeiro: Zahar Ed. 1966, pág.45. 
MELEIRO, Alessandra. (org) Cinema no mundo: indústria, política e mercado: Estados Unidos. São Paulo: Escrituras Editora, 2007.

MENEZES, Paulo. À meia luz: cinema e sexualidade nos anos 70. São Paulo: Ed. 34, 2001

. Cinema: imagem e interpretação. Tempo Social; Ver. Sociol. USP, S. Paulo, 8(2): 83-104, outubro de 1996.

Les Maîtres Fous, de Jean Rouch: questões epistemológicas da relação entre cinema documental e produção de conhecimento. RBCS, Vol.22 n⿳603, fev 2007, p. 84.

O cinema documental como representificação: verdades e mentiras nas relações (im)possíveis entre representação, documentário, filme etnográfico, filme sociológico e conhecimento. In: NOVAES, Sylvia C. [et. al]. (orgs) Escrituras da Imagem. São Paulo: FAPESP. Ed. da Universidade de São Paulo, 2004.

Representificação: as relações (im)possíveis entre cinema documental $e$ conhecimento.Rev. bras. Ci. Soc., São Paulo, v. 18, n. 51, fev. 2003. Disponível em $<$ http://www.scielo.br/scielo.php?script=sci_arttext\&pid=S010269092003000100007\&1 ng=pt\&nrm=iso $>$. Acesso em 20 abr. 2013.

MERLEAU-PONTY. O cinema e a nova psicologia. In: Xavier, I. (Org.). A experiência do cinema: antologia. Rio de Janeiro: Ed. Graal: Embrafilmes, 1983, págs. 103-117.

MESZÁRÓS, István. Para além do capital. São Paulo: Boitempo editorial/Ed. UNICAMP, 2002.

MOORE, Michael. Stupid white men: uma nação de idiotas. [tradução de Laura Knapp com Patrícia De Cia e Ana Carolina de Carvalho Mesquita]. São Paulo: Francis, 2003.

. Adoro Problemas: histórias da minha vida. [Tradução de Carlos Szlak] São Paulo: Lua de Papel, 2011.

2004.

. O livro oficial do filme Fahrenheit 11 de setembro. São Paulo: Francis,

MORIN, Edgar. Cultura de massas no século XX: neurose. Tradução de Maura Ribeiro Sardinha - 9 ${ }^{\text {a }}$ Ed. - Rio de Janeiro: Forense Universitária, 1997. (1 ${ }^{\text {a }}$ edição de 1962). Edição brasileira de $O$ espírito do tempo.

MOURÃO, Maria Dora \& LABAKI, Amir (Orgs). O cinema do real. São Paulo: Cosac Naify, 2005, pág. 69-75.

NICHOLS, Bill. Introdução ao documentário. Tradução de Mônica Saddy Martins Campinas,SP: Papirus, 2005. (Coleção Campo Imagético).

La representación de la realidad: cuestiones y conceptos sobre el

documental. Ediciones Paidós Ibérica, S.A: Barcelona, 1991. 
ODIN, Roger. Film documentaire, lecture documentarizante. In: ODIN, R; LYANT, J.C. "Cinéma et réalites". Saint Etienne: Universidade de Saint-Etienne, [trad. Samuel Paiva],1984, pág. 263-277.

OROZ, Silvia. Melodrama: o cinema de lágrimas da América Latina. Rio de Janeiro: Funarte, 1999.

PRYLUCK, Calvin. Ultimately We Are All Outsiders: The Ethics of Documentary Filming. In: ROSENTHAL, A; CORNER, J. New Challenges for Documentary. Manchester University Press, 2005, pág. 255-268.

PURDY, Sean. O século Americano. In: KARNAL, L. (org.) História dos Estados Unidos: das origens ao século XXI. São Paulo: Ed. Contexto, 2010.

RAMOS. Fernão P. (org). In: Teoria contemporânea do cinema: documentário e narratividade ficcional. Volume II. São Paulo: Editora Senac São Paulo, 2005.

Paulo, 2008.

. Mas afinal... O que é mesmo documentário? São Paulo: Editora Senac São

RATO, Vasco. Compreender o 11 de setembro dez anos depois. São Paulo: Edit. Babel, 2011.

RENOV, Michael. Investigando o sujeito: uma introdução. In: Cinema do real. MOURÃO, Maria Dora \& LABAKI, Amir (Orgs). O cinema do real. São Paulo: Cosac Naify, 2005, pág. 244-245.

RIESMAN, David. A multidão solitária: um estudo da mudança do caráter americano. [Tradução de Rosa R. Krausz e J. Guinsburg]. São Paulo: Ed. Perspectiva, 1995, p. 67.

RODRIGUES, José A. (Org). Émile Durkheim (Sociologia). São Paulo: Ática, 2005. (9a edição).

ROSENFELD, Anatol. A Crise da Democracia. In: Texto e contexto II. São Paulo: Perspectiva/Edusp/; Campinas: Ed. Unicamp, 1993, pág. 205 - 216.

RUBY, Jay. The Ethics of Imagemaking; or, "They're Going to Put Me in the Movies.They're Going to Make a Big Star Out of Me...”. In: ROSENTHAL, A; CORNER, J. New Challenges for Documentary. Manchester University Press, 2005, pág. 308.

SCHAMA, Simon. O futuro da América: uma história. Tradução de Carlos Eduardo Lins da Silva, Donaldson M. Garschagen, Rosaura Eichenberg. - São Paulo: Companhia das Letras, 2009.

SENNETT, Richard. A cultura do novo capitalismo. Tradução Clóvis Marques. Rio de Janeiro: Record, 2006.

A corrosão do caráter: as consequências pessoais do trabalho no novo

capitalismo. Tradução de Marcos Santarrita. - 10a Ed. Rio de Janeiro: Record, 2005.

Respeito: a formação do caráter em um mundo desigual. Tradução: Ryta Vinagre. - Rio de Janeiro: Record, 2004. 
SONTAG, Susan. Diante da dor dos outros. Tradução de Rubens Figueiredo. São Paulo: Cia das Letras, 2003. Título original: Regarding the pain of others.

SORLIN, Pierre. Sociologia del cine: la apertura para la historia de mañana. México: Fundo de cultura econômica, 1985.

TELLES, Edward. Os mexicanos-americanos e a nação americana: resposta ao professor Huntington. Tradução: Alexandre Massella. Tempo Social: revista de sociologia da USP, v.18, n2. Também disponível em: www.scielo.br/pdf/ts/v18n2/a08v18n2.pdf. Acesso em dezembro de 2010.

TOTA, Antonio. P. Os americanos. São Paulo: Contexto 2009.

VALIM, Alexandre Busko. Imagens vigiadas: uma história social do cinema no alvorecer da Guerra-Fria, 1945-1954. Tese (doutorado). Niterói: UFF, 2006, pág. 17.

VIRILIO, Paul. Guerra e Cinema: a logística da percepção. [Tradução de Paulo Roberto Pires]. São Paulo: Boitempo, 2005. (Coleção Estado de Sítio).

WEBER, Max. A ética protestante e o "espírito" do capitalismo. Tradução: José Marcus Mariani de Macedo. Revisão técnica, edição de texto, apresentação, glossário, correspondência vocabular e índice remissivo: Antonio Flávio Pierucci. - São Paulo: Companhia das Letras, 2004.

. A "objetividade" do conhecimento nas ciências sociais. IN: COHN, Gabriel. Weber: Sociologia. São Paulo: Ática, 2005 (7ªedição), p. 79-127.

. Confucionismo e puritanismo. IN: COHN, Gabriel. (org). Weber: Sociologia. São Paulo: Ática, 1979.

. As Seitas Protestantes e o Espírito do Capitalismo. IN: Ensaios de Sociologia. Tradução: Waltensir Dutra. Rio de Janeiro: Ed. Guanabara Koogan S.A. 1982.

WESTERN, Bruce. Punição e desigualdade na América. Coimbra: Edições Almedina. S.A, 2009.

WINSTON, Brian. A maldição do "jornalístico" na era digital. In: Cinema do Real. MOURÃO, Maria Dora \& LABAKI, Amir (orgs). O cinema do real. São Paulo: Cosac Naify, 2005, pág. 21.

Xavier, Ismail. O discurso cinematográfico - A opacidade e a transparência. São Paulo: Paz e Terra, 1977. (4ª edição, 2008).

Embrafilmes. 1983.

(org). A experiência do cinema: antologia. Rio de Janeiro: Edições Graal: Melodrama ou a sedução moral negociada. In: O olhar e a cena. São Paulo: Cosac \& Naify, 2003, pág. 85 - 99.

2007.

Sertão Mar: Glauber Rocha e a estética da fome. São Paulo: Cosac Naify, 
ZIZEK, Slavoj. Bem vindo ao deserto do real! cinco ensaios sobre o 11 de setembro e datas relacionadas. Trad. Paulo Cézar Castanheira. São Paulo: Boitempo editorial, 2003 (Estado de Sítio).

\section{V- Filmografia e websites citados.}

Born Into Brothels. Direção de Zana Priski e Ross Kauffman, (India, 2004).

Canadian Bacon. Direção de Michael Moore, (EUA, 1995).

Capitalism: a love story. Direção de Michael Moore, (EUA, 2009).

Carrier: mais um dia no paraíso. Direção de Mitchell Block, Maro Chermayeff, (EUA, 2008).

Celsius 41.11: The truth behind the lies of Fahrenheit 9/11. Kevin Knoblock, (EUA, 2004).

Corner In Wheat. Biograph. Direção de D.W.Griffith. (EUA 1908-1913). Vol. 1.

Elefante. Direção de Gus Van Sant. (EUA, 2003).

Fahrenheit 9/11. Direção de Michael Moore, (EUA, 2004).

Fahrenhype 9/11. Direção de Alan Peterson, (EUA, 2004).

Manufacturing Dissent: uncovering Michael Moore. Direção de Rick Caine e Debbie Melnyk (Canadá, 2007).

Metrópolis. Direção de Fritz Lang (Alemanha, 1927).

Michael Moore Hates America. Direção de Michael Wilson, (EUA, 2004).

Michael \& Me. Direção de Larry Elder, (EUA, 2004).

Procedimento Operacional Padrão. Direção de Errol Morris, (EUA, 2008).

Roger \& Eu. Direção de Michael Moore, (EUA, 1989).

Slacker Uprising. Direção de Michael Moore, (EUA, 2008).

SICKO. Direção de Michael Moore (EUA, 2007).

Super Size Me. Direção de Morgan Spurlock, (EUA, 2004).

Tiros em Columbine. Direção de Michael Moore, (EUA, 2002).

The Awful Truth. Direção de Michael Moore, (EUA, 1999).

The Corporation. Direção de Mark Achbar; Jennifer Abbott; Joel Bakan, (Canadá, 2003).

The fog of war. Direção de Errol Morris, (EUA, 2003).

Touching the Void. Direção de Kevin Macdonald, (Inglaterra, 2003).

Winged Migration. Direção de Jacques Cluzaud, Michel Debats e Jacques Penin, (França, 2003). 
11 de setembro. (França 2002).11 curtas, 11 diretores: Youssef Chahine (Egypt); Sabrina Dhawan (Índia); Amos Gitai (Israel); Alejandro González Iñárritu (México); Paul Laverty (United Kingdom); Claude Lelouch (France); Ken Loach (United Kingdom); Samira Makhmalbaf (Iran); Idrissa Ouedraogo (Burkina-Faso); Sean Penn (USA), Marie-Jose Sanselme (Israel); Danis Tanovic (Bosnia-Herzegovina); Daisuke Tengan (Japan); Pierre Uytterhoeven (France); Vladimir Vega (United Kingdom).

\section{Websites citados.}

http:// www.amway.com

http://www.albionmonitor.com/9805a/copyright/ns-springer.html.

http://www.adl.org/special_reports

http://www.armyguide.com

http://www.bobeubanks.com

http://www.boxofficemojo.com

http://www.buchanan.org

http://www.gm.com

http://www.cadillac.com/experience/history/

http://www.barrypopik.com/index.php/new_york_city/entry/fat_cat/.

http://www.time.com/time/printout/0,8816,877421,00.html.

http://www.time.com/time/world/article/0,8599,2082979,00.html

http://seattledrillteamassoc.com/teams.html

http://www.dogeatdog.com

http://www.imdb.com

http://www.michaelmoore.com/

http://www.michiganmilitia.com/

http://www.nytimes.com/1990/02/01/movies/roger_and_me_documentary_satire_or_bo

th.html.

http://www.scielo.br

http://www.usa.gov

http://www.ca.gov

http://www.dof.ca.gov

http://www.whitehouse.gov

http://www.theamericancause.org/

http://rogerebert.suntimes.com

http://www.youtube.com/user/copstv

http://www.barnesandnoble.com/Downsize_This/Michael_Moore.

http://www.youtube.com

http://edant.clarin.com

http://www.angelfire.com/art/antinike.

http://www.oxfam.org.au/explore/workers_right/nike.

http://www1.folha.uol.com.br/folha/ilustrada/ult90u69786.shtml

http://cinema.terra.com.br/noticias/0,,OI109003-EI1176,00-

Revista+acusa+Michael+Moore+de+forjar+cena.html

http://www1.folha.uol.com.br/folha/mundo/2000_eua_eleicoesfinal.html

http://www.archives.gov/federal-register/electoral-college/index.html 